\title{
CHECK LIST
}




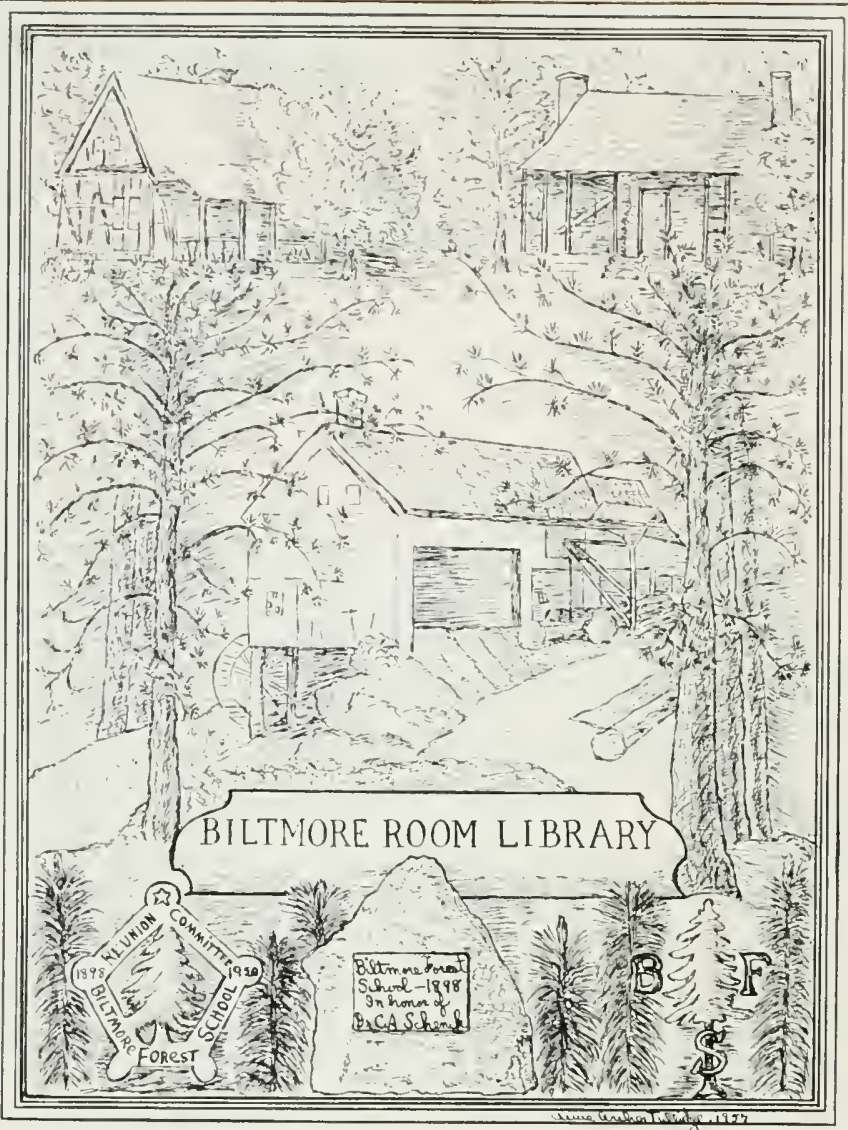

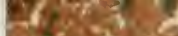

1d

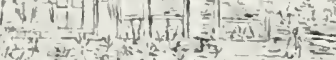

of do

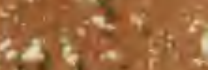

स. $3:$

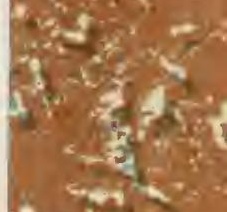

$8 x^{3}+3$.

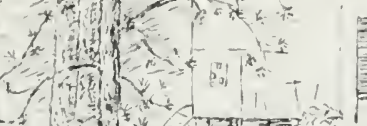

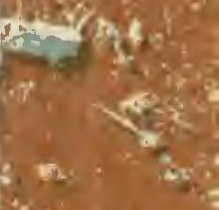

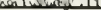

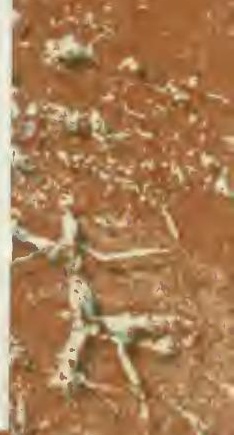

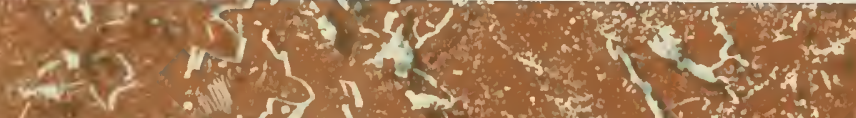

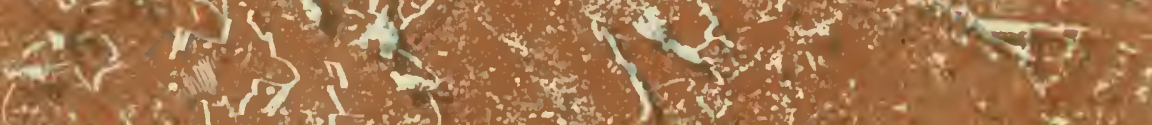

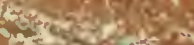

a. 582825

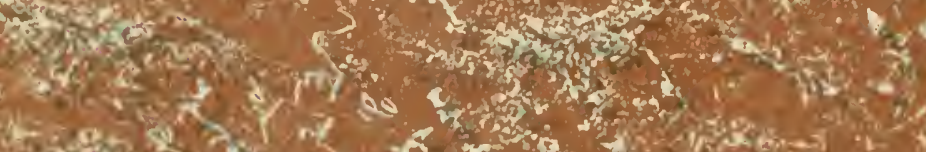

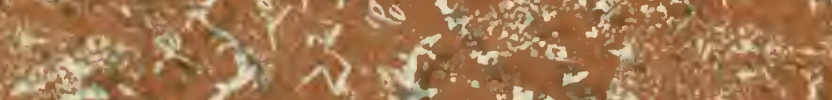

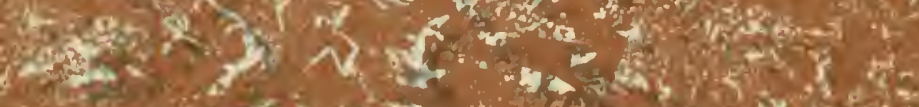

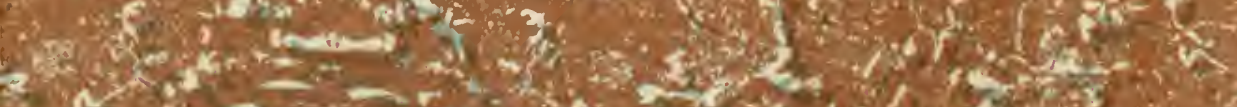

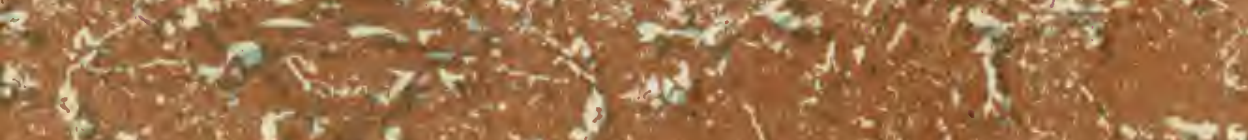

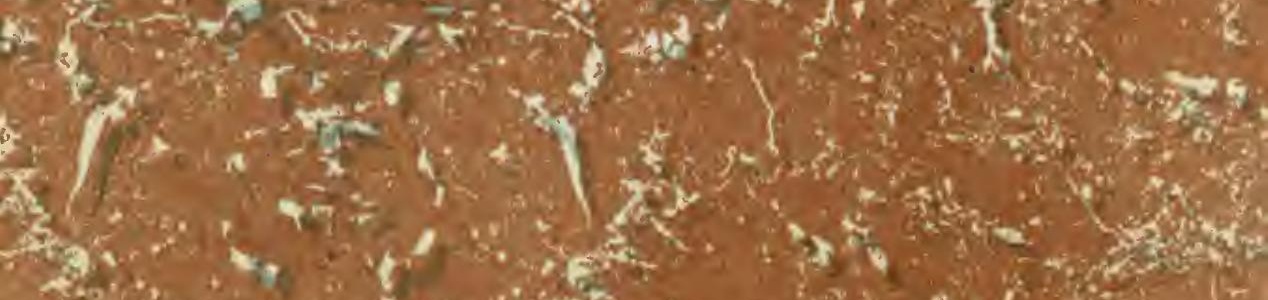




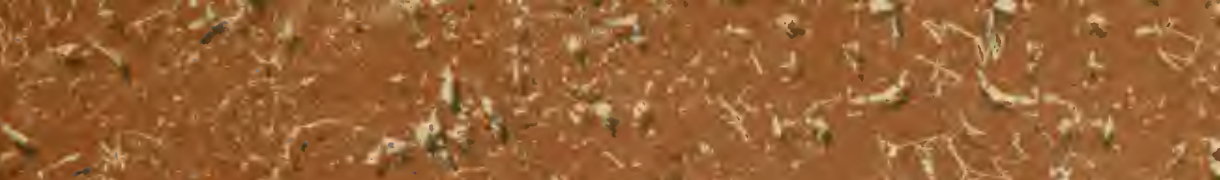

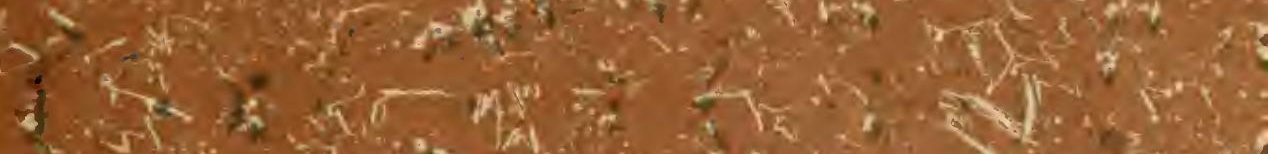

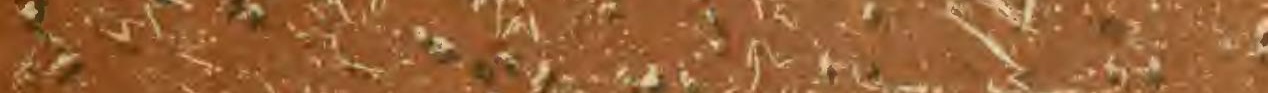

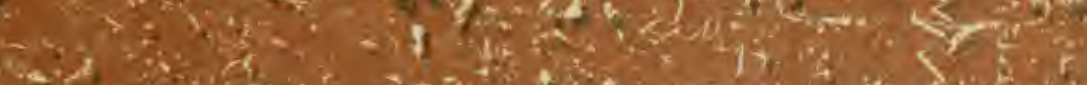


Digitized by the Internet Archive in 2009 with funding from NCSU Libraries 
BULLETIN No. 17.

tot conds. 33.9

avan in 1.31 l

U. S. DEPARTMENT OF AGRICULTURE.

DIVISION OF FORESTRY.

\section{CHECK LIST}

CF THE:

\section{FOREST TREES OF TIE UNITED STATES,}

THE1R NAMES AND RANGES.

13Y

GEORGE B. SUDWORTH,

Dendrologist of the Division of Forestry.

Issued November 5, 1898 .

PREPARED UNDER THE DIRECTION OF

13 E. FEIRNOW,

Chief of the Division of Forestry.

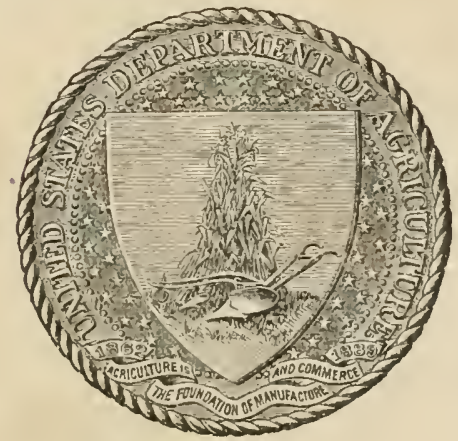

WASHINGTON :

GOVERNMENTT PRINTING OFFICE.

1898. 
$\vdots$ 


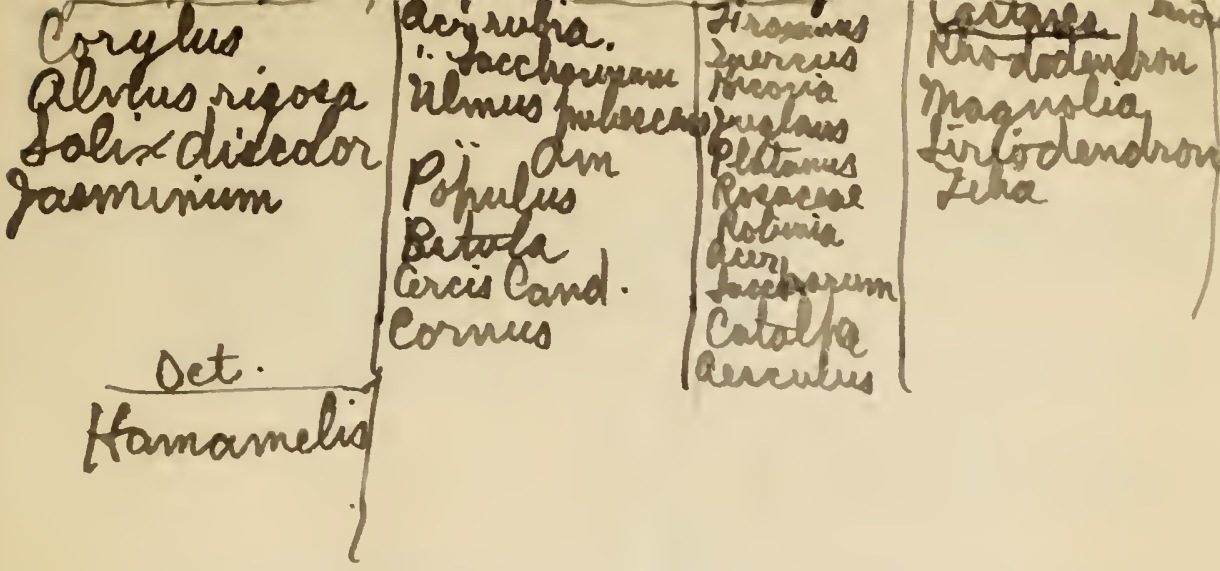

LETTER OF TRANSMITTAL.

\section{U. S. IEPARTMENT OF Agriculture, Ditision of Forestry, Washington, D. C., March 7, 1898.}

SIR: I have the honor to transmit herewith for publication a Check List of the Forest Trees of the United States, prejared by Mr. George B. Sudworth, Dendrologist of the Division.

It represents in the main a condensed reproduction of Balletin No. 14, Nomenclature of the Arborescent Flora of the Uuited States, by the same author, with notes on the distribution of trees added for better identification.

This shorter list, it is believed, will be helpful in bringing about a more uniform and stable nse of names by lumbermen, nu'serymen, and others interested in forest trees.

Respectfully,

Hon. JAMES WILSON,

Secretary of Agriculture.
B. E. FERNow, Chief of Division.

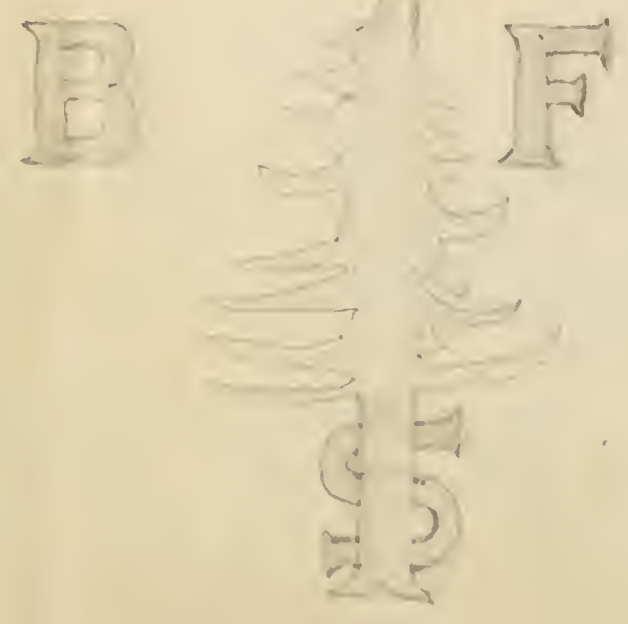




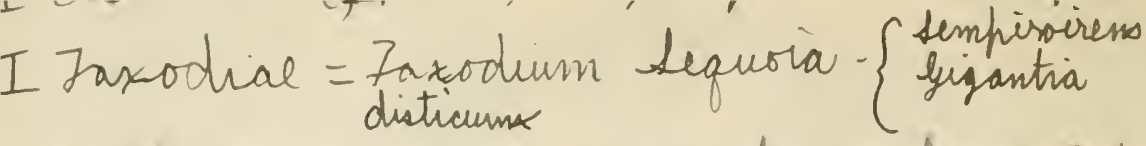

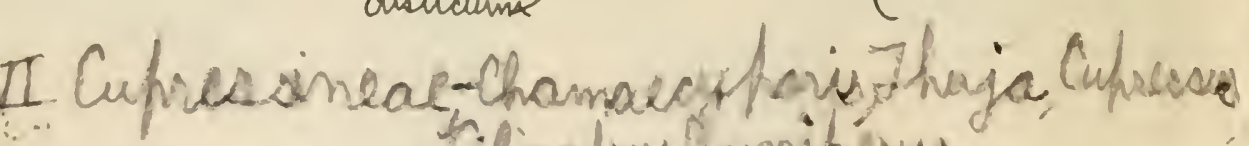
ilecedres gunipers. 
Igxertiac linear or awo theled

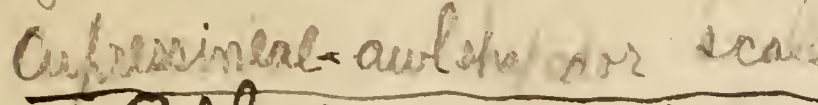

I wotheretaly cuspidata, greqgii, dihtal

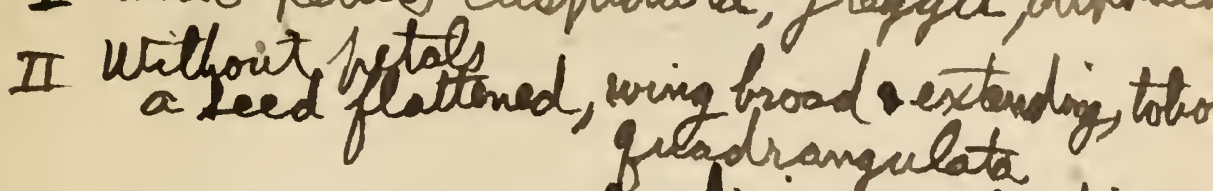
cardiniang 7 lo nigra bleed teteste anmala, profunda.

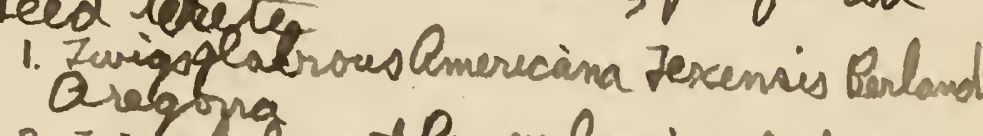

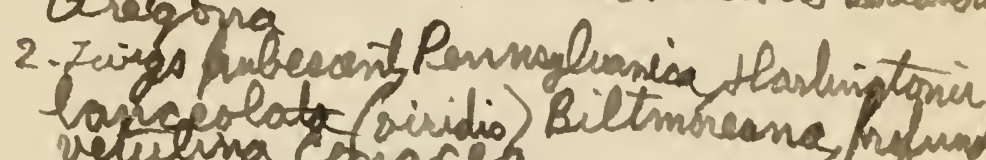
vatuenato oividio) B

Ericaspalodendrons

Hybred rigas ag leas R indicum

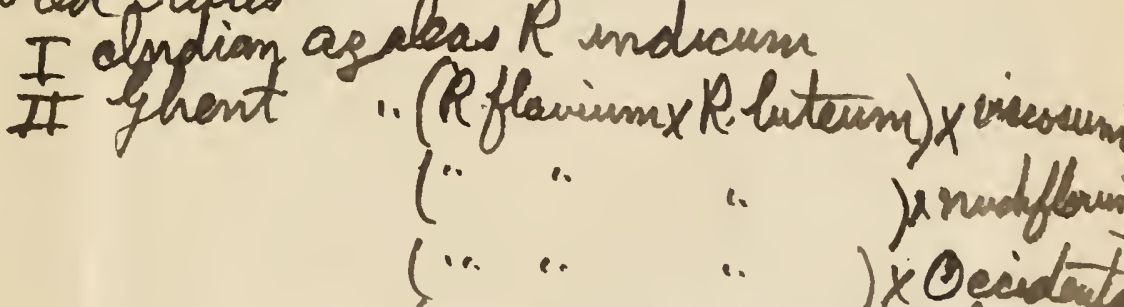

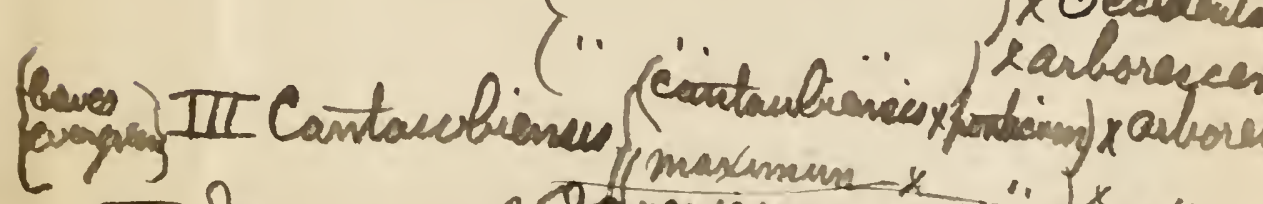

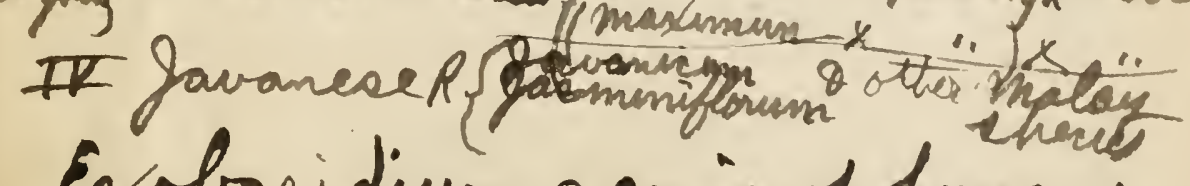
Exobasidium gannis of fingris on rhodenction leaves. 



\section{INTRODUCTION.}

The first necessity for any forestry work is a knowledge of the trees which the forester is apt to meet in the forest, and again the first knowledge before he can think or talk of trees is that of their names.

While most of our forest trees are naned both by botanists and laymen, a great number of entirely different kinds, or species, have receired the same name, and also the same species lias received a great number of names by which it is called in different parts of its range of occurrence. This confusion of names has led not only to many annoying inconveniences and misunderstandings, but often to fatal mistakes, as when a nurseryman fills an order with an entirely different kind of tree than was intended by the customer, or when a lumberman supplies an architect with an nusuitable material because their ideas as to what was ordered are at variance. Hence, the Division of Forestry has considered it a first duty to arrive at a uniform and stable nomenclature, both of scientific and vernacular uames, by a revision of the existing names, or synonymy, in the hope that, while neither uniformity nor stability cau be loronglit about by the mere publication of a list of names, such publication, carefully considered, might at least pave the way for such a desired end.

The botinical names have been revised according to certain laws now adopterl by many botanists. The revision lias been made by the competent Dendrologist of the Division, Mr. George B. Sudworth, and has been printed with a full synonymy and explanations in Bulletin No. 14 of this Division, Nomenclature of the Arborescent Flora of the United States. This bulky publication was, however, printed only in limited numbers, thereby preventing its widespread use. Since for practical uses it mas not necessary to state the entire botanical synonymy, aud in order to make the work more accessible, the present eleck list, being in part an abbreviated and amended reprodnction of Bulletin No. 14, has been prepared.

For hetter identification, and in order to increase the value of the list, the geographical range of the species has been added in a few brief words.

The list of names comprises an enumeration of all tlie trees indigenous to the Uniterl States, 495 in number, the designation of "tree" being applied to all woorly plants which produce naturally in their native habitat one main, erect.stem bearing a definite crown, no matter what size they attain. 
A few thoroughly maturalized trees are also noted, and natural or artificial varieties and hybrids have been fully cited.

Underneath the name adopted as correct according to the laws of nomenclature referred to, whenever a change has been marle from the name usually found in current text-books, the text-book name is also given, in different type.

The selection of a vernacular mame from the multitude of those in use is much more difficult, especially since the same name is often applied to many totally diflerent trees. Thus, we lave 12 Irouwoods, 16. Junipers, (i Yellow Pines, S Balsans, ete., each referring to ditlerent species and often to different generil. There are also many speries which have no vernacular name, not being recognized by the layman. There is no law upon the basis of which a selection could be made. The selection, therefore, had to be based on a few common-sense rules as a guide and with the principle of conservatism, the only rational one, in the foreground. A large mumber of correspondents were asked to subuit lists of names in common nse in various localities. Upon the basis of these iists the name used in the greatest number of localities has been given the preference unless it was also applied to some other tree, when, as an interference had to be avoiled, either another name inost commonly used or a name most descriptive and pertinent was selected. When possible, and where no vernacular names existed, a translation of the botanical name was taken, keeping, howerer, in mind the "name quality" of the combination, that is, a combination into the use of "wlich as an nume it would be natural to fall.

In some cases, where confinsion or undesirable inconsistency was caused by one name serving different genera, an attempt at segregation withont too much violence to well-established usage has bren made, as, for instance, in the ease of Cedar. This name is used indiscriminately for Juniperus, Thuja, Chamecyparis, and Libocedrus. Wo have with consistency alopted the names Juniper for the first. Arborvitar for the seencl, and Cedar, for the last two, well aware that it may be diflicult to overeome the objection of the logger's practice, at least to the name Arborvitar.

To enable ready reference and pave the way for general adoption of these names, not only a complete index to all the common names in the list, but a full synonymy grouped hy States is added, so that the lay. man or botanist ean realily determine what plant probably is meant by the native.

Changes in practice can only come gradnally and as the desirability for change appears; then what is sensible and arlaptable will be adopted and what lacks in adaptability will fail of acceptance. This list, therefore, is to be considered only as a first step to improvement and will serve as basis for further work of this Division.

B. E. liERNOW. 


\section{NOTE ON RANGE OF SPECIES.}

The first attempt in recent years to enumerate all of the North American trees (nortl of the Mexican boundary), with a description of their range anl hibbitat, was made by Prof. C. S. Sargent, and the catalogne was published in a bulky volnme (IX) of the Tenth Census (158t). The rapid increase of knowledge of American trees since then, however, has made many additions necessary, both as to newly discov. ered species and as to a better understanding of the range of many of those new or little known and also of the rell-known species. The elaborate Silva of North America, which Professor Sargent has now nearly completed as a sequel and amplification, with botanical features, etc., of the Tenth Census catalogue, will be the most complete rork issued, but from its high price it must unfortmately remain inaccessible to many.

Aside from these two works our best information conceruing the number of species aud rauge of North American trees is to be found chiefly in such regional works on botauy as Gray's Manual of Botany of the Northern States, Synoptical Flora of North Ameriea (unfinished), Chapman's Flora of the Southern States, Coulter's Manmal of Rocky Mountain Botany and Botany of Western Texas, and the Botany of Cillifornia, by Sereno Watson and other collaborators; also, recently, the Illustrated Flora of the United States and Canada, by Britton and Brown. Other sources of information are found in the modest and often little known State and county catalognes of plants issued by local botanists, together with various articles seattered through American and foreigu scientific journals and proceedings of seientific societies.

Moreover, the army of professional and amateur botanists engaged in botanical research are yearly bringing to light new facts, which are constantly enlarging our understanding of the geographical distribution of trees and other plants. But our knowledge of the range of tree species alone, especially sinee so vast a territory, with nearly 500 different species, has to be compassed, must long remain a variable quantity; and the sum total of facts concerning the geographical range of any of our trees must necessarily be an expression of the nnited efforts of all working botauists; for the unaislerl diligence of one man's lifetime could never earry his search and study into all of nature's hiding places for even trees alone. The geograplical range notes presented in this volume are, therefore, drawn from all the reli- able botanical publications available, supplemented by new facts personally gathered in recent field work. 
In ontlining the range of each speeies care has been taken, whenever ruliablo information was available, to indicate as exactly as possible points of limitation by the mention of counties, water courses, mountain systems, etc., and especially has this been aimed at in the case of new, rare, or little-known species. Wherever the range appears in more general terms speeific information has not been at hand with which to give more definite limits. In the case of very common, wirlely, and eontinuously distributed speeies, however, the range often appears in somewhat general terms, for the reason that the ready detection of the species within the general lines renders more detailed delineation unneeessary.

A lack of space has excluted fiom the present catalogne any but oceasional statements of the manner of occurrence of each species, that is, whether found in forests of pure growth, as in the ease of Beech, Sugar Maple, White Oak, White I'iue, ete., or as single individuals or scatterel groups in a mixed growth, as is the case with the magnolias, basswoods, ashes, etc. Related and alike interesting faets which have been omitted are the special characters of soil, moisture, and altitude appearing to limit the natural occurrence of individuals to certain sites within a species' broaler range; as, for example, the exclusive occupancy of low, mueky ground in the Northeast by the 'Tamarack, while the arljoining stiffer soils may bear Black Ash, with Red Naple and Yellow Birch, and the still drier contignons mpland soils may bear Red Oak, White Oak, Sugar Maple, ete.

A gain, many trees are found to be more or less continuously distributed throughont their range, so that they are likely to be met with at frequent intervals. Thus, in traversing the territorial range of the familiar White Oak, individuals may be found in nearly every county and township, while less common species will be met with only in moro widely separated stations, iu some cases occurring as apparently aceidental individuals. Peeuliar, but usually accontable, phenomena are also seen in tree distribution where extensive areas of forest-forming species are very widely disconnected. A faniliar example of this is the distribution of Pinus palustris in the falf region, where the species sullenly fades out east of the Mississippi River, but reappears again and in commercial quantities about 100 miles restward, in eastern Texas. Other less marked examples might be citerl.

It is, therefore, to be understood by the layman thit within the ranges, as statel in general terms, the speeies may be absent in many localities, and personal observation must aid the siudent to properly interpret the general range.

ADVENTIVE TREES.

In enumerating the indigenous trees of North America, it seems proper from time to time to include also certin exotic species which show the power of existing and spreading independently and without cultivation: Oecurrence under such conditions mav be taken as fairly indicative of 
naturalization. Such trees as the poplars, willows, Ailanthus, ete., having been more or less extensively cultirated, have escaped and become widely and thoroughly naturalized. Still other exoties, such as the Paulownia, Paper Mulberry, Tallow-tree, etc.. of less extensive adaptability to varying elim tic conditions, have become natmalized in certain restrictel regions. There are also many indigenons trees, such as locusts and catalpas, whieb, throngh wide enltivation. have largely increased the area of their distribution and become natmalized outside of their original rauge.

No systematic census of the actual rauge of snch naturalized speeies in North America has been attempted in the present eatalogue, the statements of their presence being often basell upon more or less incomplete observations, but in all cases sufficient to warrant their introduction as as:ociates of untive species. Sereral cultivated exotic species, not inchuled in the present catalogne, show a tendency to become naturalized. But the existence of such species seems for the most part to be coufined to old and neglected gromuds where, to a limited extent, the trees have become self-propagated, though hardly capable of ad vancing and holding their own against the vicissitudes of more exposed localities and other contestant: for the soil. It is thought best, therefore, to exclude such trees till further observation proves them to be naturalized.

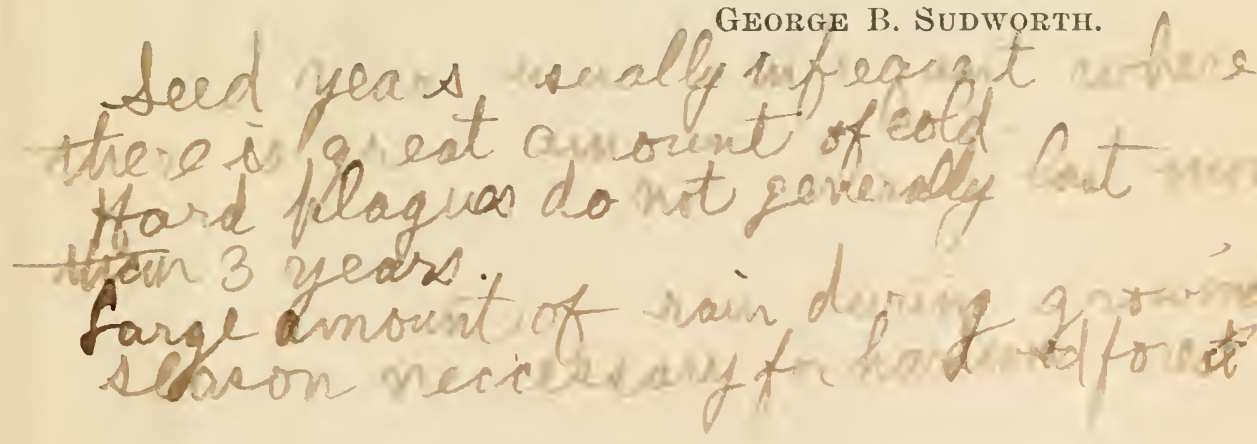





\section{CHECK UIST OP FORRST TREES OP THR UNITED STATRS.}

\section{G YMNOSPERM A.}

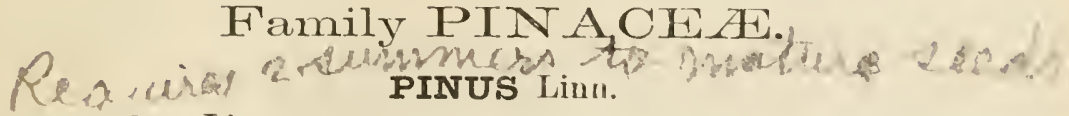

Pinus strobus Linn.

White Pine.

RAxGE.-From Newfoumdland (White Bay region) and along the northern shows of St. Lawrence Gulf to northern Ontario (ucar Abittibi and Nipigon lakes) sonthern Manitoba (near sontheru end of Lake Winniper); sonthwarl through northern and eastern Minuesola, northeastern (Mitchell Comty) and eastern border of Iowa (to Scott Connty), northern (counties) Illinois, sonthern shores of Lake Michigin, southern Michigan (uorth of Allegan, Eaton, and St. Clair counties), worthensteru and eastern (border counties) Ohio, and along the Allegheny Mountaius to northern Georgia ('Tallulah Falls).

Names ix Use.-White Pine (Me., N. H., Vt., Mass., R. I., Conn., N. Y., N. J., Pa., Del., Va., W. Va., N. C., Gal, Ind., Ill., Wis., Mich., Minu., Ohio, Ont., Nebr.); IVeymouth Pine (Mass., S. C.): Soft P'ine (I’a.); Northern Pine(S.C.); Spruce Pine (Tenn.).

VARIETIES DISTINGUISHED IN CULTIVATION,

Pinus strobus brevifolia Lond.

Pinus strobus umbraculifera Knight.

Pinus strobus minima Beissu.

Pinus strobus fastigiata (Koch) Beissn.

Pinus strobus viridis Carr.

Pinus strobus gracilifolia Sudw.

Pinus strobus nivea (Knight) Carr.

Pinus strobus aurea Carr.

Pinus strobus variegata Carr.

Pinus strobus zebrina lieissn.

Pinus strobus prostrata Hort. liew.

Pinus strobus unifolia ${ }^{1}$ nom. nov.

Pinus monticola Dougl.

Silver Pine.

RAxie.-From Vandonver lsland and sonthern British Columbia (coast and gold ranges) through northern Idilho (Cour d'Aleue and Bitter Root mountains) to northern Montana (Flathend River) and southward through Washingrtou and Oregon (Cascade Mountains) to California (ou Sierra Nevada Mountains to Calaveras County).

' P'imus strobus unifolia nom. nov. = Pinus strobus forma nova monophylla Tubenf, in Forstl.-naturw. Zeitschr., VII., 34, (t.) 35, 1898, not I'. monophylla Torl. \& Frem. 1845. A form recently detected in Germany and characterized by Dr. Tubeuf as having tle needles more or less cohering throughout their length and formiug a single needle. 
Names in Us:F,--White Pine (Cal., Nev., Oreg.); Finger-eone Pine, (Cal.); IIonutain P'ine (Cal.); Soft Pine (Cal.); Little Sugar Pine (Cal.); Mountain Weymouth I'ine; Western White Pine.

tPinus lambertiana Dongl.

Sugar Pine.

Ravals-Coant region from Oregon (head of MeKinzie and Rogme rivers) to Califoruia (Sierra Nevirla Mountams anil coast ranges to Santa Lueia Mountains: San Beruarulino and Cusamaca monutains).

Names in rse.-Sugir Pine (Cal., Oreg.); Big Pine; Shatle Pine (Cal.); Great Sugar P'ine; Little Sugar Pine; Gigantic Pine (Cal. lit.); P'urple coned sugar Pine.

\section{Pinus flexilis James.}

Limber Pine.

RANGE.-Rocky Monutain region from Moutana to western Texas (Gualalupe and Limpia montains) and New Mexico; in monntains of northern Arizona, Utah, Nevarla, aud California (Inyo Monntains and Mouvt Sillman).

Nayes In Use. - White Pine (Cal., Ner., Utah, Colo., N. Mex.); I'ine (Utah. Mont.); Bull Pine (Colo.); Rocky Mountain WVhite Pine (Cal.); Rocky Mountain Pine; Limber-twig Pine (Cal. lit.); Western White Pine (Cal. lit.); Arizona lilexilis Pine.

Pinus albicaulis Engelm.

White-bark Pine.

RANGi. From liritish Columbia (coast ranges and Lltasyonco River) sonthward and through Washington and Oregon (on Blue Mountains); eastward throngrh northeru Washiugton to northeru Montana (eastern base Rocky Monntains); California (Sierra Nevarla to San Beruardino mountains; Seotts Mountain and Monnt Shista).

Narres IN USE.-White-stem I'ine(Cal., Mont.); Scrub Pine (Mont.); Pitch Pine (Mout.); White-bark (Oreg.); White-bark Pine (Cal.); Creeping Pine (Cal. lit.); Alpine White-bark Pine (Cal. lit.).

Pinus strobiformis Engelm.

Mexican White Pine.

RAxGs. - Southwestern Now Mexico (monntains) to Arizona (Sauta Rita and Santa Cat:lina monntinins); monntins of Mexico and Guatemala.

Nanes IN Usis.-Ayacahnite Pine; White Pine (Ariz.); Mexican White Pine; Arizona White Pine.

Pinus quadrifolia Parl.

Parry Piñon.

Pinus parryana Engelm.

RAN(iE.-Sonthern California (San Diego Connty) and soutinward iuto Lower C'alifuruia.

Naues in Use.-Nut Pine (Cal.); Parry's Pine (Cal.); Parry's Nut P'ine (C'al.); Parry Nut Pine (Cal. lit.); Piñon (Cal.); Mexican Piñon (Cial. lit.).

Pinus cembroides Zunce.

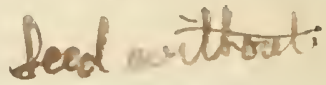

liaxge.-Arizona (Santa Catalina Mountains) and northern Mexieo.

Names in Use.-Nut l'ine (Ariz., N. Mex.); Piñon (Mex.); Stoneseral Mexican Piñon (lit.); Mexi(an Cembra-like Pine (lit.).

Pinus edulis Engelın.

Piñon.

Raxip.-From Coloralo (eastern base Pikes Peak) through New Mexico and to westen 'Texas (mountains).

Nanes in u'se.-Piñon (Tex., Colo.); Nut Pine (Tex., Colo.); Piñon Pine (Colo.); New Mexican Piñon (lit.). 
Pinus monophylla Torr. \& Frem.

Single-leaf Piñon.

liaxcik.-From Itah (near Utah Lake) to California (eastern foothills Sierra Nevala Mountains) and sonthward into eastern Arizona (San Francisco Monntains).

Nayles ix tose.-Piñon (Cal., Ariz., Nev., Utah); Nut Pine (Cal., Ariz., Ner., Utalı); Gray Pine (Nev.); Nevala Nut Pine (Cal.); Singleleaf (Ual. lit.); Fremont's Nut Pine (Cal. lit.).

Pinus balfouriana Murr.

Foxtail Pine.

Ravge.-California (Scotts Mountain in Siskiyon County; Momnt Whitney and sources of king and Kern rivers).

Names IN USE.-Spruce Pine (Cal. lit.); Foxtail Pine (Cal.).

Pinus aristata Engelm.

Bristle-cone Pine.

RANGE.-From Colorado through sonthern Utah, northern Arizona, and Nevadal to sontheastern California.

Names in use.-Hickory Pine (Cal. lit.); Bristle-cone Pine (Cal. lit.); Foxtail Pine (Cal. lit.).

\section{Pinus resinosa Ait.}

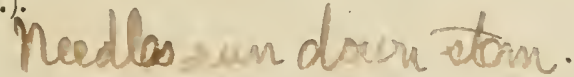

Red Pine.

RAxGE.-From Newfonnlland and along the northern shores of St. Lawrence Gulf to northern Ontario (north of Abittibi Lake) to sonthern Manitoha (near sonthern end of Lake Winnipeg); sonthwarl through the Northern States to Massachusetts (Midllesex County), Pennsylvania (Chester County), nortleastern Ohio (north of Clevelaud), central Michigan (Saginaw), northeru Wiscousiu (Oshkosh aud Eau Claire), and northeastern Minnesota.

Names in Use.-Red Pine(Vt., N. H., N.Y., Wis., Minn., Ont.); Norway Pine (Me., N. H., Vt., Mass., N. Y., Wis., Mich., Minn., Ont.); Hard Pine (Wis.); Canadian Red Pine (Eng.).

Pinus torreyana Parry.

Torrey. Pine.

RavgE.-Southern California (Soledad River in Sau Diego County).

Nanes in Use.-Solediad Pine (Cal.); Del Mar Pine (Cal.); Lone Pine (Cal.); Torrey Pine (Cal. lit.); Torrey's Pine.

Pinus arizonica Engelm.

Arizona Pine.

RAxGE.-Southern Arizona (Chiriealuna, Santa Catalina, El Rincon, and Santa Rita mountaius).

Namis in Use.-Arizona Yellow Pine (Cal.); Arizona Pine: Arizona 5-leavel Lumber l'ine (Cal. lit.).

Pinus ponderosa l.aws.

Bull Pine.

Raxge.-From British ${ }^{\circ}$ Colunhia (interior south of latitude $51^{\circ}$ ), and Datsota (Black Hills region) sonthward in the Pacific and Rocky Mountain region to western Texas aud llexico.

Names in Use.-Tellow Pine (Cal., Colo., Mont., Irlaho, Utah, Wash., Oreg.); Bull Pine (Cal., Wash., Utab, Idaho, Oreg.); Big Pine (Mont.); Lonn-leaved Pine (Utah, Nev.); Red Pine; Pitch Pine; Sonthern Yellow Pine; Heavy-wooled Pine (Eng.); Western Pitch Pine; Heavy Pine (Cal.); Foothills Yellow Pine; Sierra Brownbark Pine; Montani Black Pine (Cal. lit.); "Gambier Parry's Pine" (Eng. lit.).

Pinus ponderosa scopulorum Engelm.

Rock Pine.

RANGE.-Rocky Monntitin region.

Nanes in UsE.-Yellow Pine (Mont., Nebr.); Bull Pine (Colo.); Long-leaved Pine (Colo.); Rocky Mountain Yellow Pine (lit.). 
VARIFTY HISTIXGCISIIED IN CELTIVATION.

Pinus ponderosa penduliformis Sndw.

Weeping Bull Pine.

Pinus apacheca Lemmon.

Apache Pine.

$R+x$ F.-Sontheastern Arizona (Chiricahna Monntains). Species insufficiently umberstood, and mas jove to be at form of $I$ '. ponderosa.

Pinus mayriana Sulworth.

I'INU'S LATIFOLIA Sarg., not of author's.

Arizona Long-leaf Pine.

Ravgr.--Sonthern Arizona (Sauta Rita Mountains). Range insufficiently known.

M.Mnes in UsE.-Broad-leaf Pine(lit.); Arizona Broad-leaf P'ine(lit.); Mayr I'ine (lit.).

Pinus jeffreyi "Oreg. Com."

Jeffrey Pine.

RANG1.-C'alifornia (Scotts Mountain in Siskiyon Connty and along Sierra Nevala Monutains to Sun bernardino and San Jacinto mountains); Southern Oregon (Dongl.ıs Connty, 30 miles nonth of Roseburg).

Nanes Ix UsE.-Bull Pine (Cal.); Black Pine (Cal.); Western Black l'ine (Cal. lit.); P'inos (Cal.); Truckee P'ine (Nev.); Saprood Pine (Cal.); Jeffrey Pine (Cal. lit.); Blackbark Pine (Cal. lit.); Relbark Pine (Cal. lit.): Peninsula Pine (Cal. lit.); Sierra Redbark Pine (Cal. lit.); Peniusula Black Pine (Cal. lit.).

Pinus chihuahuana Engelm.

Chihuahua Pine.

RANiE.-Sonthwestern New Mexico and Arizona (Santa Rita and San Francisco momtains) and sontluard in Mexico.

NAMEs in tse.-Chihmahna Top-cone Pine (Cal. lit.).

Pinus contorta Loud.

Shore Pine.

RAN(iE.-Const region from Alnska to California (Mendocino County).

Nanes in USE.-Scrub P'ine; Knotty l'ine; Tamarack (Cal.); Sand Pine (Oreg.): North Coast Scrub Pine (Cal. lit.); Bolander's Pine; Ifenderson's I'ine.

Pinus murrayana "Oreg. Com."

Lodgepole Pine.

RANGE. From Alaska (Yukon River) and sonthward throngh interior Brilish Columbia; tho monntaius of Washington and Oregon to California (Sierra Nerala Mountains to San Jacinto Mountains); platean east of the Rocky Monntains (latitnde $56^{\circ}$ ) and south through the locky Monntain region to New Mexico and northern Arizon:a.

NAwes in USE.-Tamarack (Wyo., Utah, Mont., Cal.); Prickly Pine (Utalı); White Pine (Mont.); Black Pine (Wyo.); Lodgepole Pine (Wyo., Mont., Ilaho); Sprnce Pine (Colo., Idaho, Mont.); Tamarack Pine (Cal.); Murray Pine (Cal. lit.).

Pinus sabiniana Dougl.
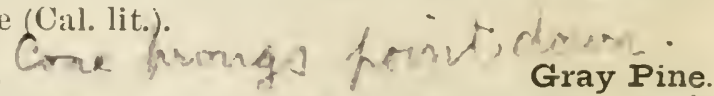

lis.il:-Califoruia (Sliasta County and sonthward in foothills of coast ranges and on 1 estern slopes of Sierra Nevala Ilonntans).

NAMes in Usk.-Sabine's Pine (Cal. lit.); Gray-leaf Pine (Cal.)? Pinus coulteri Laml.

Coulter Pine.

Raxge.-Califoruia (from Monte Diablo to Cuyamaca Mountánins); possibly farther sonthward in lower Califorvia.

Nanes IN t'se.-Coulter's Pine (Cal.); Nut Pine (Cal.); Bigeone Pine (Cal.): Large-coned Pine (Lng. lit.). 
Pinus radiata $\mathrm{D}$ (11.

Monterey Pine

l'INTS INSIGXis Domglas in herb. ex Loudon.

Raxge-Califuruia (Point Pinos on Monterey Bay, and along the coast from l'es. eadero to San simeon Bay).

NAMES IN T'se.-Monterey Pine (Cal.); Sprearing-cone Pine (Cal. lit.): Nearly smooth.cone l'ine (Cal. lit.); liemarkable Pine (Cal. lit.); Small-coned Monterey Pine (Cal. lit.); Two-leaved Insular Pine.

\section{Pinus attenuata Lemmolı.}

Innobcone Pine

l'int's tubERCULATA Gorl.

RAxGE.-Oregon (Melinzie River and sonth on western slopes of Cascaule and Sierra Nevala mountains) to ('aliforuia (coast ranges from Santa Cruz to San Jacinto Monutains).

Names IN Use.-Knobcone Pine (Oreg., Cal.); Prickly-cone I'inc (Ilaho); Sun-loving Pine (Cal. lit.); Sumy-slope l'ine (Cal. lit.); Narrow-cone Pine (Cal. lit.); Tuberculated-('oned Pine (Eug. lit.).

\section{Pinus tæeca Linn.}

Loblolly Pine.

RaxGl. - Sonth Atlantic and Gulf states from New Jerses (Cape Yay), sontliern Delawaro and West Virginia (Woorl, Mineral, Hampshire, and Hardy eounties! to centual Florida (Cape Malabar and Tampa Baly) and west to eastern Texas (C'olozado River; in Bastro; Conuty); nortloward into sontheastern Indian Territors, Arkansas, and southern border of midhle and west Temuessee.

Tayes In USE.-Loblolly Pine (Del., Va.. N. C.. S. C.. Cia., Ala.. Fla.. Miss., La., Tex., Ark.): Oldfirld l'ine (Del., Va., N. C.. S. C.. Ga., Ala., Fla., Miss., La., Tex., Ark.); Torch Pine (Eıg. lit.); Rosemary Pine (Ta., N. C.., in part); Slash Pine (Va., N. C., in part); Lougschat Pine (Del.); Longshncks (IId., Va.); Black Slash Pine (S. C.); Frankincense Pme (lit.); Shortleaf Pine (T'a., N. C., S. C., La.); Bull Piue (Texas anıl Gulf region); Tirginia Pine; Sap Pine (Va.. N. U.); Meadow Pine (F]..): Colustalle Pine (Ta.); I lack Pine (Ta.); Foxtail Pine (Ta.. Mrl.); Inclian Pine (Va., X. C.); Spruce Pine (Ta., in part); Bastard Pine ( Var., Y. C.); Jellow Pine (uorth Ala., N.C.); Swamp Pine (Ta.. N. C.); Lougstraw Pine (Va.,N. C., in part).

\section{Pinuṣ rigida Mill.}

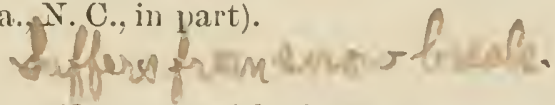

Pitch Pine.

Raxge,-Fiom sonthern New Brunswick (St. Johns River) to eastern Outarin (north shore of Lake Ontario and Lower Ottawa River) and sonth ward in tle Atlantic: region to sontheru Virgiuia ( (Atlanta); west to western New York (Ithaea), northeastern I'emsylvania, pasteru Ohio (borler connties south of Cauton) and lientucky, eastern 'Teumessee (to ('umberland Mountains).

Thares in use.-Piteh l'ine (Tt., N. H.. Mass, R. I., Comn., N. I., N. J., Pa., Del., WT: Va.. N. C., S. C., Ga., Ohio, Ont.. Mrl.. Eng.); Long. leared Pine (Del.); Longschat Pine (Del.); Hard Pine (Mass.); Yelluw Pine (Pa.); Black Pine (N. C.); Blıck Norway Pine (X. Y.); Rigicl Jine (Eug. lit.); Sap I'ine (lit.).

${ }^{1}$ Refers to the two-leaferl form Pinus radiata hinnata (Fingelm.) Lenmi, found on Santa Rosa, Sauta Cruz, and Guadalonje islauds.

$19193-\mathrm{No} .17-2$ 
Raxar.-Coast region from North Carolina to Florida (head of St. Johns River, aul probilily farther sonth; on the west const from Ponsacola to Citrus County and probally unuel, farther sonth). Range imperfectly known.

Nanes in l'sls.-Marsh l'ine (N. C.); Meallow l'ine (N. C.); P'ond Pine (N. C., S. C., Iili., Miss., La.); Loblolly P'ine (N. C., Fliı): Spruce Pine (S. C., Ga.); Bastard Pine (S. C., Ga.); Bull Pine (S. C., (iar.).

\section{Pinus virginiana Mill.}

P’nUS INOPS Solander ex Ait.

Scrub Pine.

RangE.-From New lork (Staten Island) to South Carolina (Aiken River) and northern Alabuma (Winston, Cullman, and Dekall connties); west into sonthern Indian:i, to midhle 'Tenuessee (Putnan Connty).

Names in rse.-Jer:y l'ine (N. J., Pa., Del., N. C., S. C.); Suruh Piue (li. I., N. Y., l’a., Del., N. C., S. C., Ohio); Short Shuclis (Mu., Va.); Shortshat Pine (Dul.); Spruce Pine (N. J., N. C.): Shortleaved (N. C.): Cenar Pine (N. C.); liver Pine (N. C.); Nigger Pine (Temn.); New Jersey Pine (lit.).

Pinus clausa (Engelm.) Sargent.

Sand Pine.

Raxge.-Coast of Alibama (Baldwin County) and western Florida (to I'ease Creek); east "oast of Florida from St. Angustine to Halifax River.

Nharas in UsE.-Sand Pine (Fla., Ala.); Oldfield Pine (Fla.); Florida Sprure l'ine (Ala.); Serub Piue (Fla.); Spruce Pine (Fla.); Uplaul Spruce Pine (Fla.).

Pinus pungens Michx. f.

Table-mountain Pine.

RANcil.-Dintrict of Columbia, Maryland, and Allegheny Mountain regrion from Pennsylvania to easteru and mildle Tennesseo avd Georgia (Tallulah Falls).

Nares in UsE.-Table mountain Fine (Pa., Del., Mal, S. C.); Suntheru Mountain Pine (Tenu.); P’rickly Pine (N. C.).

\section{Pinus muricata Don.}

California Swamp Pine.

RAxGe,-California coast (Fort Bragg, Mendoeino County, and sonth in coast ranges to Sin Lnis Obispo Connty); Lower California (Cedros Islands aud const of Liscoldo and San Quitau).

Nanes in USE.-Swamp Pine (Cal.); Dwarf Marine Pine (Cal.); Prickle.ene I'ine (Cal.); Bislıop's Pine (Cal. and Eng. lit.); Anthony's Prickle cone Pine (Cal. lit.); Obispo Piue (Cal.)

\section{Pinus echinata Mill. \\ PINUS MITIS Michx.}

Shortleaf Pine.

Raxge.-From New York (Staten Island) to Florida (Chattahoocheo region) and west to sontheru Missomi, easteru ludian Territory, and northeastern Texas.

Na.res in UsE.-Yellow I'ine (N. Y., N. J., Pa., Del., Va., N. U., Ala., Miss., La., Ark., Mo., I!l., Ind., Kans. (searce),(Ohio, Lng. lit.); Shortleaved Pine (N. C., S. U., Ga., Ala., Miss., Fla., La., Tex., Ark.); Spruce Pine (Del., Miss., Ark.); Bull Pine (Va.); Shortshat Pine (Del.); P'itch Pine (Mo.); Poor Pine (Fla.); Shortleaved Yallow P'ine; Rosemary l'ine (N. C.); Virginia Yellow l'ine (Va, in part); North Carolina Yellow Pine (N.C. and Va., in part); North Carolina Pine (N. C. and Va., in part); Carolina Pine (N. C. and Va., in part); Slash P'ine (N. C., Va., in part); Oldtield Pine (Ala., Miss.). 
Pinus glabra Walt.

Spruce Pine.

Raxis.-Coast regrion, from Sontl Carolina (between latitude $31^{\circ}$ and $33^{\circ}$ ) to Florida (Chattalioochee region) and west to Louisiana (Pearl liver).

Names in use.-Sprnce P'ine (S. O., Aliı., Fla.); Cerlar Pine (Miss.); White P'ine (S. C., Fla.); Walter's I'ine (S. C.); Lowland Spruce I'ine (FIa.); P'oor P'ine (Fla.); Kingstree (S. C.).

Pinus divaricata (Ait.) Du Noyt de Cours.

I'INUS BANISSIANA Lamb.
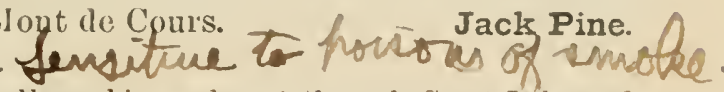

Range-New Brumswick to New llampshire and west throngh Great Lake and Hutson Bay (sonthern shoresi region to Great Bear Lake, Mackenzie Ruver, and Rocky Ilonutains; south into northerd Naine, northern New York, northern Indiana and lllinois, and central Minnesota.

Names in Use.-Scrub Pine (Me., V't., N. Y., Wis., Miel., Minn., Ont.); Gray Pine (Vt., Mimn., Ont.); Jack Pine (Mich., Minn., Canala); Princes Pine (Unt.); Black .Jack Pine (1/is.); Blakk P'ine (Minn.); Cypress (Quebec to Hulkon Bay); Camala Honn-cone Pine (Cal. lit.); Chek Pine; Sir Joseph Bank's Pine (L̀n.); "Juniper" (Canada); Banksian Pine (lit.).

\section{Pinus palustris Mill.}

RAxre. - Coast region, from sonthern Virginia (Norfolk) to Florida Timpa Bay and Cape Canaveral) to eastern Texis (T'rinity River); northwarl un Alabima to the northeasteru part of the State (Clay and Walker counties), and northwestern (borler eounties) Georgia.

Names in Use.-Longleaved Pine (Va., N. C., S. C., Ga., Ala., Fla., Miss., Ia., Tex.); Sontleın Pine (N. C., Ala., Miss., La.); Yellow Pine (Del., N. C., S. C., Ala., Fla., La., Tex.); Turpentine Pine (N. U.); Rosemary Pine (N.C.); Brown Pine (Tenn.); Hard Pine (Ala., Miss., La.); Georgia Pine (general, Del.); Fat Pine (Southern States); Southern Yellow Pine (general); Soutlern Hard I'ine (general); Sonthern Heart Pine (general); Southeru Pitch Pine (general); Heart Pine (N. C. and South Atlantic region); l'itch Pine (Atlantic region); Longluaved Yellow Pine (Atlantic region); Longleaved Pitch Pine (Atlantic region); Longstraw Pine (Allantic region); Nortl Caroina Pıtch Pine (Va., N. C.); Georgia Yellow Pine (Atlantic region); Geolgia Heart Pine (general); Georgia Longleaven Pine (Atlantic region); Georgia Pitch Pine (Atlantic region); Florida Yellow Pine (Atlantic regnon); Florida Pine (Atlantic region); Florida Longleaved Pine (Atlantic region); Texas Yellow Pine (Atlantic region); Texas Longleaved Pine (Atlintic region).

Pinus heterophylla (Ell.) Sudworth.

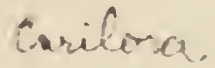

\section{Cuban Pine.}

Pinus cubensis Griseb.

Range.-Coast regiou (60 to 100 miles inland), from Sonth Caroluua (Cliarleston) to southern Florida (Capè Canaveral and Biscayne Bay') and west to Louisiaua (Pearl River).

Na.ues in USE.-Slash Pine (Ala., Miss., Ga., Fla.); Swamp Pine (Fla., Miss., Ala., in part); Bastard I'ine (Ala. lumbermen, Fla.); Meadow Pine (Fla., eastern Miss., in part); I'itch Pine (Fla.); She Pitch Piue (Ga.); Slıe Pine (Ga., Fla.); Spruce Piue (southern Ala.). 
LARIX AMERICANA Michx.

Rdxis,-From Nowfonmilland and Lathrudor to northern l'ennsylvania, uorthern Indiana, Illinois, central Minuesota, and northwestward to Hudson Bay (Ciıpe Churchill, Great liear Lake, and Maekenzio liver) (in Arctic Circle).

NAMES IN UNE. - Laurch (Vt., Mass., R. I., Comm., X. Y., N. J., P'a., Del., Wis., Miun., Ohio, Out., Minn.); Tamarack (Me., N. II., Vt., Mass., R. I., N. Y., N. J., Pa., hnd., Ill., Wis., Mich., Minn., Ohio, Ont.); Hackmatack (Me., N. H., Mass., R. I., Del., Ill., Minnn., Ont.); American Lareh (Vt., Wis., nurserymen); Juniper (Ie, N. Bruns. to IIndson Bay); Black Lareh (IInn.); Epinette Ronge (( leaves fall" (Indians, N. Y.); Red Larch (Mich.); Hacmack (lit.).

\section{Larix occidentalis Nitt.}

Western Larch.

RANGE.-Sonthern British Colnumbia (sonth of latitnde $53^{-}$) and south in the Cascade Momntains to the Columbia River, and to Western Montana; also in Blue Mountaius of Washington and Oregon.

NAMUS IN USE.-Tamarack (Oreg.); Hackmatack; Larch (Idaho, Wash., etc.); Red American Lareh; Western Tamarack: Great Western Larch (Cal. lit.); IVestern Lareh (Eug.)

\section{Larix lyallii P'arl.}

Alpine Larch.

RANGE.-High momntains (6,000 to 7,000 feet) of northwesteru States, from Montana to Washington and Oregon, and northward in adjacent territory. Range imperfectly known.

NAMES IN USE.-Tamarack (Idaho, Wash., Oreg.); Larch (Idaho, W'asa., Oreg.); Momntain Larch; Lyall's Larch (lit.); Woolly Lar(ch (Cal. lit.).

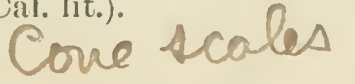

Picea mariana (Mill.) B.S. P.

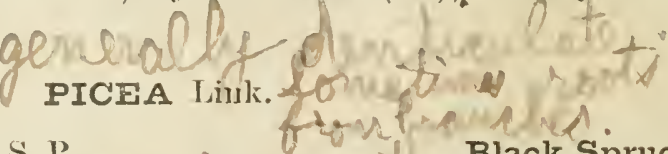

Picka Nigra link. ence, eabo

Black Spruce.

RANGe. - Newfomdland to Ilulson Bay and northwestwad to the Mackenzio River; sonthward in Mirhigan, Wisconsin, Minnesota, and in the eastern mountains to North Carolina aut Tennessie.

NAMes in Use.-Black Spruce (N. H., Vt., Mass., R. 1., N. Y., Pa., W. Va., N. O., S. C., Wis., Mich.. Minn., Ont., Eug.); Double Spruce (Me., Vt., Minn.); Blue Sprnce (Wis.); Sprnce (Vt.); White Spruce (W. Va., ; lew Pine (W. Va.); Jniper (N. C.); Spruce Pine (W'. Van, Pa.); H a Balsam (Del., N. C.); Epinette.Jaume (Quebec): Water Spruce (Canad., Me.).

VARIETIES DISTINGLISIIEU IN ('ULTIVATION.

Picea mariaua doumetti (Carr.) Beissn.

Picea mariana pumila (Carr.) Sndw.

Picea mariana humilis Sndw.

Picea mariana argenteo-variegata (Beissu.) Sulw.

Picea mariana aurescens Sudw.

Picea mariana albescens Sudw. 
Picea rubens Sargent.

Red Spruce.

Picea rubia ijiet.

Raxgk.-Nova Scotia to North Caroliua aud Tennesseo. Range imperfertly known.

Nanes IN UsE.-Red Spruce; Yellow Sprure (N. I.); North Ameri can Red Spruce (foreign lit.).

\section{VARIETIES DISTINGUISIIEI IN CULTIVATION.}

Picea rubens corulea (Loul.) nom, nov.

Picea rubra coridea (Loitl.) Forbes.

Picea rubens pendula (Carr.) now. nov.

Picea Rubra pendula Carr.

Picea rubens gracilis (Knight) nom. nov.

Picea rubra Gracilis (Knight) Carr.

Picea canadensis (Mill.) B. S. P.

PiceA ALba Link.

White Spruce.

RaxGk.-Newfoundland to Hudson liay and northwestward to Alaska; sonthward to northeru New York, Michigan, Wisconsin, Minnesota, South Dakota, Montanil, and British Columbia.

Naues In USE.-White Spruce (Vt., N. H., Mass., N. Y., Wis., Mich., Minn., Ont.); Single Sprnce (.Me., Vt., Minn.); Bow Sprnce (Yew Eng.): Sliunk Spruce (Wis., Me., New Eng., Ont.); Cat spuruce (Me., New Eng.); Spruce (Vt.), Pine (Hudson Bay); Double Spruce (Vt.).

VARIETIES DISTINGUISHED IN CULTIVATION.

Picea canadensis glauca (Moench.) Sudw.

Picea calladensis acutissima (Beissn.) Sudw.

Picea cauadensis compressa (Beissn.) Sudw.

Picea canadensis nana (Loud.) Sudw.

Picea canadensis naua glaucifolia Suct $w$.

Picea canadensis echinoformis (Carr.) Sisdw.

Picea canadensis compacta gracilis (Beissn.) Sudw.

Picea cauadensis compressiformis Suctw.

Picea canadensis nutans Sulw.

Picea canadensis aurea (Beissur.) Sudw.

Picea engelmanni' Engelm.

Engelmann Spruce.

Raxik.-Northeru Arizona aud througl the Rocky Mountain regrion to British Columbia.

NAMEs Ir Tse.-Engehmann's Sprnee (Utah); Balsam (Ttah); White Spruce (Oreg., Oolo., Utah, Idaho); White Pine (Idaho); Monntain Spruce (Mont.); Arizolla Spruce (C'al. lit.).

YARIETIES HISTINGULIHED IN CLLTIVATION.

Picea engelmanni griseifolia Sudw.

Picea engelmanui argyrophylla Suclw.

Picea engelmanni minutifolia Sudw.

Picea parryana (André) Parry.

Picen PUNGexs Engeln.

RaxGe.-Ceutral Rocky dlountain region-Colorado, Ltah, and Wyoming.

NaIres in UsE.-ParTy"s Spruce(Ctah); Blue Spruce(Colo.); Spruco;

Balsan (Colo., Utah); White Spruce (Utal, Colo.); Silver Spruce (Colo.); Colorado Blue Spruce (Colo.); Priekly Spruce (lit.)

${ }^{1}$ Prof. J. G. Lemmon has recently described the following as distinct from the Engelınan Spruce: Picea colımbiana Lemm. (=I'. engelmanni Engrelm. in part). 
Picea parryana glaucescens nom. nov.

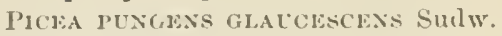

Picea parryana cyanea $10 m$. nov.

Picea puxgexs cranea Sulw.

Picea parryana argentea (Beissn.) nom. nov.

Picka puxiexs argentia lieissn.

Picea parryana glauca pendens nom. nov.

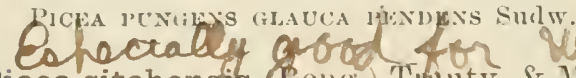

Picea sitchensis (Bong.) Thantr. \& Mayer.

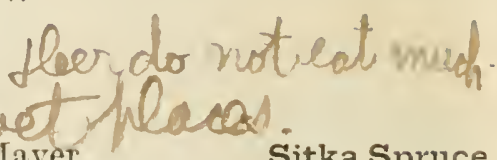

RAxrir.-Const recrion ("xtending inland about 50 miles) from Alaska to northern California (Mendocino Comby).

Namis IN UsE.-Tideland Spruce (Cal., Oreg.. Wash.); Menzies' Spruce; Western Spruce; Great Tidelaud spruce (Cal. lit.).

'Picea breweriana $\mathrm{I}^{+}$ats.

Weeping Spruce.

RAx(ik.-Northern California (Siskiyou Mountains), very local, aud southern ()regent.

Nambs in UsE.-Weeping Spruce; Brewer's Spruce: Siskiyou Spruce (Germ. lit.).

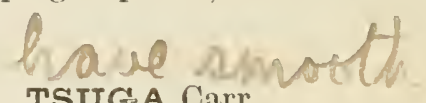
TSUGA Carr.

Tsuga canadensis (Linn.) Carr.

Hemlock.

Rav(ris-Nova scotia to Nimesotil (Carleton Connty), Wisconsin, Michigan, and sonthwarl in the Athutic region along the mountains to northern Alabaua (Winston (Comuty) and (ioorgit.

Naines 12 list.-Hemlock (Me., N. H., Vt., Mass., R. I., Conn., X. Y., N. J., P’a., Del., V'a., N. C., S. C., Ky., Wis., Mich., Minn., Ohio. Ont.); Hemlock Spruce (T't., R. I., N. Y., P’a., N. J., W. Va., N. C., S. C., Engliurl, cult.); Spruce (Pa., IV. Va.); Spruce Pine (I'a., Del., Va., N. U., (xa.); Oh-nch-tah="Gleens on the stick" (N. Y. Indians); Canadian Hemlock (lit.); New England Hemlock (lit.).

VARIETIES IISTINGUISHED IN CULTIVATION.

Tsuga canadensis pumila Sudw.

Tsuga canadensis compacta minima Sudw.

Tsuga canadensis globosa lieissn.

Tsuga canadensis gracilis Carr.

Tsuga canadensis milfordensis Nichol.

Tsuga canadensis erecta Suclw.

Tsuga canadensis columnaris Beissn.

Tsuga canadensis macrophylla lieissn.

Tsuga canadensis paucifolia sndw.

Tsuga canadensis microphylla lieissn.

Tsuga canadensis parvifolia (Veitch) Beissn.

Tsuga canadensis pendula lieissn.

Tsuga canadensis aurea Beissn.

Tsuga canadensis albo-spica (Gord.) Beissu.

Tsuga canadensis argenteo-variegata Sudw.

Tsuga canadensis argentifolia Sudw. 
Tsuga caroliniana Engelm. Carolina Hemlock.

RAxGn.-Mourtains of southwestern Virginia, western Nortl Carolina, and north. eru feorgia; very local.

Names in Usk.-Hemlock (N. C., S. C.); Sonthern Hemlock (lit.). Tsuga heterophylla (liaf.) Sirgent. Western Hemlock.

TSUGA IERTENSIANA anthors, not Carr.

RAxGl:-Alaska to Id:aho and Montaua and sonthrard (in the Cascale and const ranges; to California (Marin Comnty).

NAIES IN Lisk.-Hemlock Spruce (Cal. ; Western flemlock (Cal.); Hemlock (Oreg., ldalıo, Wash.); Western Hemlock Sprnce (lit.): Callifornia IJemluck Spruce; Westeru Hemlork Fir (Eng.); Prince Albert's Fir (Eng.); Alaslia Pine (Northrestern Imbermen).

VARIETY DISTIXGLISIILD IN CULTIVATION.

Tsuga heterophylla latifolia nom. nov.

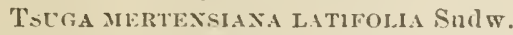

Tsuga mertensiana (Bong.) Carr. Black Hemlock.

TSLGA PAT'TONIANA (Jeffir.) Engelm.

RAXige,-Yorthem British Columbia to lilaho and northern Nontana, and sonthward to California (Sierra Nevalla Mountains); usu: lly above 10,000 feet; at seal level only in region of Sitlia.

Thans IN TsE.-Williamson's Spruce (Cal.); Weeping Sprnee (Cal.); Alpine Spruce (Cal.); Hemlock Spruce (Cal.); Pattou's siruce; Alpine Western Spruce.

Tsuga mertensiana hookeriana (Uarr.) nom.nov. Hooker Hemlock. TSUga PaTTONIAXa hooḱRiana (Carr.) Lemmon.

VARIETY DISTINGUISHED IN CULTIVATION.

Tsuga mertensiana argentea (Beissn.) nom. nor.

Tsuga pattoniana alzentea beissn.

\section{Mel wotind PSEUDOTSUGA Carr.}

Pseudotsuga taxifolia ${ }^{1}$ (Lam.) Britton.

Douglas Spruce.

Pseudósuga douglasil Carr.

RAxGk.-From the Rocky Momntain region (iu United States) and northward to central British Colmubia; Pacific coast.

Names iN l'se.-Rerl Fir (Oreg., Waslr., Idalıo, Italu, IIont., Colo.); Douglas Spruce (Cal., Colo., Mont.); Donglass Fir (Utilh, Ureg., Colır.);

'Duyglas SPRCCE (P'seudotsuga faxifolia vs. Pscudotsuga uncronata). - The retention of the specific term taxifolia in the wenus P'scudotsnga is lield by smo botanists to be at variance with the meanin of the law exclucling the use of synonyms and homouyms. Lambert first described the Donglas sprnce as I'inns laxifolia (l’inus esl. 1, 51, t.33) in 1803, not knowing that in 1796 Salisbury hat alrealy described another conilerons tree, a trua fir and now known is Abies balsamea (L.) Mill., as I'iuns laxifolia. At this point, according to hotinical laws now observed, the Donglins Spruce was without a wame, since supposing the tree to be a true pine, there conlal exist hnt one P'inus taxifoliu and that one only the earlier, or P'inns taxifolia Sialisbury (1796). So far as is known Poiret (in Lamairek, Enc. Meth. Bot., vi, 5'23) was the noxt to describe this tree in 1804, muler the following designation: "Abies tuxifolia lammbert." But as we know Lamlert did not write "Abics larifolia," but P'inus larifolia, 
Yellow Fir (Oreg., Mont., Idaho, Wash.); Spruee (Mont.); Fir (Mont.); Oregon Pine Cal., Wishl., Oreg); lied Pine (Utalı, Irlalı, Colo.); I'nget Somul Pine (Wash.); Donglas-tree; Cork-barked I)ouglas Spruce (Var. suberosia Lemm.).

\title{
Pseudotsuga taxifolia pendula (Engrelı.) Sulwortl.
}

Weeping Douglas Spruce

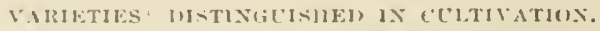

\author{
Pseudotsuga taxifolia pendula cærulea sindw. \\ Pseudotsuga tazifolia glauca (Beissi.) Srulw. \\ Pseudotsuga taxifolia fastigiata (Kntrht) Sullw.
}

the fbies furifolia must he talien as original with l'niret, and is the first namo in the plint's listory whiel eould be eonsielered tenable, as there is nome other lilis it in form. liafinescye, lowever. subsequently deseribud the Donglas Sprnee undrertill mother name, Abies mncromala (Atl. Jomrn., 120, 18:32), whieh brings us to the point of controversy".

Jow, this trex at prosent being eousideren a Pscudofsuga. shomld luear its earliest specifie mane in eombination. It is heremaintained that thiscombinalin shomle ho

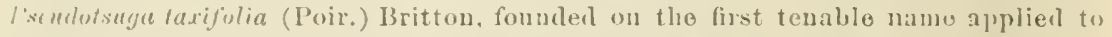
the plint, that is, Abies tarifolia Poiret (l.e.). It is helal by others, however, tliat

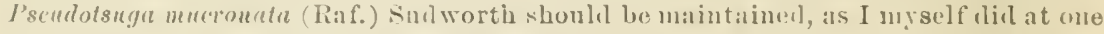
time, to the exclusion of P'sendotuge tarifolia. Thuse opposing the nse of the lattur

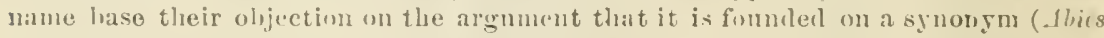
faxifulia) derived from the homonym Piuns tasifolia Lambert (1803), which is, to be sure, invalidatul ly Pinns taxifolia Salishury (1796). Clearly Pinus tarifolia Lambort (I80:3) is an inert nam. to which molerivative roferenco can be manle. 'l'he sil]position, however, that Abies taxifolia l'oiret (1804), heing fumbled or cleriverl by

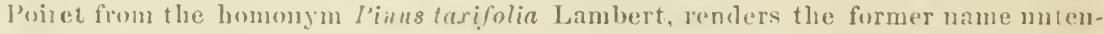
ahlo, is heliever to lie an entirely erronews interpretation of the meaning of the law tomeling this mooterl question. For, so far as is known, and imlepenr.ent of ils

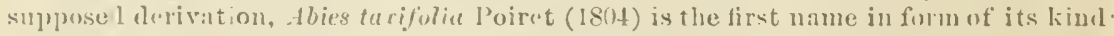

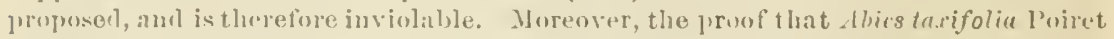
is aetnally derived from the lomonsm Pinus turifolia Lambert, and therofore unten-

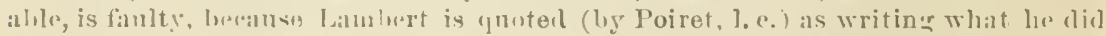
mot write. lint fom still another point of view and dismegarling the taxmonic

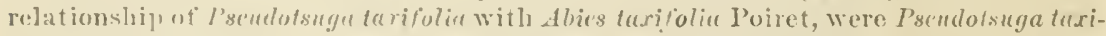
foliu not now in existence, no one emule deny that accuriling to present praetice

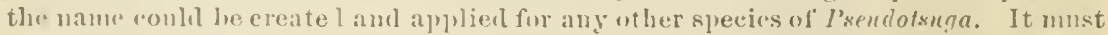
stamel her:ause it wanld be the first and only one of its tyje publislecl. For the same ruisun tho sporific: teru taxifoliu seems perfectly temable for tlu J)onglas Sprnco,

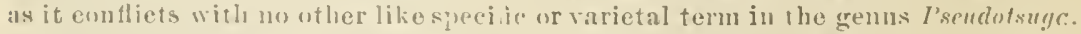

ls would applear that tluo esisatial point in tho application of the law preventimer tha: nso of duplieato or sfmm oue, regardless of any s.. uthetic relationship which may exist between name.s.

I'rof. J. G. Lemmun has propused the following varieties of the Donm]as sprure, whiclı are as yet nnknown to mo in nature:

l'sendofsugu taxifolia rarr. subcrosa Jemm.- Small tree, distinnnished by its thick, corliy hark, thin foliage, and sinall wouto eomes, 1 to 2 inclues long, and fommd on the principal momntains of northern Arizona amol New Mexico.

Psendutsuga terifolia var. fongata Lemm.-1)istinguisłell 'y its " compantively

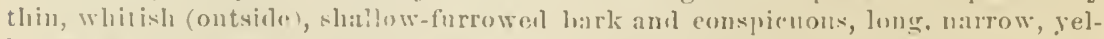

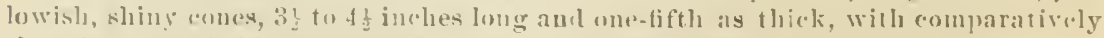

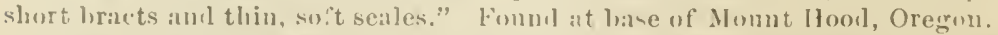

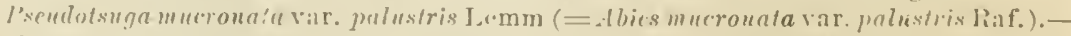

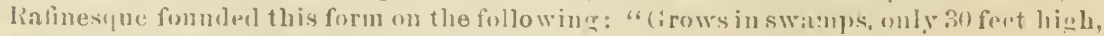
and with sprealing hraneles." said to orenr in tho regim of the luwer ("olnubia River. 
Pseudotsuga taxifolia standishiana (Goril.) Sndw.

Pseudotsuga taxifolia dumosa (Carr.) Sulw.

Pseudotsuga taxifolia compacta (Beissu.) sudw.

Pseudotsuga taxifolia elegans (Reissn.) Sudw.

Pseudotsuga taxifolia argentea (Beissn.) sulw.

Prszidotsuga taxifolia argentea densa Suclw.

Pseudotsuga taxifolia variegata (McDon.) sindw.

Pseudetsuga taxifolia stairi (Beissu.) \&ulw.

Pseuciotsuga taxifolia brevifolia (Hort. liew.) Sulw.

Pseudotsuga taxifolia revoluta (Hort. Kew.) Sudw.

Pseudotsuga macrocarpa (Torr.) Mayr.

Bigcone Spruce

li.s.se.-Sonthern California (Sau liernarlino Nountains to the Cuymara Monntaius).

SAries in Use.-Sprnce (Cal.); Hemlock (Cal.); Bigcone spruce (lit.); Bigeone Douglas Spruce (lit.).
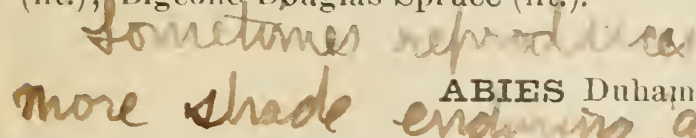

Abies fraseri (Pursh) Linnll.

ABIES Duham.

Raxgr.-Mountains of Tolth Carolina and Teunessee.

Nayes in Use.-Balsam (N. C., Temm.); Balsam Fir (N. ( .); Donble Fir Balsan (T(nn.); Donble Sprnce (X. C.); She Balsam (N. V.); She Balsam Fir (N. C.); Momtain Balsam (N. C.); Healing Balsam.

\section{Abies balsamea (Linn.) Mill.}

Balsam Fir.

RAxGE-From Newfomdlam and Labralor to Hudson Bay and nortluwestward to Great bear Lake region, and sonth to Peunsylvania (and along high momntains to Virgmia), Michigan, and Minnesota.

Nayes ix Use.-Balsam Fir (N. H., Vt., Mass., R. I., N. Y., Pa., W. Va., Wis.. Mieh., Minn., Nebr., Ohio, Ont.; Eng. cult.); Balsam (Vt., N. H., N. Y.): Canarla Balsam (N. C.): Balm of Gilead (Del.): Palm of Gilead Fir (N. Y., Pa ); Blister Pine (W. Ta.); Fir Pine(W. Va.); Firtree (Vt.); Single spmuce ( . Bruns. to Hudson Bay); Silver Pine (Hudson Bay); Sapin (Quebec); Cho-koh-tung="Blisters" (N. Y. Indians).

\section{VARIETIES DISTINGCISHED IN CULTIVATION.}

Abies balsamea hudsonia (Knight) Veitch.

Abies balsamea brachylepis Willk.

Abies balsamea longifclia (Luul.) Endl.

Abies balsamea cærulea Carr.

Abies balsamea hemisphærica sindw.

Abies balsamea prostrata (Kuight) Carr.

Abies balsamea paucifolia Sulw.

Abies balsamea mudicaulis Cirr.

Abies balsamea versicoior Sindw.

Abies balsamea argentifolia sudw

Abies lasiocarpa (Hook.) Nutt.

Alpine Fir.

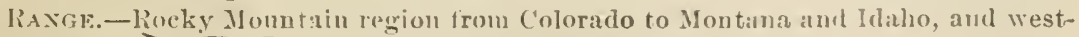

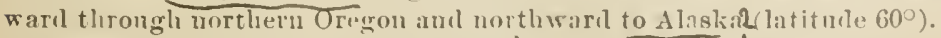

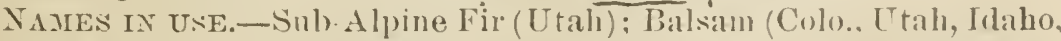
Oreg.); White Fir (Idaho, Mont.); White Balsam; Oregon Balsam tree 
(Cal.); Pumpkin-tree; Alpine l'ir: Mountain Balsam (mountains of Itall and Idalıo); Down-cone Fir (lit.); Downy-cone Sub-Alpine Fir (Call. lit.).

VARIETY DISTIXGUISHED IX CULTIVATION.

Abies lasiocarpa cerulescens (Beissn.) Sudw.

Abies arizonica Merrian.

Arizona Cork Fir.

RAxis.-At present known only from A rizona (San Eramcisco Hountaius).

Abies grandis Lindl.

Lowland Fir.

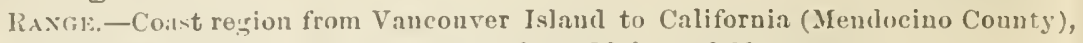
ancl from Washineton and Oregon to northern Iflatio and Montana.

NaMbs IN UsE.-White Fir (Cal., Oreg., Idaho); Silver Fir (Mont., Idilıo); Fellow Fir (Mnnt., Idaluo); Oregon White Fir (Cal.); Testern White lir; Grand or Oregon White Fir (Cal. lit.); Great Califurnia Fir (lit.).

VAIIETIES DISTIXGUISHEI) IN CULTIVATIOX.

Abies grandis aurifolia sudw.

Abies grandis crassa sillw.

Abies concolor (Goril.) P'arry.

White Fir.

lisidis-Oregon (Siskiyon Mountains) to sontluern California (Sinn Bernardino Connty); worlhern Arizona and New Mexico to Coloralo and Utah (Wasatch Intulains,

Nanes in Uste-White Fir (Cal., Idaho, Utal, Colo.); Balsam Fir (Cal., Itaho, Colo.); Silver Fir (Cal.); Balsam (Cal.); White Balsam (Ctalı); Bastard Pine (Ctah); Balsam tree (Ilaho); Black Gum (Utalı); Californial White Fir (Cal.); Colorado White Fir (Cal. lit.); Concolor Silver Fir (Eug. lit.).

VARIETHES DISTINGUISHED IN CULTIVATION.

Abies concolor pendens (Beissn.) Sudw.

Abies concolor varia Suciw.

Abies concolor purpurea Suclw.

Abies concolor purpurea compressa sudw.

Abies concolor angustata Sulw.

Abies concolor lowiana (Murr.) Lemmon. Pale-leaf White Fir. RANGE.-Ciliforuia (Sierra Nevala Moutains) and southern Oregron (Siskigon Monutilins).

Names in Use.-Pale-leaved White Fir (Ual. lit.); Califoruia White Fir.

Abies venusta (1)orgl.) Koch. Lyl. leaflet.24 Bristle-cone Fir.

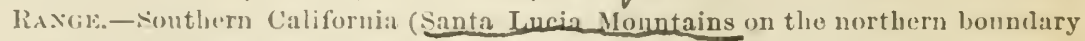
of sin luis Obispo Couity and 40 miles north warl).

NAmis in Ust.-Fringed Sןruce, Bristle-cone Fir (Cal.); Santa Lucia Fir (Eng. lit.).

Abies amabilis (Lond.) Forb.

Amabilis Fir.

RANis.-lirom british Columbia (Fraser River and sonthwarl in the Cascarle SIonutilus) to Wishington aud Oregrou.

Naliss In UsE.-Red Fir; Red Silver Fir (Westeru Mountains); Fil (Cal.); Lovely Rerl Fir (Cal. lit.); Lovely Fir (Cal. lit.); Amabilis or Lovely Fir (Call. lit.); "Larch" (Oreg. lumbermen). 
Abies nobilis Lindl.

RaxGL. - Washington (coast monntains in sonthwestern part of State; Olympio Monntains on Soldnc River; from Monnt Laker sonthwarl in the Cascade Mountains) to Oregon (Browdir Ridgo ou load waters of Mc linzin liver in lane Connty). liange at present but little known.

Nanes in USE.-Reşl Fir (Oreg.); "Larch" (Oreg. lumbermen); Noble Iir (Oreg.); Bigtree; Featler-cone Tiell Iir (Cal. lit.); Noble or Bracted Red Fir (Cal. lit.); Tuck Tuck (Pacific Indiaus).

VARIETIES DISTIFGUISIIED IN CULTIVATION.

Abies nobilis glaucifolia Sudw.

Abies nobilis robustifolia Sulw.

Abies shastensis Lemmon.

Shasta Fir.

RAxGi-Sonthern Oregon (Cascade Monutains) and California (Monut Shasta, Monnt Elds, Trinity Mountain, Scotts Mountain). Range as yet insufficiently unilerstond.

NAules In Use.-Shasta Red Fir (Cal. lit.); Slıastal Firir (Cal. lit.).

Abies magnifica Mnrr. heavy otrong wood Red Fir.

Ravgre-Californial (Nomnt Shasta and along the wrestern slopes of Sierra Nevada, Mountains).

NaMes Is UsE.-Red Fir (Cal.); California Re(l-bark Fir (Cal.); Magnificent Fir (Cal. lit.); Calitornia Red Fir (Cal.lit.); Golden Fir (Cal. lit.).
easter
firs
ron-durable.
atietilis mistinglished IN CULTIVATION.

Abies magnifica cyanea Sulw.

Abies magnifica xanthocarpa Lemmon.

Yellow-fruit Fir.

TAXODIUM Rich.

Taxodium distichum (Linn.) Rich.

Bald Cypress. 2

RAxGe.-From southern Delaware (Snssex County and sonthwarl in the coast region) to Florida (Mosfuito Inlet and Cape Romano); westward in tho (inlf coast region to Texas (Devils River) and northwarl through Lonisianil, Arkansas, and eastern Mississippi and Tennessee, sontheastern Missouri, western anu northwestern Kentucky, sontheru Illinois, and sonthwestern Indiana (Knox Connty).

Tayes ix UsE.-Balel Cypress (Del., N. C., S. C., Ala.. La., Fla., Tex. Ark., Mo., Ill., Ind.); White Cypress (N.C..S. C., Fla.. Mliss.); Black Cypress (N.C., S. C., Ala.. Tex.); Red Cypress (Ga.. Miss.. La., Tex.); Smamp Cypress (La.); Oypress (Del., X. C.. S. C.; Fla., Miss., Ky., Mo., I1l.); I ecidnous Cypress (I)el., Ill.. Tex.); Sonthern Cypress (Ala,

VARIETIE DISTINGUISHED IN CULTHATION. 
Taxodium distichum microphyllum (Brong.) IHunk, and Ifachst.

Taxodium distichum intermedium Carr.

Taxodinm distichum nanum Cirr.

Taxodium distichum nigrum Gorl.

\section{SEQUOIA Endl.}

Sequoia washingtoniana ${ }^{1}$ (Winsl.) Sudworth.

SEQUOIA GIGANTEA Decaisne.

liaxgl:-Califurnia (from latitude $39^{\circ}$ to a little sonth of latitude $36^{\circ}$, that is, from midile fork of Ameriean River and along the western slope of Sierra Nerarla IIountains to the hearl waters of Deer Creek).

NAXES IN USE.-Seqnoia (Cal.); Bigtree (Cal.); Giant Sequoia (Ual.); Mammoth-tree (Cal., and in Eng. cult.)

\section{VARIETIES MISTNGLISIHD IX CULTIVATION.}

Sequoia washingtoniana pendula (Beissn.) Snılw.

Sequoia washingtoniana glauca (Gorl.) Sndw.

Sequoia washingtoniana aurea (bei-sn.) sultw.

Sequoia washingtoniana argentea (Beissu.) Sudw.

Sequoia washingtoniana variegata (Gord.) Sudw.

Sequoia washingtoniana holmsi (Beissu.) Sulw.

Sequoia washingtoniana glaucescens prramido-compacta sudw.

Sequoia washingtoniana pygmra (Beissı.) Sudw.

Sequoia sempervirens (Lamb.) Endl.

Redwood.

Ravae.-From tho sonthern boriers of Oregon (on chetro River, abont 6 mil.s from montl, and on Winchuek liver), and sonth xard in the east region (20 to 30 miles inl:ud) throngl Califoruia (to Salmon Creek ('auyou. 12 miles sonth of Punta Gorla, Monterey Connty).

NAules IN Ust.-liedwood (Cal. and Am. lit.): Sequoia (Cal.); Coast Redwood (Cal.); Cal fornia Redwood (Eng. lit.).

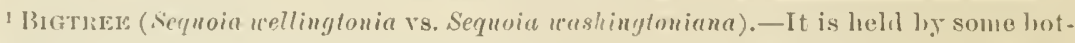
anists that since the long-used name for this tree, s. yigantea, is now axeluded (for reasons shown below), s. wellingtonia is the mext tunslule nime, and the rally oldrr name S. mashingtoniana should be neglected becanse thoilnht not to be technienlly established. The first name ipplied to this tree is Hellingtonia giganter lindley

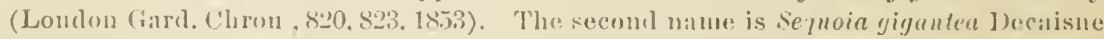

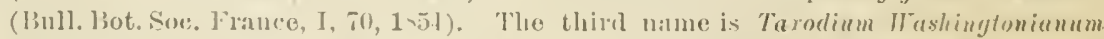

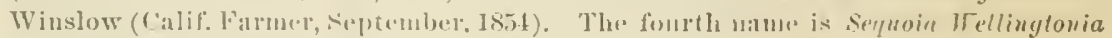

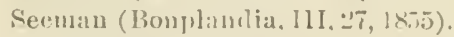

The Bigtree is nuw concerles to lighty belong to the genus sernoin of Eudlicher

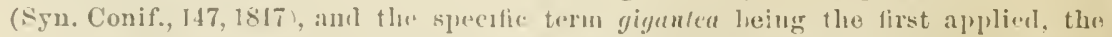
apparently eorrect natmo would he sequoin giganlen, the name applied by Decitisne: (1. e., 1851). But this name In ing identical with one previons'y applienl ly Eulliolur in $1 \times 17$ to the califormia Reilwool, unst. by realsm of boing antedited, fall into synulumy and thes mext uld st name be songht for the ligetres.

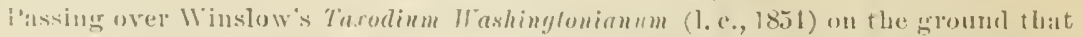

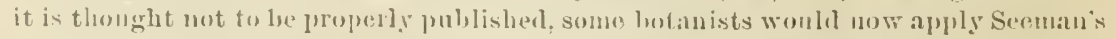
Srynoin. Wellinglonin. (I. e., 185.i). It is here maintained, however, that tho rightfin] nane should be sirquoia whingloniana (Wiuslow) sudw., and for the following reasous :

It has heen asserted that Taxodinm. Washingtonianum Winslow (1. (., 1851) is teehnically mpublished, and therefore to be disregarded. The writer belioves this name 
Sequoia sempervi ers gracilis Carr

Sequoia sempervirens tazifolia Carr.

Se zuoia sempervirens adpressa ('arr.

Sequoia sempervirens picta nur!w.

Sequoia sempervirens albo-spica (Gorl.) Beissn.

Sequoia sempervirens glauca Gorl.

\section{LIBOCEDRUS Endl.}

\section{Libocedrus decurrens Torr.}

Incense Cedar.

RAxGe.-From Oregon (North Fork of Santian River and southward on the westeru slopes of tho Cascade Monntains); throngh Cirlifornia (westrun slopes of Sierra Nevada Mountains and coast ranges from sontheru boriler of Menilocino County to San Bernardino, San Jacinto, and ('nayamaea mountains); western Nevarla; Lower California (Mount San Pelro Martir).

Nanes IN UsE. - White Údar (Cil., Oreg.); Cedar (Cal., Oreg.); Incense Cedar (Cal., Oreg.): Post Cedar (Cal., Nev.); Juniper (Nev.); Bastarl Cedar (Cal., Wash.); Red Cedar; California Post Cedar /Cal. lit.).

\section{VARIETIES DISTINGUISIIED IX CULTIVATION.}

Libocedrus decurrens depressa Gord.

Libocedrus decurrens columnaris Beissu.

Libocedrus decurrens compacta Beissn.

Libocedrus decurrens glauca lieissn.

was tenably published, a couviction which is supporterl by tho following quotation from Winslow's published letter (1. c., 185t):

"The name that has been applied to this tree by Proftssor Lindley, an English botanist, is Wellingtonia gigantea."

"If the tree be a Taxodium, let it be called Taxodium Washisgtonianum. If a new genus, Washingtoria Califoruica."

According to Articlo VI of the Rochester Code of laws adopterl for botanical nomenclature, Winslow's Taxo.7ium Woshingtoniaum is valilly publisherl by reason of his having fulfilled the essential couditions of the following elanse of Irticle V1: "Publication of a species consists * - * (2) in the publishing of a linomial with reference to a previonsly publisher species as a type."

This is a conmon and expedient method employerl by botanists in pnblishing new names for plants fomm to have been previously characterized rincler synonyms, which results in duplicate names in the simo genus, and therefore often leaves a plant withont a tenizlo name. The unethod of referring to tho "previonsly published species as a type" is nsually toprint such species' name and anthor in connection with the newly proposed uame, and in such a way that the two lesignations are seen to be presentedi as e:privaleuts, the one to replace the other.

Now, sinco Wellingtonia giganten Limlley is a reco"nizen "previonsly published species," it wonl.I seem undeniable that Wiuslow's intention was to supplaut Lindley's name by Taxodium Washingtouiunun-eutirely, of conrse, hecause his American patriotism preferred that an American monster tree slould bear tho name of an American rather than that of an English general. It is maintained here that Winslow definitely pointerl ont the tree he harl in minil by stating that Lindley had called it Fellingtonia giganea (an undisputably publisherl name), and that loe effecterl the publication of Taxolinu Washingtonianum for this tree by proposing this name as a substitute for Lindley's name.

In interpreting the fimlamental object of the article rited for the publication of species and applsing it to all cases likely to arise, it wonld seen! the duty of the interpreter to abide by the principle involved in tho law, and to be intluencel rather by the actual meaning of a describer's combined worrls than l,y his unfortunate lack of technical procedure in lescription. 


\section{-Holiage}

\section{THUJA Linn.}

:?huja occidentalis Lim!.

Arborvitæ.

lis.ris.-From Xow lirunswick to Lake Winnipeg and south to central Minnesota aud Mlichigan, northeru Illinwis, aud in the Atlantic region along the mountains to North ('arolina aurl easte:n Tenuessee (Holston River).

Nhmes Ix Use.-Aiborvitie (IEe, Vt., Mass., R. I., Conn., N. Y., N. J., Pa., I)el., Vil., W. Va., Ind., Ill., Wis., Mich., Minn., Ohio, Ont.); White Cedar (Me., X. II., Vt., I. I., Mass., N. Y., N. J., Ta., X. C., Wis., Mich., Minn., Ont.); Cedar (Me., Vt., X. Y.); American Arborvitu (X. Y. and in cult. Eng.); Oo-soo-lia-tah = Feather-leaf (Indians); Vita (Del.); Atlantic lied Cedar (Cal. lit.).

VAJIETIES MISTIXGUISHED IY CULTIVATION.

Thuja occidentalis ellwangeriana ((iord.) Beissn.

Thuja occidentalis spaethi Beissu.

Thuja occidentalis warealna Gord.

Thuja occidentalis wareana lutescens Beissu.

Thuja occidentalis wareana globosa Beissn.

Thuja occidentalis densa (iorll.

Tuuja occidentalis walthamensis fiord.

Thuja occidentalis fastigiata Beissu.

Thuja occidentalis fastigiata nova Beissn.

Thuja cccidentalis l'haveana Beissn.

Thuja occidentalis rosenthali Beissn.

Thuja cccidentalis viridis Beissn.

Thuja occideutalis theodonensis Beissn.

Thuja occidentalis tatarica Beissn.

Thuja occidenta'is riversi beissn.

Thuja occidentalis vervæneana Gord.

Thuja occidentalis lutea Veitch.

Thuja occidentalis lutea humilis Sudw.

Thuja occidentalis aurea frord.

Thuja occidentalis varia Sudw.

Thuja occidentalis pendula Gord.

Thuja occidentalis pendula glaucescens Sndw.

Thuja occidentalis reflexa Carr.

Thuja occidentalis bođmeri Beissu.

Thuja occidentalis athrotaxoides Beissn.

Thuja occidentalis recurvata Beissn.

Thuja occidentalis recurvata argenteo-variegata lieissn.

Thuja occidentalis recurva pus:lla Sudw.

Thuja occidentalis denudata Beissu.

Thuja occidentalis asplenifolia Carr.

Thuja occidentalis gracilis Goril.

Thuja occidentalis filicoides lieissu.

Thuja cccidentalis cristata Gord.

Thuja occidentalis boothi lieissu.

Thuja occicientalis globosa Gord.

Thuja occidentalis globularis Beissn.

Thuja occidentalis hoveyi ford.

Thuja occidentalis spihlmamni Beissn

Thi:ja occidentalis frœbeli 13eissn.

Thuja occidentalis parva Sudw. 
Thuja occidentalis albo-variegata Beissn.

Thuja occidentalis aureo-variegata Beissn.

Thuja occidentalis argentea Gord.

Thuja occidentalis alba frorl.

Thuja occidentalis little-gem leissn.

Thuja occidentalis silver-queen l3eissn.

Thuja plicata Don.

Giant Arborvitæ.

TIUYL GIGANTEA Nutt.

RAxGi-lirom coast of sonthern Alaska to northern California (Mencloeino County); castward throngh British Colnmbia and northern Washington to uonthern Ilabo (Ceur d'Alene, Bitter loot, and silmon River monntains) and Montana; wristern slopes Rocliy Mountains.

Names in use.-Red Cedar (Idaho, Oreg., Wash.); Canoe Cedar (Oreg., Wạsh.); Arborvitie (Cal.); Shinglewood (Irlaho); Gigantic Cediır (Cill.); Cedar (Oreg.s); Gigantic Red Cedar (Call. lit.); Western Cedar; (Gigantic or Pacific Red Cedar (Call.lit.); Lobb's Arborvita (in cult. Eng.); Pacific Red Cedar (Cal. lit.).

VARIETIES IISTINGUISHED IN CULTIVATION.

Thuja plicata gracillima (Beissn.) Sıdw.

Thuja plicata atrovirens (Gord.) Sudw.

Thuja plicata aurescens (Beissn.) Sudw.

Thuja plicata argenteo-versicolor Sudw.

Thuja plicata flava Sudw.

Thuja plicata variegata Carr.

Thuja plicata compacta (Curr.) Beissn.

Thuja plicata Ilaveana Gord.

Thuja plicata minima Gord.

Thuja plicata erecta (Gord.) Sudw.

Thuja plicata pumila (Gord.) Sudw.

Thuja plicata penduliformis Sulw.

Thuja plicata cristatiformis Suds.

\section{Cupressus Linn.
Cupressus macrocarpa Hart 1 .} Bay aucl on Point Lobos).

NAIrE IN UsE.-Donterey Cypress (Cal.)

VARIETIES DISTINGUISHEN IN CULTIVATION.

Cupressus macrocarpa angulata Lemm.

Cupressus macrocarpa lambertiana (Carr.) Mast.

Cupressus macrocarpa crippsii liast.

Cupressus goveniana Gord.

Gowen Cypress.

RAxge,-California coast region (.Iendocino Connty to San Diegro Connty).

NAME IN USE.-North Coast Cypress (Cai. lit.).

VARIETIES DISTINGUISIED IN CULTIVATION.

Cupressus goveniana parva Sudw.

Cupressus goveniana huberiana Carr.

Cupressus goveniana glaucifolia Sudw. 
Cupressus goveniana gracilis (Nels.) Carr.

Cupressus goveniana cornuta Carr.

Cupressus goveniana viridis Carr.

Cupressus goveniana attenuata (Gorl.) Carr.

Cupressus macnabiana Murr.

Macnab Cypress.

lixcile- - ('alifornia (sonth and west of Clear Lake, Lake County; very rare; nnce reported from the sunthern base of Mount Shasta, but at present not known tw exist there).

NAMes IN UnE.-Cypress; White Cedar; Shasta Cypress (Cal.); Maciab's Cypress (cult. Eng., Eu.); California Mountain Cypress (Cal. lit.).

Cupressus arizonica Greene.

Arizona Cypress.

CUPRESSTS GUADALUPENSIS Sarg., not Wats.

RA.cik-Arizona (central, eastern, and sonthern mountains; Santa liita, Santa Catalina, and Chihnahua monstains); Mexieo (mountains of Sonora and Chuhubua).

Nanies in Use.- Yew (Ariz.); Arizona Cypress (Ariz.); Red bark Cypress (Ariz.): Arizona liel-bark Cyliress.

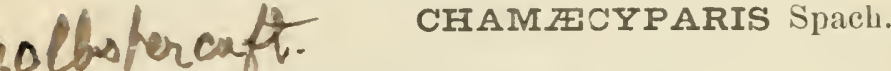

Chamacyparis thyoides (L.) B.S. P.

White Cedar.

Chadracrparis spil eroidea spach.

RANGE-Cloast regiou from southern Maine to northern Florida and westward to Mississippi (Pearl River).

Thues in Ust.-White Cedar (Mass., R. I., N. Y., N. J., Pa., Del., N. C.. S. C.. Fla., Ala., Miss.); Swamp Cedar (Del.); Post Cedar (Del.); Inniper (Ala., N. C., Va.).

IALIETIES DISTIXGUISIIED IN CVLTIVATION.

Chamacyparis thyoides glauca (Eull.) Sulw.

Chamæcyparis thyoides crocea Sulw.

Chamæcyparis thyoides variegata (Lourl.) Such.

Chamæcyparis thyoides atrovirens (Kinight) Sudw.

Chamzeyparis thyoides pyramidata (Beissn.) sudw.

Chamzeyparis thyoides fastigiata cinereo-folia Sudw.

Chamæcyparis thyoides penduliformis sudw.

Chamæcyparis thyoides hoveyi (Veitch) Sulw.

Chamæcyparis thyoides nana (Loud.) Sindw.

Chamæecyparis thyoides leptoclada ((iorl.) Sulw.

Chamecyparis thyoides pumila (Carr.) sudw.

Chamacyparis thyoides ericoides (Knight) suitw. cati.

Chamecyparis nootkatensis (Lamb.) Spach.

CHAM.ECYPARIS NUTKA îNSIS Sịach.

Yellow Cedar.

liavgl:-Coast royion and islands from Sitkil through Washington and Urigon (in (ascade Momtains as filr as the santiam River and Momnt Jefierson); east in Washiugton to the head waters of Yakima Rirer.

Nambs IN Use. - Yellow Cedar (Oreg.); Sitka Cypress (Oreg.. Cal.); Yellow Cypress (Oreg., Wash.); Nootka Cypress (Cal. lit.); Noutka Sound Cypress (cult. Eng.); Alaska Ground Cypress (Cal. lit.); Alaska Cypress (Cal. lit.). 


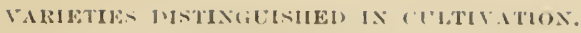

Chamæcyparis nootkatensis viridifolia Sudw.

Chamæcyparis nootkatensis cinerascens Sudw.

Chamæcyparis nootkatensis cinerascens genuina surlw.

Chamæcyparis nootkatensis cinerascens aureo-discolor Sulw.

Chamæcyparis nootkatensis argenteo-varians Sudw.

Chamæcyparis nootkatensis aureo-versicolor sulw.

Chamæcyparis nootkatensis zantlophylla sudw.

Chamæcyparis mootkatensis pendens sulw.

Chamæcyparis nootkatensis compacta (Veitch) lieissn.

Chamæcyparis nootkatensis compressa I3eissu.

Cjamæcyparis nootkatensis nidiformis beissn.

Chamæcyparis nootkatensis albo-picta Sulw.

Chamæcyparis nootkatensis aureo-viridis (Hort. Kew.) Sudw.

Chau cyparis nooktatensis picta sulw.

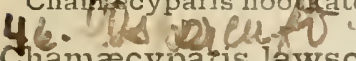

Chamecyparis lawsoniana (Murr.) l'arl.

Port Orford Cedar.

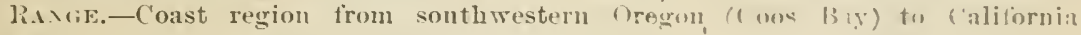
(Klamath liver), extending inlancl alont 40 milow.

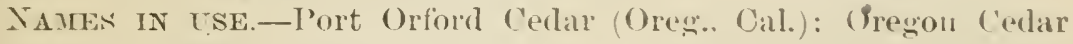
(Oreg., Cal.): White Cedar (Oreg., Cal.): Ginger I'ine (Cal.); Layson's Cypress (Cal., Oreg.).

VARIETIES MISTINGISHEI, IX CULTLATION.

Chamæcyparis lawsoniana erecta (forl.) sulw.

Chamæcyparis lawsoniana erecta viridis (Jeitch) lieissu.

Chamæcyparis lawsoniana erecta glaucifolia sulw.

Chamæcyparis lawsoniana erecta glaucescens Sudw.

Chamæcyparis lawsoniana pyramidalis leucophylla Snil $\mathrm{w}$.

Chamæcyparis lawsoniana pyramiỏalis flaveola Sulw.

Chamæcyparis lawsoniana pyramidalis luteo-tenuis sulw.

Chamæcyparis lawsoniana rosenthali Beissn.

Chamæcyparis lavsouiana worlei Beissu.

Chamzcyparis lawsoniana alumi Beissn.

Chamæcyparis lawsoniana monumentalis nova Beissn.

Clramæcy paris lawsoniana monumentalis albescens Sulw.

Chamæcyparis lawsoniana fraseri Reissn.

Chamæcyparis lawsoniana robusta Beissn.

Chamæcy paris lawsoniana robusta aurifolia sudw.

Chamæcyparis lawsoniana robusta cinerea sudw.

Chamæcyparis lawsouiana robusta argentifolia Sudw.

Chamæcyparis lawsoniana atroviridis Sndw.

Chamæcyparis lawsoniana cyanea Snilw.

Chamæcyparis lawsoniana cyanea pendems Sudw.

Chamæcyparis lawsoniana beissueriana Smith and r'ie.

Chamæcyparis lawsoniana nivea Reissn.

Chamæcyparis lawsoniana lutea (Gord.) IBcissu.

Chamæcyparis lawsoniana lutea flavescens (fold.) Sulw.

Chamæcyparis lawsoniana aurea (Gorl.) Beissn.

Chamæcy paris lawsoniana aurea magn.fic (lieissn.) . Nulw.

Chamæcyparis lawsoniana westermanni Beis:nl.

Chamæcyparis lawsoniana versicolor lieissn.

Chamæcyparis lawsoniana argenteo-variegata (V'eiteh) Beissu.

Chamæcyparis lawsoniana argenteo-variegata novicia snlw.

Chamæcyparis lawsoniana aureo-variegata (Veiteh) Beissn.

19193-No. $17--3$ 
Chamacyparis lawsoniana aureo-spica Briss11.

Chamzecyparis lawsoniana albo-spica (Curl.) Beissn.

Chamzecyparis lawsoniana overeynderi Heissn.

Chamacyparis lawsonicma nutans Sulw.

Chamecyparis lawsoniana nutans vera (Beissn.) . sndw.

Chamæcyparis laws uniana nutans alba (fivrrl.) Sulw.

Chamæeyparis lawsoniana filiformis (Veitch.) Beissn.

Chamæcyparis lawsoniana filiformis globosa lieisin.

Chamæcyparis lawsoniana intertexta (Vitch.) lieissn.

Chamzecyparis lawsoniana gracilis (Goril.) lieissn.

Chamæcy paris lawsoniana gracilis pusilla sudw.

Chamæcyparis lawsoniana laxa Beissn.

Chamacyparis lawsoniana crispa Beissn.

Chamæcyparis lawsoniana casuarinifolia Beissn.

Chamæcyparis lawsoniana tortuosa Beissn.

Chamzeyparis lawsoniana compacta recens Sulw.

Chamæcy paris lawsoniana fragrans (find.) Beissu.

Chamæcyparis lawsoniana fragrans argyropsis sulw.

Chamzeyparis lawsoniana fragrans conica Brissu.

Chamæcypatis lawsoniana parva Sulw.

Chamæcyparis lawsoniana parva candida sudw

Chamæcyparis lawsoniana parva albo-variegata (Gorl.) Sudw.

Chamzeyparis lawsoniana parva albo-spiciformis sudw.

Chamæcyparis lawsoniana parva densa Surlw.

Chamzeyparis lawsoniana shawi lieissn.

Cham cyparis lawsoniana minima (Gork.) Sudw.

Chamæcyparis lawsoniana argentea ((iord.) Beissn.

Chamæcyparis lawsoniana argentea depanperata Sudw.

Chamæcyparis lawsoniana argentea minuta sudw.

Chamæeyparis lawsoniana argentea prostrata (Beissn.) sndw.

Chamecyparis lawsoniana forstekiana Beissn.

Chamæcyparis lawsoniana weisseana Mœll.

Chamzeyparis lawsoniana silver-queen Heisin.

Chamzeyparis lawsoniana amabilis (Hort. Kew.) Sudw.

Chamæcy paris lawsoniana bowleri (Hort. Kew.) Sudw.

Chamzecyparis lawsoniana californica (Hort. kew.) sudw.

Chamæcyparis lawsoniana darleyensis (Hort. Kew.) Sudw.

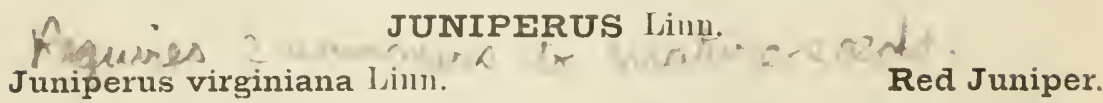

Ravie.-Nova Scotia and New Brmnsiek to Florida and west in Ontario (freor gian liay) to Dakota, central Nebraska and limsas, and ludian Territory. Actual rangu imperfectly known at present, the supposed Rocky Mountain and Westeru range being represented by a new, distinct species (.J. scopularum Sarg.).

Nayes in Úsk.-Red Certar (N. II., Vt.. Mass.. R. I., N. Y., N. J., Pal., Mel., Va., W. Va., N. U.. S. C., Ga., Fla., Ala., Miss., La., Ky., Mo., Ill.. Ind., Wis.. Iowa, Mich.. Minn.. Ohio, Ont.); Cedar (Conu., Pa., X. J., S. C.. Ky., Ill., Iowa, Ohio); Savin (Mass., R. I., N. I., Pa., Mium.); Juniper (N. Y., P’a.); Juniper Isush (Mimn.); Cedre (La.).

VARIFTIE DISTIXGLISIINI IN CULTIVATION.

Juniperus virginiama caroliniana (Marsh.) Willd.

Juniperus virginiana gracilis (Endl.) Sarg.

Juniperus virginiaua pyramidiformis Sulw.

Juniperus virginiana pyramidiformis glaucifolia Sudw. 
Juniperus virginiana pyramidiformis viridifolia Sudw.

Juniperus virginiana cannarti (kiuh.) Beissn.

Juniperus virginiana polymorpha Beissn.

Juniperus virginiana pendula Carr.

Juniperus virginiana smithi penduliformis Sudw.

Juniperus virginiana chamberlayni Carr.

Juniperus virginiana nutans lieissn.

Juniperus virginiana interrupta (Wend.) Beissu.

Juniperus virginiana dumosa Carr.

Juniperus virginiana pumila fiord.

Juniperus virginiana pumila nivea (Beissı.) sndw。

Juniperus virginiana schotti Gord.

Juniperus virginiana tripartita Gord.

Juniperus virginiana tripartita aureo-versicolor sudw.

Juniperus virginiana kosteriana Beissu.

Juniperus virginiana glaucescens Sudw.

Juniperus virginiana cinerascens Carr.

Jumiperus virginiana plumosa alba (Carr., Beissn.

Juniperus virginiana plumosa candıda sulw.

Juniperus virginiana albo-spica Beissn.

Juniperus virginiana albo-variegata Beissn."

Juniperus virginiana aureo-spica Beissn.

Juniperus virginiana aureo-variegata Veiteh.

Juniperus virginiana aurea superba Snd $\%$.

Juniperus virginiana elegantissima Beissn.

Juniperus virgiuiana horizontaliformis Sudw.

Juniperus virginiana triomphe d'angers Beissu.

Juniperus barbadensis Linll.

JUYIPERU's VIRGINIANA author's in part, not L.

RAxGE.-Sonth Atlantic aud Gulf Coust region aul southward through Florida. Range imperfectly known at present. Formerly not distinguished from the more northern true J. rirginiana.

Juniperus occidentalis Hook.

Western Juniper.

RaxGe.-From westeru liaho, eastern Oregon, un Cascale, Nierra Nevada Mountains to southern ('alifornia (Sin Buruariino Jountains).

Nanes in Use.-Imiper (Oreng., Cal.. Colo., Utah, Nev., Mont., Idaho. N. Mex.); ('edar (Itaho. Mont.); Yellow Cerlar (Colo., Mont.); Westerm Cedar (Idaho); Westeru Red Cedar; Western Juniper (Cal. lit.)

Juniperus scopulorum Sargent.

Rocky Mountain Juniper.

JUNIPERU' VIRGINIANA author's in part. not L.

RAxGE,-Nebraska aud Dakota (Jlack Hills) to Montana, Idaho, northern Washiugton and British Columbia to Vancouver Islaud; Rocky Mountains from Montina to Arizona and Yevala. Range imperfectly known.

Juniperus monosperma ${ }^{1}$ (Engeln.) S:11'g.

One-seed Juniper.

RAxGE.-Eastern base Rocky Mountains of Colorado (Platte and Arkansas rivers) and sonthwarl into western Texas; sonthern Utah to central New Mexico and Arizona.

Nanes IN USE.-One-seeded Juniper: Yaked-seederl Juniper" (Cal. lit.)

1.Juniperus Fnighti Nelson, in But. Gaz.. XXT, 198, f. 1, 2, 1898. Prof. Aven Nelson descrihes this species as " "scragry shrul, "1 suall tree" common in the lient Desert regrion of Wyoming from the seminole Mlountains to the Grecu livire. I have not examined specimens, lut its affiuities appear to be with o. monosperma and $J$. scopulorum. 
Juniperus sabinoides (H. B. K.) Sargent.

Mountain Juniper.

lisitil:-Central Texas ('oloralo River), sonthward and westward.

Names ix Usk.-Iunper Cedar (Tex.); Momtain Celar (Tex.); Juniper; Monntain .Inuiper; Rock Cerlar (Tex.).

Juniperus californica Carr.

California Juniper.

lisiocis:-('entral California (lower sacramento River) and sonthward through California in coast ranges and in Sierra Nerala to kernville and Lower California.

Natres in rse.-White Cerlar: Juniprer (Cal.); California " muiper (Cal. lit.): Sweet-fruited Juniper (Cal.); Sweet-berrierl Cerlar.

Juniperus utahensis (Eugelm.) Lemm.

Utah Juniper.

Ra.NGl-Desert region from wastern ltal (Wasatch Momutains) to southeastern California, uorthern Arizona, and western Coloralo.

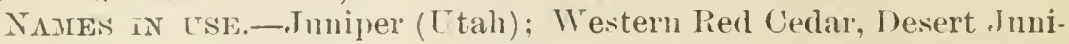
per (Cal. lit.); Utalı Imniper.

Juniperus pachyphloea 'I'orr.

Alligator Juniper.

Raxcis.-Couthwestern Texas (Eagle and Linpia mountains), and westward on desert ranges of New Mexico and Arizona sonth of Colorado River platean; umnntains of northern Arizona; Mcxico.

NAMIss IN UsE.-Juniper (Ariz., N. Mex.); Oak-barked Cedau ( A riz.); Alligator Juniper (Ariz): Oakbark Jumiper (Ariz): Momtain Cerar ('Tex.): Thick-barked Juniper (Cal. lit.); Checkered-barked eluniper (lit.).

Juniperus flaccida Sehl. liavg:-Conflowestern Texas (Chisus Morntains); northeastern Mexico.

Tuniperus communis Linn.

Dwarf Juniper.

RAxGH.-From Gremlaml to Alaska and in the east sonthwarl to l'enusylvinia and uorthern Nebriskil: in the Rocky Momtains to Texas, New Mexico, and Arizona; in the Pacific region to uorthern California: also in Old Worlu.

VARIETIES DISTINGUISHEI IN A'LTIVATION,

Juniperus communis cracovia (lioch) Beissn.

Juniperus communis snecica (Mill.) Lonil.

Juniperus communis hibernica (Loill.) Gord.

Juniperus communis hibernica compressa Carr.

Juniperus communis oblonga (Rieb.) Lontl.

Juniperus communis oblongo-pendnla (l.oud.) ('art.

Juniperus communis pendens Sndw.

Juniperns communis hemispliarica (Presl.) l'arl.

Juniperns communis echinoformis (linight) lieissn.

Jumiperus comnunis variegata aurea Carr.

Juniperus communis sibirica (Burgstl.) Rydluerg.

Juniperus communis argyrophylla Sudw.

Juniperus communis pygnzea (Koch) Sudw.

\section{Fiumily 'TA NACEAE.}

TUMION Raf.

Tumion taxifolium (Aru.) Greene.

Florida Torreya.

'TORREYA TAXIFOLIA Arn.

Raxik, - Westeru Florida (east bank of A palachicola River from River Junction to Iristol, Gadselen County); viry loceal.

NAmEs IN UsE.-Stinking Cedar (Fla.): Savin (Fla.); 'Torrey-tree (Fla.); Stinking Savin (Fla.); Fetid Yew (Eng. lit.). 
Tumion californicum ('Torl.) Greene. TORREYA CALIFORNICA Torr.

California Torreya.

RANGe.-California (Mendocino (onnty to santa Cru\% Momntains in Santal Clara Conuty).

NAmes IN USE.-California Nutmeg (Cal. : Stinking Cerlan; Yew (Idaho): California False Nutmeg (Cal. lit.): ('oast Nutmuge (Cal. lit.).

Taxus brevifolia Nutt.

TAXUS Lim.

h.LxGe.-Pacific coast region from liritish ('olmubia (Qmeen ('harlotte Island and Skeena River), and east to Selkirk Jomntains: through Western Washington and Oregon to California (coast ranges to . lonteres liay and wastern slopes of sierra Nevada Mountains to Tulare Countý): monntains of eastern Washington and Oregon to Montana (westeru slopes of Rocky Monntains).

NAMEs IN USE.-Yew (Cal.. Illaho. Oreg.); Mountain Mahogany (Ialho); Western Yew (Cal.); Pacific Yew (Cal. lit.).

Taxus floridana Nutt.

Florida Yew.

RANGE.-Westeru Florida (east bank of Apalachicola River, (iadscleu ('omnts, from Aspalaga to the vicinity of Bristol): vers locial.

NAJEs IN USE.-Vew (Fla.): Savin (Fla.).

\section{MONOCO'TYLWDONHES Family P.ILAICHAS. \\ THRINAX Lim, f.}

Thrinax parviflora Swart\%.

Silktop Palmetto.

Raxar,-Southern Florida keys (from Bahia Honda kiey to Longs Key); Bahamas.

NAMEs IN USE - Sillitop) Palmetto (Fla.): Silver Thatch (Fla.).

Thrinax microcarpa Sargent.

Silvertop Palmetto.

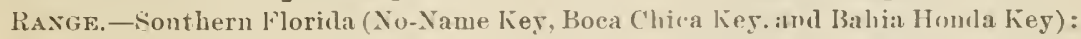
also on Augar Loaf somucl.

NAMEx Ix UsE.-Silvertop' Palmett, (Fla.): Prickley 'Thatch (Fla.): Brittle Thatelı (Fla.).

SABAL A dans.

Sabal palmetto (Walt.) R(tem. \& Sell.

Cabbage Palmetto.

RAxGE,-Coast region from Jorth ('arolina (Nmiths Island, Cape lear River) to Florida (Key Largo), and wis the (inlf coast to the Apilachicola River.

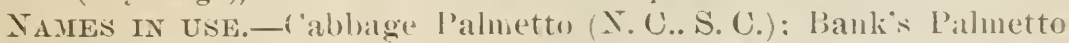
(N. ('); Palmetto (N. C.. S. C.): Cabbage-tree (Miss.. Fla.); Tree Palmetto (La.).

Sabal mexicana Ilart.

Mexican Palmetio.

RAxGE.-Sonthwestern Texas (Rio (iranle River from near Edinlurg nearly to the Gulf of Mexico) awd southward into Mexico (in coast menion to sonthern part).

PSEUDOPHOENIX Wendl.

Pseudophœnix Sargentii Wend.

Sargent Palm.

RAxGe.-Sonthern Florida keys (lillotts liey and ling Latyo); Bahamas.

Names in USE.-Filorida Palm (Fla.); Sarcent's Palm. 


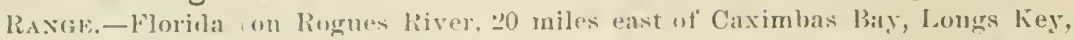
IBiscayne liay, near month of Little liver); West Indies, and Ceutral America.

NAMl: in USE.-Royal Palm (Fla.).

\section{NEOWASEINGTONIA 'Sndworth.}

Neowashingtonia filamentosa (Weurl.) Surw.

- Fanleaf Palm.

WASHINGTONIA PILIFERA WeudI.

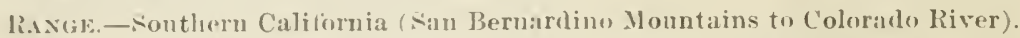

Naxes in UsE.-Washington Paln (Cal.): California Fan Palm (Cal.); Arizona Palm (Cal.ı: Wild Date (Cal.); Fanleaf Palm (Cal.).

\section{Farnily I,ITIACIEAE.}

YUCCA Linn.

Yucca treculeana Carr.

Spanish Bayonet.

RAxtil-CTexas (Matagoria Bay) and sonthward into Mexieo (Sierra Madre Momntilius, Ninern Laon), and along the Rio Grande to the eastern base of nom tains of westeru Texas.

NAMr IN USE.-Spanish Bayouet (Tex.).

Yucca arborescens ('Torr.) Trelease.

YTCCA BRETHOLLA Ëngelm.

Joshua-tree.

RAxGk-Conthwestern L'tah to California (to the irestern aud northern borders of the Mohave llesert).

Names IN tos.-Tree Incea (Cal.); Iurea Cactus (Cal.); The Joshua (Utalı): Josinua tree (Utih, Ariz., N. Mex.).

Yucca brevifolia 'Torr.

Schott Yucca.

Raxcie.-Southern homdury ut Arizonil Mexico.

Yucca constricta Buckl.

RAN(iw.-Sonthwestern Texas wo sonthern Arizona; northern Mexien.

Yucca macrocarpa ('Torr.) Coville.

\section{Broadfruit Yucca.}

Ravge.-sonthwentern T'exis (desert plateaur).

Yucca mohavensis Sargeut.

Mohave Yucca.

lisxGe.-From northeistern Arizonal and sontheru Nevacia into California (aleross tho Mohave Desert); and from sonthern base of san Bernarlino. Mountains to the coast and northward to Monterey Bay.

Yucca aloifolia Limm.

Aloë-leaf Yucca.

RANar.-Coast of North Carolina to Florida and (iulf eoast to lonisiana.

TAare IN USE.-Spanish Bayonet.

Yucca gloriosa Linn.

Spanish Dagger.

RAN(il:-C'oast of sonth Carolina aud is!ands.

VAIETIFA DISTINIIINIIED IN CULTIVATION.

Yucca gloriosa plicata ('arr.

Yucca gloriosa recurrifolia lingelın.

$1=$ Washingtonia Wendl. (1879), not of Winslow (1854) uor of Carr. (1867). 


\section{DICOTYLEDONES. \\ Family JUGIAANDACTAE.}

JUGLANS Lin!l.

Juglans cinerea Linn.

Butternut.

RaxGe.-Sonthern New Brunswick to Delaware and on the A pralachisn Mountains to Georgia and Alabana (head waters of likck Warrior River, Winston Connty); westward through Ontario to Ibakota, suntheastern Nobraska, sonthern Missonri, anıl northeastern Arkansas.

Names in Use.-Buttermut (Me., N. H.. Yt., Mass., R. I., Comn., N. Y., N. J., Pa., Del., W. Va., N. C., S. C., Ala., Ark., Ky., Mo., Ill., Iowa, Ind., Mich., Minn., Wis., Kans., Nebr., Ohio. Ont.); White Walunt(Del., Pa., Va., W.Va., N.C., S. C.. Nli., Ky., Mo., Hl.. Ind., Wis., lowa, Nebr., Mim., S. Dak.); Waluut (Minm.); Oil Nut (Me., N. H., S. C.); Buttunt (N. J.).

Juglans nigra Linn.

Black Walnut.

RAxce.-Southern (1utario to Florida, central Alabama aud Mississippi, and westwarl throngh southern Michigan, Wisconsin, and Minuesota to Neloraskit, Kansas, aud Texas (San Antonio River).

Names in USE.-Blark Walmut (N. H., Vt., Mass., R. I., Conn., N. I., X..J., Del., Pa., Va., W. Va., N. C., Ga., Fla., Ala., Miss., 'Tex., La., Ark., Ky., Mo., Ind., Ill., Kans., Nebr., Iowa, Mich., Ohio, Ont., S. Dak., Minn.); Walunt (N. Y., Del., W. Va., Fla., Ky.. Mo., Ohio, Ind., Iowa); Walunt-tree (Pa., S. C.); Dent-koo-kwa-no-ne ( Round Nut, N. Y. Indians).

Juglans rupestris Engelm.

Mexican Walnut.

RAx(if.-Central Texis (Colorado, Llano, and Gnataloupe rivers) westward through sonthern New Mexien ank Arizona and sonthwarl into Mexico.

Names IN UsE.-Westem Walnut (Tex.); Dwanf Walnut (Tex.); Litle Walnut(Tex.); Califormia Walnut(Ariz.); Walnut(N. Mex., Ariz.).

Juglans californica Wats.

California Walnut.

RANGE.-Califurnia const region (from the Sileramento liver to the san Barnardino Mount:ins).

NAMES IN USE.-Walnut (Cal.): California Wainnt (Cal.).

Hicoria pecan (Marsh.) Britton. CARYA OLIV AEFORMIS Nitt.

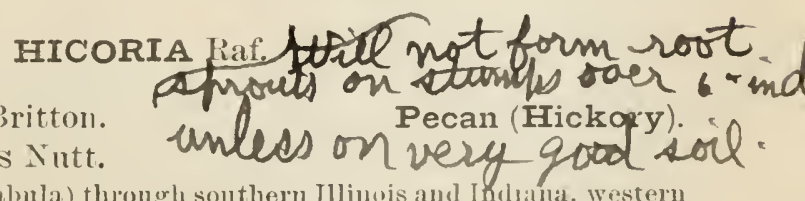

RANGE.-Iowa (vicinity of Sabula) throngh sonthern Inlinois and Ihlsana, westeru lieutucky and Temmessee to central Alahanua and Missıssippi, through Missonri and Arkansas to sontheastern Arkansas, Indian Territory, western lonisiana and central Texas (Concho River); Mexicn. Consilerably extended hy cultivation.

NAMes in Use.-Pecall (Va.. X. ('., S. (... (ia.. cult.). Ala., Misis., Tex., La., Ark., Mo., Ill. Ind., lowa, Kanss.); Pecan Nut(Laz.); Pecallier (La.); Pecan-tree (La.). 
Hicoria pecan $\times$ minima Trelease.

Hicoria pecan $\times$ alba Trelease.

Hicoria pecan $\times$ laciniosa Trelease. Nussbaum Hybria (Hickory).

Hicoria minima (Marsh.) Jritton.

Bitternut (Hickory).

Carya airatia Nutt.

lisxtik.-Sonthern Maine and (Intario to Florida (Apalachicola River); west throngh central Wirhigan to Minnesota, Nebraska, Kansas, lulian Territory, and Texis (Trinity Rivir).

NAMES in Use.-Bittermut (X. II., Mass., R. I., N. Y., X. J.. Pa., Del., Ta.. W. Va.. X. C.. S. (.., Fla., Ala., Miss.. La., Tex.. Ark., Mo.. Ill., Kans., Nebr., Mich., Minn.. Ohio, Ont.); Swamp Hickory (Del., I'a.. X. C., S. C., Miss., Tex., Ark., Iowa, Mimm.); I’ig Hickory (III.); P’i Nut (1. Y., Wr. Va., Mo., Ill., Iowa, Kans.); Bitter Pecan Tree, Pecanier Aner, Pecanier Sanvage (La.); Bitter I’ig Nut(T. Y., N.J.); Hickory (Nebr.); Bitter Jickory (N. H.); Pig Walnut (N. H.); Bitter Walnut (Vt.); Noyer Jur (Quebec); White Hickory ('rex.)

Hicoria myristicaformis (Michx. f.) Britton.

Carya mirlistic RFormis Nutt.

Nutmeg Hickory.

RAxide.-Coast region of South Carolina (Goose Creek, Cooper River); (rentral Alalo:ma (between Tombigbee and Alabama rivers, from Demopolis to Galliom; central Mississippi (Mhoons Valler); southern Arkansas (I'ine Bluft to Arkansas Cits, and in lied River hottoms above Fulton). Often cultivated in the middlw. Atlantie region.

Nares IN UsE.-Nutweg Hickory (S. C., Ala.); Bitter Wateruut (Iia).

Hicoria aquatica (Michx. t.) Britton.

CARYA AUUATCA Nitt.

Water Hickory.

Raxae.-Const region Virginia (Mobjack Bay) to Florida (Cape Malabar and Cousa), and in the Gulf regim to Texas (Brazos liver) extemling northwarl in western Lonisiana to northeastern Arkausas, eastern Mississippi and southeru Jllimois (fiallatiu (ounty, near Equality).

TAMEs IN ISE.-Water Hirliory (X. C., Fla., Ala., Miss., La., Tex., Mo.); Swan!) IIckory (S. ('., Fla., Miss., La.): Bitter Pecan (.Miss., Lat., Tex.); Watter litternut (S. C.. 'T'enn.).

Hicoria ovata (Mill.) lirittol:.

CAR\A ALBA Nutt.

Shagbark (Hickory).

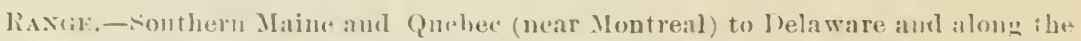
Appalachian Momutains to Florida, northern Alabamal and Mississippi; went through sonthern Michigan to central Mimnesota and northeastem Noloraska, central Kansis. Indian Territory, and castern Texils.

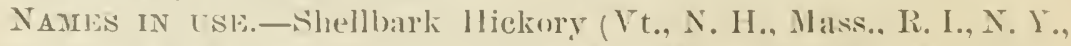

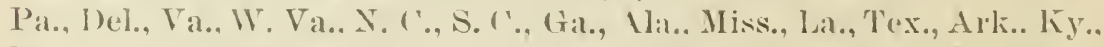
Mo., Ind., Ill., Wis., Iowa, Kans., Neb., Ohio, Ont., Mi.h.); Shatgbark Hickory (Vt., N. H., Mass., R. I., Conn., N. Y.. N. J.. Pa., Del.. S. C.. Ala., Miss., Tex.. Irk., Mo., Ill., Wis., Mich., Minu., Kans., Neb., Iowa):

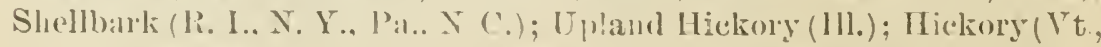

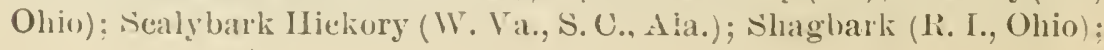


Shellbark-tree (Del.); White Walnut (N. J.); Walnut(Vt., N. Y.); White Hiekory (Iowa, Ark.); Shagbark Walnut (Vt.); Sweet Walnut (Vt.); Redheart Hickory (Miss.).

Hicoria laciniosa (Miehx. f.) Sargent.

Shellbark (Hickory). CARYa SULCA'TA Nutt.

RANGE.-Iowa (vicinity of Mnscatine) throngh Missonri, Arkansas, eastern Kinsas, and Indian Territory (near Ollachita). southern Illinois and Indiana to midkle Teunessee, western and central New York and eastern Peunsylyania.

NaMes IN UsE.-Big Shellbark (R. I., Pa., W. Va., Ky., Mo., Ill., Kans.); Bottom shellbark (Ill.); Westeru Shellbark, Shellbark (R. I., Ky.,) Thick Shellbark (S. C., Tenn.. Ind.); Thick Shellbark Hickory (N. C., Ark.); King Nut (Temı.).

Hicoria alba (Lim.) Britton.

CARTA TOMEN'TOSA Nutt.

Mocker Nut (Hickory).

Ravge.-Ontario to Floricla (Cape Canaveral and Tampa Bay) aud west to Missouri, eastern Kansas, Indian Territory aul Texas (Brazos River).

Names in UsE.-Mocker Nut (Mass., R. I., N. Y., N. J., Del., Ala., Miss., La., Tex., Ark., Ill., Iowa, Kans.); Whiteheart Hickory (li. I., N. Y., Pa., Del., N.C., Tex., Ill., Ont., Iowa, Kans.. Minn., Nebr.); Bulluut (N. Y., Fla., Miss., Tex., Mo., Ohio, Ill., Minn.); Black Hickory (Tex., Miss., La., Mo.); Big-bud, Red Hickory (Fla.); Hickory (Ala., Tex.); Hardbark Hickory (Ill.); Hickory (Pa., S. C., Nebr.); Common Hickory (Y. C.); White Hickory (Pa., S. C.); Hickory Nut (Ǩy.); Big Hickory Nut (W. Va.); Hog Nut (Del.).

Hicoria glabra (Mill.) Britton.

Pignut (Hickory).

Caria porcina Nutt.

RANGE.-Sonthern Maine and southern Ontario to Florida (ludian River and Peare Creek); west through sonthern Michjgan to sontheastern Nebraska, eastern Kransas, Indian Territory and eastern Texas (Nueces River).

Nayes in Use.-Pignut (N. H., Vt., Mass., Conn., R. I., N. I., X.... Pa., Del., W. Ya., N. C., S. C., Fla., Ala., Miss., La., Tex., Ark., Kị., Mo., Ill., Ind., Wis., Iowa, Kans., Nebr., Minn., Ohio, ()nt.); Bitternnt (Ark., Ill., Iowa, Wis.): Black Hickory (Miss., La., Ark., Mo., Ind., Iowa); Broom Hickory (Mo.); Brown Hickory (Del., Miss., Tex., Tenn., Minn.); Hard-shell (IV. V.); Red Hickory (Del.); Switch-bud Hickory (Ala.); White Hickory (N. H., Iowa).

Hicoria odorata (Marsh.) Sargent.

Small Pignut (Hickory).

CARIA MICROCARPA Nutt.

RAxGE.-Eastern Massuchusetts, Connecticut, easteru and central New York, eastern Penusylvania, Delaware, I) istrict of Columbia, Maryland (Mutgomery 'onnty), central Michigan, sonthern Illinois, Indiana, and Missonri.

Names IN USE.-Small P'igutt (Md.); Little Pignut (Md.); Little Shagluark (Md.).

Hicoria villosa (Sarg.) Ashe.

Pale-leaf Hickory.

Hicoria gLABlia villosa Sarg.

Hicoria PALLIDA Aslie.

RANGE-Missonri (Allentown); millle Tennessee and northern Alabima to Georgia and southern Virginia. Distribntion insufficiently known. 


\section{Family MYRICACEA.}

MYRICA linn.

Myrica cerifera Linn.

Wax Myrtle.

RAxGe.-Couthern Marylad to sonthern Florida and west in the finf States to Texis (Rockport, Arkansis liay); northward west of Mississippi River to Arkansas (Washita River). In the Bahamas, Bermuda, West Indies.

NAyes IN r'se.-Wax Mrrtle (R. 1., N. J., Del., N. C., S. C., Ala., Fla.): Bayberry (Mass, R. I., N. J., N. Y., Pa., Del., N. C., S. C., Mla., Fla.); Waxberry (R. I., Pa., S. C.); Cirier (La.); Candleberry (Fla.); Myrtle (Fla.); Myrtletree (Fla.); Puckerbush (Fla.).

Myrica inodora Bartr.

Odorless Myrtle.

RAxGl.-Noir Apalachicola, Fla.; Mobile and Stockton, Ala., and Poplarville, Miss. Rine.

Myrica californica Cham.

California Wax Myrtle.

RAxGe.-l'acitic coast region from Puget Sound to California (Santa Monica).

NANIEs IN USE.-California Bayberry; Myrtle; Bayberry (Cal.): California Myrtle (Cal.); Wax Myrtle (Cal.).

\section{Family LEITNERIACEAE.}

\section{LEITNERIA Chapm.}

Leitneria floridana Chapm.

Corkwood.

RAN(ik.-Westeru Florida (swamp near Apalachicola); Missouri (Butler and Juncan conuties); Arkansas (near Varner). Very local, and range imperfectly unilerstood.
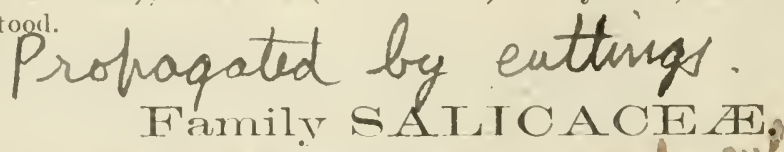

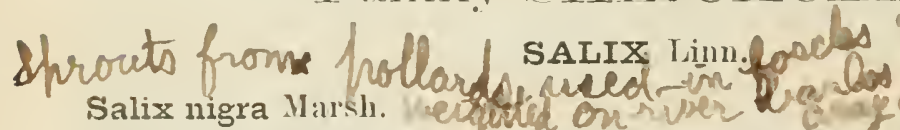

Ravgl.-New Brunswick to sonthern Florida and wust to eastern Dakota, Nehraska, Kansas, Indian Territory, sonthern Arizon:ı, and sonth into Mexico. In ('ilifornia (from the Sierra Nevadas to C'olusa County, and fom Sacramento liver to Arizonia).

NAMES IN USE.-Black Willow (N. H., Vt.. R. I.. N. Y., Pa.. Del., S. C., lia., Alı., Miss., La., Tex., Ariz., Cal., N. Mex., Utah, Ill., Wis., Mich., Minn., Nebr., Kan., Ohio, Ont.. N. Dak.); Swamp Willow (N. C., S. C.): Willow (N. Y. P’a., N. C.. S. C.. Miss., Tex., Cal., Ky., Mo., Nebr.). Salix nigra falcata (Pursh) Torr.

Crescentleaf Willow

Salix nigra $x$ amygdaloides Glatf.

Salix nigra $\times$ alba Belb.

Saliz wardi Bebb.

Rasce.-Y̌irginia (Potoma" River near Washington, D C.), Kentucky (Ohi” River), central Tennessee, Illinois (Horse Shoe Lake, near Venice), southern Missouri, Indian Territory. Distribution insufticiently known. 
Salix occidentalis longipes (Anderss.) Bebb. Longstalk Willow.

lix.ie. - Florida (Jacksonville) and westwarel througl 'Pexas to New Mexiro, Arizoun, and the southern Sierra Novarlas, California. Mlso in northern Mexico.

Salix amygdaloides Anderss.

Almondleaf Willow.

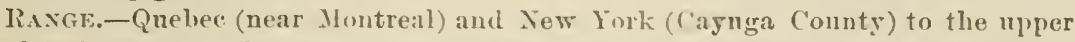
Saskatehewan; sontluard to Ohio and Missonri. and westward in the Plains region to the Rocky Mountains, where it ranges from sontly western Texas to Oregon, Washington, British Columbia.

NAMES IN CSE.-Willow (Nev., (Oreg., Colu., Utah,, Mont.); Black Willow (Mo., Idaho); Common Willow (Mont.).

Salix levigata Bebb.

Smoothleaf Willow.

Raxge.-California (Siskiron Connty to the sonthern bonndiry of the State).

NAMES IN CSE.-Willow (Cal.): Black Willow.

Salix lævigata angustifolia Bebh.

Narrowleaf Willow.

Salix laevigata congesta Bebb.

Salix lasiandra Bentlı.

Western Black Willow.

RAxGE.-Californial (west of the Sielra Yerada): western Oregon, Washington, and sontlıern British Columbia (Selkirk Monntains).

YAMEs IN USE.-Willow (Cal.. Oreg.); black Willow.

Salix lasiandra lyalli Sargent.

Lyall Willow.

RAxGE. - Western Oregon, Washngton, and sontharn British Colmmhia.

Salix lasiandra caudata (Nutt.) Sndworth.

Ravgr.-Northern Californi: (Sierra Nevada) to northern Montana, Coloralo, and northern New Mexico.

Salix bonplandiana H. B. K.

Bonpland Willow.

RAxge.-Arizona (Sabino Canyon and santa Catalina mountains); central and southeru Mexico.

Salix lucida Muehl.

Glossyleaf Willow.

liaxgf.-Newfoumlland (Exploits River) to Hudson bay and nortluwestward to Great Bear Lake, Mackenzie River, and to the Rocks Mountains; sonthwarl to Pennsylvania and west to eastern Nebraska.

Salix fluviatilis Nutt.

Longleaf Willow.

SALIX LONGIFOLIA Muehl.

RANGE.-Quebec (Lake St. John and Island of Orleans) and sonthwirl through western New England to the Putomac Rirer; northmestward to the Aretic Cirele (valles of Mackenzie River) and British Columbia aud California ; soutluward in tha Mississippi River basin to northern Mexico and Lower California.

Names ix UsE.-Sanrlbar Willow (R. I.. Miss.. Cal., Kans., Nebr., Minı., S. Dak., Wis., Ont.); Longleaf Willow (Ala., Kaus., Mich.); Lnug-leaved Willow (Tenn., Minu., Nebr., Colo., Cal., Idaho, Wash.); Narrow-leaved Willow (Nebr.); Shrub Willow (Nebr.); White Willow (Mo.); Red Willow (Mont.); Osier Willow (Mont.); Willow ( a.s. X. I., Ǩy., Ind., Miss., Tex., CaI.. Nev., Utah. Mont.).

Salix fluviatilis exigua (Nutt.) Salgent.

Raxge.-Western Texas to northern California.

Salix fluviatilis argyrophylla (Nutt.) Sargent.

RANGE.-Western Texas to northern Califormia 
RAxGE.-From Puget Sund to sonthwestern California, ranging through western Washington ane Oregon, western slupes of California, Sierra and eoast ranges.

Names rx tsli.-IVillow (Cal., Oreg.); Silver Willow (Cal.).

Salix taxifoila II. B. K.

Yewleaf Willow.

lixas.-Texas (near lil Paso), southern Arizona (near Tueson and on monntain streans); Mexico to Guatenala and lower ('aliforuin.

Salix bebbiana Sirgyent.

Bebb Willow.

SALIX ROSTIRTA lích.

RAXGE.-it. Lawrence liver " In-ver valley) to Hudson bay and northwestward to tho Aretic Cirelo (Alarkenzie Rivor) and British Columbia (coast ranges); sonth to l'ennsylvania and West to Minnesota; western Iflaho and northern Montana to Dakota (Black Hills): western Yebraska, through Colorado to northern Arizona.

Saliz discolor Muthl.

Glaucous Willow.

RAxGE.-Nora Scotia to Nlanitobal aud sonth to Dulaware; sonthern Indiana and Illinois and northeastern Missonri.

Na.nes In USE.-Glancous Willow (R. I., N. I., Pa., Miss., Mich., Mimn., Ont.); P’ussy Willow (N. J., Mimn.); Silver Willow: Swamp Willow (T. J.); Willow (Vt., N. Y., Mo.).

Salix discolor eriocephala (Nichx.) Andểss.

Salix discolor prinoides (l'ursh) Anderss.

Salix corda'a mackenzieana Hook.

Mackenzie Willow.

R.A.Gk-Great Slave I ake and sonthward (throngh rogion along eastern hase of Rocky Mountains) to northern Idaho :nd ('alifornia (Lake Comnty).

Saliz cordata lutea (Nutt.) Bebb.

Yellow Willow.

R.dxiE.-Sonthern Assiniboia and northeru Montaua.

Salix missouriensis liebl.

Missouri Willow.

SALIX CORDATA Var. VHét'ita siargent, not Pursl.

RAxcie.-Western Missomi (Courtney, Jackson County, Fort Osage, and near Watson, Atehison ('ounty).

Saliz lasiolepis lientl.

Bigeiow Willow.

linge. - Northern California (Klamath kiver) and south ward through the westerm part of the State to Lower (anlitornia and sonthern Arizona ('Tamm ('anyon on Huachuca Mlomatans, and White River (anyon on Chericahua Monntains).

NAMr In tse.-Willow (Call. Nev.).

Salix nuttallii Sargent.

Nuttall Willow.

SALIX FLAVEscexs Nutt.

RaxGe,-From sonthan Assiniboia and British Columbia (Colnmbia liver nea bonald) sontluward in the Roeky Monntain region to northern Vew Mexuen and Arizm: (San Francisco Momntain): ('alifornia (Sierra Novada to the San liemardino M(suntains).

Names IN Us].-Mountain Willow (Mont.); Willow (Oreg., I tah): Black Willow.

Saliz nuttallii brachystachys (Bentl.) Sargent.

Raxid - Western Washington and Oregon, and California coast regrom.

Saliz piperi beub.

Piper Willow.

R.uxcw.-Western Washington.

Saliz hookeriana Barratt.

Raxil:-Vanconver Islanl to somthern Oregon-coast region. 
Salix alba Linı.

White Willow.

RANGE.-Eurone. Widely naturalized in the Inited States.

Salix alba $\times$ lucida Pebb.

Salix fragilis Liı11.

RAxGE.-Europe. Naturalized in ensteru North Anerica.

Crack Willow.

Salix babylonica Linn.

Ravise.-Enrope. Natmralized in fow localities in Atlantio region.

Salix sitchensis Sans.

Silky Willow.

liaxar.-AIaska to sonthern (alifornia (Santal Barbarara)-coast region.

Names IN UsE.-Silky Willow (Oreg.): Sitka Willow (Germ. lit.). $X$ POPULUs lim. thring uh gunchly after

Populus tremuloides Michx. Whe Curopean Fremula. Aspen. Lrad to the Maekenzie River (near month) and Alaska (Y'ukon River); sontliward to thon Peunsylvania (mountains), northeastern Missouri, sonthem Nelıraskal, and thronghont tho western monntains to northern New Nexico and Arizona and central California; Lower Calıfornia (San Pedro Matir Mountains) and Mexion (monntains of ('hihnahna). transcon.

Nayes IN Use.-Aspen (N. H., Mass., R. I.. Comn, N. Y., N J., Pa., Del., Ill., Ind., Wis., Mich., Mimn., N. Dak., Nebr., Ohio, Ont., Oreg., Utah, Idalı, Nev., Mont., Colo., Cal.); Quaking Asp (N. Y., Pa.. Del., Cal., N. Mex., Idaho, Colo., Ariz., Ill., Iowa, Minn., Mont., Nebr., Utılh, Oreg., Nev.); Mountain Asp (Mont.); American Aspen (Vt.); Aspen Leaf (Pa.); White Poplar (Mass.); Trembling Poplar (Minn., Colo.); American Poplar (Minu., Colo.); Poplar (Vt., N. Y., Ill., Inıl, Minn., Mont.); Popple (Wis., iowa, Mont.); Tremble (Quebec); Trembling Aspen (Iowa); Aspen Poplar (Cal., Mont.). '

VARIETY DISTINGIISHED IN CULTIVATION.

Populus tremuloides pendens Sudw.

Populus grandidentata Michx.

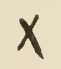

Largetooth Aspen.

Ravie.-Nova Seotia through Yew Brunswick, sonthern Quebec, aud Ontario to northern Minnesota; sont bward to Delaware (and along the Allegheny Monntains to North Carolina, central Kentucky, and Tennessee), sonthern Indiana, and Illinois.

Nanes in UsE.-Large-toothed Aspen (N. J., Pa., Del., S. C., Mich., Minu.); Poplar (Me., N. H., Vt., Mass., R. I., Conn., N. Y., N. J., Pa., W. Va., N. C., S. C., Ga., Ill., Ohio); Large-toothed Poplar (N. C.); Large Poplar (Tenn.); White Poplar (Mass.); Popple (Ile.); Large American Aspen (Ala.).

\section{VARIETY DISTINGUISHED IN CULTIVATIOY.}

Populus grandidęntata penduliformis Sudw. Weeping Largetooth Aspen.

Populus heterophylla Linn.

Swamp Cottonwood.

RaNGE.-From Connectient (North Gilford) and Long Islaud (Northport) southward near the coast to southern Georgia; westward in the Gulf region to western Louisiana and throngh Arkansas to southeastern Missonri, western Kentucky, and Tennessee, and southern Illinois and Incliana. 
TAMES IN ISF.-River Cottonwood (R. I., Miss., La., ()hio); Swamp Cottonwond (S. C., Miss., 1)el.): l3lak:k Cottonwood (Ali.); Cottonwood (N. Y., Ya., Y. (.. S. C.. Mis..); Downy Poplar (Tenn., Ala., Ark.); Swamp Poplar (N. I.); ('otton-tree (N. C.); Liar (La.): Langues de femmes (La.).

Populus balsamifera Linn. Transcou.

Balm of Gilead.

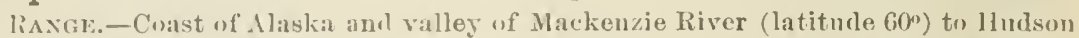
Bay and Norfoumlland; sontlusurl to northern New England and New York (Tanghanuock Falls, ('aynga lakke), exntral Michigan and Minnesota, Dakota (Black Itills), northwestern Neloraski, northeru Juntana, Jdaho, Oregon, and Nevada.

Thues ro UsE.-Balsam (N. H., N. Y., Wis., Mich., Minn., Nebr., Mont., Ohio, Ont.); Balm of Gileal (Me., N. H., Vt., Mass., R. 1., Conu., N. Y., Mich., Nebr., Miun., N. Dak., Ont.); (Jottomwool (Idalıo); Poplar (Wis., Miın.); Balsam Poplar (X. H., V't., Nebr., Minn.); Tacamahac (Minn.); Banmier(Yuebec); liough-barked Poplar(Hudson Bay region).

Populus balsamifera candicans (Ait.) Gray.

Hairy Balm of Gilead.

NATHE IN USE.-lialm of Gilead (Me., N. H., V't., Mass., N. Dak.. Minn., Ont.): Balsam (Mich., Md., and $\mathrm{V}^{\top}$ a. Cult.).

VAIIITIEX DISTINGUISHED IN CULTIATIUN.

Populus balsamifera intermedia Lout.

Populus balsamifera viminalis Lomul.

Populus balsamifera latifolia (Mcench.) l.oml.

Populus acuminata Rydberg.

Lanceleaf Cottonwood.

RAvic.-Soutlr Dakota (13ack IIills) and western Nebraska to the eastern base of the Rocky Momntains of Colurado. Range insufficienfly understood.

Populus angustifolia James. Wef udrow Narrowleaf Cottonwood.

Raxtik.-Frum sonthwestern Assiniboia (Milk and lielly rivers) to Dakota (Black Hills) and northwestern Nebraska; sonthwarl in the monntain regions to central Nevarli, New Mexico (Mogollon Mountains), central Arizona.

Tamis in Use.-Black Cottouwood (N. Mex., Utah, Colo.); Narrowleaved Cottonwood (Colo., Utah); Narrow-leaved Poplar.(Nont., Utah); Balsam (Mont.); Cottonwood (Ilaho, Colo.); Willow Cottonwood (Idaho); Bitter Cottouwrood (Idaho); Willow-leaved Cottonwod (Mont.).

Populus trichocarpa Torr. \& Gr.

Black Cottonwood.

RAxGE.-From sonthern Aliska through western British Columbia (east to Columbia River), western Washington, Oregon, California (and islands) to the sonthern slope of the san Bernardino Monntains. Northern range insuffieiently understoot.

NAMEs IN USE.-Black (Jottonwood; Cottonwood (Oreg., Cal.); Balsam Cottonwood; Balm (Oreg.); Baln Cottonwood (Cal.).

\section{tPqupulus deltoides Marsh.}

T'OPUlus Monilifera Ait.

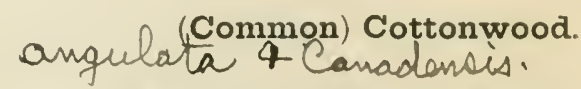

Raxgl.-From Qnebec (Lower Manrice River) and Vermont (Lake Champlain) through western Now lingland and New York, Y'onnsylvania (west of Alleghenies), Marylanel, and Atlantic States to western Florida and west to the Rocky Mountains from sonthern Alberta to northern New Mexico. 
47

NAme IN USE.-Cottonwood (N. H., Yt., Mass., R. I., N. Y., N. J., W. Va., N. C., Ala., Fla., Miss., Ja., Tex., Cal., Ky., Mo., Ill., Wis., Kans., Nebr., Iowa, Minn.. Mich., Ohio. Ont., Colo., Mont., N. Dak., S. 1)ak.): Big Cottonwood (Miss., Nebr.); Yellow ('ottonwood (Ark., Iowa, Nebr.); Cotton-tree (X. Y.); Carolina l'oplar (Ipa., Miss., La., X. Ilex.: Ind., Ohio): Necklace Poplar (Tex., (oho.); Vermont Poplar (Vt.); Whitewood (Iowa): Broarl-leaverl cottonwood (Colo.).

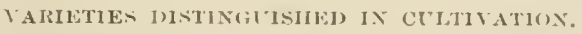

Populus deltoides area (Nichols.) sinew. Populus deltoides erect (Nelys) Sud. Populus deltoides crisp (Lip.) Sud.

Populus fremontii ${ }^{1}$ Wats.
Goldenleaf Cottonwood. Erect Cottonwood. Crisp-leaf Cottonwood.

Fremont Cottonwood.

RANGe. -Western California (Sacramento River) to Lower California; eastward to central Nevada, southern Utah aud Colorado, western Texas and northern Mexico.

NAMES IN USE. -Cottonwood (Cal., Utah); White Cottonwood ( $\mathrm{N}$. Mex.).

Populus alba Linn.

White Poplar.

RANGE. -Europe. Widely naturalized in the Liter States by cultivation.

VARIETIES DISTINGUISHED IN CULTIVATION.

Populus alba nivea (Willed.) Loud.

Populus alba canescent (Smith) Loud.

Populus alba canescent umbraculifera suit.

Populus alba bolleana Louche.

Populus alba nutans Sud.

Populus alba globose Lip.

Populus nigra Limn.

RAxGe.-Europe. Naturalized in several localities in the East.
Snowy Poplar.

Silver Poplar.

Weeping Silver Poplar.

Role Poplar.

Weeping White Poplar.

Round top Poplar.

Black Poplar.

VARIETIES DISTINGUISHED IN CULTIVATION.

Populous nigra italic Du Roo.

Populous nigga italic Du Roo.
Populous nigga ligans Bailey.

Staminate Emily BF T WT TA CE AE.

BETULA Linn.

Betula populifolia Marsh.

White Birch.

RaxGE.-From Nova Scotia, New Brunswick, and Lower st. Lawrence River southward (mostly in coast region) to Delaware (Newcastle County) aud westward through northern New England and New York to Lake Ontario (southern shores).

Yales IN USE. - White Birch (Vt., Mass., R. F., Conn., N. Y., Y. J., Penn., Del., Ont.); Gray Birch (Me., R. I., Mass.); Oldfield Birch; Poverty Birch (Me.); Poplar-leaved Birch; Small White Birch ( $V t_{0}$.).

Betula populifolia $\times$ papyrifera Sargent.

RANGE. -Massachusetts and New Hampshire-local.

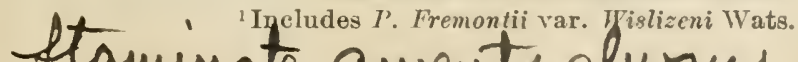


Betula populifolia purpurea IIort. AnI.

Betula papyrifera Marsh.

Paper Birch.

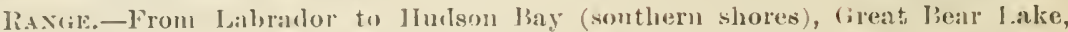
lukon River and coist of Aliska; southwarl to New York (long Islanci) and north(rn I'enusylvania, central Michigan, and Minnesotal, northern Yeloraska (blulls of Niobrara River), liakota (Black llills), wortheru Montana, and northwestern Wralıington (near Seattle).

Names I. Tist.-Paper Birch (N. H., Vt.. Mass., R. I.. Oomm., N. I., Wis., Mieh.. Mimm., Ont.); Canoe Birch (Me., Vt., N. H., R. I., Mass., N. I.. Pa., Wis., Mich., Minn., Ont.); White Birch (Me.. N. П.. Vt., R. l., T. Y.. N. J.. Mis., Minn., Mich., Nebr., Ont.); Silver Birch (Minn.); Iarge Whito Bireh (Vt.); Bolean (Quebec).

Betula papyrifera minor (Tuck.) Wats. \& Coult.

Alpine Paper Birch.

Lixis.-Northeru New England (mountains).

\section{Betula occidentalis Hook.}

\section{Western Birch.}

Ravits, - Prom Britisl, Columbia (upper Fraser and Pease rivers) sonth to Califoruia (valleys of Monnt Shasta and eastern slopes of the northern Sierra Novada); eastward in British Anerica to eastern Alhertil and along the Saskatehewan River to Edmonton, and sonth in the Rocky Mountans and other interior ranges to Nevala, Utah, northern New Mexico; east to I akota (lilack llills), northwesteru Nebraska, ancl eastern luase of Rovekies in Colorato.

Nanes is trse.-Black Bireh (Cal., Colo., Mont., Utah); Cañon Birch (Utah); Sweet Birch (llaho); Cherry Birch (Idaho); Gray Birch (Mont.); Water Birch (Colo.); Western Birch.

\section{Betula nigra limm.
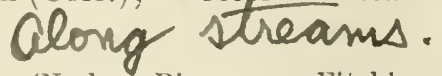

River Birch.

liavik-Missachusetts (Nashua River near Fitchhnrg; Merrimac River near Lawrence and l.owell; Spicket and Shawshen rivers); New York (Walling River, Lonc lsland) and southwarl east of the .lleghenies to western Florida; west in (rulf States to Texas (Trinity liver) and north through Mississipp to Indian 'Trrritory, astern Kansas, eastern Nebraska (Missouri Ruver bottoms), central Minuesota, sontheru Wisconsin (nein Madison), and Ohio.

NAגis IN UsE.-Red Birch (Mass., R. I., N. I., N. J., Pa., Del., N. C., S. ('. La.. Mo., Wis., Kans., Nebr.. Ohio); River Birch (Mass., R. I., N. H.. 1)el., Pa., W. Vi., Ala., Miss., Tex., Mo., Ill., Wis., Ohio); Water Birch (W. Va., Kans.); Blne Birch (Ark.): Black Birch (Flı., Teun., 'Tex.); Birch (N. C., S. C.. Miss., La.).

Betula lutea Michx. $t$.

Yellow Birch.

Raxik.-From Newfomilland and along the northeru shores of St. Lawrence Gulf to Alittibi Lake and Rainy River; smithwarl to northern Minnesota and througl the Northern Stites to easiern Tennessee, North Carolina, and Jelaware.

Names in t'sE.-Yellow Birch (Me., N. H., Vt., Mass., Comm., R. I., N. I., N..I., I'a., N. C., S. C., Ill., Mich., Minn., N. Dak., Ont.); Gray Birch (Vt., R. I., I’a., Mich., Mim.); Swamp Birch (Mimn.); Silver Birch (N. H.); Merisier (Quebec); Merisier Rouge (Quebec). 
Betula lenta Liun.

RAxGE.-Newfondland to northwestem Ontario and soutluwarl to sonthurr: Indiana and Illinois, and along the Allegleny Ilountains to rentral Kenturky, Tennesser, and western Floridla.

Names in vise.-Sweet Birch (Me., N. H., Vt.. Mass., R. I., N. I., N. J., Pa., Del., S. ' '., Mich., Minn.); Birch (N. U.); Black Birch (N. H., Yt.. Mass., R. I., Comn., N. I., N. J., Pa., W. Va., Gå., Ill., Ind., Mich., (bio); Cherry Birch (N. H., R. I., X. Y., l'a., Vaı, 1)el., N. C., S. C., Fla., Wis., Mich., ()nt.): liver Birch (Mimn.); Mahogany Birch (N. C., S. C.): Mountain Mahogany (S. C.).

\section{ALNUS Ehrh.}

Alnus maritima (Marsh.) Muehl.

Seaside Alder.

RAxge.-Soutbern part of the peninsula of Delaware and Maryland (Nanticokn River near Seaford. Del.; Wicomico River near Salisbury, Md.); Indiun T'erritory (Rerl River).

Narres In Use.-Seaside Alder (Del.); Alder (Del.).

Alnus acuminata H. B. K.

Lanceleaf Alder.

Alnus oblonglfolia Torr.

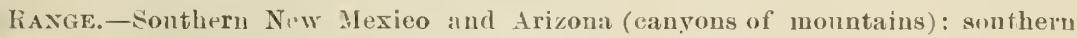
Mexieo, Central Ameriea to Peru (Andes,.

Alnus rhombifolia Nutt.

White Alder.

RAxGE.-From northern Idaho to the eastern slope of the Cascade Mountains of Washington and southeastern Oregon, and southward throngh California (eoast ran-es, western slopes Sierra Nevalla, San Beruardino, San Jaeinto, and ('napamaca monutains).

Names in Use.-Alder (Ual., Oreg.): Western or California Alder (Idaho); Mountain Alder.

Alnus tenuifolia Nutt.

Paperleaf Alder.

AlNUS INCANA Vall. VIREscens Wats.

Raxge.-From British Columlia (Kieking Horse Lake to Lower Fraser River) through the Rocky Momutains to northern New Mexieo, to sonthern California (Sierra Nevada), and Lower ('alifirnia.

Alnus oregona Nutt.

Red Alder.

RAxciE.-From Sitka (throngh islands and coast ranges of British Columbia, western Washington, and Oregon) to California (coist ranges to Santa Inez Monntains, near Santa Barbara).

NAMIES IN USE.-Alder (Cal., Oreg.); Red Alder (Cal., Oreg.); Western or Red Alder.

Alnus glutinosa (Linn.) (Giertn.

European Alder.

lisxaf.-Enrope and northern Asia, but naturalizerl in few loenlities in the United States.

VARIETIES DISTINGUISIIII IN CULTIVATION.

Alnus glutinosa quercifolia Willı.

Aluus glutinosa laciniata (Ehr.) Willd.

Alnus glutinosa incisa Willd.

Aluus glutinosa aurea (Korll) Nichol.

19193-No.17-4 


\section{CASTANOPSIS Spach.}

Castanopsis chrysophylla (Hook.) dle C. Goldenleaf Chinquapin.

Raxge.-Pacific eoast region fiom the ('olnmbia River (along western slopes of Caseade Mountains and Sierra Yeviula) to somthern California (san Jacruto Nonutains).

Nanes in tose.-Chinçuapin (Cal., ()reg.); Chrestmut (Cal.): W'esterm Chinumapin.

\section{CASTANEA Adius.}

Castanea pumila (Limm.) Mill.

Chinquapin she

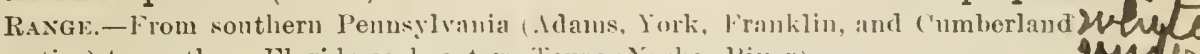
counties) to uorthern Florila and eastern lexas (Neches librr).

Nanes in USE.-Chinquapin (Del., N. I., Pa.. Va.. W. Va., N. C., Ceawe S. C., Ga., Ala., Fla.. Miss., La., Tex.. Ark., Ohio, Ky., Mo., Mich. (cult.).

Castanea dentata (Marsh.) Burkh.

CAstanea VEsca $/ 3$ IMERICANa Michx.

Castaxea tulgaris ?' Amfricaxa A. de C.

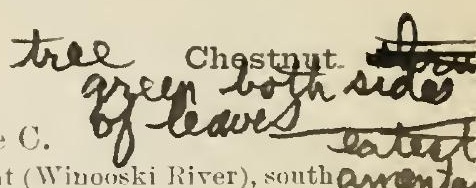

RANGE,-From soutlern Maine to northwestern Vermont (Wiuonsi River), south anda ern Ontario, and southern shores of Lake Ontario to sumtheastern Michigan; sonth- to GCoO ward to Delaware and sontheastern Indiana, and on the Allwhen Nountains to central Kentucky and Tennessee, central Alabama, and Wississippi.

Naues iN UsE.-Chestunt (Me.. N. H., Tt.. Mass.. R. I.. Conn.. N. Y., N. J.. Pa.. Del, Va., W.Va., N. C., (ra., Ala., Miss., Ky, MIg., Migh, Ont.); O.helh-yalytab = "Prickly Binr" (Indigns, X. T.)

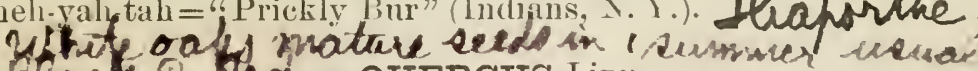

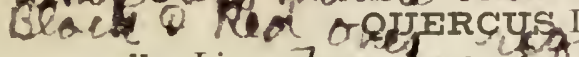

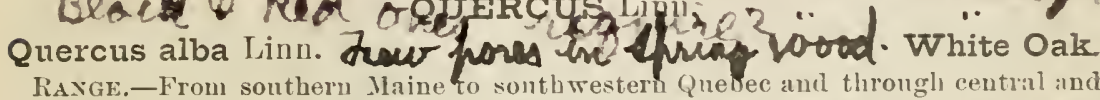
sonthern Ontario, lower peninsula of Michigan and sontheru Mimesota to sontheastern Nehraska ąni eastern Kansas; sonth to nortbern Florila and Texis (Brazos River). Fets the

NAMEs in USE.-IThite Oak (Me., N.H., Tt., Mass., R.I., Coun., N.Y., N.J., Pa., Del., Va., W. Ta., X. C., S. C., Ala., Fla., Ga.. Miss.. La.. Tex. Ky., Mo., Ohio, Ill.. Ind., Kans., Nebr.. Mieh., Wis.. Minn., S. Dak. (cult.), Iowa, Ont.); Stave Oak (Ark.).

Quercus alba $\times$ macrocarpa Engelm.

RaxGe, - Illinois (near Fountaindale and Athens); Virmont (near ('harlotte).

Quercus alba $\times$ minor Coulter.

RAxGE.-Illinois (Fonntaindale); Marrland (Silver Springs); Missouri (Allentown).

Quercus alba $\times$ prinus Engelı.

Raxae.-Dintret of Colmubia; Vermont (near ('barlotte); Ternossee (near Fowler).

Quercus lobata Née.

California White Oak.

RANGE. - Western California (Sierra Nevirla to the ocean, from the upper sacra-,

minto to Tejon Pass, thence to Antelupe Valley and to Santa Monica).
Names Iv USE.-California White Oak (Cal.): Weeping Oak (Cal.);

Valley Oak (Cal.): "Roble" (Mexyans); White Oak (Cal.): Swamp Oak (Cal.). 
Quercus breweri Engelm.

Shin Oak.

liaxgk-Californi: westeru slopes of sierra verada from northern border of the State to Tulare County.

Quercus garryana Dougl.

Pacific Post Oak.

RAxGE.-From sontheru Vanumwr Islamil and southwestem Britisl Columbia (lower Fraser River) sonth throngh western Washington, and oregon and California (coast valleys to Santa ('ruz Mountains).

NAMrs in I'sE.-White Oak (Cal., Oreg.): Oregon White Oali (Cal.); Parific Post Oak (Ureg.); Oregon Oak (Oreg.): Westeln White Oak (Oreg.).

Quercus gambelii Nutt.

Gambel Oak.

QTERCLS LNDULATA :T GAMBELII ENingelm.

RAxGis - From Colorado (eastern slopes Rocky Mountains and as far worth as the vivile between Platte and Arkansas rivers) to Ltah (Wasateh Momntains), and sonthwarl throngh the momtains to westeru Texas (Pecos River region) and southwestrrn Nerada (('harlestown Momutains); Mexico (mountaius of northern Souora).

Nines in TSE.-Serub Oak (N. Mex., Ariz., Colo., Nev.. Utalı); Rocky IInutain Scrub Oak (Nev.); Mountain Oak (Nev.): Pin Oak (Ariz.): White Oak; Shin Oak.

Quercus minor (Marsh.) Sargent.

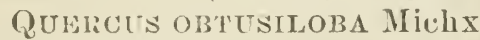

Post Oak.

RAsGe.-From sontlern Massachnsetts (uear istewster, Cape Cod, and islands of Iarthas Vineyarrl and Nanshon), lihode Island (Vorth Kingston), and N('W York (Lomgr Island) to northern Florila, southern-Alabaua, nud Mississippi; west from Long Island to Mlissouri, eastern Kansas, Indian Territory, and Texas (hero sonth to San Antonio liver and west to one lunderdth meridian).

Names in Use.-Post Oak (Conn., R. I., X. J., Pa, Del., W. V'Ta, N. C., S. C., Ala., Ga., Fla., Miss., I a., Tex., Ark., Ky., MIo., Ill., Iur., fowa, Kans., Febr., Ont.); Box White Oali (R. I.); Iron Oak (Del., Miss., Tebr.); Chêne etoile (Quebee): Over('mp) Oak (Fla.); White Oak (Ky., Ind.); Box Oak (Ml.): Brash Oak (MId.).

Quercus chapmani Sargent.

Chapman Oak.

RANGE.- Sonth C'aroliua to Florida

Quercus macrocarpa Nichx.

River valles, Ontario, southwestern Wauitolu (oouth Cré. $\mathrm{Ri}$ nuthach 'enobsent River region), Termont (shores Lako ('hamplain), Massachusetts (Ware L River), Peunsylvinia (Lancaster Comny) west to Moutana (eastern liase hocky Go .Monntans), western Noliraska, centym Kansis, and sonthwestwarl into rentral Tenuasiner, Indian Territory, and Lejay (to Tneces River).

Names in tise.-Bur Oali X t., N. Y., Pa., Del., W. Va., Ala., Miss., Liı., Thx., Ark., Mo., Ohı, Ill., Ky., Iowa, Kans., Nebr., Wis., Mich., Minn., N. I)ak.. S. Dak.):r.Mossycup Oak (Mass., Pa., Del., Miss., La., Tex., Ark., Ill., Iowa, Nebr., Kins., Ont.); Overcul Uak (R. 1., I)el., Pa., Miss., La., Ill., Minn.); Blıe Oak (Ont.); Sclub Oak (Nebr.. Minu.); Orercup White (Oak (Vt.): Mossyeup White (Gak (Mmm.)

Quercus lyrata Wilt Junt ue 0 - in Lonfthe Overcup Oak.

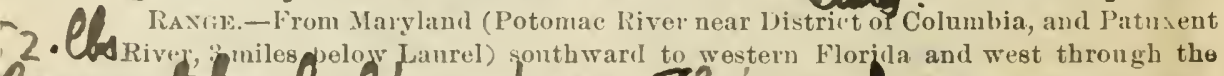

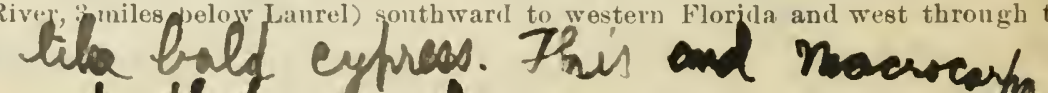


Gult region to Texas (Trinity liver), throngh . Irkansas, sonthwostorn Missour (only near Allentou), rentral T'musssee, southeru Indiana, Illinois (kafes Mill on Limbaras River in sontheastem Jasper ('muty).

Names rN UsE.-Overcmp) ()ak (N.C., S. C., Ga., Fla., Ala., Miss., Lal., Tex., Ark., Ill.): Swamp Post ()ak (Ala., S. C., Miss., lat., Mo.); Watel White Oak (S. C., Miss.): Oak (Ala.); Swamp White (Oak (Tex.).

\section{Quercus primus Linu.}

RAxGe. From southem Maine (Sido Fivic? and Mlount Agamentions) and eastern

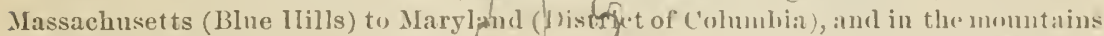
to northern Georgia and Alabama ; westward fu lake ('hamplain and the (inesee River in New lork, to Lake Lrie (uortlem shures from Niagara River to Amlurstburg), to central lientucky and Tounessede.

NAunes Ix USE.Chestnut Oak (Mass., R. I., ('onu., N. Y., N. J., Pa., Del., Ta., IT. Ta., N. U., (ia.. Ky.)); Rock Chestnut Oak (Mass., R. I.. Pa., Del., Ala.); Rock Oak (X.to Del., Pa.): Taubark Oak: Swamp Chestunt Uak (N. C.); Momntain Qia (Ala.).

Quercus acuminata (Mir.hx.) Hquba.

Chinquapin Oak.

RANiE.-From New York (Gardeuers Island in Lake ('hamplain and on lludsou River north of Newburg) westward though southern Ontario to sontheastern Nebraska and eastern Kansas; suththard in the Atlantic recrion to the llistrict of

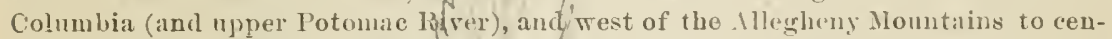
tial Alabama and Mississippi, throngh Arkansas and northeru Lourisian to the eastern borler of Indian Territuy aud Texas (to Nueces River, and cingons of Gua(lalnpe Mountains in extreme westeru part of stato).

Names rN UsE.-Chestmut Oak (Yomn, Tel., Ala., N. C., Miss., La., Tex, Ohio, Ill., Mich., Kiams, Nebr.); Chinquapin ()ak (Mass., R. I., Pa., Del., N. C., S. C., Alı., Ark., Miss., Tex., Mo., Ind., Nebr., Kans.) Pin Oak (Kans., Ark.); Yellow Oak (Ill., Kans., Nebr., Mich.); Scrub Oak (N. Y.); Dwarf Chestunt Oak (Mass., N. (j., Tenn.); Shrub ()ak (Nebr.); White Oak ('Tenn.); Rock Oak (.1 rk.).

Quercus prinoides Willl.

Dwarf Chinquapin Oak. 87 s

RANGE.--Massachusetts (Essex ('mnty) to North ('arolina and westwarl to south-

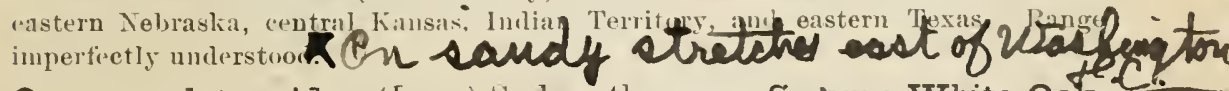
Quercus platanoides (Ian.) Surwortl. -t Swamp White gak QUERCUS BICULOR Willd. White underneate teauas.

RaxGE.-From sonthern Maine fownthern Vermont and southwestern Quebec; Grod west throngh Ontario aud southern fieninsula, of Michigan to sontheastern Iowa and Voriar western Missonri; sonth to the District of Columbia, northern Fentucky and Arkansas, and along the Appalachian Momntaing to northern (reorgia.

NAMES IN USE.-Swamp) TVhite Oak (Vt., Mass., R. I., Conn., N. Y. I. J., Pa., Del., W. Ya., Mo.. Ill., Ind.. Iowa, Mich.gQnt.); Swamp Oak (R. l., Pa., Mich.).

Quercus michauxii Nutt.
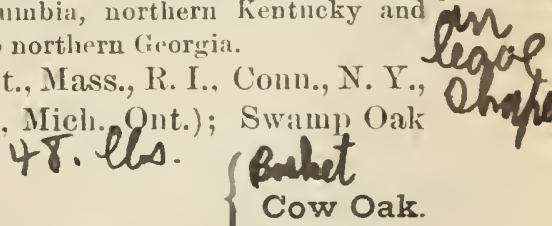

RANGE.-From Delaware (near IVilmington) to northern Floridit; west through. the (illf region to Texas (Trunity River), and through Arkansas and sontheastern Missonri to central Tennessee and Kentukg, flinois, an Indiana (in valley lower Wabash River). Seaces woritud hemeath.

Names IN USE.-Basket Oak (Mla.. Miss.. lia.. Tex.. Ark.); Cow Oak (Ala., Miss., Tex., Ark., Mo.); Swzup White Oak (Del., Ala.); Swamp Chestnut Oak (Fla.) 
Quercus michauxii $\times$ macrocarpa Sudworth.

RaxGl._- Noutlwestern Tennessee (near Covington).

Quercus breviloba (Torr.) Sargent.

Durand Oak.

Quereus ditrandi Buckl.

RAxGE-Central Alabama (and to Mulberry Fork of Tombigbee River, in Blount County) and Mississippi (near Columbus and near Mhoons Valley); Louisiana (Red River near shreveport); Texas (from near Dallas west to central part of the State ancl sonthward on streatus flowing into the (iulf to near Monteres).

NayEs IN Lsk.-White Oak (Tex.): Texas White Oak (Ala.); Shin Oak (Tex.); l’in Oak (Tex.): Bastard Oak (Ala., La., Tex.); Basliet reat Oak (Ala., La., 'Tex.); Hunal's Oak (Ala., La., Tex.).

\section{aritwo Quercus undulata Torr

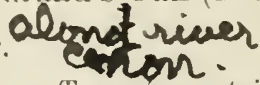 Arizona to southeru Ltah and Nevada; northern Mexico. \\ NAMES IN T'Sk. -Sicrub Oak: Shin Oak.}

Rocky Mountain Oak.

RAxGE.-Coloralo to westeru Texas monntains) and thropgh Nigw Mexieo and

Quercus douglasii Hook. \& Arn.

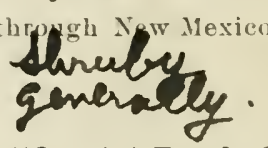

California) Rock Oak.

liason.-California (from Meulocino County and valley of npper sommento Rirer sonthward on westward slopes of Sirra Nevadil and valleys of the eoast rangis to the Tehachapi Pass and across to the border of the Mobave Jusert .

NaAes IN USE.-Momutain White Oak (Cal.); Rock Oak (Cal.); White Oak (Cal.); Blue Oak (Cald. t hanterent

Quercus engelmanni Greene.

Engelmann Oak.

RavGl:-Southwestern California (in a helt 15 miles wide from vicinıty of sierra Madre to the mesil east of San Diego).

NAMEs IN USE.-Wigelmann's Oak; Evergreen White Oak.

Quercus oblongifolia Tol'r.

Blue Oak.

RAxGe-Western Tpxis (Chisos Mountains) throngh southeru New Mexiro and Arizona, and sonth into northeru Mexico.

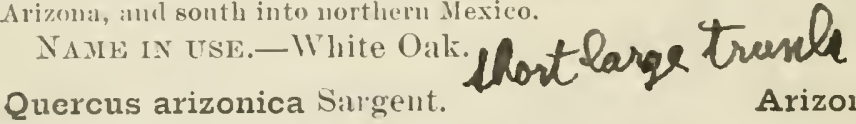

Arizona White Oak.

RAxie.-Conthern New Mexico and Arizgna.

NAME 1N USR,-White Oak.

Evergrees.

Quercus reticulata Humb. \& Bompl.

Netleaf Oak.

RAxil:-Sonthern Now Mexiro (Jount Graham, Santa Rita, Ilnachne:a, Chirirahua, and Santa Catalina monntains) aud Arzona (San Lu1s :ncl Animas momntitiıs).

Quercus toumeyi Sargent.

Toumey Oak.

Ravil:-_iontheastern Arizona (Mnle Hountain, Coehise County)

RAxGN,-Califoruia (western slopes of Sieria Nevada; coast ranges south of sinn Jranciseo liay; islands off suutlueru coast and mland to Molıve Descrt; San Beruardino and San Jiento nountains); Lower Califoruia (to near San Teluo).

Quercus dumosa revoluta hararent.

Curl-leaf Scrub Oak.

Ravili- - Northern Calturula (San Francisco Bay to Mendociuo Connty and Napa Valley). 
Annualing

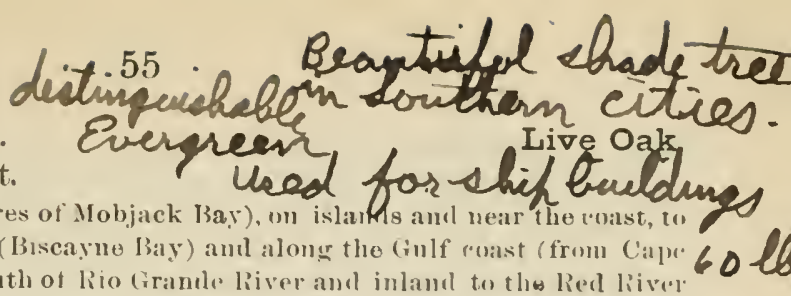
Romano) to western Texas (mouth of Rio Crando liver and inland to the Red liver.

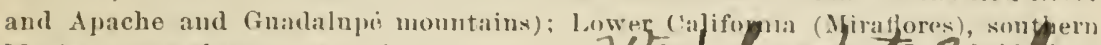
Mexico. Ceutral America, ant Cuha.

Wad hard to vorle.

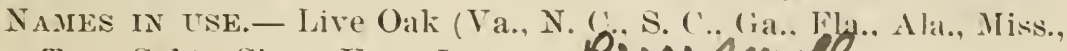
Lal. Tex., Cal.); Chine Vert (La.).

\section{Quercus emoryi Torr.}

Emory Oak.

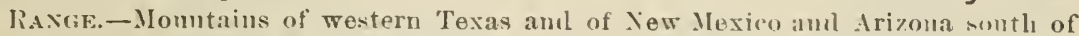

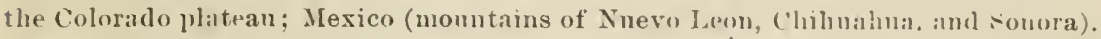

NAMES IN USE.-Emory's Oak (Cal.); Blilek ()ik (A ri\%. N. Uex.

Quercus chrysolepis Liebm.

acorns mative onlis in 2 ceasond

Raxie.-From somthern Oregon (Cow Crete Valley) thomeh Califumia (ronat ranges, western slopes Sierra Xerada, San Beruilulino, sin .laciutu, and Cuyauata momntains) to Lower Calıformia (Iount Sall Pedro Martir): (aml momntain sımmits) sonthern Arizona and New Mexico; Mexico (northern Somora).

Nayes IX U'SE.-Live Oak (Cal., Oreg.): Maul Oak (Cal.): Iron Oak (Cal.): Valparaiso Oak (Cal.); Black Live ()ak (Cal.): Canyou live Oak (Cal.), Canyou Oak (Cal.); Golrlen-(•up Oak (Cal.); Hickory Oak (Kern Comity, Cal.).

Quercus chrysolepis palmeri Engelm.

Palmer Oak.

RAxGE.-Bonmlary between California aud Lower California.

Quercus chrysolepis vaccinifolia (Kell.) Engelm. Inuckleberry Oak. Ravge.-Calıfornta (highest elevations Sierra Nerada).

Quercus tomentella Engelm. Acorn matures in 2 seasors

Raxge.-Santa Rosa. Sauta Crnz (sonth of santa Barbata , Santa ('atolina lslancls, sunth of Cape Vincent, off coast of California: Gualalune Islausls, off coatst uf' Lower California.

Quercus agrifolia Née.

California Live Oak.

Raxis.-From torthern California (Mendoeino f omoty and along the coant langes and islands) to Lower California (Mownt San Pedro Martir).

Nayes IN USE.-Coast Live Oak (Cal.): California Live Oalk (Cal.); Enciua (Cal.): Everogreen Uak (Cal.)

Quercus hypoleuca Engelm.

Whiteleaf Oak.

liaxgk.-From restern Texas (Limpio Monntains) over mountains of New Mexico and Arizona, south of the Coloralo l'latean: Nexico (northern ('hihuahua and Sonoril).

NAMES IN USE.-Oak (Ariz.); Mexican Oak; White leaved Oal.

'Dr. J K. Sunall has recently described the following species as new. I hatve not seen sperimens of it, but 1 appears to be very closely related to ('nercus rirginiana.

('nercus geminata Small (Bull Torr. 13it. Club, vol. 21, 11. 135, 1897). A slirub or small tree 6 to 15 feet high. "Leaves narrowly oblong, elliptic, or oblong-oblanceolate, 3-6 cm long, entire, obtuse or apuculate, strongly revolute, mostly gradually narrowed at the base, glabrous and parchment-like above, finely tomentose and conspicnously ruguse on the promment nerves beneatl * * - ; acorns, usually 2 at the encof a peduncle * * * cups turlunate * * *" Florida (sandy soil).

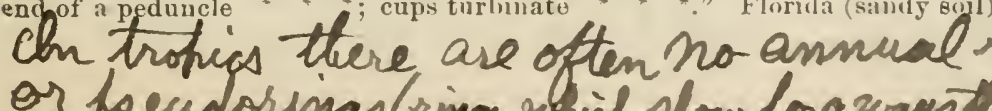


Quercus wislizeni A. de C.

Highland Oak.

RANGE.-From nortlıern C'alifornia (lower slopes Mount shasta and soutlıwarl thromgh the euast region to Sauta Lucia Mlomtains, Santa Rosi and sauta Cru\% Islankls, and lower slopes of sierra Nevarla to l’ijon Pass; San liernadmo, Sau Jacinto, and Cnyamaea momutains) to Lower California (Monnt San l'erlro Martir).

NAMES IN TSE.-live ()ak (Cal.); Highland Live Oak (Cal.).

Quercus morehus Kiell.

Morehus Oak.

Raxge,-Califurnia (Lilke County).

Quercus myrtifolia Willı.

Myrtle Oak.

JAaxal:-From South Carolina (on enast and islanils) to easteru Florila, and from

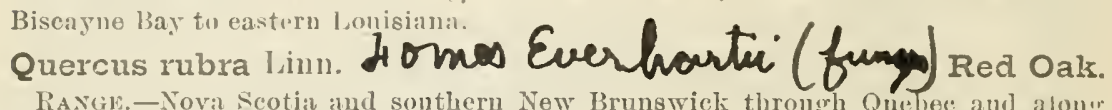

Ravin.-Nova Scotia and sonthern New Brunswiek throngh Quober and alon: the north shones of lake Hurom to near Lake Namekagon; sonth to Midkle 'lennessec and Virginia, and along the Appalachian Mountains to northern feorgia; went to easteru Yebraska, central katisas.

NA.res In t'sE.-lied Oak (Me., Vt., N. H., Mass., R. I.. N. I., X. .I, Pa., I)el., Va.. W. V'a., N. C., S. C., Giı., Ark., Mo., Ky., Ill., Ind.. lowa, Nebr., Kans., Mich., Minn., S. Dak., Ont.); Black Oak (Vt., Conn., N. I., Wis , lowa, Nebr., S. Dak., Ont.); Spanish Oak (Pa., N. U.).

Quercus rubra runcinata 1 . de $\mathrm{C}$.

Ravil:-Missouri (bottom lanıls opposite st. Louis).

Quercus texana Bnckl.

Texan Oak.

Raxin. -From northeastern lowa (uear Waterloo) and central llinois through Gýthern lllinois and Inlliana, western Kentucky and Tennessee to Fioridia (ralley fpalachicolin River) and through sonthern Missouri, Arkansas, and Lonisiana to estern 'l exus (Limpio Monntaus). liange imperfeetly known.

Tames IN Ust.-lierl Oak (Tex.); Spotted Oak (Tex.); Spanish Oak ('Tex.).

Quercus coccinea Mnenchl.

Scarlet Oak.

RANGE.-From Maine (Androseoggin Rirer) through sonthem low Hampshire and Vermont and central Vew York to sonthern Ontario; west thromeh centril Michigan and Minnesuta to southeastern Nebraska, and sonth to the Distriet of ("olumbia, northern Illinois, and on the Allegheuy Mountains to North Carolina and eastern 'linnesseo.

Names iN Use.-Scarlet Uak (Vt., Mass., R. I., Comm., N. Y., N. J., Pa., I)el., N. C., Mo., Ill., Ind., Wis., Minn., Mich., Nebr., Iowa, Ont.); Red Oak (N. C., Ala., Wis., Nebr., Minn.); Black Oak (Mo., Ill., Iowa, Wis.); Spatish Oak (N. C.).

Quercus coccinea $\times$ pumila sudwortl.

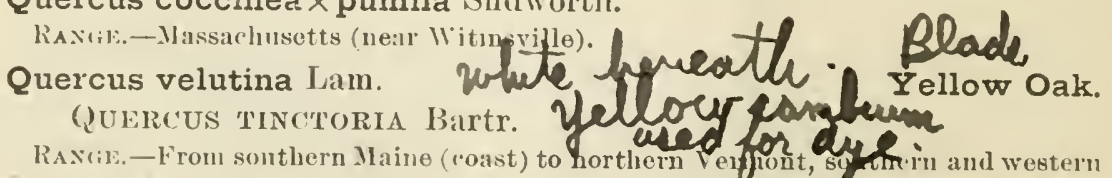
Ontario and ceutral NIinmesota; sonth to northern Florma, west to eastorn Kansas, ludian Territory, and eastern Texas.

NAMES IN TSE.-Black Uak (Vt., Mass., R. I., N. Y., N. J., Pa,, Del, Va., W. Va.. N. C., S. O., Ga.. Ala.. Fla., Miss., La.. Tex., Ohio. Jll., Iowa. Kans., Nebr., Hich.. Wis., Minn., Ont.); Quergitron Oak (Der,S. C.,La., 
Kans., Minn.); Y.llow Oak (R. I., N. I., Ill., Tex., Kans, Minn.); Taubark Oak (Ill.); Yellow-barked (Oak (Minn.): Spotted Oak (Mo.); Yellow-bark (R. I.): Iyer's (Oak ('Tex.).

Quercus californica (Torr.) ('oop).

California Black Oak.

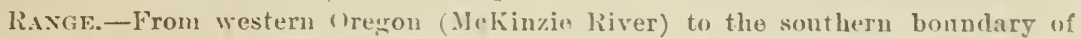
California (through eoast monutains and on westem slopes of Sierra Nevarla, San Burnardino, san Jarinto, aml Cuyamara monutains).

NAIEs Ix UsE.-Black ()ak (Cal., Oreg.); Mrountain Black Oak (Cal.); Kellogg*s Oak (Cal.); California Black Oak (Cal.).

Quercus catesbæ: Michx.

Raxge. - In constegion from North Carolina Florid if Cape MaIabar aud I'ease Creek) and west (x) eastern Lonisiani.

Nanes IN Use.-Turkey Oak (Fla., Ga., Ala., Miss., La.); Scrub Oak (X. C., S. C., Fla... Miss.): Black .Jack (S. C.); Barren Scrub Oak; Forked-leaf (S. C.); Forked-leaf Black Jack.

Quercus catesbæi $\times$ brevifolia Sudworth.

Raxge-Florida (lake County).

Quercus catesbæi $\times$ laurifolia Enngelm.

liavge--South Carolina (Bhuliton).

Quercus sinuata (Lam.) Walt.

RANGE.-Sonth Caroliua (near Bluffton; tree now destroyerl.)

Quercus digitata (Marsh.) Sndworth. Rech in tam Spanish Bak
QUERCTS FALCATA Michx. RAXGE.-From southern New Jersey to central Florida and throngh the Gulf States to eastern Tesa: (Brazos River), Arkausas, southwestern Missouri to middle Tennessee and Kentncky, southern lllinois and lulirna.

Names IN Use._Spanish Gak (Del., Ta.. N. C.. S. C., Ala., Fla., Miss., La.. Tex., Mo., Ill.); Red Oak (N.C.. Va.. Fra.. Fla.. Ala.. Miss.. Ia.. Ind.); Spanish Water Oak (La.).

Quercus digitata $\times$ velutina Sudworth.

RAxiE.--Tennessee (near Corington).

Quercus palustris Muenchh.

Pin Oak.

Raxge.-From Massachnsetts (Connecticut River, near Amherst) to sontheastern Missouri, and south to Virginial (Lower Potomac River), central Kentucky, northern Arkansas, and easteru horler of Indian Territory.

Naures IN T'SE.-Pin Oak (Mass., Conn.. R. I.. N. Y.. Pa., Del.. Ta., Mı., Ark., Mo., Ill.. Wis., Iowa, Kans.); Swamp Spanish Oak (Ark., Kans.); Water Oak (R. I.. Ill.); Swamp Oak (Pa., Ohio, Kans.): Water Spanish Oak (Ark.).

Quercus pumila (Marsh.) S'ulworth.

Barren Oak.

QUERCUS ILICIFOLIA Wang.

Raxge.-From Maine (Mount Desert Island off the coast) throngh eastern and sonthern New England; in New York (Lake George aud valley of Hudson River); New Jersey (pine barrens); eastern Pennsylrania (and along the Allegheny Mountains-east in Maryland to Montgomery County) to northwestern North Carolina (King auıl Crowders mountains).

NAIIES IN :USE.-Bear Oak; Bären Oak (Md.): Dwarf B3lack Oak; Scrub Oak. 
Quercus georgiana Curtis.

Georgia Oak.

Raxge.-Central Georgia (Stone Nonntain, Little Stone Mountain, 9 uniles sonth of : tome Monntain, anl of her granite hills 12 to 18 miles eastwarl in Dekalb Connty).

Quercus georgiana $\times$ marilandica Sargent.

Raxgk-Centril (feorgia (Stone Jountain, Dekalb County).

Quercus marilandica Muenchh.

Black Jack.

Q QERCE's NIGRA of anthors, not of $\mathrm{L}$.

kixGl:-From New York (Forbells Landing and l'ine Island, Loug Island) throngh northern Ohio, ludiana, and sonthern Michigan (Aun Arlor aud Lansing) to southeastern Neluraska, eentral liansas, and Indian Territory; sonth to Florida (Matanzas Inlet and 'T'ampa liay) and west to Texas (Noces River).

NaAns In Tre.-Black Jack (Pa., Del., IV. Va., N. C., S. C., Ga., Mla.. Miss., La., Tex., Ark., Mo., Ill., Ind., Kans., Nebr., Mich., Minn., Iowa., S. Mak.); Jack Oak (N. I., W. Ta., Miss., Tex., Mo., Ohio, Ill., Kans.. T(elır.): Iron Oak (Temn.); Black Oak (Ark., Wis.); Barren Oak (Kans., Temı.); Barrens Oak (Fla.); Scrub Oak (S. C.).

Quercus marilandica $\times$ velutina Bush.

Raxck.-Indian 'Territory (near Sapnla).

Quercus brittoni Davis.

Britton Oak.

RAxcis.-Niw York (Watehogne, Staten Island).

Quercus nigra Lim.

Water Oak.

Querces AuUATica Walt.

Raxge.- Gonthern Delaware to Florida (Cape Malabar and Tampa Bay); west to the Alpilat clian Mointains and through the Gulf States to Texas (Coloralo River); throngh Arkansas anil eastern border of Indian 'Territory to sontheastern Missouri (Black liver), midhld 'Trumessee, and kentucky.

NAMEs in Usk.-Water Oak (Del., N. U.. S. C., Nla., Fla., Miss., I.a., Tex., Ark.. Mo.): Spotted Oak (Tex., Ala.); Duck Oak; Possum Oak; P'unk Oak.

Quercus laurifolia Michx.

Laurel Oak.

Raxide-('oist regun from sontheastern Virginia (Dismal Swamp) to Florirla (Mostuito Inlet and Cape Romano) anil west in the Gulf region to Lonisiana.

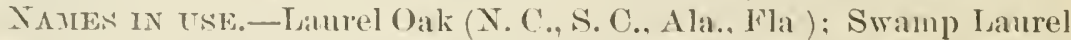
Oak ('Temm.); l)arlington Oak (S. O.); Willow Oak (Fla., S. O.); Water Oak (Ga.).

Quercus brevifolia (lam.) Sargent.

Blue Jack.

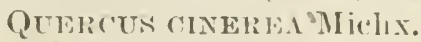

Raxch. - From Nolth Carolina (in a maritime belt 40 to.50 mules inland) to liorula (Capre IIalabar and l'ease ('reek arross the peninsula); west on Gulf coast to Texis (Brazos liver and inland as far as l)allas).

Yaues IN Usta.-Upland Willow Oak (N. C., Ala., Tex.): Blue Jaek (X. C.. Fla., 'Tex., (ia.); Sand .Tack ('Tex.); Hıgh-gromed Willow Oak (S. C.); Turkey Oak (S. C., Gra.); Slun Oak ('Tex.); Ummamon Oak (Fla.).

Quercus imbricaria Michx.

Shingle Oak.

Raxcis-From l'ennsylvania (Lehigh County) west through sonthern Michigan (Washtenaw Connty, Kalanazoo County), and Wrsconsun to northeru Missouri anıl 
northeastern Kansas; south to the District of ('olnmbia and (in the Allegheny Mountains) to northern feorgia and dlabama, to mildle Temuesseo and northern Arkansas.

Nanes in USE.-Shingle Oak (Del., N. C., S. C., Ky., Mo., Ind., Ill., Kan., lowa, Nebr.); Laurel Oak (Pa., Del., s. C., Ky., Ill., Nebr.); Jack Oak (Ill.); Water Oak (N.C.).

\section{Quercus imbricaria $\times$ palustris Engelm}

RaxGe.-Missouri (8 miles west of St. Lonis: hut tree since destroyed).

Quercus tridentata (de C.) Engelm.

Trident Oak.

RAxGE.-Missonri (near St. Louis-but tree now destroyed-and near Allentown) and Michigan (Washtenaw County).

Quercus leana Nutt.

Lea Oak.

RAxfe.-Ohio (near Cineinnati); District of Columbia and western North Carolin: to sonthern Michig:n, central and northem Illinoị, and southeastern Missouri. Range imperfectly known.

Quercus phellos Linu.

Willow Oak.

liAxGE.-From New York (Tottenville, Staten Island) to northeastern Florilausually in the low maritime plain, and through the Gulf region to Texas (Sabine River), and throngh Arkansas to sontheastern Missonri, central Tennessee, and sonthern kentucky.

Naures in Use.-Willow Oak (R. I., N. T.. Pa.. Del.. Ala., N. C., S. C., Fla., Miss., La., Tex., Ark., Mo.); Peach Oak (N.J., Del., Ohio); Water Oak (S. C.); Swamp Willow Oak (Tex.).

\section{Quercus phellos $\times$ digitata Small.}

RaNgE. - North Carolina (Stanley Combty).

Quercus phellos $\times$ pumila Sudworth.

RAxGe.-New Jersey (Mays Lauding).

Quercus heterophylla Michx. f.

Bartram Oak.

Raxge.-Peunsylvania (ne..r Philatelphia-but tree long since destroyed); New Jersey (near Camden); Delaware (Wilmington); New York (Staten Island); Virginia (near Alexandria); Dustrict of Colnmbia; westeru North Carolina; Temmesse (Coffee County); Alabama (near Falkrille); Texas (Houston).

NaIes IN USE.-Bitram's Oak (Del., Ala.); Burrier's Oak (lit.).

Quercus subimbricaria (de C.) Sudworth.

QUERCUS PHELLOS $\times$ TINCTORIA Gray.

QUERCUS PIELLOS $\times$ NIGRA Britt.

Raxge.--New Jersey (between koyport and South Ambor); New York (Staten Island); North Carolina (Yadkin liver); Sontl Carolina (near Aiken).

Quercus densiflora Hook. \& Arn.

(California) Tamarkania

RAxGe.-Sonthern Oregon (Umpqua River) and sonthwarl throngh California (coast ranges to Santa Ine\%. Monntains-east of Santa Barbara, and western slopes of the Sierra Neviala to Mariposa County).

NAMEs IN tose.-Tanbark Oak (Cal.); Chestunt Oak (Cal.); Califormia Chestuut Oak (Oreg.); Peach Oak (Oreg.); Live Oak (Oreg.).

Quercus densiflora echinoides (R. Br. Campst.) s'argent.

RAxGE.-Sonthern Oregon (Canyon Creek) aud northeru California (Monnt Shasta and Sierra Nevada). 


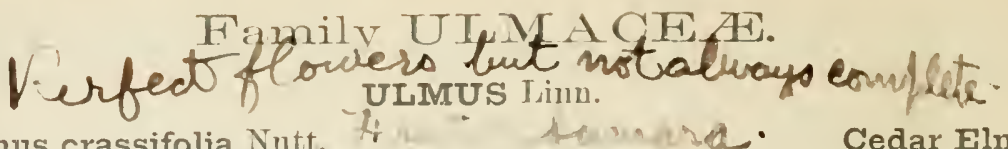

thi Ulmus crassifolia Nutt.

- liavis.-From Mississippi (sunflower River) through sonthern Arkansas mel

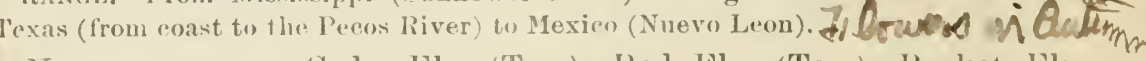
YAMFs IN Usw.-Celar Elm (Tex.): Red Elm (Tex.); Basket Elm (Ark.).

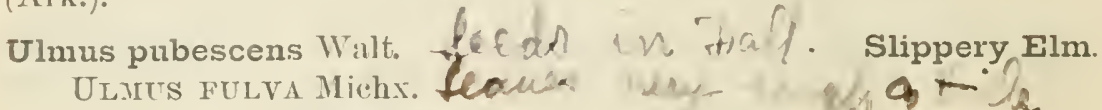

Raxfis.-From Lower St. Lawrenct River (Orleans Island) throngh Ontario to North Daliota anl eastern Nehraska; sonth to western Florida, central Alabama, fand Mississippi and Texas (San Antonio River).

Names IX Un.-Slippery Elu (Vt.. N. H., Mass., R. I., N. I., N. J., Pa., Del., Va., W. Va., Y. C., S. C., Fla., Ala., Gı., Miss., La.. Tex., Ky., Mo., Kans.. Nebr., ()hio, Ill., Ind., Wis., Mieh., Iowa, Minn., Out.); Reci Elı1 (Tt., Mass., N. I.. I lel., Pa., W. Va., S. C., Ala., Miss.. Ia.. 'Tex., Ark., Ky., Mo., Ill., Kins.. Nebr., Iowa, Olıo, Ont., Wis., Mich.. Mimn.): Rerlwoorled Elm (Tenn.); liock Elm ('Tenu.); Orme gras (La.); Moose Elm; Oo-hoosk-alı ="It slips" (Indians. N. Y.)..

\section{Ulmus americana Linn.}

White Flm

RAxGi.,-From sonthern Newfonndland to Lake superior (north shores) and to the eastern base of the lioeky Monntains (here up the Saskatehewan kiver to latitudis $5.1030^{\prime \prime}$ ); sonth to F'lorida (Cape Canaveral and l'oase Creck); west to Hakota (Black Hills), western Nebraska, western Kansas, Indian Territory, and Texas (Rio Coneho River).

Najns in Usw.-American Elm (Vt., Mass., R. I., N. X., Del., Pa., N. C., Miss., Tex., Iil., Ohio. Kans., Nebr., Mieh.. Minn.. Ont.); W'hite Elm (Me., N. M.. Vt., Mass.. R. I., N. Y.. Pa.. N.... Mel.. Va.. W. Va., N. C., S. C., Ala., Fla., Miss., La., Tex., Ark., Ky.. Mo.. Ill., Ind.. Kans., Nebr., (Olio, Ont., lowa, Mich., Minn., N. Mak., S. Mak.); Water Elm (Miss., Trx., Ark., Mo., Ill., Iowa, Mich., Olio.. Minn., Nebr.); Elm (Mass., R. I., Conn., N. J., P’a., N. C., S. C., Iowa, Wis.); Orme Maigle (La.); Swamp Eilm; Rock Iilm.

\section{VARIETY DISTINGUISHEI IN CULTIVATION.}

Ulmus americana pendula Ait.

Weeping American Elm.

\section{Ulmus racemosa 'Thomas.}
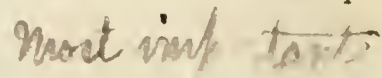

Cork Elm.

RaNGE.-From Quelue (eistern townships) through Ontario, and south through northwestern New Hampshire to southern Vermont; westward thromgh northern New York, southern Michigan, and Wiscousin (Lako Mendota, near Madison) to northeastern Nebraska (Moadville, Keyapaha County), sontheastern Missonri, am midille 'Tonnessee.

NAmes IN USE.-Cork Elm (Vt., Mass., R. I., N. Y., N. J., Ark., K! , Mo., WVis., Mich., Ohio, Iowa); Rock Elın (R. I., W. Va., Ky., Mo., Bil., Wis., Iowa, Mich., Nebr., (Ont.); Hickory Elm (Mo., Ill., Ind., Iowa). 
White Elm (Ont.); Thomas Elm (Tenn.); Northeru Cork-luarked IIm (Temn.); Corkbark Elm (N. Y.); Northeru Cork Elm (Vt.); Wahoo (Onio); Chrf Elur (Wis.); Corky White Llm.

Ulmus alata Michx.

Wing Elm.

RANGE - From sonthern Virginia to western Florida, and from sonthern Jllinois and Indiana throngl western Kientucky and 'Tennessee to the Gulf, and west throngh sonthern Missonri, Arkansas, eastem Indian Territory, and Texas (to Trinity liver).

Names in Usk.-Winced Elm (N. C., S. C., Ark., Tex., Ill., Ind.); Walnoo (W. Va., N. U., S. U., La., Tex., Ky., Mo.): Walıo Elm (Mo.); Witch Elm (W. Va.); Elm (W. Va.); Cork Elm (Fla., S. C., Tex.); Water Elm (Ali.); Small-leaved Elm (N. O.); Red Elm (Fla., Ark.); IVhahoo (S. G.); Corky Elm (Tex.); Mountain Elın (Ark.).

\section{Wemus \\ 1}

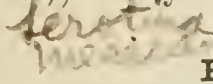

\section{PLANERA Gmelin.}

Planera aquatica (Walt.) Gmel.

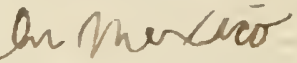

havge.-From North Carolina (Cape Fear River) to westeru Florilla, and west Ihrough sonthern Alabạma anıl Mississtppi to Texas (Trinity River); northward tbrongb restern Lonisiana and Arkansis to sonthern Missonri, west Tennessee (Frumsville), central Kentueky, and Illinois (to lower Wabush River).

NAures in UsE.-American Planetree (Ala.); Planertree (N. C., S. C., Fla., La., Tex., Ark., Tenı.); Water Elm (Fla.); Sycamore (N. C.); Plene (La.).

\section{CELTIS ' Lim.}

Celtis occidentalis Limn.

Fackberry.

Ra.cie.-From St. Lawrence River (St. Helens IsIaml, near Montreal) to sunthern Ontario; in the Luited States from Massachusetts (Massachusctts Bay) to northwestern Nebraska, North Dakota, sonthern Jlaho (Boise ('ity), eastern Wislington and Oregon (Snake River), western Washington (Puget Sound), Nevada? (East Finmboldt Monntains), New Mexico, and south to Florila (Biscayne Bay and Cape Romano), middle Tennessee, Missonri, eastern Kansas, Indian Territory. and eastern Texil:

NAגes Ix Use.-Hackberry (N. H. Vt., R. I., N. I., N. J., Del.. Pa., W Pa., N. U., S. U., Ala., Fla., Miss.. lak.. Tex., Ariz., Ark., Ky., MIo.. Ill.,

'Dr. J. K. Small has recently described the following ntw species, specimens of whicl l have not seen:

Celtrs Gtorgiana Small (Bull. Torr. Bot. Club, vol.24, p.439, 1897). "A low species ('diffuse shrnb') related to $C$. pumila, from which it may be distinguisher loy its smaller, nearly acute leaves, the very short pedicels, and smaller tan-colored drupes" North central Georgia (Yellow River Valley, near McGuire's mill in Gwnett Connty, and in vicinity of Stone Mountain).

Celtis Helleri Small (l.c.). A tree abont 30 feet high and 3 feet in diameter, with unch brauched and wide-sprearung crown. Bark of trunk and main branches with corky warts. The leaves are clescribed as "rather firm, the hlacles wate to oblong, 4 to $7 \mathrm{~cm}$. long, obtuse or acute, crenate-serrate, * + rounderl or sulueorilate at the base, - - scabrous pulescent above, pale and tomentos beneath." Between Sali Antonio and San Antonio River, Texas. This tree appears to he very closely related to Celtis occidentelis reticulata

${ }^{2}$ Shrubly variety, C. occidentalis pumila Gr., common from sonth Atlantic States to Mlissomri, Colorado, Utah, and Nevarla. 
Ind., Wis., Iowa, Kans., Neur., Mich., Mimn., S. Dak., Ohio, Ont.); Sugarberry (N. Y.. Pa., Del., X. C., S. C., Minn.); Nettle-tree (R. I., Mass., Jel., Mich.); American Nettle tree (Temu.); IIoop Aslı (VT.); One-berry (R. I.); Hack-tree (.Minu.); Juniper-tree (N. J.); Bastarl $\operatorname{Elm}$ (N. J.).

Celtis occidentalis reticulata ('Torr.) Sargent.

Palo Blanco.

RAxGE-Fron eistcrn Texis (1)allis) to the Rio Grande River amb through New Mexico and Arizona to southern I tilh, Nevala, California (western rim of Colorado Disert); Lower Califoruia (San .Julio Cauyon and Cerros Island).

NAMEs IN UsE.-Hackberry (Tex.); Palo Blanco (Tex.).

Celtis mississippiensis Bose.

Sugarberry.

RAxGE.-From southern Indiana and Illinois through Kentucky and Trunessue to Florida (Biseayne Baỹ), anul throngh Missouri, Arkansas, and 'lexas to Mexico (Nnevo Leon).

NAMES IN UsE.-Sugarberry (Fli.. Ala.. Miss.); Connu (La.); liois inconnu (La.); Hackberry (Tenn.). Af

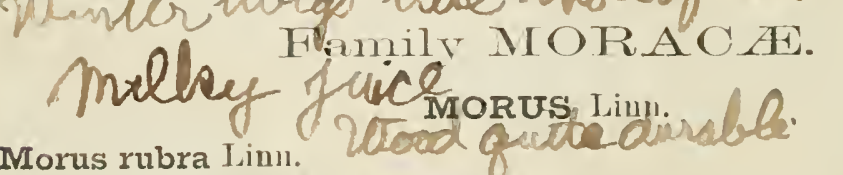

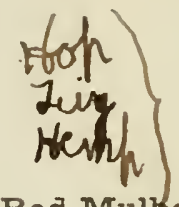

Red Mulberry.

RANGE.-From western Mlassar.lusetts and New York (Long Islind) to southern Untario, rentral Mirhigin, southenstern Nebraskil, eastem kansas; sonth to Florirla (Biseayo liay and Capo Romano) and Texas' (Coloralo River).

Naurs IN Use.-Red Mulberry (Me., Vt., Mass., R. I.. N. Y., N. J., Pa., Del., Ta., W. Ta.. N. C.. Fla. Ala., Ga.. Miss., La., Tex., Ark., Ky., Mo.,Ohio. Mirch.. Ill.. Inci.. Kans., Nebr.,Ont.); Mulberry (Pa., N. C., S.C.. Fla., Ala., Ark.. Tex.. Ky., Мo.. Ohio. Ill.. Iowa, Nebı.); Black Mulberry (N. J., Pa., W. Va.): Virginia Mulberry-tree ('Temu.); Murier Sanvage (La.).

Morus celtidifolia H. B. K.

Mexican Mulberry.

RAxGs. - Fom lexas (south from the coloralo River and monntalins of western part of the State) and southern Xew Mexieo to Arizonal (Santal lita Mlomtinis); Mexico (from Nurvo Leon to Chihuahna and through sonthern Mexico) to CentraI America aud Peru.

Name ix TSE.-Mexiunn Mulberry ('Tex.).

Morus alba Limin.

White Mulberry.

RANGE.-China; but willy cultivated and naturaluzed in the l'uited states.

VAIIETHES IHSTINATISILD IN CULTIVATION.

Morus alba tatarica (Liun.) Loud.

Russian Mulberry.

Morus alba rosea lumel.

Morus alba macrophylla (Moretti) Lond.

Largeleaf Mulberry.

Morus alba vilgaris tokwa (Sieb.) Bur.

Morus alba pyramidalis Seringe.

Morus alba pendula (Dipp.) Sudw.

Morus alba constantiuopolitana (Poir.) Loud.

Morus alba multicaulis (Parr.) Lond.

Morus alba venosa Delile. 


\section{wore apiny when clifled}

Broussonetia papyrifera Vent.

Paper Mulberry.

RANGE.-Japan. ('nltivated and natnralized in the Somthern States.

Indionm felienel rox

Toxylon pomiferum Raf.

MACLURA AURANTIACA Nutt.

RAxGE.-From southern Arkausas (sonth of Arkansas River) throngh southenstern Indian Territory aud southern Texas (to about latitude $35^{\circ} 56^{\prime \prime}$ ). Wielely clis. tributed elsewhere by enltivation.

Naines in Use.-Osage Orange (Mass., R. I., N. Y., N. J., Pa., Del., Va., IV. Va., N. C., S. C., Ga., Ala., Miss., La., 'Tex., Ky., Mo., Olio., Ill., Kans, Nebr., Iowa, Mich.); Bois D'Are (La., 'Tex., Mro.); Bodock (Kans.); Nock Orange (La.); Bow-wood (Ala.); Osage Apple-tree (Teun.); Yellow-wood (Tenn.); Helge (III.); Hedge-plant (Iowa, Nebr.); Osage (Iowa).

VARIETY DISTINGUISIIED IN CULTIVATION.

Toxylon pomiferum inerme André.

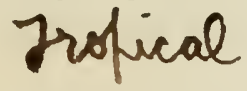

Ficus aurea Nutt.

Thornless Osage Orange.

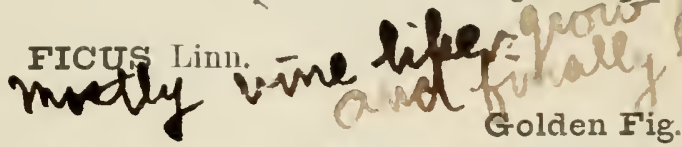

Raxge.-Sonthern Florida (shores and islands from Indian River on the east coast, and Tampa Bay on the west coast to the sonthern keys); Bahama Islands.

NA IES IN UsE.-Wild Fig (Fla.); India-Rubber-tree (Fla.); IVild Rubber-tree (Fla.).; Rubber-tree (Fla.).

Ficus populnea Willd.

Poplarleaf Fig.

Ficus pedunculata Nutt.

RANGe.-Florida (Biseayne Bay region and Kes Largo, l'mbrella Key, Boca Checa Key, Pumpkin liey, and Key West); West Indies.

Najes IN UsE._Wild Fig (Fla.); Iudia-Rubber-tree (Fla.).

\section{Family POLYGONACFAE.}

\section{COCCOLOBIS Browne.}

Coccolobis uvifera (Linn.) Sargent.

Sea Grape.

Ravge.-Couthern FIorisla (shores from Mosqnito Inlet ou the enst coast to the southern keys, and from Tampa Baj on the west coast to (ape Sable); Bermuda and Bahama Islands, West Indies, and in Sonth America from Colombia to I3razil.

Nanes IN USE.--Sea Grape (Fla.); Seaside Plum.

Coccolobis laurifolia (Jacr.) Sargent.

Pigeon Plum.

Coccoloba Floridana Meism.

RAxGe.-Southeru Florida (east const from Cape Canaveral to the southern keys, and on the west eoast from Cape Romano to Capesable; Bahamas, West Indies, and Venezuela.

NAME IN USE.-Pigeon Plum (Fla.) 


\section{Family NYCTAGINACEAE.}

PISONIA LimI.

Pisonia obtusata Jacq.

Blolly

RAxge.-Sonthern Florila (shores on the east coast from rape Canaveral to the southern islands; especially large on Elliotts and Olil lihules liey); West Indies to Brazil.

NAJEs IN UsE.-Pigeon-wool (Fla.); Beef-wood (Fla.); Cork-wood

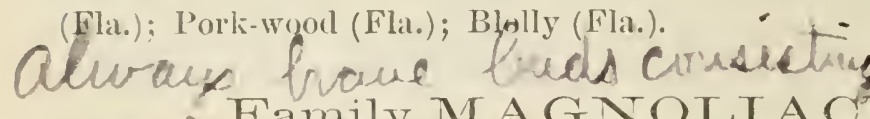

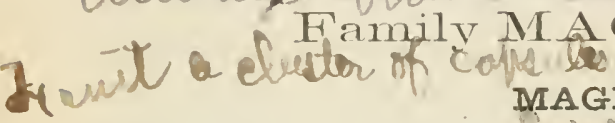

MAGNOLIA LIMU.

Magnolia fœtida (Linn.) Sargent.

\section{Lare: Toaned}

werarel M MGNOLIA GRANDIFLOR A Linn.

RANGe.-Coast region North Carolina (sonth of Cape Fear River) to Florida (Mosquito Inlet and 'Tampa Bay) and westward in the Gulf coast region to T'exas (Brazos River); throngh western Lonisiana to sonthern Arkansas.

Naures in Use.-Maguolia (N. O., S. C., Ala., Fla., Miss., La., Tex., Ky.): Big Laurel (X. C., S. C., Miss., La.); Bull Bay (Ala., Ga., Miss.); Great Laurel Magnolia (Alı.); Laurel-leaved Magnolia; Large-flowered Evergreen Magnolia; Bat-tree; Laurel Bay; Lamel (S. C.).

VARIETIES DISTINGUISIIED IN CULTIVATION.

Magnolia fœtida lanceolota (Ait.) Sndw.

Exmouth Magnolia.

Magnolia fœtida præcox (Lond.) Sarg.

Magnolia fotida angustifolia (Lond.) Sar.

Magnolia fœtida ferruginea (Sims) Sudw.

Magnolia glauca Linn.

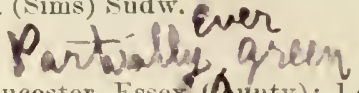

Sweet Magnolia.

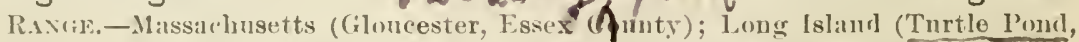
Suftolk ('ounty); from Now Jersey to Florisla (Biscalyue Bay on the cast enast, and to Tampa Bay on the west coast); west in the Gnlf region to Texas (Trinity River).

Names in Use.-Sweet Bay (Mass., R. I, Pa., N. J., N. C., S. C., Ala., Fla., Miss., Ia.., Ark., Mo.); White Bay (N. ('., S. C., Ala., Fla., Miss.. La.); Swamp Laurel (Mass., N. C., Ga., Miss.); Swamp Sassafias (Del., Pa., Temu.); Swamp Magnolia (N. .J., Pa., Tenn.); Maguolia (N.J., Del., Pa.); White Laurel (Del., Miss., Iab.); Beaver-tree (Del., S. C.. Miss.): Bay (S. C.). Ee an unte tereatr.

VARIETLES DISTINGUISHED IN IILTIVATHON.

Magnolia glauca longifolia Ait.

Magnolia glauca major Sims.

Magnolia acuminata Limn.

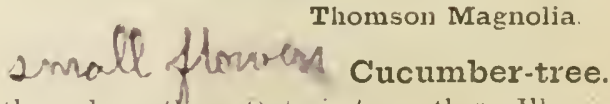

RANGE.- l'rom western New York through vouthern (Intario to southern Illums aud sonth in the Appalachian Mountains to southern Alabama (Stockton) and oortheastern Mississippi (Meridian); central lientneky and Tennessee (near Nashrulle and eastern part of Stato); northeastern, southern, and southwesteru Arkansas.

NAJfs In USE.-Cucumber-tree (R. I., Mass., N. Y., Pa., D. C. (cult.), N. C.,pS. C., Ala., Miss., La., Ark., Ky., IV. Va., Ohio, Ind. Ill.); Moun-

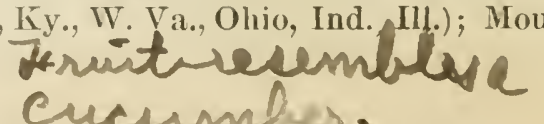


Poplar (Ta.. W. Va., N. C.); Popple (R. 1.); Cncmber-tree (N. I.); Canoe-rood (Tenn.); Oll-Wife's shirt-tree ('Temu.); Ko-yen-ta-ka-ahta =" White-tree" (Onandag"a Indians, N. I.); Basswood (Ohio).

VARIETIEA IMSTINGLISHED IN NILTINATINN.

Liriodendron tulipifera obtusiloba Michx.

Liriodendrou tulipifera pyramidalis Dipp.

Liriodendron tulipifera penache Elw. \& B.

Pyramidal Tulip-tree.

Variegated Tulip-tree.

Liriodendron tulipifera aureo-maculata (Arb. liew.) Sudw.

\section{Farnily ANNONACHAE.}

Asimina triloba (Iinn.) Dnual.

ASIMINA Adans.

Pecubiar

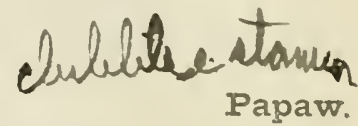

RAxil:- From western Niw York to the north shores of Lake Haron: from enstern and central Pennsylvania through southeru Michigan, eastern liansas: south to midlle Floricla and Texas (to the Sabine River).

M.M.Ames in UsE.-l'apaw (P. I., Del., N. Y., N. J., D. C.. Va., W. Va., W. C., S. C., Ga., Miss., La., Ky., Ohio, Jll., Ind., Mo., Iowa. Kans., Nebr.); Custard Apple (Ont., Del., Pa., Ohio, S. C., Miss.): Banana (Ark.); False Banana (Ill.); Jasmine (Ia.); Jasminier (La.); Fetirl Shrub (X. C.).

\section{ANNONA Linn.}

Annona glabra Linı.

Pond Apple.

RAxGE. - Southern Florida (shores on the east coast from Biscayne Bay to ('ilpe Malalıar, and on the west coast from Pease Creek to Caloosa River); Bahama, san. Domingo, St. Thomas, and St. Croix islands.

Names in USE.-Pond Appie (Fla.); Custarl Apple (Fla.).

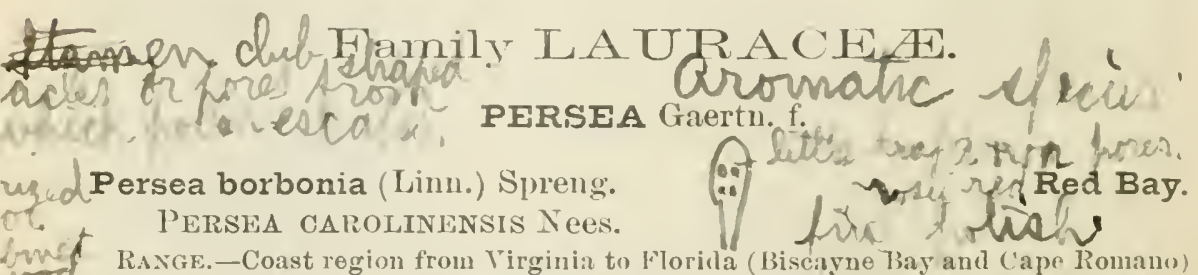

RAxGE.-Coast region from Virginia to Florilla (Biscayne Tay and Cape Romano) amd the Gulf region to Texis (Brazos River); uorthwark through Louisiana to OCosmuthern Arkansis.

NAJIEs IN UsE.-Red Bay (N. C., S. C., Ga.. Fla., Ala., Miss., La.); Bay Galls (Temn.); Lanrel-tree (La.); Laurier Petit Magnolia (La.); Florida Mahogany (Fla.); Sweet Bay (Fla.); False Mahogany (lit.)

Persea pubescens (Pursh) Sargent.

PERSEA CAROLINENSIS var. PALUSTRIS Chapm.

RAxGE.-South Atlantic and Gulf coast region from North Carolina to Mississippí. Naues In Use.-Swamp Red-Bay (Fla.); Bay (Ga.). 
OCOTEA Anble`s

Ocotea catesbyana (Michx.) Sargent.

Lancewood.

NeCTANDRA WILLDenoviana Meisner.

RAxge.-Southern Florida (shores aud islands on the east "oust ronth of Capo Canaveral, and on the west coast sonth of Cape Romino).

NAIES IN USE.-Lancewood (Fla.); Sweetwood (Jamaic:a); Cigua (Cuba); Avispillo (Puerto Rico); Canela ( Prerto Rico).

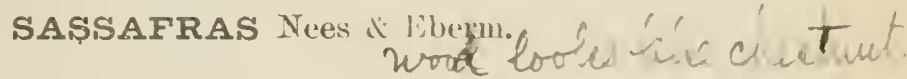

Sassafras sassafras (Lim!.) Karst.

SAssafras OFFICINALE Nees \& Eberm.

Ravgk.-From eastern Missal huset ts through southeru Vermont, sout hern Ontario, and central Michigan, southeastern Iowa, eastern Kansas, and Indian 'Territory; south to ceutral Florida and Texas (Brazos River).

Nayes in use.-Sassafras (Vt., N. H., Mass., Conn., R. I., N. Y., N. J., Pa., Delo, Mu., Ta., IV. Va., N. C., S. C., Ga., Fla., Miss., La., Tex., Ark., Ky., Mo., Ill., Ind., Kans., Nebr., Mich., Olio, Ont.); Saxifrax 31.5 (Fla.); Saxifuax-tree (Ten1.); Sassafac (W. Va.); Sassafrac (Del); Gumbo file (La., Negro dialect); Wah-eh-nali-kas " "Syelling stigk"

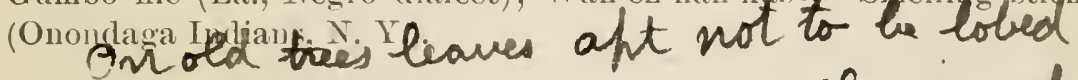
UMBEILULARIA. Nutt.

Umbellularia californica (Hook. \& Arn.) Nutt. California Laurel

RAvge.-From Oregon (Rogne River) through Calitornia (coast ranges and western slopes of Sierra Nevada to sonthern slopes of San Bernardino Monntains).

NAMEs in Use.-Califoruia Laurel (Cal., Nev.); Mountain Laurel (Cal., Nev.); California Bay-tree (Cal., Nev.); Myrtle-tree (Oreg.); Cajeput (Oreg.); California Olive (Oreg.); Myrtle (Oreg.); Spice-treo (Nev., Oreg.); Laurel (Cal.): Bay-treg (Cal.); Prequphne (Ca.); Cali. fornian Sassafras.

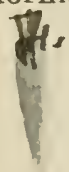

$40.6 \mathrm{lb}$.

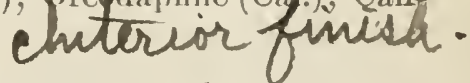

\section{Family CAPPARIDACHAE.}

CAPPARIS Linu.

Capparis jamaicensis Jacq.

Florida Caper.

RANGL.-_outhern Florida (coast from Cape Canaveral to the southern keys).

NAME IN USE.-Cilper-tree (Fla.).

\section{Family SAXIFRAGACEA.}

LYONOTHAMNUS Fray.

Lyonothamnus floribundus Gray.

Santa Cruz Ironwood.

RANGE.-Santa Catalina and Santa Cruz islands off the southern coast of California. 


\section{Family HAMAMTEID ACEA.}

\section{Filowers}

EAMAMELISUIIn.

Hamamelis virginiana Lim11.

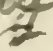

Witch Fazel

RaxGl.-From Nova Scotia, New Brunswick, anul valley of the St. Lawrence River to southern Ontario, Wisconsin, ancl eastern Neluraska; south to northern Florida and easteru 'Texas.

Naxies in UsF.-Witch Hazel (Me., Vt., Mass., R. I., Conn., N. Y., N. J., Del., Pa.. Va., W. Va., N. C., S. C., Ga., Ala., Fla., Miss., La., Tex., Ky., Mo., Iil., Wis., Iowa, Ohio. Mich., Nebr.); Oe-eh-nalı-kwe. ha-he = "Spotted stick" (Onondaga Indiaus, N. I.); Winter Bloom, Snapping Hazel, Spotterl Alder (lit. of domestic medicine).

\section{Chumese variety IIQUIDAMBAR Linn. Leaves 5 lobd.} Liqulambar styraciflua finm.

(Red, or) Sweet Gum.

Raxge.-From Connecticnt (Fairfield County) to sontheastern Missonri and Arkansas; sonth to Florida (Cape Canaveral and Tampa Bay) and Texas ('Trinity River).

Nayes in UsE.-Sweet Gum (Mass., R. I., N. Y., N. J., Pa., Del., Va., W. Va., N. C., S. C., Ga., Ala., Fla., Miss., La., Tex., Ark., Ky., Mo., Ill., Ind., Ohio); Liquidamber (R. I., N. Y., Del., N. J., Pa., La., Tex., Olıio, Ill.); Red Gum (Ta., Ala., Miss., Tex., La.); Gum (Va.); Gum-tree (S. U., La.); Alligator-mool (N.J.); Bilsted (N.J.); Starleaved Gum; Satin Walnut (lumber markets).

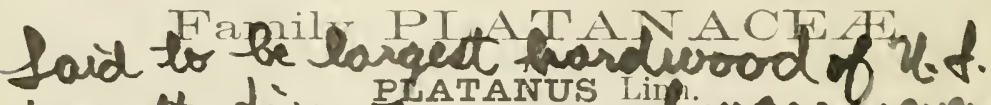

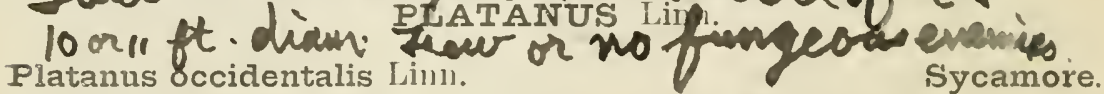

Raxas.-Sontheastern New Hampshire and southern Maine to northern Fermont 'and Iake Ontario (Don liver, near north shores of the lake): west to eastern Nebraskiu and Kansas, aud sonth to northern Florida, central Alahana and Mississippi, and Texas (Brizos River aul thence south to Devils River).

Names in UsE.-Sycamore (Y't., N. H., Mass., Comm., R. I., N. I., X.rard Pa., Del. Va., Wr. Ira., N. C., S. C., Cra.. Fla.. Ala., Miss., La., Tex., ky., Ark., Mo., Ill.. Ind.. Iowa. Kan.. Nebr.. Mich.. Wis.. (Ohio. Ont.); Buttou-wood (Vt., N. H.. R. I.. Mass., N. Y.. N. J., Pa.. Del., S. C., Ala., Miss., La.. Tex., Ark., Mo., Ill., Nebr., Mich., Miın., Ohiı, Ont.); But. tomball-tree (Mass., R. I., Conn., N. Y., N..J., Pa.. Del., Miss.. La., Mo., Ill., Iowa, Mieh., Nelur.. Ohio): Bnttonball (R. I.. N. Y.. Pa., Fla.); Plane-tree (R. I., Del., S. C., Kans., Nebr., Iowa); Water Beech (Del.); fintane (La.); Cotonier (La.); Bois puant (La.); Oo-da-te-clua-wunnes = "Big" stoekings" (Indiaus, N. Y.).

Platauus racemosa $\mathrm{N}_{1} \mathrm{tt}$.

California Sycamore.

RAxGE.-California (from the lower sacramento River through interior valleys and coast ranges) to Lower Calitornial (San Pedro Martir Momtain).

Nanes IN USE.-Sycamore (Cal.); Buttonwood; Buttonball-tree ¿Cal.); Buttonba'l (C'al.) 


\section{and boll \\ Platanus wrightii Wats. \\ RAxge.-Southwestern New Ilexico and sonthern Arizona; Mexiro (Sonora). \\ Names in USE.-Sycamore (Ariz.): Arizona Sycamore (Cal.).}

\section{Family ROSACHAE.}

VAUQUELINIA Cormea $\mathrm{X}$ H. В. K.

Vauquelinia californica ('Torr.) Sargent.

VAUQUELINIA 'TORREYI Wats.

RANGE.-Southern Arizona (monntains; arhorescent on Santa ('atalina Mountains) and Mexico (Sonora) to Lower California.

\section{Cercocarptî̀ leâfólius Nutt.}

Vauquelinia.

RANGE.-From western Wyoming to Montana (western slopes Rocky Monntains), Idaho (Cour d'Alene Mountains), Oregon (eastern Blue Monntains), and sontluward (throngh Wasatch Monutains and ranges of the Great Basiu) to California (eastern slopes Sierra Nevada and northern slopes of San Bernardino Mountains), and to northern New Mexico and Arizona.

NAME IN Use.-Mountain Mahogany (Cal.. N. Mex., Utah. Idaho. Mont.).

Cercocarpus parvifolius Nutt.

Valley Mahogany.

RAxGE. - From western Nebraska to Oregon (Siskiyou Mountains), sonth to western Texas and northern Mexico; California (west of Sierra Nevada and sonth to San Jacinto mountains; Santa ('ruz Islands); Lower California (monntains).

Names IN USE.-Mountain Mahogany (Cal., N. Mex., Utah, Idaho, Colo.); Talley Mahogany (Cal.); Feather-tree (Cal.).

Cercocarpus parvifolius betuloides (Nutt) Sargent.

Birchleaf Mahogany.

RAvge.-California (coast ranges).

Cercocarpus parvifolius breviflorus ( $\mathrm{Gl}$.) Jones.

Short-flower Mahogany.

RAxGe.-Sonthern bonndary of New Mexico, Arizona, and California.

Cercocarpus parvifolius paucidentatus Wats.

Entireleaf Mahogany.

RANGE.-Northern, New Mexicn and sonthern Arizona.

\section{PYRUS Linn.}

Pyrus coronaria Linu.

Sweet Crab.

RAxge.-Canada (from Humber River went on shores of Lake Erie) and sonth throngh western New York aud Penusylvania to the District of Columbia, and on the Allegheny Mountains to central Alabana; west to sonthern Minnesota, eastern Nebruska, eastern Kansas, Indian Territory, northern Lonisiana, and eastern Texas.

Nanes IN UsE.-American Crab (R. I.. X. J., Del., Pa., Ala., Miss., La., Ill., Ohio, Ont., Kaus., Nebr., Mich.. Minu.); Sweet-scented Crab (Mass., Del., Pa., N. C., S. C., Miss., Ill., Ohio, Iowa); Crab Apple (S. O., L.a., Ky., Mo., Ill., Olıio, Iowa, Kaus.. Nebr̃); Wild Crab (N. Y., Ill.. lud., Wis., Iowa, Kans., Minn., Mo., Ark.); Crab (W. Va., N. C., Ga., Miss., Wis.); American Crab Apple (Nebr.); Fragrant Crab. 
Pyrus ioensis (TVoođ) Bailey.

Iowa Crab.

RANGk.-Wisconsin. lllinois, Iowa, and Kinsas. Range imperfectly understood.

Pyrus soulardi Bailey.

Soulard Apple.

RANGE.-Minnesota to Texas, Less common in nature than in cultivation.

Pyrus malus Linn.

Wild Apple.

RAx(is.-Europe. Widely naturalized in the C'niter States and running wild in many localities.

Pyrus angustifolia Ait.

Narrowleaf Crab.

RAxGi.-From Peunsylvania (Allegheny Connty), New Jersey (Cape llay County), and sonthern Delaware sonthward (in coast region) to western Florida (Chattahoocheo River); west throngh the Gulf States to Louisiaua (Red River), and north to midrle (Bonair, Dickson County) surl eastern 'Temessee.

NAues in UsE.—Sonthern Crab Apple (Del., N. C., Ala., Miss., La.); American Crab Apple (K. I., N. J., Miss.); Narrowleaf Crab (Ala.); Crab Apple (N. C., S. C., Ga.); Wild rirab Apple; Narrowleaved Crab Apple (N. (.)); Narrowleaved Crab (S. C.); Crabtree (Va., Fla.).

Pyrus rivularis Dougl.

Oregon Crab.

RANGE.-From the Alentian Islands soutb along the coast and islinis of Alaska and British Columbia through western Washington and Oregou to Califoruia (Sonoma and Plumas counties).

NaMes In UsE.-Oregon Crab Apple (Cal., Wash., Oreg.); Crab or Will Apple.

Pyrus americana (Marsh.) de C.

Mountain Ash

RAxge.-From Newfoundland to Manitoba, and south throngh Qnebec aud Ontario, Great Lake region, and high elevations in northeastern United States to easteru 'l'ennessee, Virgiuia, and North Caroliuir.

NAMEs IN UsE.-Mountain Ash (Vt., N. H., Mass., R. I., N. X., N. J., Pa., Va., W. Va., N. C., Ky., Mich., Ont.): American Mountain Ash (Pa.); Mountain Sumach (N. C., S. C.); Wine-trec (N. C.); Roundwood (Me.); Life of Man (N. Y.); Rowan-berry; "Peruve" (mts., Tenn.).

Pyrus americana microcarpa (Pursh) Torr. \& Gr.

RANGk.-Allegheny Monutains.

Smallfruit Mountain Ash.

Pyrus sambucifolia Cham. \& Schl.

Elderleaf Mountain Ash.

RaxGE.--Southern Greenlaud to Labrador and northern New Euglaud (monntains); westwarl on the northerm shores of the Great Lakes to Little Slave Lake, throngh the Rocky Monntains to Alaska (Kanchatka and northeastern Asia, Knril Islands to Japan); south (in mountains) to New Mexico and central Califoruia (Yosemito Valles).

NAMES IN USE.-Mountain Ash (Vt., Ont.); Elder-leaved Mountain Ash.

\section{AMELANCHIER Medic.}

Amelanchier canadensis (Limm.) Merlic.

Serviceberry.

RANGE.-From Newfonudland southward to northern l'lorida, and west along tho northeru shores of the Great Lakes to Minnesota, eastern Nebraska, eastern Kansas. Lonisiana, and southern Arkansas.

Names IN USE.-June-berry (Mass., N. Y., Pa., Del., Ill., Kans., S. Dak.); Shad Bush (Mass., R. I., N. Y., Pa., Del., S. C.); Service- 
berry (Del., Ill., Ark., Fla., S. Dak.); Service-tree (Pa., Del.); May Cherry (Pa., N. C.); Indian Cherry (Pa.); Wild Indian Pear (Newfoundand); Currant tree (Fla., Ala.); Shad-berry (Fla.); "Savice" (Tein.).

Amelanchier canadensis obovalis (Michx.) B. S. P.

Longleaf Service-tree.

RANGE.-Nova Scotia, New Brunswick, Quebec, Ontario, anl northwestward to the Mackenzie River (lititude 65) ; sonth to Virginia, and west to Minuesota and Missonri; Sonth Curolina (coast region) to Alabana (Mobilo Bay).

Amelanchier canadensis spicata (Lam.) Sargent.

Amelanchier alnifolia Nutt.

Western Serviceberry.

RAxGe.-From Alaska (Yukon River, latitude $62^{\circ} 45^{\prime}$ ) to California (sonthern boundary); eastward throngh British Columbra, Siskitchewan, and Manitoba to Lake Superior (western shores), northern Miehigan, Nubraska, Colorado, and New Mexico (Rocks Monntains).

NAMEs IN UsE.-Pigeon-berry (So. Oreg.); Serviceberry; Westeru Serviceberry; "Sarvice" (Wyo.).

\section{Cratæegus douglasii Lindl.}

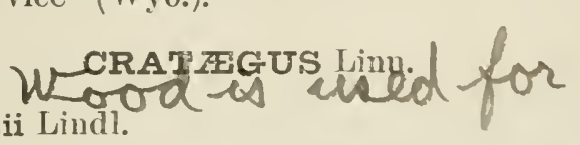

RAxGE. - From British Columbia (Parsnip River) through Washington and Oregon to California (Pitt River), and through Idaho and Montana (Flathead River at western base of Rocky Mountains).

Naues in Use.-Thorn Apple (Cal., Utah, Wash., liaho, Nev.); Hawthorn (Cal.); Blarek Haw (Mont.); Western Haw (Oreg.); Thorn (N. Mex., Mont., I(bho); Haw (Oreg.); Black Thorn (Idaho, Utah, Wash.); Western Hawthorn (Utah); River Hawthorn (Utah); Wild Hawthorn (Utalı); Thorn-tree; Wild Thorn (Oreg.).

Cratzegus brachyacantha Sarg. \& Engelm.

Hog Haw.

RAxge.-Northwestern Lonisima (valley of Bayou Dorcheat) and western Luuisiana to eastern Texas (Sabine River).

Nayes in UsE.-Hog's Haw (La.); Red Haw (La.); Pomette Blene (La.).

Cratægus saligna Greene.

Willow Haw.

Raxge,-Lower Cimarron hiver, Coloraro.

Cratægus crus-galli Linn.

Cockspur.

Raxge.-From the st. Lawrence River to Lake Erie (north shores) and southward to western Florida (Chipola River); westward to Missonri and Texas (Colorado River).

Nayes in USE.-Cockspur Thorn (Vt., N. H., R. l., N. Y., N. J., Pa., Del., W.Va., N. C., S. C., Ala., Fla., Miss., Mo., Mll., Kans.,Ont.); Red Haw (Tex., Mll., Mich., Miss.); Newcistle Thorn (Del., Miss.); Thorn Apple (N. Y., W. Va.); 'Thoru Bush (Pa.); Thorn (Pa., Ky.); Pin Thorn (W. Ta.); Thorn Plum (Me.); Cockspur Hawthorn (l'a.); Hawthorn (Pa.); Haw (S. C.).

Cratægus crus-galli salicifolia (Medic.) Ait.

Willowleaf Cockspur. 
Cratægus crus-galli prunellifolia (Poir.) Sudw.

Broadleaf Cockspur

Cratægus crus-galli angustifolia (Ehr.) Sulw.

Narrowleaf Cockspur.

Cratægus crus-galli prunifolia (Marsh.) Tor'r. \& Gr.

Plumleaf Cockspur.

Cratæegus crus-galli fontanesiana (Spach) Wenz. Cratzegus crus-galli berberifolia (Torr. \& Gr.) Sarg.

Barberryleaf Cockspur.

RANGE.-South Atinntie States, and in western Louisiana and eastern Texas.

Cratæegus coccinea Linn.

Scarlet Haw.

RANGE.-From Newfondland (western shores) throngh Qnebec and Ontario west throngh Winnpeg nearly to the eastern base of the Rocky Monntains; sonth to northern Florida, and west to eastern Texas, Nebraska, and Kansas.

Naues in Use.-Scarlet Haw (N. H., Mass., N. Y., N. J., Pa., N. C.. S. C., Miss., Ark., Mo., Ill., Nebr., Iowa, Minn.); Red Haw (R. I., X. I., W. Va., S. C., Ga., Miss., La., Tex., Mo., Ill., Nebr., Ohio, Iowa, Minn.. S. Dak.); White Thorn (Vt., R. I., Del., Miss., lowa, Ill., Kans., Minn.. Ont.); Scarlet Thorn (Vt., Mass., R. I., N. J., Del., Ont.); Scarlet-fruited Thorn (Mich., Minn.); Red Thorn (Ky.); Hawthorn (Pa., Iowa); Thorn (Vt., N. Y., Ky., Mont.); Thorn Bush (R. I., Pa.); Thorn Apple (Vt., Mont.); Thorn Apple-tree (Minn.); Thorn Plum (Me., VT., N. Y.): Haw Bush (Mont.); Scarlet Thorn-Haw (Fla.); Hedge Thorn (Mont.); Red Thorn Bush (Ky.. Ind.).

Cratægus macracantha (Lindll.) Lond.

Longspine Haw.

RAxGE.-Eastern Massachnsetts, Maine (coast), northern New Hampshive and Vermont, Qnebec, and west through Winnipeg, sonthorn Michigan, Missouri, southwestern Colorado and Now Mexico (Rocky Monntains), eastern Oregon and Washingto' (eastern s.opres (asiogle Monntains).

Cratægus mollis (Torr. \& (ir.) Scheele.

Downy Haw.

Cra'thas 'TOMen'Tosa val'. Mollis Gray.

liAxor.-From Massachusetts (Bay) to northern New England and Queloec, and west through sontlern Michigan (as far north as Roscommon County) to Missouri, and throngh middle 'Temnessee to northern Al,bama, and throngh Arkansas to 'Texas (San Antonio liver): Mexico (Sierra líatre, near Saltillo).

NAMES IN USE.-Scarlet Haw; Red Thorn-aplele (Mich.).

\section{Cratægus oxyacantha linin.}

English Hawthorn.

Raxas.-Enope. Widely cultivated, and nituralized in a few localities in the Eastern United states.

IARHTHS DISTIXIHISHED IN CULTIVATION.

Cratægus oxyacantha oxyacanthoides ('lhuill.) lieich.

Cratægus oxyacantha monogyna (Juc.) loukl.

Cratægus oxyacantha laciniata (liorkh.) de C.

Cratægus oxyazantlıa diversifolia (l'oir.) Sndw.

Cratregus oxyacantha incisa hengel.

Crategus oxyacantha auriculata l)ipp.

Cratægus oxyacantlia sorbifolia (Desf.) l)ipp.

Cratægus oxyacantha pimnatiloba (Lange.) sudw.

Cratægus oxyacantha ferox lipp.

Cratægus oxyacautha curtispina Suclw. 
Cratægus oxyacantha flexuosa Loud.

Cratægus oxyacantlia stricta Loul.

Cratægus oxyacantha pendula Lond.

Cratægus oxyacantha aurea Lond.

Cratægus oxyacantha variegata (Dipp.) Snitr.

Cratægus oxyacautha splendens (Koch) Sudw.

Cratægus oxyacantha el iocarpa Loud.

Cratægus oxyacantha oliveriana (Poir.) Loud.

Cratægus oxyacantha aurantiaca Loul.

Cratægus oxyacantha leucocarpa Loud.

Cratægus oxyacantha apetala Lond.

Cratægus oxyacantha præcox Loud.

Cratægus oxyacantha multiplex Lour.

Cratægus oxyacantha rosea Lond.

Cratægus oxyacantha punicea Loud.

Cratægus oxyacantha punicea plena Sudw.

Cratægus oxyacantha semperflorens Dipp.

Cratægus oxyacantha gratanensis (Boiss.) Sndw.

Cratægus oxyacantha macrocarpa (Hegetsch.) Sudw.

Cratæegus tomentosa Liun.

Pear Haw.

Ravge.-From New York (Hudson Rivernear Troy) toeastern Pennsçlvania (Chestnut Hill); west throngh central New York to Michigan (as far north as lioscommon County) and Missonri; Allogheny Mountains from northern Georgia to Middle Tennessee (near Nashville); through Arkansas to easteru Texas (near Dallas).

Naines IN USE.-Black Thorn (R. I., N. J., Pa., Del., Ga., Fla., La. Miss., Ky., Ill., Ind., Ohio); Pear Haw (Miss., Ohio); Red Haw (Miss., Mo.); Pear Thorn (R. I., N. J., Mich.); White Thorn; Thorn (N. I., Ky.); Common Thorn (Pa.); Hawthorn; Thorn-apple (Ill.); Thorn Plum.

Cratæegus punctata Jacq.

Dotted Haw.

ORAT EGUS TOMENTOSA var. PUNCTATA Gray.

RANGe.-From Quebec (Chateangay River near Hontreal) to Ontario (Detroit River); northern Jew Hampshire and Vermont and south through southern Michigan and Western Massachnsetts to Middle Tennessee, and along Appalachian Mountains to northern Georgia and Alabama.

NAIE IN USE.-Dotted-fruited Thorn (lit.).

Cratægus punctata canescens Britton.

White Dotted Haw.

RaNGE.-Vermont (Ferrisburg).

VARIETY DISTINGUISHED IN CULTIVATION.

Cratægus punctata zanthocarpa (Medic.) Lav. Yellowfruit Dotted Haw.

Cratzegus spathulata Michx.

Spatulate Haw.

RANGE.-Coast region from sonthern Virginia to northeru Florida aud west to Arkansas (Hot Springs) and Texas (Colorado River).

Crataegus cordata (Mill.) Ait.

Washington Haw.

RANGE.-From Pennsylrania (Lebanon County) and Virginia (upper Potomac River) sonth in Appalachian foothills region to northern Georgia; west to Middle Tennessee, Kentucky, and southern Illinois (lower Wabash River).

Names IN UsE. - Washington .Thorn (N. J., Pa., Del., N. C., S. C., Ill.); Virginia Thonn (Del.); Heart-leaved Thorn (Temn.); Thorn (Ky.); Red Haw. 
Cratæegus viridis Linn.

Green Haw.

RAxGl:-From Sontlı (arolina (Savannah River) to westeru Floricla (Chattahoochee River); Alabama (mountain rewon to coast planu), from the Mississipu River (up to mear St. Lanis) to Texas (Coloralo River).

Naines in Use.-Tree Haw (Ala., Miss., La., S. C.); Red Haw (Ala., Miss., La.); Ilaw (Ala.); Senellier (La.); Tree Thorn (lia.).

Cratzegus apiifolia (Marsh.) Michx.

Parsley Haw.

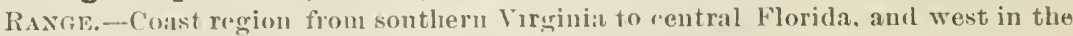
Gulf region to south'ru Arkansas :nd Texas (Trinity hiver).

NAMles in Ust.-Parsley Haw (N. C., Asla., Fla., Miss., La.); Red Haw (Miss.); Parsley-leaved Hiw (S. C.).

Cratægus flava Ait.

Yellow Haw.

Ravge.-Coist region from sonthern Virginia (in North Carolina to western slopes of the Allegheny Mountaius) to Florida (Tampa Bay); west throngh Alabima (monntain region to coast pine belt) and Mississippi.

NAMEs in USE.-Haw (Fla.); Yellow Haw (Fla.); Red Haw.

Crategus elliptica Ait.

Downy Yellow Haw.

RANGE.-Middlo districts of Nortl Carolina, South Carolina, and Georgia to the coast plain of Alabama.

NAME IN UsF.-Summer Haw (S. C., Ga.).

Cratæegus uniflora Muenchl.

Small-leaf Haw.

Crategus parvifolia Solander in Ait.

RANGE.-From New Jersey (Delaware River) to Florida and west in the Gulf Statis to Louisiana and soutliern Arkansas.

Cratægus æestivalis (Walt.) Torr. \& Gr.

Summer Haw.

RAxGe.-Coast region from South Carolina (Savannah River) to northern Florida and west in the Gulf States to Texas (Sabine River).

Nanes in Use.-May Haw (Tex.); Apple Haw (Fla.); Summer Haw (Fla.).

\section{HETEROMELES Roem.}

Heteromeles arbutifolia (Poir.) Roem.

Christmas-berry.

RANGE.-Through Califormia (coast regron from Mendocıno County) and islands to Lower California; iuland to Sierra Nevarla and San Bernardmo mountans.

NaImes IN USE.-California Holly (Cal.); Christmas-berry (Cal.); Chamiso (Cal.); Toyon (Cal.); Tollon (Cal.).

\section{CHRYSOBALANUS INIn.}

Chrysobalanus icaco Linn.

Cocoa Plum.

RaNGi:-Sonthern Florida (on the east coast from Cajo Canaveril to Biscayne Bay, and on the west coast from Caxumbas bay to the southern koys); shores of West Indies, sonthern Mexico, and Central America; Sonth America (northern and eastern coast to southern Brazil); Africa (west coast from Senegambia to Congo country).

Names in USE.—Cocoa Plum (Fla.); Gopher Plum (Fla.). 


\section{PRUNUS Lill1。}

Prunus nigra Ait.

Canada Plum.

Ravge.-From Newfoundland through the St. Lawrence River valley to Manitoba (Rainy and Assinibone rivers and Lake Manitoba). By cnltivation, natnralized in parts of Michigan, northern New Fugland, Now York, and eastern Massachusetts, and may also be looked for in northern Wiscousin and Minnesotil.

Names In Use.-Canada Plum (Mass., N. Y., Mich., Ont.); Rerl Plum (Me., Vt., Ont., Mich.); Horse Plum (Me., Vt.); Will Plum (Me., Mass., Vt., N. Y.).

\section{Prunus americana Marsl.}

Wild Plum.

R. A NGE.-From midlle and northeru Now Jersey and central New York to Montana (Mrssouri liver), Nebraska, Colorado (eastern base liocky Monutaius), sonthern New Mexico (Rio Graude River), and sonth to western F'lorida; mortheastern Mexico (mountains).

Names in Use.-Wild Plum (R. I., N. J., IJel., Pa., Va., W. Va., N. C., S. C., Ga., Fla., Ala., Miss., La., Tex., Ky., Mo., Ark., Ill., Ind., Ohio, Mich., Ont., Kans., Nebr., Iowa, Colo.): Yellow I'lum (N. Y., Del., Pa., Mıss., Nebr.); Red Plum (Del., Pa., N. C., Miss., La., Nebr.); Horse Plum (Miss., Ark., Colo.); Hog Plum (Colo., Mo.); August Plum (\$. C.); Native Plum (Iowa); Plum (Ill.); Plum Granite; Goose Plum (Ind.); Sloe (Fla.).

Prunus americana lanata Sud worth.

Woollyleaf Plum.

RANGE.-Missonri to northern Mexico.

Prunus hortulana Bailey.

Garden Wild Plum.

Raxge.-Illinois (near Oqnawka on Mississippi River); Missonri (near St. Lonis; Maramec River); middle Tennessee (uear Lebanon and Lewishurg). Ramge imperfectly known and may be looked for from sontheru Illinois and Indiana to eastern Texas.

NAmes in Use.-Wild Gonse Plum (Temm.); Groose Plim ('Temm.).

Prunus hortulana mineri Bailey.

Miner Plum.

Naye in USE.-Goose Plum (Tenn.).

Prunus angustifolia Marsh.

Chickasaw Plum.

Prunus chicasa Michx.

RANGE.-Natural range uncertain. Widely naturalizerl from southern Delaware and Kentucky to eastern Kansas and sonth to central Florida and eastern Texas. Appears like a tree escaped from cultivation.

Nayes in Use.-Chickasaw Plum (Del., W. Va., T. C., Ga., Fla., Ala., La., Tex., Miss., Ill., Kans.); Hog Plum (Miss., Tex.): IVild lied Cherry (La.); Mountain Cherry; Yellow Plum (Fla.).

\section{Prunus allegheniensis Porter.}

Allegheny Sloe.

Raxge-Central Pennsylvania (Tusseys Monntain, Inntinglon Comuty; Bald Eagle Mountain and valley, and Alleghenies in Cleartield and Filk counties).

Prunus subcordata Benth.

RAxGE.-Sonthern Oreyon to central California (west of the C'asculles and Sierri Marlre mountains).

Nane in Use.-Wild Plum. 
Prunus umbellata' Ell.

Black Sloe.

liaxcis. - Coast region fiom South Carolina to Florida (Mosngnito Inlet ou the cast coast, and on the west enast from Tampa Bay) west to eastern Misissippi in Louisiana (Mississippi River near laton Jonge and Red liver from Alexandria to Shreveport) to southern Arkinsas (near Camilen).

Nanes In UsE.-Black Sloe (S. C., Ga., Ala., Miss.); Sonthern Bullace Plum (S. C., Ala., Miss.); Hog Plum (Fla.); Wild Plum (Fla.); Sloe.

Frunus emarginata (Dougl.) Walp.

Bitter Cherry.

RAsGe.-From Montaua (upper Jocko liver) througl the momitains of Iduho and Washington, and sonthern British Columbia to Vanconver lsland; south throngh western Washington, Oregron, and northern California (on eoast ranges, to near San Francisco Bary); southward in California (on western slopes Sierra Nevarla to the Yosemite Valley, and on easteru slopes Sierras to Lake Talioe aud vicinity of Carson City, Ner.); also un Santa Lnvia Monntains; Nerara (Washo Monntain).

Nanes Ix t'se.-Wild Plum (Cal.); Bitter Cherry (Idaho, Cal.); Wild Cherry.

\section{Prunus emarginata villosa Sulworth.}

Woollyleaf Cherry.

Prunds exarginata var. jollis Brewer, not Torr.

RaxGe.-Southern California (San Bernarlino Mountains).

Prunus pemsylvanica Lim. f.

Wild Red Cherry.

liasGE. - From New fonndland and Labrador (Strait of Bellisle) northward to Hndson liar (near lig River), sonth Inlian Lake, and west to liritish Columbia (eastern slopes eoast ranges in valley Fraser River); south to Pennsyivania and along the Allegleny Momntains to western North Carolina and eastem Tennessec, to Michigan (as fir south as Ionia Conuty), northern Illinois, central Iowa: Colorado (eastern slopes of Rocky Mountains).

Saues in Usk.-Wild Red Cherry (Me., V't., N. H.. Miss., R. I., Conn., N. Y., Y. J., Pa., Va.. N. C., Mich., Ont., Ill., Wis., Iuwa, Minn., N. Dak.); Pin Cherry (N. H.. Vt., N. I., Mich., Iowa, N. Dali.); Pigeon Cherry (Tt., X.H., R.I., N. Y.,Ont., N.I)ak.); Will Cherı (N. Y., Tenn.); Bird Cherry (Io., N. H., N. I., Pa., Minn.. Iowa): Reel Cherry (Me., R. I.); Fire Cherry (N. Y.).

\section{Prunus cerasus Linn.}

Sour Cherry.

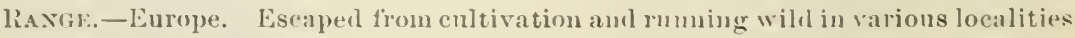
in easteru Luited States.

\section{Prunus mahaleb Linn.}

Mahaleb Cherry.

Raxgk-Enrops. Escaped from cultivation and ruming wild in sonthern New York and eastern Pennsylvania.

\section{Prunus avium Linn.}

Sweet Cherry.

Raxis.-Europe. Escaped from eultivation and runuing will in varions localities iu eastern Uniterl itates.

Prunus virginiana Limn.

Choke Cherry.

RANGE.-From Lahralor and Hndson Bay region to the Malienzie livor (latitucle $62^{\circ}$ ) and northeru british (Columbia ('onst region); south to southern Georwia. Lonisiana, Texas, and northem Mexico.

Names IN USE.-Choke Cherry (Mich., Wis.); Wild Cherry.

'Dr. J. K. Small has rerently des'riberl the following new species: I'rumus injucunda Small, in 13nll. Torr. Bot. Cluh, rol. 25, p. 149, 1898. Detecter on Stone Momtain and Little Stone Monntain, Georyia. Said to be a tree 1.s 10 20 feet high, and formerly confinsel witl I'rumus umbellata. I have not seen specinens of this species. 
VARIETIES IMSTIXGLISIIEI IN CULTINATIS.

Prunus virginiana letucocarpa Wats.

Prunus virginiana pendens sndw.

Prunus virginiana nana (1)u Roi) Dipp.

\section{White-fruit Choke Cherry. Weeping Choke Cherry. Dwarf Choke Cherry.}

\section{Prunus demissa (Nitt.) Walp.}

RaxGE-Rocky Mountaius to the Pacific (in United States).

Nàes in Use.-Wild (herry (Cal., N. Mex., Ctah, Idaho, Mont., Oreg.); Choke Cherry (Cal., Nev., Ilaho, Utah); California Cherry (Cal.); Western Choke Cherry.

\section{Prunus serotina Ehrh.}

Black Cherry.

RANGE.-From Nova Scotia westward through Canadian l'rovinces to the k. ninistipuia River; sontl to Florida (Matauzas Inlet and Taun lay) and west to North Dakota (Missonri River), eastem Nebraska and Kansas. Indian 'lerritory, and Gastern Texas; westeru Texas (mountains).

NAMes in UsE.-Wild Black Cherry (Vt., Mass., R. I., N. Y., N. J., Del., Pa., N. C., Ala., Miss., La., Ky., Mo., Ill., Iowa, Wis., Kins., Nebr., Minn, Ohio, S. Dak. (cult.), Ont.); Wild Cherry (Conn.. N. J., Pa., Del., W. Va., N. C., S. C., Ala., Fla., Tex., Ark., Ky., Ind., Ill., Iowa, Wis.); Black Cherry (Me., N. H., Vt., R. I., N. I., Miss., Ky., Mich., W'is., Ind., Nebr.); Rum Cherry (N. H., Mass., R. I., Miss., Nebr.); Whisky Cherry (Minn.); Choke Cherry (Mo., Wis., Iowa).

\section{Prunus serotina neomontana Sudworth. Mountain Black Cherry}

RAxge.-Southwestern Virginia ("balds" on White Top Mountain); Alabima (Talladega and Clay counties).

VARIETIES DISTINGUISIIED IN CULTIVATION.

Prunus serotina penduliformis Sudw. Prunus serotina asplenifolia Dipp.

Prunus salicifolia H. B. K. Prunts capuli Cav.

Raxge.-Sonthern New Mexico and Arizona (mountains); Mexien (mountains); Central America (Pacific coast region); Colombia aud Peru.

NaMes in UsE.-Mexican Cherry-tree; Mexican Cherry.

Prunus caroliniana (Mill.) Ait.

Laurel Cherry.

RANi.E.-Coast region and islands ( 15 to 20 miles inlaud) from Sonth Carolina (Cape Fear hiver) to Florula (Biscayne Bay and Kissimmee River): west in the (fulf region through southern Alahama, Mississppli, Louisiana, and Texas (to Ginalalupe River).

Names in Use.-Wild Peach (Miss., La., Tex.); Wild Orange (N. C., S. C., Mrss., Tex.); Mock Orange (N. C., S. C., Ala., Miss., La., Tex.); Lanry Mundy (La.); Lanrii amande (La.); Cherry Laurel (Fla.); Evergreen Cherry (Tex.); Mock Olive (Fla.); Carolinian Cherry (lit.); Lamrel Cherry.

Prunus sphærocarpa Swartz.

West India Cherry.

Raxge.-Florıda (IBiscayne Bay); West Indies; Brazil.

NAME IN USE.-West India Cherry (Fla.). 
Prunus ilicifolia (Nutt.) Walp.

Hollyleaf Cherry.

RAxGe,-California (from San Francisco Bay throngh the coast ranges, also on western slopes of San Bernardino Monntains and on Santa ('ruz aud Santa Rosa islands) to Lower California (San Jnlio ('anyon).

NAMES IN USE.-Spanish Wild Cherry (Cal.); Islay (Cal.); Evergreen Cherry (Cal.); Holly-leaved Cherry (Cal.); Oakleaf Cherry (Cal.); Holly Cherry (('al.); Wild Oherry (Cal.); Holly (Cal.); Mountain Evergreen Cherry (Cal.).

Prunus icilifolia integrifolia Sudworth.

RAxGE, - California (coast islands and mainland).

Entire-leaf Cherry.

Prunus persica (Lim.) stokes.

Peach.

RAvGe.-China. Escaped from "ultivation and running wild in various localities in the Urnited states, especially in the Micldle and sunth Atlantic region.

\section{Family LAGUMINOSAE. ZYGIA Browne.}

Zygia unguis-cati (Linn.) Sulworth.

Florida Catsclaw.

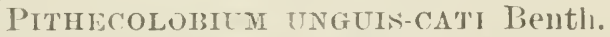

RaxGik.-Florida (Ciamlias Bay) aud sonthern keys; West Indies to Venezuela and New Granalla.

NaMes in r'se.-Cat's Claw (Fla.); Iong Pod (Fla.).

Zygia brevifolia (Benth.) Sudworth.

Huajillo.

Pithecolobica mRevifolium Bentl.

Ravge.-Texals (Lower Rio (irande River from lijo Frande City to mouth of the river); Mexico (mouth of Rio frande liver to Siorril Mallo Momntains, ete.).

Zygia flexicaulis (Benth.) Sudworth.

Texan Ebony.

Acacia Flexicatilis Benth.

Raxge, -Gulf const of Texas (from Matagorda Bay) to Mexieo (Sierra Madre Mountains in Nuevo Leun): Lower ('alifornia (1,a l'a\%).

LYSILOMA Benth.

Lysiloma latisiliqua (Linn.) Benth.

Wild Tamarind.

liANGe.-Florilil keys-Largo, Elliotts, Plantation, Boca Chica; Bahamas; West Inclies.

NAIE IN USE.-IVild Tamarind (Fla.).

\section{ACACIA Adans.}

Acacia farnesiana (Limn.) Willd.

Huisache.

RAvgl.-Native in America (from lỉo (irande River to northern Chile); Australia (northeasteru aud north central); Africa (subtropical); naturalized in West Indies, Guiana, Brazil, Argentiną, Africa (northern and north-tropical), ludla, Clina (southern), Indian Arehipelago, and islands of Pacitic Ocean. Widely cultivated and naturalized from the Gulf coast region to sonthern California.

Naties in Use.-Huisache (Tex.); Cassie (Tex.).

Acacia wrightii Benth.

Tezas Catsclaw.

Raxar.- Western Texas (from the Guadalupe River) to Mexico (Sierra Marre Mountaus in Nuero Leon).

NAJE IN USE. -Cat's Claw (Tex.). 
Acacia greggii Gray.

Devils Claw.

Ravge.-From Westurn Texas (Rio Grande River) throngh sonthern Now Mlexico and Arizona to sonthern California.

Names in Usk.-Cat's Claw (Tex., ('al., Ariz.); P'aradise Flower (N. Mex.); Devil's Claws (Nev.); Ramshorı; Uña de Gato.

LEUC㞋NA Hooker.

Leucrena glauca (linn.) lienth.

Leucæna.

Raxge.-Western Thexas (from San Salua tu llevils IRiver); Florilla (Key West); Mexico; West Indies and Bahanas; Gonth America (down to sonthern Brizil); tropical Africa and Asia. Nitive ramge nneertan; setablished mostly ly cultivation.

Leucæna pulverulenta (Schlecht.) Benth.

Chalky Leucrena.

Iisage. - Texas (few miles above month of lín irancle liver); Mexico (from Mitamoras to Monterey in Nuero Leon: Misantla River, near San Autouio; at Orizaba and Corilova, near eity of Mexieo).

NAUE IN USE.-Mimosa.

\section{PROSOPIS Linn.}

Prosopis odorata Torr. \& Frem.

Screwbean.

Prosopis pubescens Benth.

Range. - Western Texas (valley of Rio Grande River, from Devils River to El Paso); west through New Mexico, Arizona, southern borders of Utalı anl Nevacta to California (arid region of Colorato liasin to San Diego (onnty); northern Mlexico.

NAines in Use.-Scrembean (Tex., Utah, N. Mex., Ariz., Yer., Cal.): Screw-Pod Mesquite (Tex., Utal, Ariz., N. Mex., Nev., (Gal.): Tornillo (Tex., Utah, N. Mex., Ariz., Nev.); Mescrew (Nev.); Screwbean Mesquite (Ariz.).

Prosopis juliflora (Swartz) de C.

Mesquite.

RAxGE.-From the sonthern border of Indian Territory and northern and western Texas (eastern limit defined by a line from the intersection of latitule $37^{\circ}$ with the one hundredth meridian to Dallas; thence sonth to the Colorado River and southwestward within 20 or 30 miles of the Gulf, which is reached near the month of the Rio Grancle River) into northern Mexico. Also from the sonthern borders of Coloraclo and Utah throngh New Mexico, Arizoni, and sonthern Nevada to southern California (western limit defined ly a line from Tejon Pass over Los Angeles to San Pedro); in Lower California; weste.n South America (Andenn region to Chile); Argentma and sonthern Brazil; Jamaica.

Nanes IN USE.-Mesquite (Tex., N. Mex.. Ari\%., Cal.); Algaroba (Tex., N. Mex., Ariz., Cal.); Honey Loenst (Tex., N. Mex); Honey Pod (Tex.); Irouwood (Tex.).

\section{CERCIS Linn.}

Cercis canadensis Linn.

Redbud.

RAxGe.-From New Jersey (Dehaware River) and southern Michigan (Grand and Raisin rivers) to Florida (Tampa Bay), northern Alabana (Tennessee River to Madison, Monte Sano, Cullman, Tuscaloosia) and Mississippi; west to Missouri, eastern borders of Indian Territory, Loussana, Texas (Brazos Rıver); Mexieo (Sicria M:ıdre in Nuevo Leon).

Names in USE.- Redbud (Mass., N. Y. (cult.), N. J., Pa., Del., D. C., Va., W. Va., N. C., S. C., Ala., Fla., Ark., Miss., La., Tex., Mo., Ill., Ind., 
Mich. (cult.); Judas-tree (Mass., R. I., N. Y. (cult.), N. J., Del., Pa., D. C., Va., N. C., S. U.. Miss., La., Tex., Ky., Mll., Ind., Ohio., Mich., Minn. (cult.); Red Judas-tree; Salad-tree (I)el.); Canadian Judas tree (lit.).

Cercis canadensis pubescens l'ursh.

Downy Redbud.

RavGe.-Typo locality, "Geormia:" westwarl.

VARIETY DISTINGUISHED IN CULTIVATION.

Cercis canadensis plena Sudw.

Double-flower Redbud.

Cercis reniformis Engelm.

Texas Recbud.

RAxGe.-Eastern Texas (from near Dallas) to Mexico (Sierra Madre m Nnevo Le(ni).

NAMEs IN USE.-Redbud (Tex.); Texas Redbud.

Gleditsia triacanthos Linn.

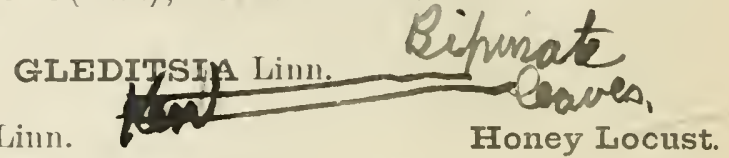

liaxge.-From Pennsylvania (western slopes Allegheny Momntains) west through sonthern (Ontario (Pelee Island, Iake Erie), southern Michigan (up to River liaisin) to eastern Nebraska and liansas, Indian T'erritory (to longutule $96^{\circ}$ ); kouth to Georeria and through $\Lambda$ la hama, Mlississippi, aud Texis (to lirazos River). Range more or less extended elsewliere by seeding from cultivated trees.

Thanes in Usi:-Honey Locust (Vt., N. H., Mass., R. I., N. Y., N. J., I’a., Del., 1). C., Va., IV. Va., N. C.. S. C., Ga., Fla., Ala., Miss., La., Tex., Ark., Ky., Mo., ()hio, Ill., Iud., Kans., Nebr., Mich., Iowa); Black Locust (Miss., Tex., Ark., Kans.. Nebr.); Sweet Locust (S. C., La., Kans., Nebr.); Three-thorned Acacia (Mass., R. I., La., Tex., Nebr., Mich., Ont.); Thorn Locust (N. Y., Ind., La.); Thorntree (N. Y., Ind., La..); Thorny Locust (N. J.); Locust (Nebr.); Honey (R. I., N. .., Iowa); Honey Shuteks (R. I., N.J.. Ta., Fla., Iowa); Thorny A cavia ('T(mn.); Eoney-Shucks Locust (Ky.): Pi(pant Amonrette (La.); Confederate Pintree (Fla ).

Gleditsia triacanthos lavis (Loud.) Sudworth.

Thornless Honey Locust.

(rLEDITSIA TRIACANTHOS, var. INERMIS Wil\}.

Gleditsia triacanthos brachycarpos Michx.

Short-pod Honey Locust.

VARIETY DISTINGUISIIED IN I'ULTIVATION.

Gleditsia triacanthos bujotii (Nenm.) nom. nov.

Bujot Locust

Gleditsia izUJotil Neumann.

Gleditsia aquatica Marsh.

Water Locust.

Gleditsia MoNosperva Walt.

RaNGE.-Coast region, from Sonth Carolina to Florida (Matanzas Inlet and Tampa Bay), from whel it extends along the Gulf eoust to Texas (Brazos River); northware throngli western Lonisiana and sonthern Arkansas, sonthern Missouri, midde and west Tenuessee and Kentucky, southern Illinors, and Indiana.

NAMe IN USE.-Water Locust (Fli., La., Tex., Mo., Ind., Ill.). 


\section{CLADRASTIS Raf.}

Cladrastis lutea (Michx. f.) Koch.

Yellow-wood.

Cladiastis tinctolili liaf.

RAxGe.-Central lientncky (Kentncky and Dick rivers); middle 'Tennessece (near Nashville) and eastem Tennessee (Great Suoky Momntains in Cocke and Sivier comnties); North Carolina (Cherokee County); Aliabuma (Trunessee River Valley, near Colbert, sheftield Landing).

Naves IN USE.-Yellww-wood (Tenn., N. C.); Yellow Locust (Ky., Teun.); Yellow Ash; (ropherwood ('Tenn.)

\section{EYSENHARDTIA H. B. K.}

\section{Eysenhardtia orthocarpa (Gray) Wats.}

Eysenhardtia.

lisxgE.-From western Texas (upper Guadalnpe River) to sonthern Arizom (Santa ('atalina and Santa Rita monntains) and south into Mexico (to sonthwestern Chihuahua and to near Sin I,uis Potosi).

\section{DALEA Willd.}

\section{Dalea spinosa Gray.}

Indigo Thorn.

Raxge.-Southern California (Colorado Desert-at Agna Caliente auıl Toras) and eastward into Arizona (to lower Gila River); south into adjacent Jexico (Sonora) ancl Lower California (to Calamminet).

Yaues in use.-Dalea (Cal.); Indigo Bush (Cal.).

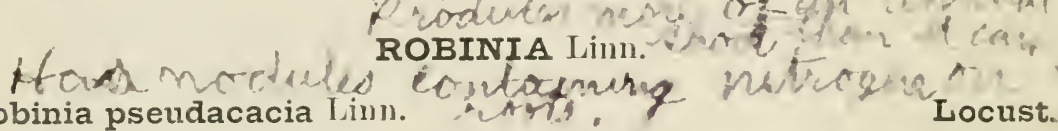

\section{Robinia pseudacacia Limm.}

$$
\text { Nart. }
$$

Locust.

RAxGe.-Frum l'ennsylvania (ou th" Appalacbian Hountains from Lorust Rillge in Marion County) to northern Goorgia. Willely naturabed through enltivation and other agencios thunghout the Inited states east of the Rocky Monntains; possibly

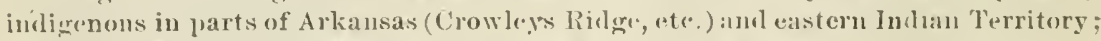
also in the (ireat Smoky Monntains of anstern Temesses (Serier ('ounty).

NAans IN UsE.-Locust (Me., N. H., Vt., Mass., R. I., Comn.. X. Y., N. I., Pa., Del., W. Va., N. C., S. C., (ra., Ala., Miss., Tex., Ky., Ark., Ariz., Ill., Wis., Olio, Ind., Kinns., Nebr., Mrch., Iowa, Minn.); Blark Locust (I’a., Va., W. Va., N. C., S. C., Ala., Misis, La.. Tex., Ark., Ky., Mo., Ill., Ohio, Ind.. Iowa, Kans., Nebr., Mich., Minm.); Yellow Lo(ust (Tt., Mass., N. I., Pa., Del., Va., W. Va., Miss., La., Ill., Iud.. Ǩaus., Nebr., Mimu.): White Locust (R. I., X. Y., T'un.); Red Lucust ('Temn.); (rreen Iocost (Temn.); Aracia (La.); False Acacia (S. ('., Ala., Tex., Minn.); Honey Locust (Minn.); Bastard Acacia (lut.); I'ea-1lower I.ocust; Post Lownst (MId.).

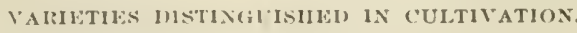

Robinia pseudacacia decaisneana Carr.

Robinia pseudacacia crispa do C.

Robinia pseudacacia amplifolia Sudw.

Robinia pseudacacia angustifolia (lund.) lav.

Robinia pseudacacia monophylla l'etz. ¿l Kirrhı.

Robinia pseudacacia tortuoga (Hullin.) dle (".
Pink Locust. Crimkleleaf Locust. Broadleaf Locust.

Smalleaf Locust.

Simpleleaf Locust.

Twistbrangh Locust. 
Rooinia pseudacacia pyramidalis l'etz. \& Kirchn.

Robinia pseudacacia pendula (Ortega) Lond.

Robinía pseudacacia inermis (Jacq.), Sulw.

Robinia pseudacacia spectabilis (Du Mont Cour.) Koch.

Robinia pseudacacia latisiliqua Loud.

Robinia pseudacacia dissecta (línch) Sarg.

Robinia pseudacacia glaucescens Koch.

Robinia pseudacacia aurea (Koch) Dipp.

Robinia pseudacacia purpurea l lipp.

Robinia pseudacacia argenteo-variegata (Koch) sndw.
Pyramid Locust. Weeping Locinst.

Parasol Locust.

Thornless Locust.

Broađ̃pod Locust.

Cutleaf Locust.

Blue Locust.

Goldenleaf Locust.

Purpleleaf Locust.

Spotted Locust.

Robinia neo-mexicana Gray.

New-Mexican Locust.

Range.-Colorallo (from Purgatory River) through northern New Ilexiro and Arizona (to Santa Catalina and santa Rita monntains) and to southern ltah (near Kanah and in Ionnt Zion (anyon, west fork of lio Virgen River).

Naje in UsE.-Locust (Ariz.. N. Mex.).

Robinia viscosa Vent.

Clammy Locust.

RANGE.-Mountaius of North ('arolina. Widely naturalized ly cultivation east of the Mississippi River.

Names in USE.Clammy Locust (Mass., R. I., N. Y., N. I., Pa., N.C., S. C., La., Miss., Ill.); Honey Locust (X. Y., N. J.); Red-flowering Locust (Ala.); Rose-Hlowerung Locust (Tenn.); Rose Acacia (Vt., R. I., Pa.).

VARIETIES DISTINGLISHED IN GYLTIVATION

Robinia viscosa albiflora Dipp.

White-flower Clammy Locust.

Robinia dubia Fonc.

Robinia bella-rosea Nichol.

OLNEYA Gray.

Olneya tesota Gray.

Sonora Ironwood.

RAxGe.-Sonthern ('aliforuia (from Colorado River south of Moluave Momntans) to sonthwestern Arizona and throngh adjacent Mexion (Nonora) and Lower California (between ('ommolee and ('alamujuet).

NaMes in Usfo.-Iron Wood (Cal.); Arbol de Hierro (Cal.); Palo de Hierro (Ariz.).

ICHTHYOMETHIA Browne.

Ichthyomethia piscipula (Linn.) Kmutze. Jamaica Dogwood.

Piscidia ERYTirina Lim.

RaxGe.-Sonthern Florilil (Biscayue: Bay on east coast, and ou the wost from Pease Creek to Cape Sable) aur suthern keys; West Indies and southeru Mexiro.

NAME IN TSE.-Jamaica Thowoml (Fla.).

$$
\text { Family / Y GOPII YTIA I E A A. }
$$

GUAJACUM Lim.

Guajacum sanctum Linn.

Lignum-vitæ.

R.A.Ge.-Florida keys from Key West matward (upper and lower Mratacombe keys. Lignum vita liegs, I mblella lieys); Babanas, san Domingo, and puerto lico.

NAMES IN USE.-Ligmum-vitie (Fla.); Iromwood (Fia.). 


\section{Family RUT ACFA:}

XANTHOXYLUM Linn.

Xanthoxylum clava-herculis Linn.

Prickly Ash.

RANGE, - Coast region from sonthern Virminia to Florida (Biscayne Bay and Tampa Bay); west through the Gulf states to northrestern Lonisiana, sontlern Arkansis, and through Texas (to Devils River).

NAuEs IN USE.- Prickly Ash (N.C., S. C., Ga., Fla., Miss., La., Tex., Ark.); Toothache-tree (N. C., S. C., Fla., Miss., Lal., Ark.); Pepper-wool (Miss.); Sea Aslı (Miss., Fla.); Sonthern Prickly Ash (Ala.); Ash (Va.); Frêne-piquant (La.); Sting-tongue (Fla. Negroes, Ark.); IVaita-bit, Tear-blanket (Ark.); Wild Orange.

Xanthoxylum clava-herculis fruticosum Gray.

Xanthoxylum cribrosum Spreng.

Satinwood.

Ravge. - Florida keys (Marquesas Keys, Sonth Bahia Hondil, and Bow'al Chica. Keys); San Domingo, Puerto líco, Bahamas, and liermuda.

NAMES IN USE.-Yellow-wood (Fla.): Satinwood (Fla.).

Xanthoxylum fagara (Linn.) Sargent.

Wild Lime.

Xanthoxyluit P'TERota H. B. K.

RANGE.- Southern Florida coast and islands (on the east coast south of Mosquito Inlet aud on the west cuast south of latitude 29) ; coast of Texas (from Matagorda Bay to the Rio Grande Piver): West Indies; northern Mexico; Central and South Auerica (to Brazil and Peru).

NAME IN USE.-Wild Lime (Fla.).

PTELEA Liun.

Ptelea trifoliata Linn.

Hoptree.

Ravis.-Sonthern Ontririo (Point Pelee, Lake ()ntario); New York (Long Islanel); Penusylvania and west throngh sonthem Michigan (up to Montealu Cominty) to Minnesota; sonth to northern Foricia and west to Texas, and through New Mexico to Colorarlo (Mimbres River): northern Mexico.

NAHEs IN USF.-Hoptree; Wafer Ash: Whahoo; Quinine-tree (Mich.).

VARLET MISTINGUISHEN IN CELTIVATION.

Ptelea trifoliata aurea $\mathrm{Ni} \cdot \mathrm{h}$.

Golden Hoptree.

\section{HELIETTA T'ulasue.}

Helietta parvifolia Benth.

Baretta.

Raxfik-Cexas (near Rio Grande City); Mexico (sonth of the lomer Rio Grande to the lower slopes of the Sierra Madre. Monutains and though Nuevo Leon).

\section{AMYRIS liowne.}

Amyris maritima Jaeq.

Torchwood.

AMYRIS SYLVATICA de C.

RAxge, - Sonthern loricla (from Mosquito Inlet on the east const to the suntherv keys); bahamas, St. Thomas, Cubi, and Jannura lslants.

NAMIE IN USE.-Terchwood (Fliı.). 
Canotia holacantha Torr.

Canotia.

RANGE.-Arizona (from White Ionntain region to the Bill Williams (liver) Fork); southern California ('Providence Mountains).

NAME IN USE.-Canotia (Ariz.).

$$
\text { Hamily SIMA ROUBACIAE. }
$$

SIMAROUBA Aublet.

Simarouba glauca de C.

Paradise-tree.

RANGE. - Southern Florida (from Cape Canaveral, on the west coast, to the southern keys aud to Biscayne Bay); Cubn, Jamaica, Nicaragua, and Bruzil.

NAmES IN USE.-Paradise-tree (Fla.); Gumbo Limbo (Fla.); Bittelwood (Fla.).

\section{KCEBERIINIA Zucc.}

Kokerlinia spinosa Zucc.

Kœberlinia.

RAxGE.-Texas (from valley of Rio Grande River southward) to northern Mexicu (to near Altar River, in Sonora, and to near San Luis Potosi).

Ailanthus glandulosa Desf.

\section{AILANTHUSDesf.}

RANGE.-China; but widely naturalizerl in Edstern United States. VARIETIES DISTINGUISHED IN CULTIVATION.

Ailanthus glandulosa rubra Dipp.

Ailanthus glandulosa pendulifolia Dipp.

Ailanthus glandulosa aucubæfolia Dipp.
Redfruit Ailanthus.

Drooping Ailanthus.

\section{Family BURSERACEA.}

\section{BURSERA Jacq.}

Bursera simaruba (Linn.) Sargent.

Gumbo Limbo.

BURSERA GUMMIFERA Lim.

RANGE.-Southern Florida (on the east coast from Cape Canaveral to the sontlern keys; west coast on Caloosa River and Caximbas Bay); West Indies, sonthern Mexico, Guatemala, New Grenarla, Venezuela.

Nayes in UsE.-Grum Elemi (Fla.); Gumbo Limbo (Fla.); West Indian Birch (Fla.).

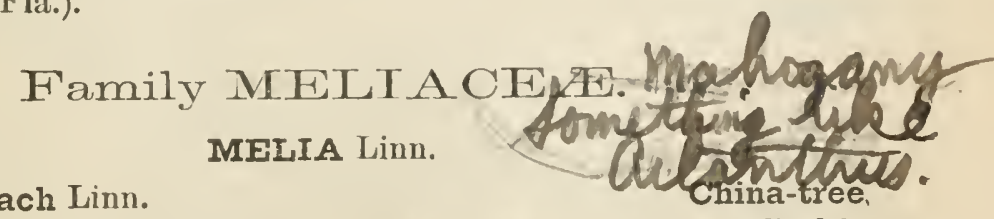

Melia azedarach Linn.

Ravge,-Persia. Widely cultivated in Old and Now Worlu and naturalized by cultivation in Southern United States.

Melia azedarach umbraculifera Sargent. Umbrella China-tree. 
SWIETENIA Jacq.

Swietenia mahagoni Jacq.

Mahogany.

RaNGE.-Florida keỵs (Key Largo and Elliotts Key); Bahamas, West Indies, vouthern Mexi('o, Central America, aud Peru.

NAMEs IN USE.-Mahogany (Fla.); Madeira (Fla.); Redwood (Fla.).

\section{Family EUPHORBIACEA:}

\section{DRYPETES Vahl.}

Drypetes lateriflora (Swartz) Urban.

Florida Plum.

DRYPETES CROCE $\Lambda$ Poit.

RANGE.-Southern Floriıla (Biscayne Bay) and several of the sonthern keys; Bahamas, Cuba, San Domingo, Jamaica, Puerto Rico.

NAIES IN USE.-Gniana Plum (Fla.); Whitewood (Fla.).

Drypetes keyensis Urban.

Guiana Plum.

RaxGE.-Florida keys (Key West, Umbrella Koy, Elliotts Key).

NAMES IN USE.-Guiana I"1um (Fla.); Whitewood (Fla.).

GYMNANTHES Swartz.

Gymnanthes lucida Swartz.

Crabwood.

Sebastiana lucida Muell.

RANGE.-Coast of sonthern Florida (from Biscayne Bay to the Marqnesas lieys); Bahamas, West Indies.

Nayes in USE._Crabwood (Fla.); Poisonwood (Fla.).

\section{HIPPOIMANE Linn.}

Hippomane mancinella Limn.

Manchineel.

RAxGE.- Wrom the keys of sonthern Florida through the Bahamas and West Indies to northern Sonth America and eastern and western coast of Central America and southern Mexico.

NAME IN USE.-Manchineel (Fla.).

\section{SAPIUM Browne.}

Sapium sebiferum Roxb.

Tallow-tree.

STILLINGIA SEBIFERUM Michx.

liangE.-China and Japan. Cultivated and uaturalized in the Gulf States.

\section{Fimily CHEIRANTHODFNRFA.}

FREMONTODENDRON Coville.

Fremontodendron californicum (Torr.) Coville.

Fremontia.

Freiontia CaLIfolinica Torr.

RANGE.-California (from Mariposa) to Lower California.

NAMES IN USE.-Slippery Elm (Cal.); Silver Oak (Cal.); Leatherwood (Cal.); Fremontia (Cal.). 
87

Family THEACEAE.

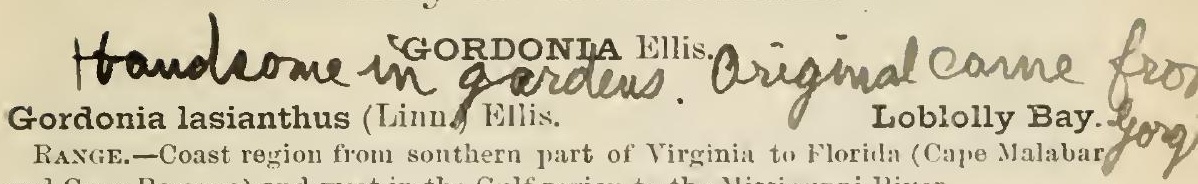
and Cape Romano) and west in the Gulf region to th. Mississippi liver.

Names IN USE. -Loblolly Bay (N. C., S. C., Ga., Ala., Fla., Miss, La.); Tan Bay (Miss., Fla., La.); Black Laurel (N. C.).

Gordonia altamaha (Marsh.) Sargent.

Franiklinia.

Goldoni pubescexs L'Her.

RANGe. - At present known only in cultivation. Originally (1 7fin) funnel growing wild in Georgia (near Fort Harrington on the Altamaha River), lot not seen since 1790.

Family CANFLIACEA.

CANEILA Browne.

Canella winterana (Linn.) Grertn.

Cinnamon-bark.

Canella alba Mar. in Linn.

RANGE. -Florida keys

NAUES IN USE.-Cimuamon-bark (Fla.); Whitewood; Wild Gina. mon.

Family ANACARDIACEAE.

COTINUS Aras.

Cotinus cotinoides (Tut.) Briton.

American Smoke-tree.

Rus CotinoIDEs Nit.

RAxGE.-Indian Territory (Grand River); Alabama (north of 'Tennessee River and on southern slopes of Cumberland Mountains near lluntsrill"); ("astern Tennesee (Cheat Mountain); Texas (Medina River).

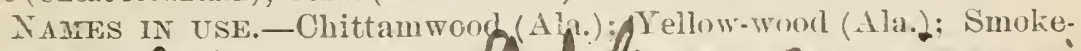
trace has resulted from coming in

connection

Thus metopium Linn.

Poisothood.

lisise.-Southern Florida (Biscayne Bay) and southern kegs; Bahamas, Cuba, Jamaica, Honduras.

Names IN USE.-Poisonwood (Fla.); Coral Snmach; Mountain Marchineel; Bumwood; Hog Plum; Doctor Gum.

Rhos horta (Limn.) Sulworth.

Staghorn Sumach.

RHUS TYPHINA Linn.

Raxge.-From New Brunswick (through the St. Lawrence River Valley) to southen Ontario and Minnesota; south through the Northern States and along the Aleghent Mountains to northern Georgia, central Alabama, and Mississippi.

NAvies IN USE.-Staghorn Sumach (Vt., N. H., Mass., R. I., Conn., N. Y., N. J., Del., Pa.. N. C., S. U., Miss., Mo., Mich., Wis., Ohio, Ont.); Sumach (Me., Vt., N. I., Pa., W. Va., Ark., Ky.. Ind., Wis.); Virginia Sumach (Tenn.); Hairy Sumach. 
Rhus copallina Linn.

Dwarf Sumach.

Raxge.-Xow England to Florida (Maniteo and Caximbas Bay), and west to Missouri, Arkinsas, and Texas (San Antonio River); Cuba.

Names in tóE.-Dwart' Sumach (Vt., N. H.. R. I., Mass., N. Y., Del., Pa., Ala., Fla., Miss., La., Kans.); Sumach (Vt., Pa., W. Va., S. C.. Fla.. Ga., Miss., Jal., Tex., Ky., Mo.. Kans.); Smootl Sumach; Momutain Sumach (Vt., Temn.); B!ack Sus..uch (Ark.. Tex.); Wing-rib Monntair Sumach (S.C.); Common Sumach (S. O.).

Rhus copallina leucantha (Jacq.) de C.

\section{White-flowered Dwarf Sumach.}

Raxgr.-Texas (near Now Irannfels).

Rhus copallina lanceolata (Gray.

Isanceleaf Dwarf Sumach.

Raxae.-Lasteru Texis (to Rio (irande River).

Rhus vernix Linll.

Poison Sumach.

RHUS VENENA'rA de C.

RANGE.-Northern New England to northern feorgia and Alahama; west to northern Minnesota, Arkansas, and western Louisiana.

NAIEs iN Use.-Poison Sumach ( $Y$ t. Y Y. H. Mass., R. I., Conn., N. I., N. J., Del., N. C., S. C., Ala., Miss., La., Mo., Iowa. Wis., Mich., Minn., Ohio, Ont., Nebr.); Poison Elder (Vt., Mass., R. I., N. Y.. Del., S. C., Ga., Ala., Miss.. La., Mo., Nebr., Minn.); Poison Dogrood (N. H., Vt., N. J., Pa., M. C., Mo., Mich., Minn.): Dognood (Vt., Mass., R. I., Wis., Mich.. Iowa, Nebr., Miun., La.); Swamp Sumach (R. I., N. Y.. X. J.. Tenn.. Minn.); Sumach (R. I.); Poison Oak (La.); Poison Ash (Pa.); Poisonwood (Tenn.); Poisontree; 'Thunderwood (Ga.).

Rhus integrifolia (Nutt.) Benth. \& Hook.

Western Sumach.

RANGE.-Coast of southern California (from Santa Barbara) to sonthern Lower California (Magdalena Bay); Santa Barbara and Cedros Is]ands.

\section{Family CYRILLACEA.}

\section{CYRILLA Linn.}

Cyrilla racemiflora Liun.

Ironwood.

RANGE.-Coast region from North Carolina to Florida (to latitude $30^{\circ}$ and on southern keys); inland in South Carolina and Georgia to near Angusta; west on Gulf coast to Texas (Neches River); Cuba, Jamaica, Dominica, Demerara, and Brazil.

Naues in UsE.-Ironwood (S. C., Ga., Fla., Miss., La.); Leatherwood (Ala., Fla.); He Huckleberry (S. C.); Burnwood; Burnwood-bark; Firewood (Ga.); Burning-wood (Ga.); Red Titi (Fla.); White Titi.

\section{CLIFTONIA Gartn. f.}

Cliftonia monophylla (Lam.) Sargent.

Titi.

Cuiftonia Ligustrina Sims ex Spreng.

RANGE.-Coast region from Sonth Carolina (Savannah River) to northern Florida, and west in the Gulf region to castern Louisiana.

Names In UsE.-Titi (S. C., Ga., Ala., Fla., Miss.); Buckwheat-tree (Fla., La.); Black Titi (Fla.); Ironwood. 


\section{or have

\section{Family AQUTHOLIACTAA.}

\section{ILEX Linn.}

Ilex opaca Ait.

American Holly.

liaxge.-Coast region from Massichusetts (Massachusette liay, near (Juiney) to Florida (Mosquito Inlet and Charlot te Harbor); from sonthern Inoinal (through Mississipy. River Valley) to the Gulf, and through Missouri, Arkansas, Lonisinua, and eastern Texas.

Namies in Use.-Holly (R. I., Del., W. Va., Pa., N. C., S. U., Ga., Fla., Miss., La., Ark); Anerican Holly (Mass., R. I., Conn., N. Y., N. J.. Pa., Del., N. C., Ala., Miss., La.); White Holly (Va.).

Ilex cassine Linn.

ILEX DAHOON Walt.

Dahoon (Holly).

RANGE.-Coast region from sonthern Virginia to Florida (Biseayne liay and T'ampa Bay); west on the Gulf eoast to western Lonisiana.

\section{Ilex cassine angustifolia Willk.}

Ilex cassine mytifolia (Walt.) Sargent.

R.AxGE.-North Carolina to Lonisiana.

Names in Use.-Dahoon (N. C., S. C., Ga., Ala., Fla., Miss., La.); Dahoon Holly (N. C., S. C., Fla.); Yaupon (Fla.).

IIex vomitoria Ait.

\section{ILEX CASSINE Walt.}

Range.-Coast region from sonthern Virginia to Florida (St. Johns River and Cerlar lieys); west on the Gulf coast to sonthern Texas (Matagorda laty) and to western Texas (Rio Blanco River), and west of the Mississippi River northward to southern Arkansas.

Names in Use.-Yopon (N. C., Ga., Ala., Miss., Tex.); Yaupon (N.C.. S. C.. Fla., Miss., La.); Cassena (N.C., S. C., Fla., La.); Cassine (La.); True Cassena; Evergreen Cassena; Cassio-berry Buslı: L̇metic Holly (S. C.).

\section{Ilex decidua Walt.}

Deciduous Holly.

RANGE. - From sonthem Virginia (ranging from the coast to the eastern base of the Appalachian Mountains) to western Floridis: from sonthern Illinois to the Gulf anil through sonthwestern Missonri, Arkansas, and eastern 'Texas (Colorado River).

Naxes IN UsE.-Holly (Tex., Ark., Mo.); Bearberry (Miss.); Possum Haw (Fla.).

\section{Ilex monticola Gray.}

Mountain Folly.

Ravgk.-From New York (Catsisill Mountains and Catturangus County) southward in the mountains (and in Pennsylvania as fur east as Northaupton County) to northern Alabama. Arboreseent chielly in the muntains of North Carolina, south Carolina, and eastern 'Tenuessee (Great Smoky Mountains).

\section{Family CFLASTRACEAE.}

\section{EVONYMUS Linn.}

\section{Evonymus atropurpureus Jacer.}

Waahoo.

RAxGE.-From western New York through Michigan to Nebraska (and in Montana on upper Missouri River): south to northern F'lorida, sonthern Arkansas, and Indian Territory.

Tames is UsE.-Burning Bush (R. I., N. Y., N. J., Pa., Del., Md., N. C., s. C., Miss., Ark., Ky., Ohio, Ill., Ind., Iowa, Kaus., Nebr., 
Mich.); Waahoo (N. Y., N. J., Pa., W. Va., N. C., s. C., Miss., Ky., Ark., Mo., Nebr.. Ill., Iowa, Kans., Ohio, Ind.); Spindle-tree (R. I., Del., Pa., N. C., Ill.); Arrow.wood (Miss., Lal., Ill., Mo.); Strawberrytree (N. Y.); Strawberry Bush (Tenn.); "Moses in the Burning Bush" (N. .J.); Bleeding Heart (N. C.); Indian Arrow (Ind.).

GYMINDA Sargent.

Gyminda grisebachii Sargent.

Gyminda.

MYGINDA PALLENS Smitlı ex Sargent.

Rangb.-lslands of southern Floriclal (from Marquesas to Upper Metacombe Key); Cuba, and Puerto Rico.

NAMES IN USE,-False Boxwood (Fla.); Gyminda.

Gyminda grisebachii glaucifolia (Griseb.) Sudworth.

RANGE.-Cuba.

Pale Gyminda.

SCHAFFERIA Jacq.

Schafferia frutescens Jacr.

Florida Boxwood.

RANfis.-Islauds of southern Florida (vicinity Caloos hiver, and from Metaleombe

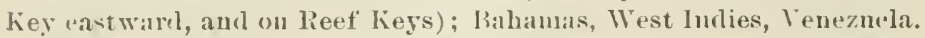

Nayes IN USE.-Y'(ellow-Wood (Fla.); Boxwood (Fla.).

\section{Family ACIRACFAE.}

ACER Linn.

Acer spicatum Lam.

Mountain Maple.

RaxGl.-From the lower st. Lawrence liver to northern Minnesuta and reglon of the siskateluewan River; south throngh the Northern states (in Hichigan down to Eaton (ounty) and along the Appalachian ILoutains to northern Goorgia.

Names ix Usk.-Womtain Maple (Vt., N. H., R. I., Conn., N. Y., N. I. Pa., N. U., S. U., Mich., Minn.); Hoose Maple (Vt. Fow Maple (Teun.); Water Maplele (Ky.).

Acer pennsylvanicum Lim
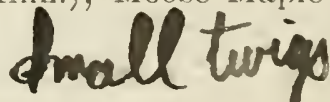

liaxgr, - From Quehoe (Ha-lla Bay, on Sagnenay River) westwarl along the shores of lake Onlario and islants of Lake Iluron to northeastern Minnisota; soutluwarl into the Northern and North Atlantic States (in Michigant/Loscongon County) and along the Appalachian Momutains to northern Georgia. ALhe Ge

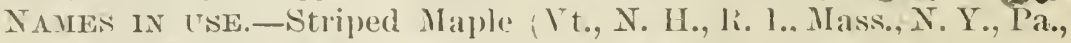
N. J., … Ga., Ky., Mieh., Minn., Ont.); Moosewood (Me., Vt., N H., R. I., Mass., N. Y., I'a., N. U., Mich., Minn.); Northern Maple (Minn.); Striped Jomwood (N. I... N. C.); Mountaiu Alder (N. U.); Whostlewool (Mich.); Goosefoot Maple.

Acer macrophyllum l'ursl..

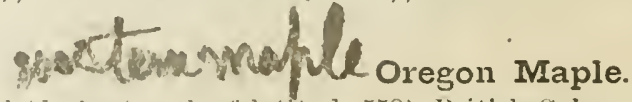

RAxGE.- From the coist region of Alaska'(sonth of latitucle 55'), British Colum. bia, and isIturls southward through Washington and Oregon (west of the Cascade Monntains) and Cillifornia (coast ranges and west (ern slopes of Sierra Nevada Monntains to Sin Bermarino Mountans and Hot Spriug Valley in San Diego Connty).

Nanes in UsE.-Bigleaf Maple (Oreg.), Broad-leaved Maple (central Cal.; Oreg., Willanette Valley); (regon Maple (Oreg., Wash.); White Mapleg Oreg., WVash.); Maygo (Cal.). 
Acer circinatum Pursh.

Vine Maple.

RANGE.-From the coast rogion of British Columbia sunth through Washington, Oregon, and California (to Mendocino Connty).

NAmES IN USE.-Vine Mapple (central and northern Cal.; OregonWillamette Valley); Mountaju Maple.

Acer glabrum Torr.
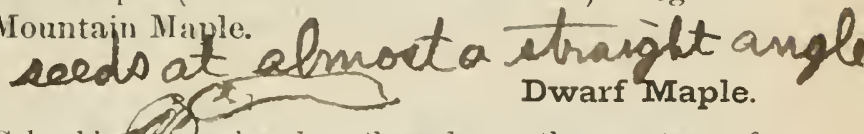

RAxGe.-From liritish Colmmbian fifuarl and sonthward over the monntans of the West to California (onsiorra Nerala Mountains to Yosemite Valley), Colorarlo , eastern slopes of liocky (Momntains), eastern New Mexico, and western A rizona.

Names IN USE.-Dwarf Maple (Oreg., Utah, Cal., Colo.); Mountain Maple (Colo., Mont.); Soft Maple (Utalı); Shrnbby Maple (Utah); Bark Maple (Idaho); Maple (Monp).

Acer saccharum Malsh.

ACER SACCHARINUM TVang.

RANGE.-From sonthern Newfoundland (along the St. Lawrence and Saguenay rivers, Lake St. John, and northern borters of Great Lakes) to Lake of the Woods aud Minnesota; south (through the Northern States and on the Allegheny Mountains) to northern Georgia and western Florida; west to eastern Felfras/a, eastorn kansas, and ovd shing comes suddenty Leogar s

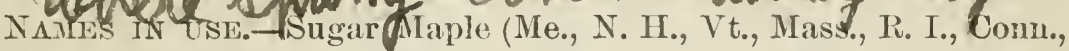
N. I., N. J., Pa., Del., Va., W. Va., N. C., S. C., Alı., La., Kýy., Mo., Ohio, Ill., Ind., Iowa, Kans., Nebr., Mich., Minn., Wis., Ont.); Hard Maple (Vt., R. I., N. Y., N. J., Pa., Va., Ala., Ky., Mo., Kaus., Nebr., Ill., Ind., Iowa, Mich., Ohio, Minn., Ont.); Sugar tree (MLe., T't., R. I., Pa., Va., Wr. Va., Ala., Miss., La., Ark., Ky., Mo., Ill., Ind., Ohio, Kans.); Rock Maple (Me., Vt., N. H., Conn., Mass., R. I., N. I., Tenu., Ill., Mich., Iowa, Kans., Wis., Minn., Ont.); Black Maple (Fla., Ky., N. C.); Maple (S. C.).

Acer saccharum nigrum (Michx. f.) Britton.

Black Maple.

ACER SACCHARINUM IVang.

RANGE.-From Vermont (Lake Champlain) to Minnesota, casteru Kansas, and sonthwestern Arkansas; southwaril (west of the Allegheny Mountams) to morthern Alabama and Mississippi (Chickusaw River).

NAuEs IN USE.-Black Sugar Maple (Mich., Mo.); Black Maple (Mich., Iowa); Hard Maple (Minn.).

VALIFTY DISTINGIISHED IN CUITIVATION.

Acer saccharum nigrum monumentale (Temple) Sudw.

Acer saccharum barbatum (Michx.) Trelease.

IiAxGE.-Nearly the same as the precelling, hut insufficiently known.

Acer saccharum leucoderme (Small) Sudwortl.

Raxge.-North Carolina to (ieoryı ind Alabana.

Whitebark Maple.

Acer saccharum floridanum (Chapm.) Small di Heller. 
ACER SACCHARINUAI Wang. var. FLoridanum Chapm.

RaxGk.-From western Florida through southern Alabama (to eentral prairie region) to 'Texas (Cibolo River) and into Mexico (Sierra Madro Momtains in Nuevo Leon).

Acer saccharum grandidentatum (Nutt.) Sriworth.

Large-tooth Maple.

ACER GRaNDIDENTatum (Nutt.! mss.) in Torr. \& Gr.

RAxGE.-Montana (head waters of Colnmbia liver); Utah (Wasatch Monntains); soutbern Arizona. (IInachnaca Mlountains and otbers); New Mexico (Mongolion Monntains); western Texas (Gnadalompe Mountains); Mexico (momntains of Coahuila).

NAMES IN USE.- - IVestern Sugar Maple; Hard Maple (Utah); Largetoothed Maple.

\section{Acer saccharinum Limn.}

Silver Maple.

ACER DASTCARPUNi lihr.

RaNixl:-From New Brunswick (St. Johus River) to western Florida; west to sonthern Ontario, through Mlichigan to eastern Makota, Nebraska. Kansas (BIne River), and Indian Territory.

Nanes IN Usk.-Silvel Maple (Me., Vt., Mass., R. I., N. I., N. J., Pa., Del., Va., IV.Va., N. C., S. C., Fla., Miss., Ky., Ohio, Ill., Ind., Mo., Kans., Nebr., Iowa, Mich., Minu., S. Dak.); Soft Maple (Vt., N. H., Mass., li. I., N. Y., N. J., Pa., W. Va., Ala., Miss., La., Tex., Mo., Ohio, Miı.h., Ont., Ill., Ind., Kans., Nebr., Iowa, Wris., Minn., S. Dak.); W'hite Maple (Me., Vt., l.. I., N. Y., N. J., Pa., W. Va., N. C., S. C., Ga., Flı., Ala., Miss., La., Ky., Mo., Ill., Ind., Kans., Nebr., Minn.); River Maple (Me., N. II., R. I., W. Va., Iinn.); Silver-leaved Maple (I)el., N. J.); Water Maple (Pa., W. Va.); Creek Ilaple (W. Va.); Swamp MIaple (W. Va., Mr.).

\section{VARIETIES DISTINGUISHEI) IN CULTIVATION.}

Aceı saccharinum peudulum (Nich.) Sudw.

Weeping Silver Mapie.

Acer saccharinum aureo-variegatum (Nich.) Suclw.

Acer saccharinum wierii (Pax) Sndw.

Variegated Silver Maple.

Acer saccharinum dissectifolinm Sudw.

Acer saccharinum lutescens ( Pax) Sndw.

Acer saccharinum noyn (Ellw. \& Barp) Sulw. Crisp-leg/Silver Maple.

Acer rubrum Linn.

Raxiss.-From New Brunswick, Quebee, and Ontario (laticute 19) to Plorida (Caloosa and Indian rivers); west to Lake of the Wood, eastern l)akota and Nehraska, Indian 'Territory, and 'Texas (T'rinity River).

Naues in USE.-Red Miple (Me., N. H., Vt., Mass., R. I., Conn., N. Y., N. I., Pa., Del.. Va., W. Va., N. C., S. C., Ga., Fla., Ala., Miss., La., Tex., Ky., Mo., Ill., Ind., Ohio, Ont.. Iowa., Wis., Nebr.); Swamp Maple (Vt., N. H., Mass., Coun., R. I., N. Y., N. J., I'a., Del., N. C., S. C., Fla., Ala., Miss., La., 'Tex., Mo., Ind., Ont., Minn.); Soft Maple (T't., Mass., N. Y., Va., Miss., Mo., Ill., Ind., Ohio, Ont, Mich., Kans., Nebr., Minu.): Water Maple (Miss., La., 'Tex., Ky., Mo.); White Maple (Me., N. H.); Shoe-peg Maple (W. Va.); Erable (La.); Ah-weh-hot-kwah = "Red Flower" (Onondaga Inplians, N. I.); Scarlet Maple (Tex.).

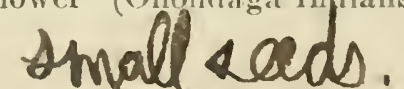


Acer rubrum ärummondii (Hook. \& Arn.) Sargent.

Drummond Maple.

RAxGe.-Sonthern Goorgia and Alahama (colst plain), southwesteru 'T'mnesseo (Covington), western Lonisiana, southeru Arkansas, eastern Tex:as.

VARIETY IDTINGEYSIIEI IN (T'LTIVATION.

Acer rubrum sanguineum (s'geh) Pax

Acer negundo Iinn.

TEGUNDO ACFROIDES Moench.

Raxge.- Termont (Lake Champlain and Winooski River), New York (Cayuga Lake), eastern Penusylvania, and sunth to Florida (Heruando (ounty); northwestward to Winnipeg (Dows Heal Lake and along southern branch of the Saskatchewau River), to the easteru base of the Rocky Monntains (in I3ritish Ameriea), to Montana (Roeky Momntains), L'tah (Wasateh Mountains), Wrstern Texas, New Mexico, and eastern Arizona.

NAMEs IN UsE.-Boxelder (Vt., Mass., R. I., Del., N. Y., N. J., Pa., Ta., W. Ta., N. C., S. C., Ala., Fla., Miss., La., Tex., Ark., Mo., Ariz., Y. Mex., Mont., Ill., Iud., Wis., Uhio, Mich., Iowa, Kans., Nebr., N. Dak., S. Mak., Minn.); Ash-leaved Maple (R. I., Mass., T. .I., Pa., Del., Va., ৯. O., La., Tex., Ill., Wis., Iowa, Ont., Kans., Nebr., Mont., N. Dak., IIich., Minn.); Cut-leaved Maple (Colo.); Negundo Maple (IIl.); Red River Maple (N. Dak.); Thee-leaver Mapie (Pa.); Black Aslı (Tenn.); Stinking Ash (S. C.); Sugar Ash (Fla.): Water Ash (Dakotas).

Acer negundo califormicum (T. \& Gr.) Sargent.

\section{Negundo CALiforicun Torr. \& Gr.}

RANGE.-Sonthern California (valley lower Sacrameuto River; valleys anel coast ranges from San Franciseo Bay to abont latitnde 350 ; western slopes San Bernardino ilountains).

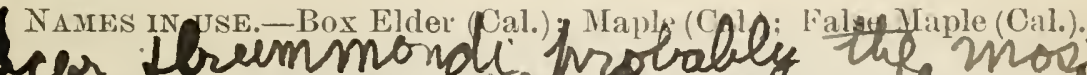
- ver incem mónde Acer negundo variegatum líntze. Acer neguudo angustissimum (Рax) Sudw. Acer negundo crispifolium Sudw.

\section{California Boxelder.}

Acer negundo violaceun (Kioch) Dipp.

\section{Family HIPPOCASTANACF. AE.}

\section{府CULUS Lin!.}

Æsculus glabra Willd.

Ohio Buckeye.

Raxge.-From I'ennsylvania (western slopes Allogheny Monntains) to northern Alabama (Tennessee River Valley and unountaius) aud west to southern Iowa, rentral Kansas, and Indian Territory.

Naufs IN USE.-Ohio Buckeye (Miss., Ga., Ark., Mo., Ohio); Buckeye (Pa., Ky., Mo., Ill., Ind., Ohio, Iowa, Kans.); Fetil Buclieye (W. Va.); Stinking Buckeye (Ala., Ark.); American Horse ('hesinnt(Pa.). 


\section{loobd

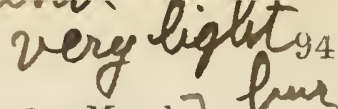

Assculus octandra Marsh.

Aiscult's FLAVA Ait.

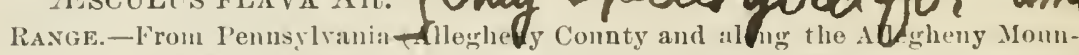
tains to (jeorgia (Angusta) and northern Alabama (mountans); westward to sonthern Iowa, Indian Territory, and western T'exas (upper Ciholo liwer, near Buerne).

NAIF' IN UNE.-Buckeye (N. C., S. C., Alı., Miss., La., Tex., Ky.); Sweet Buckeye (W. Va., Miss., Tex., Mo., Ind.); Yellow Buckeye (S.C.. Ala.); Large Buckeye (Tenu.); Big Buckeye (Tex., Tenu.); Ohio Buckeye (Pa., ('ult.)

Fsculus octandra hybrida (de C.) Sargent.

ASCULUS FLAVA Ait. var pURIURAsCENS Gray.

Purple Bucleye.

Range.-From West Virginia sonthwarl ion Allegheny Monutains); Texas.

Æssculus californica (Spach) Nutt.

California Buckeye.

Raxge.-California (from sacramento River in Mendocino Connty along coast ranges to San Luis Obispo Connty; western foothills of Sierra Nevada Momntains to northern slopes of Tejon Pass in Kern Conuty; Antelope Valjey of san Gahriel Mountrius in Los Angeles Connty). reacuore laved.

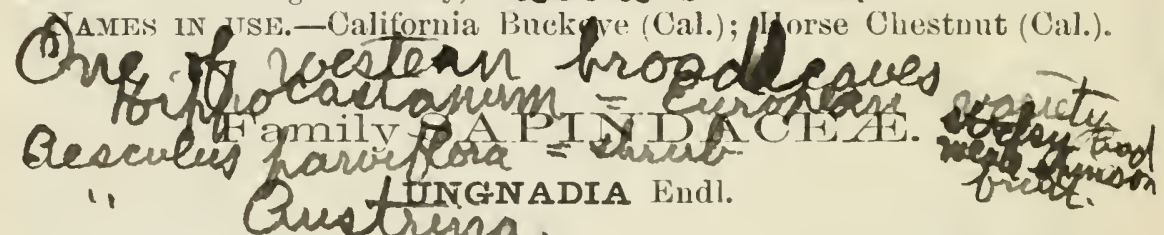

Ungnadia speciosa Endl.

Texas Buckeye.

RAx(ie,-From Texas (Trinity River) to New Mexico (Organ Monntains), and sonthwarl into Mexico (Sierra Marle Mountains in Novo Leou and monutious of ('hibualıa).

Nanks In USE.--Spanish Buckeye (Tex.); Texas Buckeye ('Tex.).

\section{SAPINDUS Linu.}

Sapindus saponaria Iinn.

Soapberry.

RANGE.-Sonthern Florida (Cape Sable, shores and islands of Caximbas Bay and Biscayne Bay) and keys (Key Largo and Elliotts Key); West Indies and Veneznela.

Names Iy UsE.-False Jogwood (Fla); Soapberry (Fla).

Sapindus marginatus Willa.

Wild China.

Ravgl:- From Georgia (Savannah River) to Florida (St. Johns River on the east coast and on the west coast from Cedar Keys to Manatee River); Alibana (escaped from enltivation and running wild near Mobilej; from western Louisiana to sonthern Arkansas (Washita River) and suthern Kansas, through Texas to sonthern Jew Mexico, southern Arizona, and into northem Mexico.

NAins IN UsE.-Soapberry (Fla., La., Tex., Ark.); Wild China (Fla., La., Tex.); Chinaberry (N. Mex.).

EXOTHEA Macfadyen.

Exothea paniculata (Juss.) liadlk.

Inkwood.

HYP'ELATE 'PANICULATA Caml).

Raxik.-Sonthern Florida (from Mosyuitu Inlet to the sonthern lieys); Sau Domingo, Cuba, and Januica.

NAMES IN USE.-Inkwood (Fla.); Houwood. 
HYPELATE Browne.

Hypelate trifoliata Swartz. White Ironwood.

Raxgk.-Florida keys (Upper Metaloombe anI Umbrella keys); Jamajca :nd Cuba.

NAME IN USF.-White lronwool (Fla.).

\section{Family RHAMNACEAE.}

REYNOSIA Griseb.

Reynosia latifolia Griseb.

Red Ironwood.

RAxge.-Southern Flurida (Marquesas Islands to IBiscayne Bay); Cuba, Virgin and Bahama islands.

NAMES IN USE.-Red Ironwood (Fla.); Darling Plum (Fla.).

CONDALIA Cav.

Condalia obovata Hook.

Bluewood.

RAxge. - Western Texas (Matagorda Bay to the Rio Grande River) and northlimastern Mesico.

- Nantes in use.-Bluewood (Tex.); Logwood (Tex.); Purple Haw (Tex.).

RHAMNIDIUM heissek.

Rhamnidium ferreum (Vahl) Sargent.

Black Ironwood.

CONDALIA FFiREA Griseb.

RANGE. - Southern l'lorida (coast from Cape Canaveral and keys to Biscayne Bay); St. Croix, San Domingo, St. Thomas, Puerto Rieo, and Jamaica.

NAuE iN USE.-Black Ironwood (Fla.).

\section{RHAMNUS Linn.}

Rinamnus crocea Nutt.

Evergreen Buckthorn.

RAxgE.-California (upper Sacramento River, west of Sierra Nevala Mountains, to latitule $29^{\circ}$ ) to Lower California (Guidalupe lslands).

Rhamnus crocea insularis (Greene) Sargent.

RAxGE.-Southern California (Cedros and Santa Barbara islands and adjacent mainland).

Rhamnus pirifolia Greene.

RAxGl.-Off́ coast southern ('alifornia (Santa Cruz Islands).

Rhamuus caroliniana Walt.

Yellow Buckthorn.

RAxGe.-From New York (Long Jsland) to Florida, and west (through the Ohio River Valley) to eastern Nebraska, eastern Kiansas, and eastern 'Texas.

NAmes IN UsE.-Indian Cherry (W. Va., X. C., Miss., La., Tex., Ark., Nebr.); Buckthorn (Ark., Iowa, Nebr.); Alder Buckthorn ('T'x.', Nebr.); Yellow-woor (Ala., Ila., La.); Stinkwood (La.); Ing Bireh (Minn.); Stink Berry (Nebr.); Stink Cherry (Nebr.); Carolina Bnckthorn (S. C., Pa.); Polecat-tree ('Tex.); Polecat-wood (Ark.); Brittlenood'Ark.). 
Rhamnus purshiana de C.

\section{Renders a drug.}

PavGr-From Puret Sound soutlimard into Lower Californin; wistwurl throurb northern Washington to Idaho (liitter Root Momntains), Montana (Flat llead Lake); eastern slopes Sierva Nevada Monutaius; monntains of Colorado and western 'Tras.

Naves IN USE.-Shittimwood (Oreg., Idaho, Wash.); Cascara Sagrada (Cal., Oreg.); Beırberry (Oreg., Idaho, Wash.); Bearwood (Oreg.); Tellow-wood (Oreg.); Buckthorn (ldaho); Pigeon-berry (Idabo); Oregon Bearwood (Oreg., Wash.); Cotlee berry (Cal.); Wild Coffee-bush (Cal.): W'estern Cofiee (1)reg., Cal.); Bayberry (Oreg., Cal.); Wild Coffee (Cal.): California Coffee (Cal.).

\section{CEANOTHUS Linn.}

Ceanothus thyrsiflorus Esch.

Blue Myrtle.

Ravgl:-Western C:Ilifornia (from Mendocino Connty to San Lnis liey River).

Nanes In TsE.-Blue Myrtle: California Lilac (Cal.); Wild Lilac (Cal.); Blue Blossom (Cal.).

Ceanothus arboreus Greene.

Tree Myrtle.

Raxie.-Otr coast of sonthern California (Santa Catalina, Santa Cruz, Santa Rosa Islands).

\section{COLUBRINA Brongn.}

Colubrina recinnata (L'Hér.) Brongin.

Naked-wood.

liscir.-Sonthern Florila (Lubrella Ker, north end of key Largo, and islands sontl of Elliotts Fey); Jamaica, San Lucia, st. Vincent, Cuha, St. Croix, Haiti, Virgin auıl Bahama islauls.

NAuEs IX USE.-Naked-Wood (Fla.); Soldierwoul (Fla.).

\section{Family TILIACEA.}

TILIA Linn.

Tilia americana Limm.

Basswood.

RANcil-Now lsrunswick to Yirginia and (along Allegheny Momtains) to Georgia and Alaluna (momtains); west (in Canala) to Lake superior (eastern shores) and o Lake Wiunipug (southern shores) and Assinihoino River (in United States), to eastern Dakota, eastern Neliraska, liansas, Indian Territory, and eastern Texas.

Najes Ix UsE.-Basswond (Me., N. H., Vt., R.I., Mass., Conn., N. Y., N.J., 1)el., ]’a., W. Ta., 1).C.. N. C., S. C., Ga., Ala., Miss., La., Ark., Ky.. Mll, Ind., Iuwa, Wis., Mich., Ohio, Ont., Nebr., Kans., Minn., N. Dak.); American Linden (Me., N. H., R. I., N. Y., Pi.. Del., N. C., Miss., Ohio. Ill., Nebr., N. Dak., ()ıt., Minn.): Limn (Pa., Vil., W. Va.. Ala., Ja., Hll., Ind., Ohio, Mo., lowa., Kans., Nebr., Wis., S. Dak.); Linden (Vt., R. I., Pa., W. Va., Nebr., Mimn); I.imetree (K. I., N. C., S. C., Ala., Miss., La., Ill.); Whitewood (Vt., W. Va., Ark., Mim., Ont.); Beetree (Tt., W. Ta., Wis.); Black Limetres. ('Tenn.); Smonth-leaved Limetree (Tenn.): White Lind (W. Va.); Wiekup (Mass.); Iellow Basswood (Indi.); L(in (Ind.).

\section{Tilia pubescens Ait.}

Downy Basswood.

TILIA AIERICANA 3 PUBESCENS LOUd.

RAxGe.-Niw York (Long Island-swamp in Wading River, Suffolk County); coast of North Carolina, South Carolina, feorgia; uorthern Florida, Louistana, Texas (liin liluneo River). Range insuffieiently known.

NAME: IN USE.-Wahoo (Fla.). 
Tilia pubescens leptophylla Vent. Thinleaf Downy Basswood.

Tilia heterophylla Vent. G weredite hachite Basswood.

liAxis - Fro:u Penusylvania (througlı the Allegheny Monhtiins) to western ancl central Florida (Lake Charm in Orange Comby) and Alabaua ('Tennessce River valley to central prairie region); west to sonthom Indiana and Illinois, Keutucky and Tonnessee (to Nashville).

Nanes in use. - White Basswood (Ind., Ala.); Wahoo (Ga., Fla.); Wild Linden; Smooth-fruited, White-leaved Limetree ('Tem.); Largeleaved Limetree (Tenn.): Silverleaf' Poplar (Ky.); Cottonwood (Ky.); Rilia michandii o Eburna

CEREUS Mill.

Cereus giganteus Engelm.

Giant Cactus.

RA.TG.-Central and sonthern Arizona (from libll Willians River to the san Pedro River) and sonthward into Mexico (Sonora).

Nanes in Use.-Giaut Cactus (N. Mex., Ariz.); Sahuara (Ariz.): Saguaro (Ariz.).

Cereus thurberi Engelı.

Thurber Cactus.

RAxGe- - Sonthwestern Arizona; Mexico (Sonora); Lower ('alifornia.

NAMrs IN USk.-Pitahaya (Mex.); Pitahaya dulce (Mex.).

Cereus schottii Lugelm.

RAxGF.-Southern Arizona; Mexico (Sonora); Lower California.

NAMIES in Use.-Zina. Sina, Sinita, Hombre viejo, aud

Schott viejo (Ariz., Mex.).

\section{OPUNTIA ${ }^{1}$ Mill.}

Opuntia fulgida Engelm.

Cholla

Raxge,-From southern Neracla (Cottonwoud Springs) through Arizona (sonth of ('oloralo platean in Prma, Maricopa. Pinal, and Corhise connties) into Mexico (Sonora), and Lower Calıfornia.

Opuntia fulgida mammillata (Scott) Coult.

RAxgE.-Through sonthern Arizona (sonthern foothills of santa Catalina Monutains, ete.) into Mexico (Sonora).

Although several species of Opuntias have long lieen kuown to be of tree-like form and limensions, these arborescent species have usully not been considered strictly trees. It is evident, however, that they should be regarded as true trees, both from their tree-like form, and also from their truly woody internal structure. Prof. J. W 'Tonmer, of the University of Arizona, who has conducted many critical studies on southwestern Cactaces, writes the following concerning one of the tree? Opuntias :

"The reticulated wool is used to some rxtent in the manufacture of light finrniture, fancy articles, canes, picture frames, etc. A factory was estalılished in salt River Valley (Arizona) some three years ago for the purpose of manufacturing articles trom this wood."

For excellent illustratious of the greneral appearance of these trees, the reacler is referrerl to followng articles by Professor Toumey: Opuntia fulgidu, farlen and Forest, VIII, 324, f. 45, 1895; Opuntia arborescens, Garden and Forest, IX, 2, f. 1, 1896

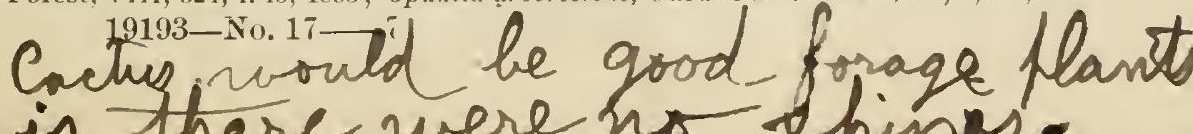


Opuntia versicolor Engelm.'

Raxie. - ionthern Arizona (fonthills and low momtans).

Opuntia sponsior (Engelm.) Toumey. ${ }^{2}$

liavik.-Southern Arizona. Range not yet perfactly known.

Opuntia sponsior neomexicana 'Tommey.2

Ravia.-sonthern Arizona.

\section{Family RIIILOPHORACWA.}

RHIZOPHORA Lim.

Rhizophora mangle Linu.

Mangrove.

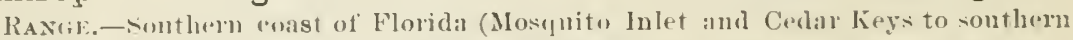
islamds): Ilississippi delta; 'Trxas coast: (astern and western coasts of Mexien; Low.r California; from ('entral Amerimal along uorthern and easterm wast of south America to the limits of the tropies; Permudas, Bahamas, West Indies; Cralapagos Islands.

NAJE IN TAB.-Mangrove (Fla.).

$$
\text { Family MYRTACFA. }
$$

ANAMOMIS (iriseb.

Anamomis dichotoma (Poir.) Sargent.

Naked Stopper.

Eugenia dichotoma de C.

RAsGe. -Florida coast (Mosyuito Inlet to Cape Canareral on the east, and on the west ('aloosa River to Cape Romano; Key West, liseayne liay); West Indies.

Nanks in UsE.-Naked-wood (Fla.); Naked Stopler.

\section{CHYTRACULIA Browne.}

Chytraculia chytraculia (Linn.) Sudworth.

Stopper.

CALYPTRAN'IIES CHYTRACLLIA Swart\%.

Raxtik-Florila (Lake: Worth; Key West, Key largo; liseayne Bay); West Inclies and sontlern Vexien.

Chytraculia chytraculia genuina (Herg.) Sudw.

Chytraculia chytraculia ovalis (Berg.) Sudw.

Chytraculia chytraculia trichotoma (Berg.) Sudw.

Chytraculia chytraculia pauciflora (Berg.) Sudw.

Chytraculia chytraculia zuzygium (Linn.) Sudw.

EUGENIA linn.

Eugenia buxifolia (Swart/) Willd.

Gurgeon Stopper.

RAxGl.-Florila coust ( $m$ the east, ('ape Canavernl to sonthern key; and on the west, Caloosa River to ('ape Sable).

I In Coulter, Contr. IT. ト. Nat. Herl., III, 452, 1896.

-Bot. Ga\%, XXV $119,1898$. 
Eugenia monticola (Swartz) de C.

White Stopper.

Raxge.-Florida coast st. Johns River to Key Largo, Key West, Tpper Metacombe liey, Vlliotts Key); West Inrlies.

Names IN UsE.-White Stopper (Fla.): Stopper (Fla.).

Eugenia procera (Swartz) Poir.

Red Stopper.

Raxge.-Florida keys (líy West ank I'mbrella liey); sim loningo, ('uba, . Iamaica, Santa C'ruz, Martinique.

NAMEs in UsE.-Red Stoppel (Fla.); Spiceberry (1*la.).

Eugenia garberi Sargent.

Garber Stopper.

EUGENIA PROCERA Sargent.

lisid.-Florila (hammock, thren-lourths mile "ast of mouth of Miami liver; (1/, Rhorles Key and Elliotts Key; Babamas (one), New l'rovidence Island, West Iuclies (Antigna).

\section{Family COMBRET ACEAE.}

TERMINALIA Benth. \& Hook.

Terminalia buceras (Browne) Benth. \& Hook. Black Olivetree.

RAxGE.-Sonthern Florida (Elliotts Key); West Inılies, coast Caribbean Fea, and Bay of Pauama.

\section{CONOCARPUS Linn.}

Conocarpus erecta Linn.

Florida Buttonwood.

RAXGE.-Coast of southern Florila (Cape Canareral and Cedar lieye to sonthern islands West Indies): Central and Sonth America; Galapagos Islands; east coast of Africa.

NAMES IN USE.-Buttowwood (Fla.).

Conocarpus erecta arborea de C.

Conocarpus erecta procumbens (Linn.) de C.

Conocarpus erecta sericea de C.

LAGUNCULARIA Grertn. f.

Laguncularia racemosa (Liml.) Giertn. f:

White Buttonwood.

RAxGe.-Coast of sonthem Florida (Cape Canaveral and Cedar keys to sulthern islands); West Inclies, Mexico, Central and South America, and western If fical.

Names IN Use.-White Buttonwood (Fla.); White Mangrove (Fla.); Buttonwood (Fla.).

\section{Family ARALIACEAE.}

ARALIA Lim.

Aralia spinosa Linn.

Angelica-tree.

RAxGe.-From Pennsylvania (Allegheny Mountains in Cleartield, Cambria, Westmoreland, and Fasette comnties) to Florida, and to southern Indiana, southeastern Missouri, Arkansas, and eastern Texas.

NAMEs tạ use.-Angelica-tree, Hercules" Club. 


\section{Family COIR $\mathrm{CCF} A \mathrm{CE}$.}

\section{CORNUS Lim.}

Cornus florida Linn.

(Flowering) Dogwood.

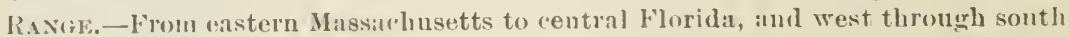
ern (Hutario, southern Michigan (up to Montealm County) to sonthwestern Missouru and Texas (lirazos River); Mexico (Sierra Madre Mountains).

NAMEs IN USE.-Flowering Dogwood (Mass., R. I.. N. Y., N. J., Jel., Pa.. Ya., N. C., S. C., Miss., La., Ark., Mo., Ill., Kans., Mich., Unt., Ohio, Ind.); Dogwood (N. J., Pa., Del., W. Va., N. C., S. C., Ala., I'lı.. Liı, Ky., Ohio, Inl., Mich.); Boxwood (Comu., R. I., N. Y., Miss., Mich., Ky., Ind.. Ont.); False Box-dogwood (Ky.): New lingland Boxwood (Tenu.); Flowering Cornel (li. I.); Cornel (Tex.).

VARIETIES INTIXGLISHEI, IN CULTIVATION.

Cornus florida pendula Temple.

Cornus florida rubra Temple.

\section{Cornus nuttallii Aud.}

RANGE.-From sonthern coast of British ('olumbia (Lower Fraser River and Vanconver Island) through Washington, Oregron, and California (eoast ranges to San lieruardino Mountains and western slopes of Sierra Nevada Mountains).

NAMES IN UsE.-Dogwood (Cal., Oreg., Wash.); California Dogwood (Cal.); I'lowering Dogwood (Oreg.. Cal.); Western Dogwood.

Cornus alternifolia Linn. f.

Blue Dogwood.

RANGE.-From Nova Scotia and New Brunswick (through St. Lawrence River Valler) to Lake siperior (northern shores) and Ninnesota; sonth throngh the Northern States (and along the Allegheny Mlountains, to northern Georgia ind Alabama.

NAMEs in ist.-Dogwood (Vt., Mass., R. I., Conn., X. Y., N. J., Pa., Va., IV. Va., N. C., Ga., Fla., Miss., La., Ark., Ky., Ill., Wis., Minlı., Ohio, Ont.); Blne J)ogwood (Pa.); Purple Dogwood (1'a.); Umbrellatree (R. I.); Pigeonberry (N. Y.); Alternate-leaved llogwood (Mich.); Green ()sier ( $\mathrm{T} t$.).

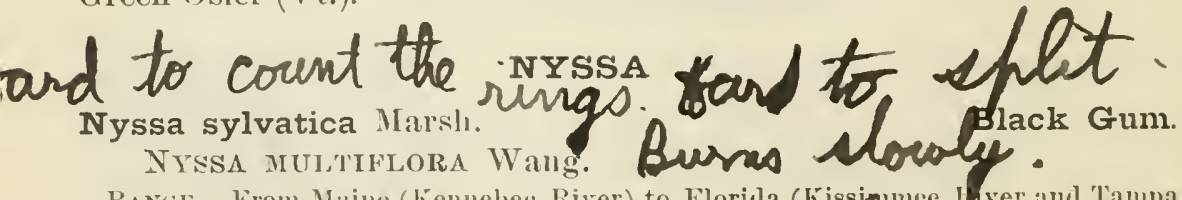

RaNiE,-lrom Mitue (Kenneber River) to Florila (Kissinme IMver and Tampa Bay) and wesı to sonthern Ontario, sonthern Michigan (11) to Gratiot County), sontheasteru Missuri, and Texas (Brilzos láiver).

NAMles IX Use.-Black Gum, (N. J., P’a., Del., Va.. W. Va., N. C., S. C., Ga., Mla., Hla.. Miss., La., Tex., 1ll., Ind.); Sonr Gum (Vt., Mass., R. I., N. Y., N. J., Pa., Del., Va., W.Va., S. C., Fla., Tex., Ohio, Ind., Ill.); Tupelo (Mass., R. I., N.J., Del., S. C., Ala., Fla., Miss., Tex., Ill., Ohio); Pepperidge (Vt.. Mass., R. 1.. N. Y.. X. J., S. C., Tenn., Mich., Ohio, Ont.); Wild Peartree (Tenn.); Yellow (Gumtree (Tenn.); Gum (Md.); Stink rood (W. Va.); Tupelo Gum (Fla.). 


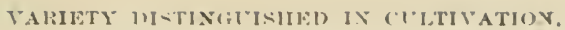

Nyssa sylvatica pendula ('Temple) sulw.

Nyssa biflora Wialt.

Water Gum.

NYSSA ArLATICA Limm.

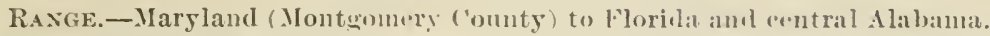

Nyssa ogeche Marsh.

Sour Tupelo.

Nrssa CAPITATA Walt.

RaNGE.-From sontherm borders of sonth C'arolina (near coist and throngh the Ogeerher River Valley in fieoryia) to northern Florilia (Clay Connty) and westeru Florida (Washington Comntr).

Naufs in UsE.—Sour 'Tupelo (s. C., Fla.); ('geechee Lime (S. C. Fla.); Gopher Plum (Flit.): Tupelo; Will Limetree; limetree.

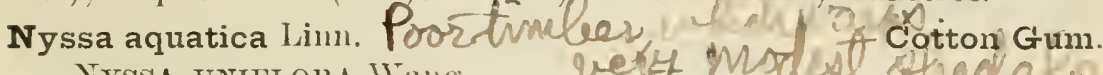

Nyssa tinffLORA Willg.

RAxGe.-Coast region trom sonthern Virginia to northern Florida, and throngh the Ginf States to Texas (Nuenes River); northward throngh Arkansas. West Tennessee and Kentucky, somthem and sontheastern. Missonri to sonthern Illinois (lower Wabash River).

Nanes in use.-latrge Tupelo (Ala., Lat., Tex.); Thuelo (rum (Ga., Ala., Miss., La.); Sour Gum (Ark., Mo.); Swamp Tupelo (\$. C., La.); Cotton Gum (N. C., S. C., Fla.); Tupelo (Y. C.. S. C.); Wild Olivetree (La.); Olivier à grandes fenilles (La.): Olivetr(e) (Miss.).

\section{Family ERICACAE.}

VACCINIUM Linı.

Vaccinium arboreum Marsh.

Tree Huckleberry.

liswie.-From North Carolina to Florida (Hernando Connty) and through the Gulf States to eastern Texas (Matagorda Bay): nolthwald through Arkansas ancl Temmessee to southern lllinois and Missouri.

NATES IN USE.-Farkleberry (N. C., S. C., Fla.. Miss.. La., Mo.); Sparkleberry (‥ C., S. C., Ala., Fla.); Myrtle Berries (La.); Bluet (La.); Tree Huckleberry (S. C.); Gooseberry (N. C.).

\section{Arbutus ninziesii Parsly:}

\section{ARBUTUS Lim.}

RAvie.-Coast region from British Colnmbia (islands at Seynonl Yarrows) te Califurnia (coast ranges tu sautil Lucia Monntaius).

Names Is UsE.-Maulroña (Ual., Oreg.); Madrovo (Cal.); Laurel-

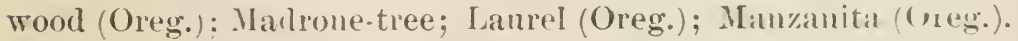

Arbutus zalapensis 1 . I. K.

Mexican Madroña.

ARBUTUS TALAPENSIS var. TExaxa (iray.

RAxGE.-Texas (Travisand Hays-Rio lilanco liver-connties to Eagle and Guadalupe nonntains): Mexico (Sirra Macle Mountains in Nuevo Lan, to mountains near Jalapa).

Nanes IN tSk.-Manzanita; Madroña; Madrome-tree; Lamrel. 
Arbutus arizonica (Gray) Sargent. Arizona Madroña.

ARIBUTUS XALAPTENIS Val. ARIZONICA Griy.

R.Ack.-Foutlern Arimona (Santa ('atalina anel sinta Rita mountains); southwarl into Mexico (Sierra Malle Mountain in Chibuahna).

\section{ANDROMEDA Linn.}

\section{Andromeda ferruginea Walt.}

Andromeda.

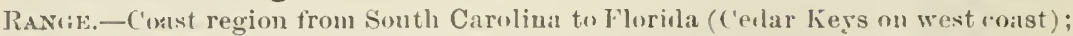
Mexico (region of San luis l'otosi, mountilins of Uaxaca, Urizabil, Jitotole, and Talein): West Indies.

NAME IN UNE.-Titi (Flia.).

Andromeda ferruginea arborescens Michx.

Andromeda ferruginea fruticosa Miclix.

\section{OXYDENDRUM de C.}

Oxydendrum arboreum (Liun.) de C.

Sourwood.

RANif.-l'rom ['musylvania (Mount Pleasant, in Westmoreland Connty, and along the Allegheny Mountains) to westeru Floridla aud southeru Alabuma (eastern shores Mobile Jay), westwald to southern Indiana, Arkansas (momtains) and western Lonisiana.

NAJES IN USE.-Somrworl (W. Ta., X. C.. S. C.. Gia.. Fliı.. Ala., Miss., La., Ky., Ohi(o); Sorrel-tree (I’a., X. C., S. C., Miss., La., Ohi(o); Sour Gum Bush (Ohio); Sour (tum (W. Va.): Arrow-wood (W. Va.); Titi (S. C.); Lily of the Valley-tree.

\section{KALMIA Linn.}

Kalmia latifolia Tinu.

Mountain Laurel.

Raxis.-From New Brunswiek to Lake Jirie (northeru shores ant uainly along the Appalachian Mountains) to western Florida: west through the Gulf States to western Lonisiana and Arkansess (Red River).

NAMlis IN USE.-Ianrel (N. H., Yt., Mass,, R. I., Comn., N. .I., N. Y.. Pa.. Del., Va., W. Va., N. C., S. C., Miss., La., MIo.); Calico Bush (Tt., R. 1., N. I., Ma., Del., N. C.. S. C., Ala.. Miss., La.); Spoonwood (N. H., Mass., T. I., Pa., Miss.); Ivy (Comu., Md., Ta., X. C., S. C., Miss.): Poison Ivy (Tenn., Ala.): I'oison Laurel (Ala.); Mountain Laurel (Vt., Mass.. W. Va., Ky., Teun.); Sheep Isanrel (1'a.); Wood I aurel (Pa.); Small Laurel (IV. Va.); Kalıia (I’a.. S. C.); Calieotree (Temn.); Calieo Flower (Teun.); Mountain Ivy 'Ta.); Big-leaved Ivy (lit. domestie medicine); Ivywood (S. C..).

\section{RHODODENDRON Linn.}

Rhododendron maximum Limu.

Great Rhododendron.

lisxis-From Nora sintia to Lake Eri॰ (nortlı shores) and southward in New England and Naw York (and along the Allogheny Momntains) to northern Georgia.

Namis in tisw.-Groat Lamel (N. H., Mass., R. I., N. Y., N. J.. Pa., N. C., Minu.); Rose Bay (R. I., Pa., N. C., S. C.): Bigleaf Iaumel (Pa.); Big Laurel (W. Va.); Laurel (R. I., Va., N. C., S. C.); Momntain Lamrel (I’a.. S. ('.); Rhododendron (R. I., N. I.. Pa.. Ta.. S. C.); Dwarf Rose Bay-tree ('I'enn.): Spoon Hutch (N. H.); Wild Rose Bay and Deertongue Lamel (lit. of domestic medieine). 
VAIRTIES DISTINGCISHLD IN CULTIVATION.

Rhododendron maximum roseum P'ursh.

Rhododendron maximum purpureum Pursh.

Rhododendron maximum album I'ursh.

Rhododendron catawbiense Michx.

Catawba Rhododendron.

RAxite.-Mnutains flom Virminia and West Virginial to Georgia and Alabana (Lowkout Mountain, ou Little Liver in Dekalb County).

\section{Family MYRSTNACEAE.}

ICACOREA Aublet.

Icacorea paniculata (Nutt.) Sudworth.

ARDISIA PICKRRINGIA Nutt.

RaxGE. - C'nast of southern Florida (on the east coist from Mosquito Inlet to sontheru islands and on the west coust from Caloosa River to Cape Romano); Bahamas, ('ulai, and southern Mexico.

Names IN USE.-Marlberry (Fla.); Cherry (Fla.).

JAQUINIA LiUn.

Jaquinia armillaris Jacq.

Joewood.

RANGE. - Off the coast of southern Florida (Sanibel Islands to sonthern leess and Everglades): Mexico, Central America, Venezuela, and northeru brazil.

NAMIE IN USE. 一Joewood (Fla.).

\section{Fannily SAPOTACE AE.}

\section{CHRYSOPHYLLUM LIIn.}

Chrysophyllum monopyrenum Swartz.

Satinleaf.

CHRYSOPHYLLUM OLIVIFORME LAm.

Ravitie-Coast of sonthern Florida (on the east coist from Mosinito Inlet to southern kescs and on the west coast from Caloosa River to Cape Sable); Bahimas and West Indies.

NaıE IN USE.-Satinleaf (Fla.).

\section{SIDEROXYLON Lim.}

Sideroxylon mastichodendron Jacq.

Mastic.

RAxGE. - Coast of soutlern Florida (on the east const from Cape Canaveril to southern keys and on the west coast from Cape Romano to Cape Sable); Bahamas aud West Indies.

Nadre iN USE.-Mastic (Fla.); Wild Olive (Fla.).

BUMELIA Swart\%.

Bumelia tenax (Linı.) Willd.

'Tough Bumelia.

RANGe.-Coast region Yorth Carolina to F'lorida (Cape Canaveral and Corlar Kerss).

NAMES IN USF.-Black Haw (Fla.); 'Tough Buckthor'u (S. C.); Iron$\operatorname{wood}(\mathrm{S} . \mathrm{C} ., \mathrm{Fla}$.). 
Bumelia lanuginosa (Miclix.) Pers.

Shittımwood.

RAxi:E.--From sonthern Georgia and northern Floridal throngh Alahinuil (Tennessee liver Valley to eonst plaiu); from sonthern Illinois and sonthern Missuuri through Arkansas anul Texas to Mexion (Nuevo Leon).

NAMEs IN UsE.-Gum Elastic; Shittimwood (Tex.); Black Haw (Fla.).

\section{Bumelia lanuginosa rigida Gray.}

liasie. - Western Texas to Arizona and south into Mexieo (Nuevo Leon).

Bumelia lycioides (Lim.) Gieltn. f.

Buckthorn Bumelia.

Rux(ik.-From sontheru Virginia to Florida (Mosquito Inlet and ('aloosa River) and west to sontheru Illimois, sonthern Miscouri, Arkansas, and Texas (Rio l'oncho liver).

TAyes in Use.-Ironwood (Va., S. C., Ga., Fla., Miss., Ky.): Soutlern Buckthorn (Miss., La., Tex., Ill.); Carolina Buckthorn (X. U.); Buckthorn (S. C.); Chittimwood (Tex.); Mock Orauge (Fıa.).

\section{Bumelia angustifola Nutt.}

Saffron Plum.

RANGE. - Floridil coast region (on the east from Indian River to southern kers, and on the west coast from Cedar Keys to Cape Romano); Texas (Rio Ciramle liver helow Laredo); Mexico (Nuevo Leon); West Indies.

YAMEs in USE.-Saffrou Plum (Fla.); Downward Plum (Fla.): Ants. rood (Fla.).

\section{DIPHOLIS A. de C.}

Dipholis salicifolia (Linu.) A. de C.

Bustic.

RAxir:-C'oast of sonthern Florida (Biscayne Bay and a number of southern keys); Bahamas and West Indies.

NAJEs IN USE.-Bustic (Fla.); Cassada (Fla.).

\section{MIMUSOPS Linn.}

Mimusops sieberi A. de C.

Wild Sapodilla.

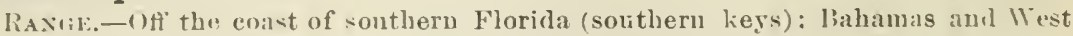
Iullies (?).

Names I Use. - Wild Dilly (Fla.); Wild Sapodilla (Flil.).

\section{Quber Diospyros virginiana limn. When eut wior. Persimmon.} Famifr FBEN ACEA. lis.rif.-Connectient (Light-honse Point, New Haven); New York (Longl-land);

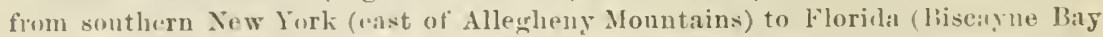
and ('aloosa liver): from sonthern (hio to sonthern Alabaua aud west to sonthwestern Iowa, sontleru Missouri, aud castern hansas (Franlilin, Anderson, Bourbon, ('riwiord, and Cherokee comnties), Indian Territory and Texas (Colorarlo River).

YAmes IX Usk.-Per'simmon (Conn., N. Y., N. J., Pa., Del., Va., W. Ta., N. C., S. I'., Ga., Fla., Miss., La., Ky., Mo., Tex., Ark., Ill., Ind., Towa, Ohio); Date Plum (X..J., Temı.); Plaqueminier (La.); Sim. mon (Fla.): Possumwood (Fla.). 
Diospyros texana Scheele. Mexican Persimmon.

RANGe.-Texas (Colorado and Rio Concho rivers) to Mexicu (Nnevo Leoni.

Nanes in UsE.-Mexican Persimmon (Tex.); Black l'ersimmon (Tex.); Chapote (Tex.).

\section{Family Y YPTOOCACEAE.}

Symplocos tinctoria (Linn.) L'Hér.

\section{SYMPLOCOS Jag 1 has a weet tacte
Linn.) L'Hér.}

RAxge. -From sontheru Delaware (peninsula) to Florida; west in the Atlantic region to the Blne Rirlge Monutains, and through the (inlf States (in Alahama up to Temuessee River) to western Louisiana and southern Arkansas (borler connties).

NAMEs ix UsE.-Sweetleaf (Del., X. C., S. C., Fia., Ala.); Yellow. wood (X. C.. S. C., Ala.); Horse Sugar (Del.. Ala.. La.); Florida Laure? (Fla.).

\section{Family STYRACACFA.}

MOHRODENDRON Britton.

Mohrodendron carolinum (Linn.) Britton.

Silverbell-tree.

HALESIA TETRAPTERA Ellis.

RAxiE.-From West Virunia (mountains) to southern Illinois and south to midell, Florida, northern Alabama (Landerdale, C'ullman, and Talliklega ronuties . and Mlississippi through Arkansas and western Lonisiana to eastern Texas.

YAuEs IN USE.-Showdrop-tree (R. I., Pa. (cult.). N. U., s. C.. Fla.. La.): Silverbell-tree (R. I. (cult.), Ala., Fla., Miss.); Silverbell P’a., cult.); Wild Olive-tree (Tenn.): Bell-tree (Tenn.): Fonr-winger Halesia (Ala.); Opossum-wood (Ala.); Rattlebox (Tex.): Calicomoud ('Tex., Ill.): Tisswood (Teun.).

Mohrodendron carolinum meehani (Sarg.) nom. nov.

Meehan Silverbell-tree.

RAxGe,-Originated in the nursery of Thomas Jeehan of Sons, Germantown, Pa., and so far knowu only in enltivation.

Mohrodendron dipterum (Ellis) Britton.

Snowdrop-tree.

HALESIA DIPTERA lillis.

RAxuE.-Coast region foun Sonth Carolina to northem liklorida, and thrmen the Gulf States (mainly in coast plain of Alabumil) to Texas: northwarl thromgh Lomisiana to ceutral Arkansis.

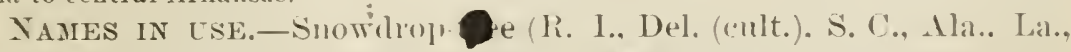
Tex.): Silverbell-tree (K. I., Del. (cult.), Miss.. Tex.): Cow licksis (i.a.).

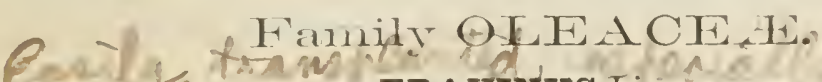
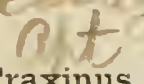

\section{FRAXINUS Linin.}

Fraxinus cuspidata Tol'l.

Fringe Ash

RAxGE,-From soutbwesteln Texas (canyou of Rio Grande livor) through sonthern

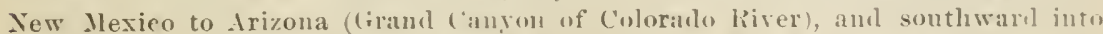
Mexirn (momtains of Cohahuila anl Nuevo Leon to Santa Ënlalia Mountain- in (i)ihuahua). 
Fraxinus greggii Gray.

Gregg Ash.

RAsis. - Western T'xas (from month of San l'edro kiver to Pecos Rirer) and sonthwarl into Mexiro (momtains of Nievo len, Cobahmila, and ('hibuahua).

Fraxinus quadrangulata Miehx.

Blue Ash.

RAxGe.-From Michigan, Illinois, and Iowa sonthwarl (ranging into sontheastern liansis in sumner and Lherokee connties) to nortbern Alibanil (Jackson and Midison comntes and to northeastern Arkansas. liane insufticiently kuown.

Na.re Ix USE.-Pihe Ash (Pa. (eult.), Alı., Ky., Mo., Ill., Mirh.).

Fraxinus nigra Marsh.

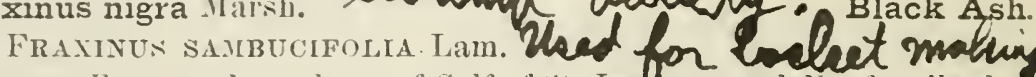

RANGE. - From northeru shores of Gulf of st. La Uence and Newfomdland th Manitobal (Lake Wiunijeg) and southwarl to Delaware (Newcastlo County), Virginia (muntains), sonthem Illinois, central Missonri, ind northwestern Arkansas.

NAYEs Ix UsE.-Black Ash (Me., N. H., Vt., Mass., R. I., N. Y., N. J., På. I)(.l.. Wr. Va.. Mo.. Ohio, (Ont., Mich., Ill., Minu.); Hoop A.sh (Vt., X. Y.. Del.. Ohio, Ill., Ind.): Basket Ash (Mass.): Brown Ash (X. H., Tenn.): Smamp Ash (Vt., R. I., N. Y:); Water Ash (W. Va., Tenı., lilt.).

Fraxinus anomala Wats.

Dwarf Ash.

RAxiE. -From sonthwestern Colorarlo (McElmo liver) throngh southern Utul,; sonthern Vevalla (Charleston Monntains).

NAMES IN UsE.-Ash (Utah); l)warf Ash (Ari\%., Utah).

Fraxinus anomala triphylla Jolles.

Trifoliate Dwarf Ash.

lixw, F.-Arizona (type locality "Pagmupa in the Grand Wash, 4,000 feet al titucle.").

Fraxinus velutina Torr.

Leatherleaf Ash.

PraAixus PISTACI JFOLIA Torr.

lis.ik- From western Texas (monntains) throngh sonthern New llexico ind

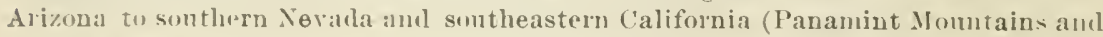
(Oweus Lake).

TMIE IX Ust.-Ash (Tex., Aliz.. Nev.).

Fraxinus americana Linll. wigo imootte.

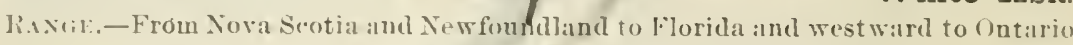
aul nurlbern Minnesota, eastern Nebraska, Kansis, Indian Territory. and Texas (Trinity liver).

Naines in Lisk.-White Ash (Me. N. H., V't., Mass., R. I., Conll., N. Y.. Y. ... Del., I’a., Va., W. Va., N. C., S. C., Ga., Fla., Mla., Miss., Lá. Tex.. Ky.. Mo.. IH., Ind.. Iowa, Kans., Tebr., Mich., Ohio, Out., Minn.. N. l)ak., Wis.); Ash (Ark., Iowa, Wis., Ill., Mo., Mun.); Aneriean Ish (lowa); l'ranc-Frene (Quebec); Cane Ash (Ala., Miss.. La.).

Fraxinus americana curtissii (Tasey) Sudworth.

\section{Small-fruit White Aslo.}

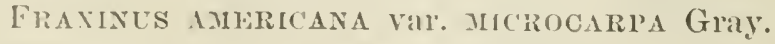

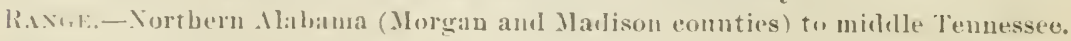

Fraxinus texensis (Gray) Sargent.

Texas Ash.

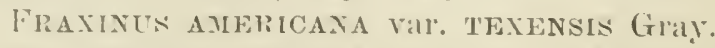

liaxil.- Vorthern, ("ultral, alld western Texas (from near Dallas to valley of Imils live?:

NAME IN USE.-Mountain Ash (Tex.). 


\section{7}

Frazinus pennsylvanica Marsh.

IFRAIINUS PUBESCENS Lam.

Raxge.-From New Brunswick to northern Florida and westward to sonthern (1)tario, Dakota (Black Hills), castern Nobraska, northeastern and eastern (borior counties) Kansas, to west Tennessee and through northeru Alabama (mountain region in St. Clair and Cullwan counties).

NAMEs in USE.-Red Ash (Me., N. II., Vt., Mass., R. I., N. Y., N.J., I’a., Del., W. Va., N. C., S. C., Fla., Ga., Ala., Miss., La., Ky., Mo., Ill., Kans.. Tebr., Mich., Minn., Ont.); Brown Ash (Me.); Black Ash (N....);

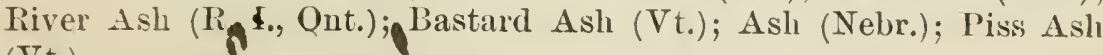
(N.t.).

Fraxinus profunda Bush.

Pumpkin Ash.

RAxGe.-Western Florida and southern Missouri (New Madric County); Arkansas (llear Varner). Rauge insufficiently known.

NAIIE IN USE.-Pumpkin Ash (Ark.).

Fraxinus lanceolata Borkh.

FRAXINUS VIRIDIS Michx. f.

RAxige-From Vermont (Lake Champlain and southward in the Alpalachian region) to northern Flonda; westward to the Saskatchewan River, eastern ranges of the Rocky Mountains and extending into Utah (Wasatch Monntains) and eastern and northern Arizona (mountains), and through eastern Texas (to Colorado River).

Names Ix Use.-Green Ash (Mass., R. I., Comn., N. Y., N. J., Pa., Del., ‥ C., S. C., Ala., Miss., La., Tex., Mo., Ill, Kans., Nebr., Mich., Minn.. S. Dak., Ohio, Ont., Iowa); Blue Ash (Ark., Iowa); White A.h (Kans., Nebr.); Swamp Ash (Fla., Ala., Tex.); Ash (Ark., Iowa, Nelir.); Water Ash (Iowa).

Fraxinus berlandieriana $\mathrm{A}$. de $\mathrm{C}$.

Berlandier Ash.

RAxie.-- Western Texas (banks of Nueces and Rio Blanco rivers and otlier streams), but probahic established in northeastern Mexico anil in the Uuited States only through the agency of man; iuch gevous in sonthern Mexico (mountains of Michorean).

\section{Fraxinus caroliniana Mıll.}

FAIINT'S PLATYCARPA Michx.

Water Ash.

Raxcin--Coast region from southern Virginia to Florida (Cape Canaveral and Caloosa Piver) and in the Gunl region (in Alabana up to Tuscaloosa, Baldwin, Clank, and llobile comnties) to Tuxas (Sabine liver); northward throngh westeru Louisiana to sontluestern Arkansas

Naver ry use.-Water Ash (N. C., S. C., Fla., Ala., Miss., La., Tex.); Carolina Ash (Pa.. cult.): Poppy Ash (Ala.): Pop Ash (Fla.).

\section{Fraxinus oregona Nintt.}

Oregon Ash.

RAverE.-From Puget Sound (shores) southward through Washington, Oregon and Califoruia (coalst region to San Francisco Bay; on foothills of Sierra Nerada Mountains to mountains of San lernardino and San Diego (-onnties).

NAME IN USE.-Oregon Ash (Cal., Wash., Oreg.).

\section{CHIONANTHUS Linn.}

Chionanthus virginica Liun.

Fringetree.

RANif., - From l'eunsylyanial (Lancaster aud ('hester counties), DeIaware, West Virgina (Jackson aud summers eonuties), aud Kintucky (Warren Comuty) to Florila ('Tampa Bay): west through the Gulf' States to Texals (Brazos River) anci sonthern Arkinsas; eastern Kansas (Allen County).

NauIS IN UsE.-Fringetree (R. I. (cult.), N. I. (cult.), N. J., l'a., Del.. D. C., N. C., S. C., Fla., Miss., La., Tex., Mo.); White Fringe 
(Mass., R. I., I’a.); American Fringe (W. Va.); White Ash (IV. Va.); Old Man's Beard (N. C., S. C., Ala., Fla.. Miss., La.); Flowering Ash (S. C.); Suntlower-tree (Temu.).

\section{OSMANTHUS Laureiro.}

Osmanthus anıericanus (Limu.) Benth. d Hook.

Devilwood.

Ravil:-Coast regrion from North Caroliua (Cape lear River) to Florida (Kissimmee River and Tampa Bay) aud west to oastern Lonisiana ; Arkansas ( ${ }^{J}$ ).

NAmes IN USE.-Devilwoorl (Ala., Fla.); Wild Olive (Fla.).

$$
\text { Hamily BORTAGGINACHA: }
$$

CORDIA Limm.

Cordia sebestena liun.

Geigertree.

lisxis.-.Sonthern Florida islands (Key West and other southeru islanls);

Bahamas, West Indies, Guiama, New Gramada.

NAME IN USE.-Geigertree (Fla.).

Cordia boissieri A. rle $\mathrm{C}$.

Anacahuita.

Rangl.-From! Texas (Rio (iraude River) and sonthern New Mlexi'o inte north. ern Mexic'o.

\section{BOURRERIA Browne.}

Bourreria havanensis (Roem. \& Sch.) Miers.

Strongback.

RAxGk-Florida kejs (líy West, Key Largo, Upper Metacombe, ant Elliotts K(s.); Rahamas and several of the West Indies.

NAMES IN USE.-Strongbark (Fla.); Strongback (Bahama Islands). Bourreria havanensis radula (Poir.) (iray.

\section{Bristle-leaf Strongback.}

\section{EHRETIA Browne.}

Ehretia elliptica de C.

Anaqua.

RAx(iv.-Westem Texas (from upper San Marcos River to the Rio (irande River); Mexirn (Nnevo Lem and Coahnila to mountains of san luis l'ntosi).

Naines rN UsE.-Ḱnaekaway ('Tex.); Anaqua ('Tex.).$$
\text { Finnily VERBHANACFAE. }
$$

CITHAREXYLUM Linn:

Citharexylum villosum Jacq.

Fiddlewood.

liaxis:-Sunthern Florida (from Capo Canaveral to the sonthern keys).

NAME IN USE.-Fiddlewood (Fla.).

\section{AVICENNIA Linn.}

Avicennia nitida Jacq.

Blackwood.

RA.V(iF.-Floricta coast (from it. Augustine to the southern keys on the cast cuast and on the west eortst from Ceelar Keys to Capes Sahlej; Lonisiana (Mississipji River delta); several of the Wost Indies and lirazil.

NAגes IN USE.-Blackwood (Fla.); Hlacktree (Fla.); Black Mangrove (Fla.). 


\section{Family SCROPHULARI ACFA.}

PAULOWNIA Sieb. \& Zuc:.

Paulownia tomentosa ('Thunb.) Stendel.

Paulownia.

Raxide.-Japan. Cultivated in the Middle Atlantic aud sonthern States and running will in many localities (near Wilmington, Iel.; Waslington, I. C.; Mobile, Ala.. ('t".).

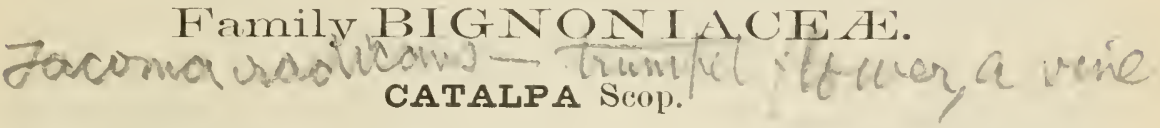

Catalpa catalpa (Linn.) Karst.

(Common) Catalpa.

CATALPA BIGNONIOIDES Walt.

RAxGE.-Supposed to be indigenous onl $y$ in sonthwestern (ieorgia, western Florida, central Alabama and Mississippi, but widely cultivated and naturalized elsewhere east of the Rocky Mountains.

Names in Use.-Catalpa (Mass., R. I., Conn., N. T., N. J., Pa., Del., W. Va.. N. C., S. C., Ala,, Ga., Fla., Miss., La., Ark., Ky., Mo., Ill., Kans., Nebr., İowa, Mich.. Wis., Ohio, Minn.): Indian Lean (Mass., R. I., X. Y., N. J., Pa., N. C., Ill.); Beantree (N. J., Del., Pa., Va., La., Nebr.): (atawba (W. Va., Ala., Fla., Kans.); Cigartree (R. I., N J., Pa., W. Va., Mo., Ill., Wis., Iowa); Catawba-tree (Del.); Indian Cigar tree (Pa.); Smoking Bean (R. I.)

Catalpa speciosa Warder.

Hardy Catalpa.

RANGE.-Through southern Illinois (from the Vermilion River) and Indiana, western Kentucky and Tennessee, southeastern Missouri and northeastern Arkansas; elsewhere naturalized through cultivation, especially in southern Arkunsas, western Louisiana, and eastern Texas.

Naties IN USE.-Hardy Catalpa (III, Iowa, Kaus., Mich., eult.); Western Catalpa (Pa. (cult.) Ohio, Kans., Nebr. (cult.) Ill.); Catalpa (R. I., X. Y. (cult.) La., Ill., Ind., Mo., Wis., Iowa, Nebr., Minn., cult.); Cigartree (Mo., Iowa, cult.); Bois Puant (La.); Indiau Bean (Ind.); Shawneewood (Ind.).

\section{CHILOPSIS DoH.}

Chilopsis linearis (Cav.) Sweet.

Desert Willow.

RANGE.-Through southwestern (from neal Laredo) and western Texas, sonthern New Mexico, Arizona, southern Utah and Nevada, and sonthern California (San Diego County); northeru Mexico.

Names rn Use.-Desert Willow (Cal., Tex., N. Mex., Ariz., Utah, Nev.); Texas Flowering Willow (Tex.); Flowering Willow (Tex.).

\section{CRESCENTIA Lim.}

Crescentia ovata Burm.

Black Calabash.

Crescentia cucurbitina Linu.

RANGE.-Coast of sonthern Florida (Biscayne Bar, east of mouth of Miami River; also on Little River); West Indies; southern Mexico; Pacific coast of Panama; Venezuela.

Nàies in UsE._Black Calabash-tree (Fli.); Black Calabash (Fla.). 


\section{Family RUBIACEAE.}

EXOSTEMA Richard.

Exostema caribæum (Jac!). Roenl. \& Schult.

Princewood.

liavge.-Sonthern Florila kiegs (alundint on Key West and Upper Metacomlio Key); West Indies; soutlern Mexico and west coast of Nicaracua.

NAME IN USE.-Princewond (Fla.).

PINCKNEYA Michx.

Pinckneya pubens Miehx.

Fevertree.

RAxcis, - Coast region from Sonth Carolina to Grorgia and Florila (mpler Apalachicola River and trihntaries in Florida and (Georgia). Tery rare.

NAMES IN UsE.-Georgia Bark (S.C., Fla.); Fevertree (Ala.); Florilla Quiniue Bark (Fla.).

GUETTARDA Vent.

Guettarda elliptica Swartz.

Guettarda.

Raxil:-Southern l'lorida keys (near coist); Bahamas; Jamaical (coast.

NAME IN USE.-Naliedwood (Fla.).

\section{Fannily CAIRIFOI, ACF A. SAMBUCUS Linn.}

Sambucus mexicana Presl.

Mexican Elder.

R.xik.-From western Texas (Nueces River) through sonthern New Mexicu anc Arizona to sontlern ('alifornia; also in northern Califoruia (Plumas ('ounty); sonthward through Mrexiro to Central America.

NAMEs in Use.-Elder (N. Mex., Tex.); Elderberry-tree.

Sambucus callicarpa Greene.

Redberry Elder.

RANGE.-California (coast ranges).

Sambucus glauca Nutt.

Pale Elder.

Ravge.-From sontheru British Columbia (Fraser River) and Vaneonver Island to the sonthern borders of Catifornia and eastward to the Bhe Mountains in () regon and the Wasatcli Monntinin in Utah.

NAMrs IN UsE.-Elder (Cal., Utah, Oreg.); Elderberry (Cal.); Black Elderberry (Utah); Mountain Elder.

\section{VIBURNUM Linn.}

Viburnum lentago Linn.

Sheepberry.

Raxgk,-From Quehee (Rivire dn Loup) to the Saskatchewan River and southwayl through the Northern States (and along the Allegheny Monntans) to northern Georgua and in western range sonth to sonthern Indiana, southwestern Missonri, and eastern Nelıraski.

NAMES IN USE.-Sheepberry ( $V^{\prime}$ t., N. II., Mass., R. I., Conn., N. Y., N.J., P’a., Del., S. C., Ǩy., Ill., Iowa, Mich., Nebr., Minn., N. Dak., Ohio); 
Nanuyberry (Vt., X. Y., Mich., Ohio, Ont., Iowa, Minu., N. Dak.): Nanny Plum (Vt.); Black Haw (Ill., Mo., Mimm., N. Dak.); Wild Raisin (Me.); Sweetberry (Minn.); Sweet Viburnum (R. I., Tenn.. Nebr.); Viburnum (R. I.).

Viburnum prunifolium Linn. Nannyberry.

liaxge.-From Conuecticut (Fairfield ('ounty and Lower Indson liver) to northern Georgia; westward through southern Michigan to eastern Kausas (borinr counties); Indian Territory. The sonthern range of this spocies, to which some authors unite the following species, is insufficiently known.

Names IN USE.-Black Haw (R. I., N. Y., N. .T., Pa., Del., Va., W. Va., N. C., S. C., Ala., Ga., Fla., Miss., La., Tex., Ky., Mo., Kins., Ill., Ind., Ohio); Sloe (Temn.); Sheepberry (N. .J.); Namnyberry (N. J.); Alisier (La.); Stagbush; Haw (Md., Ta.); Sweet Haw.

Viburnum rufotomentosum Small.

Rusty Nanuyberry.

VIBURNuM PRUNIFOLIUM $\beta$ FERRUGINeUM Torrey \& Graj.

RANGE.-Sonthern Virginia to (ieorgia and west to western Texas. Range insutiociently known. 
acom ally withen, teaces bristle liphed

if Ceaves secidusus pinnately lobed

Leaves green both sides

cur saucer thaped ttide broad baves dual grien - Rubra $\Leftrightarrow$

$\log$

Cup thig. narrow, baves butiones Rautriso

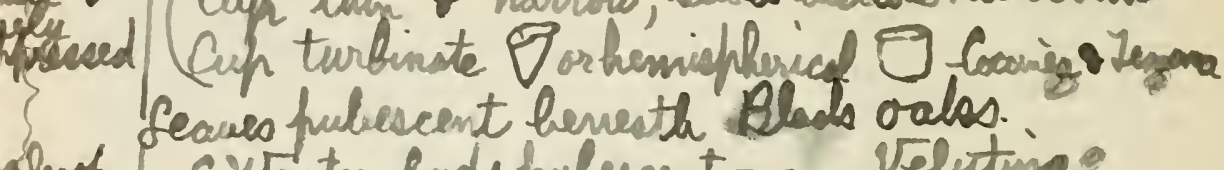

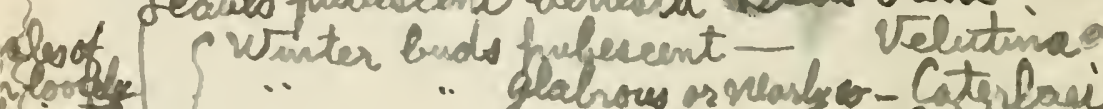

crientive

- Seaves whitich or qrayish beneatidinthe. - Entire leaves (reatlow oales glabroves benath Evergreen or Persintont

Micra tamifh.

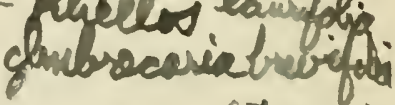

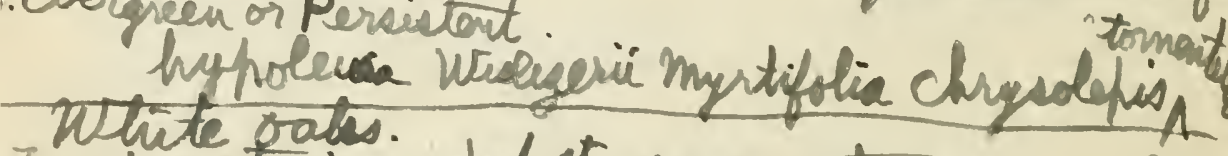

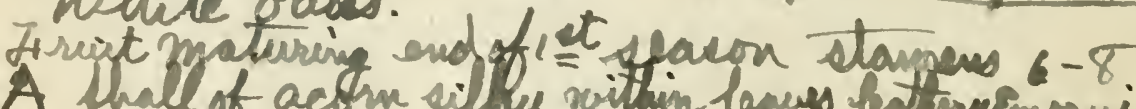

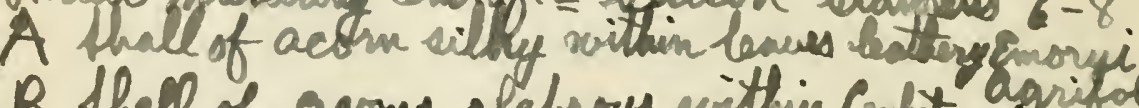

$B$ thell of acom labrous inithin (whte argifolia)

1. Seques wittout bristle tiva deciduores

feaves fyrate pimntifid

glacous berat benat

cary benattobata

to. Rochies - Garnbllic

cactern boves - minor

t 5 tere caphasi

- mondians

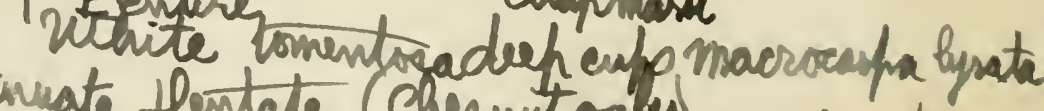

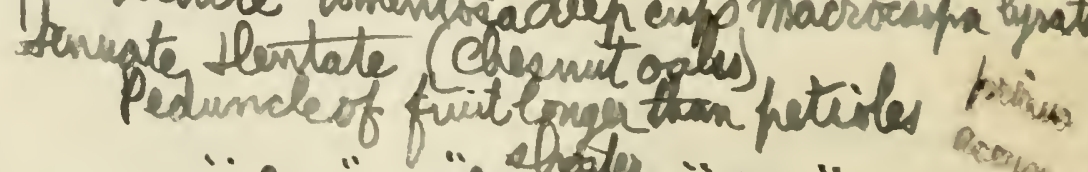

"Leaver sutitebone"ste

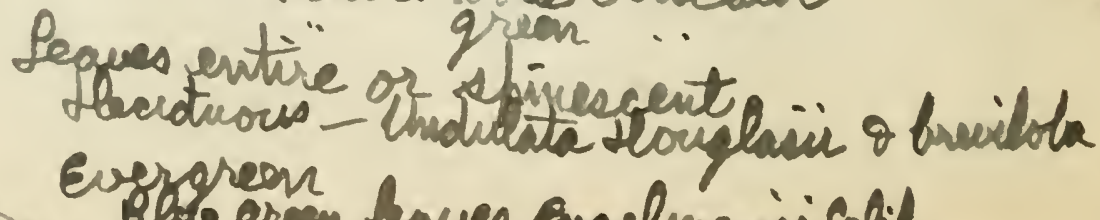

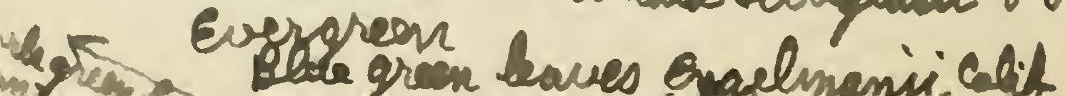




\section{INDEX OF LATIN NAMES.}

Accepted names in heavy-face type; names commonly usec hitherto in sM.LL. CAPITALs; varietic 3 distinguished in cultivation in italies.]

ABIES Inliam., 25.

Abies amabilis (Loud.) Forb., 26.

Abies arizonica Merriam, 26.

Abies balsamea (Linn.) Mill., 25.

Abies balramea argentifolia Su]w., 25.

Abies balsamea brachylepis Willk., 25.

Abies balsamea corulea Carr., 25.

Abies balsamea hemisphcerica Sudw., 25.

Abies halsamea hudsonia (Knight) Veiteh, 25.

Abies balsamea longifolia (Lond.) Endl.. 25.

Abies balsamea nudicaulis Carr., 25.

Abies balsamea paucifolia sudw., 25 .

Abies balsamea prostrata (Kuight) Carr., 25.

Abres balsamea versicolor Sudw., 25.

Abies concolor (Gori.) Parry, 26.

Abics concolor angustata Sudw., 26.

Abies concolor lowiana (Murr.) Lelmmon, 26.

Abics concolor pendens (Beissn.) Sudw., 26.

Abies concolor purpurea Sudw., 26.

Abies concolor purpurea compressa sudw., 26.

Abres concolor raria sudw., 26.

Abies fraseri (Pursh) Lindl., 25.

A bies grandis Lindl, 26.

Abies grandis aurifolia Sudw., 26.

Abies grandis crassa Sudw., 26.

Abies lasiocarpa (Hook.) Nutt., 25.

Abies lasiocarpa ccerulescens (Beissn.) Sudw., 26.

Abies magnifica Murr., 27.

Abics magnifica cyanea Sud $w ., 27$.

Abies magnifica xanthocirpa Lemmon, 27.

Abies mueronata car. palustris Raf., 24.

Abies nobihs Linell., 27.

Abieg nobilis glavcifolia suctw., 27.

A bies nobilis robustifolia Sulw., 27.

Abies shastensis Lemmon, 27.

Abies taxifolia Lambert, 23 .

Abies taxifolia l'oiret, 24.

Abies venusta (Dougl.) Koch, 26.

ACACIA Adans., 78.

Acacia farnesiana (Linn.) ITilld., 78.

- Acacia flexicaulis Benth., 78.

Acacia greggii Gray, 79 .

Acacia wrightii Benth., 73.

ACER Linn., 9).

Acer circinatum P'ursh., 91.

ACER D.ASYCARPLM Ehr., 9:.

Acer glabrum Torr., 91.

Acer grandidentatry (Nintt.? ms..) in Torr. \& Gr., 9:.

Acer macrophyllum Pursh., 90.
Acer negundo Linn., 93.

Acer negundo angustissimum (Pax) Sulw., 93.

Acer negundo californicum ('T. \& (ir.) Sargent. 93.

Acer negundo crispifolium Sudw., 93.

A cer negundo variegatum Kuutze, 93.

Acer negunto violaceum (Í́och) Dipp., 93.

Acer pennsylvanicum Linil., 90.

Acer rubrum Linı., 92.

Acer rubrum drummondii (Hook. \& Arn.) Sar. gent, 93 .

Acer mbrum sanguineum (Sןach) P'ax, 93.

Acer saccharinum Linn.,92.

Acersaccharinum aureo-variegatum (Nich.) Sulw. 92.

Acer saccharinum elissectifolium sudw., 92.

Acer saccharinum lutesecus (Pax) Sulw., !2.

Acer snccharinum nokum (EIIw. \& Barr.) Sudw. 92.

I cer saccharinum pendulum (Nich.) sindw., 9.2.

ACER SACCHARINUM Wang., 9I

ACER SACCHARINCM Wang, var, FLORIDANLM Chatm., 91.

- Leer saccharinum wierii (1'ax) Sudw., 92.

Acer saccharum Marsh., 91.

Acer saccharum barbatum (Michx.) Trelease, 91.

Acer saccharum floridanum (Chapm.) small \& Heller, 91.

Acer saccharum grandidentatum (Nutt.) Sudworth, 92.

Acer saccharum leucoderme (small) Sudworth, 91.

Acer saccharum nigrum (Michx. f.) Britton, 91 .

Acer saocharum nigrum monumentale ('lemple) Sulww., 91 .

Acer spicatum Lam., 90.

ACERACEE, 90.

ESCULUS Linn., 93.

Esculus californica (Sprach) Nutt., 94.

Esclet's Flava Ait., 94.

Escelt's Flava Ait. rar. I'CUPLRASCENS Gray, 9s

Esculus glabra Willd., 93.

Esculus octandra Marsh., 94.

Esculus octandra hybrida (de C.) Sirrgent, 94.

AILANTHUS Degf., 85.

dilanthus glandulosa aucuhefolia Dipp., 2.5 . Ailanthus glandulosa penduligolia Iipp., w5. Ailanthus glanlulosa rubra Dipp., 85.

ALNUS Ehrh., 49.

Alnus acuminata H. B. K., 49.

Alnus glutinosa (Linu.) Gartı., 49.

Alnus glutinosa aurea (Kioeh) Nichol., 49. 
Alnus glutinosa incisa Willd., 49.

Alnus glutinosa lariniata (Elır.) Willd., 49.

Alnus glutinosa quercifolia Willd., 49.

AlNes incana var. Vunescens Wath., 49.

Alnus maritima (Marsh.) Mnehl., 49.

Al.ve's obloNGIFoliA Torr., 49.

Alnus oregona Niutt., 49.

Alnus rhombifolia Nitt., 49.

Alnus tenuifolia Nintt., 49.

AMELANCHIER Melic., 70.

Amelanchier alnifolia Nutt., 71 .

Amelanchier canadensis (Linn.) Melic., 70.

Amelanchier canadensis obovalis (MIirhx.) B. S. P., 71.

Amelanchier canadensis spicata (Lam.) Sargent, 71.

AMYRIS Browne, 84.

Amyris maritima Jacq., 84.

A.MTris SYLVATICA de C., 81 .

ANACARDIACE无, 87 .

ANAMOMIS Griseb., 98.

Anamomis dichotoma (Poir.) Sargent, 98.

ANDROMEDA Linv., 102.

Andromeda ferruginea Walt., 10:2.

Andromeda ferruginea arborescens $M$ ichx., 102.

Andromeda ferruginea fruticosa Mirlix., 102.

ANNONACE $\mathbb{E}, 66$.

ANNONA Linn., 66.

Annona glabra Linn., 66 .

AQUIFOLIACE E, 89.

ARALIA Linn., 99.

Aralia spinosa Linu., 99.

ARALIACE $\mathbb{E}, 99$.

ARBUTUS Linn., 101

Arbutus arizonica (ìray) Silrgent, 102.

Arbutus menziesii P'ursh, 101.

Arbutus xalapensis H. I. K., 101.

A libetus xalapexsis var. arizunir a Gray, 102.

A RBL'TUS XALAPENSIS var. TEXANA G iray, 101.

A ndisia PICKerisula Nitt.. 103.

ASIMINA Adans., $60^{\circ}$.

Asimina triloba (Linn.) 1)mal., 66.

AVICENNIA Linu,, 108.

Avicennia nitida Jacl., 108.

BETULA Linu., 47.

Betula Ienta Liun., 49 .

Betula lutea Michx. f., 48.

Betula nigra Linu., 48.

Betula occidentalis llook., 48.

Betula papyrifera Marsh., 48.

Betula papyrifera minor ('Tuck.) Wats. \& Conlt., 48.

Betula populifolia Marsh., 47.

Betula populifolia $\times$ papyrifera Sargeut, 47 .

Iietula populifolic purpurea, IIort. Am., 48.

BETULACE $\approx, 47$.

BIGNONIACE $Æ, 109$.

BORRAGINACE无, 108.

BOURRERIA Bromne, 108.

Bourreria havanensis (Roem. \& Sch.) Miers, 108.

Bourreria havanensis radula (J'ojr.) Gray, 108.

BROUSSONETIA L'II Ier., 63.

Broussonetia papyrifera Vent., 63.

BUMELIA Swartz, 103.

Bumelia angustifolia Nnit., 104.

Bumelia lanuginosa ( $\mathrm{Mi}$ ichx.) I'ers., 104.

Bumelia lanuginosa riguda Gray, 104.

Bumelia lycioides (Linu.) Gertn. f., 104.
Bumelıa tenax (Linn.) Willd,, 103.

BURSERA Jacr., 85.

BURSERA GLMMIFERA Linn., 85 .

Bursera simaruba (Linu.) Nargent, 85 .

BURSERACE $₫, 85$.

CACTACE E, 97 .

Calyptranthes CIYTRACUli. Swart $z, 93$

CANELLA Browue, 87.

Canella alba Minr, in Linn., 87.

Canella winterana (Linu.) Grertn., 87.

CANELLACE无, 87.

CANOTIA Torr., 85.

Canotia holacantha Torr., 8.

CAPPARIDACE $\approx, 6 \bar{i}$.

CAPPARIS Linn., 67.

Capparis jamaicensis $\mathrm{Jacq}$., 67.

CAPRIFOLIACE $\mathbb{A}, 110$.

CARPINUS Linu., 50.

Carpinus caroliniana Walt., 50 .

Carya alba Nitt., 40. •

Caria amara Nutt., 40.

Carya aquatica Nutt., 40.

Carya jicrocarpa Yutt., 41 .

Calya mYistic.

Carya oldyforuis Nutt, 39.

Carra porcina Nutt., 41.

Carya silcata Nott., 41.

Carya tostentosa Nutt., 41.

CASTANEA Aclans., 5 :

Castanea dentata (Marsh.) liorkh., 51.

Castanea pumila (Linn.) Mill., 51.

Castanea vesca $\beta$ A mericana Miclix., 5I.

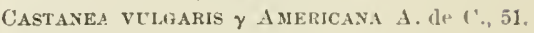

CASTANOPSIS Spach, 51.

Castanopsis chrysophylla (II ook.) dle C., 51.

CATALPA Śeop., 10 .

Catalpa biano:ioides Walt., 109.

Catalpa catalpa (Linn.) Kiarst., 109.

Catalpa speciosa Warder, 109.

CEANOTHUS Linn., 96.

Ceanothus arboreus Greene, 96.

Ceanothus thyrsiflorus Esch., 96.

CELASTRACE压, 89.

CELTIS Linn., 61.

Celtis Goorgiana small, 61.

Celtis Helleri small (I. c.), 61.

Celtis mississippiensis Bose., 62.

Celtis occidentalis Lim., 61 .

Celtis occidentalis pumila $G r ., 61$.

Celtis occidentalis reticulata ('Torr.) Sargont, 62.

CERCIDIUM Tulasne, 81.

Cercidium floridum lient $l_{1 .,} 81$.

Cercidium torreyanum (Wats.) Sargent, 81

CERCIS Linn., 79.

Cercis canadensis Lin $1 ., 79$.

Cercis canadensis plena sud w., 80.

Cercis canadensis pubescens Pursh, 80.

Cercis reniformis Eugelm., 80.

CERCOCARPUS II. B. K., 69.

Cercocarpus ledifolius Nitt., 69.

Cercocarpus parvifolius Nutt., 19.9

Cercocarpus parvifolius betuloides (Nutt.) Sar. gent, 69.

Cercocarpus parvifolius breviflorus (Gr.) Jone.3. 69.

Cercocarpus parvifolius paucidentatus WaI, 69 .

CEREUS Mill., 97. 
- Cereus giganteus Engelm.,97.

Cereus schottii EngelıI., 97.

Cereus thurberi Engelm.. 97.

CHAM ECY PARIS spach, 32.

Chamæcyparis lawsoniana (Mur.) Parl., 33.

Chanacyparis lawsoniana albo-spica (liord.)

Beissn., 34 .

Chamecyparis lawsoniana alumi Beissu., 33.

Channecyparis lawsoniana amabilis (IItrt. Kiw.) sudw., 34.

Chameeyparis lawsoniana argentes (frord)

Beissn., 34.

Chamacyparis lauseniana argentea depuuprutu Sulw., 34.

Chamacyparislausoniana argentea minuta sul w., 34.

Chamecyparis latsoniana arentea prostrata (Beissı.) Sudw., 34.

Chamacyparis lausoniana argenteo-rariegutu (Veitrh) Beissn., 33.

Chamecyparis lawsoniana argenteo-variegata noricia Sulw., 33.

Chamacyparis lawsoniana atroviridis sut w., 33.

Chancecyparis lazesoniana aurea (Gorll.) Beissn., 33.

Chamacyparis lawsoniana aurea magnifica (Beissn.) Sudw., 33.

Chamceyparis lausoniana aurev-spica Brissn.,34. Chamecyparis lavsoniana aureo-variegata (Veitr $l_{1}$ ) Beissu., 33.

Chamesyluris lassoniana beissneriana smitl and Cie., 33.

Chamacyparis lacsoniana bouleri (Hort. Kew.) sudw., 34 .

Chamerynaris lawesoniana californicu (Hort. Ker.) Sudw.. 34.

Chamaeyparis lausoniana casuarinifolia Beissu., 34.

Chamecyparis la moniana compacta recens. Sudw., 34.

Chamecyparis lux'soniana crispa Beissn., 34.

Chamacyparis lausoniana cyanea Sudw., 33.

Chamucyparis lausoniana cyanea pendens Sudw. 33.

Chamacyparis larsoniana darleyensis (Hort. Kew.) simlw. 34.

Chamacyparis lansoniana eistu (Gurd.) Sulw. 33.

Chancecypris lawsoniant erpeta glamescens sudw., 33.

Chamacyparis lausmiane erecta glancifolia Sudw., 33.

(hanceyparis larosoniana erecta viridis (Veitch) Beissn., 3\%.

('hamecyparis lnesoniana filiformis' (Veiteli) Beissn., 34.

rhamenymaris laresoniana jiliformis ylubusa Beissn., 34 .

('hancecyparis lausonianu forstekiana Lieissn., 34.

Chamceyparis latsoniana fiatruns (Crori.) Beissn.. 34.

Chamocyparis leusoniana frayrans argurenusis SudT., 34 .

('hamecyparis larsoniant fragrans cmica Brissn., 34.

Chamacyparis lausoniana fraseri Beissn., 33.
Chamacyparis lawsmiona gracilis (Gord.) Heissn., 34.

Chamecyparis lawsoniana yracilis pusilla sudw. 34.

Chamceyparis lausoniant intertexta (V.iteh) अ(+iвะn., 34.

r'hamucyparis lausoniuna laxa Jieissn., 34.

('la ancecypa ris lau'soniana lutea (Gord.) Heissn., 33.

('hain arcyparis lussoniana luter flaveseens (tiord.) Sudw., 33 .

Chamecyparislaresoniana minima (tiort.) sulw., 34.

rhanceyparis lawsonian mnnumentalis alles. cens Sudw., 33.

Chamecyparis larsoniana monumontalis nova Beissn., 33.

Chandeyparis lausoniana niter lieissu., 33.

('hameyparis lawsoniana mutans . Lulw., 34.

Chamopyparis lawsoniana nutans alba (Goril.) sindw., 34 .

Chamecyparis lausoniana uutans tera (Beissu.) Sudw., 34 .

Chantecyparis lawson iana wereymeri Beissn... 34. ('hanucy aris lawsoniant parea siulw., 34.

('Hamesyparis lamsoniane parre abo.spicifonis Sulw., 34 .

Chamacyparis lausonimun parpa ulbo-errimata (Gorel.) Sudw., 34.

Chameyparis lansaniand parea randida sindw., 34.

Chamaeysaris lausonianu parve densa sulw., :34.

Chamereyparis lawsoniana miamirlalis farenla sndw., 33 .

Chamacyparis lausoniana yyramidalis leuro. phylla Suilw., 33.

rhamecyparis lavsonianu pyramidalis luteo. ıсu uis Sudw., 33.

Chamecyparis huesonianu rubusta Ib-issn., 33.

Chanceyparis lausoniana robusta argentifulia sindw., 33.

"hamrecypuris Lansoniann robusta aurifolia sudw., 33.

Chance'yparis lar"soniana robusta einerea sudw., 33.

Chameryparis lansuniuna rosenthali Beissu., 33. Chamecyparis lamsoniun shawi Beissn., 34.

Chamcecyparis lawsmiana silwer-queen Beissn., 34.

Chancecyparis lan'sonienn turtuna Beissn., 34.

Chamecyparis lawowiana rersicolor Beissn.. 33.

Chameryparis len'somiana weisseana Mall., 34.

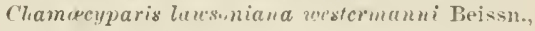
33.

Chamecuparis lan'smiana uorlci Beissn., 33.

Chamæcyparis nootkatensis (Laul..) Spach, 3\%.

Chanucyparis noothatensis albr.picta Sudw., 3:;.

Chamacyparis nothatensis aryenteo-rarinns sudw., 33.

Chumeryparis nouthetensis anen-versiculor siutw., 33.

Chamuryparis nootkatrusin aureo-viridis (Hort. liew.) Sulw., 33.

Chamecyparis nootkatensis cinerasccns Sudw.. 33. r'hamesyparis noothatcusis cinerascens aurco. discolor Sudw., 3is. 
Chamcecylaris nootkatensis cinerascens genuina Sindw., 33.

Chamocyparis nootkatensis compacta (Veitch) lieissn., 33 .

Chamacyparis nothatensis compressa lieis*n., :33. Chumacyparis nootkatensis nidiform is Brissu., "33. Clamacyjaris nootkatensis pendens Susw., 33.

Chamecyparis noutkatensis picta Sulw., 33.

Chamecyparis notkatensis viridifolia sulw., 33.

Chamcecyparis nootkatensis zanthophylla sulw.. .33.

Chanferpakis Nothä̈sis Spach, 32.

CHAJACYPARIN SHILEROIDEA Spach, 32.

CHAM ECYPARIS THYOIDES (L.) I3. S. I'., 32.

Chamacyparis thyoides atrovirens (linight) Sulw., 32.

Chamecyparis thyoides fastigiata cinereo-folia Sudw., 32.

Chamecyparis thyoidcy crocea sutw., 32.

Chamroyparis thyoides ericondes (Knight) Sudw., 32.

Chamceyparis thyoides glauca (Endl.) Sulw., 32. Chamcey/2 aris thyoides hoveyi (Teit(h) sudw., 32.

Chamecyparis thyoides leytoclada (Gord.) Sudw., 32.

Chancecyparis thyoides nana (Loul.) Sulw., 32.

Chanceyparis thyoides peuduliformis Sudw., 32.

Chamocyparis thyoides pumila ((: $12 \mathrm{r}$.) Surlw., 32.

Chamocyparis thyoides myramidata (Beissn.)

Sudw., 32.

Chamaryparis thyoudes rariegata (Lourl.) Sudw., 32.

CHEIRANTHODENRE E, 86 .

CHILOPSIS DOI., 109.

Chilopsis linearis (Car.) Sweet, 109.

CHIONANTHUS LimL., 107.

Chionanthus virginica Linn., 107.

CHRYSOBALANUS Linn.. it.

Chrysobalanus icaco Linn., 74 .

CHRYSOPHYLLUM Linn., 10?.

Chrysophyllum monopyrenum swartz, 103.

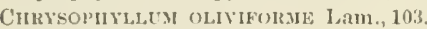

CHXTRACULIA Browne, 98.

Chytraculia chytraculia (Jinn.) Sulworth, 98.

Chytraculia chytraculia genuina (Berg.) Sudw., 98.

Chytraculia chytraculia ovalis (Mer.r.) Sudw., 98.

Chytraculia chytraculia pauciflora (Berg.) Suclw., 98.

Chytraculia chytraculia trichotoma (Berg.) Sudw., 98.

Chytraculia chytraculia zuzygium (Linn.) Sulw., 98. CITHAREXYLUM Lim.., 108.

Citharexylum villosum $J_{\text {acc }}$., $10 \mathrm{~s}$.

CLADRASTIS lial'., 82.

Cladrastis lutea (Michtx. f.) Kóch, 82.

Cladiastis tive"toria lílf", 82.

CLIFTONIA Girtu. I., gs.

Chiftusia huiremixi Sims ex Spreng., $8 R$

Cliftonia monophylla (Lilu.) Sargent, 88.

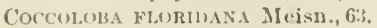

COCCOLOBIS Jirowne, 6:3.

Coccolobis laurifolia (Jard.) Sargent, 63.

Coccolobis uvifera (l.inn.) Sirgent, 63.

COLUBRINA Brongu., 96.

Colubrina reclinata (L'IIrr.) lirougn., 96.

COMBRETACEA. 99.

CONDALIA CaY.. 95.

CoNdalia FERHea Grisub., 95.
Condalia obovata Ilook., .15 .

CONOCARPUS Lim... 99.

Conocarpus erecta Linu,, 99.

Conocarpus erecta arborea de C., 99.

Conocarpus erecta procumbens (Limu.) ite C..,93.

Conocarpus erecta sericea le C.. 93.

CORN ACE $\mathrm{E}$, 100.

CORDIA Linn., 108.

Cordia boissieri A. le C., 108.

Cordia sebestena Linn., 108.

CORNUS I.iun., 100.

Cornus alternifolia Linn. f, 100 .

Cornus florida I.inu.. 100.

Cormus plorida pendulu Tromle, 100.

Cornus jorida rubra Temple, 100.

Cornus nuttallii A $11 ., 100$.

CoTINUS Adans., 87.

Cotinus cotinoides ( $\mathrm{N} u \mathrm{tt}$.) Britton, 87.

CRAT庆GUS Linu., 7 .

Cratægus æstivalis (Walt.) Torr. \& Gr., Jt.

Cratægus apiifolia (Marsh.) Mivhx., 74.

Cratægus brachyacantha Sarg. \& Engelm., 71.

Cratægus coccinea Linn., i2.

Cratægus cordata (Jill) Ait., 73 .

Cratægus crus-galli Linn., 71.

Cratægus crus-galli angustifolia (Elır.) sildw., 72.

Cratægus crus-galli berberifolia (Torr. \& Gr.) Sarg., 7.2.

Cratægus crus-galli fontanesiana (Spachl) W(nz., i2. Cratægus crus-galli prunellifolia (Poir.) sudw., 7:2.

Cratægus crus-galli prunifolia (Marsh.) Torr. \& Gr., i2.

Cratægus crus-galli salicifolia (Medic.) Ait., 71.

Cratægus douglasii Lindl., 71.

Cratægus elliptica Ait., 74 .

Cratægus flava Ait., $7 t$,

Cratægus macracantha (Lindll.) Loul., 72.

Cratæg us mollis (Torr. \& (ir.) Scheele, 72.

Cratægus oxyacantha Linn., 72.

Cratoegis o.xyacantha apctala Lond., 73.

Cratagus oxyucanthe aurea L,oud., 73.

Cratwgus oxyacantha aurantiaca Lond., 7is.

Cratagus uxyacantha auriculata Diple., 72.

('ratargus oxyacanthu curtisprina Sudw., 72.

Cratayus oxyacantha diversifolia (Poir.) sudw., 72.

Crategus oxyacantha eriocana Loud., 73.

Cratregus oxyacantha ferox Ilip]., 72.

('ratogus ox! !acantha flexuosa Lotul., 73.

Cratagus oxyacuntha gratanensis (Boiss.) Sudw., 73.

C'ratagus oxyacantha incixa Regel, 72.

Cratorgus oxyacantha laciniata (liorkh.) de C., 72.

Cratagus oxyacantha leucocarpa I.nud., 73.

Cratcegus oxyacantha macrocarpa (Hegetsib.) Sudw., 73.

Crategus oxyreantha monogyna (Jacu.) Lotul., i.. (ratrous oxyacantha multiplex Lond., 73.

Cratagus oxyacantha olivcriana (J'oir.) Loud., 73.

('ratiryus oxwacantha oxyacanthoides (Thuill.)

lieich., 72.

Cratceyns nxyacantha pendula Loml., 73.

('ratergus oxyacantha pinnatiloba (Lange.) siudw. i2.

Cratayus oxwacantha precox Loud., 73.

Cratagus oxyacantha punicea Loud., 73. 
Cratcegus oxyacantha punicea plena Sudw., 73.

Cratagues oxyacantha rusea Loul., 73.

Cratagus oxyacantha semperjlorens Dip])., 73.

('rategus oxyacantha sorbifulia (Desf.) Diplp., 72. ('rategus oxyacantha splendens (Koch) Sulw.. 73. Cratagus oxyacantha stricta Lomd., 73.

('rategus oxyacantha varirgata (Dipp.) Sulw., 73.

Crategl's l'arvifolia Solabler in Ait., it.

Cratægus punctata Jacq., 73.

Cratægus punctata canescens Britton. 73 .

("ratae:us lunctata xanthocarpa (Medir.) Lal

Cratægus saligna Greene, 71 .

Cratægus spathulata Michx., 73.

Cratægus tomentosa Liun., 73.

Cratigrs tonento-sa rar. nollis Gray, 72.

C'Rat.egles tomextosa var. penctata Gray. 73.

Cratægus uniflora JI uenchb., 74.

Cratægus viridis Linn., 74.

CRESCENTIA Linu., 109.

Crescentia ceccribitina Linn., 109.

Crescentia ovata Buru., 109.

CU PRESSUS Linn., 31.

Cupressus arizonica (ireene, 32.

Cupressus goveniana Gorl., 31.

Cupressus goveniana attenuata (Gord.) Carr., 32.

Cupressus goveniana carnuta Carr., 32.

Cupressus goveniana glaucifolia Sudw., 31.

Cupressus goveniana gracilis (Nels.) Carr., 32.

Cupressus yoveniana huberiana Carr., 31.

Cupressus goveniana parva Sudw.. 31 .

Cupressus goveniana viridis Carr., 32.

CCPRESSts GUADALUPExsis Sarg., not Wats, 32.

Cupressus macnabiana MInrr., 32.

Cupressus macrocarpa Hartw., 31.

Cupressus macrocarpa angulata Lemm., 31.

Cupressu\& macrocarpa crippsii $\mathrm{M}_{\text {ast., } 31 .}$

Cupressus macrocarpa lambertiana (Carr.) Mast., 31.

CYRILIA Linn., 88.

Cyrilla racemitora Linn., 88 .

CYRILLACE无, 88.

DALEA Willd., 82.

Dalea spinosa Gray, 82.

DICOTYLEDONES, 39.

DIOSPYROS Lunn., 104.

Diospyros texana Scheele, 105.

Diospyros virginiana Linn., 104.

DIPHOLIS A. cle C., 104.

Dipholis salicifolia (Linn.) A. de C., 104.

DRYPETES TahI., 86.

Drypetes crocea Poit., 86.

Drypetes keyensis Urban, 86.

Drypetes lateriflora (Swartz) Urban 86.

EBENACE正, 104.

EHRETIA Browne, 108.

Ehretia elliptica de C., 108.

ERICAC瓜, 101.

EUGENIA Linn., 98.

Eugenia buxifolia (Swartz) Willd., 98

Ecgenia dichotoma de C., 98.

Eugenia garberi Sargent, 99.

Eugenia monticola (Swartz) de C., 99.

Eugenta Procera Sargent, 99.

Eugenia procera (Swartz) Poir., 99.

EUPHORBIACE IE, 86.

EVONYMUS Linn., 89.
Evonymus atropurpureus Jac? 89.

EXOSTEMA Richard, 110 .

Exostema caribæum (Ja.q.) liomu. . Sirhult., 110.

EXOTHEA Macfulyen, 94.

Exothea paniculata (Juss.) Raullk...94.

EYSENHARDTIA H. B. K., 82.

Eysenhardtia orthocarpa (Gray) Wat8.. 82.

FAGACE $E, 50$.

FAGUS Linu., 50.

Fagus atropunicea (Mlarsl.) Sudworth, 50.

Fagts ferreginea Ait., 50.

FICUS Linu., 63.

Ficus aurea Nutt., 63.

Fice's pedexculat.1 Nutt., 63.

Ficus populnea Willd., 63.

FRAXINUS Linn., 105.

Fraxinus americana Limn., 106.

Fraxinus americana curtissii (Taser) Sul Sorth, 106.

Fraxisus ayericaxa var. uicrocarpa liray, 106.

FraxiNe's Americaxa var. Texexsis Gray, 106.

Fraxinus anomala Wats., 106.

Fraxinus anomala triphylla Jones, 106.

Fraxinus berlandierıana A. lle C., 107.

Fraxinus carolinıana 11 ill, 107.

Fraxinus cuspidata Terr., 105.

Fraxinus greggii Gray, 106.

Fraxinus lanceolata Borkh., 107.

Fraxinus nigra Marslı., 106.

Fraxinus oregona Siutt., 107.

Fraxinus penusylvanica Marsh., 107.

Fraxines pistactefolia Torr, 106.

Fraxincs platycarpa Miehx., 107.

Fraxinus profunda Busl, 107.

Fraxines PUBescexs Lam., 107.

Fraxinus quadrüngulata Michx., 106.

Fraxixt's sambecifolia Lam., 106.

Fraxinus texensis (Gray) Sargent, 106.

Fraxinus velutina Torr., 106.

Fraxives virivis Michx. f., 107.

FrejoNta califorica Torr., 86.

FREMONTODENDRON Corille, 86.

Fremontodendron californicum (Torr.) Coville, 86.

GLEDITSIA Linn., 80.

Gleditsia aquatica Marsl., 80 .

Gleditsia bejotil Neumann, 80.

GLEDITSIA MONOSPERMA Walt., 80.

Gleditsia triacanthos Linn., 80.

Gleditsia triacanthos brachycarpos Michx., 80.

Gleditsia triacanthosbujotii (Ncum.) nom. nov., 80. Gleditsia triacavthos var. IXERMis Willd., 80.

Gleditsia triacanthos lævis (Loud.) sud worth, 80.

GORDONIA Ellis, 87.

Gordonia altamaha (Marsl..) Sargent, 87.

Gordonia lasianthus (Linn.) Ellis, 87.

GoRDoNiA PUBEsceNs L'Her., 87.

GUAJACUM Linn., 83.

Guajacum sanctum Linu., 83.

GUETTARDA Vent., 110.

Guettarda elliptica Swartz, 110.

GYMINDA Sargent, 90.

Gyminda grisebachii Sargent, 90.

Gyminda grisebachii glaucifolia (friseb.) Sud worth, 90 .

GYMNANTHES Swartz, 86.

Gymnanthes lucida Swartz, 86 .

GYMNOCLADUS Lam.. 81 . 
G YMTOCLADUS OANADENSTS Lam., 81.

Gymnocladus dioicus (Linn.) Koch, 81 . GYMNOSPERM $\approx, 13$.

11 alesia diptera Ellis, 105.

IIALESIA TETRAPTERA Ellis, 105.

HAMAMELIDACE压, 68.

HAMAMELIS Linn., 68.

Hamamelis virginiana Linn., 68.

HELIETTA Tulasne, 81.

Helietta parvifolia Benth., 84 .

HETEROMELES Hoem., 74 .

Heteromeles arbutifolia (Poir.) Roem., 74 .

HICORIA Raf, 39.

Hicoria aquatica (Michx. f.) Britton, 40.

Aicoria alba (Liun.) Britton, 41.

Hicoria glabra (Mill.) Britton, 4 1.

HICORIA GLABRA villosa Sarg., 41 .

Hicoria laciniosa (Michx. f.) Sargent, 41.

Hicoria minima (Jarsh.) Britton, 40.

Hicoria myristicæformis (Miclux. f.) Britton, 40.

Hicoria odorata (Marslı.) Sargent, 41.

Ficoria ovata (Mill.) Britton, 40.

Hiconia Pallida Aslie, $\$ 1$.

Hicoria pecan (Jarsh.) Britton, 39.

Kricoria pecan $\times$ alba Trelease, 40 .

Hicoria pecan $\times$ laciniosa Trelease, 40 .

Hicoria pecan $\times$ minima Trelease, 40 .

Hicoria villosa (Sarg.) Ashe, 41.

HIPPOCASTANACE $Æ, 93$.

HIPPOMANE LinU., 86.

Hippomane mancinella Linn., 86.

HYPELATE Browne, 95.

Hrpelate paxicelata Camb., 94.

Hypelate trifoliata Swartz, 95.

ICACOREA Aublet, 103.

Icacorea paniculata (Nntt.) Sud worth, 103.

ICHTHYOMETHIA Browne, 83.

Ichthyomethia piscipula (Linu.) Kuntze, 83.

ILEX Linn., 89.

Ilex cassine Linn., 89.

ILEX CA-SINE Walt., 89.

Ilex cassine angustifolia Willd., 89.

Ilex cassine mytifolia (TValt.) Sargent, 89.

ILEX WAHOON Walt., 89 .

Ilex decidua. Walt., 89.

Ilex monticola Gras, 89.

Ilex opaca Ait., 89.

Ilex romitoria Ait., 89.

JAQUINIA Linn., 10 s.

Jaquinia armillaris Jacq., 103.

JUGLANDACE $\approx, 39$.

JUGLANS Linn., 39.

Juglans californica Wats., 39.

Juglans cinerea Jinn., 39.

Juglans nigra Liun., 39.

Juglans rupestris Engelm., 39.

JUNIPERUS Linn., 34. ,

Juniperus barbadensis Linn., 35.

Juniperus californica Carr., 36.

Juniperus communis Linn., 36.

Juniperts communis argyrophylla Sud $\mathbf{w}, 36$.

Juniperus communis cracovia (Koch) Beissn., 36.

Juniquerüs communis echinoformis (Knight) Beissn., 36.

Juniperus communis hemisphorica (1'resl.) Parl., 36.
Juniperus communis hibernica (Lould.) Gord., 36.

Juniperus communis hibernica compressa Carr. 36.

Juniperus communis oblonga (Bieb.) Loud., 36.

Juniperus communis oblongo-pendula (Loud.) Carr., 36.

Juniperus communis pendens Sudw., 36.

Junipcrus communis pugmea (Koeli) Sudw., 36.

Juniperus communis sibirica (Burgsd.) Rydberg 36.

Juniperus communis suecica (Mill.) Loud., 36.

Juniperus communis variegata aurea Carr., 36.

Juniperus flaccida Sehl.: 36 .

Juniperus Knightij Nelson, 35.

Juniperus monosperma (Engelm.) Sarg., 35.

Juniperus occidentalis Hook, 35 .

Juniperus pachyphlœa Torr., 36.

Juniperus sabinoides (H. B. K.) Sargent, 36.

Juniperus scopulorum Sargent, 35.

Juniperus utahensis (Engelm.) Lemm., 36.

Juniperus virginiana Linn., 34.

JUNiPERC's viRgINIANA authors in part, not L.. 35.

Juniperus virginiana albo-spica Beissn., 35.

Jumiperus virginiana albo-rariegata Beissn., 35.

Juniperus virginiana aurea superba Sudw., 35 .

Juniperus virginiana aureo-spica Beissn., 35.

Juniperus virginiana aureo-variegata Veitch., 35.

Juniperus virginiana tripartita aureo-versicolor Sudw., 35.

Juniperus virginiana cannarti (Koch) Beigsn., 35.

Juniperus z'irginiana caroliniana (Mlarsh.) Willi., 34.

Juniperus virginiana chamberlayni Carr., 35.

Juniperus virginiana cinerascens Carr., 35.

Juniperus virginiana dumosa Carr., 35.

Juniperus virginiana elegantissima Beissn., 35.

Juniperus virginiana glaucescens Sudw.,35.

. Tunipenus virginiana gracilis (Endl.) Sarg., 34.

Juniperus virginiana horizontaliformis Sudw., 35 .

Juniperus virginiana intermpta (Wend.) Beissn., 35.

Juniperus virginiana kosteriana Beissn., 35.

Juniperus virginiana nutans 1Beissn., 35.

Juniperus virginiana pendula Carr., 35.

Juniperusvirginiana plumosa alba (Carr.) Boissn., 35.

Juniperus virginiana plumora candida Sudw., 35.

Juniperus virginiana polymorpha Beissn., 35.

Juniperus virginiana pumila Gord., 35.

Juniperus virginiana pumila nivea (Beissn.) Sudw., 35.

Juniperus virginiana pyramidiformis Sudw., 34.

Juniperus virginiana pyramidiformis glaucifolia Sudw., 34.

Juniperus virginiana pyramidiformis viridifolia Sulw., 35.

Juniperus virginiana schotti Gord., 35.

Juniperus virginiana smithi penduliformis Sulw., 35.

Juniperus virginiana triomphe d'angers Beissn., 35.

Juniperus virginiana tripartita Gord., 35.

KALMIA Lin1., 102.

Kalmia latifolia Linn., 102.

KEBERLINIA Zncc., 85.

Kœberlinia spinosa Zucc. 85. 
IAGU NCULARIA Grertn. f., 99.

Laguncularıa racemosa (Limu.) Giırtn. f., 99.

LARIX Duham., 20.

L.ARIX A.IERICANA Michx., 20.

Larix laricina (Du Roi) Koch. 20.

Larix lyallii Parl., 20.

Larix occidentalis Nutt., 20.

LAURACERE, 66.

LEGUNINOS $E, 78$.

LEITNERIACEE, 42.

IEITNERIA Chaj $11 ., 42$.

Leitneria floridana Chajm., 42.

LEUC ENA Hooker, 79 .

Leucæna glauca (Liun.) lienth., 79.

Leucæna pulverulenta (schlecht.) Bentlı., 79.

LIBOCEDRUS Enill., 29.

Libocedrus decurrens Torr., 29.

Lilincedrus decurrens columnaris Beis8n., 29.

Libucedrus decurrens compacta Beissn., 29.

Libncetrus decurrens depressa Gord., 29.

Libucedrus dccurrens glauca Beissn.. 29.

LILIACE $\approx, 38$.

IIQUIDAMBAR Liun., 68.

Liquidambar styracillua Liuu., 68.

LIRIODENDRON Linמ., 65.

Liriodendron tulipifera Linn., 65.

I,iriodendron tulipifera aureo-maculata (Arb.

kew.) Sulw., 66.

Liriodendron tulipifera obtusiloba Michx., 66.

Liriodendron tulipifera penache Elw. \& B., 66.

Lisiodendron tulipifera pyramidalis Dipp., 66 .

LYONOTHAMNUS Gray, 67.

Lyonothamnus floribundus Gray, 67.

LYSILOMA Bentli., 78.

Lysiloma latisiliqua (Linn.) Benth., 78.

M.aclera atrantiaca Nutt., 63.

NAGNOIIA Linn., 64.

Magnolia acuminata Linn., 64.

Magnolia acuminata cordata (Miclux.) Lond., 65.

Magnolia fœetida (Linn.) Sargent, 64.

Iragnolia fortida angustifolia (Loud.) Sarg., 64.

Magnolia fatida ferruginea (Sims) Sud $\pi ., 64$.

Ifagnolia fetida lanceolata (Ait.) Sudw., 64.

Magnolia fa'tida proecox (Loud.) Sarg., 64.

Magnolia fraseri Walt., 65.

Magnolia glauca Linn., 64 .

Magnolia glauca longifolia Ait., 64.

Magnolia glauca major Sims, 64.

MAGNOLIA GRANDIFLORA Linn,, 64.

Magnolia macrophylla Michx., 65.

Magnolia tripetala Linn., 65.

Magnolia cubrella Desrouss., 65.

MAGNOLIACE无, 64.

MELIA Linn., 85.

Melia azedarach Linu., 85.

Melia azedarach umbraculifera Sargent, 85 .

MELIACEÆ, 85.

MIMUSOPS Linn., 104.

Mimusops sieberi A. de C., 104 .

MOHRODENDRON Britton, 105.

Mohrodendron carolinum (Linn.) Britton, 105.

Mohrodendron carolinum meehani (Sarg.) nom. nov., 105.

Mohrodendron dipterum (Ellis) Britton, 105.

MONOCOTYLEDONES, 37 .

MORACE, 62 .

MORUS Linn., 62.
Morus alba Linu., 62.

Moms alba constantinopolitana (Poir.) Loud., 62.

Morus alba macrophylla (Moretti) Lourl., 62.

Morus alba multicanlis (l'arr.) Lond., 62.

Morzs allua pendula (Dipl.) Sudw., 6:.

Morus allua pyramidalis Sieringe, 62.

Horus alba rosia Loul., 62.

Momes allua tatarica (Livn.) L,ond.. 6:.

Horus alba renosa Delile, 6.2.

Morus alba rulgaris tokua (Sieb.) 13ur., 62.

Morus celtidifolia II. I. K., 62.

Morus rubra Linn., 62.

MYGINDA PALIENS Sinitl $+\mathrm{x}$ Sirgent, 90.

MYRICA Linn., \$2.

Myrica californica Cham., 42.

Myrica cerifera Linn., 4 ?.

Myrica inodora Bartr., 43.

MYRICACE 死, 42 .

MYRSINACE E, 103.

MYRTACE $\approx, 98$.

NectaNdRA Willdenoviana Meisner, 67.

Negrxipo aceroldes Moench., 93.

Negundo Califorsicum Torr. \& Gr., 93.

NEOWASHINGTONIA sud worth, 38.

Neowashingtonia filamentosa (Wend.) Sildw., 38.

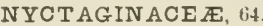

NYSSA Linn., 100.

Nyssa áquatica Linu., 101.

NYssa AQtatica Linn., 101.

Nyssa biflora Walt., 101.

Nissa Capitata Walt., 101.

NYsid Meltiflora Wang., 100.

Nyssa ogeche Marsh., 101.

Nyssa sylvatica JIarsh., 100.

Irssa srlvatica pendela (Temple) Sindw., 101.

NYSSA triflord Wang., 101.

OCOTEA A ublet, 67 .

Ocotea catesbyana (Michx.) Sargent, $6 \bar{i}$.

OLEACE $\approx, 105$.

OLNEYA Gray, 83.

Olneya tesota Gray, 83.

OPUNTIA Mill., 97.

Opuntia fulgida Engelm., 97.

Opuntia fulgida mammillata (Nicott) Coult., 97.

0puntia sponsior (Engelm.) Toumes, 98.

Opuntia sponsior neomexicana Toumey, 98.

Opuntia versicolor Engelm., 98 .

OREODOXA Willd., 38.

Oreodoxa regia $\mathrm{H} . \mathrm{B} . \mathrm{K}, 38$.

OSMANTHUS Laureiro, 108.

Osmanthus americanus (Linn.) Benth. \& Hook., 108.

OSTRYA Scop., 50.

Ostrya knowltoni Corille, 50.

0strya virginiana (Mill.) Koch., 50.

OXYDENDRUM de C., 102.

0xydendrum arboreum (Linu.) de C., 102.

PALMACEE, 37 .

PARKINSONIA Linn., 81 .

Parkinsonia aculeata Linn., 81.

Parkinsonia microphylla Torr., 81 .

Parkinsonia torrerasa Wats., 81.

PAU LOWNA sieb. \& Tilc., 109.

Paulownia tomentosa (Thunb.) Steudel, 103.

PERSEA Gaertn. f., 66 .

Persea borbonia (Linn.) Spreng., 66.

Persea carolinensis Ñees, 66 . 
PERSEA 'AROLINExSIS var. PALC'stRI: Clapm., 66. Persea pubescens (l'urslu) Sargent, 66 .

PICEA Link, 20).

PICEA ALi3a I,juk. 21.

Picea breweriana Wats., 2:-2.

Picea canadensis (Mil.) l..... I'., 21.

Pice a cunaleusis acutizsima (likinsu.) Sndw., s1.

P'icea cunadensis antea (lin-issu.) Sulw... 21.

l'icea canadensis cumpucta tracilis (Beissn.) sudw., 21.

I'icea canalensis compressa (1Beissn.) Sudw.. 21. I'icea canadensis compressiform is sulw., 21.

Picea canalensix eclinaformis (' ('an r.) sndw., 21.

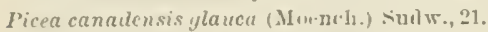

l'icea canade nsis nana (Loml.) Sulw.. 21.

I'icea canadensis nana glancifulia sind $6 ., 21$.

I'ic: a canadensis mutans sudw.. 21.

Pic a columbiana Lemm.. 21.

Picea engelmanni Engelm.. 21.

I'icea engelmanni arg!r rophylla sudw.. 21.

l'icea engclmanni ariseirnlia sulw., 2].

I'icea engelmanni minutifolia sudw., 21 .

Picea mariana (Mill.) E. \$. I'., 20.

I'icea mariana aluescens . Findw., 20.

I'icea mariana a rgenteo $v$ arietjata (Beis:m.) Sudw. 20.

l'icea mariana aureserns sulw., 20.

I'icea mariana dunmetti (Carr.) lieissn., 20.

Picen mariana humilis Sul $w ., 20$.

I'icea mariana pumila (Carr.) Sudw.. 20.

'IC'EA NiriRA Link, 20.

Picea parryana (André) I'arry, 21.

Jicea pa, ryana aryentea (13eissu.) num. nov., 22.

I'icea parryana eyanea jour. nor., 22.

I'icen parryana glanca pentens nom. nos., 22.

l'icca parryana glaucescens nom. noพ., 22.

PICE.A PLXGEXs Engelm., 21.

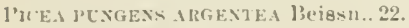

l'ICEA PUNGEXS CYASEA SHUW., 22.

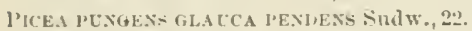

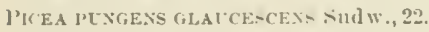

Picea rubens Sargent, 21.

I'icet rubens corrulea (Loul.) nom. nov., 21.

l'icea mibens gracilis (Kuight) num, nov , 21.

I'ic"a rubens pudula (Carr.) num. nor., 21.

I'JCEA RL'BRA l biet.. 21.

Picea ribria cont"Lea (1,omd.) Forbes, 21.

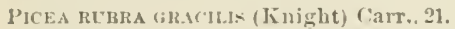

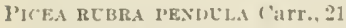

Picea sitchensis (13oug.) Traut $v$. Af Myer, 22.

PINCKNEYA Michx., 110.

Pinckneya pubens Michx., 110.

PINACEIE, 1:.

PINUS Limn., 15.

Pinus albicaulis Engelm., 14

Pinus apacheca Lemuon, 16.

Pinus aristata Enge1m., 15.

Pinus arizonica Eingelm., 15.

Pinus attenuata Lemmon, 17.

Pinus bolfouriana MI urr., 15.

Pint's BaNksiaxa Lamb., jo

Pinus cembroides Znec., 14.

Pinus chihuahuana Engelm., 16.

Pinus contorta Loul., 16.

Pinus coulteri Lamb., 16.

Pinus clausa (Engelm.) Sargent, 18.

Pint's CUBENSIs Griseb., 19.
Pinus divaricata (Ait.) Dil MIont de Coura..19.

Pinus echinata MIIll., 18.

Pinus edulis lingelm., 14 .

Pinus flexilis Jame's, 14.

Pinus glabra Walt., 1!.

Pinus beterophylla (Ell.) sndwortl. 19. th the?

Pixcs ixops ciolanter fx Ait.. 18

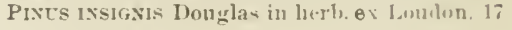

Pinus jeffreyi "()reu. Conı.." 16.

Pinus lambertiana Dougl.. 14.

Pixt's latifolia Sarg., not of amliors, 10.

Pinus mayriana sud worth, 16.

Plives mitis Mlichix.. 18.

Pinus monophylla Torr. \& Frem., 15.

Pinus monticola Dongl., 13.

Pinus muricata Dom., 18.

Pinus murrayana "' oreg. Com.," 16.

Pinus palustris Mill., 19.

J'INL PARRYaxa Engelm., 14.

Pinus ponderosa 1.aws., 15.

Pinus ponderosa priduliformis Sulw., 16

Pinus ponderosa scopulorum Engeln.. 15.

Pinus pungens Miclux. f.. 18.

Pinus quadrifolia Parl.. 14.

Pinus radiata Don., 17.

Pinus radiata hinnata (Engelm.) Hemm.. 17

Pinus resinosa Ait., 15.

Pinus rigida M[ill., 17 .

Pinus sabiniana Dougl., 16.

Pinus serotina Michx., 18

Pinus strobiformis Engelı.. 14.

Pinus strobus Linn., 13.

Pinus strobus aurca Carr.. 13.

Pinus strobus brevifolia Lous]., 13.

Pinus strobus fastigiata (Kuch) Beis-n., 12

Pinus strubus gracilifolia Sudw., 13.

Pinus strouts minima reissn., 13.

Pinus strobus niva (Kinjuht) Carr., 13.

Pinus strobus prostrata Hort. Kew, 13.

J'inus strobus umbraculifira Kinight. 13.

Pinus strobus unifolia usmut. nev., 13.

T'inus strobus varieguta Citr.. 13.

Pinus aloubus rividis Carr., 13.

T'inus strobus zebrina Bejisn.. 13.

Yimus taxifolia ,iulislury, 23.

Pinus tæda Linu.. 17.

Pinus torreyana Parry, 15.

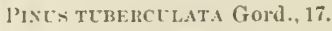

Pinus virginiana Mill., 18.

PIscidia eRYTIIINA Linn. 8:3.

PISONIA I,iun., 64.

Pisonia obtusata Jacg.. 64.

PITIECOLOBICXI BREvifolit'M Benth., 73.

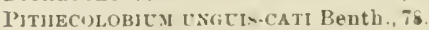

PLANERA Gmelin, 61.

Planera aquatica (Walt.) fimel., 61.

PLATANACE正, 68.

PLATANUS Limn., 68.

Platanus occidentalis Liun., 68.

Platanus racemosa Nutt, 68.

Platanus wrightii Wats.. 69.

POLYGONACEF, 63 .

POPULUS Linı., 45.

Populne acuminata liydberg, 46.

Populus alba Lir.a., 47.

Populıs alla bolleana Lauche, 47.

Populus alba canescens (Snith) Loud., 47 
Populus alba canescens umbraculifera Sudw., 47. I'opulus aloa ylobnsa Dipp., 47.

Populus alba nivea (Will\}.) Loud., 47.

Populus alba mutans Sudw., 47.

Populus angustifolia James, 46.

Populus balsamifera Linn., 46 .

Populus balsamifera candicans (Ait.) Gray, 46.

Populus balsamifera intermedia Loud., 46 .

Populus balsamifera latifnlia (Mo'neh.) Loul., 46.

I'opulus balsamifera viminalis I,oud., 40.

Populus deltoides Marsh., 46.

I'opulus deltoides aure! (Nichol.) Snelw., 47.

I'upulus deltoiles crispa (Dijpl.) Sudw., $4 \overline{\text {. }}$

Populus alcltoides irecta (sielys) Sudw., 47.

Populus fremontii $W$ ats., 47.

Populus fremontii var. Wislizeni Wrats., 47 .

Populus grandidentata Michx., 45.

I'opulus grandidentata penduliformis Sudw., 45.

Populus heterophylla Linu., 45 .

POPtLC' MoNiliferA Ait , 46.

Populus nigra Linn., 47.

Populus nigra elegans Bailey, 47.

I'ounlus nigra italica Du Roi, 47 .

Populus tremuloides Michx., 45.

l'opulus tremuloides pendens Sud $\pi ., 45$.

Populus trichocarpa Torr. \& Gr., $\$ 6$.

PROSOPIS Linn., 79.

Prosopis juliflora (Swart $\%$ ) de C., 79.

Prosopis odorata Torr. \& Freul., 79.

Prosopis ptBescens Benth., 79.

PRUNUS Linu., 75.

Prunus allegheniensis Porter, 75.

Prunus americana Marsh., 75.

Prunus americana lanata Fud worth, 75.

Prunus angustifolia Marsh., 75.

Prunus avium Linu., $; 6$.

Prexus Caplli Cav, it.

Prunus caroliniana (Mill.) Ait., 77.

Prunus cerasus Limn., 76.

PRCx's chicasa Michx., 75.

Prunus demissa (Nutt.) Walp., 77.

Prunus emarginata (Dougl.) Walp., 76.

Prunus emarginata villosa Sud worth, $; 6$.

PRLNi's ENARgIsata var. Mollis Brewer, not

Turr., 76.

Prunus hortulana Bailey, 75.

Prunus hortulana mineri Bailey. 75.

Prunus ilicifolia (Nutt.) Walp., 78.

Prunus icilifolıa integrifolia Sudworth, 78 .

Prunus injuennda S'mall. 76.

Prunus mahaleb Linn., 76 .

Prunus nigra Ait., 75.

Prunus pennsylvanica Lium. f., $i$.

Prunus persica (Linn.) Stokes, 78.

Prunus salicifolia H. B. K.. 77 .

Prunus serotina Elirh., 77.

Prunus serotina asplenifolia Dipp., 7 T.

Prunus serotina neomontana sudworth, 77.

Prunus serotina penduliform is Sudw.. 7 .

Prunus sphærocarpa Swartz. 7\%.

Prunus subcordata Benth., 75.

Prunus umbellata Ell., 76.

Prunus vurginsana Liun., 76.

Prunus virginiana leucocarpa Wats.. 77.

Prunus virginana nana (Du Roi) Dipp., 77.

Prunus virginiana pendens Sudw., 77.
PSEUDOPHANIX Wenill.. 37.

Pseudophœnix Sargentii Weul., 37.

PSEUDOTSUGA Carr., 23.

Pseudotsiga douglasil Carr., 23.

Pseudotsuga macrocarpa ('Torr.) Mav' 25.

Pseudotsuga mucron:ta var. yalustris $L$ cmm., "24.

Pseudotsuga taxifolia (Lam.) Britton, 23.

Preulotsuga taxifolia argentea (Beissn.) Sudw.. 25.

Pseudotsuga taxifolia argentea densu sudw

I'reudotsuga taxifolia brevifolia (Hort. Kew) Sudw., 25.

Pseudotsuga taxifoliu compucta (Boisin.) silulw., 25.

Pseudotsuga tarifoliu dumosa (Carr.) sudw., "-5.

I'seudotsuga taxifulia rlegans (Beissn.) Sudw., 25.

Psendotsuga trxifulia fastigiata (Knight) Sindw., 24.

Prendotsuga taxifolia glanca (Boissu.) Sudw., 24.

Pseudotsuga taxifolia pendula (Engelm,) siul. wortli, 24.

Pseudotsuga taxifolia pendula comlea sindw., 24.

Pseudotanga taxifolin revoluta (Hort. Kew.) Sindw., 25 .

Pscudotsuga taxifoliu stairi (Beissn.) Sudw.. 2.5.

Pseudotsuga taxifolia standishiana (Gord.) Sutw." 25.

Preudotsuga taxifolia rariegate (MeDon.), sulw., 25.

Pseudotsuga taxifilia rar. suberosa Lemm.. 24.

PTELEA Liun., 84

Ptelea trifoliata Linu., 84.

Ptelea trifoliata aurea Nich., 84.

PYRUS Linn., 69.

Pyrus americana (Marsh.) de C., 70.

Pyrus angustifolia tit., To.

Pyrus americana microcarpa (I'urslı) Torr. \& (ir.,7i)

Pyrus coronaria Linu., 69.

Pyrus ioensis ( Trood) Bailey. T0.

Pyrus malus Linn., 70.

Pyrus rivilaris Dougl., 70.

Pyrus sambucifolia Cham. \& tichl., 70.

Pyrus soulardi Bailey, 70.

QUERCUS Linn.. 51.

Quercus acuminata (Michx.) IJouba, 53.

Quercus agrifolia Tie, 55.

Quercus alba Linn., 51.

Quercus alba $\times$ macrocarpa Engelm., 51.

Quercus alba $\times$ minor Coulter, 51 .

Quercus alba $\times$ prinus Engelm., 51.

QUERCES AQLATICA Walt., 58.

Quercus arizonica Sargent, 54.

Qcerces Bicolor Willi., 53.

Quercus brevifolia (Lam.) Sargent, 58 .

Quercus breviloba ('Torr.) Sargent, 54.

Quercus breweri Eugelm., 52.

Quercus brittoni Davis, 58 .

Quercus californica (Torr.) Cool.., 57.

Quercus catesbæi Mielix., 57.

Quercus catesbæi $\times$ brevifolia Sul w., 57 .

Quercus catesbæi $\times$ laurifolia Engeln.. 57 .

Quercus chapmani Sargent, 52.

Quercus chrysolepis Liebm., 55.

Quercus chrysolepis palmeri Engelm., 55.

Quercus chrysolepis vaccinifolia (Kell.) Engelm., 55.

Querces clierea Michx., 58.

Quercus coccinea Muevchl., 56. 
Quercus coccinea $\times$ pumila Sudworth, 56 .

Quercus densifiora IIook. \& Arn.. 59.

Quercus densiflora echinoides (1R. Mr. Campst.) Sargent, 5 ?.

Quercus digitata (MI:arsh.) Suil worth, 57. Quercus digitata $\times$ velutina sulworth, $5 \bar{i}$.

Quercus douglasii II ook. \& $\lambda$ rn., 5 .

Quercus dumosa Nintt., 54 .

Quercus dumosa revoluta Sargent, 54

QUElict's DTRANDII Buckl., 54.

Quercus emoryi Torr., 55.

Quercus engelmanni Greene, 54.

Q UERC'S F.ILCATA $\mathrm{Mlichx}, 57$.

Quercus gambelii Nutt., 52.

Quercus garryana Dongl, ,52.

Quercus geminata simall, 5.5 .

Quercus georgiana Curtis, 58.

Quercus georgiana $\times$ marilandica Sargent, 58 .

Quercus heterophylla Miclıx. f., 59.

Quercus hypoleuca lingt.ln., 55.

() UELCL'S ILICIFOLIA Wrang., 57 .

Quercus imbricaria $\mathbf{~ I l} i \cdot h x ., 5 \%$.

Quercus imbricaria " palustris Engeln., 59.

Quercus laurifolia Michx., 58.

Quercus leana Nutt., 59

Quercus lobata Née, 51.

Quercus lyrata Walt, 52.

Quercus macrocarpa Michx., 52.

Quercus marilandica Mnenchh., 58.

Quercus marilandica $\times$ velutina lush. 58 .

Quercus michauxii Nutt., 53.

Quercus michauxii $\times$ macrocarpa sulworth, 54 .

Quercus minor (Marsl.) Sargent, 52.

Quercus morehus Ḱell., 56.

Quercus myrtifolia Willl., 56.

Quercus nigra Linn.. 58.

() UERCUS NigRA of authors, not of L., 58 .

Quercus oblongifolia Torr., 54 .

QUER'CS OBTUSILOBA Mliclix., 5:.

Quercus palustris Muenchl., 57.

Quercus phellos Linn., 59.

Quercus phellos $\times$ digitata Small, 59 .

QUERCL'S I'IIELIOS $\times$ NIGRA Britt., 59 .

Quercus phellos pumila suitworth, 59 .

QCERCI'S PHELLOS $\times$ TINCTORIA Gray, 59.

Quercus platanoides (Lim.) Sulworth, 53.

Quercus prinoides Willd., 53.

Quercus prinus Linu., 53.

Quercus pumila (Mlarsh.) sindworth, 57 .

Quercus reticulata Kumb. \& lionpl., 54.

Quercus rubra Linn., 56.

$Q$ ercus rubra runcinata $A$. 1 le C., 56 .

Quercus sinuata (Lam.) Walt., $5 \%$.

Quercus subimbricaria (de (..) Sudworth, 59 .

Quercus texana Buckl., 56.

(ILUEICUS TINCTORIA Bartr., 56.

Quercus tomentella Engelm., 55.

Quercus toumeyi Sargent, 54 .

Quercus tridentata (do C.) Engelu., 59.

Quercus undulata Torr., 54.

Qvercus cndulata a Gameli lingelm., 52.

Quercus velutina Lam., 56.

QueTrUs VIRENS Ait., 55.

Quercus virginiana Mill., 55.

Quercus wislizeni A. de C., 56.

REYNOSIA Griseb., 95.
Reynosia latifolia Gris(-)]., 9.3.

RHAMNACEE, 95

RHAMNIDIOM lieissck, 95 .

Rhamnidium ferreum ( $\mathrm{T}$ ahl) Sargent, 95.

RHAMNUS Linn., 95.

Rhamnus caroliniana Walt., 95 .

Rhamnus crocea Nutt., 95.

Rhamnus crocea insularis (Greene) Sargent, 95.

Rhamnus pirifolia Greene, $9 \overline{5}$.

Rhamnus purshiana de C. 96 .

RHIZOPHORA Linn., 98.

Rhizophora mangle Linn., 98.

RHIZOPHORACE王, 98 .

RHODODENDRON Linu., 102.

Rhododendron catawbiense Michx., 103.

Rhododendron maximum Linn., 102.

Rhododendron maximum album P'ursh, 103.

Rhododendron maximum purpureum I'ursh, 103.

l'hododendron maximum roseum Pursh, 103.

RFUS Liun., 87.

Rhus copallina Linn., 88.

Rhus copallina lanceolata Gray, 88.

Rhus capollina leucantha ( $\mathrm{Jac}_{1 .}$ ) do (., 88 .

Rit's cotixoldes Nutt., 87.

Rhus hirta (Linn.) Sindworth, 87.

Rhus integrifolia (Nutt.) Benth. \& Hook., 88.

Rhus metopium Linn., 87.

Rilus TYphixa Linn., 87.

Rhus vexf.Nata tle C., 88 .

Rhus vernix Liun., 88.

ROBINIA Lind., 82.

Robinia bella-rosea Nichol., 83.

liobinia dubia Fonc., 83.

Robinia neomexicana Gras, 83.

Robinia pseudacacia Linu., 82.

Robinia psendacacia amplifolia Sudw., 82.

liobinia pscudacaciu angustifolia (Loul.) Lar., 82.

Robinia riseudacacia aureu (Kólı) Dipl)., 83.

liobinia psezdacacia argenteo-varieyata (Koch)

sindw., 83.

Robinia pseudacacia crispa de C., 82.

Robinia psendacacia decaisneana Carr., 82.

liobinia pseudacacia dissecta (Ḱoch) Sarg., 83.

líobinia pseudacacia glaucescens Koch, 83.

Irobinia pseudacacia inermis (Jacq.) Snel w., 83.

Robinia pseudacacia latisiliqua Loud., 83.

Robinia preudacacia monophylla Petz. \& Kirchn., 82.

hobinia pseudacacia pendula (Ortega) Loud., 83.

Robinia pseudacacia purpurea Dipp., 83.

Robinia pseudacacia pyramidalis P'etz. \& Kirchn., 83.

liobinia pseudacacia spectabilis (Du Mont Conr.) Koch, 83.

liobinia pseudacacia tortuosa (Hottm.) de C., 8:.

Robinia viscosa Vent., 83 .

liobinia viscosa albiflora Dip]'., 83.

ROSACE $E, 69$.

RUBIACE E, 110.

RUTACE $\mathbb{E}, 84$.

SABAL Adans., 37 .

Sabal mexicana Mart., 37 .

Sabal palmetto (Walt.) Røm. \& Sch., 37.

SALICACE $\&$, 42.

SALIX Linn., 42.

Salix alba Linn., 45 . 
Salix alba $\times$ lucida Bebb, 45

Salix amygdaloides Andersa., 43

Salix babylonica Linn., 45.

Salix bebbiana Sargent, 44 .

Salix bonplandiana II. B. K., 43 .

Salix cordata lutea (Nutt.) Bebb, 44.

Salix cordata mackenzieana Hook., 44.

Salix Cordata var. vestita Sargent, not Pursl, 44.

Salix discolor Muehl., 44.

Salix discolor eriocephala (Michx.) Anderss!, 44.

Salıx discolor prinoides (Pursh) Anderss., 44.

SAlix Flavescexs Nutt., 44.

Salix Guriatilis Nutt., 43.

Salix furiatilis argyrophylla (Nutt.) Sargent, 43.

Salix furiatilis exigua (Nutt.) Sargent, 43.

Salix fragilis Linn., 45.

Salix hookeriana Barratt, 44.

Salix lævigata Bebb, 43.

Salix lærigata angustifolia Bebb, 43.

Salis lævigata congesta Bebb, 43.

Salix lasiandra Benth., 43.

Salix lasiandra caudata (Nutt.) Sudworth, 43.

Salix lasiandra lyalli Sargent, 43.

Salix lasiolepis Benth., 44.

SALIX LONGIFOLIA Muehl, 43.

Salix lucida Mnehl., 43.

Salix missouriensis Bebb, 44.

Salix nigra Marsh., 42.

Salix nigra alba Bebb, 42.

Salix nigra $\times$ amygdaloides Glatf., 42.

Salix nigra falcata (Pursh) Torr., 42.

Salix nuttallii Sargent, 44.

Salix nuttallii brachystachys (Benth.) Sargent, 44.

Salix occidentalis longipes (Anderss.) Bebb, 43.

Salix pıperi Bebb, 4.

Salix rostrata, Rich., 44.

Salix sessilifolia Nutt., 44.

Salix sitchensis Sans., 45.

Salix taxifolia H. B. K., 44.

Salix wardi Bebb, 42.

SAMBUCUS Linn., 110.

Sambucus callicarpa Greene, 110.

Sambucus glauca Nitt., 110.

Sambucus mexicana Presl., 110.

SAPINDACE $E, 94$.

SAPINDUS Linn., 94.

Sapındus marginatus Willd., 94.

Sapindus saponaria Linn., 94.

SAPIOM Browne, 86.

Sapium sebiferum Roxb., 86.

SAPOTACE王, 103.

SASSAFRAS İees \& Eborm., 6i.

Sassafras officinale Nees \& Eberm., 67.

Sassafras sassafras (Linn.) Karst.,67.

SAXIFR AGACE $\mathbb{E}, 67$.

SCHEFFERIA Jacq., 90.

Schæfferia frutescens Jacq., 90 .

SCROPHULARIACE E, 109.

Sebastiana lecida Muell,, 86.

SEQUOIA Endl., 28.

Sequola gigantea Decaisne, 28.

Sequoia sempervirens (Lamb.) Endl., 28.

Sequoia semperirens adpressa Carr., 29.

Sequoia sempervirens albo-spica (Gord.) Beissn., 29.

Sequoia sempervirens glauca Gord., 29.
Siequoia sempervirens gracilis Carr., 29.

serquia sempervirens piota Sudw., 29.

siequoia sempervirens taxifolia Carr., 29.

Sequoia washingtoniana (Winsl.) Sudworth, 28.

Sequoia washingtoniana argentea (Beissn.) Sudw., 28.

Sequoia washingtoniana aurea (Beissn.) Sudw., 28 Sequoia uashingtoniana gla uca (Gord.) Sulw., 28.

Seruoia washingtoniana glaucescens pyramido. compacia sudw., 28.

Sequoia washingtoniana holmsi (Beissn.) sulw. 28.

Sequoia vashingtoniana pendula (Beissn.) Sulw. 28.

Sequoia vashingtoniana py.maea (Beissn.) Sulw., 28.

Sequoia washingtoniana variegata (Gord.) Sudw., $2 R$

Sequoia Wellingtonia Seeman, $2 \dot{8}$.

SIMAROUBACE正, 85.

SIDEROXYLON Linn., 103.

Sideroxylon mastichodendron Jacr., 103.

SIMARO UBA Aublet, 85.

Simarouba glauca de C., 85. •

SOPHORA Linn., 81 .

Sophora affinis Torr. \& Gr., 81.

Sophora secundifora (Car.) de C., 81.

STILLINGiA SEBIFERIM Michx., 86.

STYRACACE $\mathbb{E E}, 105$.

SWIETENIA Jacq., 86.

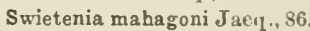

SYMPLOCACE $\approx, 105$.

SYMPLOCOS Jacq., 105.

Syruplocos tinctoria (Linn.) L'Hér., 105.

TAXACE正, 36

TAXODIUM Rich., 27.

Taxodium distichum (Linn.) Rich., 27.

Taxadium distichum denudatum Carr., 27.

Taxodium distichum imbricarium (Nutt.) Siırg., $2 i$

Taxolium distichum intermedium Carr., 28.

Taxodium distichum knighti Carr., 27.

Taxodium distichum mierophyllum (Brong.) Henk. aud Hochst., 28.

Taxodium distichum nanum Carr., 28.

Taxodium distichum nigrum Gord., 28.

Taxodium distichum patens (Ait.) Endl., 27.

Taxodium distichum pendulum (Forb.) Carr., 27.

Taxodium distichum pendulum elegans Beissn., 27.

Taxodium dislichum pendulum novum Beissn., 27.

Taxodium distichum pyramidatum Carr., 27.

Taxodium Wasbingtonianum Winslore, 28.

TAXUS Linn., 37 .

Taxus brevifolia Nutt., 37 .

Taxus floridana Nutt., 37 .

TERMINALIA Benth. \& Hook., 99.

Terminalia buceras (Browue) Benth. \& Hook., 99.

THEACE $\mathrm{E}, 87$.

THRINAX Linn, f., 37.

Thrinax microcarpa Sargent, 37.

Thrinax parviflora Swartz, 37.

THUJA Linn., 30.

Thuja occidentalis Linu., 30.

Thuja occidentalis alba Gord., 31.

Thuja occidentalis albo-variegata Beissn., 31.

Thrija occidentalis argentea Gord., 31. 
Thuja vecidentalis asplenifolia Carr., 30.

Thuja occidentalis athrotaxides Beissn., 31.

Thuja occidentalis aurea Gord., 30.

Thuja occidentalis aureo.rariegata Beissn., 31.

Thuja occidentalis bodmeri Beissn.. 30.

Thuja accidentalis boothi Beissn., 30 .

Thuja occidentalis cristata Gori., 30.

Thuja occidentalis densa Gord., 30.

Thuja orcidentalis denudata lieissn., 30.

Thuja nceidentalis elluangeriana (Gord.) Beissn., 30 .

Thuja occidcntulis fastigiata 13rissn., 30 .

Thuju occidentalis fastigiata nova Beissn., 30.

Thuja occidentalis jilicuides Jeissn., 30 .

Thuja nccidentalis fro beli Beissn., 30.

Thuju occidentalis globosa froril., 30.

Thuja occidentalis globularis Beissn., 30.

Thuja occidentalis gracilis Gord., 30.

Thuja occidentalis hoveyi Gord., 30.

Thuja vccidentalis lhaveana Jeissn., 30.

Thuja occidentalis little-gem Reis.n., 31 .

Thuja occidentalis lutea Veiteh, 30.

Thuja vecidentalis lutea humilis sudw., 30

Thuja occidentalis parra Sudw., 30.

Thuja occidentalis pondula Gort., 30.

Thuja occidentalis pendulu glancescens. Sndw., 30 .

Thuja occidentalis recure gusilla sudw., 30.

Thuja occidentalis recurvata argenteo-rariegata

Brissu., 30.

Thuja occidentalis recurvata Beissn., 30.

Thwij occidentalis rejlexa Carr., 30.

Thuja occidentalis riversi Beissn., 30.

Thuja occidentalis roscnthali lieissn., 30 .

Thuja occidentalis silver-queen Beissn., 31.

Thuja occidentalis spaethi licissn., 30.

Thuja occidentalis spihlmanni Ieissn., 30.

Thuja occidentalis tatarica lieissu.., 30.

Thrija occidentalis thcodonensis Jeissn., 30.

Thuja occidentalis varia Sudw., 30.

77.rija occidentalis verveneana Gord., 30.

Thuja occidentalis viridis Beissn., 30.

Thrija occidentalis walthamensis Gord., 30.

Thuja occidentalis wareana Gord., 30.

Thuja occidentalis ureana giobosa Beissn., 30.

Thuja occidentalis wareana lutiscens. Beissn., 30.

Thuja plicata Don., 31.

Thuja plicata argentco-versicolor Sudw., 31.

Thuja plicata atrovirens (Gord.) Sudw., 31.

Thaja plicata aurescens (13eissn.) Sudw., 31.

Thuja plicata compacta (Carr.) IBeissn., 31.

Thuja plicata erecta (Gord.) Sulw., 31.

Thuja plicata fuva Suilw., 31.

Thuja plicata gracillima (Beissu.) Surlw., 31 .

Thuja plicata llareana Gord., 31.

Thuja plicata minima Gork., 31.

Thuja piicata penduliformis Sudw., 31.

Thuja plicata pumila (Gori.) sudw., 31.

Thuja plicata variegata Carr., 31 .

THEYA gigantea Nutt., 31.

TILIA Linn., 96.

Tilıa americana Linn., 96 .

Tilia anemicana 3 pubescens Loud., 96.

Tilia heterophylla Vent., 97.

Tilia pubescens Ait., 96 .

Tilia pubescens leptopbylla Vent., 97.

TILIACE $\mathbb{E}, 96$.
TORREYA CALIFORNICA 'Jurr., "37.

TORREYA TAXIFOLIA Arn., 36.

TOXYLON liaf., 63.

Toxylon pomiferum liaf., 63.

Toxylon pomiferum inerme André, 63.

TSUGA Carr., 22.

Tsuga canadensis (Linn.) Carr., 22.

Truga canadensis albo-spica (Gord.) Jit1.sa., 20.

Tsuga canadensis argentco-variegata sudw., 2..

Tsuga canadensis argentifolia Sulw... 22

Tsuga canalensis aurea lieissn., 22.

Tsuga canadensis columnaris 13eissn., 22.

Tsuga canadensis compacta minima sudw., 22.

Tsuga canalensis e'recta Sudw., 22.

Tsuga ranadensir globosa l3eissn., 22.

Tsuga canadensis gracilis Carr., 22.

Tsuga canadensis macrophylla Beissn., '2-2.

Tsuga canadensis micruphylla B1-issn., 22.

Tsuga canadensis milfordensis $\mathrm{Niv} \cdot \mathrm{h}, \mathrm{l} ., 22$.

Tnuga canadensis parrifolia (Veit '-h) Leissn., 22.

Tsuga canadensis paucifolia Sudw., 22.

Tsuga candensis pendula Beissm.. .2.

Tsuga canadensis pumila sulw., 22.

Tsuga heterophylla (Iirf.) Sargent, 23.

Tsuga heterophylla latifolia nom. nor., 2::

Tsuga mertensiana (Bong.) Carr., 23.

Tsuga mertensiava anthors, not Carr.. 2y.

Tsuga mertensiana argentea (Beissn.) nom. unv., 23.

Tsuga mertensiana hookeriana (Carr.) nom. nor., 23.

Tsuga mertensiana latifolia Sudw., 23.

Tsuga pattoniana (Jeftr.) Engelm., 23.

Tsega pattoniana argextea Beissn., 23.

Tstga PatToniana hoOkERIANA (Carr.) Lem. non, 23.

TUMION Raf., 36.

Tumion californicum (Torr.) Greene, $3 \bar{T}$

Tumion taxifolium (Aru.) Greene, 36.

ULMACE $Æ, 60$.

ULMUS Linn., 60.

Ulmus alata Michx., 61.

Ulmus americana Linn., 60.

Clmus amcricana pendula Ait., 60.

Ulmus crassifolia Nutt., 60.

VL.IUS FlLVA Michx., 60.

Ulmus pubescens W alt., 60 .

Ulmus racemosa Thomas, 60.

UMBELLULARIA Nutt, 67.

Umbellularia californica (Hook. A Arn.) Nu1t..67. UNGNADIA Eud1., 94.

Ungnadia speciosa End1., 94.

VACCINIUM Linn., 101.

Vaccinium arboreum Marsll., 101.

VAUQUELINIA Correa ex II. H. K., 69

Vauquelinia californica (Torr.) Sarcent, 6!).

VAUQUELINIA TORREYI Wats., 69

VERBENACERE, 108.

VIBURNUM Linn., 110.

Viburnum lentago Linn., 110.

Viburnum prunifolium Linn., 111.

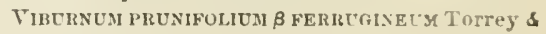

Gray, 111.

Viburnum rufotomentosum Small, 111.

W ASIHNGTONIA FILIFERA Wendl., 38.

Wellingtonia gigantea Lindley, 28.

XANTHOXYLOM Linn., 84.

Xantboxylum clara-herculis Linu., 84. 
125

Xanthoxylum clava-herculis fruticosum Gray, 84 . Xanthoxylum cribrosum spreng., 84. Xanthoxylum fagara (Linn.) Sargent, 84 XaNTHOXYLEM PTEROTA H. B. K., 84. Y UCCA Linu,., 38. Yucca aloifolia Linn., 38. Yucca arborescens (Torr.) Trelease, 38. Yucca brerifolia Torr., 38. YUCCA BRETIFOLIA Engelui., 38. Yucea constricta Buckl., 38.
Yucca gloriosa Linn., 38

Rosaceal

Fucca gloriosa plicata Carr., 38. Fucca gloriosa recurrifolia Engelm., 38. Yucea macrocarpa (Torr.) Covillo, 38. Yucea mohavensis Sargeut, 38 Yucca treculeana Carr., 38.

Zygia brevifolia (Benth.) Sudworth, 78 Zygia fexicaulis (Benth.) Sudworth, 78. Zygia unguis-cati (Linn.) Sind worth, 78.
ZYGOPHYLLACE E. 83 .

Shura I ruit a eaprule, sometimes woody, fhinas

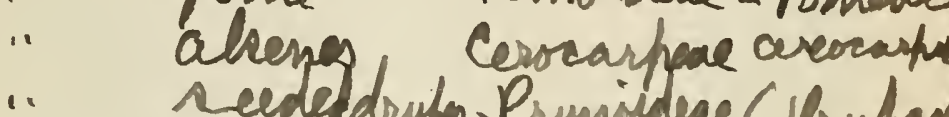

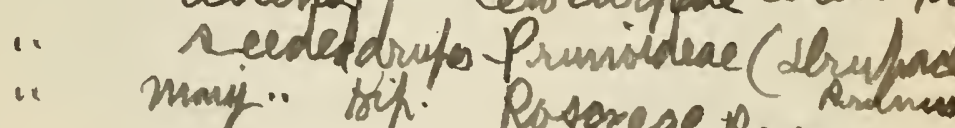
"min." sit? Rosoreal Rosa 


\section{INDEX OF COMMON NAMES.}

[Accepted names in heavy-face typ: synongus in roman type.]

Acacin (Cercidium floridum), \&1.

Acacia (liobinia pseudacacia), 82.

Ah-weh-bot-kwah, 9:.

Ailanthus, 85.

Alaska Cypress, 32.

Alaska Ground Cypress, 32.

Alaska l'ine, 23.

Alder (Alnus maritima), 49.

Aller (Alnus rhombifolia), 49.

Alder (-1 lnus oregona), 49.

Alder linckthorn, 95.

Algaruba, 79.

Alisier, 111.

Allegheny Sloe, 75.

Alligator Juniper, 36 .

Alligator-wool, 68.

Almondleaf Willow, 43.

Aloë-leaf Yucca, 38.

Alpine Fir, 25.

Alpine Larch, 20.

Alpine Paper Birch, 48.

Alpine Sipruce, 23.

Alpine Western Spruce, 23.

Alpine White-bark Pine, 14.

Alternate-leaved Dogwoud, 100.

A mabilis Fir, 26.

Amabilis, of Lovely Fir, 26.

Ameriean Arhorvita, 30.

Ameriean Ash, 106.

Anerican Aspen, 45.

American Cral, 69.

Americau Cralo A pple (I'yres curonaria), 69.

American Crab A plote (Pyms angustifolia), 70.

American Elm, 60 .

Anerican Fringe, 108.

American Holly, 89.

A merican Horse Clestnut, 93.

American Lareh 20.

American Lindeu, 96.

Anerican Mountion Asi, 70.

American Yettle-tree, 62.

American Planetree, 61.

Americau l'oplar, 45.

American Smoke-tree, 87.

Anacahuita, 108

Anaqua, 108.

Andromeda, 10:2.

Angelica-tree, 09.

Anthony's l'rickle-coue Pine, 18.

Antswoor, 104.

Apache Pine, 16.

Apple IIaw, 74 .
Arlol de Hierro, 83.

Arborvitæ, 30.

Arborrite (Thuja plicata), 31 .

A rizona Broalleleat Pine, 16.

Arizona Cork Fir, 26.

Arizona Cypress, 32.

Arizona Five-leaved Lumber Pine, 15.

Arizona Flexilis Pine, 14.

Arizona Long-leaf Pine, 16.

Arizona Madroña, 102.

Arizona P'aln, 38.

Arizona Pine, 15.

Arizona Ried-lark Cypress, 32.

Arizona Spruce, 21.

Arizona Sycamore, 69.

Arizona White 0 ak, 54 .

Arizoun White Pine, 14.

Arizona Fellow Pine, 15.

Arrow-wood (Evonymus a tropurpureus), 99.

Arrow. wood (Oxydendrum arboreum), 102.

Ash (Tanthoxylum clava-heiculis), 84.

Asli (Fraxinus anomala), 106.

Ash (Fraxinus velutina), 106.

A $\operatorname{sh}$ (Fraxinus americana), 106.

Ash (Fraxinus prnnsyleanicu), 107.

Ash (Fraxiuus lanceolata), 107.

Ash-leared Mlaple, 93.

Aspen, 45.

Aspen leaf, 45 .

Aspen Yoplar, 45.

Atlantic Real Cedar, 30.

Angust Plum, 75 .

A vispillo, 67.

A facalnuite Pine, 14.

Bald Cypress, 27.

Balı, 46.

Jain Cottonwool (Cal.), 46.

Balm of Gilearl (Abies balsamea), 25.

Balm of Gilead, 46 .

Balm of Gilead ('Popnlus bal. canricans), 4 ',

Balm of Gilead Fir, 25.

Balsam (1'icea engelmanni), 21 .

Balsam (Picea parryana), 21.

Balsim (Alies fraseri), 25.

Balsam (Abies balsamea), 25.

Balsam (Abies lasiocarpa), 25.

IBalsam (Abies concolor), 26.

Balsam (Populus balsamifera), 46.

Balsam (Populus bal. candicans), 46.

13alsam (I'opulus angustifolia), 26.

Balsam Cottonwood, 46 .

Balsam Fir, 25. 
Balsam Fir (Abies fraseri), 25.

Balsam Fir (Abics baleamea), 25.

Balsam Fir (Abics concolor), 26.

Balsam Poplar, 46.

Balsam-trce, 26.

Banana, 66.

Banksian Pine, 19.

lank's Palmetto, 37.

Barberryleaf Cockspur, 72.

Baretta, 84.

Jark Maple, 91.

Barren 0ak, 57.

Barren Oak (Quercus marilandica), 58.

Iarren Scrub Oak, 57.

Barrens Oak, 58.

Bartram 0ak, 59.

Bartram's Oak, 59.

Basket $A \mathrm{sl}, 106$.

Basket Elm, 60.

Basket Oak (Quercus michauxii), 53.

Basket Oak (Quercus breviloba), 54 .

Basswood (Liriodendron tulipifera), 66 .

Basswood, 96 .

Bastard Acacia, 82.

Bastarl Ash, 107.

Bastarl Cedar, 29.

Bastard Elm, 62.

Bastard Oak, 54.

Bastard Piue (Pinus tceda), 17.

Bastard Pine (Pinus serotina), 18.

Bastard Pine (Pinus heterophylla), 19.

Bastard Pine (Alies concolor), 26.

Bat-tree, 64.

Baumier, 46.

Bay (Magnolia glauca), 64 .

Bay (Tersea pubcscens), 66.

Bayberry (Myrica cerifera), 42.

Bayberry (Myrica californica), 42.

Bayberry (Rhamuus purshiana), 96.

Bay Galls, 66.

Bay-tree, 67.

Bearled Loe nst, 81.

Beantree, 109.

Bearberry (I lex decidua), 89.

Bearberry (Thamnus purshiana), 96.

Bear Oak, 57.

Bearwood, 96.

Beaver-tree, 64.

Bebb Willow, 44.

Beech, 50.

Beef.rood, 64 .

Beetree, 96.

Bell-tree, 105.

Berlandier Ash, 107.

Big Buckeye, 94.

Big-bnd, 41.

Bigeone Douglas Spruce, 25.

Bigcone Pine, 16.

Bigcone Spruce, 25.

Big Cottouwood, 47.

Bigelow Willow, 44.

Big Hickory Nnt, 41.

Big Laurel (Maynolia foetida), 64.

Big Lanrel (Thododendron maximum), 102.

Bigleaf Laurel, 102.

Bigleaf Maple, 90.
Big-leaved Iry, 102.

Big Pine (Pinus lambertiana), 14.

Big Pine ('inus ponderosa), 15.

Big Shellbark, 41.

Bigtreo (Abies nobilis), 27.

Bigtree, 28.

Bilsterl, 68.

Birch (Betula nigra), 48.

Birch (Iietula lenta), 49.

Birchleaf Mahogany, 69.

Bird Cherry, 70.

Bishop's Pine, 18.

Bitter Cherry, 76.

Bitter Cotton woorl, 46.

Bitter Il ickory, 40.

Bitternut (Hickory), 40

Bitternut (IIicoria minima), 40.

Bitternut (Hicoria glabra), 41.

Bitter Pecan, 40.

Bitter Pecan Tree, 40.

Bitter l'ig Nut, 40.

Bitter WValnut, 40.

Bitter Waternut, 40.

Bitterwood, 85.

Black Ash (Acer negundo), 93.

Black Ash, 106.

Black Ash (Fraxinus pennsylianica), 107.

Blackbark Pine, 16.

Black Bireh (Bctula occidentalis), 48.

Black Birch (Betula nigra), 48 .

Black Birch (Betula lenta), 49.

Black Calabash, 109.

Black Calabash-tree, 109.

Black Cherry, 77.

Black Cottonwood (Populus heterophylla), 46.

Black Cottonwood (Topulus angustifolia), 46

Black Cottonwood, $\mathbf{4} 6$.

Black Cypress, 27.

Black Elderberry, 110

Black Gum (Alies concolor), 26.

Black Gum, 100.

Black Haw, 71 .

Black Haw (Bumelia tenax), 103.

Black Haw (Bumclia lanuginosa), 104.

Black Haw (Tiburnum lcntago), 111.

Black Haw (Viburnum prunifolium), 111.

Black Hemlock, 23.

Black Hickory (Hicoria alba), 41 .

Black Hickory (Hicoria glabra), 41.

Black Ironwood, 95.

Black Jack \{Quercus catcsbai, 57.

Black Jack, 58 .

Black Jack 1'ine, 19

Black Larch, 20.

Black Laurel, 87.

Black Linuetree, 96

Black Lin, 65.

Black Live Oak, 55 .

Black Locust (Gleditsia triacanthos), 80.

13lack Locust (Robinia pseudacacia), 82.

liack Mangrove, 108.

Black Maple (Acer saccharum), 91.

Black Maple, 91.

Black Minlherry, 62.

Black Norw:ly Pine, 17.

Black Oak (Quercus emoryi), 55.

Black Oak (Quercus rubra), 56 . 
Black Oak (Quercus coccinea), 56 .

Black Oak (Quercus velutina), 56.

Jjlack Oak (Quercus californica), 57.

Iilack Oak (Qucrcus marilandica), 58.

Black Olivetree, 99.

Black Persimmon, 105.

13lack Pine (Pinus jefreyi), 16.

Black l'ine (P'inus murrayana), 16 .

Black I'ine (Pinus toeda), 17.

Blick P'ine (Pinus rigida), 17 .

Black Pine (Pinus divaricata), 19.

Black Poplar, 47.

Black Slash Pine, 17.

Black Sloe, 76 .

Black Spruce, 20.

Hack Sprnce (I'icéa canadensis), 21.

Black Sugar Maple, 91.

Black Sumach, 88.

Jiack Thorn ('ratogus douglasii), 71.

J3lack Thorn (Cratagus tomentosa), 73.

Blark Titi, 88.

Black tree, 108.

Black Walnut, 39.

Black Willow, 4:.

Black Willow (Salix lavigata), 43.

Black Willow (Salix lasiandra), 43.

Black Willow (Salix amygdaloides), 43.

Black Willow (salix nuttallii), 44.

Black wood, 108.

Bleeding Heart, 90.

Iilister I'jne, 25.

Blolly, 64.

Blue Ash, 106.

Blue Ash (Fraxinus lanceolata), 107.

Blue Beech, $\tilde{u} 0$.

Blue Birch, 48.

Jilne $\mathrm{Blossom}, 96$.

Blue Dogrood, 100.

Blue Jack, 58 .

Blue Locust, 8:3.

Blue Myrtle, 96.

Ilue ()ak (Quercus marrocarpa), 52 .

Blue Oak (Quercus douglasii), 54 .

Blue 0ak, 54 .

Blur Pojlar, 65.

lilue Sirruce (I'icea mariana), 20.

Blue Spruce, 21.

I]luet, 101.

Bluewood, 95 .

liodor $k, 63$.

Bog Birch, 95.

Bog Spruce, 21.

Bois D'A re, 63.

Bois inconnu, 62.

Buis I'uant (Platanus occidentalis), 68.

Juis l'uant (Catalpa speciosa), 108.

lBolander's I'ine, 16.

Boleau, 48.

Bolle Poplar, 47.

Bonpland Willow, 43.

Botton Shellbark, 41.

liow-wood, 63.

Boxelder, 93.

Box Eliler (Acer negundo californicum), 93.

Box ()ak, 52.

Box White Oak, 52.
Boxwool (Schaiferia frutescens), 90.

Boxwoud (Cormus jlorida), 100.

Brash Oak, 52

l3rewer's Spruce, 22.

Bristle-cone Fir, 26.

Bristle-cone Pine, 15

Bristle-leaf Strongback, 103.

Brittle Thateh, 37.

Brittlewood, 95.

Britton 0ak, 58.

Broadfruit Yucca, 38.

Broadleaf Cockspur, 7:.

Broadleaf Locust, 82.

]hoad-leaf Pine, 16.

Broad-leaved Cotton woorl, 47 .

Broad-leaved Maple, 90.

Broadpod Locust, 83.

Broom Hickory, 41 .

Brown Ash (Fraximus nigra), 106.

Brown Ash (Fraxinus penns!lvanica), 107.

Brown Hiekory, 41.

Brown Piue, 19.

Buckeye (.Esculus glabra), 93.

Buckeye (Esculus octandra), 94.

Buekthorn (Khamnus caroliniana), 95.

Buckthorn (Tha inmus purshiana), 96.

Buckthorn (Bumelia lycioides), 104.

Buckthorn Bumelia, 104.

Buckwheat-tree, 88.

Bujot Locust, 80.

Bull Bay, 64.

Bullnut, 41 .

Bull Pine (Pinus jexilis), 14.

Bull Pine, 15.

Bull Pine (Pinus ponderosa scopulorum), 15.

Bull Pine (Pinus jeffreyi), 16.

Bull Pine (Pinus taeda), 17.

Bull Pine (Pimus serotina), 18.

Bull Pine (Pinus echinata), 18.

Bumwood, 87.

Burning Buslı, 89 .

Burning-wood, 88 .

Burnwoot, 88.

Burnweod-bark, 88.

Bur 0ak, 52.

Burriers Oak, 59.

Bustic, 104.

Butternut, 39 .

Buttnut, 39.

Buttonball (I'latanus occidentalis), 68 .

Buttonball (Platanus racemosa), 68.

Buttonball-tree (Platanus occidentalis), 68 .

Buttonball-tree (Platanus racemosa), 68.

Buttonwood (Platanus racemosa), 68.

Buttunwood (Laguncularia racemosa), 99.

Buttonwood (Conocarpus erecta), 99.

Button-wood (I'latanus occidentalis), 68.

Cabbage Palmetto, 37.

Cabbage 1 r.e, 37.

Cabeza vicjo, 97.

Cajeput, 67.

Caljeo Bush, 102.

Calico Flower, 102.

Calico-tree, 102.

Calicowood, 105.

California Bayberry, 42. 
Califormia Bay-tree 67.

California Black 0ak, 57.

California Boxelder, 93.

California Buckeye, 94 .

Calitiruia Cherry, i7.

California Chestunt Uak, 59.

California Cotfee, 96.

Calitornia Dogwood, 100.

California False Nutweg, 37.

Calitornia Fau Palm, 38.

California Hemlock Sprure, :23.

(alifornia Hullr, 74.

Califorria Juniper, 36.

California Laurel, 67 .

California Lilaı, 96.

California Live Oak, 55.

Califurnia Mountain Cypress 32.

California Myrtle, 42.

California Nutmeg, 37 .

California Olive, 67 .

California Post Cedar, 29.

California Red-bark Fir, 27.

California Red Fir, 27.

California Redwood, 28.

(California) Rock 0ak, 54.

(California) Scrub Oak, 54.

California Swamp Pine, 18.

California Sycamore, 68.

(California) Tanbark 0ak, 59.

California Torreya, 37.

California Walunt (Juglans rupestris). 39.

California Walnut, 39.

California Wax Myrtle, 42.

California White Fir (Abies concolor), 26.

California White Fir (Abies conc. louiana), 26 .

California White 0ak, 51.

Californian Sassafras, 6 .

Canada Balsam, 25.

Canala Horn-cune Pine, 19.

Canada Plum, 75.

Canadian Hemlock, 22.

Canadian Judas tree, 80 .

Canalian Red Pin̨e, 15.

Candleberry, 42.

Cane Ash, 106.

Canela, 67.

Canoe Birch, 48.

Caune Cedar, 31.

Canve- rood, 66.

Cañun Birch, 48 .

Canotia, 85.

Canyon Live 0ak, 55 .

Canyon Dak, 55.

Caper tree. 6\%.

Carolina Asl, 107.

Carolina Buckthorn (Rhamnus caroliniana), 95.

Carolina Buckthorn (Bumelia lycioides), 104.

Carolina Hemlock, 23.

Carolina Pine, 18.

Carolina Poplar, 47.

Carolinian Cherry, 77.

Cascara Buckthorn, 96.

Cascara Sagraila, 96.

Cassada, 114.

Cassena, 89.

Cassie, 78.
Cassine, 89.

Cassio-berry I3ush, 89.

Cutalpar (Catalya catalpa), 109,

Cutalpa (Catalpa speciosa), $10 y$.

Catawba, 10 ?.

Catawba Rhododendron, 10:3.

Catawba.tre.o, 109.

Cat's Claw (Kygia "nguis-cati), is.

Cat's rlaw (Acacia mrightii). $7 \mathrm{~s}$

Cat's Claw (.1 cacia greggii). 7!?

Cat Spruce, 21.

Cedar (Liboredrus decurrens), 29.

Cedar (Thuja occidentalis), 30.

Celar (Thuja plicata), 31.

Cellar (Juniperus virginianu) . it.

Cedar (Juniperus oecidentalis). 35.

Cedar Elm!, 60.

Cedar l'ine (l'inus virginiana). 1\%.

Cedar l'iue (l'in"s glabra), 19.

Cedre, :is.

Chalky Leucæna, 79.

Chaniso, it.

Chapman 0ak, 52.

Chapote, 105.

Checkerel-barked Juniper, 36.

Chek Piue, 19.

Chène étoilé, 52 .

Chêne Vert, 55.

Cherry (Icacorea paniculata), 103.

Cherry Birch (Betula occidentalis), 4 s.

Clierry Birch (Betula lenta). 49.

Cherry Laurel, 7 7.

Chestnut (Castanopsis chry×ophylla), 51

Chestnut, 51.

Chestnut 0ak, 53.

Chestnut Oak (Quercus acuminata), 53.

Cbestnut Oak (Quercus densiflor a), 59.

Chickasaw Plum, 75.

Chihuahua Pine, 16.

Chihuahua Top eone Pine, 16.

Chinaberry, 94 .

China-tree, 85 .

Chinquapin, 51 .

Chinquapin ('astanopsis chrysophylla), 51.

Chinquapin $0 \mathrm{ak}, 53$.

Chittamwood, 87.

Chit tim wood, 104.

Choke Cherry, 76 .

Choke Cherry (I'runus demissa), 77.

Choke Cheriv (Prunus serotina), 7 .

Cho-koh-tung, 25.

Cholla, 97 .

Christmas-berry, 7 .

Cigartree (Catalpa catalpa). 109.

Cigartree (Catalpa speciosa), 109.

Cigua, 67.

Cinnamon-bark, 87 .

Cinnamon ()ak, 58.

Cirier, 42.

Clammy Locust, 83.

Cliff Eln, 61.

Coast Live Oak, 55.

Coust Nutmeg, 37.

Coast Red wood. 28.

Cockspur, 71 .

Cockspur Hawthorn, 71. 
Cockspur Thorn, 71.

Cocoa Plum, 74.

Coffcebean, 81.

Cofliehean-tree, 81.

Cotlie-berry, 96.

Cotleenut. 81

Coffeetree, 81 .

Coloralo lilue spruce, 21.

Ciuluraclu White Fir, 26.

(Common) Catalpa. 109.

(Common) Cottonwood, 46.

Common II ickor 5,41 .

('ommon Sumacli, 88 .

Common Thorn, 73.

('mmon Willow. 43.

Coneulor silver Fir, 26.

Conteclerut Pintree, 80.

Connu, t5:

Coral Bean, 81.

Coral sumach, 87.

Cork-harked Donglas Sprnew. 23.

Corkbark Elm, 61

Cork Elm, 60 .

Cork Elıu (Tlmus alata), 61 .

Corkwood, 42.

Cork-Wool (I'isonia odtusata), 64

(Corks Elm ( Clmus alata), (i1.

Corky Thite Elm, 61.

Cornel, 100.

Cornstallk l'ine, 17 .

Cotonier, 68 .

Cotton Gum, 101.

Cotton-tree (l'opulus heterophylla), 46.

Cottun-tres' (Populus sleltoides), 47.

Cotionwood (Populus hetrophylla). 16.

Cottonwoud (Populus balsanifera), 46.

('ottonwool (Populus angustifolia), 46.

('ottouwood (I'opulus trichocarya), 46.

Cottonwoud (I'opulus deltoides), 4ti.

Cottonwool (Populus fremontii), 47 .

Cottonwond (Tilia heterophylla), 97.

Coulter Pine, 16.

Coulter's ['iue, 16.

Cow Lirkks, 105.

Cow 0ak, 53 .

('rah (Pyrus coronaria), 69.

Crah . Pple (Pyrus coronaria), 6!).

Cralı Apple (Purus anyestifolia), î.

('rab or Wila Aplele. 70.

Crabtree, 70.

Crabwood, 86.

Crack Willow, 45.

Crrek Maple. 92.

Creeping Pine (Pinus allicaulis), 14.

Crescentleaf Willow, 42.

Crinkleleaf Locust, 82.

Crisp-leaf Cottonwood, 47.

Crisp-leaf Silver Maple, 92.

Cuban Pine, 19.

Cucumber (Maynolit acuminata). 65.

(uesumber (Maynolia macrophy lu), 65.

Cneumber (Magnolia tripetala), (is.).

Cuenmber (Jagnolia fraseri). 15.).

Cucumber-tree, 64 .

('ucumber.tre (Matmulia acm.curlata), 65.

Cucumber true (Jamnolia macrophylla). 65.
Curumber-tree (Jaguolia fraseri), 65.

Cucumber-trea (Lirintentron lulizifera), or.

Curl-leaf Boxelder, 93.

Curl-leaf Scrub 0ak, it.

Currant-tree. $i 1$.

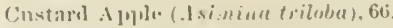

Custaril . lipite (.1 unoua glabra). 66.

Cutleaf Locust, $\& 3$.

Cutleaf Silver Maple, y2.

Cut leared Maple, 93.

Cypress (I'inus diraricala), 19.

('ypress (Tuxodiun distichun), 27.

Cypress (Cupressus macnabiana). 32.

Dalioon, 89.

Dahoon (Holly), 89.

Dahoon llolly (I lex cassine mytifulia), 32.

1)alea, 8:2.

Darliug Plum, 95.

Darlington ( )ak, 58 .

Date I'lum, 104.

Deciduous Cypress, 27.

Deciduous Holly, 89.

Deer-tougne Laurel, 102.

Del Jlar Pine, 15.

Dent-soo-kwa-úo-ne, 39.

Desert Bnsh, 81.

Desert Juniper, 36.

Desert Willow, 109.

Devils Claw. 79.

Deril's Claw's, 79.

Devilwood, 103.

Iloctor Gum, 87.

I ogwod (Rhus vernix), 88 .

l)ogwood (Cornus florida) 100.

logwood (Cornus muttallii), 100.

Dogwood (Corms alternifolia), 100.

Dotted-fruited Thorn, 73 .

Dotted Haw, 73 .

Double Fir Balsam. 25.

Double-flower Redbud, 80.

Duuble Sirnce (Picra mariana). 20.

Double spruce (Picen canallensis), 21

Dumble Sirnce (Abies jiaseri), 25.

Douglas lir, 23.

Douglas Spruce, 23.

I)ouglas sputee. 23.

Douylist-true, 24.

Jown cone Fir, 26.

Downward Plum, 104.

Downy Basswood, 96.

Downy-cone Sub-Alpine Fir, 26.

Downy Haw, 72 .

Howny Poplar, 46.

Downy Redbud, 80.

Downy Yellow Haw, it.

Drooping Ailanthus, 85.

Drooping Juniper, 36.

Drummond Maple, 93.

Duck ()ak, 58.

Durand Oak, 54.

Durant's ()ik, 54.

Dwarf Ash, 106.

Dwarf lilack Oak, 57.

1)wart Chestmut O:1k, 53.

Dwarf Chinquapin Oak, 53.

Dwarf Choke Cherry, it. 
Dwarf Juniper, 36.

Dwarf Maple, 91.

Jwarf Mariue Pine, 18.

Dwart hose Bay-1rew. 102.

Dwarf Sumach, 88 .

Wwarf Walnut, 39.

Drer's Oak, $5 \%$.

lar-leaved Cucumber'trec, 65.

Ear-l'aved Tmbrella-tree, 65.

Eller (Sambucus mexicana), 110.

Eliler (Nambucus glauca), 110.

Elilerberry, 110.

Elierberry-tree, 110.

Elderleaf Mountain Ash, 70 .

Elcler-leared Mountain $\Delta \mathrm{sh}, 70$.

Elk word, 65.

Elm (Tlmus americana), 60.

Elm (Clmus alata), 61.

Emetic Ilolly, 89.

Emory 0ak, 55 .

Emory's Oak, 55.

Eucina, 55.

Engelmann Oak, 54 .

Engelmann's Oak, 54 .

Engelmann Spruce, 21.

Engelmann's Spruce, 21.

English Hawthorn, $i 2$.

Enti-e-leaf Cherry, 78.

Entireleaf Mahogany, 69.

Epinette Jaune, 20.

Epinette Ronge, 2 ().

Erable, 92 .

Erect Cottonwood, 47.

European Alder, 49 .

Evergreen Buckthorn, 95.

Evergreen Cassena, 89

Evergreen Cherry (Prunus caroliniana), 77.

Evergreen Cherry (Prunus ilicirolia), 78.

Erergreen Magnolia, 64.

Evergreen Oak, 55.

Evergreen White Oak, 54.

Exmouth Magnolia, 64.

Eysenhardtia, 82.

False Acacia, 82.

False Banana, 66.

False Box-dogroot, 100.

False Box mood, 90.

False Dogwool, 94.

False Mahogant, 66.

False Maple, 93.

Fanleaf Palm, 3 .

Farkleberry, 101.

Fat Pine, 19.

Feather-cone Rerl Fir, 27.

Feather-tree, 69.

Fernleaf Black Cherry, $i 7$.

Fetid Buckeye, 93.

Fetid Shrub, 66.

Fetid $\mathbf{Y e w}, 36$.

Fevertree, 110.

Fiddlewood, 108

Finger-cone Pine, 14.

Fir (Pseudotruga taxifolia), 23.

Fir (Abies amabilis), 24.

Fir Pine, 25.

Fir-tree, 25.
Fire ('herry, 66

Firewoud. 88.

Florida Boxwood, 90.

Florida Buttonwood, 99.

Florida Caper, 67 .

Florida Catsclaw, is.

Florida Laurel, 105.

Florida Lougleaved I'ine, 19.

Florida Mahouany, 66.

Florida Maple, 91.

Fluricla Palnu, 37.

Floriula l'in', 19.

Florida Plum, 86.

Florid:ı Quinine: laark, 110.

Florida Spruce Pine, 18.

Florida Torreya, 36 .

Florilla Inllow P'ine, 19.

Florida Yew, 37.

Flowering $1.1 \mathrm{~h}, 108$.

Flowerine Cornel, 100.

(Flowering) Dogwood, 100.

Flowering Logwood ('ormus unflullii), I 10

Flowerine Willow, 109.

Footluills Tellow Pine, 15.

Forlied-leat. 57 .

Forkerl leat Black Jark, $5 \vec{i}$.

Four-wingerl IIalesia, 105.

Foxtail Pine, 15.

Fustail Pine ( $I^{\prime}$ inus toda), 17.

Fragrant Crab, 69.

Franc-Frêne, 106.

Frankincense Pine, 17.

Franklinia, 87.

Fraser Fir, 25.

Fraser Umbrella, 65.

Fremont Cottonwood, 47.

Fremontia, 86.

Fremont's Nut Pine, 15.

Frêne-piquant, 84 .

Frijolito, 81 .

Fringe Ash, 105.

Fringed Spruce, 26.

Fringetree, 107 .

Gambel 0ak, 52

"Gambier Parry"s l'ine," 15.

Garber Stopper, 99.

Garden Wild Plum, 74 .

Geigertree, 108.

Georgia Bark, 110.

Feorgia Heart Pinc, 19.

Georgia Longleaved Pinu, 19.

Georgia Oak, 58.

Georgia Pine. 19.

Georgia Pitclı Pine, 19.

Georgia Fellow Pine, 19.

Giant Arborvitæ, 31.

Giant Cactus, 97.

Giant :equoia, 28.

Gigantic Cerlar, 31.

Cirantie ur Paelfic liedl l'edar, 31.

Gigantic l'ine, 14.

firgantiv Iied r'erlar, 31

Ginger Pine, 33.

Glaucous Willow, 44.

Glossyleaf Willow, 43.

(iolden-eulu (lak, 55. 
Golden Fig, 63.

Gulkten Fis, 2 -

Golden Hoptree, 84

Goldenleaf Chinquapin, 51.

Goldenleaf Cotttonwood, 17.

Goldenleaf Locust, 8 ?.

Gouseberry, 101.

Goosefuot Maple, 90.

Gooso Plum ('runus americuna), i5.

Goose P'lum (P'runus hortulana), 75.

Goose Plum (Prunus hortulana mineri). 75.

Gopher Plum (Chrysobalanus icacr), 74.

Goplur Plun (Nyssa ogeche), J(1).

Gopherworl, 82.

Gowen Cypress, 31 .

Grand or Oregon White l'ir, 26.

Gray Birch (Retula populifolia). 47.

Gray Birch (Betula occidentalis), As.

Gray IBirclı (Betula lutea), 48.

Gray-leaf' l'ine, 16.

Gray Pjne, (Jinus monoplu!lla), 15.

Gray Pine, 16.

Gray Pine, (I'inus divaricata), 1!).

Great California F'ir, 26.

Great Laurel, 102.

Great Laurel Magnolia, 64.

Great-leaverl Magnolia, 65.

Great Rhododendron, 102.

Great Silver Fir, 26.

(ireat Sugar Pine, 14.

Great Tileland Siprnee, 22.

Great Western Lar'h, 20.

Green Ash, 107.

Greenbark Acacia, 81

Gren-barkel Acacia ('ercidium floridum), 81.

(ircen-barkel Acacial (revcidium torreyanum), 81 .

Green Haw, 74 .

Lireen Locust, 8 .

Green Osier, 100.

Gregg Ash, 106.

Guettarda, 110.

Guiana Plum (Drypetes lateriflora), 86.

Guiana Plum, 86.

Gum ( Iiquidambar styruciflua), 6×.

Gum (Nysse sylvatica), 100.

Gum Elastic, 104.

Gum Elemi, 85.

Gun-tree (liquidambar styrarifua), 68.

Giumbo file, 6\%.

(iumbo limbo (Nimarouba ylauca), 85.

Gumbo Limbo, 85.

Gurgeon Stopper, 98.

Gyminda, 90.

Hackberry, 61 .

Hackherry (C'eltis occ, reticulatu), 62.

Hacklorry (Celtis mississippiensis, 62.

llaclinuttack (Iarix laricina), 20.

Hackulack (Harix occidentalis), 20.

Hack.tree, 62.

llaemack, 20.

Hairy Balm of Gilead, 46.

II airy Sumach, 87.

Harlbark Hickory, 41.

Harlbac $\mathbf{k}, 50$.

Hard Maplo (A cer saccharum), 91.

Hard Maple (Acer saccharum nigrum), 91.
Hard Maple (Acer sacch. grandidentotum), 92.

Hard l'ine (I'inus resinosa), 15.

Ifard Pine (I'inus rigida), 17.

IIard Pine (Pinus palustris), 19.

Ilard-sliell, 41.

Fardy Catalpa, 109.

Haw (Crutezges douglasii), 71.

Haw (C'ratagus crus-galli), 71.

Haw (Cratogues viridis), 74.

Haw (Cratewes flava), 74.

Haw (Tiburnum prunifolium), 111.

II aw Bush, 72

IIawthoru (C'rateegus douglasii), 71 .

Hawtloru (Crategus crus.galli), 71.

Hawtlorn (Cratergus coccinea), i2

Hawthoru (Cratcegus tomentosu), 73.

Healine Balsam, 25.

lfeart-leavel Cucuuber-tree, 6.5.

Heart-leaved Tliorn, 73.

Heart Pine, 19.

Heary Pine, 15.

Heary-wooded Pine, 15.

He Balsam, 20.

Hedge, 63.

Herlge-plant, 63.

Iledge Thorn, 72 .

He Inckleberry, 8 s.

Hemlock, 22.

ITemlock (Tsuga caroliniana), 23.

Hemlock (Tsuga heterophylla), 23.

Hemlock (P'seudotsuga macrocar,a), 25.

Hemlock Spruce (Tsuga canadensis), 22.

Hemlock Spruce (Tsua heterophylla), 23.

Hemlock sipruce (Tsuga mertendiana), 23.

Heudersou's Pine, 16.

Hercules" ('lıh, 99.

Hickory (Hicorin minima), 40.

Hickory (Hicoria ovata), 40.

Hickory (IIicoria alba), 41.

Hickory Elm, 60.

Hickory Nut, 41 .

Hickory Oak, 55.

Hickory P'ine, 15.

Hickory Poplar, 65.

High-ground Willow Oak, 58.

Highland Livo Oak, 56.

Highland $\mathrm{Oak}, 56$.

Hog Haw, 71 .

Hog Nut, 41.

Hog I'lum (I'runus americana), 75 .

1Iog Plun (P'runus angustifolia), 75.

Hog Plum (P'runus umbellata), 76.

Hog Plum (Thus metopium), 87.

Hog's 11 aw, 71 .

Holly (Prunus ilicifolia), 78.

Holly (Ilex opaca), 89.

Holly (llex decidua), 89.

Holly Cherry, 78.

Hollyleaf Cherry, 78.

Holly-leaved Cherry, 78 .

Hombro viejo, 97.

Honey, 80.

Honey Locust (Frosopis julifora), 79.

Honey Locust, 80.

IIoney Lucust (Robinia pseudacacia), 82.

Ifoney Locust (Robinia viscosa), 83. 
Honey Poil, 79.

Honey shuclis, 80 .

Honey.Nhucks Locust, su.

Hooker Hemlock, 23.

Hooker Willow, 44 .

Hoop Ash (Celtisuccidentalis), 62.

Hoop Ash (Fraxinus nigra). 106.

II0], IIurnbeam, 5॥.

Hoptree, 84.

Hornbeam, 50 .

Hornbeam (Carpinus caroliniana), 50.

Horse-bean, 81 .

Hurse Chestnut, 94.

Horse Plum (T'rumus niyra), 75.

Jlorse Plum (I'runu\& americana), 75.

Horse Sugar, 105.

Huajillo, 78.

Huckleberry 0 ak, 55 .

Huisache, 78 .

Incense Cedar, 29.

India-Rnbber-tree (Ficus aurea), 63.

India-Rubber-tree (Ficus populnea), 6:3.

Indian Arrow, 90.

Indian Bean (Cutalpa eatalpa), 109.

Indian Bean (Catalpa speciosa). 109.

Indian Bitters, 65.

Indian Cherry (A melanchier canadensis), 71.

Indian Cherry (Rhamnus caroliniana).95.

Indian Cigar-tree, 109.

Indian Plrysic, 6.̃.

Inclian Pine, 17.

Inligro Bush. 82.

Indigo Thorn, 82.

Inkwood, 94.

Iowa Crab, 70.

Iron Oak (Quercus minor), 52.

Iron Uak (Quercus chrysolepis), 55.

Iron lak (Quercus marilandica), 58

Ironwood (Ostrya virginiana), 50.

Ironwood (Carpinus caroliniana), ju.

Irouwood (Prosopis julitior(t), 79.

Ironwood (Guajacum sanctum). \&:?.

Ironwood, 88.

Irowwood (Cliftonia monophylla), 8:

Iroumood (Cyrilla racemijlora), 88.

Ironwood (Exothea paniculata), 94.

Ironwood (Bumelia tenax), 103.

Iron wood (Bumelia lycioides), 104.

Iron Wool (Olneya trisota). 8:3.

Islay, 78 .

I 55,102 .

Irymood, 102.

Jack Oak (Quercus marilendica), 58.

Jack Oak (Quercus imbricaria), is.

Jack Pine, 19.

Jamaica Dogwood, 8 :3.

Jasmine, 66.

Jasminier, 66.

Jeffrey Pine, 16.

Jersey Pine, 18.

Jerusalen Thorn, 81.

Joewood, 103.

Joshua-tree, $3 \ltimes$.

Julas-tree, 80 .

June-berry, 70

"Janiper" (Pinss diveriratu), 19.
Juniper (Larix laricina), 20.

Juniper (I'icea mariana), 20.

Jiniper (libocclrus decurrens), 29.

Juniper (Cham. thynidts), 32.

Juniper (Juniperus rirginianu). 34.

Juniper (.Tuniperus arcidentalis), 33.

Juniper (Juniperus sabinoiles), 36.

Jupiper (.Juniperus californica), 36.

J uniper (Juniperus utahensis), 36.

Juniper (.Tunipenes pachyphlara), 3t).

Juniper lBush, 34.

$J$ unipur Cedar, 36.

. Inuiper-tree, 62.

Ki:alnia, 102.

Kia-neh-tens, 20.

Kinlogg: Oak, 57.

lientucky Coffeetrin, sil.

King Nut, 4J.

lingstree, 19.

Knackaway, 108.

Knobcone Pine, 17.

Knotty Pine, 16.

Knowlton Hornbeam, 50.

Kœberlinia, 85 .

Ko-jen-ta-ka-alı-ta, 66 .

Lanceleaf Alder, 49.

Lanceleaf Cottonwood, 46 .

Lanceleaf Dwarf Sumach, $\cdots$.

Lancewood, $6 \%$.

Langues die fenmes, 46.

"Larel " (Larix laricina), :0).

"Larch" (Larix lyallii), 20.

Lareh (Larix occidentalis), 20.

Larch (Abies amabilis), 26.

Larch (Abies nobilis), 27.

Large American Aspen, 4.\%.

Large Bnckeje, 94.

Large-coned Pine, 16.

L.arge-tlowered Evermreen Magnolis, 64

Largeleaf Mulberry, 6 ..

Largeleaf $\mathrm{Umbrella,} 6.5$.

Large-leared Cueumber-tre. 65.

Large-leaved Limetree, 97.

Large-leared Cmbrella-trew, 65.

Jarge Poplar, 45.

Largetooth Aspen, 45.

Lirge-tootheel Aspeu, 45.

Large-tooth Maple, 92.

Larcre-tuothed Maple, 9:.

Large-tuothed Poplar, 45.

bilrue 'Tupelo, 101.

Litree White Birch, 48.

Laurel (. I agnolia fotida), 64.

Laturel ( Fubcllularia californieu), 67.

Liturel (.1 rbutus menziesii), 101.

Linurel (.l,butus xalapensis), 101.

L:Iture] (Kulmia latifolia), 102.

Lanrel (khododendron maximum), 10:3.

L:arrel I3ay, 64 .

Laurel Cherry, 77 .

Laur.]-]eaved Magnolia, 64 .

Laurel Oak, 5s.

Lamrel Oak (puercus imbrichrit), 50.

I.anrel-tree, 60 .

L.:Iurelwered, 10 !.

Janrinr J'etit Magnulia, fil. 


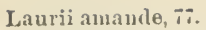

Lanry Mumly, 7 T.

Lawson's Cypress, 33.

Lea 0 ak, 59.

Leatherleaf Ash, 106 .

I.entlerwoed :Cyrilla racemiglura), 8x.

Leather-wool (Frementodendron entifornicum), sti.

Lein, 9t.

Leucæna, 79.

Liverwoul, 50 ).

L.i:tr. 46 ,

Liti. et' MI:11, T1.

Lignum-vitæ, 8:

Lily ut the Valley-1 1've, 102.

Limber Pine, 14.

Limber-twigr I'ine, 1 .

I.imetrue (Tilia americana), 96.

Limet ree (. Yyssa nepeche), 101.

Lin, 97.

Limlen, 9 i.

Linn, 96.

Liต̣uiclausber, (i8.

Little l'ignut, $\$ 1$.

Little Nlıaglo:urk. 41 .

Little Sugar I'ine (I'inus lumbertianf), 14

Little Sugar l'iue (l'inus monticola), 14.

Little Walunt, $\$ 9$.

\section{Live 0 ak, 55 .}

Live ()ak ((querens chrygulepis), 55.

Live O)ati (Quercus rislizeni), 56.

l.ive ()ak (yuerens dessiflora), 58.

1.obly's Arhorvita, 31 .

Loblolly Bay, 8i.

Loblolly Pine, 17.

Luhblly I'ine (Jinus sprotina), 1x

Lor'ust (Gleditsia triacanthos), 80.

Locust, $8^{*}$.

Locust (liobiniu nren-mexicana), n:i.

Lodgepole Pine, 16.

Lo:rwout, 95 .

Lombardy Poplar, 47.

Linlt. Pine, 15.

Longleaf Pine, 19

Longleaf Service-tree, 71 .

Longleaf Willow, 43 .

Long-leared Curumber-tree, 65.

Long.lpaved Magnolia, fí.

Long-leaved l'ine (l'inus ponderosa), 1\%.

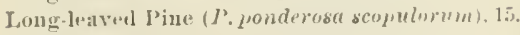

Lome-leavell l'ine (Pines rigida). 17.

Iong-leaved l'ine (V'inus yalustris), 1!

long-loved l'itrh l'ine, 19.

Longraveleal Willow, 43 .

Long.leaved Yellow Jine, 19.

Long l'oul, $7 x$.

Longsehat P'ine (Pintis tecia), 1 .

Longre'lat I'ine ( 'Pinus rigida), 7 .

Lumgshucks, 17.

Longspine Haw, 7.2.

Longstalk Willow, 43.

Lohogt law l'ine (Pinus twelu), 17.

Lungstraw l'ine (P'mus palngtris), 14.

Lovely Fir, 206.

Lorily Fed Fir, 26.

L.ow Misple, !().

Lowland Fir, 26. lewland spruce Pine, 12.

Lyall's Larch, 20

Lyall Willow, 43.

Mackenzie Willow, 4 .

Macnab Cypress, $3:$.

MacNab' ('ypress, 32.

Madeira, $x 6$.

Madroña, 101.

Madroña (Arbutus xorlapensis). 101.

Maulrune-t ree (Arbutur menziesii). 101.

Indrone-t jee (Arintus xalapensix), 101.

Malrove, 101 .

Magnificent Fir. 27.

Magnolia (Magnolia glauca), 64.

Magnolia (Ma!nolia acuminata), 65.

Magnolia (Magnolia tripetala), 65.

Mahaleb Cherry, $i 6$.

Mahogany ( Fymmocladur divicus), 81 .

Mahogany. 86.

Mahogany liireh, 49.

Mammoth-tree, 28.

Manchineel, 86 .

Mangrove, 98.

Manzavita (Arbutus menziesii), 101.

Manzanita (Arbutus xalapensis), 101.

Maple (Acer macroplyllum), , 0.

Maple (Acer glabrum), 91.

Iaple (.1 cer saccharum), 91.

Maple (Acerneg. ealifornicumi, 93.

Marlberry, 103.

Marslı I'ine, 18.

Mastic, 103.

Maul Oak, 55.

May Cherry, 71 .

May Haw, it.

Mayr Pils", 16.

Meadow Pin, (I'inus trela), 17.

Mleadow l'ine (rinus serotina), lo.

Meadow l'ine (l'imus heterophylla), 12

Meehan Silverbell-tree, 1105.

Menzies' sinuce, 2:2.

Mlerisier, 43.

Jerisier lionge, $4 \mathrm{~s}$.

Mescrew, 79

Mesquite, $7 ?$.

Mrxiean Cembra-like l'ine, 14.

Mexican Cherry,

Mexican ('herry-tree, 77 .

Mexican Elder, 110.

Mexican Madroña, 101.

Mexican Mulberry, 62.

Mexican Oak, 55.

Mexican Palmetto, 37.

Mexican Persimmon, 10.

Mlexicu I'iñon (l'inus qual rifolia), 1..

Mexican Piñon, 14.

Mexican Walnut, 39 .

Mexican White Pine, 14.

Miunosa, il.

Miner Plum, 75.

Missouri Willow, 44.

Mocker Nut (Hickory), 41.

Mork ()live, 7\%.

Alowk () range (Toxylon pomiferum, 6is. Mork l) range (Piunns carolinianm), 7i Mork (lrange (Fumclia lucioides), 104. 
Mohave Yucca, 38.

Mintana Black Pinc, 15.

Monterey Cypress, 31.

Monterey Pine, 17.

Muose Klu, till.

Mous. Malple, 40.

Mousewotul. 90.

Morehus 0ak, 56 .

"Mioses in tho Burning liush," 90.

Mossyrup, Oak, 52.

Mu-yеu, White Uak, 52.

Mountain Alder (.1 lnus rhombifulia), 49.

Mountain Alker (Acer prensylcanicum), 90.

Mountain Ash. 70 .

Mountain Aslı (Pyrus sambucifoliu), 71).

Mountain Ash (Fraxinus texensis), 106.

Mountain Asp, 45.

Momitain Jalsam (Abies balsamea), 25.

Mountain Balsam (Abies lusiocerpa), 26.

Mountain Black Cherry, $7 \%$.

II ou ut: in Black Oak, 57 .

Momintain Cedar (Juniperus sabinvides), 36.

SImutitin Colar (.Juniperus pachiphloa), 36.

Mountain Cherry, 75.

Mountain Elder, 110.

Monntain Elm, 61.

Mountain Erergreen Chury, ix.

Mountain Holly, 89.

Mosuntain Iry, 102.

Mountain Juniper, 36 .

Muntain Larch. 20.

Mountain Lanre? (Cmbellularit califormica), $6 \overline{7}$.

Mountain Laurel, 102.

Mountain Laurel (Rhododendron marimum), 102. Mountain Magnolia ( Magnolia acuminatu), 64.

Mountain Magnolia (Magnolia fraseri). 6.;.

Mountain Mahogany (Taxus brevifolia), :37.

Mountain Malıogany ( Betula lenta), 49.

Mountain Mahogany, 69.

Mountain Malnogany (Cercucarpusparrifolius), 69.

Monntain Manchineel. si.

Mountain Maple, 9!.

Monutain Maple (Acer vircinafum), .1 .

Mountain Maple (Acer glabrum), 91.

Mountain Oak (quereus gambelii), 52 .

Muntain (Oak ('quercus primus), 53.

Mountain Pine. 14.

Mountain Sipuce, 21.

Dlomutain Simach (Pyrus americoma), 70.

Mumntain sumach (Rhus ropallina). 88 .

Mountain Wermoutl Pine, 14.

Mountain White Oak, 54.

Mumtain Willow, 44 .

Mulberr, 62.

Murier Samval: 62.

Mluray Pine, 16.

Myrtie (Jurica cerifera), 42.

Mirtle (Myrien californica). 42.

Mirtle (Thullularia califormica), 1ii.

Misille Iintrian, 101.

Myrtle Oak. iti.

Myrtle-leaf Dahoon, 8?.

Mrrtletres (.Uyrica cerifera), 42.

Mrrt]-tree (T'mbellularia califomica), 67.

Nitherl-nepded .Junper, 3.5.

Naked Stopper, 98.
Naked wood (Gucttarda elliptica), 110.

Naked-wood, 96.

Naked-woenl (.I namomis dichotoma),, 33

Nannyberry (1'iburnum lentago). 111.

Nannyberry, 111.

Namy- Plum, 111

Narrow-eone I'inc, 1\%.

Narrowleaf Cockspur, 72 .

Narrowleaf Cottonwood, 46.

Narrowleaf Crab, 70.

Narrowleaf Dahoon, 89.

Narrowleaf Willow, 43 .

Narrow-leaved Cottonwom, 46.

Narrow-leaved Crah. 70.

Sarrow-leaved Cral, A pule, 70.

Narrow-leared Willow, 43 .

Native Plum, 75.

Tearly smooth-cone I'ine, 17.

Necklace Poplar, $4 i$.

Negundo Maple, $9 \%$.

Netleaf 0 ak, 54.

Nettle-tree, 62.

Nerada Nut Pine, 15.

Neweastle Thorn, 71 .

New England Boxwood, 100.

New England Hemlock. 22

New Jersey Pine, 18.

New-Mexican Locust, 83.

New Mexiean Piñon, 14.

Niekertree, 81.

Nigger Pine, $1 \%$.

Noble Fir, 27.

Noble or Bracted Red lir, 27.

Nootka Cypress, 32.

Nootla sound Cyluress, 32.

North Aneric:an Red spruce, 21.

Xorth Carolina liay-tree, 65.

North Carolina Pine, 18.

Nortl Carolina P'itch I'ino, 19.

North Carolina Fellow Pint, 18.

North Coast Cypres.. 31.

Forth Cuast Serub Line, 16.

Northern Cork-barkerl Elm, 61.

Northern Cork Elı, 61.

Northern Maple, 90.

Northern Pine, 13.

Norway Pine, 15

Noyer Dur, 40.

Nussbaum Hybrid (Hickory). 41.

Nutmeg Hickory, 40.

Nut Pine (Pinus cembroiliss), 14.

Nut Pine (Pinus quadrifolin), 14.

Nut Pine (Pinus eluliss) 14.

Nut Pine (Pinus zumolhullu), 15.

Nut Pine (Pinus coulteril. 16.

Nuttall Willow, 44.

Oak (Quercuslyrata), 5 \}.

Oak barkid C'edar, 36.

Oakluark Juniper, 36.

()ikleat Cherry. 78.

Obis]m Pine, 18.

Odorless Myrtle, 42.

Oe-elı-nalı-kwe-ha-he, 68

Ogeechee Limu. 101

()-helt-yah-tah, 51.

Ohio Buckeye, 93. 
Ohio Buckeye (. Exculus nctandra), 94 .

(Ih-nel)-t:th, 2:2.

(bil Nut, 39.

Oliltield liseh, 47 .

(1)ifialal Pine (I'inus tola). 17.

(lilfield I'ine (I'inus clausa). 18.

Olrifield J'ine (J'inus echinata), 18.

Old Man's Bearl, 108.

(1) Wife's-Shirt-tree, 66.

Olivetrue, 101.

(Hivior à gramilẹ feuilles. 101.

One-berry, 62.

One-seed Juniper, 35.

(Hue-sceded Juniper, 35.

Ou-ıla tr-claa-mun-nes, 68 .

()o-lunsk-all, 60.

Ort-s)(o-!1:atah, 30 .

Oposinm- тour, 105.

Oregon Ash, 107.

Oregun lialsam-tree, 25.

Oregon liearwood, 96.

Oregun Ceilar, 33.

Oregon Crab, 70.

()regon Cral, Apple, 70.

Oregon Maple, 90.

Oregon Oak, 52.

Oregun Pine, 24.

Oregon White Fir. 26.

Oregon White Oak, 52.

Orendapline, 67 .

Orme gras, 60.

Orme $3 l$ aigre, 60.

Osage, 63 .

Osag; A pple-trie. 63.

Osage Orange, 63.

Osier Willow, 43.

().tan-tahr-te-wels, 50 .

Overcup Oak ((Q)ercus winor), 52.

Overcup Oak, 52.

Overuı), Oak (Quercus macrocarqa), 52.

(Overcup, White Oak (Quercus macrocaipa), 52.

(Pacific) Dogwood, 100.

Pacific Plum, 75.

Pacific Post 0 ak, 52.

Parific Red Ceilar, 31.

Pacific Yew, 37.

Pale Elder, 110.

Pale Gyminda, 90.

Pale-leaf Hickory, 41.

Pale-leaf White Fir, 26.

Palmer 0ak, 55.

['aluettas, 37.

Palo Blanco, t:2.

1'alu de llierro, 83.

Talo Verıle (Parkinsonia micrmulyilla), 81.

Palo Verde, 81.

Palo Verdo (Fercidium, foriclum), s1.

Papaw, 66.

Paper Birch, $f x$

Paperleaf Alder, 49.

Paper Mulberry, 63.

Paralise Flower, 79.

Paradise-tree, 85.

Parasol Locust, 83 .

Parsley Haw, 74 .

Parsley-lived Haw, 74 .
Parry Nut P'ine, 14.

Parry Piñon, 14.

Parry's Nut Pine, 14.

I'ariy's Pine, 14.

Parri's sipuce, 21,
Paulownia, 109.
Peach, 78.

l'each ()ak (Quercus phellus). 59 .

I'each Oak (Quercus densidora), 59.

l'ea-flower Locust. 8'.

Pear Haw, 73.

Pear Thorn, 73.

Pecan (Hickory), 39.

Pecan Nut, 39.

Pecan-tree, 39.

J'ecanier, 39.

Pecanicr Amer, to.

Pecanier Saurage, 40.

l'eninsula Black Pine, 16.

Peniusula Pine, 16.

Pepperidge, 100.

Pepper-wood, 84.

Persimmon, 104

Pernve, 70.

Pigeonberry (Comus altemifolia), 100.

Pigeon-berry (A melanchier alnifolia), 71

Pigeon-berry (Thamuus purshiana), 96.

Pigeon Cherry, $; 6$.

Pigeon Plum, 63.

Pigeon-wood, 64.

Pig Hickory, 40.

Pig Nut (Hicoria minima), 40.

Pignut (Hicoria glabra), 41.

Pignut (Hickory), $\mathbf{4 1 .}$

Pig Wainnt, 40.

Pin Cherry, 76.

Pin Oak (Quercus gambelii), 52.

Pin Oak (Quereus acuminata), 53,

Pin Oak (Quercus breviloba), 54 .

Pin Oak, 57 .

Pin Thorn, 71.

Pine (l'imus flexilis), 14.

Pine (1'icea canadensis), 21.

Pink 1.ocust (Sophora afininis), 81.

Pink Locust, 82.

Piñon, 14.

Piñon (l'inus quadrifolia), 14.

Piñon (Pinus cembroilles), 14.

Piñon (Pinus monophylla), 17.

P'î̃on Pine, 14.

Pinos, 16 .

Piper Willow, 44.

['iquant Amourette, 80.

Piss $\Delta$ sh, 107.

Pitahaya, 97.

I'italuaya dulce, 97.

Piteh Pine (Pinus allsicaulis). 14.

l'itch Piue (Pinus ponderosa), 15.

Pitch Pine, 17.

Pitch Pine (Pinus echinata). 18.

Pitch Pine (I'inus heterophylla), 19.

Pitch P'ine (J'inus palustris), 19.

Planertree, 61.

Plame-tree, 68 .

Platpueminjer, 104. 
P'atane, 68.

I'lem, 6 i.

1'hum. 75.

I'lum Gratuite, 75.

Plumleaf Cockspur, 72.

Puiuted-leared Magnolia. 65.

Poison Ash, 88.

I'oison Dogwoor, 88.

l'oison Elder, 88.

I'oison Ivy, 102.

I'oison Laurel, 102.

Poison Oak, 88 .

Poison Sumacb, 88.

Poisontree, 88.

Poisonwood (Gymnanthes lucida), 86.

Poisonwood, 87 .

Poisonwood (Rhus vernix), 88 .

Polccat-tree, 95.

Polecat-wood, 95.

Ponette Blene, 71.

Pond Apple, 66.

Pond Pine, 18.

Poor Pine (Pinus echinata), 18.

Poor Pine (Pinus glabra), 19.

Pop Ash, 107.

Poplar (Populus tremuloides), 45.

Poplar (Populus grandidentata), 45.

Poplar (Populus balsamifera), 46.

Poplar (Liriodendron tulipifera), 65.

Poplarleaf Fig, 63.

Poplar-leaved Birch, 47 .

Poplle (Populus tremuloides), 45.

Popple (Populusgrandidentata), 45.

Popple (Liriodendron tulipifera), 65.

Poply Ash, 107.

Pork-Tood, 64.

Port Orford Cedar, 33.

Possum Haw, 89.

Possum Oak, 58.

I'ossnmwool, 104.

l'ost Cedar (Libocedrus dccurvens), 29.

Post Cedar (Cham. thyoides), 32.

Pust loe'ust, 82.

Post Oak, 52.

Poverty Burch, 47.

Prickle-cone Pine, 18.

Prickly Ash, 84.

Prickly cone Pine. 17.

Prickls Pise (Pinus murayanu), 14

Prickly Pine (Pinus pungens), 18.

Prickly Spruce, 21.

Prickly Thatch, 37.

Prince Albert's Fir, 23.

Princes Pine, 19.

Princewood, 110.

Puckerbush, 42.

Puget Sound Pine. 24.

Pumpkin Ash, 107.

Pumpkin.tree, 26.

Punk Oak, 58.

Purple Buckeye, 94 .

Purple-eoned Sugar Pine, 14.

Purple Dugrrood, 100.

Purple Haw, 95.

Purpleleaf Locust, 83.

Pussy Willow, 44.
Pyramid Locust, 83 .

Pyramidal Tulip-tree, 66

Quaking Asp, 45.

Quercitron (1ik, 56.

Quinine-tree, 84.

lamshorn, 79 .

Rattlebox, 10 i).

Red Alder, 49.

Fed American Larch, 20.

Red Ash, 107.

Rel-lrark Cypress, 32.

Relluark Pine, 16.

Red Bay, 66.

Red Beech, 5t.

Redberry Elder, 110 .

lied Biri'h, 48.

Red-bract Dogwood, 100.

Redbud, 79.

Redbud (Cercis reniformis), $8($.

Red Cedar (Libocednus lecurrens), 29.

lied Cedar (Thuja plicafa), 31 .

Red Cedar (Junipenus virginianu), 34.

Red Cherry, 76.

Rell Cypress, 27.

lied Elm ( $C$ linus pubescens), 60.

Resl Elu ( $T$ limss erasijolia), 60.

Red Elm (Tlmus ulatu), 61.

Red Fir (Pseulotsuga tuxifolia), 23.

Rerl Fir (Abies amabilis), 26.

Red Fir (Abirs nobilis), 27.

Red Fir, 27.

Red-Howering Loeust, 83.

Redfruit Ailanthus, 85.

Red Gum. 68.

Fed Haw (Cratagus breliyucantha), 71.

Red Haw (Crategus crus-gulli), 71.

Red Haw (Crategus cuccine(t), i2.

Rud Haw (Crategus tomentosa), 73.

Red Haw (ratregus corlata), 73 .

Red Haw (riatcegus rividis), it.

lied Haw (C'ratcegus apiifolia), it.

Red Haw (Cratcegus jiara), it.

Redheart Il ickory, 41 .

lied Hickory (Hicoria alla), $\$ 1$.

Red Hickory (Hicoria glabra), $\$ 1$.

Red Ironwood, 95.

Red Judas tree, 80.

Red Juniper, 34.

Red Larch, 20.

Red Loenst, 82.

Red Maple, 92.

Red Mulberry, 62.

Red Oak, 56 .

Red Onk (Quercus texana), 5 ti.

lied (bak (Quercus cuccinea), 50.

Red Oak (Quercus digitata), si.

Red Pine, 15.

Red Pine (Pinus ponterusa), 15.

Red Pino ( 1 's udotsuga tuxifulia). 24.

IreA Plnu (I'runus nigre). 75.

Red Plum ("runus americana), 7.5.

Red Iiver Maple, 93.

Red silver. Fir. 26.

Red Spruce, 21.

Red Stopper, 99.

Red (or) Sweet Gum, fi8. 
Retl Thor'n, 72.

lied Thorn-a)ple, 72 .

lied Thorn bush, 72.

Iivd 'Titj. 88 .

Jird Willow, 43.

Redwood, 28.

liedwoul (Nuieteria mahagoni, 86.

Fir.l-woodel Flm, 60.

Iiruarkible J'ine. 17.

Hit'tamul, $\rightarrow$ 1.

Jilioilude udron, 10:.

Xiilge Beech, 50.

Rigirl P'ine, 17.

River Ash, 107.

River Birch, 48.

Fiver liscli (Bctula lenta), 49 .

River Cuttonwood, 46.

Fiver Hawtborn, 71 .

Fiver Maple, 92.

Fiver Pine, 18.

"ioble, " 51 .

Pock Cedar, 36.

Ruck Chestnut Oak, 53.

liock Elm (Clmus pulcscens), 60.

Huck $\lim$ ( $I 7 m u s$ americana), 60.

Kork Elm (Clmus racemosa), 60.

liock Majple, 91.

livek ()ak (Quercus prinus), 53.

livek (lak (Quercus acuminata). 53 .

kuck Oak ('puercus douglasii), it.

Rock Pine, 15.

Rocky Mountain Juniper, 35.

Rocky Mountain 0 ak, 54 .

Kocky Mountain Pine, 14.

liocky Mountain Sirub ()ak, 52 .

liorky Mountain White Pine, 14.

lineky Monntain Yellow P'ine, 15.

Fose Acacia, 83.

finse $\mathrm{Ba5}, 102$.

liose-flowering Locust, 83 .

Ionsemary Pine, 17.

liosemary P'je, 18.

liosemary l’ine, 19.

liough-liarkidl Poplar, 46.

Roundtop Poplar, 47.

livmulwoud, 70 .

Iivwan-berry, 70.

Royal Palm, 38.

livbluel-tree, $6: 3$.

Run Clierry, $\div$.

Russian Mulberry, 62.

Rusty Nannyberry, 111.

Salune's Pine, 16.

Saffron Plum, 104.

Saguaro. 97.

Salnuara, 97.

Salal-tree. 80 .

simelbar Willow, 43.

siutud J:uck, 58.

sinul Piur. (Pinus contorta), 16.

Sand Pine, 18.

Fivd I'ine (Pinus clausa). 18.

Santa Cruz Ironwood, 67.

Sinta Lncia Fir, 26.

Sitjin, 23.

Sill I'ine (J'inus toeda), $1 \vec{t}$.
Sap I'ine (Yinus rigida), $1 i$.

Sapwout ['ine, 16.

Sargent Palm, 37

Sargent's Pillm, 37

"Sarrice," 71

Sassafic. 67.

Sassafrac, $6 \pi$.

Sassafras, 67 .

Satinleaf, 103.

Satin Walnut, 68 .

Satinwood, 84 .

Sarice, 71.

Saviu (Junipemes virginiana), 34 .

Savin (Tumion taxifolium), 36.

Sarin (Taxus fluridana), 37 .

Saxifrax, $6 \overline{6}$.

Saxilirax-tree, 67 .

scalybark Hirliory, 40.

Scarlet-frujtel ' Tlhoru, 72.

Scarlet Haw, 72.

Scarlet Haw (C'ratepyus mollis), 72.

Scarlet Majle, 92.

Scarlet $0 \mathrm{ak}, 56$.

scarlet Thorn, 72.

sicarlet Thorn-Haw, 72 .

Schott Cactus, 97.

Schott Yucca, 38 .

Screwbean, 79 .

Screwbean $\mathrm{Al}$-sifuite, 79 .

Serew-Pod II esiujte, 79 .

Scrub Oak (Quercus gambelii), 52.

Scrub Oatk (Quercus macrocarpa), 5:.

Serub Oak (Quercus acuminata), 53.

scruh Oak (Quercus undulata), 54.

Scrub Oak (Quercus catesbai), 5i.

Serub (Mak (Quercus pumila), 57.

Sirub Oak (Quercus marilandicu). 5 s.

Surub Pine (Pinus albicaulis), 14.

scrub l'ine (l'imus contorta), 16.

Scrub Pine, 18.

Scrub Pjue (J'inus clausa), 18.

Serub Pine (Pinus divaricata), 19.

Sea Asl, 84 .

Sea Grape. 63.

Seaside Alder, 49.

Seaside Plım, 63.

Senellier, 74 .

Sequoia (Neyuoia washinytonianaj, .28.

siequvia (siequia scmpervirens), - an.

Serviceberry, 7II.

Serviceherry (.l melanchier alnirulia), il.

Service-tree, $i 1$.

shat-betry, 71 .

Shat bush. 70.

Shate I'ine, 14.

Shagbark (Hickory), 40.

Shagbark, 11 .

Shagbark Walnnt, +1 .

Shasta Cyjuess, 32.

Shasta Fir, 27.

Shasta Iicd Fir, 27.

Slawnerwoul. 109.

she I Halsam. 2.-

She lialsam lir. 25.

Sheepberry, 110 .

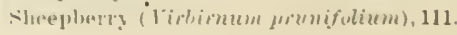


sheey Laticel. 102.

Shr.llark, Hicoria wata), 40.

Shellbark ( Hickory), 4].

Sbellbark (llicoriu lariniosa), 41.

shellbark llickury (Hicoria ovata), 40.

shellbark-tre', 41 .

She Pine, 19.

Sh. J'itch I'ine, 19.

Stin Oak. 52.

Shin Uak (Querens yambelii), 52.

Shin Oak (Quercus Ureviloba), 54.

Shin Oak (Quercus undulatu), 54 .

Sbin Oak (Quereus brevirulia), 58 .

Shingle Oak, 58 .

shinglewool, 31.

Shittionoul (Khamuus Jurshiana), 96.

Shittimmood, 104.

Shoe.peg Maple, 9:.

Shore Pine, 16.

Short-flower Mahogany, 69.

Shortleaf Pine, 18.

Shortleaf Pine (I'inustcela), $1 \bar{i}$.

Shortleaved Pine (Pinus riminiana), 18.

Shortleared Pine (Pinus, shinata), 18.

Shortleared Iellow Pine. 18

Short-pod Honey Locust, so.

Shortshat Pine (Pinur virginianu), 18.

Shortshat Pine (Piunsechinata), 18.

Short Shocks, 18.

Shrub Oak, 53.

Slurnb Wiliow, 43 .

Shrublyy Maple, 91.

- Sierra Brownbark Pine, 15.

Sierra Kelbark Pine, 16.

Silktop Palmetto. 37 .

Silky Willow, 45 .

Silverbell, 105.

Silverbell-tree, 105.

Silrerbell-tree (Mohrodendron dipterum). IU5.

Silver Birch (Betula panjsifera) 48.

Silver Birch (Letula lutea), 48.

Silver Fir (tbies grandis), 26.

silver Fir (Abies concolor), 26.

Silverleaf Poplar, 97.

Silverleaf Willow, $\mathbf{4 4}$.

Silver-leared Maple, 92.

Silver Maple, 92.

Silver Oak, 86.

Silver Pine, 13.

Silver Pine (Abies balsamea), 25.

Silver Poplar, 47.

Silver Spruce. 21.

Silver Thateh, 37 .

Silver Willow (Salix sexilifolia), 44 .

Silver Willow (Salix uliscolor), 44.

Silvertop Palmetto, 37 .

Simmon, 104.

Simpleleaf Locust, 82.

Sina, 97.

Singleleat, 15 .

Single-leaf Piñon, 15.

Single Spruce (Picea canadensis), 21.

Single Spruce (Abies baloamea), 25 .

Sinita, 97.

Sir Ju-ph Bauk's L'ine, 19.

Siokiyou Spruce, 22.
Sit ka Cypress, 32.

Sitka Spruce, 22.

Sitka Willow, 45.

Skunk sijruct: : 1 .

Slash P'iue (l'inus teplu), 17.

Slash Pine ('iuns echinata), 18.

Slash P'ine (I'inus hiterophylla), 19.

Slippery Elm, 60.

Slippery Elu (Fremontodendion californicum), 86

Sloe (Prunus americana), 75 .

Sloe (Prunus umbellata), 76.

Siloe ( Tirluernum prunifolium), 111.

Suall-conel Monterey Pine, 17.

Small-fruit Mountain Ash, 70.

Small-fruit White Ash, 106.

Simall Laurel, 102.

Small-leaf Haw, 74 .

Small-leaf Horse-bean, 81 .

Small-leaf Locust, 82.

Small-leared Elm.61.

Small Pignut (Hickory), 41.

Small White Birch, 47.

swoke-tree, 87.

smokiug Bean, 109.

Smooth-fruited. White-leitred Limetres, 9i.

Smoothleaf Willow, 43 .

Smooth-leaved Limetrev, 96)

sinooth Sumach. 88.

snappiug Hazel, 68

Suowdrop-tret (Mohrodendron carolinm $n$ ), 105

Snowdrop-tree, 105.

inowflower-tree, 108.

Snowy Poplar, 47 .

Soapberry, 94.

Soapberrs (Sapindus marmainatus), 94.

Soft Maple (.1 cer ylabrum), 91

sott Maple (Acer saccharinum), 9:.

Soft Maple (-1eer rubmum), 92.

Noft Pine (Pinzrs strobus), 13.

Soft Pine (Pinus inonticnla), 14.

Soldierwood, 96.

solerlarl Pine, 15.

Sonora Ironwood, 83.

Sophora, 81.

Sorrel-ıree, 102.

Soulard Apple, 70.

Sour Cherry, 76.

Sour Gum (Nyssu sylrutica), 100.

Sour Gum (Nyssa a quatica), 101.

somr Gum (Oxydendimn artorenan), 102

sour Gnm l’ush, 102.

Sour Tupelo, 101.

Sourwood, 102.

Southern Buckthorn, 104.

Sonthern linllace Plum. 76.

Sonthern Crab Apple. T0.

Sontliern Cypress, 27.

Sontlern Hard Pine, 1:.

Sontheru Heart I'rue. 19.

Southern Hemlock. 23.

southern Mountain l'ine. 1s.

Sonthern 1'ine, 19.

soutleru ['itcli l'iue, 19.

Southeru l'rickly. Ish, 84

Southern Red Juniper, 3.7.

soutlem Telluw I'ine (I'inus punderna , 15. 
Sontheru Yellow Pine (Pinus palustris), 19.

Spanish Bayonet, 38.

Spanisl, Bayonet (Fucca aloifolia), 38.

Sịnish Buckeje, 94.

Spanish Dagger, 38 .

Sianish Oak (Quercus rubra), 56.

Sjanish Oak (Quercus texana), 56.

Spunish Oak (Quercus coccinea), 56.

Spanish 0ak, 57.

Si:anish Water Oak, 57.

spanish Wild Clerry, 78.

Sparkleherry, 101.

Spatulate Haw, 73.

spiceberry, 99.

silice-tree, 67.

-pindle-tree, 90.

simon IIutch, 102.

spoonwood, 102.

spottel Aller, 68.

Spotted Locust, 83.

Spottel Oak ((nercus texana), 5t.

-jutted Oak ((2uercus velutinu), 57.

Slotted Oak (Quercus nigra), 58.

Sprealing cone l'ine, 17.

spruee (Picea marinna), 20.

sirnce (l'iè a ianadensis), 21.

spruce (Picea pungens), 21.

Sirnce (Tsuga canadensis), 22.

spruce (Pseudotsuga taxifolit), 23.

ipruce (rar. suberosa Lemum.), 24.

spruce (Pseadotsuga macrocarpa). 25.

Spruce Pine (Pims strobus), 13.

Sprues Pine (Pinus balfouriana), 15.

siruce Pine (Pinus murrayana), 16.

Spruce Pine (l'imus tada), 17.

Spruce Pine (Pimer viryiniana), 18.

Spruce. Pine (Piuus clausa). 18.

Spruce Pine, 19.

Siruce Pine (I'inus techinata), 18.

Spruer P'ine (P'mus glabra), 19.

Spruce Pine (Pinus palustris). 19.

Sprue Pine (Picea wariana), "?".

Sprruce I'ine (Tsuga cunadensis), 22.

Stagluisli, 111.

Staghorn Sumach, 87.

Star-leaved Gum, 68.

stare (lak, 51.

Sting.tongue, st.

Stink lierry, 95.

Sink ('leerry, 95.

Stinking . 1 sh, 93.

Sinking link keye, 93.

stinking Ceslar (Tumion taxifolim,, 36 .

Stinking ('elar (Tumion californicum), 37 .

Stinking Savin, 36.

Sitinkwool (Khamnus caroliniana), 95 .

Stinkwood (. Tyssa sylratira), 100.

stune-scel Mexiran l'iñon, 14.

Stopluer (Eugenia monticula). 95.

Stopper, 98.

Sirawberry liush, !10.

Strawberry-tree, $9 \%$.

striperl Dogrood. 90.

Striped Maple, 90.

Strongback, 108 .

strongbark. 108.
Stumptree, 8I.

Sub-Alpine Fir, 25.

Siugar Ash, 93.

Sugarberry (Celtis oecidentalis), 62 .

Sugarberry, 62.

Sugar Maple, 91.

Sugar Pine, 14.

Sugar-tree, 31.

Sumach (Rhus hirta), 87.

Sumath (Tluze copallina), 88 .

Sumach (Khus vernix), 88 .

Summer Haw (Cratcegus elliptica), it.

Summer Haw, 74.

sum-loving Pine, 1 .

sunny-slope I'ine, 1\%.

Swamp Ash (Fraxinus nigra), 106.

Swamp Ash (Fraxinus lanceolata), 10:.

Swamp Bay, 66 .

Swamp lirch, 48.

Swamp Cedar, 32.

Swamp) Chestnut Oak (Quercus prinus), 5

Swamp Chestnut Oak (ineercus miclacurii, is

Swamp Cottonwood, 45.

Swamp Cypress, 27.

Swamp Elm, 60.

Swamp Hickory (Hicoria minima), 40.

swamp Hickory (Hicoria aquatica), 40.

Swaru] Laurel, 64.

Swamp Laurel Oak, 58.

Swam] Magnolia, 64.

Srramp Miple (Acer saccharinum), (t)

swamp Iaple (Acer rubrum), 92.

Swamp Oak (Qquercus lobata), 51.

Swamp Oak (Quercus platanvisles), i3.

Swaun) Oak ((guercus palustris), 57.

Simam, Pine (Pinus teda), 17.

Swampl Pine (Pinus muricafu), 18.

Swamp l'ine (I'inus heterophylla), 19.

Swamp I'uplar. 46 .

swamp l'ost Oak, 33.

Swamu liell-Bay, 66.

Swamp Sassafras, 64.

Swamp Spunish Oak, 57.

Swamp Sumarh, 88.

Swanp Tupelo, 101.

swanp White ()ak (Curres lyrata), 5i3.

Swamp White Oak. 5:3.

Swamp White Oak (Quercus micharuri si

Swamp Willow (salix rigra), 4 .”.

Swamp, Willow (salix discolor), 44.

Swamp Willow (Mak, 59).

Swret liay (Jagnoliu glauca), 64 .

Sweet lbily (f'ersfa borbmia), (it).

Sweet-buried Cedar, 36.

Sweethery, 111.

swet liireh (Betulu nocillentalis), to.

Sweet Birch, 49.

Sweet Buckese, 94.

Sweet Cherry, 76 .

Sweet Crab, 69.

sweet-fruited Juniper, :36.

Sweet Gum, 68.

inver Haw, 111.

Sweetleaf, 105.

Sweet Loenst, ou.

Sweet Magnolia, 64 . 
Sweet-sinted Crab, 60.

siseet Viburmus, 111.

sweet Walnut 41 .

siveet wourl, 6i.

Switclı-hud Hiekory, 41.

Siramere (Planera aquatica), b1.

Sycamore, 68 .

Syeamure (Platanus racemusa), 6.2.

Sieamore (Platanus urightii). 69.

Table-mountain Pine 18.

Tacamahac, 46.

Tallow-tree, 86 .

Tamarack (Pims contorta), 16.

Timarack (Pinus murrayana), 16.

Tamarack. 20 .

Tamarack (Larix occirlentalis). 20.

Tamarark (Larix lyallii), 20.

Tamarack l'ine. 16.

Taulsark Oak (Quercus prinus'), 53.

Tanllark (1) k (Quercus velutina), 57 .

Tanbark 0ak, 59.

Tan Bay, 8 .

Tear-lllank+1. s4.

Texan Ebony. 78.

Texan Oak. 56.

Teras Ash, 106.

Texas Buckeye, 94.

Texas Catsclaw, 78.

Texa- Flowering Trillow, 109.

Texas Lungleared Pine, 19.

Texas Redtud, 80.

Texas Whitf ()ak, j4.

Texas Tellow Pine, 19.

The Josliua, 38.

Thick-barkiel Juniper, 36 .

Thick Suellbark, 41 .

Thick Shellbark Hickory, 41 .

Thinleaf Downy Basswood, 97.

Thomas Elm, 61.

Thomson Magnolia, 64.

Thorn (Cratogus douglasii), $i 1$.

Thorn (Cratcegus cmes-galli), 71 .

Thorn (Crategus coccinea), 72.

Thorn (Crategus tomentosa), 73.

Thorn (Crategus cordata), 73.

Thorn Apple (Cratugus douglasii), 71.

Thorn Apple (Cratogis crus-galli), 71 .

Tluorn A pple (Cratagus coccinea), 72.

Thorn A pple (Cratcegus tomentosa), 73.

Thorn Apple-tree (Cratagus coccinea), 72.

Thorn Bnsh (Cratcegus crus-galli), 71 .

Thorn Bush (Cratcegus coccinea), 72.

Thorn Loeunt, 80.

Thorn Plum (Cratagus crus-galli), 71 .

Thorn Plum (C'ratogus coccinea), 72.

Thorn Plum (Cra'cegus tomentosa), 73.

Thornless Honey Locust, 80.

Thornless Locust, 83.

Thornless Osage Orange, 63.

Thorn-tree (Cratogus douglasii), 71.

Thorn-tree (Gleditsia triacanthos), 80.

Thorny Acacia, 80.

Thorny Locust, 80.

Three-learch IIaple, 93.

Thiree-thornel Acacia, 80.

Thurber Cactus, 97.
Tirleland Spruce, 22.2.

Tisswoml, 10\%.

Titi, 88.

Titi (Andrumeda ferruginea), 102.

Titi (Oxydendrmm arhoreum), 102

Tollon, 74 .

Toothachi-tree, 84.

Torch Piue, 17.

Torchwood, 84 .

Toruillo, 79.

Torrey Pine, 15.

Torrey's Pine, 15.

Torrey-tree, 36.

Tough Buckthoru, 103.

Tough Bumelia, 103 .

Toumey $0 \mathrm{ak}, 54$.

Toyon, it.

Tree Haw, 74.

Tree Huckleberry, 101.

Tree Myrtle, 96.

Tree Palmetto, 37.

Tree Thorn, 74.

Tree Yueca; 38.

Tremble, 45.

Trembling Aspen, 45.

Trembling Poplar, 45.

Trident 0ak, 59.

Trifoliate Dwarf Ash, 106.

Truckee Pine, 16.

True Cassena, 89.

Tuberculated-coned Pine, 17.

Tnck Tuck, 27.

Tulip Poplar, 65.

Tulip-tree, 65.

Tupelo (Nyssa sylvatica), 100.

Tupelo (Nyssa ogeche), 101.

Tupelo (Nyssa aquatica), 101.

Tupelo Gum, 100.

Turkey 0ak, 57 .

Turkes Oak (Quercus brevifolia), 58.

Turpentine Pine, 19.

Twistbranch Locust, 82.

Twisted Pine, 16.

Two-leared Insular Pine, 17.

Umbrella China-tree, 85.

Umbrella-tree, 65 .

Umbrella-tree (Cornus alternifolia), 100.

¿ña de Gato, 79.

Upland Hickory, 40.

Upland Sprnce Pine, 18.

Upland Willow Oak, 58.

Utah Juniper, 36.

Valley Mahogany, 69.

Talley Oak, 51.

Valparaiso Oak, 55.

Variegated Silver Maple, 92.

Variegated Tulip-tree, 66.

Vauquelinia, 69.

Vermont Poplar, 47.

Viburnum, 111.

Vine Maple, 91.

Virgilia, 81.

Virginia Mulberry-tree, 62.

Virginia Pine, 17.

Virginia Sumach, 87.

Virginja Thorn, 23. 
Virginia Villow Piun, 1s.

Pit:e. : :0.

Water Ash, 84.

Wah-eh-12ah-kas, 67.

Waahoo, 89.

Wahus (Clmus racemosa), 60 .

Wahon (Tlmus alata), 61.

Walıon (Tilia pubescens), 96.

Wilhoo (Tiiia heterophylla), $9 \overline{7}$.

Wahow Elm, 6i].

Wait-a hit, 84.

Tralnut (Jaglans cincrea), :99.

Walnut (Juglans nigra), 3!).

Walnut (Juglans rupestris), 39.

Walmut (Juglans californica), 39.

Walunt (Hicuria trata), 41.

WValnut-tree, 39.

Walter's l'ine, 19.

Ward Willow, 42.

Washington Haw, 73 .

Wis hington Palm. 38.

Washingtun Thorn, 73.

Watre Asli (Acer negundo). 93.

Watr' Aslo (Fraxinus nigra), 106.

Water . I ls (Fraxinus lancelata). 10i.

Water Ash, I07.

Watur Jifeelı (' arpinus carolinianu). 50.

Water Beec]) (I'latonus aceidentalis), tis.

Water Bireh (Betuin occidentalis), 48 .

Water Jireh ( Tetula nima), 48.

Water Bittermut. 40.

Water Blu (Clmus americana), 60.

Water Elm (L'mus alata), 61.

Water Elm (Plancra aquatica), 61.

Water Gum، 101.

Water Hickory, 40.

Wiatur Lily-tree, 65.

Watcr Locust, 80.

Water Maple (Acer spicatum), 91.

Water Maple (.1 cer saccharinum), 92.

Water Maule (Acer rubrum), 92.

Water Ouk (Quercus palustris). 57.

Water 0 ak, 58 .

Water Oak ((Mucreus laurifolia). 58.

Water Oal: (Quercus imbriearia), 59.

Water Oak (Quercus phrllos), 59.

Water Spazish Oak. 57.

Wrater Sipruce, 20.

Water White Oak, 53 .

Waxherry, 42.

Wax Myrtle, 42 .

Wax Myrtle (Myrica californica).42.

Weeping American Elm, 60.

Weeping Black Cherry, 77.

Weeping Bull Pine, 16.

Weeping Choke Cherry, 77.

Weeping Dogwood, 100.

Weeping Douglas Spruce, 24.

Weeping Largetooth Aspen, 45.

Weeping Locust. 83.

Werping ()ak, 51 .

Weeping Silver Maple, 92.

Weeping Silver Poplar, 4i.

Weeping Spruce, 22.

Weeping spruee (Tsuga mertensiana), 23.

Weeping White Poplar, 47.
Weeping Willow, 45 .

Western Birch, 48.

Western Blark I'ine, 16.

Western Black Willow, 4:3.

Wextern Catulja, 109.

Western Cedar (Thuja plirata), 31.

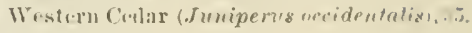

Western Chimuapin, 51.

Western Choke Cherry, 77.

Western Cullee, 96.

Western Dugwood, 100.

Western Haw, 71 .

Vestcin Hawthorn. 71.

Western Hemlock. 23.

Westuru Hemlork Fir, 23.

Western Hemlock .jprnee. 23.

Western Juniper, 35.

Western Larch, 20.

Western or Califoruia Aller, 49.

Western or Red Aliler. 49.

Western l'itch Pine. 15.

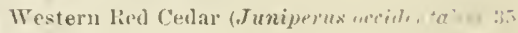

Western lied Cedar (Funiperus utahrusi.

Western Serviceberry, 71.

Western silıllbark. 41.

Western spruce, 22.

Western Sugar Maple, 92.

Western Sumach, 88.

Western Taunarack, 20.

Western Walnut, 39 .

Western White Fir, 26.

Westriru White Oak, 52.

Western White Pine (Jinus montirola, if.

Western White Pine (Pinus flexilis), it

Westeru Yin, 37.

West India Cherry. 7 .

West Indian lin? h, $\times 5$

We'snumtl l'ine, 13.

Whalın ( Tlmus alatu), 61.

Whaheso ( Magmolia fraseri), 64 .

"Thahmo (I'teleu trifoliala), 84.

Whisky Cherry. 7 :

Whistlewoul, 90.

White Alder, 49.

White Ash, 106.

WThite Aslu (Fraxinus lanceolata). 107.

White Ash (Chionanthus virginica), 10*

White Balsam (Abies laxiocarpa), 25.

White I3alsam (Abies coneolor, 26.

White-lrark, 14.

White-bark Maple, ?1.

White-bark Pine, 14.

White Basswood, 97.

Whit. Bay, 64.

White lieteh, 50.

White Birch, 47 .

White Birch (Betula papurifera), 48.

White Buttonwood, 99.

White Celar (Libocedrus decurrens), su,

White Cedar (Thuja occideutulis), 331.

White Cedar, 32.

White Cedar (Cupressus macnabiana), 32 .

White ('edar (Cham. lazsomiana), 33.

White Cedar (Juniperus californica), 36.

W'bite Cottonwoul, 47 .

Whit. Cypress, 27 . 
White Dotted Haw, 73 .

White Elm, 60.

Whlite Elm ( T゙lun racemosa), 61.

White Fir (Abies lasiocarpa), 2.\%.

White Fir, 26.

White Fir (Abie's yrundis), :6.

White Fir (Abies cuncolor). "C.

White-fower Clammy Locust. 83 .

White-flowered Dwarf Sumach. 8S.

White Fringe, 107.

White-fruit Choke Cherry, $i$.

Whiteheart II:kory, 41.

White Hickors (Hicoria minima). \$1).

White Hickory (Hiroria ovala), 40.

White II ickory a Hicoriu alba), 41.

White Hickors (Hicoria glabra), 41.

White Holly, 84.

White Ironwood, 95.

Wile Laurel, 64.

Whiteleaf 0 ak, 55 .

White-leareil ()ak, 55.

11 hite Lind. 96.

White Locnst, 82.

White Mangrove, 9 ?.

White diaple (Ace, inacio hyllum), 90.

Thite Maple (Acer saccharinum), 92.

Thite Maple (Acer rubrum), 92.

White Mulberry, 62 .

White Oak, 51.

White Oak (Quercus lobata), 51.

White Oak (Quercus garryana), 52.

White Oak (Quercus gambelii), 52.

White Oak (Quercus minor), 52.

White Oak (Quercus acuminata). 53.

White Oak (Quercus breviloba), 54.

White Oak (Quercus douglasii), 54.

White Oak (Quercus oblongifolia), 54 .

White Oak (Quereus arizonica), 54.

White Pine, 13.

White Pine (Pinus monticola), 13.

Thite Pine (Pinus glexilis), 14.

Th hite Pine (Pinus strobiformis), 14.

TI lite Pine (Pinus murrayana). 16.

White Pine (Pinus glabra). 19.

Thite Pine (Picea engelmanni), 21.

White Poplar (Populus tremuloitles), 45.

Whito Poplar (Populus grandidentata), 45.

White Poplar, 47.

Whitc Poplar (Liriodendron tulipifera), 65.

White Spruce (Picea mariana). 20.

White Spruce, 21.

White Spruce (Picea engelmanni), 21.

White Sliruce (Picea parryana), 21.

White-stem Pine, 14.

White Stopper, 99.

White Thorn (Crategnz cuccinea), 72.

White Thorn (Cratagus tomentosa), 73.

White Titi. 8.

White Walnnt (Juglans cinerea), 39.

White Talnut (Hicoria o:ata), 41.

White Willow (Salix fluviatilis), 43 .

White Willow, 45.

White wood (Populus deltoides). 47.

Whitewood (Liriodendron tulipifera), 65.

Whitewnod (Drypetes lateriflora), 86 .

Whitewood (Drypetcr hevensis), 86.
Whitewoul (C'anella quinterann). 87.

Whitewood (Tilia anericanu), 96 .

Wrickup, 96.

Wild Apple, 70.

Will Black Cherry, $r$.

Wild Cherry (I'menus emaryinutet!, 76.

Wild ('herry (Prunus pennsyleanica), it;.

Wilk Chery (l'munu nirginiana), 76.

Wild Cherry (Prumudemissa), 7 .

Will Cherry (Prunus serotinu), 77.

Wild Cherry (Prunus ilicufolia), 78.

Wild China, 94.

Will Cinnamon, 87.

Trild Coffee, 96.

Wild Coffee-bush, 96.

wild Crab. 69.

Wild Crab Apple, 70.

Wild Date, 38.

Wild Dilly, 104.

Wild Fig (Ficus aurea), 63.

Wild Fig (Ficus populnea). 63.

Wild Goose Plum, 75.

Tild Hawthorn, 71.

IVilh Indian Pear, 71.

Wild Lilac, 96.

Wild Lime, 84.

TTild Lime-tree, 101.

Till Linclen, 97.

Will Olive (Nideroxylon mastichodendron), 103.

Wild Olive (Osmanthus americauus), 108.

Wild Olive-tree (Tyssa a'uatica), 101.

Wild Olive-tree (Mohrodendron car olin $m$ m), 10:5.

Wild Orange (Prunus caroliniuna), 7 .

Wild Orange (Fanthoxylum clava-herculis), st.

Wild Peach, 77.

Wil] Peartree, 100.

Wild Plum, 75.

Tild Plum (Prunus nigra), 75.

W"ild Plum (Prunus subcordata), 75.

Wild Plum (Prunus umbellata), it.

Wild Plum (Prunus emarginafa). 76.

Wild Raisin, 111.

Tild Red Cherry (Prunus angustifolia), 75.

Wild Red Cherry, 76.

Wild Rose Bay, 102.

Wild Rubber-tree, 63.

Wild Sapodilla, 104.

Wild Tamarind, 78.

Tillt Thorn, 71 .

Williamson's spruce, 23.

Willow (Salix nigra), 42 .

Willow (Salix amygdaloides), 43.

Tillow (Salix levigata), 43 .

Willow (Salix lasianira), 43.

Willow (Salix furiatilis), 43.

Willow (Salix sessilifalia), 44.

ITillow (Salix discolor), 44.

Willow (Satix lasiolryis), 4 .

Willow (Salix mettallii). 44.

Willow Cottonwom, 4 fi.

Willow Haw, 71.

Willowleaf Cherry, 7 .

Willowleaf Cockspur, 71 .

IVillow.leaved Cottonwoul. 46.

Willow Oak (Querens laurifolia), 58.

Willow Oak, 59 . 
144

Wine.tree, 70. Wing Elm, 61 IVinged Elm, 61.

Wien-rib Mountain Snuach, 88. Winter bloom, 68. Witch Elm, 61. Witch Hazel, 68. Wrod Laurel, 10:. Woully Larch, 20. Woollyleaf Cherry, 76 . Woollyleaf Plum, 75. Taupon (Ilex cassine myfifolia), 89. Yaupon (Holly), 89 Fellow Ash, 82 Tellow-bark, 57. Yellow-barked Oak, 57 . Fellow Basswoot, 9ti. Yellow Birch, 48. Yellow Buckeye, 94. Yellow Buckthorn. 9;. Yellow Cedar, 32. Yellow Cerlar (Juniperus ar:cidentalis), 35. Fellow Cottouwood, 47. Fellow Cucumber-tree, 65. Fellow Cypress, 32. Yellow-flowered Cucumber-tree, 6.5. Yellow-flowered Magnolia.65. Yellow Fir (Yseudotsuga taxifolia), 24. Yellow Fir (Abies grandis), 26. Yellow-fruit Fir, 27. Yellow Gnm·tree, 100. Yellow Haw, 74 . Yellowfruit Dotted Haw 73.
Yellow Lortlst ('ladrastio lutea), 82. Yellow Locust (Kobinia pspuducacia), 82. Tellow Oak ((Quercus acuminuta), 5i3. Yellow 0ak, 56 . Yellow Pine ('inus ponderosa), 15. Fellow P'ine (Pinus ponderosa scop mlorum), 15. Follow P'ine (l'inus tada), 17. Tellow Pine (Pinus rigida), 17. Yellow Pine (Pinus echinata), 1n. Yellow Pine ('inus paluestris), 1!. Yellow Plum (I'runus americanai, 75. Yellow l'lum (I'runus angustifolia), 75. Jellow Poplar, 65. Yellow Spruce, 21. Yellow Willow, 44. Fellow-woorl (Twx!lon pamiferum), 6:3. Yellow-wood, 82.

Yellow.wool ( Yanthoxylum cribrosum). 34 Fellow-wood (Cotinus cotinoides), 87. Fellow-wood (Schofferia frutescens), 90. Yellow-wood (Rhamnus caroliniana), 9.5. Yellow-Wood (Lhamnus purshiana), 96. Yellow.wood (Symploros tinctoria), 105. Tew (Cupressus guadalupensis), 32. Few (Tumion californicum), 37. Few (Taxus brevifolin), 37. Yew (Taxus toridana), 37. Yow Pine, 20. Yewleaf Willow, 44. Yopon, 89.

- Yucca Cactus, 38.

Zina, 97

amentaceal Livecuousfl. monoccionsfl.

compound leaves

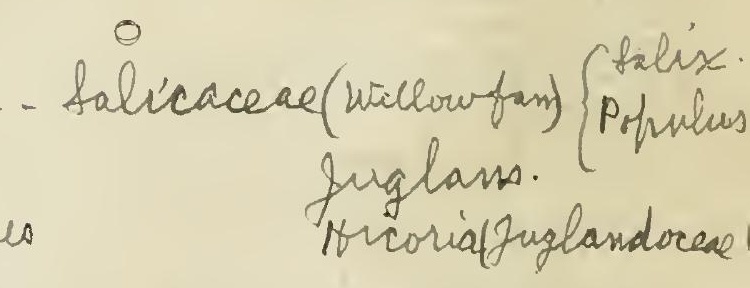
simfletenues

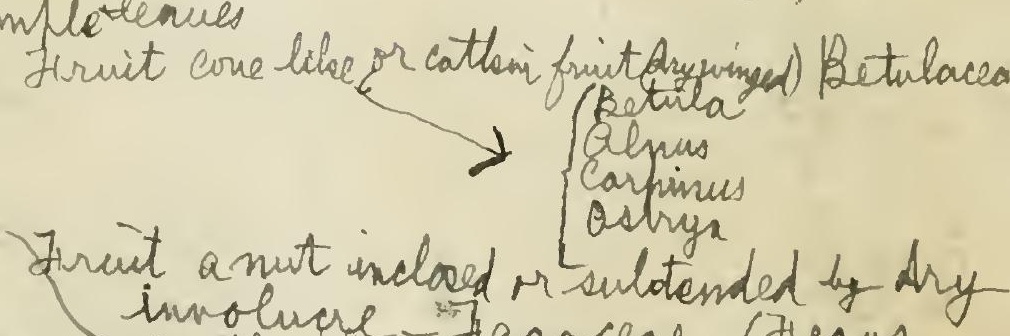
inolucre Hagaceal. (Hagus

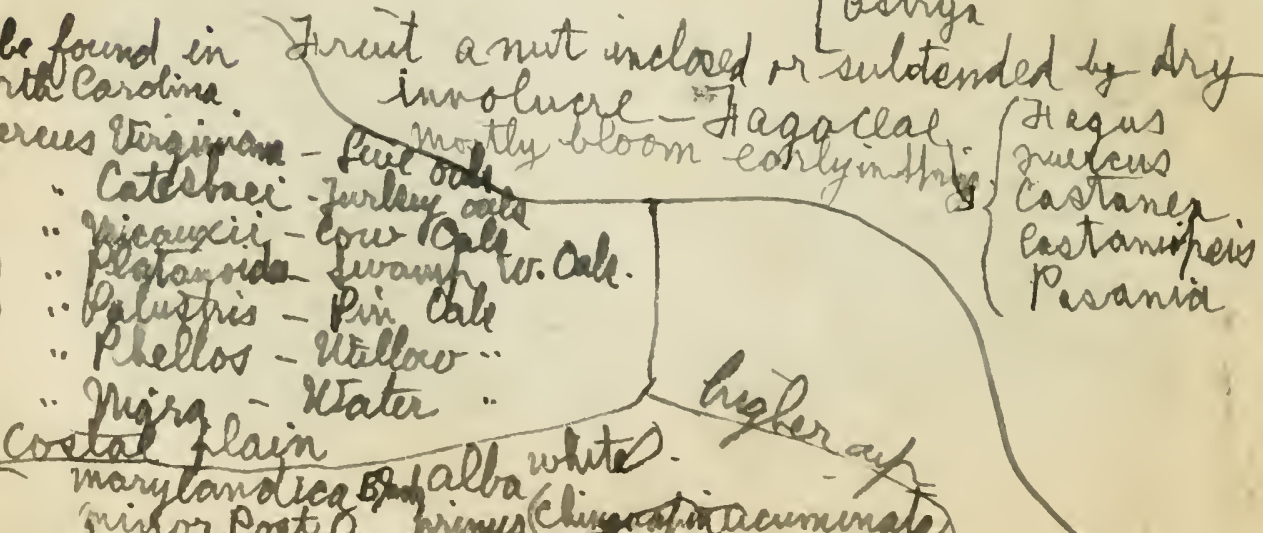


BU'-LETIN NO. 10.

U. 'S. DEPARTMENT OF AGRICULTURE.

DIVISION OF FORESTRY.

\section{T I M B E R :}

AN ELEMENTARY DISCUSSION OF THE CHARACTERISTICS AND PROPERTIES OF WOOD.

BY

FILIBERT ROTH,

Special Agent in Charge of Timber Physics.

UNDER THE DIRECTION OF

B. E. FERNOW,

CHIEF OF THE DIVISION OF FORESTRY.

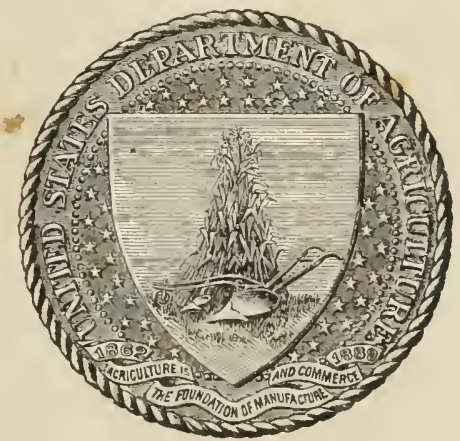

WASH I N TON :

GOVERNMENT PRINTING OFFICE. I 895 . 


\title{
LETTER OF TRANSMITTAL.
}

\author{
U. S. Departuiesí of Agriculture, \\ DIVISION OF Forestry, \\ Washington, D. C., September 15, 1895.
}

Sin: I have the homor to transmit herewith for publication a brief but comprehensive discussion of the characteristies and properties of wood in general and of our American timbers in particular, which it is hoped may be usefnl to engineers, arehitects, carpenters, lumbermen, and all wood workers. The paper was prepared by Mr. Filsbert Roth, in eharge of the investigations in timber physics.

Althongh much of the information esntaned in this bulletin exists in the experience of practical woodworker's and in books in other languages, it has never before been published in English in systematic and aceessible form and with special applieation to American timbers.

Such a publication can not, of course, exhaust any part of this great smbject. It is desired that it may be followed by a more elaborate treative when additional knowledge has been gained through the investigations now in progress. The information it contains is largely based (n) actual experiment and scientific olservation, and will, it is hoped, not only explain the experiences of the practical worker with his material, but will remove erroneous notions, and thus aid in improving the practice and lead to a morr lational nse of om firest resources.

Resprestfully.

HOH. I. S'TERLIN: MORTON,

B. 1: FERNow.

Chief of Inicision of Forestry.

secretury. 


\section{TABLE OF CONTENTS.}

Introduction

Charaeteristies and properties of wood ............................. 11

I.-Strueture and appearance ............................... 11

Classes of trees..................................... 11

Wood of coniferous trees............................. 12

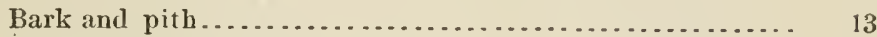

Sap and heart wood............................ 13

The annual or yearly ring.......................... 14

Spring and summer wool ......................... 15

Auatomical strueture.......................... 16

Wood of broad-leaved trees.......................... 18

Minute strueture ............................... 20

Difierent grain of wood .............................. 21

Color and odor..................................... 24

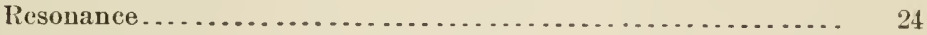

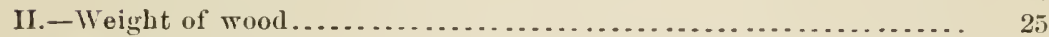

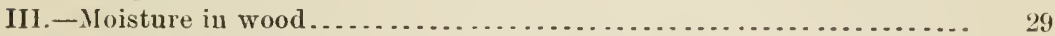

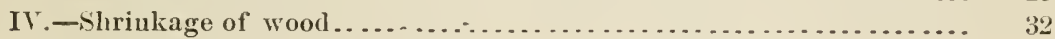

V.-Mechanical properties of woorl............................ 37

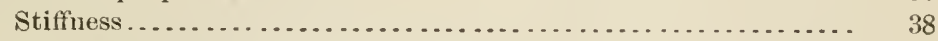

Cross breaking or bending strength.................. 41

Tension and compression........................... 43

Shearing ............................................ 45

Iufluenee of weight and moisture on streugth............ 45

Hardness and shearing across the grain .................. 47

Cleavability ...................................... 48

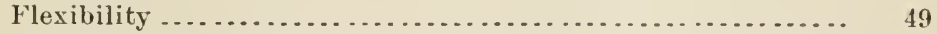

Tonghness......................................... 49

Practieal conclusions .................................. 50

VI.-Chemieal properties of wood............................ 51

VI1.-Durability and deeay ................................... 54

How to distinguish the different kinds of wood ..................... 59

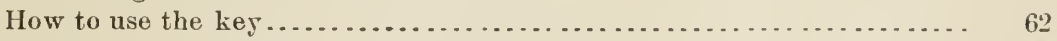

Key to the more important woods of North America................... 61

I.-Non-porous woods (ineludes all eoniferons woods)............ 64

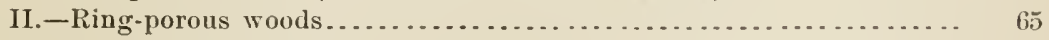

III.-Diffuse-porons woods .................................... 69

List of the more important woods of the United States............... 72

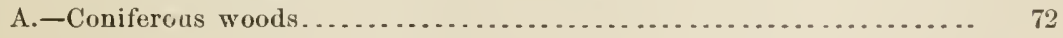

B.-Broad-leaved woods (hardwoods) ........................... 76 


\section{LIST OF ILLUSTRATIONS.}

Fig. 1. A piece of sawn timber ent througl along the pith, illustrating its

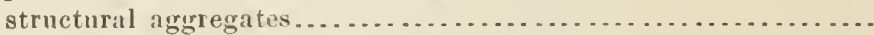

2. Possibilities of cutting timber from a $\log$ with reference to position of grain .

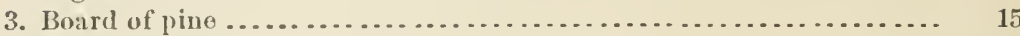

4. Wood of spruce........................................... 16

5. Group of fibers from pine wood........................... 17

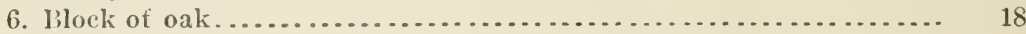

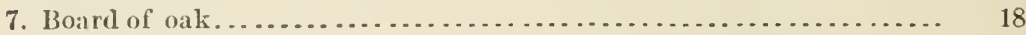

8. Cross section of oak.................................... 19

9. Isolated fibers and cells .................................. 20

10. Cross section of basswood (magnified) ..................... 21

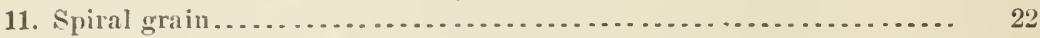

12. Alternating spiral grain in cypress ...................... 22

13. Wavy grain in bech................................ 22

14. Section of wool slowing position of the grain at base of a limb.... 23

15. Cross section of a group of wood fibers ..................... 25

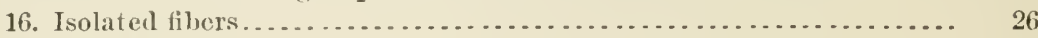

17. Orientation of wood samples ............................ 27

18. Short pieces of wool fiber .................................. 32

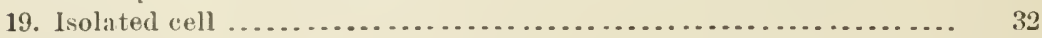

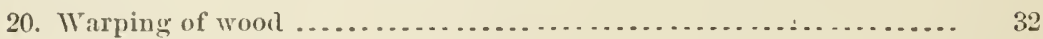

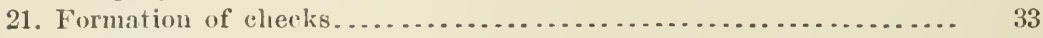

22. Small pith ray in oak.................................. 34

23. Effects of shrinkago ....................................... 35

24. Honeyrombed board .................................. 36

25. Bending a beam................................................ 39

26. Specimen in tension test................................ 43

27. Straight and cross grained wood........................... 43

28. Effect of knots and their position.......................... 43

29. Compression endwise................................... 44

30. Longitudiual slearing ................................. 44

31. Varions forms of failure ................................. 45

32. Test in hardness and shearing across tho grain................. 47

33. Cleavage ............................................... 48

34. "Shelf"-fungis on the stem of a pine ...................... 55

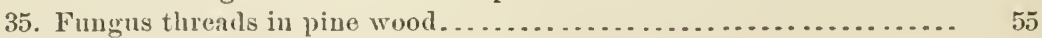

36. Cells of maple wood attackerl by fungus threads.............. 56

37. Nonporons woods ................................... 60

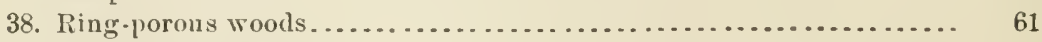

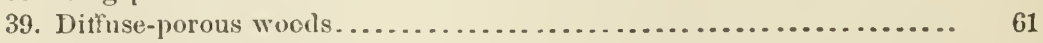

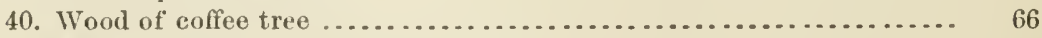

41. Wood of hlack, white, and green ash..................... 67

42. Wood of red oak..................................... 68

43. Wood of chestunt ..................................... 68

44. Woor of hickory .................................... 68

45. Wool of beech, sycamore, and birch . .................... 70

46. Wood of maple ...................................... 70

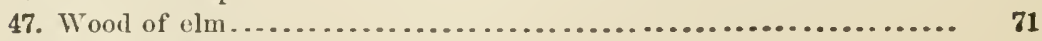

48. Wood of walnut........................................ 71

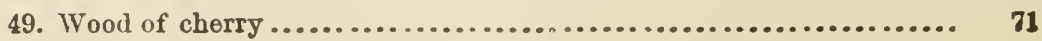




\section{INTROI)UCTION.}

Wood is now, has erer been, and will continue to be, the inost widely useful material of construetion. It lias been at the base of all material civilization. In spite of all the substitutes for it in the shape of metal, stone, and other materials, the eonsumption of wood in eivilized countries has never deereased; nay, applications in new direetions have inereased its use beyond the saving effected by the substitutes. Thus, in England, the per capita consumption has increased in the last fifty years more than double, a fact which is especially notable, as the lulk of the timber nsed there must be importerl. while irou and coal are plentiful in Great Britain.

In the United States we ean only estimate from the partial data furnished by eensus returns. By these we find the per capita consumption to have inereased for every decade since 1860 at the rate of from 20 to 25 per cent.

Although wood has been in use so long and so universally, there still exists a remarkable lack of knowledge regarding its nature in detail, not only among laymen, but among those who might be expeeted to know its properties. As a consequence, the practice is often faulty and wasteful in the manner of its use. Experience has been almost the only teacher, and notions-sometimes right, sometimes wrongrather than well-substantiated facts lead the wood consumer. Iron, steel, and other metals are much better known in regard to their properties than wood. The reason for this imperfect knowledge lies in the faet that wood is not a homogeneous material, like the metals, but a complicated structure, and so variable that one stick will behave very differently from another stick, althongh cut from the same tree. Not only does the wood of one speeies differ from that of another, but the butt cut differs from the top log; the heartwood from the saywood; the wood of the quickly grown sapling of the abandoned field from that of the slowly grown old monarch of the forest. Even the manner in which the tree was sawed and the condition in which the wood was ent and kept influence its behavior and quality. It is, therefore, extremely difficult to study the material for the purpose of establishing gemeral laws, and it becomes neeessary to make a specific inspection of the individual stiek which is to be applied to a certain purpose. The selection, not only of the most suitable kinds, but of each stick, for the 
purpose for which it is fit will enter into that improved practice to which we may look both for greater economy and greater effieieney.

The object of this bulletin is to record more systematically than has been done hitherto the knowledge which exists and which will help the wood consumer in the elovee of his material and in determining whether, and if so why, a given stick will answer his purpose. Such inspection reunires, first, a knowledge of the gross strueture and appearance, which give indications of quality and hehavior, and then, for finer application, a knowledge of the minute anatomical or mieroscopic structure. The minute structure will often explain the difterence in behaviol of varions linds of wood, and a knowledge of it is almost indispensable in distinguishing the varions linds.

In the comutries of Europe the kinds of wood used in eonstruetion and manufincture are so few that there is but little diflenlty in distingnishing them. ln onr own eountry the great variety of wools, aud of useful woorls at that, often makes the mere distinetion of the kind or speries of tree most difticult. Thus there are at least eight pines (of the thirty-tive native ones) in the market, some of which so closely resemble each other in their mimute structure that they can hardly be tolul apart; and yet they differ in quality and should be used separately, althongh they are often mixed or eonfoumled in the trade. Of the thirty-six oaks, of which probably not less than six or eight are malllieted. we can readily recognize by means of their minute anatomy at least two tribes-the white and the black oaks. The distinetion of the species is. however. as yet uncertain. The same is true as to the eight linds of hickory, the six linds of ash, ete. Before we slatl be able to distinguish the wood of these species unfailingly, more study will be necessary. 'The key given in the present publication, therefore, is by necessity only provisional, requiring further claboration. It mufortunately had to be based largely on external appearances, which are not always reliable. Sometimes, for general practical purposes, this mere appearance, with some ninor attributes, such as color, taste, etr., are together sufincient, espeeially when the locality is linown from which the species eame, and in the log pile the determination may by these means be rendered possible when a single detached piece will leave us doubtful as to the species. In the market the distinctions are often most uncertain, and a promiscuous application of names alds to the confusion. To be sure, there is not much virtue in knowing the correct name, except that it assists us in describing the exact kind of material we desire to obtain. Nor is there always much gained in being able to identify the species of wood, but that it predicates certain qualities which are msually fomm in the spocies.

In selecting material, then, for speeial purposes we first determine what species to use as having either one quality which is foremost in our requirements, or several inalities in combination, as shown by actual experience or by experiment. 
The uses ot the valions woods depend on a variety of conditions. 'The carpenter and builler, using large quantities of material and bestowing a minimm amount of labor on the greater part of the same, uses those kinds which are abundant, and hence cheap), to be had in large dimensions, light to ship, soft to work and to mail, and fairly stiff and insect proof-a combination represented in the conifers. They need not be hamdsome, haul, tongh, ol very strong, and may shrink even after they are in plare. When it comes to finishing-woods, more stress is lad on color and grain and that the wood shall shrink as little as possible.

The finmitme maker, who bestows a maximmm amount of work on his fuaterial, needs a wool that combines strength, and sometimes tonghness, with beanty and Iarlness, that takes a good polish, keejs joint. and loes not easily indent. It must not warpor shrink when once in place, but it need not be light or soft or insect proof or abundant in any one kind, and in large dimensions, nor yet particularly clieap.

Tonghness, strength, and hardness combined are sought by the wagon maker. 'The calriage builder, cooper, and shingle maker look for straight-grained, easy-splitting woods, and for a long fiber, the absence of distmbing resinoms and coloring matter, knots, etc. Durability under exposure to the weather, resistance to indentation, and the holling of spikes are required for a good railroad tie; lasting qualities, elasticity, and proportionate dimensions of length and diameter, for telegraph poles.

Sometimes in practice it is immaterial whether the stick be of white oak or red oak, and many woorl yards make no distinction, in fact do not know any, but the experienced cooper will quickly distinguish, not by name, perhaps, but by quality, the more porons red or black oak from the less porous white species. On the other hand, the rery same white oak-Curecus ulba, usmally a superior artiole-may furnish so poor material for a handle or a plow beam that a stick of red oak would be preferible. The inspertion, then, must be made not only for the species but for the quality, with reference to the purpose for which the stick is to be userl.

That the inspection should have regard to defects and unhealthy condition (often indicated by color) goes withont saying, and such inspection is nsually practiver. That knots, even the smallest, are defects which for some uses condemn the material altogether needs hardly to be mentioned. but that season checks, eren those that have closed by subseguent sluriukage, remain elements of weakness is not so readily appreciated. Yet there can not be any donbt of this, since the intimate connection of the wond fibers, once interrupter, is nerer reestablished. The careful wood user. therefore, is concerned as to tho mamner in which his material was treated after the folling, for according to the more or less careful seasoning of it the season checks, uot altogether avoidable, are more or less abundant. 'This is practically 
reeognized by splitting wagon and cooperage stock in the woods and seasoning it partly shaped, and also in maling a distinction, often unnecessarily, between air-dried and kiln-dried material.

Where strength is required, the weight of the material will give good indications, for it is now pretty well established that weight and strength go more or less together. But since weight in the green wood is made up of at least three elements, namely, that of the wood fiber itself, that of the water in the cell spaces, and that of the water in the cell walls, the weight is leceptive unless we know also the moisture condition of the stick or else ascertain the specific weight of the dry wood. That the moisture contents influence considerably the strength of the material is now well proven, strength increasing with loss of moistur?, and bence in practice allowance should be male according to whether the stick is to be used where it will be exposed to the weather or under eover and painted.

In some woods like the pines and the "ring porous" woods, such as oak, chestnut, and hickory, in which each annual layer or ring is made up of two distinct parts, the loose, porous spring wood and the dense and firm summer wood, the proportion of the latter per square inch of cross section-usually but not always depending on the width of the ring-furnishes a more direct criterion than the weight alone. The color effect of itself gives indications of the weight, since both reight and color efiect depend on the same feature, namely, quantity of material; hence the large: quantity of dense summer wood on the cross section occasions darker color, which is nsmally indicative of strength. Color, too, must be consulted to detect incipient decay. Again, the difference in firmness and hardness of the summer wood itself, as tested by the knife or recognized in the difference of color effect by the practiced eye, furnishes another eriterion in the selection of the stick.

Lastly, the manner in which the stick is sawed from the tree has a remarkable influence mpon its qualities and belıvior, and it should, therefore, either be specially sawed or selecterl with a view to its character and to the purpose for which it is to bo used. This is a matter fully appreciated among only a few wood nsers, like the wheelwrights, piano makers, ete., lut it needs to be observed much more than it is, even in building. Quarter or rift sawing, i. e., cutting sticks or boards out of the $\log$ in such a manner that the anmal rings are ent through as nearly as possible radially, has lately been practiced largely for the sake of the beanty of the even grain thus obtained, and also for flooring on account of the better wear which the even exposure of the grain (hard bands of summer wood on edge) seeures; but it should be much more widely applied to secure greater strength and more uniform seasoning and thus to reduce to some extent the one drawback to wood as a material of construction, that is, its liabilility to "working" (shrinking and swelling). The reason for the superiority of quartersawed pieces, as well as the general fact that the manner of sawing 
ont a stick affects the general eharacter and behavior of the same, will aplear from the following eonsiderations :

A square column or be:m cut so as to contain the heart or pitl of the tree in its center-which, by the way, is the weakest part on

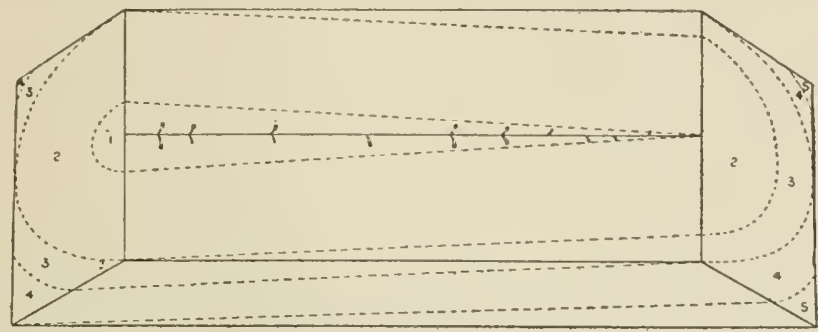

Fig. 1.-A piece of sawn timber cut through along the pith, illustrating its struetural aggregates.

aceount of the many knots which it invariably and necessarily con tains-rousists iu the main of five structural aggregates (see fig. 1), namely: (1) In the center a cone of woor fibers with the base in the butt end and the apex in the top end, the base rejresenting the rings of as many year's as it took the tree to attain the heiglit of the eolumm; none of the fibers belonging to these rings appear in the top section excepting those of the last ring which forms the apex of the eone; ( 2 ) a hollow cylinder of material surrounding the eone, all fibers of which are found in both sections and contimuously through the whole length of the column; all the entire rings at the bottom belong in this eylinder, and undoubtedly form the strongest part of the columm; (3) surromuling this cylinder a partial cylindrical enrelope of wood fibers, alt of which are represented in the top section, but only a part appear at the corners of the bottom; most of them, there. fore, do not rum through the whole length, but are ent through at vary. ing lengths, thereby presenting the "bastard faces" on the silles of the column; (t) a partial envelope whose.

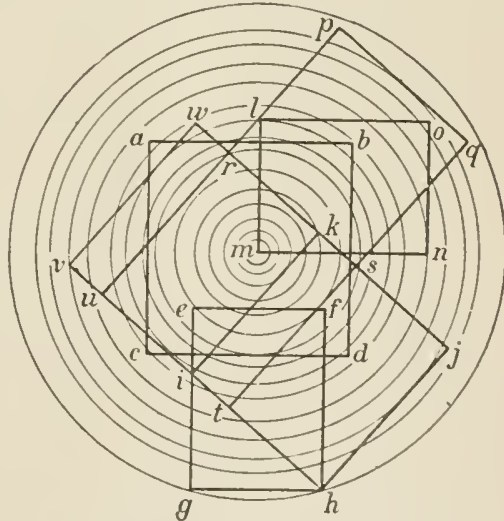

Flli, 2,-Possibilities of cutting timber from a log with relerence to position of grain. radial extent is limited by the corners of the basal section, imperfect at both ends; (J) the corners at the top, three-sided pyimids with the base in the top section, the fibers rmuning ont at varying lengths.

Now, it will be readily admitted that each of these "structural aggregates" has a clifferent value in the combined strength of the whole. If the stick be eut with the eenter or pith in one sirle (sce fig. 2 ) all these aggregates will be halved; if the stick be eut ont differently, for instance, with the heart entirely out or if it be made louger or 
shorter, or reetangular instead of square, in alch case the proportion "f each of the aggregates changes, and hence it stands to reason tirat the strength of the column, or beam, or stick, chamges aceording to the manner in which it is ent from the tree. This most evident and

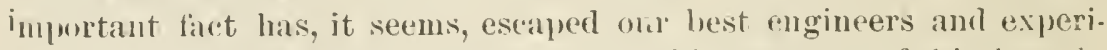
meuters. who have tester beans withont taking aceomt of this disturh. ing element, and it is certainly overlooked most generally by buller's and carpenters in their selertion of material.

While it may perhaps not be expected that the sawing at the mill will be done with more are so as to secure the best results in application, or that the sleeial advantage of quarter sawing will soon he suffiriently appreciater so as to cxtend its use in sueh a manner that the wreater efficiency of the quarter sa wed material will compensate fin the greater expense of the operation, wood users may at least be expected to make their selections from the sawer material in the yarl, and shape it for their particular use with greater care.

There is no rountry in which wood is more lavishy used than in the Inited states, and none in which nature has more bountifully provided for all reasomable repuirements. In the absence of proper efforts to secore reproduction, the most valuable kints are rapully being decimated, and the necessity of a more rational and careful use of what remains is clearly applarent. By greater care in selection, however, not only can the duration of the supply be extended, but more sintistactory results will acerne from its use.

Washington, D. C., September 15, 1895.

B. li. FERNow. 


\section{TIMBER.}

\section{(HARACTERISTICS ANI) PROPERTIIS OF WO(OI).}

\section{I.-STRUCTURE AND APPEARAIHCE.}

The strueture of wool affords the only reliable means of distinguish ing the different kinds. Color, weight, smell, and otler aplearances, which are often direet or indirect results of structure, may be heipful in this distinction but can not be relied upon entirely. In addition, struc. ture molerlies nearly all the technical poperties of this important product and furnishes an explanation why one piece differs as to these properties from another.

Structure explains why oak is heavier, stronger, and tougher than pine; why it is harder to saw and plane, and why it is so much more difficult to season without injury. From its less porous structure alone, it is evident that a piece of a young and thrifty oak is stronger than the porous wood of an old or stunted tree; or that Georgia or longleaf pine excels white pine in weight and streugth. Keeping espeeially in minl the arrangement and direction of the tibers of wood. it is "lear at onc. why knots and "crossgrains" interfere with the strengl of timber.

It is due to structural peculiarities that "honeyoumbing" oc"urs in rapid seasoning, that "checks" or cracks extend ralially and follow pith rays, that tangent or "bastard" boards shrink and warp more than quartered lumber. These same peculiarities enable cherry and oak to take a better finish than basswood or coarse grained pint.

Moreover, structure, aided by color, determines the beanty of wood. All the pleasing figures, whether in a hard-pine ceiling, a desk of quartered oak, or in the beautitul panels of "eurly" or "birr's-eye" maple decorating the saloon of a ship or a palace "ar, are due to differences in the structure of the wood. Kuowing this, the appearance of any partieular seetion ean be foretold, and almost mlimited cholce and combination are thereby suggested.

Thus a knowledge of structure not only rnables us to distinguisl the different woods, julge as to their qualities, and explain the camses of their beanty, but it also becomes an invaluable airl to the thomghtful worker, guiding him to a more careful selection and a more perfect use of his material.

\section{CLASSES OF TREES.}

The timber of the United States is furnished by three well-rlefined classes of trees: the needle-leaveil, naked-seeded conifers (pine, cedar, etc.), the dicotyledonous (with two seed leaves), broad-leaved trees (oak, 
poplar, ete.), and to an inferior extent by the monoeotyledonous (with one seed leaf), palms, yuceas, and their allies, which last are confined to the most southern parts of the country.

Broad-leaverl trees are also known as deciduous trees, although especially in warm comtries, many of them are evergreen, ${ }^{1}$ while the conifers are eommonly termed "evergreens," although the lareh, bald eypress, and others shed their leaves every fall, and even the names "broad-leaved" and "roniferous," thougl perhaps the most satisfactory, are not at all exact, for the conifer ginkgo has broad leaves and bear's no rones.

In the Inmber trade, the woods of broad leaved trees are known as "landwoods," thomgh poplar is as soft as pine, and the coniferous woods are "soft woods," notwithstanding that yew ranks high in larrness even when compared to " hard woods."

Both in the number of different kinds of trees or speries and still more in the importance of their product the conifers and broad-leaved trees far excel the palms and their relatives.

In the manner of "growth both conifers and broad-leaved trees behave alike, adding each year a new layer of wood which cover's the old wood in all parts of the stem and limbs. Thus the trunk coutinues to grow in thickness throughont the life of the tree by additions (anmal rings) which in temperate climates are, barring accidents, acomate records of the tree. With the palms and their relatives the stem remains generally of the same diameter, the tree of a lundred years being as thick as it was at ten years, the growth of these being only at the top. Even where a peripheral increase takes place, as in the yuecas, the wool is not laid on in well-defined layers; the structure remains irregular throughout.

Though alike in their manner of growth, and therefore similar in their seneral make-np, ennifers and broad-leaved trees differ markedly in the details of their structure and the character of their wood. The wood of all conifers is very simple in its stmoture, the fibers compos. ing the main part of the wood being all alike and their arrangement regular. The wood of broalleaved trees is complex in structure; it is male up of several different kinds of eells and fibers and lacks the regularity of arrangement so noticeable in the conifers. This difference is so great that in a study of wood structure it is best to consider the two linds separately.

WOOD OF CONIFEROUS TREES.

Examining a smootl cross section or end face of a well-grown log of Georgia pine or Norway jine, we distinguish an envelope of redelish, scaly bark, a small whitish pith at the center, and between these the wood in a wreat number of concentric rings.

I In Ceylon even the cultivated cherry has become an evergreen. 
BARK AND PITH.

The bark of a pine stem is thickest and roughest near the base, decreases rapidly in thickness from $1 \frac{1}{2}$ inches at the stump to one-tenth inch near the top of the tree, aud forms 11 general about 10 to 15 per cent of the entire trunk.

The pith is quite thick, usually one-eighth to one-fifth inch in Norway pine and in the southern species, thongh much less so in white pine, and is very thin, one-fifteenth to one twenty-fifth inch in eypress, cedar, and larch.

In woods with a thick pith, this latter is finest at the stump, grows rapidly thicker upward, and becomes thinner again $i$ the crown and limbs, the first 1 to 5 rings adjoining it behaving similarly.

S.IP AND HEART WOOD.

A zone of wood next to the bark, 1 to 3 or more inehes wide, and containing 30 to $50 \mathrm{or}$ more anmual rings, is of lighter color; this is the sapwood, the inner, darker part of the log being the heartwood. In the former many cells are active and store up starch and otherwise assist in the life processes of the tree, although only the last or onter layer of cells the cambium, forms the growing part and the true life of the tree. In the heartwood all cells are lifeless cases, and serve only the mechanical function of keeping the tree from breaking under its own great weight, or from being laid low by the winds.

The darker color of the heartwood is due to infiltration of chemical substances into the cell walls, but the eavities of the cells in pine are not filled up, as is sometimes believed, nor do their walls grow thicker, nor is their wall any more lignified than in the sapwood. Sapwood varies in width and in the number of rings which it contains, even in different parts of the same tree; the same year's growth which is sapwood in one part of a disk may be heartwood in another. Sapwood is widest in the main part of the stem and varies often within consicierable limits, and without apparent regularity. Generally it becomes narrower toward the top and in the limbs, its width varying with the diameter, and being least, in a given disk, on the side which has the shortest radius. Sapwood of old and stmert pines is composed of more rings than that of young and thrifty specimens. Thus in a pine 250 years old, a layer of wood or anmual ring does not elange from sapwood to heartwood until seventy or eighty years after it is formed, while in a tree 100 years old, or less, it remains sapwood only from thirty to sixty years. The width of the saprood varies considerably tor different kinds of pines; it is small for longleaf and white pine, and great for loblolly and Norway pines. Occupying the peripheral part of the trunk the proprortion which it forms of the entire mass of the stem is always great. Thus even in old trees of longleaf pine the sapwood forms about $\dot{t 0}$ per cent of the merchantable $\log$, while in the loblolly and in all young trees the bulk of the wood is sapwood. 
THE ANNUAL OR YEARLY RING.

The eoncentric, ammual, or yearly rings, which appear on the end face of a $\log$ are cross sections of so many thin layers of wood. Each such layer forms an (nvelope around its imer neighbor, and is in turn covered by the aljoinmg layer without, so that the whole stem is built up of a series of thin hollow cylinders, or rather cones. A new layer of rood is formed each season, covering the entire stem, as well as all the living branches. The thickness of this layer, or the wirth of the yearly rung, vares greatly in different trees and also in different parts of the same tree. In a nomally grown, thrifty pine log the rings are widest near the pith, growng more and more narrow toward the bark. Thus the central 20 rongs in a disk of an old longleaf pine may each be one erghth to one-sixth inch $(3$ to 4 mm.) wide, while the 20 rings next to the bark may arerage only one-thirtieth inch (0.7 1 mm.). In our forest tres rings of one-half inch in width ocenr only near the eenter in disks of very thrifty trees of both conifers and hard woods; one-twelfth inch represents good thrifty growth, and the minmmm width of abont one two hundredths inch (0.2 mm.) is often seen in stunted spruce and pine. The average wilth of rings in well-grown old white pine will vary from one-twelfth to one-eighteenth inch, while in the slower growing longleaf pine it may be one twenty-fifth to onethirtieth of an incll. 'The same layer of wood is willest near the stump in rery thrifty young trees, especially it grow in the open park, but in old forest trees the same year's growth is wider in the upper part of the tree, being narrowest near the stump and often also near the very tip of the stem. Generally the rings are widest near the center, grow. min narrower towarls bark. In logs from stmuted trees the orter is often reversed, the interior rings being thin and the outer rings widest. Frequently, too, \%ones or bands of very narrow rings, representing un favorable periods of growth, disturb the general regularity. Few trees, even among pines, furnish a log with truly circulal cruss section; msually it is an oval, and at the stump commonly cuite an irregular figure. IIoreover, even in rery regular or eircular disks the pith is rarely in the center, and frequently one radins is conspicuously longer than its opposite, the width of some of the rings, if not all, buing greater on one side than on the other. This is nearly always so in the Iimbs, the lower radius axeeding the mper.

In extreme cases, especially in the limbs, a ling is frequently conspienens on one side and almost or entirely lost to view on the other. Where the rings are extremely narrow, the clark portion of ring is often wanting, the color being quite miform and light. The greater regularity or irregularity of the anmial rings has much to do with the rechuical qualities of the timber. 
SPRING AND SUMMER WOOD.

Examining the rings more closely, it is notieed that each ring is made up of an inner, softer, light-colored, and an onter, or peripheral, firmer and darker-colored portion. Being formed in the fore part of the season, the inner, light-colored part is termed spring wood, the onter, darker portion being the summer wood of the ring. Since the latter is very heary and firm, it determines to a large extent the weight and strength of the wood, and as its darker color influences the shade of color of the entire piece of wood, this color efrect becomes a valuable aid in distinguishing heary and strong from light and soft pine wood. In most hard pines, like the longleat, the dark smmmer wood appears as a distinet band, so that the yearly ring is composed of two sharply defined bands-an inner, the spring wood, and an outer, the summer wond. But in some cases, even in hard pines, and normally in the rood of white pines, the spring wood passes grathally into the darker smon. mer wood, so that a sharply definerl line oceurs only where the spring wood of one ring abuts agaiust the summer wood of its neighbor. It is this clearly defined line which enables the eye to distinguish even the rery narrow rings in old pines and spruces. In some cases, espeeially in the trunks of Sonthern pines, and normally on the lower side of pine limbs, there oceur

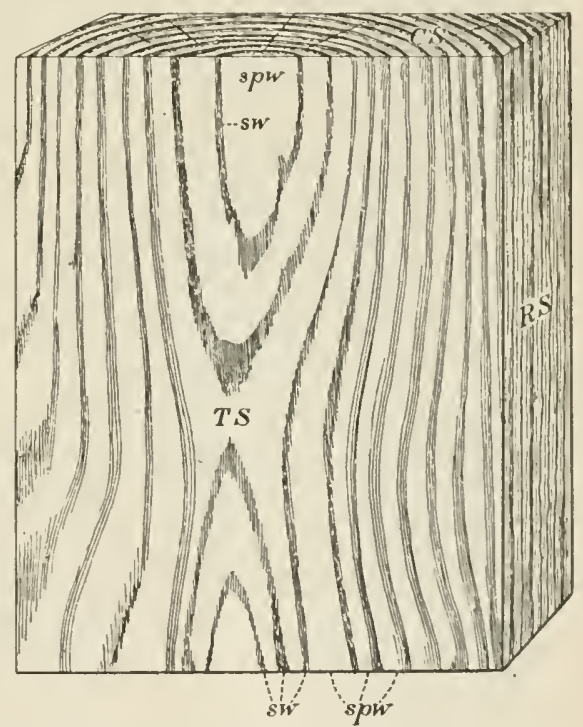

FIg. 3.-Buard of pine. Cs; cross section; Rs, radial section: Ts, tingential section: su', summer wool; spe, spring woud.

dark bands of wood in the spring wood portion of the riug, criving rise to false rings which mislead in a superficial comnting of rings. In the disks ent from limbs these rark bands often oceupy the greater jart of the ring and appear as "lunes" or sickle-shaped figures. The woor of these dark bauds is similar to that of the true smmmer "rood-the rells have thick walls, but nsnally lack the compressed or Hattened form.

Nornally, the summer wood forms a greater proportion of the ring in the part of the tree formed duriug the periorl of thriftiest growtls. In an old tree this proportion is very small in the first 210 is rings about the pith, and also in the part next to the bark, the internediate part showing a greater proportion of summer wood. It is also greatest in a disk taken from near the stump and decreases upward in the stem, 
thus fully accounting for the difference in weight and firmness of the wood of these lifferent parts. In the longleaf pine the summer wood often forms scarcely 10 per cent of the wood in the central 5 rings; 40 to 50 per cent of the next 100 rings; about 30 per cent in the next 50 , and only abont 2 () per cent in the 50 rings next to the bark. It averages 45 per cent of the wook of the stmmp and only 24 per cent of that of the top.

Sawing the log into boards, the yearly rings are represented on the board faces of the middle board (radial sections) by narrow, parallel stripes (see fig. 3), an mner, lighter stripe, and its outer, darker neighbor always corresponding to one annual ring.

On the faces of the boirds nearest the slab (tangential or "bastard" boards) the several year's' growth should also appear as parallel, but

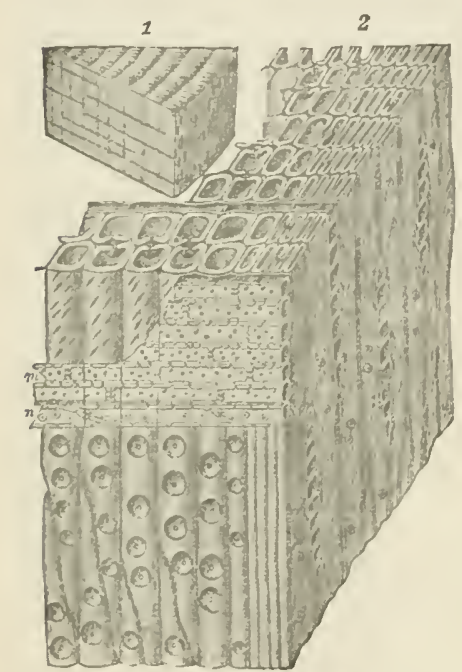

F10.4.- Wool of spruce. 1, natural size; 2, small part of one ring maguified 100 times. The vertical tubes are wood fibers. in this case all "tracheids." $m$, medullary or pith ray; $n$, transverse traclueids of pith ray: $a, b$, and $c$, bordered pits of tho tracheids, more enlarged

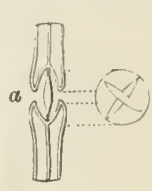
much broader stripes. This they do only if the log is short and very perfect. Usually a variety of pleasing patterus is displayed on the boards, depending on the position of the saw eut, and on the regularity of growth of the log. (See fig. 3.)

Where the cut passes through a prominence (bump) or erook) of the log, irregular, concentrie circlets and ovals are produced, and on almost all tangent boards, arrow, or V-shaped forms occur.

ANATOMICAL STRUCTURE.

Holding a well-smoothed disk, or cross section oneeighth inch thick toward the light, it is readily seen that pine wood is a very porous structure. If viewed with a strong magnifier, the little tubes, especially in the spring wood of the rings, are easily distinguisher and their arrangement in regular straight radial rows is apparent. Scattered through the summer wood portion of the rings, numerous irregular grayish dots (the resin ducts) disturb the uniformity and regularity of the strueture. Magnified 100 times, a piece of spruce, which is sinilar to pine, presents a picture like that shown in fig. 4. Only short pieces of the tubes or cells of which the rood is composed are represented in the picture.

The total length of these fibers is one-twentieth to one-fifth inch, being smallest near the pith, aud is 50 to 100 times as great as their 
width (fig. 5). They are tapered and elosed at their ends, polygonal, or rounded and thin walled, with large eavity, lumen or internal space in the spring wood. thick walled and flattened radially with the internal space or lumen much reduced in the summer wood. (Ste right-hand portion of fig. 4). This flattening, together with the thicker walls of the cells which reduces the lumen, causes the greater firmness and darker color of the summer wood-there is more material in the same volume. As shown in the figure, the tubes, cells, or "tracheids" are decoratel on their walls by circlet-like structures, the "bordered pits," sections of which are seen more magnified at $a, b$, and $c$, fig. 4 . These pits are in the nature of pores, covered by very thin membranes, and serve as waterways between the cells or tiacheids.

The dark lines on the side of the smaller piece (1, fig. 4) appear when magnified (in 2, fig. 4) as tiers of 8 to 10 rows of cells, which run radially (parallel to the rows of tubes or tracheirls) and are seen as bands on the radial face and as rows of pores on the tangential face. These bands or tier's of cell rows are the medullary rays or pith rays, and are common to all our lumber woods. In the pines and other conifers they are quite small, but they can readily be seen, even withont a magnifier, if a radial surface of split wood (not smoothed) is examined. The entire radial face will be seen almost covered with these tiny structures, which appear as fine but conspicuous cross lines. As shown in fig. 4 the cells of the medullary or pith rays are smaller and very much shorter than the wood fibers or tracheids and their long axis is at right angles to that of the fibers. In pines and spruces the cells of the upper and lower rows of each tier or pith ray have "bordered" pits like those of the wood fibers or tracheids proper, but the cells of the intermediate rows, and of all rows in the rays of cedars, etc., have only "smple" pits, i. e., pits levord of the saucer-like "borler" or rim.

In pine, many of the pith rays are larger than the majority, each containing a whitish lne, the horizontal resin duct, which, though much smaller, resembles the vertical ducts seen on the

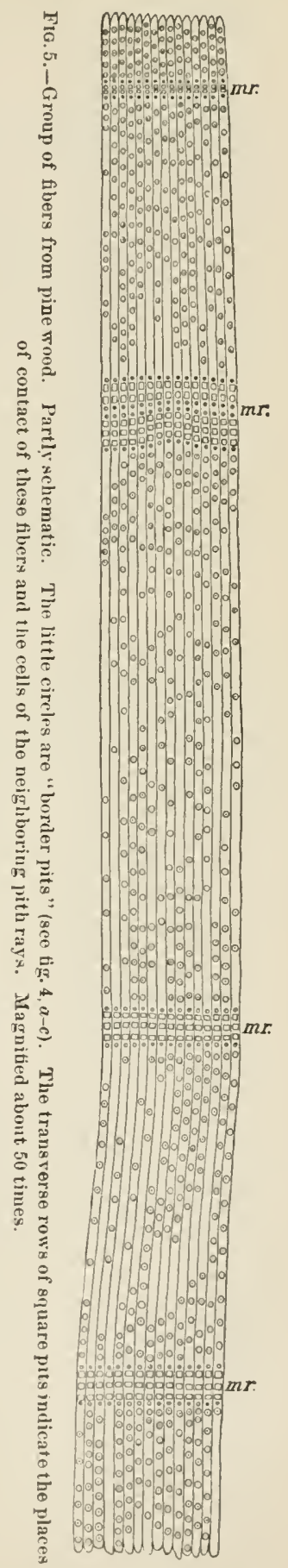
cross section. The larger vertical resin ducts are best observed on 3521-No. 10—2 
removal of the bark from a fresh piece of white pine, cut in winter, where they appear as conspicnus white lues, extcucling often for many inches

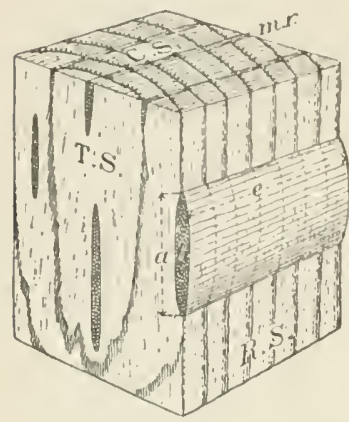

FIG. 6.-Block of oak. C. S. r.ross section; R. S.. radial sec. tion: T. s., 1angential section; $m$. r., medullary or pith ray ; $\alpha_{1}$ hejght, $b$, width, and $e$, length of a pith ray. i1) and down the stem.

Neither the horizontal nor the vertical resin ducts are ressels of eells, lont are openings between eells, i. e., intercellular spaces, in which the resin acemmulates, freely oozing out when the duets of a fresh piece of sapwood are cut. They are present only in onr coniferous woods, and even here they are restricted to pine, spruce, and larch, and are normally absent in fir, cedar, cypress, and yew.

Altogether the structure of coniferons wood is very simple and regular, the bulk being mate ul of the small fibers ealled tracheisk, the disturbing elements of pith rays and resin ducts beinginsignificant, and hence the great miformity and great technieal value of coniferous wood.

\section{WOOD OF BROAD-LEAVED TREES.}

On a cross section of oak, the same arrangement of pith andi bark, of sapwood and heartwood, and the same ilisposition of the wood in well-defined concentric or anmual rings oecurs, but the rings are marked by lines, or rows, of conspicuons pores or openings which oc cupy the greater part of the spring wood of each ring (see tig. 6, also tig. S) and are, in fact, the hollows of ressels through which the rut has been made. On the ranlialsesetion, or quarter-sawerl board, the several layers appear as so many parallel stripesis (see fig. 7); on the tallgential section or "bastard" firce, patterns similar to those mentioned for pine wood are observed. but while the patterns in lam pine are marked by the darker summer wood aud are composed of plain, alternating strupes of darker and lighter wood, the figures

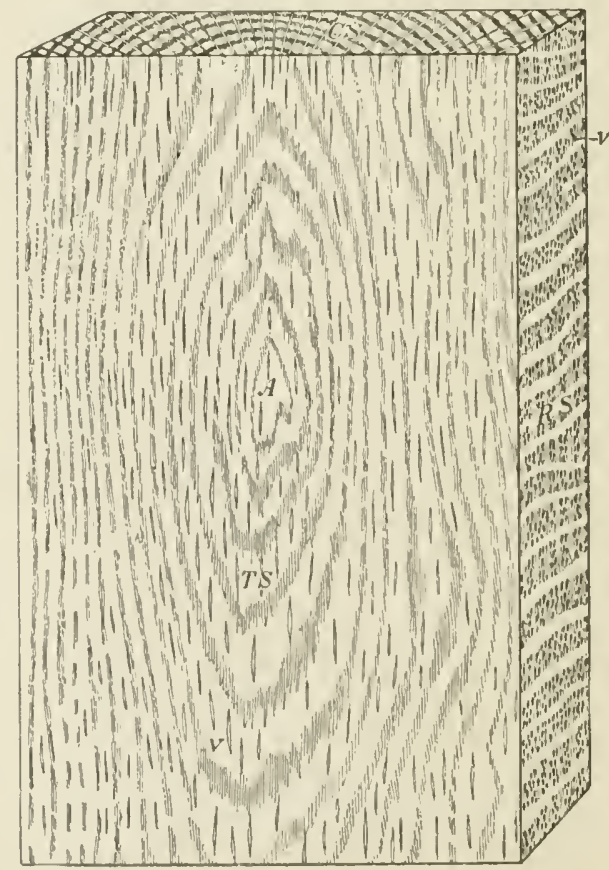

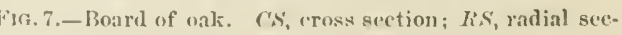
tiun: Ts, tamential section; $v$, vessels or pores, cut lirough; 1 , slight curve in log which appears in sec. fion as an islin. in oak (and other broad-leaved woods) are date chiefly to the vessels, 
those of the spring wood in oak being the most conspicuous (see fig. 7); so that in an oak table the darker, shaded parts are the spring wood, the lighter, unicolored parts the summer wood.

On closer examination of the smoother cross section of oak, the spring wood part of the ring is found to be formed, in great part, of pores: large, round, or oval openings made by the cut through long

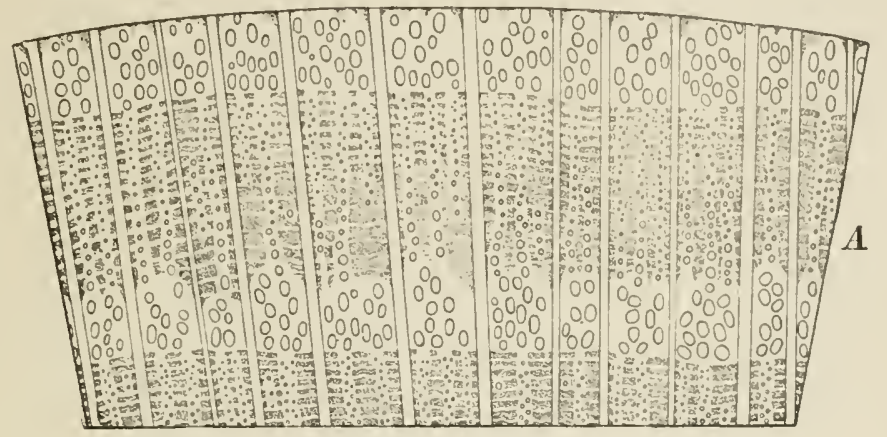

FIG. 8 A.-Cross section of oak magnified about 5 times.

vessels. These are separated by a grayish and quite porous tissme (see fig. $\mathrm{SA}$ ), which continues here and there in the form of radial, often branched, patches (not the pith rays) into aud through the summer wood to the spring wood of the next ling. The large vessels of the spring wood, ocenpying 6 to 10 per eent of the volume of a log in very good oak, and 25 per cent or more in inferior and narrow-ringed lumber, are a very important feature, since it is evident that the greater their share in the volyme, the lighter and weaker the wood. They are smallest near the pith, and grow wider outward; they are wider in the stem than limb and seem to be of indefinite length, forming open channels in some cases probably as long as the tree itself.

Scattered through the radiating gray patches of porous wood are ressels similar to those of the spring wood, but decidedly smaller. These vessels are Fia. 8 B.-l'ortion of the tirm bodies of usmally fewer and larger near the spring wood, and smaller and more numerons

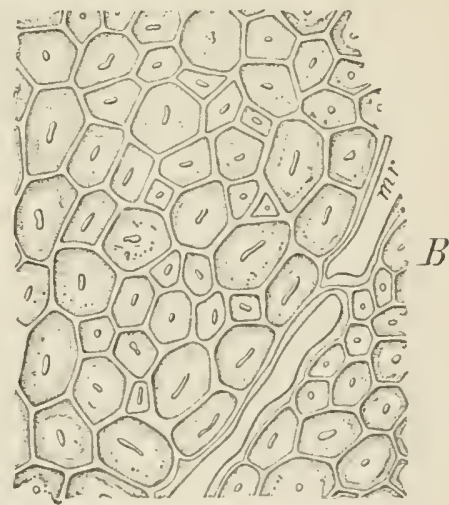
in the outer portions of the ring. Their number and size an be utilized to distinguish the oaks classed as white oaks from those classerl as black and red oaks; they are fewer and larger in red oaks, smaller but much more numerous in white oaks. The summer wool, except for these radial grayish patches, is dark colored and firm. This firm portion, divided into bodies or strands by these patches of porous wood 
and also by fine wavy concentric lines of short, thin-walled cells (see fig. S A), consists of thick-walled fibers (see tig. S B) and is the chief element of strength in oak wood. In good white oak it forms one-half and more of the wood: it ents like horn, and the cut surface is shiny and of a deep choeolate-brown color. In very narrow-ringed wood and in inferior red oak it is msually much reduced in quantity as well as quality.

The pith lays of the oak, minlike those of coniferous woods, are at least in part very large and conspicuous (see fig. 6 , their height indicated by the letter ", and their width by the letter $b$ ). The large medullary rays of oak are often twenty and more cells wide and several hmolred cell rows in height, which amomnt commonly to one or more inches. These large rays are consplicuous on all sections. They appear as long, sharp, grayish lines on the cross section, as shert, thick lines, tapering at each end, on the tangential or "bastarl" face, and as broad, shing bands, the "mirrors," on the radial section. "In addition to these coarse rays, there is also a large number of small pith rays, which ean be seen only when magnitierl. On the whole, the pith rays form a much larger part of the wood than might be snpposed. In specimens of good white oak it has been found that they formed about 16 to 25 per cent of the wood.

MINUTL: STHECTURF.

If a well-smoothed, thin disk, ol' cross section of oak (say one-sixteenth inch thick) is held up to the light, it looks very much hle a sieve, the pores or vessels appeiring as cleancut holes; the spring woorl and gray patclies are seen to be quite porous, but the firm hodies of tibers between them are dense and opaque. Examined with the maguifiel it
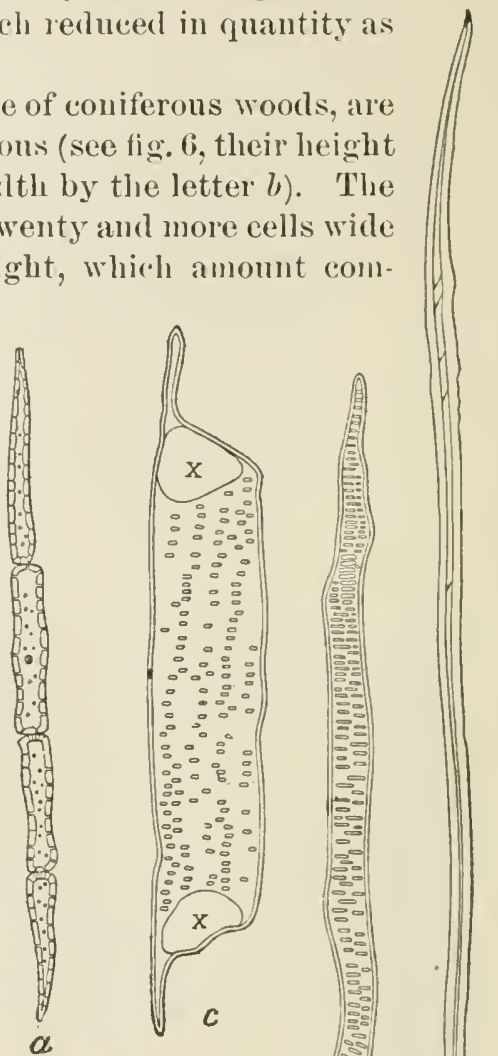

will he moticel that there is no such regularity of arrangement in straight rows as is conspicnous in the pine; on the contrary, great irregularity prevails. At the sime time, while the pores are as large as pin holes, the cells of the denser wood, unlike those of pine wood, 
are too small to be distinguished. Studied with the mieroseope, each vessel is found to be a vertical row of a great number of short, wide tubes, joined end to end (fig. 9, c). The porous spring wood and radial gray tracts are partly composed of smaller vessels, but ehiefly of tracheids like those of pine, and of shorter rells, the " wood parenehyma," resembling the cells of the medullary rays. These latter, as well as the fine eoncentric lines mentioned as oecurring in the summer wood, are eomposed entirely of short, tube-like parenchyma cells with square or oblique ends (fig. 9, a and $b$ ). The wood fiber's proper, which form the dark, firm bodies referred to, are very tine, thread-like cells one twenty fifth to one-tenth ineh long, with a wall commonly so thick that searcely any empty internal space or lumen remains (figs. 9, e, and $8, B)$.

If instead of oak a piece of poplar or basswood (fig. 10) had been used in this study, the structure wonld have been fomm to be quite different. The same kinds of anl-elements, ressels, etc., are, to be

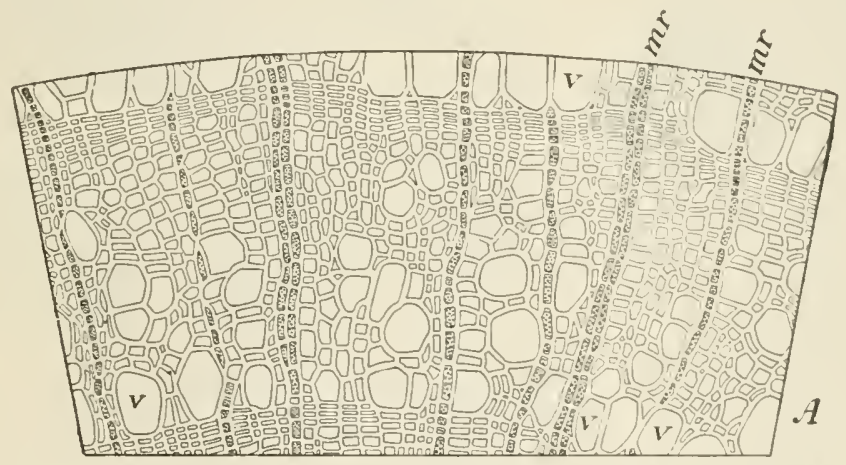

FIG. 10.-Cross section of basswood (magnified). $v$, vessels; $m r$, pitl rays.

sure, present, but their eombination and arrangenent is different, and thus from the great variety of possible combinations results the great variety of strueture and, in 'onsegnence, of the qualities which distinguish the wood of broad-leaved trees. The sharp distinction of silpwood and heartwood is wanting: the rings are not so clearly defined, the ressels of the wood are small, rery numerous, and rather evenly seattered throngh the rood of the ammal ring, so that the distinetion of the ring almost vanishes and the medullary or pith rays, in poplar, ean be seen, without being magnified, only on the radial section.

\section{DIFFERENT GRAIN OF WOOD.}

The terms "fine grained," "coarse grained," "straight qrained" and "cross grained" are frerguently applied in woodworking. In common usage, wood is "coarse grained" if its annual rings are wide, "fine grained" if they are narrow; in the finer wool industries a "finegrained" wood is capable of high polish while a "coarse-grained" wood 
is not, so that in this latter case the distinction depends chiefly on liardness, and in the former on an accidental case of slow or rapirl gromth.

Generally the dirertion of the wood fibers is parallel to the axis of the stem or limh in which they oremr, the wood is straight graned, but

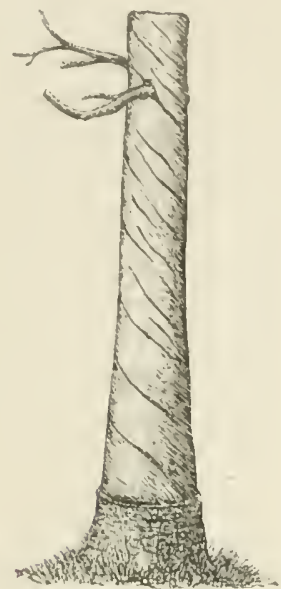

FIG. 11.-spiral g $r$ ain. Seasun checks, aiter r. moviti of bark, indicat. the clirection of the fibers or grain.
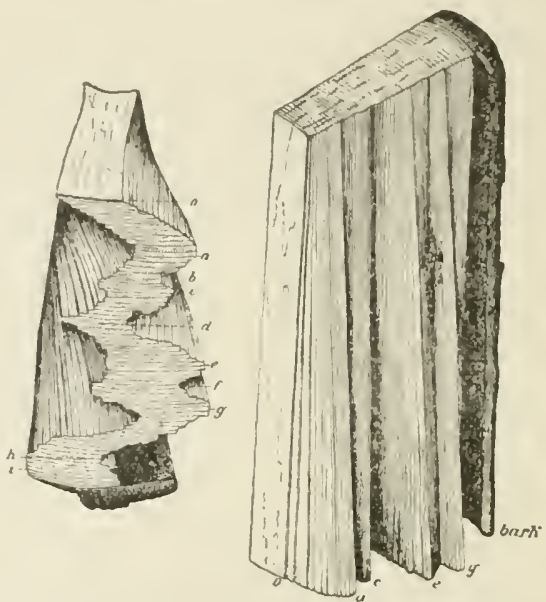

Fig. 12.-Allemating spiral grain in eypress. Side and ind riew of same picce. When the batk was at o the grain at this point was straight. From that time rach year it grew more oblique in one lireetion, reacling a climax at $a$, and then turned back in the opposite direction. These alternat tions were repeated periodically, the hark sharing in these changrs.

in many cases the comrse of the fibers is spiral or twisted aromm the tree as slown in fig. 11, and sometimes (commonly in butts of gum and crpress) the fibers of several layers are oblique in oae direction, and those of the next series of layers are oblirue in the opposite.
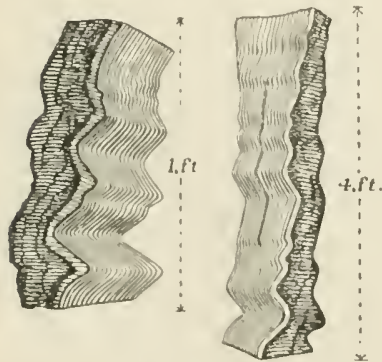

FIg. 13.-Wayy grain in leereh; after Nïrllinger. lirection, as shown in fig. 12; the wood is cross or twisted grained. Wary grain in a tangential plain as seen on the radial section is illustrated in fig. 13, which represents an extreme case observed in beech. This sime form also oecurs on the ranlial plain, causing the tangential section to appear wary or in transverse folds. When wary grain is fine, i. e., the folls or ridges small but numerous, it gives rise to the "curly" structure frequenty sean in maple. Ordinarily, neither wayy, spiral, nor alternate grain is visible on the ross section; its existence often escapes the eye even on sunooth, longitudinal fices in sawed material, so that the only safe guirle to their diseovery lies in splitting the wood in the two normal plains.

Generally the surface of the wood under the bark, and therefore also that of any layer in the interior, is not nuiform and smooth, but is 
channeled and pitted by numorous depressions which ditfer greatly in size and form. Usually, any mo depuession or (levation is restrieted to one or few anmal layers (i. e., sern only in one or few rings) and is then lost, heing eompensited (the sulfice at the particular spot evened np) ly gow goth. In some wook, however. any dejuession or elevation omer attained wows from year to year and reaches a maximum size which is maintaned for many years, sometimes throughont life.

In maple, where this tendency to preserve any particular conton is rery great, the depressions and elevations are msually suall (commonly less than one-righth inch), but rery numerous. On tangent boards of sneh wood the sections of these pits and prominemees applear as cinclets and give rise to the beatutiful "hirlls eye" or "landscupe" structure. Similar structures in the burls of blark ash, maple, etr., are frequently due to the presence of dormant buds, which eanse the surface of all the layers thromgh which they pass to be covered by suall conical elevations, whose cross sections on the sawed boarel appear as irregular circlets or islets earch with a dark speck, the section of the pith or "trace" of the dormant hud in the center.

In the wood of many broalleaved trees the wood fibers are much longer when full grown than when they are first formed in the cambium or growing zone. 'This anses the tips of each filser to crowl in between the fiber's above and below. and leads to an irregular interlacement of these fibers, which adds to the loughness hut reduces the rleavability of the woorl.

At the junetion of limb and sten the fibers on the npper and lower sides of the limb belar ve differently. On the lower side they run from the stem into the limb, forming an uninterrupted strand or tissue and a perfect

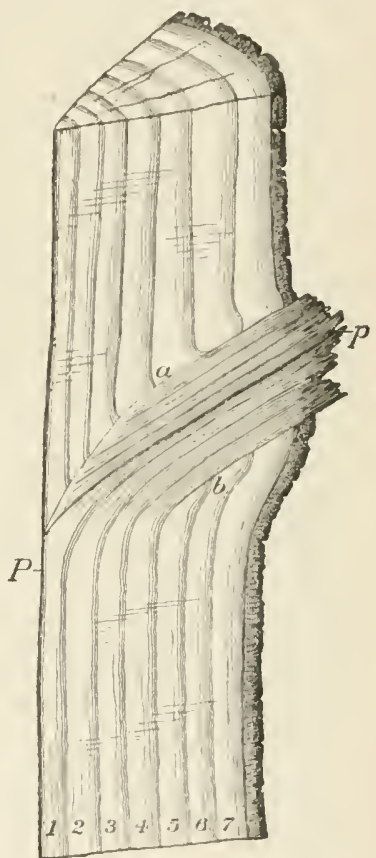

Fiti. 14.-Section of woud showing position of the grain at base of a liml,. $I$, pith of both stem and limb: $1-\bar{i}$, siren rearly layers of wood; $a, b$, knot ur basal part of a limb which lived forr years, then didal and broke ofl' near the stem. lewving tlue part to the left ol" $\alpha, b, \mathrm{a}$ "sound" knot, the part to the right a "duad" knot, which would soon be entirely envered by the growing stem.

mion. On the nper side the fibers bend aside, are not continums into the limb, and hence the connection is imperfeet (fig. 1t).

Owing to this arrangement of the fibers, the cleft make in splitting never rums into the knot, if started on the sirle above tho limb, but is apt to enter the knot if starter below, a finct well molerstood in wood craft. When limbs die, decay, and brea's off, the remaining stmbs are surrounded and may finally be covered by the growth of the trunk, and thus give rise to the annoying "rlead" or" "loose" knots. 


\section{COLOR AND ODOR.}

Color, like structure, lends beanty to the wood, aids in its identifieation, and is of great value in the determination of its quality. Considering only the heartwoorl, the black color of the persimmon, the dark brown of the walunt, the light biown of the white oaks, the reddish brown of the red oaks, the yellowish white of the tulp and poplar, the brownish red of the redwood and cedar, the yellow of the papaw and sumac, are all reliable marks of distunction; and color together with luster and weight are only too ofton the only features depended upon in practice. Newly formed wood, like that of the outer few rugs, has but little color. The sapwood generally is light, and the wood of trees which form no haartwod changes but little, except when stained by forerumers of disease.

The different tints of colors, whether the brown of oak, the orange brown of pine, the blackish tint of wahnut, or the redilish cast of cedar, are due to pigments, while the deeper shade of the summer-wool bands in pine and cedar, or in oak or walnut, is due to the fact that the wood being denser, more of the colored wood substance oceurs on a given space, $i$. e., there is more colorel matter per square inch.

Wood is translncent, a thin disk of pine permitting light to pass through quite freely. This transincency affects the luster and brightness of lumber. When wood is attacked hy fungi it becomes more opaque, loses its brightness, and in practice is designated "dead" in distinction to "live" or bright timber. Exposme to air darkens all wood; direct sunlight and occasional moistening hasten this change and cause it to penetrate deeper. Prolonged immersion has the same effect, pine wood becoming a dark gray while oak changes to a blackish browll.

Odor, like color, depends on chemical componnds, forming no part of the wood substance itself. Exposure to weather reduces, and often ehanges the odor, but a piece of dry longleaf pine, cedar, or camphor wood exhales apparently as much odor as ever, when a new sufface is exposed.

Heartwood is more olloriferous than sapwood. Many linds of wood are distmguished by strong and peculiar odors. 'This is especially the case with eamphor, cedar, pine, oak, and mahogany, and the list would comprise every lind of wood in use, were our sense of smell developed in keeping with its importance. Decomposition is nsually ancompanied by pronounced odors; decaying pojlar emits a disagreeable odor, while red oak often becomes fragrant, its smell resembling that of heliotrope.

RESONANCE.

If a $\log$ or seantling is struck with the ax or hammer, a sound is emitted which varies in piteh and character with the shape and size of the stıck, and also with the kind and condition of wood. Not only can 
sound be produced by a direct blow, but a thin board may be set vibra. ting and be made to give a tone by merely producing a suitable tone in its vicimty. The ribrations of the air, caused by the motion of the strings of the piano, conmmnicate themselves to the board, which vibrates in the same intervals as the string and reenforces the note. The note which a given piece of wook may emit varies in piteh directly with the elasticity, and indireetly with the weight, of the wood. The ability of a properly shaped sombling board to respond freely to all the notes within the range of an mstrument, as well as to reflect the character of the notes thus emittel (i. e., whether melodions or not), depends, first, on the strncture of the wond and next on the miformity of the same thronghout the boart. In the manufacture of musical instruments all woorl containing iefects, knots, cross grain, resinons tracts, alternations of wide and narrow rings, and all wood in which sunmer and spring wood are strongly contrasted in structure and variable in their proportions, is rejected, and only radial sections (quarter samed, or split) of wood of uniform structure and growth are used.

The irregularity in structure, due to the presence of relatively large pores and pith rays, excludes almost all our broad-leaved woods from such use, whle the number of eligible woods among conifers is limited by the necessity of combining sufficient strength with miformity in structure, absence of too pronouncel bands of summer wood, and relative freedom fiom resin.

Spruce is the farored resonance wood; it is used for sounding boards both in pianos and violins, while for the resistant back and sides of the latter, the highly elastic hard maple is nsed. Preferably resonance wood is not bent to assume the final form; the belly of the violin is shaped from a thicker piece, so that every fiber is in the original as nearly unstrained condition as possible, and

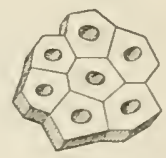

Fig. 15.-Cross section of a group of wool fibers. therefore free to vibrate. All wood for musical instruments is, of course, well seasoned, the final drying in kilı or warm room being preceded by careful seasoning at ordinary temperatures often for as many as seven years or more. The improvement of violins, not by age but by long usage, is probably due, not only to the adjustment of the numerous com. ponent parts to eaclu other, but also to a cliange in the wool itself; years of vibrating enabling any given part to vibrate much more readily.

\section{II.-WEIGHT OF WOOD.}

A small cross section of wool, as in fig. 15, dropped into water, sinks, showing that the substance of which woon filser or wood is bnilt up is heavier than water. By immersing the wool sucessively in heavier liquids, until we find a liquid in which it does not sink, and comparing the weight of the same with water, we find that wook substance is about 1.6 times as heavy as water, and that this is as true of poplar as of oak or pine. 
Separating a single cell, as shown in fig. 16, a, drying and then dropping it into water, it floats. The air-filled cell cavity or interior reduees its woight, and, like a corkerl empty bot tle, it weighs less than the water. Soon, however, water soaks into the cell, when it fills up and sinks.

Many such cells grown together, as in a block of wood, sink when all or most of them are filled with water, but will float as long as the majority are empty or only partly filled. This is why a green, sappy pine pole soon sinks in "driving" (floating). Its cells are largely filled before it is thrown in, and but little ardditional water snftices to make its reight greater than that of the water.

In a good-sized white pine log, emposed chiefly of empty cells (heartwood), the water requires a very long time to fill up the cells (five years would not suffice to fill them all), and therefore the log may float for many months. When the wall of the wood fiber is very thick (fiveeighths or more of the volume), as in fig. 16, $b$, the fiber sinks whether empty or filled. This applies to most of the fibers of the dark summerwood bands in pines, and to the compact fibers of oak or

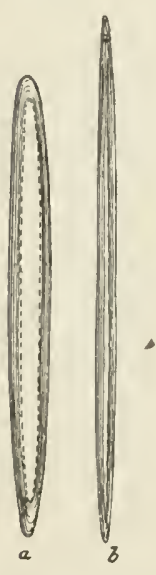

Fia. 16,-l lsolated fibers. hickory, and many, especially tropieal woods, have such thick-walled cells and so little empty or air space that they never lloat.

Here, then, are the two main factors of weight in wood: The amount of cell wall, or wood substanee, constant for any given piece, and the amount of water contained in the wood, variable even in the standing tree, and only in part eliminated in drying.

The weight of the green wood of any speeies raries chiefly as the second factor, and is entirely misleading if the relative weight of different kinds is songlit. Thus some green sticks of the otherwise lighter 'ypress and gum sink more reatily than fresh oak.

The weight of sapwood, or the sappy peripheral part of our common lumber woods, is always great, whether ent in winter or summer. It rarely falls much below 45 pounds and commonly exceeds in pounds to the cubie foot. even in our lighter wooded speeies.

It follows that the green wood of a sapling is hearier than that of an old tree, the fresh wood from a disk of the upper part of a tree often heavier than that of the lower part, and the wool near the bark heavier than that nearer the pith, and also that the advantage of drying the wood before shipuing is most important in sappy and liglit kinds.

When kiln dried, the misleading moisture factor of weight is nniformly redueerl and a fair comparson possible. For the sake of convenience in complatison the weight of wood is expressed either as the weiglit per cubie foot, or, what is still more convenient, as sperifie weight or density. If an ohl longleaf' pine is cut np as shown in fig. 17, the wood of disk No. 1 is heavier than that of disk No. 2 , the latter heavier 
than that of disk No. 3 , and the wood of the top alisk is found to be only about three-fomths as heary as that of disk No. 1.

Similarly, if disk No. "2 is (ut up) as in the figure, the specific weight of the difterent pieces is:

$$
\begin{array}{r}
a \text { about } 0.52 \\
b \text { about } 0.61 \\
c \text { about } 0.67 \\
d, e, f \text { about } 0.65
\end{array}
$$

showing that in this disk, at least. the wood formed during the many

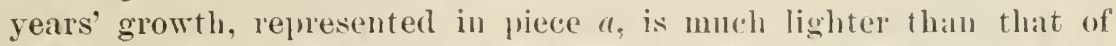
former years. It also shows that thr best wood is the mudale part. with its large proportion of dark summerwood bands.

Cntting up all disks in the same way, it will be found that the piece $a$ of the first disk is heavier than piece $a$ of the fifth, and that piece $c$ of the first disk excels the piece $c$ of all the other disks. This shows that the wood grown during the same number of years is lighter in the upper parts of the stem; and if the disks are suoothed on their radial surfaces and set nu) one on top of the other in their regular order for sake of comparison, this decrease in weight will be seen to be accompanied by a decrease in the anount of summer wood. The color effect of the npper disks is eonspicuously lighter.

If our old pine had been cut one humdred and fifty years ago, before the outer, lighter wood was laid on, it is evirlent that the weight of the wood of any one disk would have been found to inerease from the center outward, and no subsequent decrease could have been observed.

In a thrifty young pine, then, the woor is heavier from the center ontwatd, and lighter from below upward; only the wood laid on in

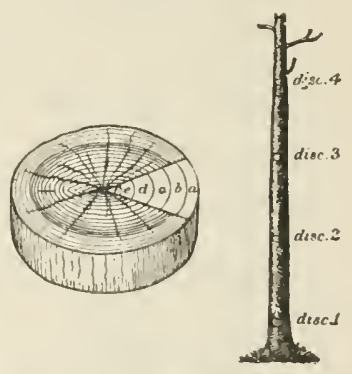

FIG. 17.-( )rientation of wool sample:s. old age falls in weight helow the average. The number of bownish bands of summer wool are a direst indication of these differences.

If an old oak is cnt up) in the same manner, the butt ("ut is also found heaviest and the top lightest, but. unlike the disk of pine. the disk of oak has its firmest wood at the center and each successive piece from the center ontward is lighter than its inner neighbor.

Examining the pieces, this difference is not as realily "xplained by the appearance of each piece as in the case of pine woor. Nevertheless, one couspicuons point appears at once, the pores. so very distinct in oak, are very minute in the wood near the center and thins the wood is far less porous. Studyiug different trees it is found that, in the pines, wood with narrow rings is just as heavy as, and often heavier than the wood with wirler rings, but if the rings are musmally narrow in any part of the disk the wood has a lighter color; that is, there is less summer wood and therefore less weight.

In oak, ash, or elm trees of thrifty growth, the rings fairly wide not less than one-twelfth inch), always form the heaviest wood, while any 
pieee with very narrow rings is light. On the other hand, the weight of a piece of hard maple or birch is quite independent of the width of its rings.

The bases of limbs (knots) are usually heary, very heary in conifers, and also the wool which surromuls them, but generally the wood of the limbs is lighter than that of the stem, and the wood of the roots is the lightest.

In general, it may be said that none of the native woods in eommon use in this comntry are, when thy, as heary as water, i. e., 62 pounds to the enbic foot. Few exceer 50 ponnds, while most of them fall below 40 pounds, and much of the pine and other coniferons wood weighs less than 30 pounds per cubic foot.

The weight of the wood is, in itself, an important quality. Weight asists in distinguishing maple from poplar. Lightness, eonpled with great strength and stiffiness, recommends wood for a thousand different nses. To a large extent weight predicates the strength of the wood, at least in the same species, so that a heavy piece of oak will exceed in strength a light piece of the sune species, and in pine it appears probable that, weight for weight, the strength of the wood of various pines is nearly equal.

Weight of kiln-dried wood of different speeies.

(a) Very heavy woots:

Hickory, vilk, prsinmon, osage orange, black lorust, hackberry,

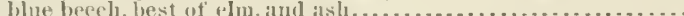

(b) Ileary wools:

Ash, elm. (lherry, bir.h, maple, heeh, walunt sour gum, coflee tree, buney locust, brst uf soutlueru pine, and timiarick........

(c) Wools of neilium weight:

conthern piue, pitelt pine, taunarack, Inunglas spruee, western hemlock, swipt gum, soft maple, syeamore, sassalfras, mul.

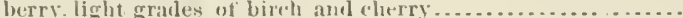

(d) Light wools

Norway aml inll pine, red ewlar, cypriss, lumbek, the heavier spruce and tir, reaiwoul. bassworkl, chestunt, hutternut, tulu, eatalpa, buckere, leavier grarles of poplar ...................

(e) Tery lierlit wouds:

White piue, spruee, tir, white redar, poplar

\begin{tabular}{|r|r|r}
\hline \multicolumn{2}{|c}{ Approximate. } \\
\hline $\begin{array}{l}\text { Specific } \\
\text { weigbt. }\end{array}$ & $\begin{array}{r}\text { Treight of }- \\
\text { 1 cubic } \\
\text { fuot. }\end{array}$ & $\begin{array}{c}1,000 \text { feet } \\
\text { uf lum- } \\
\text { ber. }\end{array}$ \\
\hline $0.70-0.80$ & $\begin{array}{r}\text { Tounds. } \\
42-48\end{array}$ & Pounds. \\
& 3,700 \\
$.60-.70$ & $36-42$ & 3,200 \\
$.50-.60$ & $30-36$ & 2,700 \\
$.40-.50$ & $24-30$ & 2,200 \\
$.30-.40$ & $18-24$ & 1,800 \\
\hline
\end{tabular}

For scientific names seo list, p. 72.

Since ordinary hmber contains knots and also more water than is here assmuer, and also sinco its limensions either exceed or fali short of perfeet measmrement, the tionres in the table are only approximate.

'Thus, 1,000 feet, B. M., of longleaf pine weighs:

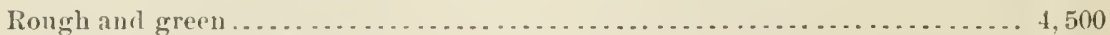

Boards, rongh but seasomed....................................... 3, 500

Boards, dressed and seasoued . . . . . . . . . . . . . . . . . . . . . . . . 3, 000

Flooring, matched, dressed and seasuned............................ 2,500

Weatherboardiug beveled and dressed............................ 1,500 


\section{III.-MOISTURE IN WOOD.}

Water may oceur in wood in three conditions: (1) It forms the greater part (over 90 per cent) of the protoplasmic contents of the living cells; (2) it saturates the walls of all cells, and (3) it entirely or at least partly fills the cavities of the lifeless cells, fibers, and ressels. In the sapwood of pine it oceurs in all three forms; in the heartwood only in the second form, it merely saturates the walls. Of 100 pounds of water associated with 100 pounds of dry wond substance in 200 pounds of fresh sapwod of white pine, about 35 pounds are needed to saturate the eell walls, less than 5 pounds are contained in living cells, and the remaining 60 pounds partly fill the cavities of the woorl niber's. This latter forms the sap as ordinarily understood. It is water brought from the soil, eontaining small quantities of mineral salts, and in certain species (maple, bireh, etc.) it also contains at certain times a small percentage of sugar and other organic matter. These organic substances are the dissolved reserve food, stored during winter in the pith rays, ete., of the wood and bark; generally but a mere trace of them is to be found. From this it appears that the solids contained in the sap, such as albumen, gum, sugar, etc., ean not exereise the influence on the strength of the wood which is so commonly claimed for them.

The wood next to the bark contains the most water. In the species which do not form heartwood the decrease toward the pith is gralual, but where this is formed, the change from a more moist to a dier condition is usually quite abrupt at the sapwood limit. In longleal pine, the wood of the outer 1 inch of a disk may eontain 50 per cent of water, that of the next, or seeond inch, only 35 per cent, and that of the heartwood only 20 per cent. In such a tree the amount of witer in auy one section varies with the amount of sapwood, and is therefore greater for the upper than the lower euts, greater for limbs than stems, and grealest of all in the roots.

Different trees, even of the same kind and from the same place, differ as to the amount of water they contain. A thrifty trec eontains more water than a stunted one, and a young tree more than an old one, while the wood of all trees varies in its moisture relations with the seatson of the year.

Contrary to the general belief a tree contains abont as much water in winter as in summer. The fact that the bark peels easily in the spring depends on the presence of incomplete, soft tissue found bet ween wood and bark during this season and has little to do with the total amount of water contained in the wood of the stem.

Even in the living tree a flow of sap from a cut ocenrs only in certain kinds of trees and under special circmustances; from boards, timber, etc., the water does not flow out, as is sometimes believed, but must be evaporated. ${ }^{1}$

'The seeming exceptions to this rule are mostly referable to two causes, namely: (a) Clefts or "shakes" will allow water contained in them to flow ont. (b) From sound wood, if very sappy, water is forced out whenever the wood is warmed, just as water flows from green wood in the stove. 
The rapidity with which water is evaporated, that is, the rate of drying, depends on the size and shape of the piece and on the strueture of the wook. An inch board dries more than four times as fast as a 4-inch plank and more than twenty times as fast as a 10-inch timber. White pine dries faster than oak. A very moist piece of pine or oak will, during one hour, lose more than four times as much water per square inch from the cross section, but only one-half as much from the tangential, as from the ralial seetion.

In a long timber, where the end or cross seetions form but a small part of the drying surfice, this difference is not so evident. Nevertheless, the ends dry and shrink first, and being opposen in this shrink. ing by the more moist alljoining parts, they check, the cracks largely disappearing as seasoning progresses.

High temperatures are very effective in evalorating the water from womb, no matter how humid the air. A fresh piece of sapwood may lose weight in bonling water. and can be dried to quite an extent in hot steam.

Lept on a shelf in an ordinary dwelling wood still retains $S$ to 10 per cent of its weight of water, and always contains more water per pomnd than the surrounding air. Nor is this amount of water constant; the weight of a pan full of shavings varies with the tme of day, being on a summer day greatest in the morning and least in the afternoon.

Desiceating the air with chemicals will canse the wood to dry, but wood thus dried at $80^{\circ} \mathrm{F}$. will still lose water in the kiln. Wood dried at $1200^{\circ} \mathrm{F}$. loses water still if dried at $2000 \mathrm{~F}$., and this again will lose more water if the temperatme is raised. So that absolutely dry wood ean not be obtained, and rhemical destruction sets in before all the watei is driven off.

On removal fiom the kiln the womi at once takes un water from the dir, even in the driest weather. At first the absorption is quite rapid; at the end of a week a short piece of pine, $1 \frac{1}{2}$ inclies thick, has regained two-thirds of, and, in a few months, all the moistme which it had when air dry, 8 to 10 per cent, and also its former dimensions.

In thin boards all parts soon attain the sanne degree of dryness; in lieavy timbers the interion remains moister for many months, and even years, than the exterior parts. Finally an equilibrium is reached, and then only the outer parts change with the weather.

With kiln-hlieil wook all parts are equally dy, aml when exposed the moisture coming from the air.unust pass in through the onter parts, and thus the order is reversed. Ordinary timber requires months before it is at its best; kiln-dry timber, if properly landled, is prime at once.

Dry wood, when soilied in water, soon regains its original volmme, and in the heartworl portion it may eren surpass it: that is to say, swell to a larger dimension than it hat when green. With the soaking it continues to increase in weight, the cell cavities filling with water, 
and if left many months all pieces sink. Yet even after a year's immersion a piece of oal 2 by 2 inches and only (inches long still contains air, i. e., it las not taken np all the water it can. By rafting, or prolonged immersion, wood loses some of its weight, soluble materials being leached out, but it is not impiriren either as fuel or as building material. Immersion and, still more, boiling and steaming reduce the lyggroscopicity of wood and, therefore, also the troublesome "working" or shrinking and swelling.

Exposure in dry air to a temperature of $3000 \mathrm{~F}$ for a short time reduces, but does not destroy, the hrgroseopicity and with it the tendency to shrink and swell. A piece of red oak, which has been sulr. jected to a temperature of over $300{ }^{\circ} \mathrm{F}$., still swells in hot water and shrinks in the kiln.

In artificial drying, temperatures of from $158^{\circ} \mathrm{F}$. to $180^{\circ} \mathrm{F}$. are usually employed. Pine, spruce, eypress, cedar, etc., are dried fresh from the saw, allowing fonr days for 1-inch boards; lard woods, especially oak, ash, maple, birch, sycamore, etc., are air-seasoned for three to six months, to allow the first slırinkage to take place more gradually, and are then exposed to the above temperatures in the kiln for abont six to ten days for 1-inchl lumber. Freshly cut poplar and cottonwood are often dried directly in kilns.

By employing lower temperatures, 1000 to 1200 F.. green oak, ash, etc., can be seasoned in dry kilns without danger to the material. Steaming the lumber is commonly resorted to in orler to prevent elreck. ing and "casehardening," but not, as has freqnently been asserted, to enable the board to dry. Yard-dried lumber is not dry, and its moist. ure is too unevenly distributed to insure good beharior after maunfueture. Careful piling of the lumber, both in the yard and kinn, is essential to goorl drying. Piling boards on edge or standing them on encl is believed to hasten drying. This is true only because in either 'alse the air can circulate more freely around them than when they are pilen in the ordinary way. Boards on end dry medpally: the upper halt Iries much faster than the lower halt and horizontal piling is, therefore, preferable.

Since the proportion of sap and heart wood varies with size. age, species, and individual, the following figures must be regarded as mere approximations:

Pounds of water lost in drying 100 pounds of green wood in the kiln.

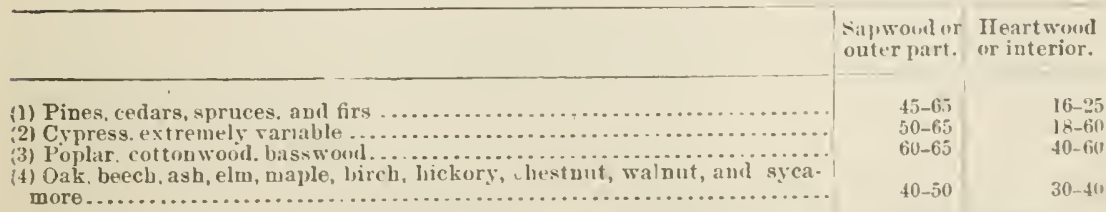

The lighter kinds bare the most water in the sapweml, thus sycaurore has more than hirkory. 


\section{IV.-SHRINKAGE OF WOOD.}

When a short piece of wood tiber, such as that shown in fig. $18, A$, is dried it shrinks, its wall grows thinner (as moluated by dotted lines),
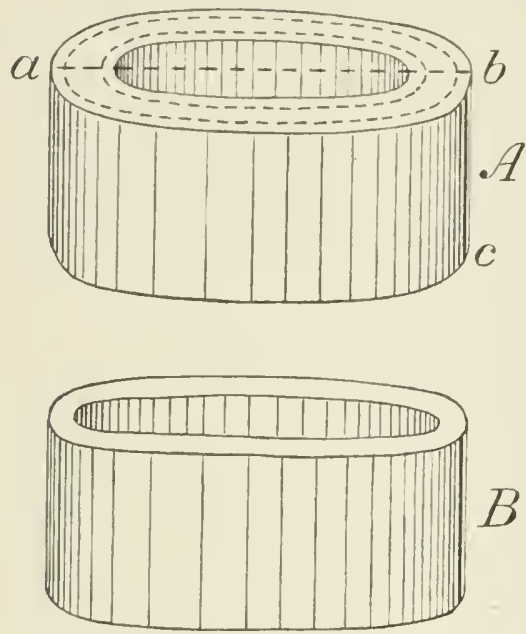

Fig. 18. Short pieces of wood tibors, one thick, the other thin wallid, magntied. its width, $\| b$, the thickness of the fiber, becomes smaller, and the cavity or openung larger, but, strallge to say, the helght or length, $b c$, remains the same. In a smimiar piece of tiber with a thumer wall (fig. 1S, B) the effect is the same, but the wall being only lialf as threk the total change is only about half as great.

If sections or pieces of fibers are driel and then placed on moist blotting paper, they will

$B$ take up witel and swell to their original size, thongh the water las been taken n) only by their walls and none has enteled into their openings of luminil. Tluis inclicates that the water in the cavity or humen of a tiber has nothing to do with its dimensions, and that if the cell walls
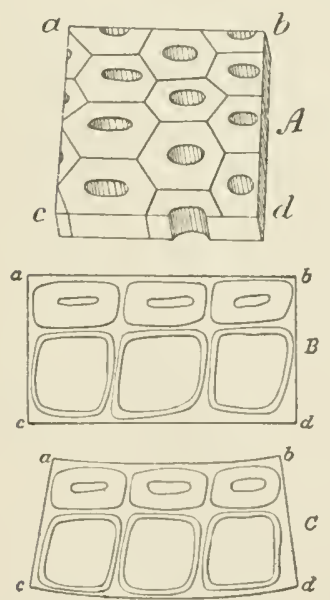

Flg. 20.- Warping w wool are saturated it makes no difference in the rolume of a block of pine wood whether the cell cavities are empty as in the heartwor or three fourths filled

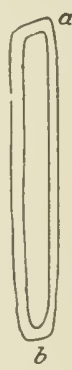

1.16. 19, Irolated c..ll. as in the sapwood.

If an entire tiber, as shown in fig. 19, is dried, the wall at its ends " and $b$, like those of the sides, grow thimner, and therely the length of the entire rell grows shorter. Since this length is often a humbled or more times as great as the dianeter, the effect of this shrinkage is inappreciable; and if a long board slorinks lengthwise, it is largely due, as we shall see, to quite another cause.

A thin cross section of several fibers (see fig. 2()$, A)$ like the piece of a single fiber shrinks when dried, the wall of earh filser becomes thiuner, and thms each piece smaller, and the piece on the whole necessarily

1 Thongh generally true, it must not be supposed that the fibers of all species, or even the filsers of the same tree, shrink exactly in proportion to the thickuess of their walls. 
shares this diminution of size, the distances, $a b$ and $" d$, each becoming shorter. Where the cells are very similar in size and in the thickness of their walls, as in the case of piece $A$, fig. 20, " $l$ and $c$ d become shorter by about the same amonnt; but if the piece is male up of fibers, some of which have thin and others thick walls, as picee $B$, fig. 2 (), then the row of thick-walled cells shrinking nuth more than the row of thin-walled cells, the piece becomes mevenly shmuk or warped as shown in fig. 20, $C$. Not only is the piece warped, but the force which led to this warping continues to strain the interior parts of the piece in different directions.

Since in all our woods cells with thiek walls and cells with thin walls are more or less intermixed, and especially as the spring wood and summer wood nearly always differ from each other in this respect, strains and tendencies to warp are always active when wood dries out, because the summer wood shrinks more than the spring wook, heavier wook in general more than light wood of the same kind.

If the piece $A$, fig. 20 , after drying, is

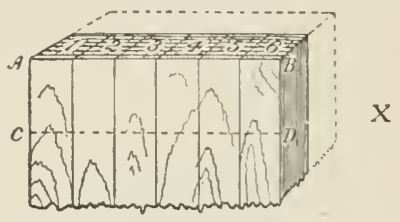
placed edgewise on moist blotting paper, the cells on the unclerside, at $c d$, take uj, moisture from the paper and swell before the mpper cells at $a b$ receive any moisture. This eanses the underside of the piece to become longer than the npper side and, as in the ease of piece $C$, warping ocenrs. Soon, however, the moisture penetrates to all the cells and the piece straighteus ont. A thin board behaves exictly like this minnte piece, only the process is slower and nore casily observed. But while a thin board of pine curres laterally, it remains quite straight lengthwise, since in this direction both shrinkage and swelling are small. A thin disk or cross

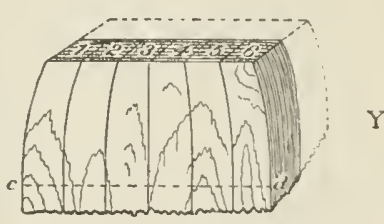
section swells, and when moistened on one side warps as readily in one direction as in another. If a green board is exposed to the sun with one side, warping is produced hy removal of water and consequent shrinkage of the upper side, and the course of the process is simply reversed.

As already stated, wool loses water faster from the end than from the longitudinal faces. Henee the ends shrink at a different rate from the interior parts.

In a timber, the width $A B$ (fig. 21, $\mathrm{X}$ ) may have shortened (lig. 21 . $Y)$, while a short distance from the end " $d$, the original wilth is still preserved. This shonld produce a bending of the parts towarl the center of the piece as shown in exaggeration at $\mathrm{K}$, but the rigility of $3521-$ No. $10-3$ 
the several prarts of the timber prevents such bending and the eonse quent strain leads to their separation as shown at $Z$, the end surface of the timber being "checked."

As the timber rlries ont, the line $:$ d becomes shorter, the parts 1 to $A$ are allowed to approach again, and the checks close up and are no longer visible.

The faster the drying at the surface, the greater is the difference in the moisture of the different parts, and hence the greater the strains and consequently also the amonnt of cliecking. This beemes very evident when fresh wool is placed in the sun, and still more in a hot kiln. While most of these smaller checks are thus only temporary, closing up agaiu, some large radial dheeks remain and even grow larger as drying progresses. Their canse is a different one and will presently be explained.

The temporary cheeks not only oceur at the ends, but are developed on the sides also, cnly to a much smaller degree. They become especially an-

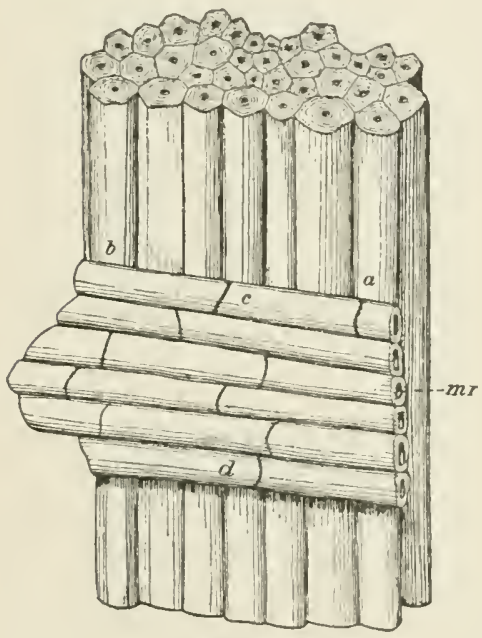

Fig. 22.-Simall pith ray in wak. $a, b$, wood fibers; $c, d$. cells of pith ray. noying on the surface of thick planks of hard woods, aud also on peeled logs when exposed to the sum.

So far we have considered the wood as if made up only of parallel fibers all placed longitudinally in the log. 'This, however, is not the ease. A large part of the wood is formed by the medullary or pith rays. In pine over 15,000 of these oecur on a square inch of a tangential section, and even in oak the very large yays, which are readily visible to the eye, represent scarcely a hundredth part of the number which the microscope reveals.

As seen in fig. 22 the cells of these rays have thei length at right angles to the direction of the rood fibers.

If " large pith ray of white oak is whittled ont and allowed to thy it is found to shrink greatly in the direction from c to d (fig. 22), while, as we have stated, the fibers to which the ray is firmly grown in the wood lo not shrink in the same direction. Therefore, in the woor, as the rells of the pith ray dry, they pull on the longitudinal fibers and try to shorten them. and, being upposed by the rigidity of the fibers, the pith ray is greatly strained. But this is not the only strain it has to bear. Since the fibers from " to b (fig. 22) slurink as much again as the pith ray in this, its longitudinal direction, the fibers tend to slorten the ray, and the latter, in opposing this, prevents the former from 
shrinking as much as they otherwise would. Thus the structure is subjeeted to two severe strains at right angles to each other, and herein lies the greatest dificienly of wond seasoning, for whenever the wood dries rapidly these fiber's have not the chance to "give" or acconmondate themselves, and hence fiber's and pith rays separate and eherks result which, whether visible or not, are detrimental in the use of the wood.

The contraction of the pith rays parallel to the length of the board is probably one of the canses of the small amount of longitudinal shrinkage which has been observed in boards.' The sualler shrinkage of the pith rays along the radius of the log (the length of the pith ray) oppos. ing the shrinkage of the fibers in this direction becomes one of the eanses of the seeond great tronble in wood seasoning. namely, the differenee in the amount of the shrinkage along the radius and that along the rings or tangent.

This greater tangential shrinkage appears to he due, in part, to the cause just mentioned, but also to the fact that the greatly shrinking bauds of summer wood are interrupted, along the radins, by as many bands of porous spring wood, while they are contin nous in the tangential direction. In this direction, therefore, each such band teuds to shrink, as if the entire piece were composed of summer wood, and since the summer wood represents the greater part of the wood substance, this tendency of greater tangential shrinkage prevails.

The effect of this greater tangential shrinkage affects every phase of woodworking. It leads to permanent cheeks, and rauses the $\log$ to split open on drying.

Sawed in two, the that sides of the log become convex, as in fig. 23; sawed into a timber, it ehecks along the median line of the four faces, and if converted
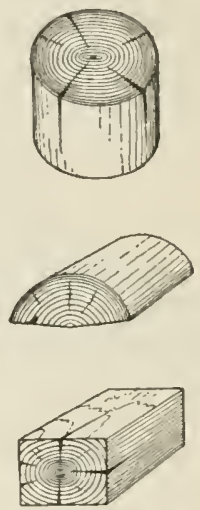
inte boards, the latter take on the forms shown in fig. 2:3, all owing to the greater tangential shrinkage of the wool.

Briefly, then, shrinkage of wood is due to the fact that the cell walls grow thinner on drying. The thicker cell walls and therefore the heavier wood shrinks most, while the water in the cell cavities does not influence the rolume of the woorl. ()wing to the great differenee of cells in shape, size, and thickness of walls, and still more in their arrangement, shrinkage is not miform in any kind of wood. This irregnlarity produces straius, which grow with the difference between

I In addition to this all filcers having an oblique position, as those at pith rars and knots, also the ohlinne, tapering ends of all fibers contribute to this longitudinal shrinkage, since one eomponent of their normal shrinkage is longitudiual. 
adjoining cells and are greatest at the pith rays. These strains eause warping and checking, but exist even where no ontward signs are risi. ble; they are greater if the wood is dried rapidly than if dried slowly, but can never be entirely aroiled.

Temporary checks are cansed by the more lapid drying of the onter parts of any stick: permanent checks are dne to the greater shrinkage, tangentially, along the rings than that along the radius. This, too, is the cause of most of the ordinary phenomena of shrinkage, such as the difference in behavior of entire and quartered logs "bastard" (tangent) and "rift" (radial) boards, ete., and explains many of the phenomena erroneonsly attributed to the influsuce of bark, or of the greater shrinkage of onter and inner parts of any log.

(nee dry, wood may be swelled again to its original size by soaking in water, boiling, or steaning. Soaked pieces, on drying, shrink anain as before; boiled and steamed pieces do the same, but to a sliwhtly less degree. Neither hygroseopicity, i. e., the eapacity of taking up water, nor shrinkage of wood ean be overcome by drying at temperatures below $2000 \mathrm{~F}$. Higher temperatmes, however, reduee these pualities, but nothing short of a coaling heat robs wood

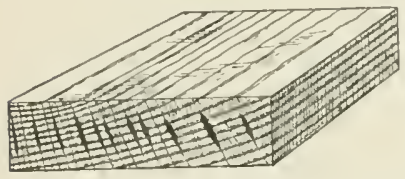

Fin. 24.- "llonescombed" buaral. The eliecks or eracks form along the pith rays. of the eapacity to shrink and swell. Rapidly dried in the kiln, the wood of oak and other larkl woods "ease-harden," that is, the outer part dries and shrinks before the interior has a chance to do the same, and thus forms a firm shell or ease of shrunkell, commonly rheeked wood around the interior. Thisshell does not prevent the interior from drying, but when this drying oerur's, the interior is commonly checked along the mednllary rays, as slow wn in fig. ‥t. In prartice this occurrence ean be prevented by steaming the lumber in the kiln, and still better by drying the wood in the open air or in a shed lefore placing in the kiln. Since only the first shrinking is apt to eheek the wood, any kind of lumber which has once been air dried (three to six months for 1 -inch stufi') may be subjected to kiln heat without any danger. Kept in a bent or warped eondition during the first shrinking, the wood retains the shape to which it was bent and firmly opposes any attempt at subserquent straightening.

Sapwool, as a mle, shriilis more than heartwood of the same weight, but very heavy heartwood may shrink more than lighter sapworl. The amonut of water in wood is no criterion of its shrinkage, since in wet wood most of the water is held in the eavities, where it has no efiect on the volume.

The wood of pine, spruce, "Ypress, ete, with its very regular structure, dries and shrinks evenly and suffers much less in seasoning than the wood of broalleafed trees. Among the latter, oak is the most diffenlt to dry withont injury. Simall-sized split ware and "rift" boards season better than ordinary boards and plauks. 
To avoid "working" or warping and checking, all high-grale stock is carrefully seasoned, preforalbly in a kiln, hofore mannfacture. Thicker pieces may be marle of several parts ghed together; larger sulfures arr

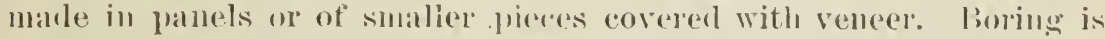
sometimes iesorted to to prevent the cherking of woorlen colmmms.

Since repeated swelling increases the injuries due to seasoning, woor should be protected against moistme when once it is lly.

Since the shrinkage of on wools has never been cirefully stuchierl, and since wood, even from the same tree, varies within considerible limits. the figures given in the following table are to be regarder as mere approximations. The shrinkage alomg the raclius and that along the tangent (parallel to the rings) are not stated separately in tho following table, and the figures represent an average of the shrinkane in the two directions. Thus, if the shrinkage of soft pine is given at 3 inches per humdred, it means that the snm of radial and taugential shrinkage is about i inches, of which about 4 inches fall to the tangent and : inches to the raclius, the ratio between these varying from 3 to 2 , al latio which practically prevails in most of our woods.

Since only an insignificant longitudinal shrinkage talies place (being commonly less than 0.1 incl per humiled), the rhauge in volume ruming llying is about, equal to the sum of the radial and tangential shrinkage, or twice the amount of linear shrinkage indicated in the table.

Thus, if the linear avrage shrinkage of soft pine is 3 inches per lnundred, the slurinkage in volume is abont 6 enbic inches for each 10() rolbic inches of fresh wood.

Approximate shrinkage of a board, or set of boards, 100 inches wide, drying in the open air.

Sirinkage.

(1) All light conifers (soft pine, spruce, cedar, cypress)

Incher.

(2) Heary conilers (hard jine, tamarack, yew), hone locust hox elder, wood of oli vaks...

(3) Asl, elu, waluut, ponlar, male beech syeauore, cheiry, black locust.

(4) Basswond, hirch, chestnut, horse ehestunt, blue beech, joung locust..

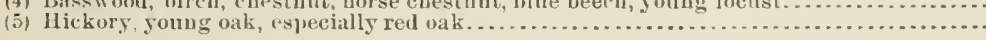

is

\section{V.-MECHANICAL PROPERTIES OF WOOD}

Every joist and studding, every rafter, sash, and door, the chair we sit on, the floor we walk on, the wood of the wagon or boat we risle in are all contimally tested as to their stiffuess and strength, their hard. ness and tonghness. Every step from the simple splitting of a shingle, or stave to thre construction of the most elegant carriage or sideboard involves a knowledge, not only of one, but of several, of the mechanienl properties of the material.

In the shop the fitness of the wood for a given purpose never depends on any one puality alone, lut inrariably mpon a combination of several qualities. A spoke must not only be strong, it must be stifi' to bold its 
shape. it must be tomgh to avoid shattering to pieces, and it must also be hark or else its teums will berome lonse in theil mortises.

Selecting wood in this way, the worlworker has learned almost all that is at present linown abont his material, but in many cases the great difficnlty which always attends the jurgment of complex phenomeua has led to erroneons anclusions, and not a few well-establisherl beliet's have their origin more in accidental errol of observation than in finct.

The experimenter endeavor's to aroid this complexity by testing the wood for each kind of resistance separately; when tested as to their stiffiness, the pieces are all shaped, placed, and loaded alike. The wood is selected with a letinte object in view: it is green or dry, rlear or" knotty, straight or erossgrained, according as he wishes to fuul out the influence of each of these conditions. If pine and oak are to be compared, the pieces are from the same position in the tree and are tried under exactly the sine conditions, and thus the case is simplified.

But even results thus arrived at ean not be used indiscriminately, and the figures on the strength of oak given in any book must not be sup)posed to apply to all oak. if tested in the given manner. This is due to the fact that a piece of wool is not simply a material but a structure, just as much as a railroald bridge or a balloon frame, and as such varies greatly even in the wool of the same tree, nay, more than that, even in the same year's growth of the same cross section of a log.

A scantling resists bending: it is stiff. On removal of the load it straightens; it is elastic. A column, a pro], or the spoke of a wagon wheel resists being crushed endwise. So does the upper side of a joist or beam when loaded, while the underside of the beam or of an ax handle sufters in tension. The teuons of a window sash or door tend to breali ont their mortises. the wood has to resist shearing along the fibers: the steel erlge of the eye tends to ent into the hammer handle, it tries to shear it across the grain, and every nail, screw, bore hole, or mortise tends to split the board and tries the wood as to its cleavability, while all "bent" ware, from the wicker basket to the one-pieee felly or ship"s knee, involves its flexibility.

\section{STIFFNESS.}

If 100 pounds placed in the middle of a stick 2 by 2 inclies and 4 feet long, supported at both ends, bend or "detlect" this stiek one.eighth of" an inch (in the middle), then 200 pounds will bend it about one-fourth inch, 300 poumls three-eighths inci, the detlection varying directly as the load. Soon, however, a point is reached where an additional 100 pounds adds more than one eighth inch to the deflection-the limit of elasticity has been reached. Taking another piece from the straight grained and perfectly elear plank of the same depth and wioth, but is feet long, the load of 100 pounds will anse it to bend not only oneeighth inch, but will deflect it by about 1 ineh. Doubling the length 
reduces the stiffness eightfold. Stiffiness then froreases as the rube of the length.

Cntting out a piece " by 4 inches and 4 feet long. placing it flatwise so that it is double the width of the former stick and loading it with 100 ponuds, we fund it bending only one-sixteenth inch; doubling the width doubles the stiffurss.

Setting the same 2 by 4 inch piece on edge, so that it is "2 inches wide and 4 inches reep, the load of 100 pounds bends it only about one sixty-fourth inch: donbling the thickness inereases the stiffiness ahont eightfold.

It follows that if we double the length and wish to retain the same stifliness we must also domble the thickness of the piece.

A piece of wood is usually stiffer with the anmul lings set vertically than if the rungs are placed horizontally to the load.

Crossgrained and linotty woor, to be sure, is not as stiff as clear lumber; a knot w the upper side of a joist; which must resist in compression, is, however, not so detrimental as a knot on the lower side. where it is tried in tension.

Every large timber which comes from the central part of the tree contains linots, and much of its wood is

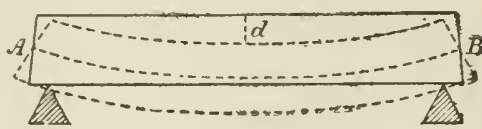

Fic. 25.-Bezdivg at beam. ent more or less obliquely across the grain, both conditions rendering such material eomparatively less stiff than small clear pieces.

The same stick of pine, green or wet, is only about two-thirds as stiff as when dry. A heary piece of longleaf pise is stiffer than a light piece; heavy pine in general is stiffer than light pine, but a piece of hickory, although heavier than the pine, may not be as stiff as the piece of longleaf pine, and a good piece of larch exceeds in stifiness any oak of the same weight.

In the same tree stiffuess varies with the weight, the heaviel wood being the stiffer; thus the heavier wood of the butt log is stiffer than that of the top; timber with much of the heary summer wood is stiffer than timber of the same kind with less summer wood. In old trees (of pine) the center of the tree and the sap are the least stiff; in thrifty young pine the center is the least stitf, but in young second growtl hard woorls it is the stiffest.

Since it is desirable, and for many purposes essential, to know before hand that a given piece with a given load will bend only a given amount, the stiffness of wood is usually stated in a uniform manner and under the term "modulus (measure) of elasticity."

If $\mathrm{AB}$, fig. 25, is a piece of wood, and il the deflection produced by a weight or load, the elisticity of the wood, as usually stated, is found by the formula:

$$
\text { Modulıs of elasticity }=\quad \begin{aligned}
& \mathrm{W} l^{3} \\
& 4 \mathrm{D} b d^{3}
\end{aligned}
$$


where $W$ is the weight. $l$ the length. $b$ and $d$ the breadth and depth of the stick. and I) the deflection for the load W. lu the tollowing table the wools are grouperl ateculing to their stiffiness. The figures are only rough approximations which are based on the data given in Vol. IX of the Tenth c'ensus. Thr first column contains the above modulus, the second shows how many pounds will produce a deflection of 1 inch in a stick 1 by 1 by 12 inches, assuming that it could endure sneh bending within the limits of elasticity. and the third column gives the number of pounds which will bend a stick 2 by 2 inches and 10 feet long through 1 inch.

The stick is assumed to rest on both ends; if it is a cantilever, i. e., fastened at one end and loaderl at the other, it bears but laalf as inuch load at its end for the same deflection.

From the third column it is easy to find how many poumls would bend a piece of the same kind of other dimensions. A 2 by 4 inclu bears aight, a 2 by 6 inch twenty-seren times as much as the 2 by 2 inch: a [neces feet long is about twice as stiff as a 10.foot piece; a piece 12 feet, only about three-fifths. 14 feet one-third, 16 feet twoninths, 18 feet one-sixth, and 20 feet one-eighth as stiff.

The number of poumds which will bend any piece of sawed timber by 1 inch may be found by using the formula:

$$
\text { Necessary weight }=\frac{4 \mathrm{E} b d^{3}}{l^{3}}
$$

where $\mathrm{E}$ is the figure in the first column, $b, d, 1$, breadth, depth, and length of the timber in inches. If the deflection is not to exceed onehalf incl. only one-half the load, and if one-fourth inch, only onc-funth the loakl, is permissible.

To allow for normal irregularities in the structure of wool itself: as well as in the aggregate structure of timbers, an allowance is mate on the numbers which have been fond by experiment; this allowance is called the "factor of saffety." Where the selection ol" the wood is not very perferet, the load is a variable one, and the safety of human life depends on the structure, the factor is usually taken quite ligh, as muth as 6 or $10, i$. e., only one-sixth or one-tenth of the fignres given in the tables is considered sof "and the beam is made six to ten times as heavy an the calculation requires. 
Table of stiffness (modulns of elesticity) of dry wood.-Cieneral aterages.

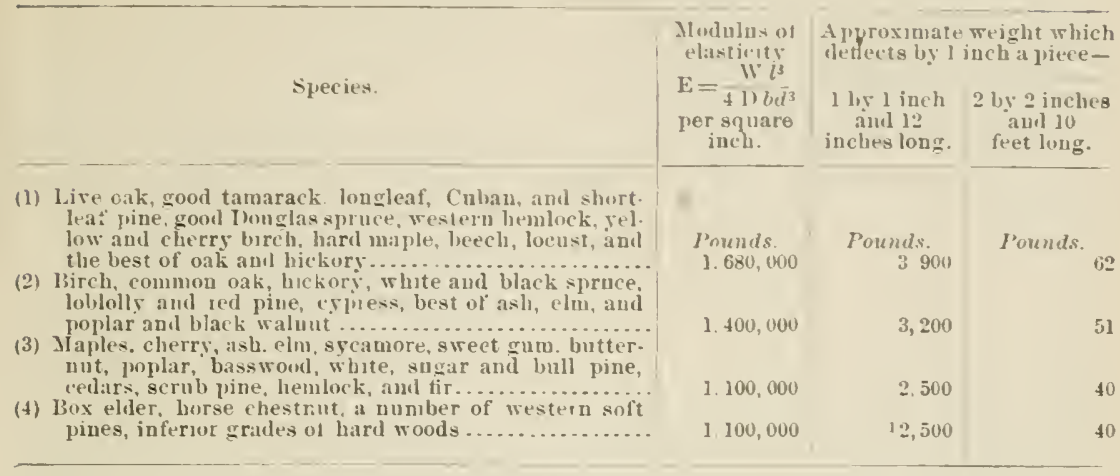

less than.

CROSS-BREAKING OR BENDING STRENGTH.

When the addition of 100 pounds to the load on our 2 by 2 inch piece begins to add more than one-eighth inch to the deflection, that is. when the stick has been bent beyond its " elastic limit." it still requires an increase of 30 to 50 per cent to the load before the stick breaks. The load which is borne before the lumit of elasticity is reached indicates the strength of the wood up to this important point; the load which causes it to break represents its absolnte strength, or the "cross-breaking or bending strength" as it is commonly called.

In longleaf pine the former (modulus of sti ength at the elastic limit). is commouly about three-fourths of the latter. If left loaded for a considerable time, a load but little greater than that which brings the stick to its elastic limit will eanse it to break, and this load should therefore not be exceeded.

Unlike the stiffness. the strength of a timber varies approximately with the squares of the thickness and decreases directly with increasing length and not with the enbe of this latter dimension. Thus, if our piece 2 by 2 inches and + feet long can bear 1,000 pounds before it breaks, a $\stackrel{2}{\circ}$ by + inch land that will break with abont 2.000 pounds, and if set edgemse, it requires about 4,000 ponnds to breals it, while a piece of the same kind of 2 by 2 inches, and donble the length ( $S$ feet). breaks with half the original load, or only 500 pounds.

All conditions of the material which influence the stifiness also influence the bending strength. Seasoning increases, moisture decreases, the strength: knots and crossgran depress it and both are more dangerous on the lower than on the upper sicle. lint while the conifers with their simple cell strueture excel in stitiness, the better hard woods

The elastic limit in this case is somewhat of an arbitrary quantity, namely, the point where 100 pounds produces a deflection 50 per cent greater than tho preceding 100 pounds. 
develop the greater strength in bending. like elasticity and stiffness, the strength is expressed in a nniform manner by the so-called "modn. lus of rupture," to permit realy estimation of the strength of any given piece. Thus modulus refers to the resistance which the parts most strained, "the extreme fiber," officl. For reasons above staterl, in mratien a fartor of safety is emplogerl. as in all these calculations of resistance. The figures nsually tabulated are obtained by the formula:

$$
\text { Strength of extreme fiber }=\frac{3 \mathrm{Wl}}{2 b \mathrm{rl}^{2}}
$$

where $W$ is the breaking load, $l$ the length, $b$ and $/$ the brealth and depth of the tested piece of wood.

The following table presents our common woods grouped as to their strength in bendmg. The load, as before, is supposed to act altogether in the middle. Column 1 gives the strength of the extreme tiber, as explained above; column 22 , the number of pounds which will break a prece $1 \mathrm{by} 1 \mathrm{inch}$ and $i 2$ inches long, and column :3, the strength of a stick "2 by "2 inches and 10 feet long, from which the strength of any given liece can reahly be estimated, allowing, however, for defects, which increase with the size. Thus, if a good piece of pine 2 by 2 inches and 10 feet long breaks with 400 poinds, a 2 by 4 ineh set on edge requires 1,600 pounds, a 2 by 6 ineh, $3,(i 00$ pounds, a 22 by 8 inch piece 6,400 pounds to break it. If a piece $2 \mathrm{by}+$ inches and 10 feet long breaks with 1,600 pomnds, a 2 by 4 inch and 12 feet long piece breaks with about 1,300 pounds, one 16 feet with 1,000 pounds, etr., and if a factor of safety of 10 is allowed, only one-tenth of the above loads are permissible.

A board one-half inch by 12 inches and 10 feet long contains as much wood as a 2 by 3 inch of the same length, and if placed edgewise should ofler four times as mueh resistance to breaking. Owing to its small breadth, however, it "twists" when loaded, and in most eases, therefore, bears less than the 2 by 3 inch. 'To prevent this twisting, joists are bracell, and the deptl of timbers is made not to exceed four times their thickness.

Short deep pieces shear ont or split before their strength in bending ean fully be called into play. 
Strength in eross-breaking of well-seasmed, selert pieres.

\begin{tabular}{|c|c|c|c|}
\hline & \multirow{2}{*}{ 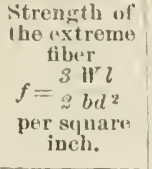 } & \multicolumn{2}{|c|}{$\begin{array}{l}\text { Approximate weight } \\
\text { which breaks a stick- }\end{array}$} \\
\hline & & $\begin{array}{l}1 \text { ly } 1 \text { inch } \\
\text { and } 12 \text { inches } \\
\text { long. }\end{array}$ & $\begin{array}{l}2 \text { by } 2 \text { inches } \\
\text { and lo firet } \\
\text { long. }\end{array}$ \\
\hline 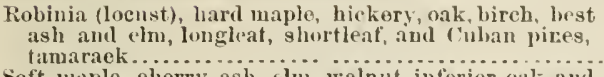 & \multirow[t]{3}{*}{$\begin{array}{l}\text { I"ounds. } \\
13,000\end{array}$} & $\begin{array}{l}\text { l'ounds. } \\
720\end{array}$ & \multirow[t]{3}{*}{$I^{\prime} m$ ind.s. } \\
\hline 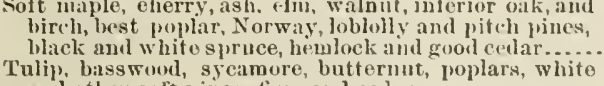 & & 550 & \\
\hline 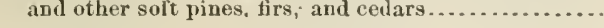 & & 350 & \\
\hline
\end{tabular}

\section{TENSION AND COMPRESSION.}

When a piece of wood is pulled lengthwise, in the manner shown in fig. 26 , part of the fibers are torn asunder. or broken, but many are merely pulled or shredded out from between their neighbors. Since failure in tension thus involves lateral adhesion as well as strengtl of fibers, it is affeeted not only by the nature and dimensions of the fibers but also by their arrangement. Owing to their transverse position the medullary rays (a large part of all woods) offer but one-tenth to one-twentieth as much resistance as the main body of fibers and moreover weaken the timber by disturbing the straight course of the fibers and the regularity of the entire structure.

The resistance is also
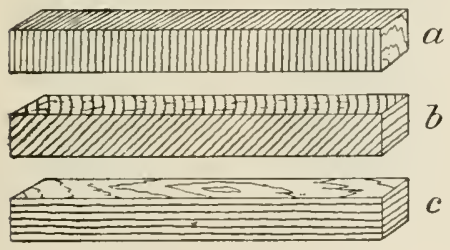

FIG. 27.-_t traight and cross grained wood.

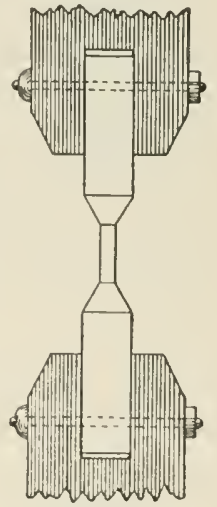

Fig. 26.-Specimen in tension test. grained piece $a$ (fig. 27 ) sustaius but about one-tenth to onetwentieth of the load which is supporterl by the straight-grained piece $c$, and it is evident that the piece $b$, which represents the ordinary case of crossgrain, is likewise weakened by the oblique position of the grain.

This explains the retrimental i fluence of a knot on the mulerside of a board, as in fig. 2S. Sinee the lower side of the board, in bending, is stretelied, the upper side being compressed, the fibers of the lower side

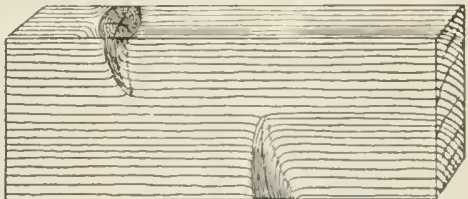

Fig. 28.-Enect of knots and their position. are subjected to teusion and the wood of the knot, like the piece of crossgrained wood, offers but little resistance. Commonly the defect is greatly increased by a season eheck in the knot itself, so that the knot affects the strength of the board like a saw cut of equal depth. 
Testerl in compression endwise (fig. e?), the fibers act as so many hollow columms firmly grown together, and when the Inirl beentes too

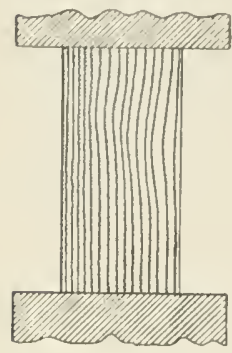

Fig. 29.-Compression endwise. great the piece fails in the manner illustrated in fig. 31. This failure is a very amplex phenomenon; in wool like pine the fibers of the plain in which failure ocems hecome separaterl into small bodies; they tear apart and cease to behave as one solid body but act as a large number of very small independent pieces. Like the strands of a rope these small borlies offer but little resistance to compression; they bend over. and the piece "buckles."

$1 \mathrm{t}$ is evirlent that a vertical position and a regular arraingement of the fibers increase the resistance, and that therefore the mednllary rays and oblique position of fibers in crossyrained and knotty timber tend to reduce the strengtli in compression.

From the following table of strength in tension and compression it will be seen that these two are not always
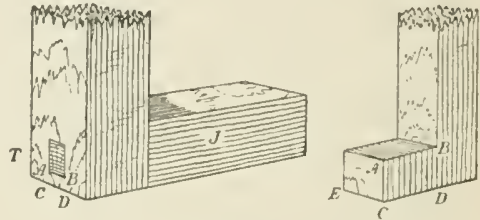

Fia. 30.- Longitulinal shearius. moportional, the stiffer conifers excelling in the latter, the tomgher laard woods in the former:

Ratio of strength in tusion und compression, shoming the difference between rigid comifers and touyh hard words.

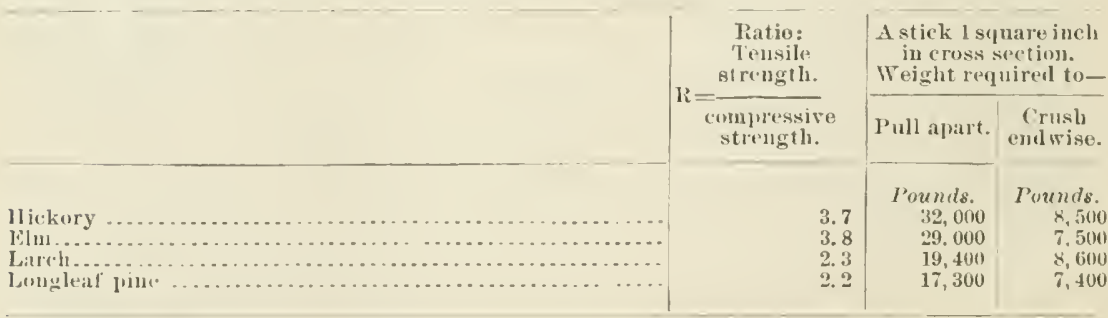

strength in compression of common Americun woods in rell-seasoned select pieces.

[Aproximate weight jer squaro iuch of cross section requisite to erush a piece of wool endwise.]

(1) black locust, yelluw and cherry birch, bark unple, best hickory, longleaf and Cuban pines, and tamatack........................ $4,000+$

(2) Common hickory, oals, hirch, soft maple, walnnt, goool elm, best ash, shortleaf and loblolly pines, westeru hemlock, and louglas fir . . . . . 7, $060+$

(3) Ash, syeanore, beceh, infurior oak, Pacifie white cerlar, canoe cerlar, Lawson's cypress, common red cedar, cypress, Norway and superior

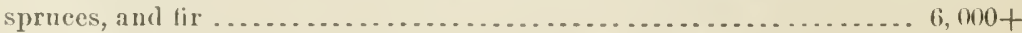

(4) Tulıp, basswood, butternut, chestnut, good poplar, whitoand other common soft pines, lemlokk, spruce, and tir . . . . . . . . . . . . . . . 5, $000+$

(5) Soft poplar, white cedar, and some western soft pines, and firs....... 4,000+ 


\section{SHEARING.}

When, in a structure like that shown in fig. 30, a weight is placed on $J$ and the tenon $T$ by downward pressure breaks out the piece $A I B C I$,
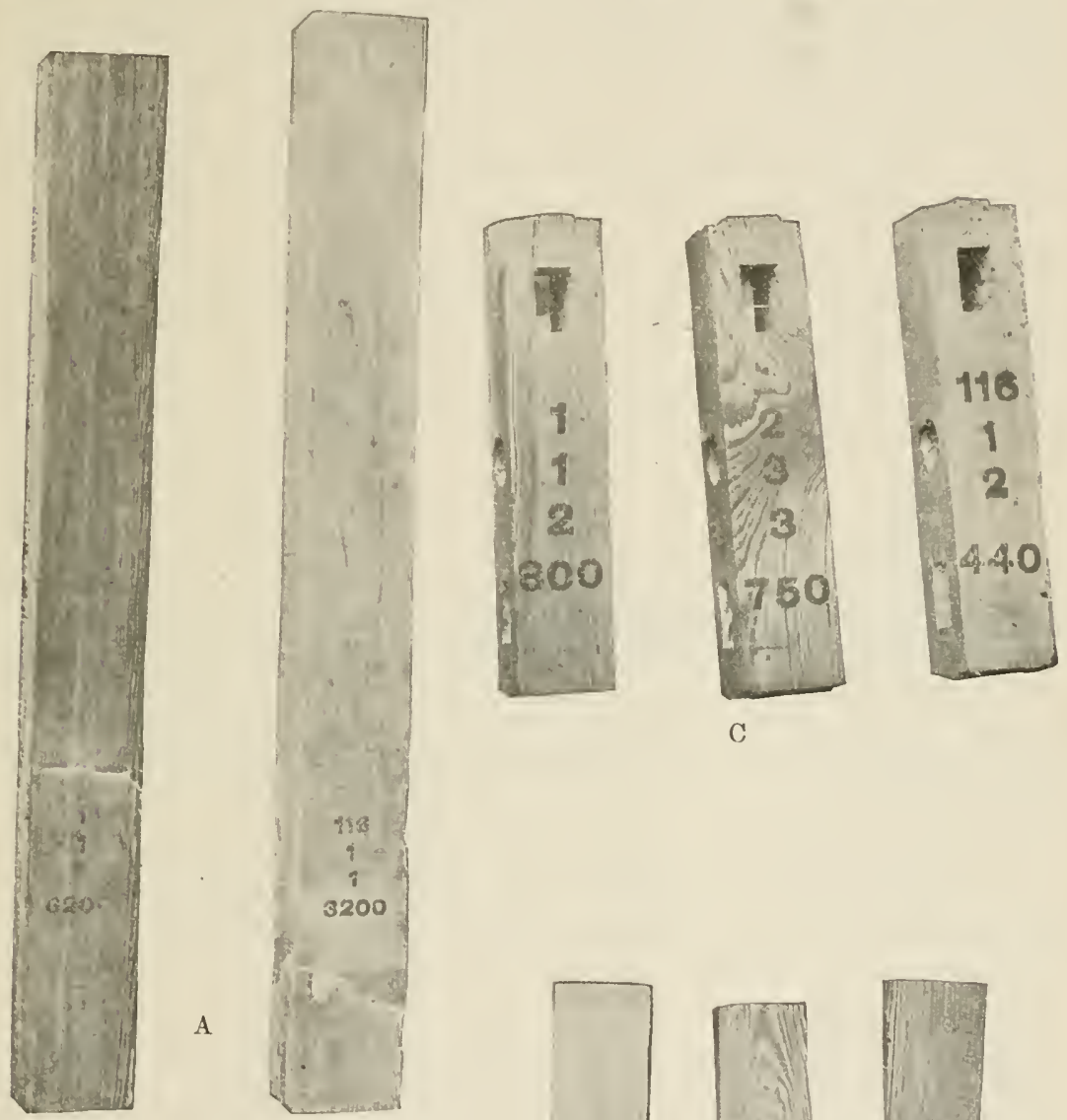

C
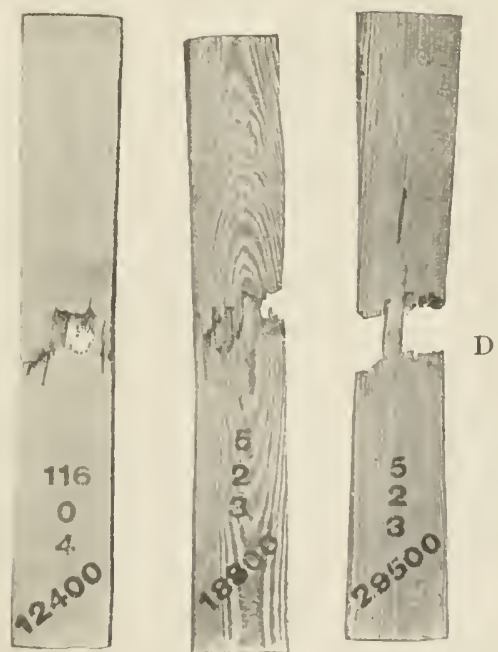

Fig. 31.- Tarious forms of failure. A and b, compression eviwise; C, shearing (the bolt of a stirup passed througin the mortise and sheared ont tue end, 1), tension. The lower figuro indicates the number of pounds per square jnch wheb producel the fallure in testy hy tho Drvisiun of Forestry. No. 116 (upper tgure on each piece) is white pine; Nos. 1, 2, ad 5 are longleaf pine, about one.fifth natural size. 
this is said to shear out along the fiber. In the same manner, if the shoulder $A B$ ( $D$ in fig. 30, is pushed off along $B$ I), it is sheared, and if $B D$ and $C E$ are each 1 inch, the surface thus sheared oft is 1 square inch, and the weight necessary to do this represents the shearing strength per square inch of the particular kind of wood. This resistance is small when compared to that of tension and compression.

In general wet or green wood shears abont one-third more easily than dry wood; a surface parallel to the rings (tangent) shears more easily than one parallel to the mednllary rays. The lighter conifers and hard woods offer less resistance than the heavier kinds, but the hest of pine shears one-third to onc-half more readily than oak or hickory, indicating that great shearing strength is characteristic of "tough" woods.

Resistance to shearing along the fiber.

(1) Locust, oak, hiekory, elm, maple, ash, bjrch

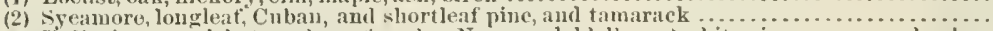

(3) Tulip, basswood, better elassol poular, Norway, lobloliy aud white pine, spruce, red colar

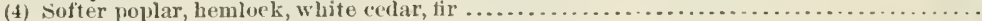

NoTE.-Resistance to shearing, although a most important quality in wood, has not hoeu satisfacto. rily studied. The values in the abovo table, taken from various authors, lack a reliable experimental basis and can be considered as only a little better than guesswork.

\section{INFLUENCE OF WEIGHT AND MOISTURE ON STRENGTH.}

It has been stated that heary wood is stronger than lighter wood of the same kind, and that seasoning increases all forms of resistance. Let us examine why this is so.

Since the weight of dry wood depends on the number of fibers and the thickness of their walls, there must be more fibers per square inch of cross section in the heavy than in the light piece of the same kind, ${ }^{1}$ and it is but natural that the greater number of fibers shonld also offer greater resistance, i. e., have the greater strength.

The beneficial influence of drying and consequent shrinking is twofold: (1) In dry wood a greater number of fibers occul' per square inch, and (2) the wood substance itself, i. e., the cell walls, become firmer. A piece of green longleaf pine, 1 by 1 inch and 2 inches long, is only abont 0.94 by 0.96 inch and 2 inches long when dry; its cross section is 10 per cent smaller than before, but it stili contains the same number of fibers. A dry piece 1 by 1 inch, therefore, contains 10 per cent more fibers than a green piece of the same size, and it is but fair to suppose that its resistance or strength is also about 10 per cent greater.

The influence of the second factor, thongh unquestionably the more important one, is less readily measured. In 100 cubic inches of wood 
substance the material of the cell walls takes 1 p about 50 cubie inches of water and thereby swells up, hecoming about 150 cubic inches in volume. In keeping with this swelling the substance becomes softer and less resistant. In pine wood this diminution of resistance, according to experiments, seems to be about 50 per cent, and the strength of the substance therefore is inversely as the degree of saturation or solution.

\section{IIARDNESS AND SHEARING ACROSS THE I RAIN.}

When the solid steel plunger $P$ in fig. 32 descends on the piece of wood $w$, the first effect is to press it into the wood of the upper surface withont affecting the interior or lower part. The wood is thus tried with regard to its harduess. If a perforated steel plate is substituted for the solid plate the effect of the plunger is at first the same, but soon the fibers some distance from the steel are seen to bend, and finally the piece of wood fails in shearing across the grain. Hardness and slearing across the grain are closely related. The

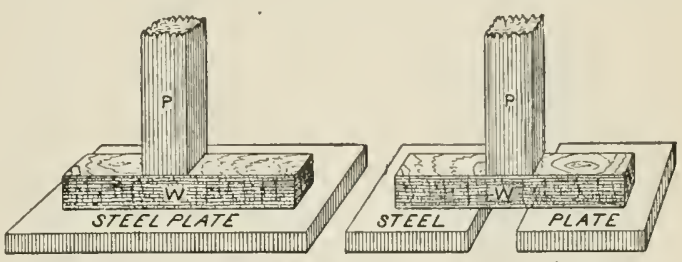

Fig. 32.- Test in harduess and shearing across the grain. former is the more important quality, however, since abrasion and indentation, the two failures in hardness, are the common canse of loosening of tenous in the mortise, of the handle in the ax, etc.

Heavy wood is harder thau lighter wood; the wood of the butt, therefore, is harder than that of the tols; the darker smmmer wood harder than the light-colored spring wood. Moisture softens, and sea soning, therefore, luardeus wood.

Placing the rings vertical lielps the wood to resist indentation. 'Though halder wood resists saw and chisel more than softer wood, the working quality of the wood is not always a safe criterion of its hardness.

The following indicates the hardness of our common woods:

1. Very hard wools requiring over 3,200 pounds per square inch to produce an indentation of one-twentieth inclı: Hickory, hard maple, osage orange, black locust, persimmon, and the best of oak, clm, ancl hackiberry.

2. Hard woods requiring over 2,400 pomuds per square inch to pro. duce an indentation of one-twentieth inch: Oak, th, ash, cherry, birch, black walnut, beech, blue beech, mulberry, solt uaple, holly, sour gum, honey locust, cotfee tree, and sycamore.

3. Middling hard woods, requiring over 1,600 pounds per square inch to produce an indentation of one-twentieth unch: The hetter qualities of Sonthern and Western hard pine, tamarack and Douglas spruce, sweet gum, and the lighter qualities of birch. 
4. Soft woods lequiring less than 1,600 pounds per square inch to produce an indentation of one-twentieth inch: The greater mass of conferons wood; pine, spruce, fir, hemlock, celar, cypress, and redwood: poplar, tulip, basswood, butterunt, elsestmut, buckeyr, and catalpa.

\section{CLEAVABILITY.}

When an ax is struck into a piece of wood as shown in fig. 33 the eleft projects beyond the blade of the ax and the process is not one of entting, but of tension across the grain. The ax presses on a lever, a $b$, while the surface in which the transverse tension takes place is reluced almost to a line across the stick at b. If the wood is very elastir, the eleft runs far ahead of the ax, the lever arm $a b$ is long, and the resistance to splitting poportionately small. Elasticity, therefore, helps splitting. while great shearing strength, a good measure for transverse tension and hardness hinder it.

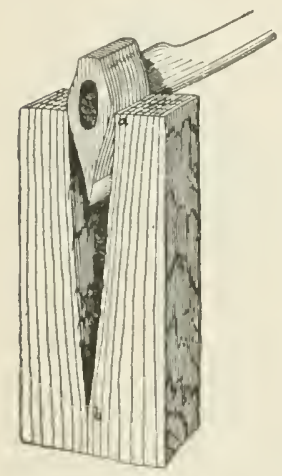

Fro. 33.- cleavage.

Wook splits natmally along two normal planes, the most readily along the radius, because the arrangement of fibers and pitl rays is radial, and next along the tangent, or with the annual rings, because the softer spring wool forms continuons planes in this direction. Cleavage along the ratlius, however, is from 50 to 100 per cent rasier. and only in ease of cross grain, ete. the clearage along the ring becomes the easier. In the wood of (onilers. wood fibers and pith rays are very legnlar, the former in perfect radial series or rows, and eleavage is, therefore, very easy in this direction. The same is broumt abont in the oak by the very high pith rays, but where they are thick and low, as in syeamore, and gencially in the lutt euts and about knots, they imperle rleavage by cansing a wratre irregularity in the course of the woorl fibers. The greater the contrast of spring and summer woml, the asier the clearage tangentially of in the direction of the rings. This is enpecially marled in confers and also in wools like oak, ash, ant elm. where the spring wook appears as a continuous series of large poles. V'ery slow growth inflenenes tangential reavage, nalrow-ringed oak breaks ont and splits less rogularly even in a ralial direction; in conifers, however, this difference seincely exists. Wright of wood affects the cleavage but little; in heary wood the entrance of the ax, to be sure, is resinted with more force, but the greater elastieity of the wood, on the other land, comnterbalances this resistance. Irregularities in the course of the fibers, whether spiral growth, crosscrain, or in form of knots, all aid in resisting eleavage. Kuntty bolts are split more easily fiom the upper end, since the cieit then runs aromul the knots (see p. 23). Moisture softens the wood and redures latelal adliesion, and therefore wood splits more easily when green than when dry. 


\section{FLEXIBILITY.}

Pine is brittle, hickory is flexible; the former breaks, the latter bends. Being the opposite of stiffuess, want of stiffuess wonld seem to indicate flexibility. This, however, is only partly true; lickory and asli are stiff and yet among the most flexible of woods. Their small dimensions cause shavings and thin strands of most worls to appear pliable. For this reason the pliable, twisted wicker willow is not a fair measure of the flexibility of the wood of this species. Cienerally hard woods are more flexible than conifers, wood of the butt surpassing in this respect that of the main part of the stem, the latter being usually superior to that of the limbs. Moisture softens wood and thereby inereases its tlexibility. Knots and erossgrain diminish flexibility, but the irregular structure of elm, ash, etc. (particularly the arraugement of bodies of extremely firm fibers, like so many strands, among the softer tissue, as well as the interlacement of fibers, due to post-cambial growth), favorably influenees the flexibility of these roods.

\section{TOUGHNESS.}

So far the load by which the exhibition of the various kinds of strength in eompression, tension, cross bending, etc., was produced has ulways been assumed as applied slowly and gradually. When a wagon woes lumbering along a cobble pavement the load on the spokes is not thus applied. Every stone deals the wheel a blow, and a mile's journey means many thousand blows to every wheel rim and spoke. In chopping, the ax handle is jarred aud a handle made of pine wood, which shears easily along the fiber, would soon be shattered to pieces. Loads thus applied are "shocks," and resistance to this form of loading refuires a combination of various kinds of strength possessed only by "tough" woods. Toughuess is a familiar word to woudworkers, and ret is rarely defined. Tough wood must he both strong and pliable. Thus a willow is not tough when dry; it is weak and brittle, and reyuires, notwithstanding its small lateral dimensions, to be moistened and twisted or sheared into still smaller strands so that its fibers are sub jected almost exelusively to tension, if great deflection and great strength are to be combined (handles of wieker baskets). Hickory is both strong and pliable; in the dimensions of a willow twig it can be used almost like a rope. The term "tough," therefore, is properly applied to woods like hickory and elm and improperly to willow.

Judging from the behavior of elm and hickory, wood nay be pronouneed "tough" if it offers great resistance to-

(1) Longitudinal shearing over 1,000 pounds per square inch,

(2) Tension over 16,000 pounds per square inch.

and permits, when tested dry, of an aggle gate distontion in conpression and tension amounting to not less than 3 per cent.

3521-No. 10—4 
For instance, of a piece of dry hickory $(H$. alba) wr may expect-

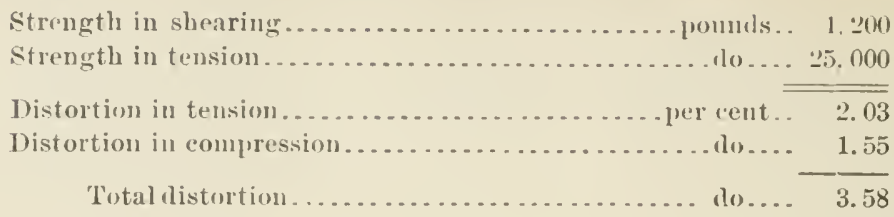

PRACTICAL CONCLUSIONS.

From the foregoing considerations a few valuable fatets, mostly familiar to the thoughtinl woodworker, may be dednced:

In framiny, where light and stift timber is wanted, the conifers excel; where heary but steady loads are to be supported, the heavier coniters, latd pine, spluce, Douglas spruce, etc., answer as well as hatrl woods, which are eostlicr and heavier for the same anomit of stiffness. On the other hamd, if small dimensions must be used, and especially if moving loads are to be sustained, hard woods are safest, and in all cases where the load is applied in form of "shocks" or jars, only the tougher hard woods shomld be employed. The hearier wood surpasses the lighter of the same species in all kinds of strength, so that the weight of dry wood and the structural features indicative of weight may be userl as sal'e sigus in selecting timber for strength.

In shaping wood it is better, thongh more wasteful, to split than to saw, because it insures straight grain and enables a more perfect seasoning.

For sared stock the method of "rift" or "quarter" sawing, which has so rapidly gained favor during the last decade. deserves every encour. agement. It permits of better selection and of more advantageous disposition of tlie wood; rift-sawed lumber is stronger, wears better, seasons well, and is least sulject to "working" or warping.

All hardwood material which checks or warps bally during seasoning should be reduced to the smallest practicable size before drying, to avoid thr injuries involved in this process; and wood once seasoned should never again be exposed to the weather, since all injuries due to seasoning are thereby aggrarated. Seasoning increases the strength of wood in every respect, and it is therefore of great importance to pro. teet wooklen structures, bearing heary weights, against moisture.

Kinnts. like crosservin and other defects, rednee the strength of timber. Where "hoice exists, the knotty side of the joist should be placed nprermost, i. e., slould be used in rompression.

Sctison checks in timber are always a source of wraliness; they are more injurions on the rertical than on the horizontal fares of a stringer or joist, and their"effect "ontinnes even when they have elosed up, as many do, and are no longer visible.

Rafted timber, liln-dried or stenmed lumber are, as far as our present knowledge extends, as strong as other kinds, and wherever any of these 
processes aids in a more miform or perfect seasoning, it increases the strength of the material.

Pine "bled" for turpentine is as strong as "unbled."

Time of felling, whether season of the gear ur phase of the moon, does not influence strength, except that summer-felled latrol worl rarely seal. sons as perfectly as that felled in the fall, and to this extent an indircet influence nay be observed, is well as by the fact that fingi and insects thave a better opportmity for tereloping.

Irarm eountries and sumy exposures generally produce heavier and stronger timber, and conditions favorable to the wrowth of the speeies also improve its quality. But exceptions occur; neitlee fast nor slow growth is an infallible sign of strong wood, and it is the character of the annual ring, rather than its width, and particulary the proportion of summer mood, which determines the quality of the material.

\section{VI.-CHEMICAL PROPERTIES OF WOOD.}

Wood dried at $300^{\circ} \mathrm{F}$. is composerl of over 99 per cent of urganic and less than 1 per cent of inorganic matter; the latter remains as ashes when wood is burned.

Wood eousists of a skeleton of "ellulose, permeated by a mixture of other organie substances, collectively designated by the name of liguin, and partieles of mineral matter or ashes.

Cellulose is the common substance of whieh plant cells form their cases or walls; in flax, the entire fiber is almost pure cellulose, bit the amount of cellulose obtained from wood, by the common processes, rarely exeeeds one-half of its dry weight. Cellulose is identieal in composition with starch, but mnlike the latter it resists aleoholie fermentation, though the plants thenselves, as well as deeay-prodneing fungi, are able to reeonvert it into stareh, from which it seems originally derived, and also to change it into varions forms of sugar. ${ }^{1}$ Lignin is as yet a ehemical puzzle. The substances forming it are earbo. hydrates like cellulose itself, but of slightly different proportions and distinguished by greater solubility in acids, and by other chemical properties.

In 100 pounds of wood (dried at $3000 \mathrm{~F}$.) and of cellulose the follow. ing proportions are found:

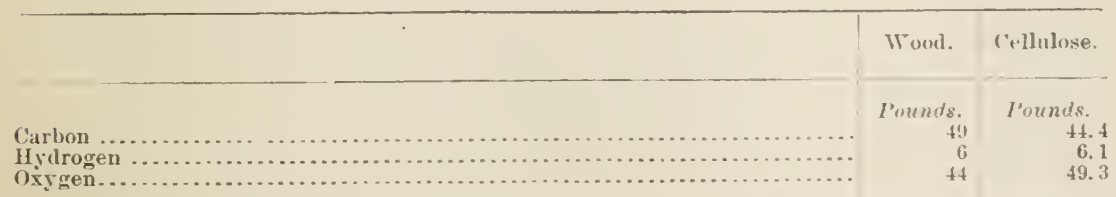

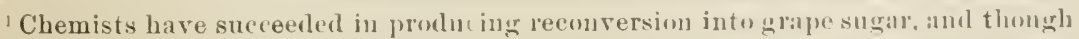
the methods thus far employed are expensire, it is to loo expecterl that in the noar finture rood will hecome the principal somrer of both vinegar ant alewhol. 
This composition of wood is fairly uniform for different species.

At mrlinary temperatures wool is a very stable compound: both in air and under water it remains the same for centuries, and only when living organisms attack it with their strong solvents and convertants do "hange and decay set in.

Heated to $3000 \mathrm{~F}$. wood gives off only water, though some slight "hemical changes are noticeable even at this temperature. If the beat is increased, gases of pungent odor and taste are evolved, and if the temperature is sufticiently raised. the gases are ignited, forming the Hanr of the fire, while the remaining solid part glows like an ignited "laderal, giving much heat, but no flame. The amount of heat pro. Inced by wood varies. If first dried at $3000 \mathrm{P}$ E.. 100 pounds of poplar wool should give as much heat as 100 pomuls of hiekory. In the matulal state, however, this is not the case. .

The beneficial effect of thorough seasoning for firewood appears from the following consideration:

One humbed pounds of wood as sold in the wood yards contains in round numbers 's. pomds of water, it ponnds of wood, and 1 pound of ashes.

The it pomds of wood are composed of 37 pounds of earbon, 4.4 pounds of hycirogen, and 32 pounds of oxygen.

In buming (which is a process of oxidation) 4 pounds of hydrogen are alleady combined with 92 pounds of oxygen and there are only the 37 pounds of earbon and 0.4 pounds of hydrogen available in heat pro. inction. Thus only abont one-half the weight of the wood substance itself is heat prodncing while every pound of water combined in the wood repuires about lino mits of heat to evaporate it, and thus diminishes the value of the wood as finel. Ilence moder the most farorable riremustanes 100 pounds ot green wood (50 per cent moisture) furnishes about 15t), 1000 mnits ${ }^{2}$ of heat; 100 pounds of half dry (30 per cent moisture) about 230.000 units; 100 pounds of air dhy (20) per cent mois. ture about 280,000 mits; 100 hundred pomds of air dry (10 per cent

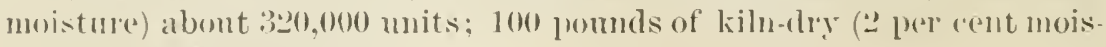
ture) about 3.00,000) mits.

In the ordinary stove or other small apparatus the evil eflect of moistmo in the worl is very much increased since combustion is materially interferecl with.

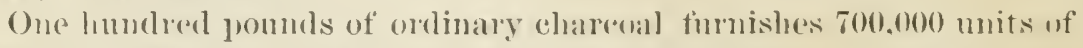
beat hut the same guantity of charcoal produced at a temperatme of $2.0000^{\circ} \mathrm{F}$. fundushes nearly 800,000 mits of heat.

Conifers and the lighter hard wouds prodnce more flame, while the lieary hard wools fiuruish a good bed of live coal and exceed the former by to 30 fere cent in produetion of heat with ordinary appliances.

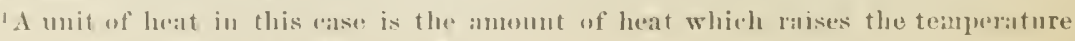
of 1 pound of water by 1.8 F. or 1 C. 
Heater in a chsol dhamber or covered with earth, as in charcoal pits, the woorl is prevented form lomming and a variety of rolluges oceur, depending on the late of heating. If the temperature is raised gradually so that thr work is heated several homs before a temperature

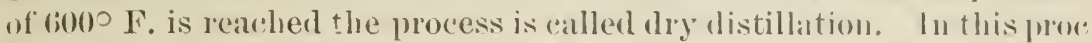
"sis the wood is destroyed. It forms at lirst "lad" or "brown" coal, still resembling wood, and tinally chareoal proper. 'This roal is darker" heavier, condurts heat aml electricity better, requires a sreater heat to ignite, and produres more heat in burning the higher the teinperatme under which it is formed.

One humdred pomds of wood (dried at 3000 F.) leaves only abont 30 pounds of chareosl. In common practice much less charroal (1s to ¿u per rent) is produced. In this change from wood to coal the volume is Aiminished by about ome-half, so that a cord of woor which contains about 100 enbic feet of wood solid would be enverter into so cubir. feet at best.

Of the 70 pounds of gaseous products which 100 ponnds of woud lose, during coaling, in being lieated un to $7000 \mathrm{~F}$, abont 63 pounds become volatile before the temperature of $5500 \mathrm{~F}$. is reacher.

If condensed in a cooler, about three-fourths of the 63 pomds of volatile matter first evolved is found to be wood-vinegar, from which about 4 pounds of pure acetic acid, the only somce of perfectly pure vinegar, is obtained. Besides acetie acid, the liquid contains woor spirits and a quantity of various allied substances.

After the first stage of dry distillation, a large part of the products developed can not be liquefied in the ordinary cooler. They are gases like the illuminating gas, mostly belonging to the marsh gas series; they lack oxygen and thus show that the available oxygen has heou nearly exhausted in the preceding part of the process. Products of the later stages are tars and heavy oils, volatile only at high tem. peratures. Herealso belong the substances known collectively as wood creosote, employed as antiseptics in wood impreguntion.

Warmed in dilute nitric acid with a little chlorate of potash, the rells of a jiece of wood maly be separated, each cell remains intact, lut its wall is reduced in thickuess and material; the ligniu substances heing dissolved ont, only the cellulose is left. In commercial cellulose mannfacture, socla, sulphates, and of late chiefly sulphites are substituted for the nitric acid. The mood is rhipped. hoiled in the respertivesolu. tion mnder high pressures, the resirlne ss washed, and the remaining cellulose bleached and ready for use. As a matter of eomomy the residual liquid is evaporated and the soda used orer again.

When resinons wool, " fat pine." "lightword," such as the linots and stumps of longleaf, pitch, and other pines, is heaterl in a kiln wr retort, the resius onze out, are collected, and in distillation with stean yield turpentine and rosin. The resins and their eompunents vary with the species; the balsam of fir is limpid, its turpentine remains clear on 
exposme; the resin of pines is very viseid, their turpentines readily oxidize and larken when bronght in eontact with air. liesins ar. gathered more commouly either from "racks, suell as "wind" and "ring" shalies," as in the case of larch ancl fir (V'enetian tmpentiue), or else from wounds male esperially for this pmpose, as in the case of naval stores gathered fiom pines. This latter process is linown as " lileerling." "tappoing," or "orelam ming," and is at present the principal method of' obtaining turpentines and rosins.

On luming resinous wool, wool tar, etc., in a smoldering fire, soot is deposited on the walls and pantitions of the specially constructed soot pit. It is then collected, but must be freed of rarions productio of dry distillatiou, by earefully lieating to red heat before it becomes the lampblack used in printers" ink and otherwise much employed in the alts.

Many kinds of wood aud the bark of most trees contain tamm. 'Tu sirve in tanning the balk must contain at least 3 per cent of' tamnin: the kinds mostly used vary fiom is to 1if per cent, and evell the best probably never fimbish over 20 per rent in the average. The use of tan bark involves consirlerable disidvantages. It is difficult to diy and preserve, very liable to mold, bulky, and therefore expensive to ship aud store, and very variable in the amonnt of tannin which it contains.

To avoid these difficulties the tannic componnds are, in recent times, leached out of the finely gromed hark and wood, condensed by evapo ration, and shipped as extracts containing 80 to 90 per eent of tamin.

The manutactme of pulp as well as the pooluction of fiber capable of being spun and woven, are also technological uses of wood, which rely partlý mpon chemical reactions.

\section{VII.-DURABILITY AND DECAY.}

All wook is equally durable under certain eomelitions. Képt dry or submeraned, it lasts indefinitely. Pieces of pine have been muearthed in Illinois which lave lain buried 60 or more feet deep for many centuries. Deposits of somnd logs of oak, buried for muknown ages, have been unearthed in Bavaria: parts of the piles of the lake dwellers, driven more than two thonsand years aco, are still intact.

On the radial section of a piece of pine timber, with one of the shelf:like, fungus growths, as shown in fig. : $; t$, both barli and woon

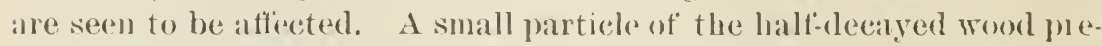
sents pictures like that of fig. :3.). Slender. branching threarls are seen to attach themselves closely to the walls of the cells, and to pierese these in all direutions. 'Tlus these little threads of hugus mycelium soon form a jerfect network in the wood, and as they increase in num. ber they dissolve the walls, and convert the woul substance and cell contents into sugar-like fond tor their own consumption. In some cases it is the woody cell wall aloue that is attacked. In other cases they 
contine themselves to eating m, the starch found in the cells, as shown in fig. 3t, and merely leave a stain (bluing of lumber). In all cases of dexay we tind the vegetative borlies, these slonder threarts of fungi, responsible for the mischief. These finc threarls are the vegetative body of the fungus, the little shelf is its fruiting body, on which it produces myriarls of little spores (the seerls of fungi). Some fungi attack only conifers, others hard woods; many are confined to one specirs of tree and perhaps no one attacks all kinds of wood. One kind produces "red rot," others "bluing."

In one case the decayed tracts are tulular,

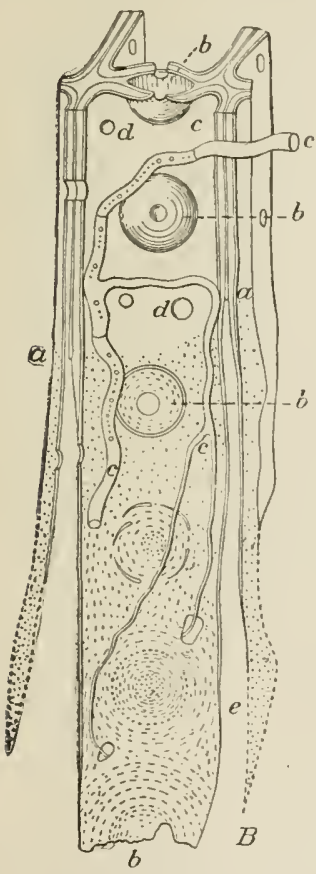

Fig. 35.-Fungus threads in pine wood. (Hartig.) $a$, cell wall of the wood fibers: $b$, bordered pits of these fibers; $c$, thread of mycelium of the fungus; $d$, holes in the cell walls mate by the fungus threarls, which gradually dissolve the walls as shown at $e$, and thus break flown tbe woml structure.

and in the direction of the fiber's the woorl is "pegry." In other cases no particular shapes are discernible.

Cutting off a disk of loblolly pine, washing it, and then laying it in a clean, shady place in the sawmill, its sapwool will be found stained in a few days. Nor is this mischief confined to the sur-

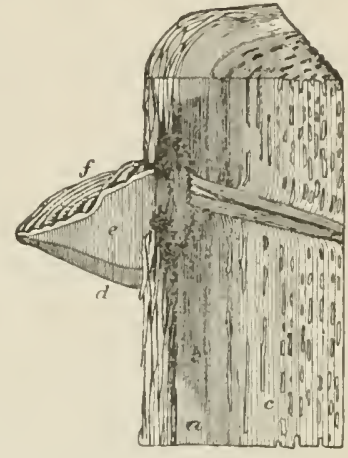

Fig. ?4.- "shelf" fungus on the stem of a pine. (Hartig.) $a$, somnd wood: $b$, resinous "light" wood; c partly decayed wood or punk ; $d$, layer of living spore tubes; $e$, old filleal uj spore tubes; $f$, thuted upper surface of the fruiting body of the fungus, which gets its foorl through a great number of fino threads (the mycelium), its regetative $t$ is sue penetrating the wood and causing its decay.

face; it penetrates the sapwoud of the entire disk. From this it appears that the spores must have been in the air abont the mill, and also that their germination and the growtl of the threads ol mycelium is exceedingly rapiol. (WVatrhing the progress of mold on a piece of brearl teaches the same thing.) Placing a fresl piece of sapwood on ice, another into a dry kiln, and soaking a few others in solutions of corrosive sublimate (mer(curic chloricle) and other similar salts, we learn that the fungus growth is retarkerl by cold, prevented and killed by temperatures over $1 \tilde{1}) \mathrm{F}$. and that salts of mercury, etc., have the same effect. The fact that seasoned pieces if exposed are not so readily attacked by fungi shows that the moisture in air-diy wood is insufficient for lungus glowth.

From this it appears that warmth, preterably between $60^{\circ}$ and $1000^{\circ}$ F., combmed with abundance of moistme (but not immersion), is the most important condition faroring deray, and that the refense lies in the proper regulation or avoidance of these 
comlitions, or else in the nse of poisonons salts, which prevent the propagation of fungi.

It is also appdrent, therefore, why wood decays faster in Alabama than in Wisconsin, faster in the swamps than on the plains, and why the prisince of lange funtities of decaying woor about the yard, "onstantly producing fresh supplies of spores, stimulates decay. Cor-

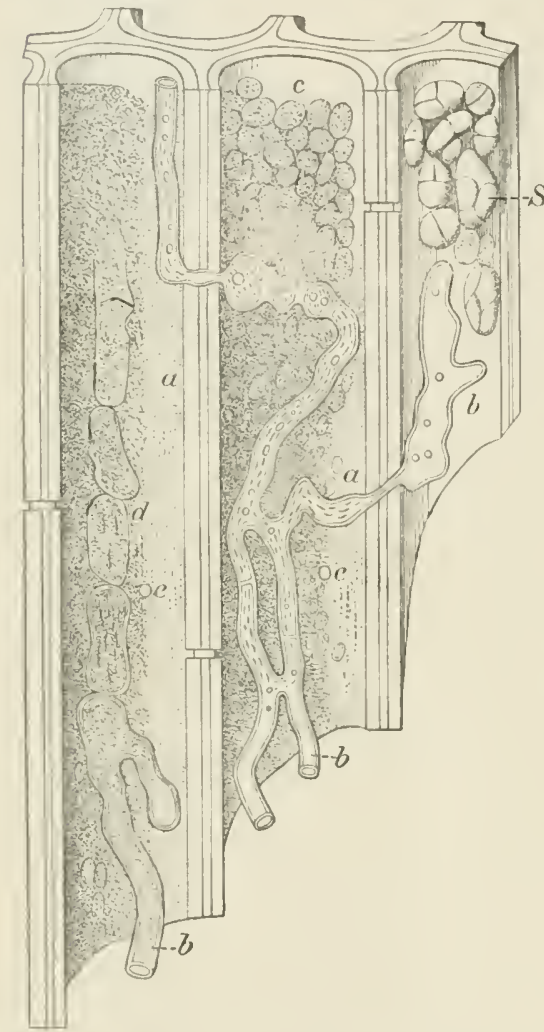

Fiti. 30.-Cells of maple mood attackerl by fungus theals (Vectria cinnabarina IIayer). Nectiou of three wood tibers sliowing the threads of the fungus branchung m their cavilies and consuming the starch sture.l u these colls. $a$, interior or cavity of celis; $b$, threads of the fungus; $c$, partiy destroyed starch errains; $d$, dead portions of the fungus threst together with dibris; $e$,

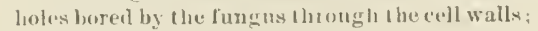
$S$, starch grains just being at tacketl. ering with tar or impregnating with ereosote. salts of mercury, ropper, etc., enables even sapwood to last under the most try. ing conlitions. Contart with the grouml assures most favorable moisture conditions for fungus growtli, ant the ligher temperatures nuar the surfare of the gromud, together with the ererfresent supply of spores, (allse rot in a post to start at the surface more rearlily than :30 inches below.

The use of means to prevent decay is therefore desirable where timber is placed in positions favor. able to fungus growth, as in lail. way ties; and all joists and timber in contact with damp brick walls, as also all building material whose perfect seasoming is prevented by the absence of proper circulation of air, should be specially proterted. In the former eases it is economy to apply preservative processes; in the latter a sanitary neeessity. Wood covered with paint, ete., before it is perfectly seasoned, falls a prey to "dry rot;" the fungus finds abundanco of moisture, and the protection intencled for the woor proterts its encuy, the fungus. Since charcoal resists the solvents of fungi. charring the onter parts of posts makes, if well clome. namely. so as not to open cheeks into the interior of the wood, a very tine protection.

Under ordinary circumstances, only the second great factor of decay, i. e., the moisture condition, can be controlled. 
Perfect seasoning, preferably kiln-rlying, before using, and protection against the entrance of moisture hy tar, paints, and othel cover's, when put in place, prolong the life of worklen structures. Where such a covering is too expensive, goul ventilation at least is necessary. Contact surfaces, where timber rests on timber or brick, should in all asises be especially protected.

Different sprecies differ in their resistance to dex"iy. Cedar is more durable than pine and oak better than beech, but in most eases the eonditions of warmth and moisture in particnlar locations have so much to do with durability that often an oak post outlasts one of cerlar, even in the same line of fence, and prealictions of durability become nere gnesswork.

Containing uore ready-marle food, and in forms acceptable to a great number of different kinds of fungi, the sapwood is more subject to decay than the heartwood, donbly so where the latter is protected hy resinons substances, as in pine and cedar. Several months of immersion improves the durability of sapwood, but only impregnation with preservative salts seems to render it perfectly secure. Once attacked by fungi, wood becomes predisposed to further deeay.

Wood ent in the fall is more durable than that cut in summer, only because the low temperature of the winter season prevents the attack of the fungi, and the wood is thus given a fair ehanee to dry. Usually summer-felled wood, on account of prevalent high temperature and exposure to sun, checks more than winter-felled wood, and since all season checks favor the entrance of both moisture and fungus, they facilitate destruction. Where summer-felled wood is worked up at once and protected by kiln-drying no difference exists. The phases of the moon lave no influence whatever on durability.

In sawing timber much of the wood is bastard cut; at these places water enters much more readily, and for this reason split and hewn timber and ties generally l'esist decay perlaps better than if sawed.

The attacks of beetles, as well as those of the shipworm, tan not here be considered; like chisel or saw they are mechanieal injuries against which none of our woods are proof.

\section{Range of durability in railroad ties.}

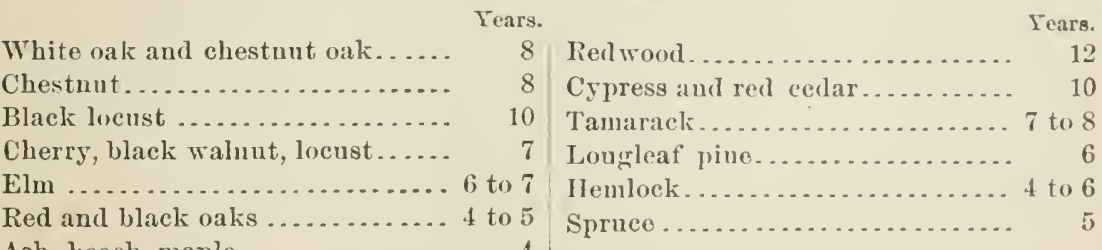

Ash, beech, maple ..............

The durability of wood, exposerl to the ehanges of the weather, and where painting, after thorough seasoniug, is impracticable, is increased 
by impregnating it with various salts or other ehemicals, which prevent the fungus from feeding on the wood. The wood is first steamed, to open the pores and remove the hardened surface coating of sap and dirt, and a liquid solution of the preservative material is then injected with the assistance of heat and pressure.

The most effieient fluids used on a large scale are bichloride of zine and "reosote, or both combined. The "life" of railroad ties is thereby increased to twice and three times its natural duration. 


\section{HOW TO DISTINGUISH THE DIFFERENT KINISS OF WOOD.}

By B. H. FerNow and Filinert Rota.

The carpenter or other artisan who handles different woods becomes familiar with those he employs frequently, and learns to distingnish them through this familiarity, withont usually being able to state the points of distinction. If a wood comes before him with which he is not familiar, he has, of course, no means of determining what it is, and it is possible to select pieees even of those with which he is well acquainted, different in appearance from the general run, that will make him doubtful as to their identification. Furthermore, he may distingruish between hard and soft pines, between oak aurl ash, or between maple and birch, which are characteristically different; but when it comes to distinguishing between the several species of pine or oak or ash or birch, the absence of readily recognizable characters is such that but few practitioners can be relied upon to do it. Hence, in the market we find many speeies mixed and sold indiseriminately.

To inlentify the different woods it is necessary to have a knowledge of the definite, invariable differences in their structure, besides that of the often variable differences in their appearance. These struetural differences may either be readily visible to the naked eye or with a magnifier, or they may require a microseopical examination. In some eases such an examination can not be dispeused with, if we would make. absolutely sure. There are instances, as in the pines, where eren our knowledge of the minute anatomical structure is not yet sufficient to make a sure identification.

In the following key an attempt has been made-the first, so far as we know, in English literature-to give a synoptical view of the distinctive features of the commoner woods of the United States, which are found in the markets or are used in the arts. It will be observed that the distinction has been earried in most instances no further than to genera or elasses of woods, since the distinetion of species can liardly be aeromplished without elaborate microseopie study, and also that, as far as possible, reliance has been placed only on such characteristics as can be distinguished with the naked eye or a simple magnifying glass, in order to make the key useful to the largest mumber. Recourse has also been taken for the same reason to the less reliable and more varia. ble general external appearance, color, taste, smell, weight, ete.

The user of the key must, however. realize that external appearance, such, for example, as color, is not only very variable but also very difticult to deseribe, individual observers differing espeeially in seeing and 
describing sluades of color. The same is true of statements of size, when relative, and not aceurately measured, while weight and hard ness ean perhaps be more readily approximated. Whether any featme is distinctly on only indistinetly seen will also depend somewlat on individual eyesight, opinion, or practice. In sone ases the resemblaner of different species is so close that only one other expedient will make distinction possible, namely, a knowled ge of the region from which the woud has come. Wo know, for instance, that no longleaf pine grows in Arkansas and that no wlite pine can cone from Alabama, and we can separate the white cedar, giant arbor vite of the West and the arbor vitie of the Northeast, only ly the difference of the locality from which the specimen comes. With all these limitations properly appreci. ated, the key will be found helpful toward greater familiarity with the woods which are more commonly met with.

The features which have been utilized in the key and with whichtheir names as well as their appearan'e-therefore, the reader must familiarize himself before attempting to use the key, are mostly deseriberl as they appear in cross seetion. They are:

(1) Saprood and heartwood (see 1). 13), the former being the woor from the onter and the latter from the inmer part of the tree. In some

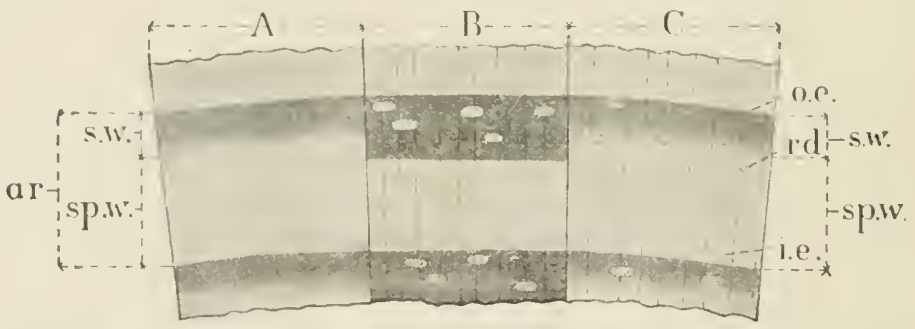

Fig. 37._"Non-prorous" wouls. A, fir; $B$, "hatrd" pine; $C$, soft pune; ar, aunual ring; o. e., outer colge of ring: i.e, inner elge of ring; $s . w$. , summer wood; $s p . w$, spring wood; rd, resin ducts.

eases they difter only in shade, and in others in kind of color, the heartwood exhiliting either a darker shade or a pronounced color. Since one can not always have the two together, or be certain whether he has saluwood or heartwood, reliance mpon this feature is, to be sure, unsatisfactory, yet sometimes it is the only general characteristic that ean be relied npon. If further assurance is desired, microseopic structure must be examined; in such eases reference has been made to the presence or absence of tracheids in pith rays and the structure of their walls, especially projections and spirals.

(ㅂ) Annual rings, their formation laving been described on page 14 . (See also figs. 3i-39.) They are more or less distinctly marked, and by means of such marking a classification of three great groups of wood is possible.

(3) Spring wood and summer wood, the former being the interior (first formed wood of the year), the latter the exterior (last formed) part 
of the ring. The proportion of each and the manner in which the one merges into the other are sometimes nsed, but more frernently the manner in which the pores appear distributed in either.

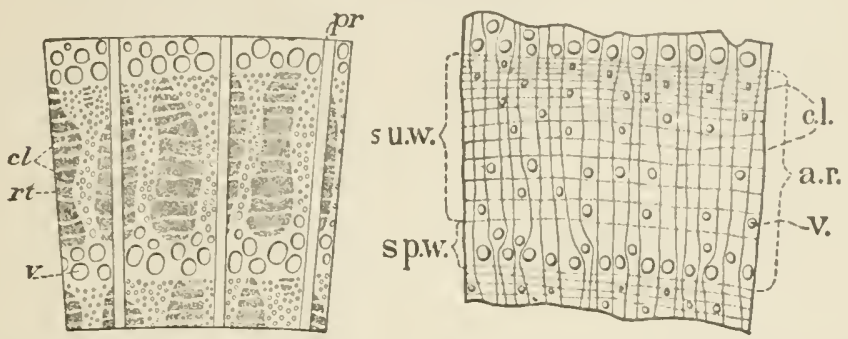

Fic, 38.- "ling-porous" woods-white oak and hickory. a.r., annual ring; su. w., summer wuod; $s p . u$.. spring wood; $v$, ressels or pores; c. l., "concentrie" lines; rt, darker tracts of hard tibers form. ing the tirm part of oak wood; $p r$, pith rays.

(t) Pores, which are vessels ent through, appearing as holes in cross section, in longitndinal section as channels, scratches, or indeutations. (See p. 19 and figs. 38 and 39.) They appear only in the broad-leared, so called, hard woods; their relative size (large, medium, small, minute, and indistinet, when they rease to be risible individually by the naker eye) and manuer of distribution in the riug being of much importance, and especially in the summer wood, where they appear singly, in groups, or short broken lines, in continuous concentric, often wavy, lines, or in radial branching lines.

(5) Resin ducts (see p. 16 and fig. 37), which appear very much like pores in cross section, namely, as holes or lighter or darker colored dots, but much more scattered. They occur only in coniferous moods, and their presence or absence, size, number, and distribution are an important distinction in these woods.

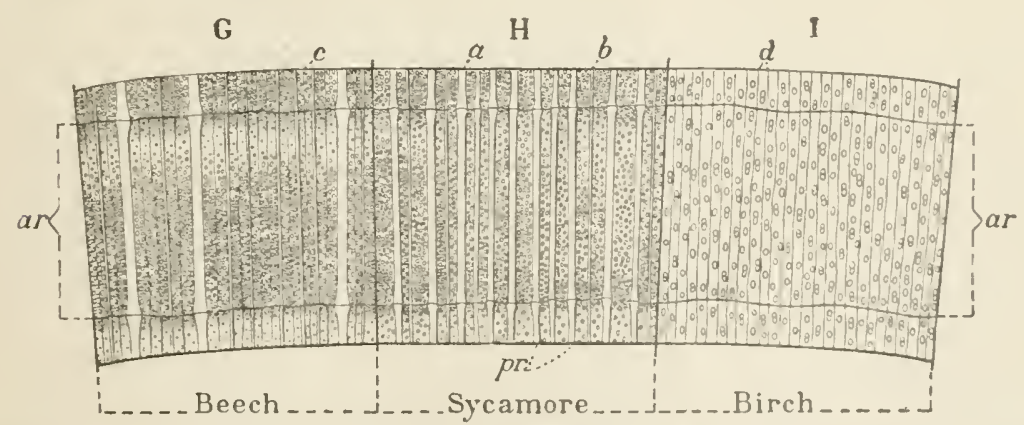

Fig. 39.- "Diffuse-porous" woods. ar, annual ring: $p r$, pitly ruys which are "broul" at a, "fine" at $b$, "indistinet" at $d$.

(6) Pith rays (see p.17 and fig's. 38 and 39), which in cross section appear as radial lines, and in radial section as interrupted bands of varying breadth, impart a peculiar luster to that section in some woods. They are most readily visible with the naked eye or with a magnitier in the 
linoad-leaved woods. In roniferous woods they are usually so fine and closely packed that to the casial observer they do not appear. Their breadth and their greater or less distinctness are used as distingnishing marks, being styled fine, broad, llistinet, very rlistinct, conspinous, and indistinct when no longer visible by the nalied (strong) eye.

(7) Concentric lines, appearing in the summer wood of certain species more or less distinct, resembling distantly the lines of pores but muel: finer and not consisting of pores. (See fig. 38.)

Of microseppic leatures, the following only have been referred to:

(8) Tracheids, a description of which is to be found on page 20.

(9) l'its, simple and boriered, especially the number of simple pits in the cells of the pith rays, which lead into each of the adjoining tracheids.

For standards of weight, eomsult table on page "S; for standards of hardness, table on page $4 i$.

Inless otherwise stated the eolor refers always to the fresh cross section of a piece of dry wood: sometimes distinct kinds of eolor, sometimes only shades, and often only general color effects appear.

HOW TO USE THE KEY.

Nobody need expeet to be able to nse suecessfully any key for the distinction of woods or of any other class of natmal objects withont some practice. This is especially trne with regard to woods, which are apt to vary much, and when the key is based on such meager generad data as the present. The hest course to adopt is to supply onc's self with a small sample collection of woods, accurately named. Small, polished tablets are of little use for this purpose. The pieces shonld be large emough, it possible, to includr pith and bark, and of sufticient width to permit ready inspection of the eross section. Iy examining these with the aid of the key, beginning with the better-known wooks, one will soon learn to see the features described and to form an idea of the relative standards which the maker of the key had in mind. To aid in this, the accompanying illustrations will be of ad vant ige. When the reador becomes faniliar with the key, the work of ideutifying any given piece will be eomparatively asy. The material to he examined must. of conrse, be suitably prepared. It should be moistened; all cuts shond be made with a very sharp knife or razor and be elean and smooth, for a hruised surface reveals but little structure. The most useful cut may be made along one of the enges. Instructive, thin, small sections may be made with a sharp penknifie or razor, and when placed on a piece of thin glass, moistened and covered with another piece of glass, they may be examined by holding them towad the light.

Finding, on examination with the magnifier, that it eontains pores, we know it is not conferoms or nomporous. Finding no pores (oollected in thos spring-wood portion of the annual ring. but all seattered (diffinsed) through the ring, we turn at once to the class of "I) if- 
fuse-porous woods." We now note the size and manner in which the pores are distributed through the ring. Finding them very small and neither eonspieuonsly gromped, nor larger nor more abundant in the spring wood, we turn to the third group of this alass. We now note the pith rays, and finding then neither broad nor conspicuons, but diffienlt to distinguish, even with the magnifier, we at once exelude the wood from the first two sections of this gromp and place it in the third, which is represented by only one kind, cottonwood. Findung the wood very soft, white, and on the longitudinal section with a silky hister, we are further assured that our determination is correct. We may now turn to the list of woods and obtain further information regarding the oceurrence, qualities, and uses of the wood.

Sometimes our progress is not so easy; we may waver in what group or section to place the wood before us. In such eases we may try each of the doubtful roads until we reach a point where we find onrselves entirely wrong and then return and take up another line; or we may anticipate some of the later-mentioned features and funding them apply to our specimen, gain additional assnrance of the direction we onght to travel. Color will often help us to arrive at al speedy decision. In many cases, especially with conifers, which are rather difficult to di-. tinguish, a knowledge of the locality from wheh the specimen comes is at once decisive. Thus, northern white cedar, and bald cypress, and the eedar of the Pacifie will be identified, even withont the somewhat inclefinite criteria given in the key. 


\section{KEY TO THE IORE IMPORTANT WOONS OF NORTH AIERICA.}

['The numbera preceding names refor to the List of Woods following the Kry.]

I Non-porous woods-T'ores not risilnle or consplemus on eross section, even with manuitier. Anmual rings distinut hy denser (dark colored) bands of summer rood (tig. 37 ).

II. Ring-porous woods,-l'ores mumeroms, usually visible ou cross section with out magufier. Ammal rings distinct hy: zome of large pores anllectol in the sjoring wool, alternating with the clenser smmmer worl (tig. 38).

III. Diffuse-porous woods.-Pores mumerons, usmally mot plainly visible on cross section witlont magnifier. Ammal rings distinet hy a fine lime of deuser smumer woul rolls, often quite indistinct; pores scattered throngh ammal ringr. mo zone of eollerted pores in spring woorl (fig. 39).

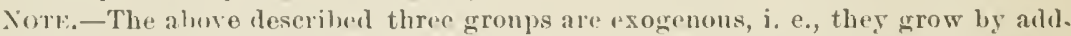
ing amunaly wool on their circumference. A fourth gromp is formed ly the endog. enous wookls, like succas and palms, which do not grow hy such aclditions.

\section{I.---NON-POIEOCS WOODA.}

(Inclutes all coniferous woods.)

A. Resin ducts wantiug.'

1. No ristinct heartwoor.

a. Color effect yellowish white; summer wood darker pellowish (undes microscope pith ray without tracheids) ............... (Nos, 9-13) l'us.

b. Coior effect redilish (roseate) (under microseope pith ray with tracheirls), (Nos. 1.1 aul 15) HEMlock.

2. Heartwool present, colon decidodly different in kind from sajwood.

a. Heartwood light orange red; salpwool, pale lemon; woorl, heavy anri hard .............................................

AHDITIONAL NOTES IOR MISTINCTIONS IN TIE GROUP.

Spruce is harolly distinguishable from tir, except hy the existence of tho resis Anet3, and microsenpically ly, tlie presence of tracheids in the medullary rays.

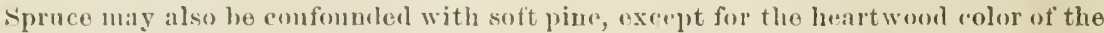
latter and the larger, more frepurut, and unore realily visible resin duets.

In the lumber yard, hemlock is manaly recoguizel by color am the slivery character of its surface. Westeru lomlocks partake of this last character to a less degreo

Microsropically the white pine call ho distinguished hy having nsually only one largo pit, whilo sprue shows threa to tive rery small pits in the paremehma cells of the pith ray communating witls the trachuid.

The listinction of the pines is pussible only ly meroscopic examination. The following distinctive features may assist in recomizing. when in tlue log or lumber pile, those msually found in the market:

The light, straw eolor, combined with grreat lightuess amol softuess, distinguishes, the white piues (white pine aud sumar piue) from the haril pines (all otliers in tho market), which may also he recoguized by th" gevalual rhange of spring woml into summer woml. This change in harel pines is abupt, making the smmmer wood a plear as a sharply defined ami more or luss broal hamol.

1 To diswerer the resin ducts a very smooth surfice is neresary, sinee resin ducts are freruently

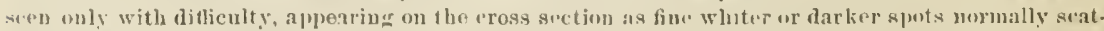
fered singly, rarely in gromps, usually in the summer word af the anuual rung. They aro often much more msily seen on radial, ant still more so on tiugential sectims, appearing there as tine lines or dots of oplen sirncture of difierent color or as indentations or pin scratches in a longitudinal direction. 
b. Heartword purplish to brownisl red; sapwood yellowish white; wood soft to medinm hard light, usnally with ammatic odor . (No.6) Rev cenar.

c. Heartwood marom to terra cotta or deep hrownish red; sapwood light orange to dirlk anber, very soft and light, no olor; pith rays very distiuct, specially pronouneed on rallial seetion ........... (No. 7) Rewwons.

3. Ifeartwood present, color only diflerent in shado from sapwood, dingyyellowish brown.

a. Oilorless and tasteless ............................ 8) B.ALD CYPRess.

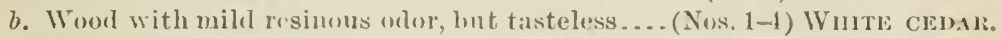

c. Wood with strong resinous odor and peplery tiste when freshly ent........................................... (No.5) INCENSE CEDAR.

B. Resin dnets present.

1. No distinet henrtwood; color white, resin duets very suall, not numerons,

2. Distinct heartwool present.

(Nos. 33-36) SPRuce.

a. Resin ducts numerous, ovenly seattered throngh tho ring.

$a^{\prime}$. Transition from spring wood to summer wool gradual; annual ring distinguished by a tine line of dense summer-wood eells; color, white to yellowish red; wood soft and light........(Nos. 18-21) SOFT PINEs.'

$b^{\prime}$. Transition from spring wool to summer wook more or less abrupt; broal bands of dark-colored summer wood; color from light to deep orange; wood medium hard and heavy .... (Nos. 22-32) HARD PINEs.'

$b$. Resin duets not numerons nor erenly distributerl.

$a^{\prime}$. Color of heartwood orange-redilish, sapwood yellowish (same as hard pine); resin ducts frequently combined in groups of 8 to 30 , forming lines on the eross section (tracheids with spirals),

(No.37) Douglas sprece.

$b^{\prime}$. Color of heartwood light russet brown; of sapwood yellowish lrown; resin ducts very few, irregnlarly seattered (tracheids without spirals).......................... (Nos. 16 and 17) Tamarack.

The Norway pine, which may be confouncled with the shortleaf pine, can be distinguished by being much lighter and softer. It may also, but more rarely, be confounded with heavier white pine, but for the sharper definition of the annual ring, weight, and hardness.

The longleaf pine is strikingly heary, hard, and resinons, and usually very regular and narrow ringer, showing little sapwod, and differing in this respect from the shortleaf pine aud loblolly pine, which usually bave willer rings and more sipwood, the latter excelling in that respect.

The following convenient and useful classitieation of pines into four groups, proposed by Dr. H. Mayr, is based on the alp pearance of tho pith ray as seen in a ratial section of the spring wood of any ring:

Section $\mathrm{I}$. Walls of the tracheids of the pith ray with dentate projections.

$a$. One to two large, simple pits to each tracheid on the ralial walls of the cells of the pith ray.-Gromp 1. Represented in this 'ountry only by $I^{\prime}$. resinosa.

b. Three to six simple pits to each tracheir, on the walls of the cells of the pith ray.-Group 2. P. taeda, palustris, ete., inclnding most of onr "hard" and "yellow" pines.

Section II. Walls of tracheids of pith ray smooth, without dentato projections.

a. One or two large pits to each tracheirl on the radial walls of each cell of the pith ray-Gromp 3. ${ }^{3}$. strobus, lambertiana, and other true white pines.

b. Three to six suall pits on the ralial walls of each cell of the pitb ray.

Group 4. P. parryanu, and wther mut pines, ineluding also $P$. balfouriana.

1 Soft and hard pines are arbitrary distinctions aud the two not distinguishable at the limit.

$3521-$ No. $10-5$ 


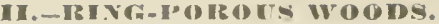

[Some of Gromp I) and cedar clm imperfeetly ring-porous.]

A. Pores in the summer woor minutr, seatterent singly or in groups, or in short broken lisus, the eourse of which is never ratial.

1. Pith ratys minute, scarealy distinet.

a. Wool heary and latud; pores in the smmmer wood not in clusters.

$a^{\prime}$ Color of zadial section not yellow ................. (Nos. 3!)-14) A.ril.

$b .^{\prime}$ Color of ralial sect tom light yellow ; hy which, toget her with its larrlness

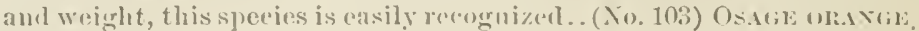

b. Wood light and soft; pores in the smmmer wool in elusters of 10 to :3), (No.56) C.ATAlPA.

2. Pith rays very fine, yot distinet; pores in smmer wool nsnally siugle or in short lines; color of heartwod redilish hrown; of sapwood gellowish white;

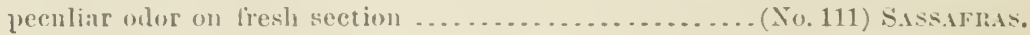

3. I'itlı rays fine, lut distinct.

a. Very lueavy and hard; heart wood yellowish brown. (No. it) BL.tck Locust.

b. Heary; medium bark to harel.

a.' Pores in summer wood rery minute, nsually in small elnsters of 3 to

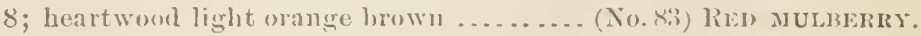

b.' Pores in summer wood small to minute, nsually isolated; heartwoul "herry red............................... (No.61) CofFeE tres.

AUDITINAL NOTES FOR IISTINTIUNS IN THE GRUUP.

Sassafras and mulberry may he confonuded but for the greater weight and hardness and the ausence of odor in the mulberry; the radial section of mulkerry alse? shows the pith rays conspienomsly.

Itoney locust, coffce tree, and black lonust are also very similar in appearanco The honey locust stands ont hy the eonspienousuess of the pith rays, especially on radial sections, on aceomut of their height, while tho hlack locust is listingnsher? by the extremely great wright and barduess', tougether with its darker browu color.

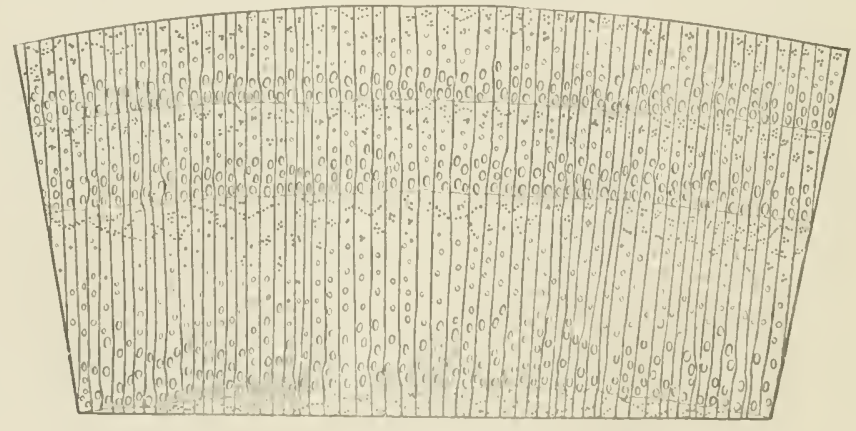

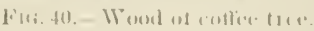

The ashes, ehus, hickories, and oukis mity, m asual ubservation, appear to "escmble one another on acemut of the pronomused zone of poroms spring wool. The sharply delined largo pith rays of the oak exclule these at ouce: the way

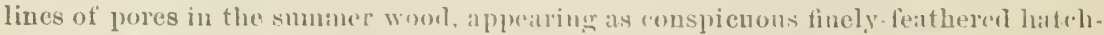
ings on tangential section, distingmish the elun; while the ashes difler from the hickory by the very couspicuonsly detimed zono of spring- wood pores, which in hickory appear more or less interrupted. The redelish hue of the hickory and the uore or less brown hue of the ash may also atd in ready vecognition. The smooth, Eadial surface of split hickory will readıly separate it from the rest. 
1. Pith rays line lut rery eonapienous, even without magnifier. Color of heart-

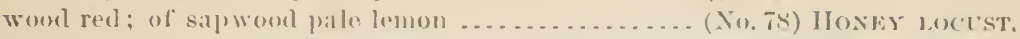

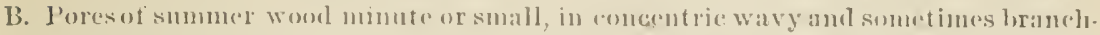

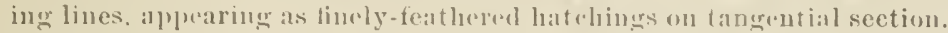

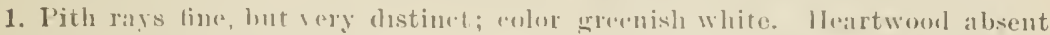

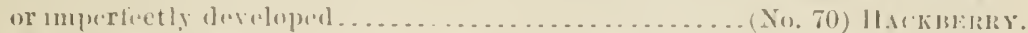

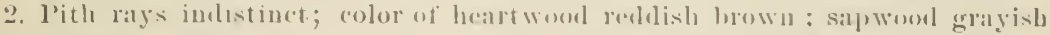

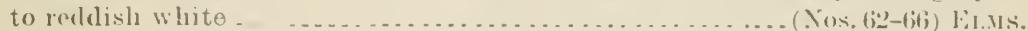

C. Pores of summer wood arranged in raldial brancling lines (when very croweded radial arrangemeat somewhat olsc(onred)

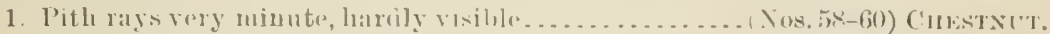

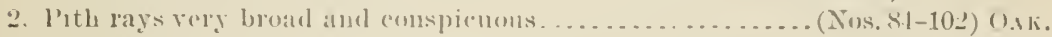

D. l'ores of smumer wook mostly but littlo smallere than these of the spring wood, isolated and scattered: rery heary and harel words. 'The pores of the sluing wood sometimes form hut in muperfeet zone. (Sonne dillise-prons woorls of groups A and li maly seren to belong here.)

1. Fine concentric lunes (not of prows) al distinct, or mearly so, as the very fine pith rays; outer summer wool with a tinge of red; leantwoul light resldish

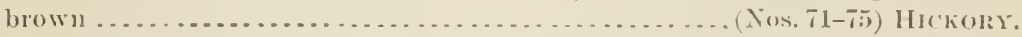

2. Fine concentric lnes, much finer thim the pith rays; no redulish tinge in summer wool; sapwood white; heartwoml blackish,

(No. 105) Plemsimon.

ADDITIONAL NOTES FOR HISTINCTIONS IN THE GRITP.

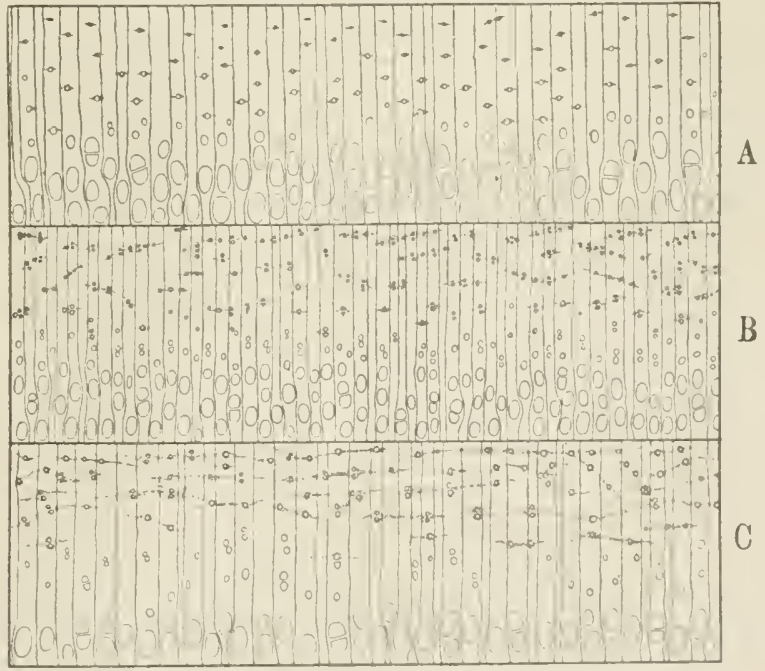

Fig. 41.-.1, black ash: I;, whife ash: C, green ash.

The different species of ish may lue identitied als follows:

1. Pores in the smmmer woorl more or less minted into linus.

a. The lines short and hrokem. ocemring mostly near the linit of the

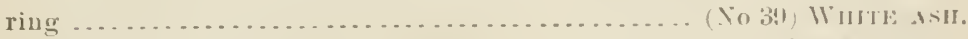

b. The lines guite long and conspinums in mest parts of the smmmer

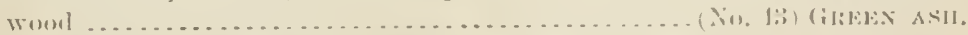

2. Pores in the smumer wouk nut united into lines, ar rarrly sto.

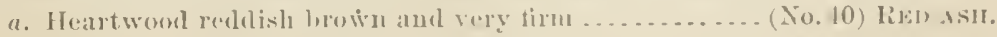

b. Heartwool grayish brown, and much mole porons.. (No. 41) BLAck AsIt. 
AmDTIOx.I. NoTrs-continued.

In the oaks, two groups ean be readily distinguished by the manner in which the pores are distributed in the smmmer woul. In the whits oilis the pores are very fine and numernss and rowder in the onter part of the smmuer wool, while in the black or red oaks the pores are larger, few in number, and mostly isolated. The live oaks, as far as structure is concerned, helong to the hlack oalis, but are mucle less porous, and are exceedingly lasary and latrel.

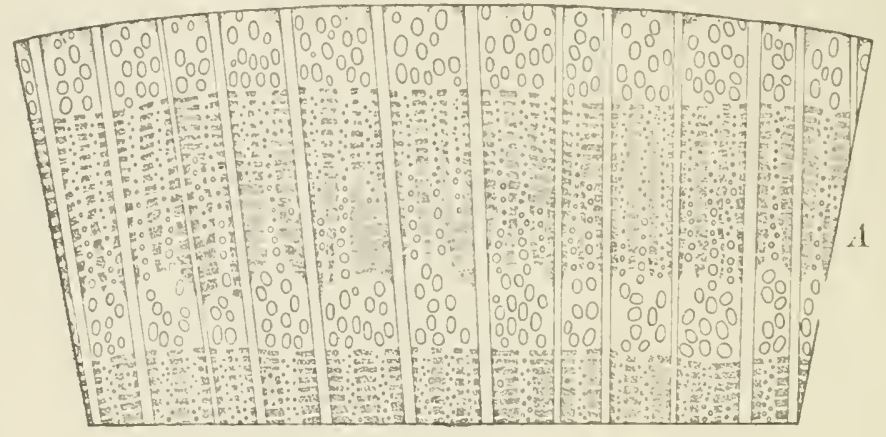

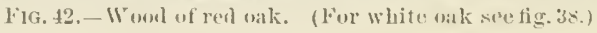

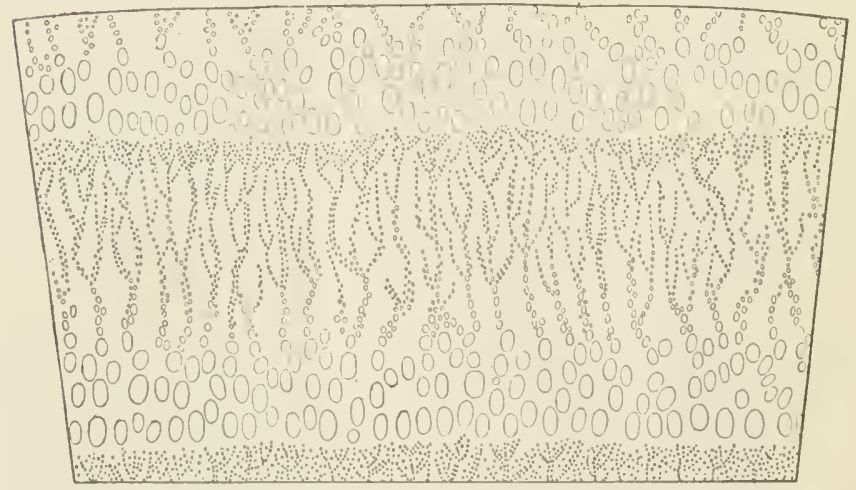

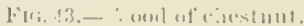

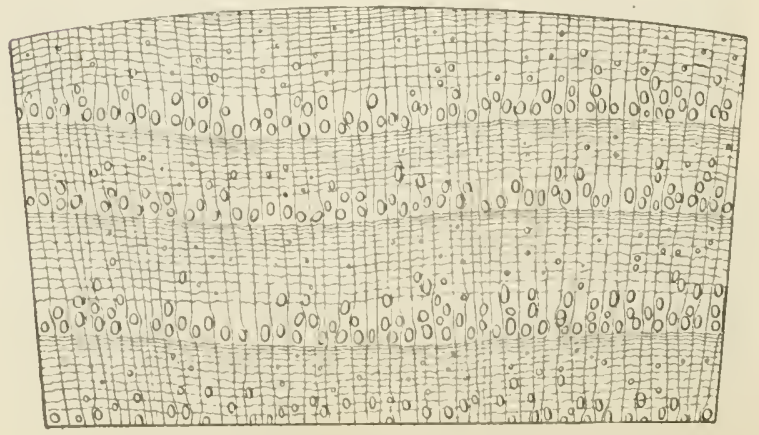

Fig. 44. - Wood of hickory. 


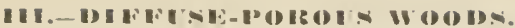

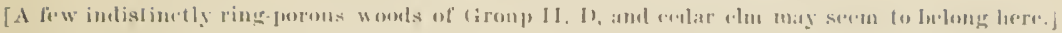

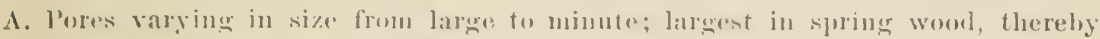

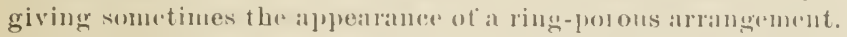

1. Heavy and laurl; color of" leartwoul (especially on longiturlinal sevtion)

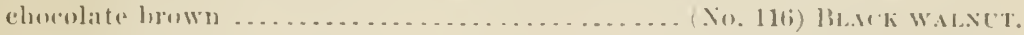

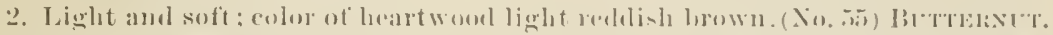

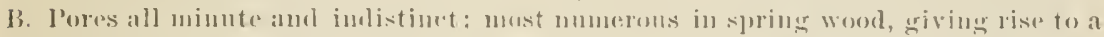
lighbter colored zono or line? (esperially on longituliual section), thereby appear-

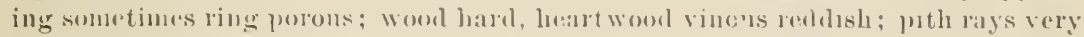

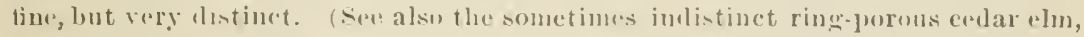
and occasionally winged elm, which are realily distinguished by the concentrice

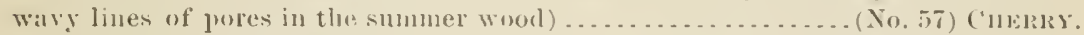

C. Pores minute or inclistuct, neither conspienously larger nor more numerous in the spring wool and evenly distributed.

1. Broad pith rass present.

a. All or mest pith rays broad, numerons, and roweder, especially on tangential sortions, medium heavy aml harel, dolifult to split.

(Nos. ils aud 113) SYC.MNORE.

b. Only part of the pith rays broacl.

$a^{\prime}$. Broal pith rays well defined, quite numerous; wool redilish-white

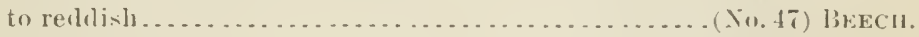

$b^{\prime}$. Broad pith rays not sharply defined, male mp of many sunall rays, not numerous. Stem furmwed, and therefore the periphery of section, and with it the annnal rings sinuons, leending in and ont, and the large pith rays generally linited to the furrows or coneave portious. Worol white, not realdish ............ (No. 52) BLUE BEECH.

2. No broad pith rays puesent.

a. Pitl rays small to very small, hut quite distinet.

$a^{\prime}$. Woot liari.

$a^{\prime \prime}$. Color reddish white, with dark reddish tinge iu outer summer

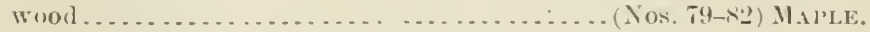

$b^{\prime \prime}$. Color white, without redilish ting(3.......... (No. 76) Hor.L.:

$b^{\prime}$. Wood sutt to very suft.

$a^{\prime \prime}$. Pures crowled, ocenpying nearly all thespace between pith rass.

$a^{\prime}$. C'olor yellowish white, olton a with greenish tinge in heart-

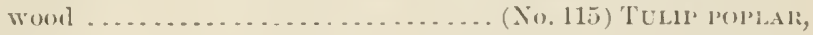

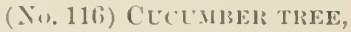

$b$. Color of silpwood grayish, of heartwood light to dark red-

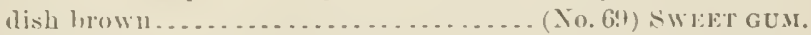

$b^{\prime \prime}$. Porrs not erowled, oecupying mot over une-thiril the space between pith rays; leartwood hrownislu whte to very light hrown,

(Xos. 45 and fii) lissswoum.

6. Pith rags scareely astiuct, yet if viewed with ordinary mannifier, plainly visilul:.

$a^{\prime}$. l'ores indi-tinet to thr naked eye.

". (olor wuiform pale yellow; jith rays not ronspienons even on

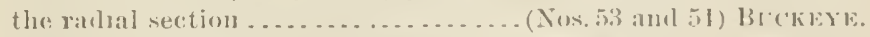

$b^{\prime \prime}$. Sapwood gellowisl gray, hastwood graysul hrown: pith rays

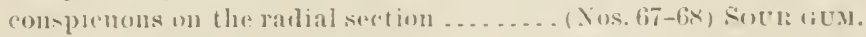

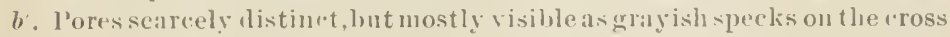

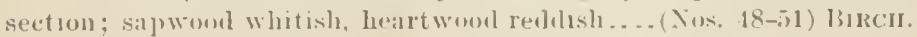

D. Pith raye not visible or else indistinct, even if viewed with magnifier.

1. Wood very soft, wlite, or m shales of l,own, usually with a silky luster, (Nus. 105-110) CotToxwoO1) (1'ol'sar.) 


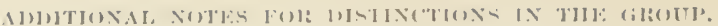

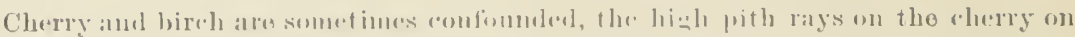

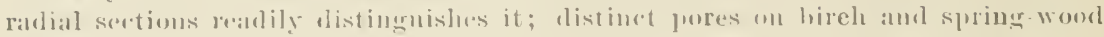
zone in ehery as well as the darker vinoms brown color of the latter wall prove lic]

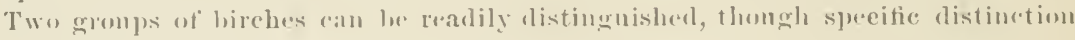
is not always posisile.

1. Pith rays fairly distinct, tho pores rather fow and mot mone abmulant in the

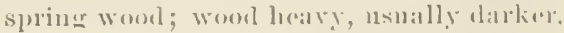

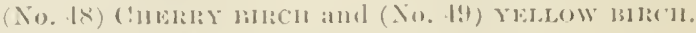

2. Pitl raps barely distimet, pores anre mumeroms and commmomly forming a more porous spring-wool zone; wool of morliun wajelst.

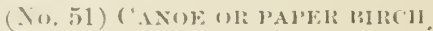

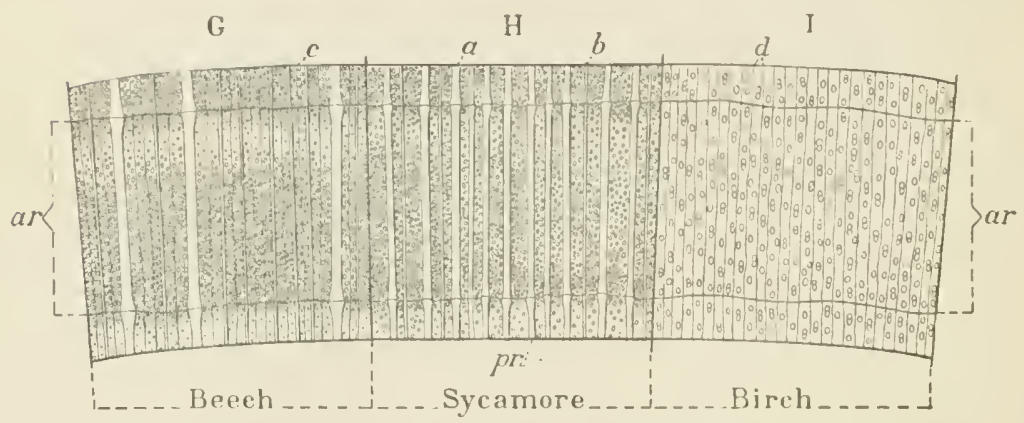

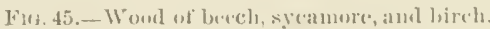

The sprecies of maple may he distiugnished as follows:

1. Most of the pith rays loralder than the pures and very conspicuoms.

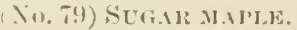

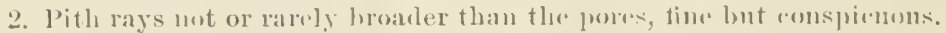

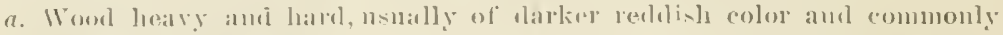

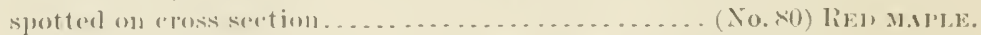

b. Wool of mulinm woinht and harluss, unually light rolored.

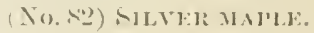

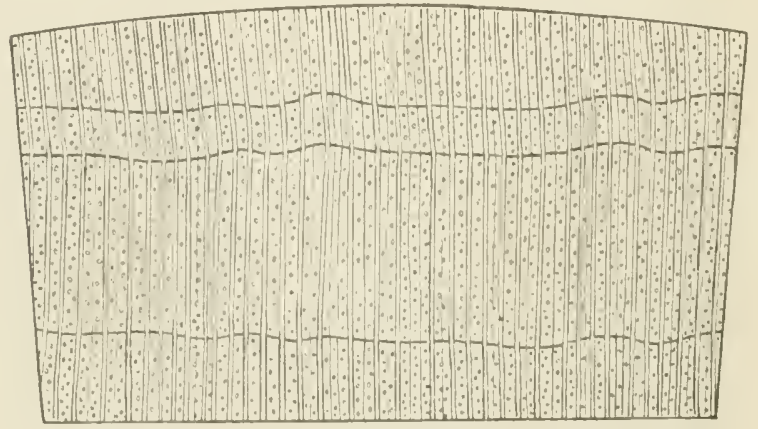

Fig. 46.-. Woosl of minlo.

Red maple is not always safuly distimguishul from soft maple. In low wher tho pores are tiner aud more mmmoroms than in soft maple. 
ADITIONAI, NoTr:i-eontinued.

Thu varions specins of elm may be distinguishod as follows.

1. lores of spring wool form a hroud hand of sevoral rows; easy splitting,

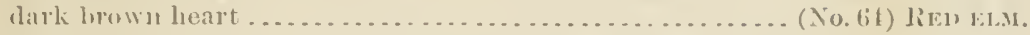

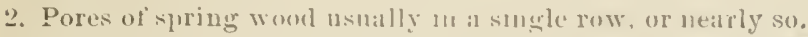

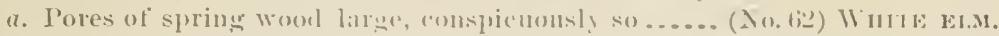

b. Pores of spring woud smatl to minute.

$a^{\prime}$. Lines of pures in summer wond finc, not as wisle as the intermediate

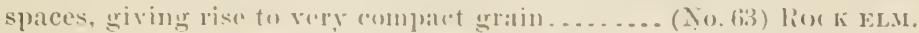

$b^{\prime}$. Lines of pores hroal. commomly as wide as the jutermediate spaces,

(No. (j6) Wixgl:1 EL,

c. Pores in spring woul indistinct, and therefure hardly a ring-porous

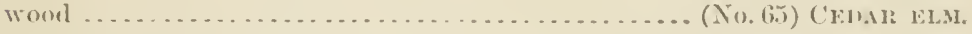

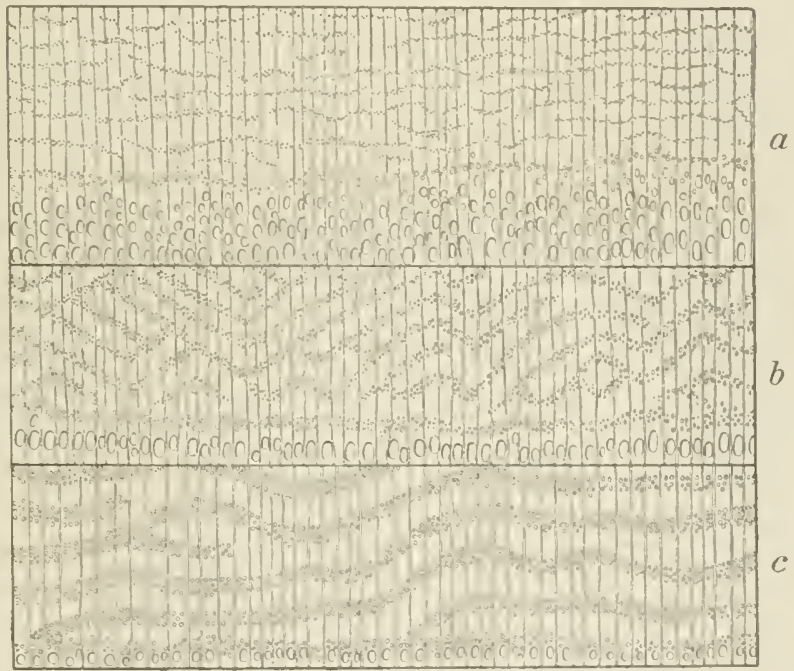

Fif. 47.- Toorl of elm. a, red elm; $b$, white elm : e. winged elu.

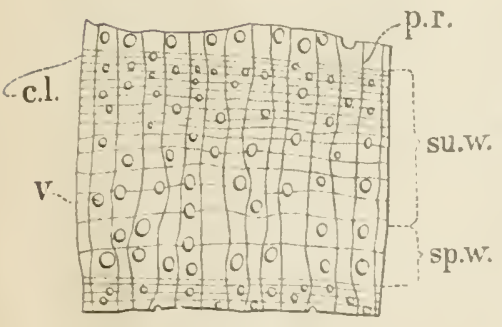

Fini. 4x.- Walnut. I\%. r.. pith rays; c. l., con contriv lumes; v, vessels or pores; su. " summer wool: $s p, w .$, spring woul

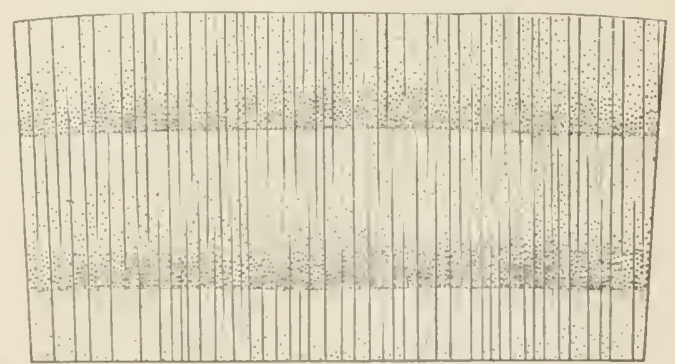

lili, 49. - Woul of cherry. 


\section{LIST OF THE MORE IMPORTANT WOOIS ()E THE UNTTED STATES.}

[Arranger] alplualuetirally.]

\section{A. CONATEREL WOODS.}

Woods of simple and unifurm structure, generally light, soft hut stiff; ahmulant in suitable dimensions and forming hy far the greatest part of all the lumber userl. CEDAR.—Light, soft, stiff, not stroug, of time texture; saj and hrartwool distinet, tho former lighter, the latter a dull. gray:sh brown, or red. The wood seasons rapialy, shrinks and elierlis lout little, and is very dnrable. Tsud like solt pine, lunt owing to its great duability preferred for shingles, e.te. Snall sizes nsesl for posts, ties, ete.' Cedars usually ocem seattered, hit they form, in certain localities, forests of considerible extent.

a. White cedars.-Heartwool a light grayish bown.

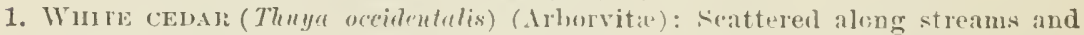
lakes, frequently covering extrnsive swamps; rarely large enongh fur bumber, but commonis used for posts, ties, ete. Mame to Mimesota aud uorthward.

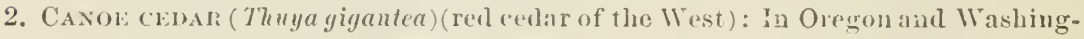
ton a very large tree, covering extensive swamps; in the monntains mueh smaller, skirting the water comres; an important lumber tree. Washington to northeru Califoruia and eastwarl to Montana.

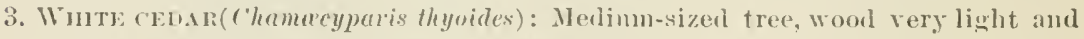
soft. Along the coast from Maine to Mississippi.

4. Whit: (EDAR (Chamncyparis laksoniana) (P'ort Orford eedar, Oregon cedar, Lawson's espress, ginger pinc): I very large tree, (x) heavier and stronger than the preveding. Along the roast line of Oregon.

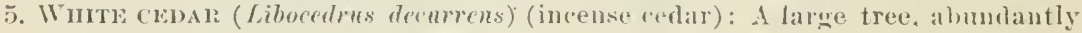
seattered among pine and tir; wood tine graind. Cascades and sierra Nevada of Oregou amd Calitornia.

b. Red cedars.-Hirartwoll red.

6. Ren Cwar (Jumiperas riminiena) (Savin juniper): Similar to white cerbr, hut of somewliat fincr texture. Isol in calbinetwork in couperage, for veneers, and especially for latal pencils, for whieh purpose alonr several million feet are mut each year. A small to medimm sized tree seatteral thromgh the forests, or, in the West, sparscly resering extensive areas (erial brakes). 'lhe red redar is the most widely distributed coniter of the l'nitud siates, oncurring from the Atlantic to the lacilie and from Forida to Minnesota, but attains a suitable sizo for lumber only in the sonthern, and more esperally the cindt, states.

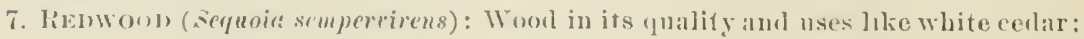

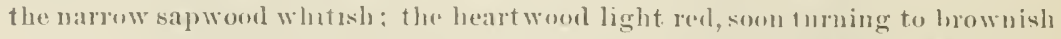
red whru exposerl. A very large tree, limited to the coast ranges of California, and forming considerable forests, which are rapidly being converted into lumber.

\section{CYPRESS.}

8. ('Yrobss (Taxodinm distichum) (bald cypress; black, white, aud red eypress): Wood in appearance, quality, and uses similar to whte cerlar. "lilack

ISine almost all kinds of wouds are used for fuel and rharenal, amd in the construction of fences. Bheds, barns, ete., the enumeration of these uses has been onitted in this list. 
eypress" and "white cypress" aro heary and light forms of the samo speries.

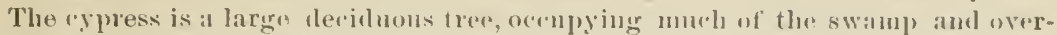
flow land alomg the east and rivers of the somthern states.

FIR.-This name is frepuently applied to woorl and to troes whirll aro not fir ;. most commonly to spunce, but also, esperially in Euglish markets, to pine. It resemblos spruec, but is easily distunguished from it, as well as from pine and larell, by tbe absence of resin duets. Quality, uses. and habits similar to spruce.

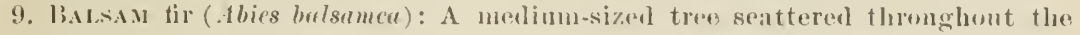
northern pinerios: cut, in humber operations whenever of suflicient size, and sold with pine or sprnee. Minnesota to Maine and northward.

10. Winte Fin (Abies grandis and Abics concolor): Medium to very large sized treo, formmg an important part of most of the Western nountain forests, anel inrmshing much of the lumber of the respeetive reginns. The former onems from Vancourer to central California and eastward to Montana; the latter from Oregon to Arizona and (astward to Coloralo aud New Mexico.

11. Wint: Fu (Abies amabilis): Gool sizen tre, often forming extensive monntain forests. Cascacle Momutains of 1 ashington amd Oreurou.

12. RED FIR (dbies nobilis) (not to be confounded witl l)onglas fir; see No. 3i): Large to very large tree, fornung with .t. uinabilis extensive forests on the slope of the momtans hetween 3,000 and 4,000 teet elevation. Cascale Monntains of Oregron.

13. REn FIR (Abies magnifica): Very large tree, forming forests abont the base of Monnt Shasta. Sicrrir Nevada of California, fou Mount Suasta sontluwarl.

HEMLOCK.-Light to medimm weight, soft, stiff bnt brittle, commonly crossurained, rough and splintery; silp wood and heart mood not well defined; the wool of a light, redilsh-gray color, free from resin ducts, moderately durable, shriuks aud warps considerably, wears rough, retains nails firmly. Used principally for dimension stuff and timbers. Hemlocks are medium to large sized trees, commonly scattered among broal-leaved trees and coniters, bnt often forming forests of almost pure growth.

14. HEмLock (Tsuga canadensis): Medium-sized tree, furnishes almost all the hemlock of the Eastern market. Maine to Wisconsin; also following tho Alleghanies sonthward to Georsia and Alabama.

15. HEмLock (Tsugu mertensiuna): Large-sized tree, wood claimed to be heavier and harder than the Eastern form and of superior quality. Waslington to California aud eastward to Montana.

LARCH OR TAMARACK.-Wood like the best of hard pine, both in appearanee, quality, and uses, and owing to its great durability, somewlat preferred in shipbniliting, for telegriph poles, and railroad ties. In its strunture it resembles spruce. The larches are leciunous trees, occasionally covering cousiderable areas, but usmally scattered among other coniters.

16. Tamarack (Larir americanu) (IIackmatack): Medimm-sized tree, uften covering swamps, in which rase it is smaller and of poor guality. Maine to Mimmesota, and southward to J'ennsyelvania.

17. TAMAneK ( $L$. occidenlulis): Larga-sized troes, seattered, locally abindant. Washington and Oreuron to Montana.

PINE.- Very variahle, very light and soft in "soft" pine, surll as white pine; of medium weight to heary and quite luard in "luarl" piue, of which lomgloaf or Georgia pine is the extreme form. Tsuslly it is stiff, 'fuite strong, we even textme, and moreor lesis resinons. 'Thesapwool is yellowish whito; the heartwoon, osango brown. Pine slurinks moderately, seasons rapidly aur without much injary; it works easily; is never too hard to nall (mulike oak or lickory); it is mostly quite durable, and if well seasomed is not subject to thes attacks of horing inserts. The heavier the wood, the darker, stronger, and harder it is, and the more it shriuks and checks. Pino is used more extensively than auy other kind of wood. It is 
the principal wood in common carpentry, as well as in all heavy construetion, hridges, trestles, ote. It is also nsed in almost every other woul industry, for spars, masts, plinks, and timbers in shiphuilulugr, in calr and wagon construetion,

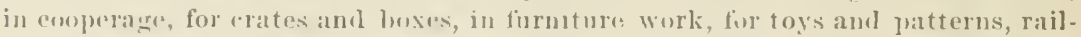
way ties, water pipes, exerlsior, etc. I'mes are usually larue trees with few branches, the straight, eylindrical, nselial stem formine ly far the wreatest part of the tree; they own gregarionsly. liorming vast forests, a faet which greatly facilitates their aploitatum. Of the many special terms applied to pine as lumber, lenoting smmetimes ditherencs in guality, the following leserve attention:

"Wlite pine," "pumplin. pune," "soft pine," in the Eastern anarkets refer to the wood of the white pine (l'inus strobus), and on the Pacifie ('vast to that of the sugar pine (Pinus lambertiuna).

"Vellow pine" is applind in the trade to all the sonthern lumber pines: in the Northeast it is also : mostly to bull pine (P. pouderosit).

"Yellow longleaf pine," "Georgia pine." "hietly used in arlvertisement, refers to longleaf pine: ( $I$. pulustris).

"Hard pine" is a common term in carpentry, and applies to ererything exerpt white pune.

"Piteh pino" inchules all sonthern pines and ilso the true piteh pine (P. rigidu), but is mostly ajplinel, especially in foreign markets, to the woul of the longlaf pine ( $P$. palustris).

For the great variety of ronfusing lowal names applieal to the somthern pines in their homes, part of which have been atopited in the markets uf the Atlantie seilboard, seo report of Chief of l)ivision of Forestry for 18!1, page 212, ete, and also the list below:

\section{(ใ. Soft pines.}

18. WrITE IxE (l'inus strobus): Large to very large sized tree; for the last fifty vears the most important timber tree of the l'nion, finnishing the best anality of soft pine. Minnesota, Wisconsin, Michigan, New Englanl, along the Alleghanies to fieorgia.

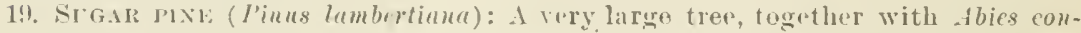
color, forming extensire lorests; important lumber tree. Oregon amb California.

20. White PINe (Pinus monticola): A large tree, at home in Nlontana, Idaho, and the Pacifie States; most eommon and low ally used in northern Irlaho.

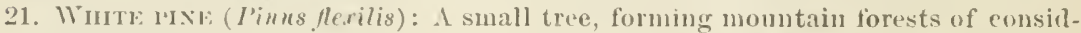
arable extent and locally userl; Eastern hocky Mlountain slopes: Montana to New Mexion.

\section{b. Hard pines.}

22. LoNGlin P'INE (I'inus palustrio) (Georgia pine, yellow pine, long straw pine, ete.): Large tree; forms extensive furests and furnishes the larilest and strongest pine lnmbre in the marliet. Coast region from Nortl carolina to Texas.

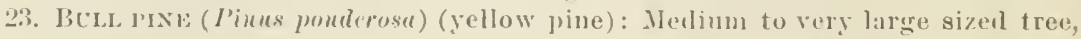
formug "xtensive forests in Pacifie and lioky Mountain regions; furuishes most of the hard jine of the West; salpwool wide; wool very variable.

21. Lablolly pixe (I'inus tuda) (slash pine, old field pine, rosemary fine, sap) line, short straw pine, ete. ) large-sized tree, forms extensive forests; wilerringed, coarser, lighter, softer, with more silpword than the longleaf pine, lut the two often eonfombled. This is the anmon lumber pine from Virginia to Sonth Carolina, and is fomnl extensively in Arkansas and Texas. Southern states; Virginia to Texas and Arkansas.

35. Nomwa pine (I'inus resinosa): Large-sized tree, never forming forests, usually scattered or in sulall groves, together with white pine; largely sapwod and hence not durable. Minnesota to Michigan; also in Now England to Pennsylvania. 


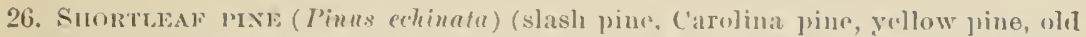

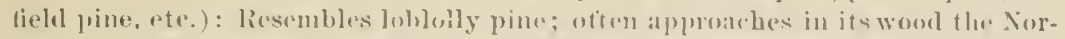

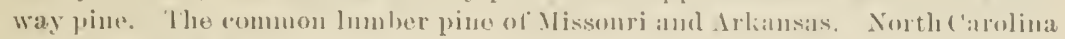
to Texas and Missomri.

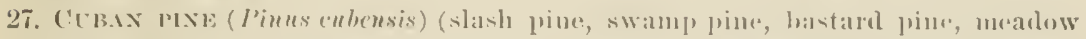
pine): liesembles longlonf pine, hut eommonsly has wider sajwoorl and courser grain; does not enter tloe markets to any great ratont. Along the coast from south Carolina to Louisiana.

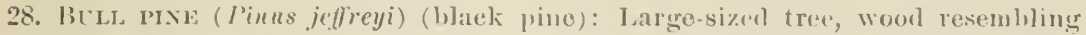
bull pine (P'. ponderosa); nsed loeally in Califontia. replan'ing $I^{\prime}$. ponderosu at high altitudes.

The following are small to mednum sizer! pines, not eommonly othered as lmulher in the market; nsed locally for timber, ties, ete.:

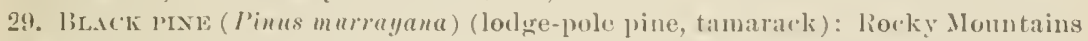
and P'acifie regious.

30. Prrcu PINE (Pinus rigita): Along the coast from New York to Georgia and along the momtains to Kentucky.

31. Jerser lise (l'inus inops) (seruh pine): Is before.

32. (HRAY PINE (I'inus banlisiuna) (scruh pine): Maine. Vermout, and Michigan to Minnesota.

\section{REDWOOD. (Sce CEMAR.)}

SPRUCE.- Resembles soft pine, is light, very soft, stiff, moderately strong, less resinous than pine; has no distinet heartwood, and is of whitish color. U'sed like soft pine, but also employed as resonance wooland preferred for paper pulp. Sipruces, like pines, form extensive torests; they are more frugal, thrive on thinner soils, and bear more shade, lut usually refinite a more humid climate. "Black" and "white spruce," as applied by lumbermen, nsually refer to narrow and wide ringed furms of the blarek spruce (l'icen nigra).

33. BLACK SPRCCE (P'icet uigr $($ ): Medinm-sized tree, forms extensive forests in uorthenstern United states and in British America; ocenrs scattered or in groves, especially in low lands throughont the Northern pineries. Important lmmer tree in Eastern United States. Maine to Minnesota, British America, and on the Alleghanirs to North ('arolina.

34. Wute sprucw (I'icea alba): Generilly associated with the preceding; most ahundant aloug streams and lakes, grows largest in Montanil and forms the most important tree of the subaretic forest of Pritish Anerica. Northern United States, from Maine to Minnesota, also from Montana fo Pacifie. l3ritisls Ameriea.

35. White sprcen (Picen engelmanni): Yedimm to larga sized tree, forming extensive foreste at elerations from 5,000 to 10,000 feot ahove sea level; resembles the precenling, hut oecupies a different station. A very inportant timber treo in the central and sonthern pautsof the Rocky Mountains. Rocky leomtans from Mexico to Montima.

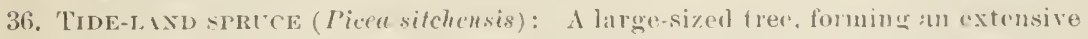
coast-belt forest. Along the seareoist from diakka to ('ontral ('aliformial.

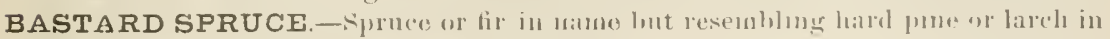
the appearance (pullity, and uses of its woul.

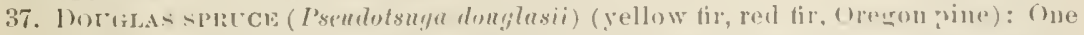
of the most important trees of the Western lnited states; grows rery lalue an the Pacific states, to fiar size in all puts of the mountains, in Cclorsdo up to about 10,000 fert aloove sea level; thrus extrusive furests, often of puras arowth. Wood very variable, usmally coarsegramed and heavy, with very pononncod smmmer wood, hard and strong ("red" fir), lut of wn fine-grained and liglit ("sellow" fir). It replaces hard pine and is esperially suited to hanv construction. From the plains to. the Pateitie Ocean; from Mexico in British Ameriea. 
TAMARACK. (See LARCH.)

YEW.- Wood leavy, hard, extremely still and strong. of find texture with a pale yellow sapwool, and an orange leed heart; seasons well and is puitodurahle. Yew is extensively used for archery, bows, turners ware, "te. The yews form nu forests, but oferur seattered with uther conifers.

38. Inw (Taxus brevifolia): I small to medium sized tree of the Pardite region.

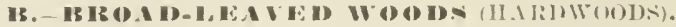

Wools of eomplex and very variable stuncture and theretore difiering widely in quality, behavior, and consequently in applicability to the arts.

ASH.--Wood heavy, luard, strong, still, quite tomgh, not duralule in contalet with soil, straight grained, rongh ou the split surfine and eoarse in texture. The wood shriuks moterately, seasons with littlo iujury, stands woll and takes a goor poliwh. In carpentry ash is uscel for tinishing lumber, starways. pounels, etc. : it is used in shiplunilding, in the eonstruetion of cars, wayns, carriages, etr., in the manulacture of farm implements, machinery, and especially of furniture of all kinds, and also for harness work; for barrels, baskets, oars, tool hamdles, hoops. (clothespins, and toys. The trees of the several speeies of ash are rapid growers, of small to molinm height with stout trunks; they form no forests, hut oceur seattered in almost all onl broall-leaverl firests.

39. Wutne AsIl (Fraxinus amerieana): Medinm, sometimes large sizen tree. Basin of the Ohio, but fomml from Maine to Ilimesota and Texas.

40. Rikn Asir (Frarinns puberens): Amall-sized tree. North Atlantic States, but extends to the Mississiplyi.

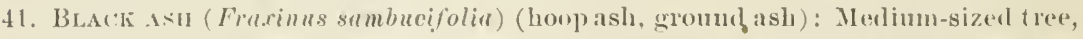
very eommon. Maine to Mlunesota, and southwarl to Virginia amb driansas.

42. Bute Asu (Fraxinus quadrangulata): Small to medinm sized. Indiana and Illinois; ocenrs from Miehigan to Minnesota and sonthward to Alabana.

43. (ireEN Asil (Fraximus virilis): Small-sizell tree. New York to the liocky Momutains, and sonthward to Florila and Arizona.

44. (1)wion Asil (Fraxinus oregana): Medinm-sized tree. Western Washington to Callitoruia.

\section{ASPEN. (Sie POPLAR.)}

\section{BASSWOOD.}

45. Basswoon (Tilia americana) (lime tree, American linden, lin, bes tree): Wool light, soft, stifl hut not strong, of tine texture, and white to light brown color. The wool shrinks consirleralbly in drying. works and stands well: it is used in carpentrs, in tho manfacture of furmiture and womlenware, both turned and earved, in cooperage, for toys, also for paneling of ear and carriage bodies. Dedinn to large sized tren, common in all Northern broad-leaver forests; fouml throughout the Eastern l hited states.

46. Wutt Isasswmon (Tilia heterophylia): $A$ small-sized tree most abundant in the Alleghany region.

\section{BEECH.}

47. Brecu (Fayus fervuginen): Wood heary, hard, stiff, strong, of rather coarse texture, white to light bown, not dumble in the ground, and sulpiect to the inroals of horing insects; it slurinks and cherks consillerably in olrying, works and stands well and takes a good polish. I'sed for finniture, in turury. for landles, lasts, ete. Abromel it is very extensively employed by the anpenter, millwright, and wagon maker, in turnery as well as worl carving. The beech is a modinm-sized tree, common, sometimes forming forest; most abmulant in the Ohio and Mississippi hasin, hut fonmel from Maine to Wisconsin and sonthwird to Florilit.

BIRCH. - Wool lieary, hard, strong, of tine texture; sapwood whitish, lieartwood in shaths of hrown with red anl yellow; rery handsome, with satiny lnster, equaling cherry. The wool shriuks considerably in drying, works aul stands 
well and takes a goul polish, lunt is not durable, if rxposen. Birch is used for

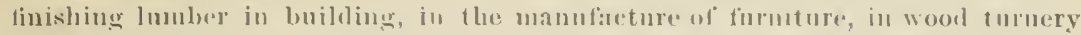

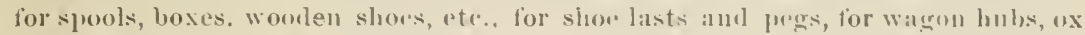

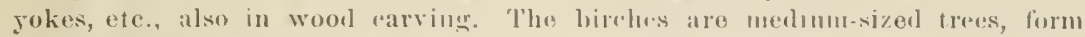

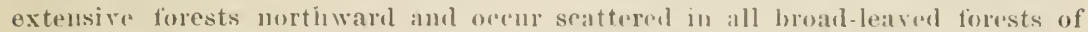
the Easteru l'nited states.

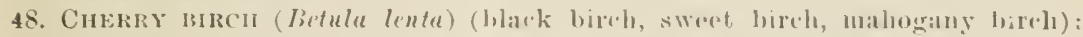

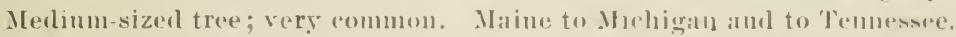

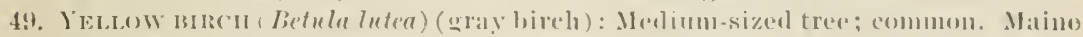
to Minnesota and soutbwarl to Temuessere.

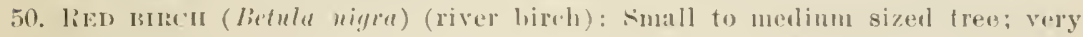
common; lighter and less valuable than the proceding. New Eugland to Texas intl Missonri.

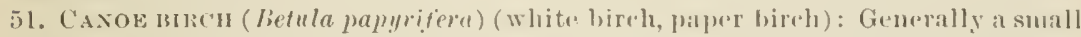
tree; common, forming forests; woorl of goul qualıty hut lighter. All along the northeru bomalary of Inited States ame northward, from the Atlantic to the Pacific.

\section{BLACK WALNUT. (See WAINTT.) \\ BLUE BEECH.}

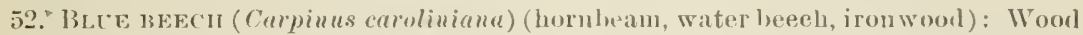
very heavy, hark, stromg. very stiti, of rather fine texture and whito color; not durable in the gromel; shrinks aud vlecks greatly, but works aud stancls well. Used shirlly in turnery for tool liandles, ate. Abroad, mueh used by mill and wheel wrimhts. A small trex, largest in the Fonthwest, but foumd in nearls all parts of the Eastern Vuited States.

BOIS D'ARC. (See OSAGE ORANGE.)

BUCKEYE-HORSE CHESTNUT.-Wuol light, suft, uot strong, often quite tough, of the and uniform texture and creamy white color. It shrinks eonsiderably, lut works and stands well. Ised for woolen ware, artiticial limbs, papel pmlp, amb locally also for huilding lumber. Small-sized trees, soattered.

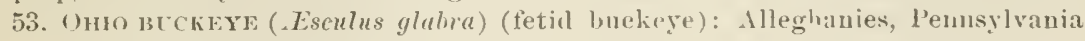
to Indian Territory.

54. SWEet ichere (. Esculus fluva): Alleghanies, Prunsylvamat to Texas.

\section{BUTTERNUT}

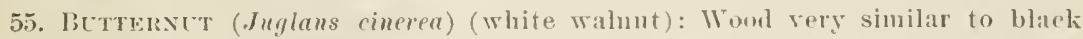
walunt, lut light, guite soft. not stromg and of light brown rolor. L'serl rhiedly for tinishing lomber, cahinetwork, aud rooperage. Mablinm-sized tree, largest and most common in the Ohio basin; Maine to Mimesota and sontluarl to (ieorgia amul Alabama.

\section{CATALPA.}

56. Catalpa (Catalpa speciosa): Wood light, sott, mot strong, brittle, dırable, of roarse texture aud lorown color: nsel for ties and posts, but well suiterl for a great raliety of uses. Medium-siztel tree; lower basin of the oluio River, lucally" common. Extensively planted, and therefore promising to become of sonso importance.

\section{CHERRY}

57. ('Inerpy (l'runus serotina): Wool liestry, hard, stronge, of fino texture; salp wood sellowish white, heartwoml redilish to bown. The wool shrinks ansiderably in dryingr, worlis and stauds well, tales a good polish, amel is murll estermed for its beanty. Cherry is chiofly used as a decorative finishing lumber for builulings, ears, and boats, also for furuiture and in turnery. It is becoming ton rostly for many purposes for which it is maturally well suitenl.

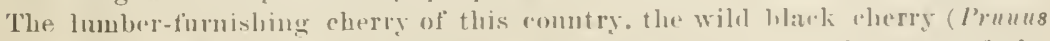

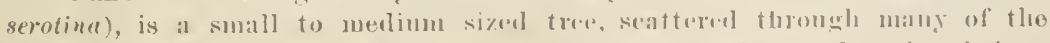
broad-leaver woorls of the western slope of the Allighanies, hint timml from Michigan to Florida and west to Texas. Other species of this genus as well 
as the hatwthorns (Cralugus) aud wild apple (Pyrus) are not commonly ofleren in the market. Thenr wood is of the same elaracter as cherry, often even liner, but in small dimensions.

\section{CHESTNUT.}

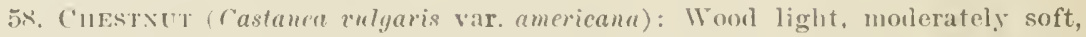
still, unt strong, of enarse texture; the sapwool light, the heartwood darker brown. It shrinlss and rhecks considerably in drymg, works atsils, stands well, and is very durable. I sed in callinetwork. (noperage, for railway ties,

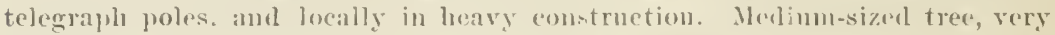
common in the Alleghanies, oceurs from Maine to dlinhigan and southwaril to Alabinma.

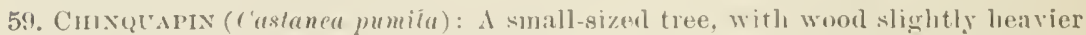
but otherwise similar to the preceling; nost commen in Arkinsis, but with nearly the same range as the chestnut.

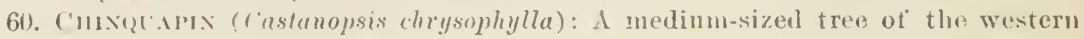
ranges of C'alifornia and (1)egon.

\section{COFFEE TREE.}

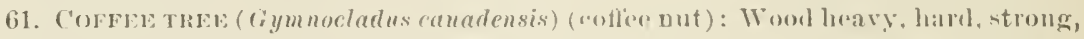

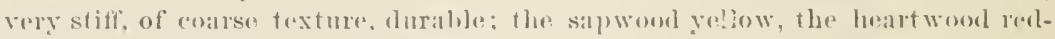
dish hrown; shrinks and rhecks ronsideralbly in drying; works and stands well and talkes a goml polislı. It is used to a limited extent in eabinetwork. A medinm to large sizerl tree; not common. Penusylynia to Minnesotal and Arkansils.

\section{COTTONWOOD. (STE POPLAL.)}

\section{CUCUMBER TREE. (Se 'TIIMP.)}

ELM.-Wool heary, harid. stroug. very tomgh; moderately durable in coutact with

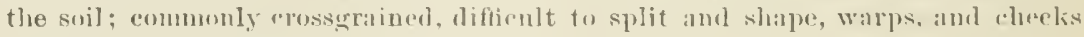

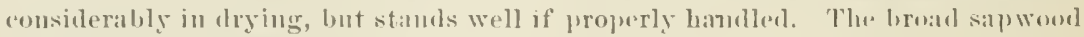
whitish, heart brown, hoth with shades of sray and red: ori split surlited rough: textme coarse to tine; "apible of high polish. Flu is used in the construetion of

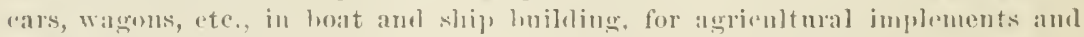
machinery; in romgla cooperage, saddlery and hamess work, lut partienlarly in the mannficture of all kimls of furniture, where the leantiful figmes, esperially those of the tangential or hastarl section, are just hegimning to be duly apploreciated.' The elms are medmm to burge sized trees, of fairly rapid growth, with

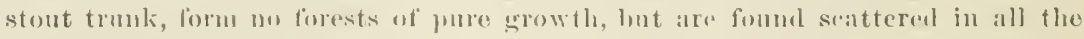
broad-beared wouls of our conntry, sometimes corming a considerable portion of the arborescent girowth.

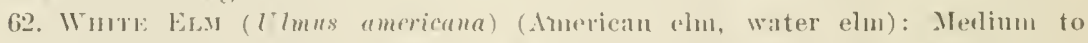
largesiznd tree, common. Mane to Minnesota, sonthward to florida and Texas.

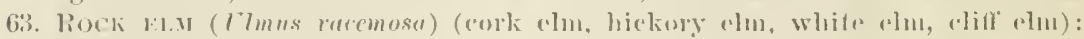
Medium to large sized tres. Michigan, (lhio, from Vermont to Jowa, sonthwarll to kenturky.

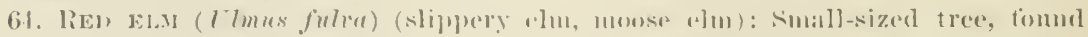
ehietly along water commses. Now Vork to Minuesota, and sonthward to Floricla and Tixis.

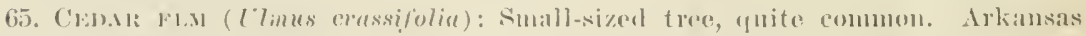
and Texals.

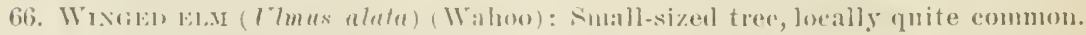
Arkatusas, .lissomit, and astem lireginial.

GUM.- This general tom refiers to f wo kindsof worl usually distingnished as sweet or red grmm, and som, biack, or tupelo gum, the former being a relative of the

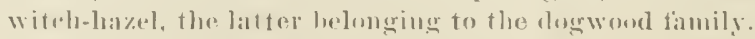

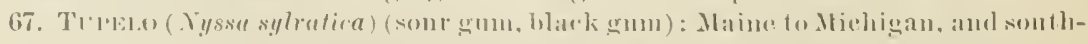
ward to Florida aud texas. Wool hary, hard, strong, tough, of line texture, 
frecuentls crossurained, of yellowish or grayish white color, hard to split and work, tronlolesono in seasoning, warps and checks cousideraloly, and is not durable if expused; nsed for wagon lubs, woulen ware, hanilles, woulen shoses, ete. Medium to large sized trees, with straight, elo:ar trunks; locally cunte abundant, lut never forming lorests of pure growth.

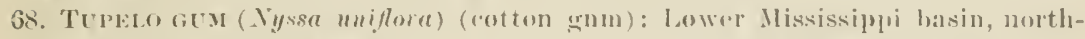
ward to Illinois and astwanl to Virginla, otherwise liko preceding species.

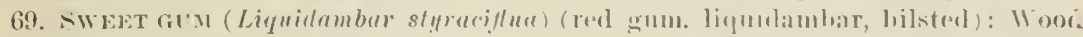

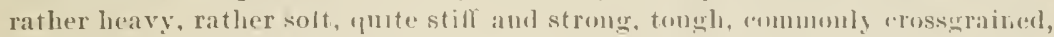
of dine texture; the hroal sapwort whitish, the heartwond redlish brown; the wool shrinks and warps considerably, lut dowes not cherli loblly, stands well when finly seasoned, and tilkes good polish. Swart gum is used in carpentry, in the mannfacture of furniture, for ent veneer, for woolden plates, plarpues, baskets, ete., also for wagon lubls, lat blocks, ete. A lare-xizel tre, very alumlant, often the principal tre in the swampy parts of the hotwums of the lewer Mississippi Valley; orenrs from New York to Texas and foun Indiana to Florisla.

\section{HACKBERRY.}

70. HACLBERr (Celtis aceidentalis) (sugar berry): The hamblsome wool heary, hard, strong, unite tongh, of morlerately fine textmre, and greenish w yellowish whitu eolor: shrinks moderately, wor a well, and takes a grood polish. So fil bnt little used in the mannfacture of furuiture. Dedium to large sized trae, locally quite common, largest in the Lower Mississippi Valley; occurs in nearly alt parts of the Eastern United states.

GICKORY.- Wood very heary, hard, and strong, proverlially tough, of rather coarse texture, smooth anil of straight grain. The hroal sapwowl white, the heart reddish nut brown. It dries slowly, shriuks and cheeks considerably; is not dura. ble in the gronud, or if expused, and, especialiy the salpowl, is always subject to the inroads of loring inserts. Ilickory excels as carriage and wachon stock, but is also extensiveiy used in the mannfacture of implements and millinery, for tool handles, timber pins. for hamess work, and cooperage. The hiokories are tall trees with sleuder strms, never form forests, oreasionally small wroves, hut usually ocenr scattered among other broad-liaved trees in stritable localities. The following species all contribute more or less to the hickory of the markets:

71. Silagbalik nuckory (Hiroria orata) (shellbark hiekory): A medimm to large sized tree, quite common; the farorite among hickories; lost dereloped in the Ohio and Mlissinsippi lasios; from Lake Ontario to Texas, Minnesota to Floricla.

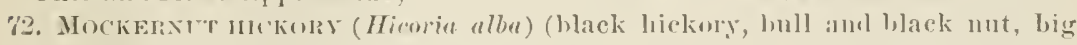
bud, and white-heart hickory): A medium to large sized tree, with the same range as the foregoing; common, especially in the sontl.

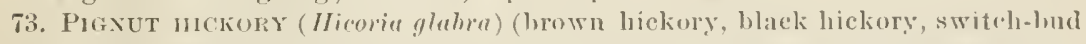
hickory): Medimu to large sized trexe, almunlaut: all Eastem United states.

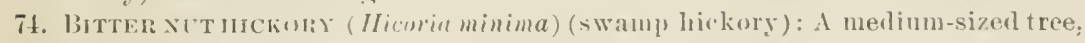
faroring wet locilities, with the silme range as the preceling.

75. Pecax (Hicoria perten) (Illinois nut): A large trees. rery (ammun in the fertile bottoms of the Western streams. Indiana to Nelsraska and sonth ward to Lonsiana and Texas.

\section{HOJLY.}

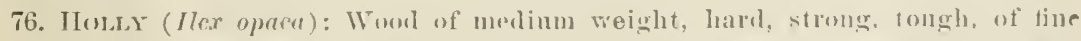
texture and white color; works and stands well, used for ablinetwork aud turnery. A small tree, most alumdant in the Lower Mississiplpi Valley and Gulf states, lut oreurring rast warel to Masanchusetts and north to fulliana.

HORSE-CHESTNUT. (See liTKNA.)

IRONWOOD. (SEC BLE'E BEECH.) 
LOCUST.-This natne applies to hoth of the following:

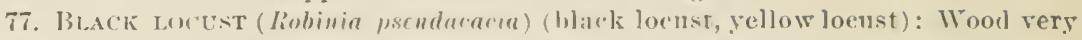
heary, hard, strong, and tungh, of coarse texture, rery durable in contact with the soil, slurinks romsieleraluly and fuffers in seasoning the very narrow silp. wood yollowish, the heartwood hrown, whth shates of red and green. Lsed

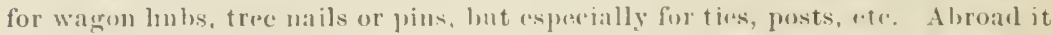
is umele used for furniture and furm implemenls and also in turnery. Small to

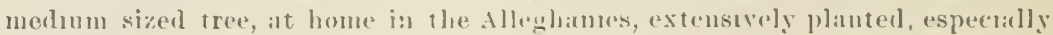
in the West.

7x. Hoxey mocest (Fileditschid trandhos) (black locust, sweet locust, threethornel acacia): Woul heary, hand, stroug, tough, of coirse texture, suserple tible of a grool polssh, the narrow sapwoud yellow, the heartwoorl brownish red. So far, lut little apprecinted racept for fencing and finel ; used to some extent for wayom hubs and in rongli monstuction. A medimm-sized tree, foumb from Penusylvanta to Nebraska, aud south rarel to Florida and fexas: locally quite abuudaut.

\section{MAGNOLIA. (Sie T'LIP.)}

MAPLE.-Wood heavy, hard, strong, stifi, and tough, of fine texture, frequently wary-grained, this griving rise to "curly" and "blister" figures; nut duralble in the gromel or otherwise exposed. Maple j: creamy white, with shindes of liglat hrown in the heart; shrinks uoderately, seisons, works and stamds well, wears smoothly, and takes a fine polish. The woul is used for ceiling, tlooriag, paneling, stairway, and other finishing lumber in honse, ship, and calr construetion: it is used for the keels of boats aud ships, in the manntacture of implemeuts and machiners, but esperially for furniture, where entire "hamber sets of maple rival those of oak. Maple is also used for shoe lasts and other form hlocks, for shor pegs, for piano aetions, school apparatus, for woul type in show bill printing, tool handles, in woor earving, turnery, and scroll work. The maples are medinm-sized trees, uf fairly rapid growtli; sometimes form forests and frepuently constitute a large proportion of the arboresceut growth.

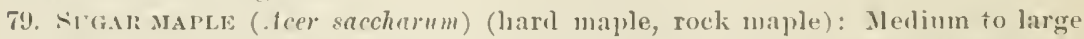
sizel tree, very common, forms consinlerable forests. Maine to Minnesota, almmdant, with birel, in parts ol the pineries; sonthward to morthern Florida; most abundant in the region of the (rocat Lakas.

60. RED WAlle (Acer rulrum) (swamp or water maple): Medimm-sized tree.

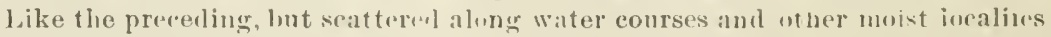

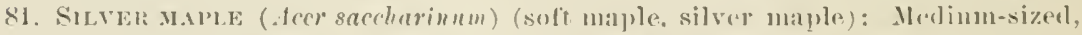
common; wood ligliter, softer, inferior to hard maple, and usually oflered in small quantities and held separate in the market. Valley of the Oinio, hut oecurs from Maine to Dakotil and sontluward to Floricla.

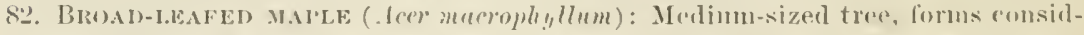
crable forests, and like the precerling has a lighter, softer, and less valualule woorl. Pacifie Coast.

\section{MULBERRY.}

83. lisu Mrumak (Morus rubra): Wool moderately heary, hard, strong, rather tough, of coarse texture, duralble; sapwoul whitish, heart yellow to orange bown; shrinks and rheeks considerahly in drying; works and stands well. lsed in cooperage and locally in shiphubling and in the mannfieture of farm implements. I small-sized tree. common in the Olio aur Mississipui valleys, hut widely distrihuted in the Kastern ITnited states.

OAK.-Wool very variahle, usmally very heary and hard, very strong and tongh, porous, and of coarse texture; the sapwoul whitish, the heart "wak" lirown to reddish brown. It shruks and rhecks bally, giving troulude in seasoning. but stands well, 1s durable, and litfle subjert to attarlik ol inserets. Oale is used for many purposes: in shipbuilding, for leary construction, in common carpentry, 
in furniture, ear, and wagon work, enoperage, turnery, mul oven in wood carving; also in the mamufacture of all kinds of farm inplements, woden mill machinery, for pules and wharves, raitway ties, ete. The oaks are nuclium to large sized trees, forming the predominant part of a large portion of on loroal-baver forests, so that these are generally. "oik forests" though they afways contan a considerable proportion of other kinds of trees. Thuee well-marked kinds, white, real, and live oak, are clistingnished and liept separate in the market. Of the two prineipal linds white oak is the stronger, tongher, less porons, and movedurable. lied oak, is usnally of coarsel texture, more porous, often brittle, less durible, aud even more troublesome in seasoning than white oak. In carpentry aul furuture rork, red oak brings about the same price at present as whi . Oalk. The red oaks everywhere accompany the whte orlis, and, like the latter, are nsmally represented by several species in any given locality. Livo oak, onco largely employed in shipbuilhugg, possesses all the good ynalities (exieg)t that of size) of white oak, even to al greater degree. It is one of the heavien, hardest, and most durable building timbers of this combtry; 1 structure it resembles the red oalss, but is much less porous.

84. WHite oxk (Guerons alba): Medimm to lirge sized tree, common in the Eastern States, Ohio and IIississippi vallexs; oecur's thronghont Eistern I'nited States.

85. Bur oAk (quereus macrocurpa) (mosss-eul aik, over-eup oak): Large-sized tree, locally abmulant, common. liottoms west of Mississippi; range farther west than preceding.

86. SwAMP WHITE 0AK (?merens bicolor): Large-sized tree, common. Most ahundant in the Lake States, but with rumge as in white oak.

87. Yellow OAK (Quercus prinoides) (chestmut oak, chinunapin oak): Mediumsized tree. Southern Alleghanies, eastward to Massichusetts.

88. BAsKet OAK (Ouercus michouxii) (eow oak): Large-sized tree, loeally abundant; lower Mississippi amel eastward to Delaware.

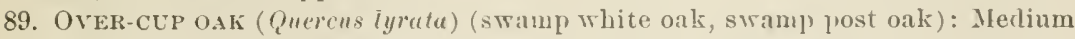
to large sized tree, rather restricted; ranges as in the preculling.

90. Post oAk (Querens obtusilubu) (iron oak): Medium to large sized tree. Arkansas to Texas, eastwanl to New England and northwall to Michigan.

91. WHIтE OAK (Quercus durandii): Medimu to small sized tree. Texas, eastward to Alabama.

92. WIITE OAK (Quercns garryanu): Medinm to large sized tree. Washington to California.

93. WhIte oAk (Quercus lobctu): Medium to large-sized tree: largest oak on the Pacitic Coast; California.

94. RED oAk (Quercus rubra) (black oak): Veclinu to large sized tres; conmon in all parts of its range. Maine to Minmesota, and southwarl to the linlf.

95. BLACK oAk (Puerens tinctoria), (yellow oals): Medinm to large sized tree; very common in the sunthera states, but ocenrring uorth as far ils Mimuesota, and eastwarl to Mariue.

96. SPANish oak ( Onerens fulcuta), (red oik): Iferlinu sized tree, common in the Sonth Atlantio and Gulf region, but fomm from Texas to Now York, and north to Missonri and lienturky.

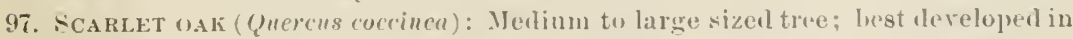
the lower basin of the Ohio, but fonnd from Mtine to Missonri, anul from Minnesota to Florida.

98. Pix OAK (Quercus pulustris) (swamp) spranish wak, water oak): Mealinu to large sized tree, eommon along borlers of streams and swamp. Arkansas to Wisconsin, and eastwart to the Alleglanies.

99. WrLlow OAK (Quercus phellos) (peacls oak): Small to medimu sizol tree. New York to Texas, and northwirl to lientucky.

$$
35: 1-\text { No. } 10-6 \text {. }
$$


100. WATER OAK (Quercus aquatica) (duek oak, possum vak, pumk oak): Medium to large sized tree, of extremely rapiu growth. Eastern finlf states, eastward to Delaware, aud northward to Missoni and Kentneky.

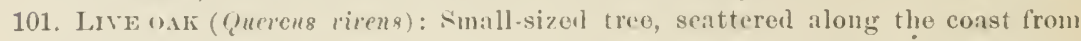
Virginia to Texis.

102. Lrve onk (Puercus sluysolepis). (manl oak, Valparaiso oak): Medimm-xizenl tree; California.

\section{OSAGE ORANGE.}

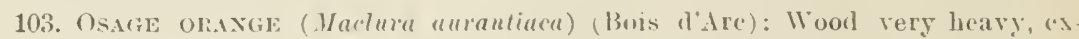
ceedingly hard. strong, not tongh, of molerately "oarse texture, and very dura ble; saprood yellow, heart brown on the cud, yellow w longitudinal faces, soon turning grayish brown if exposed; it shruks rousiclerably in drying, but once dry it stands unusually well. Formerly mueh nsed for whel stock in tho dry regions of 'Texils; otherwise emplopml for posts, railway ties, ete. Seems too little appreciated; it is well snited for turned ware and especially for wood carving. A small-sizerl tree, of fairly rapid growth, seattered throngh the rich bottoms of Arkansas and Texis.

\section{PERSIMMON}

104. Persmunon (Itospyros viryimiuna): Wood very heary and hard, strong and tongh; resembles hickory, lunt is of finer texture; the liroal sapworl eream color, the heart black; useil in turnery for shuttes, pliue storks, shoe lasts, ete. small to medinm sizerl tree. emmon and best developer in the lower ohio Valley, bnt occurs from New York to Texas and Missouri.

POPLAR AND COTTONWOOD (sce also TILLl wOOD).- Wood light, very soft, not strong, of fine texture and whitish, grayinh to yellowish color, usually with a satiuy luster. The wook shrinks moderately (some crossgrained forms warl) excessively), but checks littl'; is casily workul, but is not durable. Used as builling and furniture lumber. in eoplerage for sugar and tlour barrels, for crates and boxes (esperially eracker hoxes), for woden ware aud paper pulp.

105. CotToxwood (l'opmlns moniliforu) : Large sized tree: forms consillerable forests along many of the Western streaus, and furnishes most of the eottonwood of the market. Mississippi Valley and west: New England to the Rorky Mommtains.

106. BaLsas (Populus balsamifera) (balm of (iilead): Medimm to large sizod tree; combon all along the northern houmlary of the l'nited states.

107. BLACK COTTuxwood (Pupulus trichocurpu): The largest decidnous tree of Washington; very common. Nurthern Rocky Monntains and l'acitie region.

108. Cottoxwoon (Populns fremontii rar. wislizeni): Medim to large sized tree, common. Texas to Califoruia.

109. Poprax (Populus grandidenlata): Medium-sized tree, chietly used for pulp. Mane to Minnesuta and southward along the Alleghanies.

110. Aspex (Populus tremuloides): Small to merlinm sized tree, often forming extensive forests and covering hurued areas. Maine to Washington and iorthward, sonth in the Western monntains tu ('alifornia am New Hexico.

SOUR GUM. (Ste Gur.)

RED GUM. (See (iUM.)

SASSAFRAS.

111. Sassaflisis (Sissufrus sassufiras): Woot light, soft, not stroug, brittle, of coarso texture, durthle; sapwood pelluw, heart orange hrown. Issed in cooprage, for skifis, feneing, ete. Melium-sizel tree, largest in the lower Mississippi Valley, from New England to 'Texas and from Michign to Florida.

\section{SWEET GUM. (See fiv.r.)}

\section{SYCAMORE.}

112. SYCAnORE (Platamus arcidentulis) (button woul, button-ball tree, water beech): Wood modrutely heary, unite harl, stiti, strong, tough, usually crossurainerl, of coarse texture, and white to light brown color; the wood is 
hard to split and work, shriulis morlerately, warph and rhecks considerably, but stands well. It is used rxtensively fordrawers, backs, hottous, ete, in cabinet. work, for tobaceo boxes, iu cooperage and also for finishing lumber, where it has too long been mudrrated. A largo tree, of rapid glowth, common ambl largest in the Oloio and Mississippi valleys, at homm in mirly all parts of tho Eastern Cnited states. The ('alifornia siperies-

113. Platanus racemosa resembles in its worl the Eistern form.

\section{TULIP WOOD.}

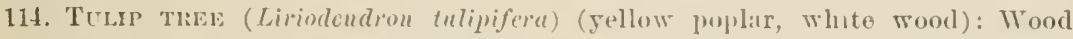
(quite varialue in weight, usually light, soft, stiff lut not strong, of tine texture, and yellowish color; the woor shrinks considerably, hut seasons withent much injury; works and stands remarkably well. Isod for siding, for paneling and finishing lmmler in lonse, car, and ship building, for sideloards and panels of wagons and carriages: also in the manufacture of furnture, umplements and machinery, for pump logs, and alnost every kiml of (ommon womlen ware, hoxes, shelving, drawers, etc. An ileal wood fur the "arver and toy man. I larege tree, doe's not form forests, but is quito common, especially in the Ohio liasin; ocenrs from New England to Missouri and sonthward to Filurida.

115. Cucumber THFE (. Maguolia acuminata): A medimm-sized tree, nost common in the Southern Alleghanies, hut distributed from New York to Arkansas, sunthwarl to Alabana and northward to lllinois. Resembling, and probably confonnded with, tulip wood in the markets.

TUPELO. (Sec Gin.)

WALNUT.

116. BLACK WALXTT (Juglans vigra): Wood heary, liard, strong, of coarse texture; the narrow sapw od whitish, the heartwood chucolate brown. The wood shrinks moderately in drying, works and stands well, takes a good polish, is yuite laudsome, and has been for a long time the farorite cabinet wood in this country. Walnnt, formerly used even for fencing, bas become too eostly for ordinary nses, and is to-day employed largely as a veneer, for insirle finish and cabinetwork; also in turnery, for gunstocks, etc. Black walunt is il large tree, with stout trunk, of rapid growth, and was formerly quite abundant thronghont the Allegbany region, occurring from New England to Texas, and from Michigan to Florida.

WHITE WALNUT. (SCe BLTTEKNTT.)

WHITE WOOD. (See TULIP, and also BAssWOOD.)

YELLOW POPLAR. (See'TumP.) 



\section{$I N D E X$}

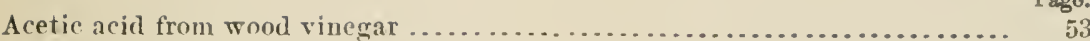

Age. inthence on stiftuess........................................ 39

Annual rings as means of distinetion............................. 60

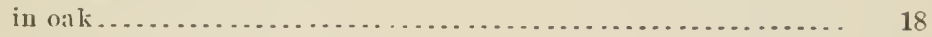

manner of formation in conifers....................... 14

record of age ....................................... 12

regnlarity . . . . . . . . . . . . . . . .

"Bastard" face, explanation .................................... 16, 20

greater shriukage................................. 35

Bending. (See Flexibility and Cross-breaking.)

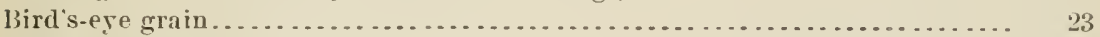

Bled pine as strong as mbled.................................... 51

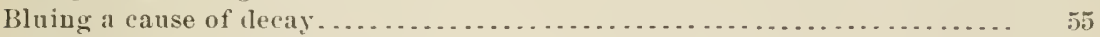

Broad-leaved woods, defivition.................................. 12

structu1 e ................................. 18-23

Casehardening ........................................................ 31,36

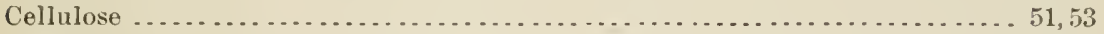

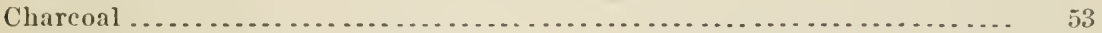

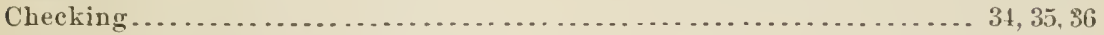

influence of time of felling .............................. 57

Chemical properties............................................... 51-54

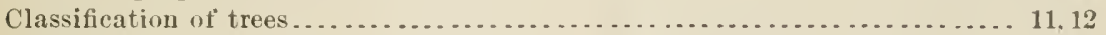

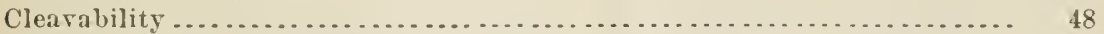

Climate, intluence on weight and strength.......................... 51

Color of heartwood, canses................................... 13

as means of distinction ........................ 60

Composition of wool, chemical .................................... 52

Compression, table of different species............................. 44

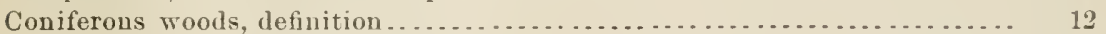

sap and heart................................. 13

anatomical structure............................ 16

Conshmption of wood per capita.................................... 5

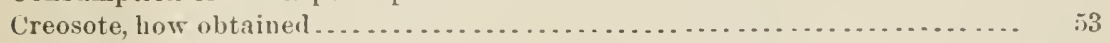

Cross-breaking strength ...................................... $41-43$

tablo of lifferent species..................... 43

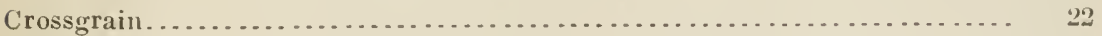

inflnence on lending strength .......................... 41

Curly grain ................................................... ${ }_{22}^{22}$

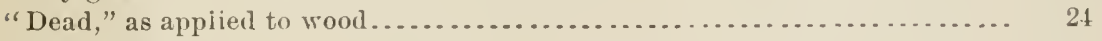

Decay, causes................................................ 55

prevention .............................................. 56,57

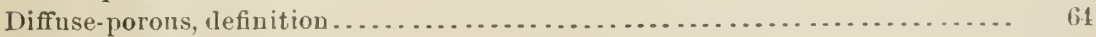

Distillation of wood . ......................................... 52,53

Distingnishing features of wood............................... 59

Dormant buds in burls....................................... 23 
Drying wood ............................................... 30

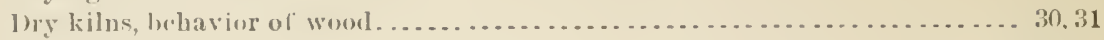

Durability . . . . . . . . . . . . . . . . . . . . . . . . . . . . . . . . . . $54-58$

list of spreies............................................. 57

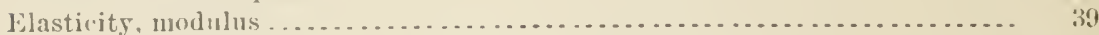

inlluence on splitting.................................... 48

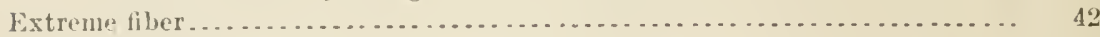

Fictor of safety ................................................ 40

Felling time, influence. . . . . . . . . . . . . . . . . . . . . . . . . . 51,57

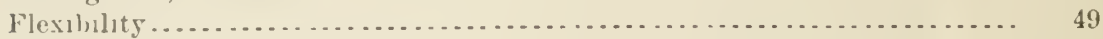

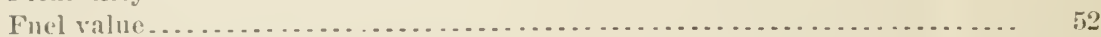

Fungus producing deray, described . . . . . . . . . . . . . . . . . . . . . 55, 56

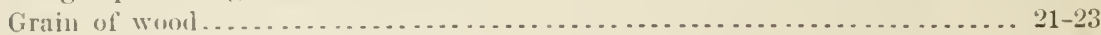

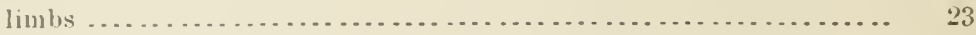

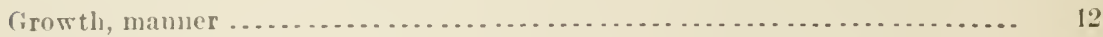

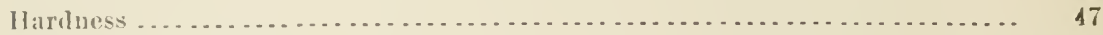

Harlworls, definition ......................................... 12

Heartwood, defintion......................................... 13

Heating power................................................ 52

Heat, elfeet of high temperature (see also Distillation) ................ 30, 31,36

Hickory, cause of tonghness .................................. 50

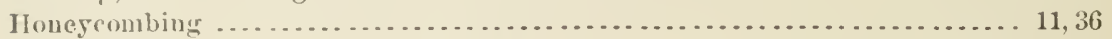

Identification of wookls, how to proeed ............................. 62

Ignorance regarding wooks, reasons........................... 5

Immersion, eftert . ....................................... 24, 30. $31,36,50$

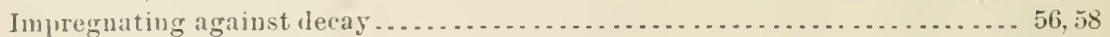

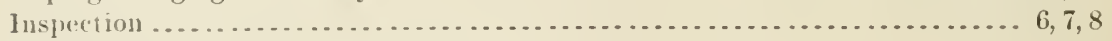

kiln ulying, influence ou durability ............................ 57

liilns. (See Dry kilns.)

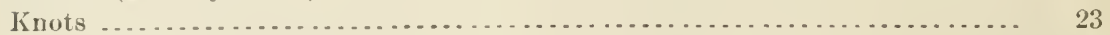

efiect of their position ................................. 41,44

influence on bending strength ................................ 41

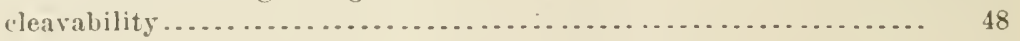

llexibility............................................ 49

Lampblack .................................................... 5 t

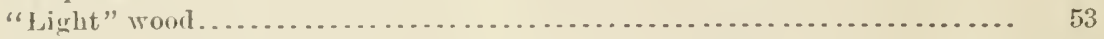

Lignin ......................................................... 51

"Live" timber ................................................. 21

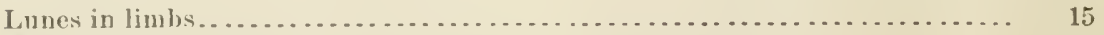

Manner of sawing alleets strength and other qualities ................. $\quad 8,9$

Mechanical properties........................................ $37-51$

influcuce in :pplication, practical conclusions ....... 50

Medullary rays. (Šee Pitlı rays.)

Mirrurs.................................................. ${ }_{20}$

Modulus of rupture............................................... 42

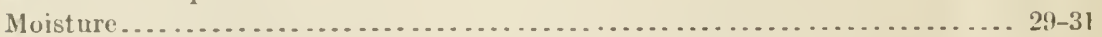

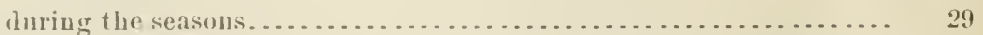

varies in tree ......................................... 29

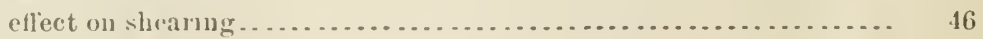

intluence on stifliness ................................. 39

bending strength............................ 41

strength ............................... 8,46

cleavaliht

flexibility............................. 49 


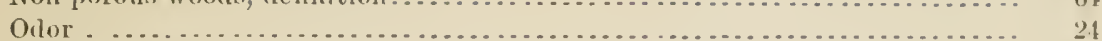

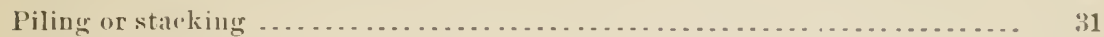

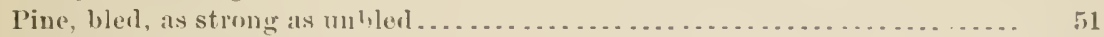

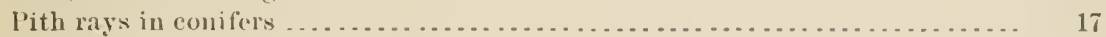

of broad-leaved trrex................................. 20

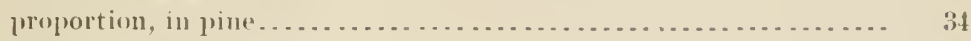

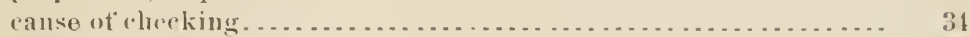

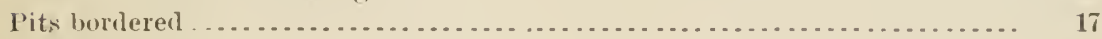

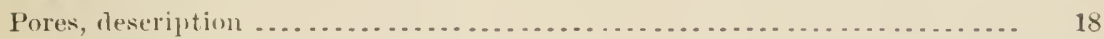

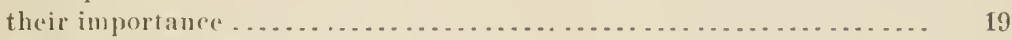

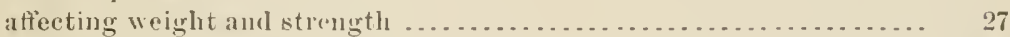

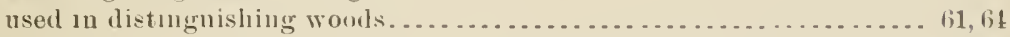

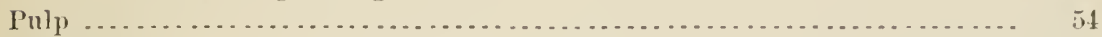

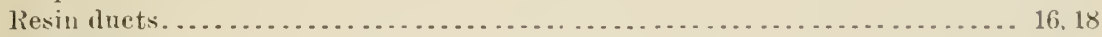

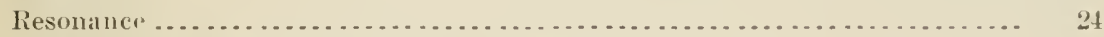

Rilt-saved boards, hehavior in seasoning . . . . . . . . . . . . . . . . . . . 36

Rinw-porous wools, definition . . . . . . . . . . . . . . . . . . . . . . . . . . . 61

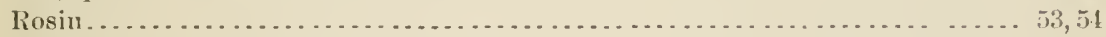

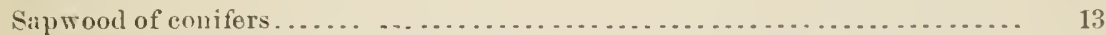

shrinks more than heartwool . . . . . . . . . . . . . . . . . . . . 36

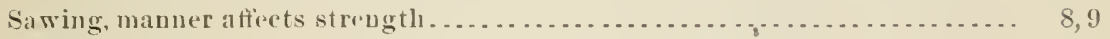

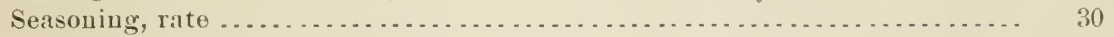

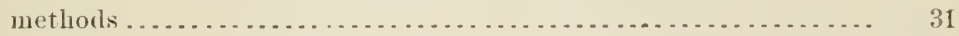

intlueuce on hending strength ......................... 41

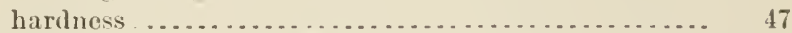

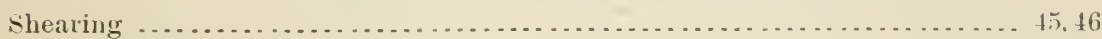

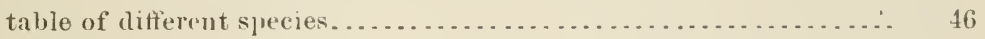

across grain ....................................... 47

Shocks, resistance . . . . . . . . . . . . . . . . . . . . . . . . . . . . . . . . . . 49

Shriukage fully discussed . . . . . . . . . . . . . . . . . . . . . . . . . . . . . $30,32-37$

tangential, influence of summer wood and spring work ......... 35

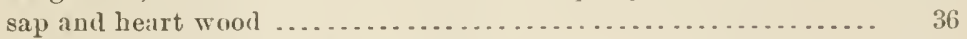

table for different species ............................ 37

conifers and broad-leaved trees......................... 36

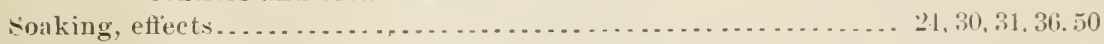

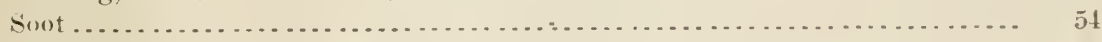

Specific gravity (sce also Wright) . . . . . . . . . . . . . . . . . . . . . . . .

Spring wood, definition ... . . . . . . . . . . . . . . . . . . . . . . . . .

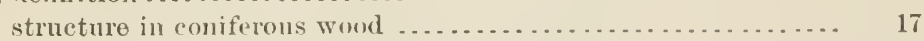

oak...................................... 19,21

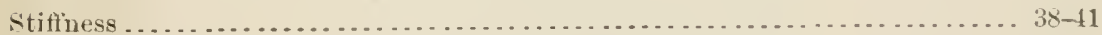

tahle of differcut species ............................... 11

Strength of rood. (See Mechanical properties.)

Structural aggregates of a stick ... . . . . . . . . . . . . . . . . . . . . . . . 9

Strueture of coniferums woul .................................. 12-18

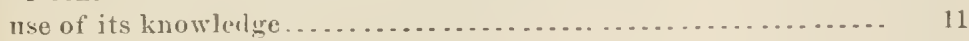

of wood of broad-leaved trees .......................... $18-23$

anatomical, of conifers............................. 10 ;

hroald-lraved trees ........................ 20,21

Snmmer wood, definition. . . . . . . . . . . . . . . . . . . . . . . . . . . . 15

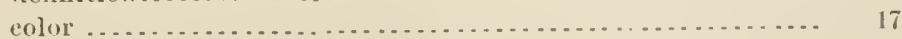

proportion in different parts of tree .................... . . . . . 16

of coniferous wood ................................... 17

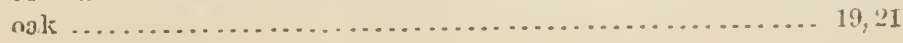


I'age.

Swelling by immersion ..................................... 36

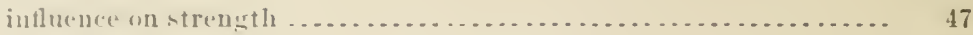

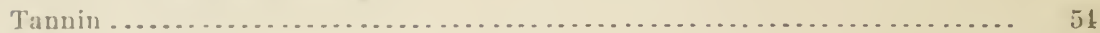

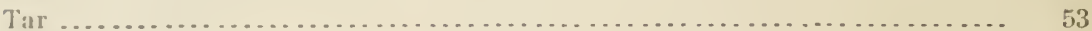

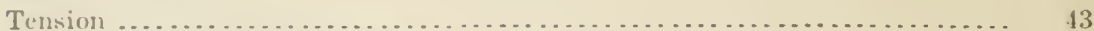

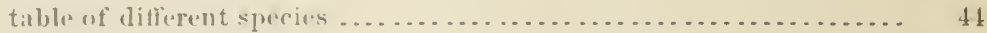

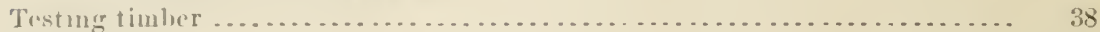

Tom

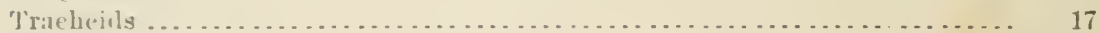

Trers, clissifiration ........................................ 11, 12

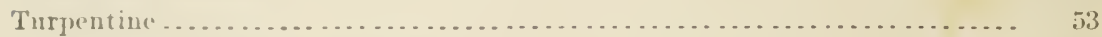

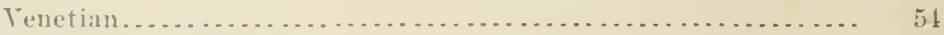

Ise of wood. (we l.ist of woods, p. T.2.)

Vessels in spring wood, proportion ............................ 19

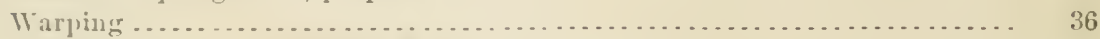

Water in wood, tahlo (sce also Moisture aur shrinkalge) . . . . . . . . . . . . 31

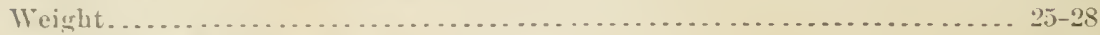

dithrent sprecies, tablr ............................ 28

distribution in tree. ... . . . . . . . . . . . . . . . . . . . . . 26, 27

intlicuce on cleavability ............................. 48

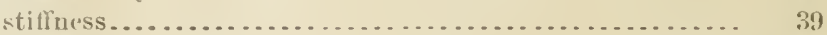

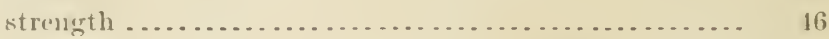

spring worl, how atheeted by moistur.................. \&, 26

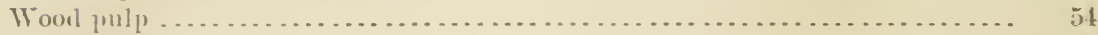

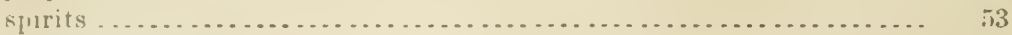

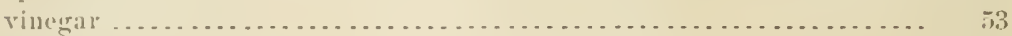

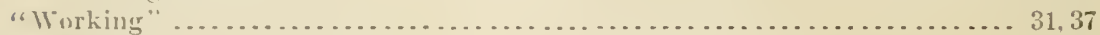


U. S. DEPARTMENT OF AGRICUI,TURE, BUREAU OF FORESTRY-BULLETIN No. 61.

GIFFORD PINCHOT, Forester.

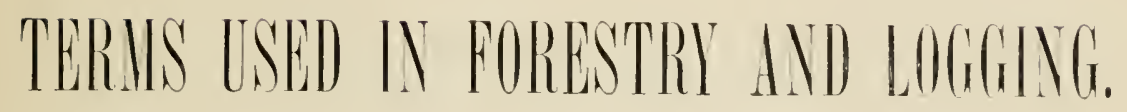

PREPAREN IN COOPERATION WITH

THE SOCIETY OF AMERICAN FORESTERS.

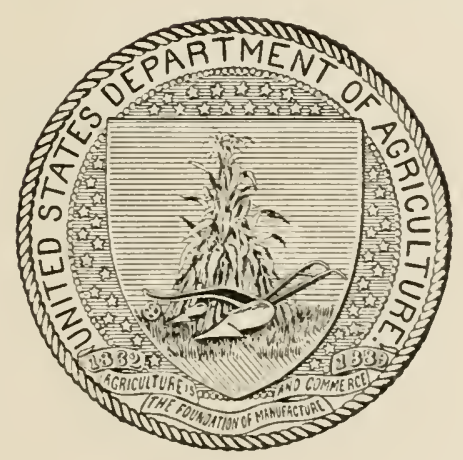

WASHINGTON:

GOYERNMENT PRINTING UFFICE。

1905 . 


\section{II.! ISTRATION.}

Plate I. Forest regions of the Cnited states . . . . . . 2 


\section{LETTER OF TRANSIITTAL.}

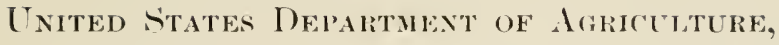

BUREAL OF FORESTR,

Waskingtom, D. C., May 15, 1905.

Sir: I have the honor to transmit herewith a manuscript entitled "Terms used in Forestry and Logging," prepared in cooperation with the Society of American Foresters, and to recommend its publication as Bulletin No. 61 of the Burean of Forestry.

The puthlication of this bulletin in its present form would have been impossible withont the cooperation of many lmmbermen, and of practically all the trained foresters in the Lnited states.

Very respectfully,

Gifforis Pinchot,

Forester.

Hon. JaMes Wilson,

Secretary of Agriculture. 



\section{TERIIS LSED) IN FORESTRI ANI) LOGGING.}

\section{INTRODUCTION.}

The terms in forestry which form a part of this bulletin comprise the English forest terminology used in this country, and the more important German and French equivalents. Many entircly new terms, and modifications of terms already in use, are included to meet the specifie needs of American forestry. The Bureau of Forestry will follow this terminology closely in all branches of its work, and it is hoped that foresters generally in the United states will still further standardize it by use.

The terms in logging comprise those commonly employed in work in the woods. Words and phrases which are merely slang, those whose use is so limited as to be of no practical importance, and those of wide application which are in standard dictionaries, have been omitted. No terms used in the mill or to deseribe its product, or relating to tie making, turpentining, the production of maple sugar, and other industries which are not essentially a part of the lumberman's work, are included. A list of such terms is now in preparation and will appear in another edition of this bulletin.

Suggestions for the correction or enlargement of the present list are invited, and may be sent to the Forester.

\section{'TERMS IN FORESTRY.}

[Terms recommended for use are defined. Terms not recommended are inserted as synonyms.]

Absolute forest land. Land fit only for forest growth.

Syn.: absolute forest soil. G., Holzboden. F., sol forentier.

Absolute forest soil. See Absolute forest land.

Absolute form factor. See Form factor.

Accident yield. Trees which are ent on account of accident, as, for example, damage by wind, snow, insects, or fire.

G., Yorgriffnutzung. Calamitätsnutzung. F., Produits accidentels.

Accretion, $n$. Increase in dianeter or height; distinguished from imerement, increatio in volume.

Accretion borer. An instrument for determining the growth in liameter of standing trees. It consists of a hollow auger, which, when bored into a tree, extracts a section showing the annual rings.

Syn.: increment borer, increment gauge. G., Zuwachsbohrer. F., sonde de Pressler. 
Arerefion enting. Sipe Aecretion thinning.

Arempinu 1 hinuing. A thinning made specitieslly to increase the rate of growth in dianeter of the trees which are left staneling. Siee Thinning.

Syn.: areretion cutting. (i., lichtungshieh. F., coup d'isolement.

Arid humus. Sire sour humus.

Artual uncolhantable longth. Sie Csed length.

Artual mereliantahle rolume. Siee Used volume.

Alvance growth, $n$. Foung trees which have sprung up in aecidental openings in the forest, or under the forest cover hefore reproduction cuttings are begun. See Volunteer growth.

(i., Vorwaths. F, semis préexistant.

Ifter-gruwfl, $u$. Young trees which have sprung up a the result of reproluetion euttings.

(i., Nachwuchs. F., repenplement naturel.

Agr class. All trees in a stuml whose ages are within given limits.

(i., Altersklasse. F., classe d'âge.

All-aged forest. See Many-aged forest.

A umal ring. The layer of wood produced by the diameter growtl of a tree in one year, as seen on a eross section. See False ring.

(i., Jahrring, Jahressebicht. F., couche annuelle, couche d'accroissement.

Anmual working. See Working.

Arillumetical mean samplo tree. See sample tree.

Artificial form factor. See Form factor.

Artilleial reproduction. Sée Reproduction.

Aspert, 1 . The direction towarel which a slope faces. The eight main points of the compass, N., NE., E., SE., S., SW., W., NW., are distinguished in forest lescription.

Syn.: exposure. G., Lage. F., exposition.

Back firm. A fire started purposely some distance ahead of a tire which is to be fought. The back fire is intended to bun only against the wind, so that when the two fires meet, both must go out for lack of fuel.

Syn.: counter fire. G., Gegenfener. F., contre feu.

Ball plantiug. A method of transplanting young trees with balls or lumps of earth around the roots.

G., liallenptlanzung. F., plantation en motte.

Bark blazer. See Scratcher.

Bark gouge. Sire Scratcher.

Basal arra. The area of a cruss section of a tree, or the smu of such areas.

Blank, $n$. An opening in the forest where, from any cause, very few or no trees are growing.

G., Blösse. F., ville.

Bluck, $u$. The unit of management treated in a working plan. A block contains always two, but nsually many more, compartments.

(i., lilock. F., serie d'exploitation.

Buarl foot. The contents of a board 1 foot square and 1 inch thick. The common unit of neasure for logs and lumber in the United States.

Board measure. The standard of lumber measurement, the unit of which is the board foot.

Syn.: board scale. 
Board rule. A graduated stick for deternining the contents of boards. The number of board feet in boards of given widths and lengths is shown upon the stick.

Buarlal soale. See Board measure.

Bole, $n$. Sie Stem.

Breasthigh, 1 . At or having a height of $4 \frac{1}{2}$ fect above the grouml.

Burn. n. An area wer which fire has run to the noticable injury of the forest.

Caliper, n. An instrument for measuring the diameter of trees or logs, usually consisting of a graluated beam to which is attached one fixed and one sliding arm. G., Kinppe. F., compas forestier.

Canoly, n. See Crown cover.

Class sample tree. Sice Sample tree.

Cloun entting. 1. The cutting of the entire stand.

Syn.: clear eutting. G., Kahlschlag. F, enupe blanche, conpe ì blane étoc.

2. An area upon which the entire stand has been cut.

Clean cutting method. A method of conservative lumbering in which the entire stand is eut at one time and reproduction is secured by sowing or planting. ice Forest management.

G., Kahlsehlagwirtsehaft. F., méthode par coupe unique.

Cleaning, $n$ I thinning made in a stand which has not reached the small-pole stage. Its main object is to remove trees of undesirable form and species. Sire Thinning.

(i., Reinigungshieb. F., nettoiement.

Clear rutting. See Clean cutting.

Clear length. In silvies, that portion of the stem of a tree free from branches. In forest measurements the meaning of the term raries with the species measured and the purpose of the measurements. For example, clear length is in some cases used to designate that portion of the stem entirely free from branches, in others that portion free from dead branches, or from growing branches of a given size.

Syn.: elear trunk. G., Stamm. F., tige.

Clear trunk. See Clear length.

Closed, a. See Crown density.

Combined cropping. The combination of forest and field crops on the same area.

G., Waldfeldbau. F., culture agricole et sylvicole combinée.

Communal forest. See Town forest.

Compartment, n. The unit of area treated in the working plan. The size and the shape of compartments are determined mainly by topographic features.

G., Abteilung, Jagen. F., pareelle, division, compartiment.

If a compartment contains a stand varying greatly in eomposition, age, or neels, it may be divided into two or more sulwompartments, which may be either temporary or permanent.

Compartuent lime. The boundary of a compartment. It may be marked by a road, a ride, or a natural feature, such as a stream or the crest of a ridge. In Europe, when other demareation is wanting, elean cuttings upon narrow strips are male to mark the boundaries of a compartment. These are known as rides (G., Schneisse. F., laie). A ride which senarates two eutting series, and thus runs paralle] to the prevailing wind flirection, is called a mojor ride (G., Wirtwchaftsstreifen. F, laie sommièr(s), while one which completes the demareation of a compartment is known as a minor ride (G., Nebensehneisse. F., lisyon).

Compartment system. See Stand method. 
foumpila forest. A forest in which loth seetlings and sprouts enenr in considerahle number. It may be either pure or mixesl.

syn.: mixed seerling and sprout forest.

fomposite system. One of the three great systems of forest management. Endor it represluetion is secure 1 by both sprouts aml seedlings. See Forest management.

('ouservative lumberiug. Practical forestry; any method of lumbering which perpertuates the forest by use.

fourersion, n. A 1 winge from one system or method of forest management to annther, as from the sprout system to the seed system.

(i., Therführung, Unwanllung. F., conversion.

Courersion period. The perion during which the change from one system or methol of forest management to another is effected.

Coppice, coppice forest. She sproat forest.

coppiere method. See sprout method.

Coppice shoot. vee siprout.

Coppice system. See Sprout system.

Copprim with slandarls. see Reserve sprout forest.

('omnter fire. se bark fire.

('rown, $u$. In silvies, the upper part of a tree, including the living branches with their foliage. In forest measurement the use of the term varies with the kind of tree and the purpose of the meannrements. For example, crown may be used to lesignate the whole leaf and bran h system, or that portion of it above a dead or a growing branch of a given size. In tree lescription the crown is described as long or short, broal or narrow, compact or raggerl, conical or flat.

(i., Krone. F., cime.

Crown eanoly. Se Crown cover.

Crown elass. All trees in a stand oceupying a similar position in the crown eover. Domiment, intermediute, ocertopped, and supipressed trees each constitute a crown class.

Crown cover. The canopy formed by the crowns of all the trees in a forest, or, in an irregular forest, by the rrowns of all trees in a speeified crown class.

syn.: canopy, crown canopy, leaf canopy. G., Kronendach, Beschirmung. F., eouvert, voute foliacée.

Crown density. The density of the crowns of the trees in a forest; it is usually measured by the extent to which the groms is shaded.

G., Beschirmungsdichte. F., épai-eeur du couvert.

The degrees of crown density in a forest are expressed by the following terms:

closed. When the crowns form an uninterrupted cover and permit little or no sunlight to reach the ground. (i., geschlossen. F., plein.

Dense. When three-fourths or more of the ground is shaded. (i.gdicht. F., desse.

Thin. When three-fourthe to one-half of the ground is shaded by the crowns. G., licht. F., clair.

Open. When less than one-half the grome is shaded by the erowns. G., lückig. F., entreompé.

Park forest is forest in which shade occurs only in isolated patches, under single trees or small groups.

Crown tire. See Forest fire.

Crown foresi. See National forest.

Cruiser's bark blazer. See Scratcher. 
Cull, 2 . To take out of a forest by selection a prortion of the trees.

Culled forest. Forest from which ruttings by selection have remored a portion of the trees.

Curent anual inerement. The volume of wool produced in a given year by the growth of a tree or stand.

Cut over, to. To eut most or all of the merchantable timber in a furest.

Cut-orer forest. Forest in which most or all of the merchantable timber has been cut.

Cutting area. The area over which muttings are to he or have been marle. G., Schlag. F., coupe.

Cutting leight. The height ahove the ground at which a tree is to be cut. See Stump height.

Cutting limit. See Diameter limit.

Cutting series. A block or a part of a block containing even-aged stands whose ages differ uniformly within given limits and which are to be cut in turu, the cuttings usually following a given direction. A perfect cutting series seldom exists, except under the clean-cutting method followed by artificial reproduction, or under the sprout method.

G., Hiebszug. F., suite des coupes.

Deaden, $v$. To kill a standing tree by girdling it.

$G$., ringeln. $F$., ceinturer.

beadening, $n$. An area upon which the trees have been deadened.

Dense, $\alpha$. See Crown density.

Diameter breasthigh. The diameter of a tree at $4 \frac{1}{2}$ feet above the ground.

Diameter class. All trees in a stand whose diameters are within prescribed limits. G., Stärkeklasse. F., catégorie de grosseur.

Diameter growtlı. The increase in diameter of a tree. G., Dickenwachstum. F., croissance en diamètre.

Diameter limit. The diameter, usually breasthigh, which tefines the size to which trees are to be measured or used for any given purpose.

Syn.: cutting limit.

Diameter tape. A tape for ascertaining the diameter of trees, so graduated that the diameter corresponding to the girth of a tree is read directly from the tape.

Dibble, $n$. A tool for making holes for planting seeds or young trees. G., Setzpfahl. F., plançon.

Dibble in, to. To plant seeds or young trees in holes marle with a dibble.

Direct returus. See Forest products.

Domiuant, $\alpha$. Having the crown free to light on all sides because of greater height. See Crown class.

G., herrschend. F., dominant.

Drill plauting. See Row planting.

Mry pruniug. Sep Pruning.

Ory topped. Having a dead or a partially defoliated crown, or discolored foliage, as the result of injury or lisease.

Syn.: stagheaded. G., gipfeldürr. F., couronné.

IDıff, $n$. See Litter.

Evell-aged forest. See Regular forest.

Expectation value. See Forest expectation value.

29273-No. 61-05-2 
lixperinent area. A forest area of known size upon which sucessive measurements or other detailed stulles are nalde for the determination of the growth and behavior of the stamb, or upon which experiments are condured to ascertain the effect of methods of treatment upon the forest. Sie Valuation area.

Sýn.: permauent sauple plot, permanent sample area. (i., Probefläche, Versuchsfläche. F., surface d'expérience, place d'essai.

Expusire. tiee Aspect.

Factor of shape. tief form factor.

Factors of the locality. See bomality.

Fail spot. A place where satural or artificial reproduction has failed.

False ring. The layer of woot, less than a full senson's growth, and seldom "xtenling aromml the stenl, which is formel whenever the diameter growth of a tree is intermpterl and begins again during the sane growing season.

G., Scheinring. F, fanse conche d'acroissement.

Federal forest. Wie National forest.

Faderal forest reserve. Sie National forest reserve.

Final entting. See Stand methor.

Final yield. All material lerivel from reproduction enttings or clean enttings. It is isually the chief erop, and narks the end of the rotation. See Intermerliate yield.

G., Haubarkeitsmutzung, Abtrielsmutzung. F., prodnit principal.

Fiuancial rotation. Sir Rotation.

Fire lane. See Fire line.

Fire linc. Astrip kejt clear of inflammable material as a protection against the spread of forest fire.

Syn.: fire lane, fire trace. G., Fenergestell. F., tranchée garde-fen.

Fire trace. See Fire line.

First growth. 1. Natural forest in which no cuttings have been made. Sce Second growth.

Syn. old growth, virgin forest. (i., Irwald. F., forêt vierge.

2. Trees grown before lumbering or severe fire entered the forest; belonging to the original stanil.

Forest. 1: To establish a forest, either by natural or artificial means.

Folest, $n$. An area whose principal crop is trees. A forest includes both the forest eover and the soil beneath it.

(i.. IVald, Forst. F., forêt.

A forest judged by the character of the stant nay be timberland or modland. These constitute the wo great elasses of forest, between which it is possible to draw a praetical but ant an absolute distinction.

Timberlend may be broadly defined as that class of forest which contains in (ommercial guantities trees of sutlicient size and of the requiren kind to furnish saw logs, pulp wood, ties, poles, or wool for similar uses.

Howlland may be broally defined as forest which contains trees fit for firewood or fencing, but noue or very few trees which are subitahle for the nses enumerated abovere.

A timber trut is a horly of timberlamel, nsually of large area.

A woodlot is a forest of small area in which the wood is used mainly for fuel, fencing, and other farm purposes.

Forestation. See Forest extension. 
Forest eapital. The capital which a forest represents. It consists of the forest land, or fixed capital, and the stand.

G., Waldkapital. F., capital forestier.

Forest cover. All trees and other plants in a forest.

Forester, $n$. One who practices forestry as a profession.

Forest expectation value. The present net value of all future returns expected from the forest capital. It is determined ly discounting to the present time, at compoumd interest, all returns and expenses anticipated.

G., Erwartungswert. F., valeur d'avenir.

Forest extension. The establishment of forest upon areas where it is at present absent or insufficient.

Syn.: forestation.

Forest finance. See Forest management.

Forest fire. A fire in timberland or woodland. A forest fire may be a ground fire, a surface fire, a stand fire, or a crom fire. A gromd fire is one which burns in the forest floor and does not appear above the gromnd. When a fire runs over the surface or burns the undergrowth, it is a smfuce fire. When a surface fire spreads from the undergrowth to the stanl, igniting the trees, it becomes a stand fire. Under certain conditions the crowns of the trees may be ignited, cansing a sroun fire.

Forest floor. The deposit of regetable matter on the ground in a forest. Litter includes the upper, but slightly decomposed portion of the forest floor; humus, the portion in which decomposition is well arlvanced.

Forest grown. Grown in the forest from self-sown seed.

Forest humus. See Mill humus.

Forest influences. All effects resulting from the presence of the forest, upon health, climate (including wind, rainfall, temperature, etc.), stream flow, and economic conditions.

Syn.: indirect effects.

Forest management. The practical application of the principles of forestry to a forest area. See Forestry.

Forest management includes Forest mensuration, or the determination of the present and future product of the forest ( $\mathrm{i}_{\text {. }}$, Holzmesskunde. F., cubage); Forest organization, or the preparation of working plans and planting plans, detailed and comprehensive schemes for the establishment and best use of the forest (G., Forst vinrichtung. F., aménagement); and Forest finance, or the determination of the money returns from forestry (G., Forstfinanzen. F., finance forestière).

Three great systems of forest management are distinguished: The seed system, the sprout system, and the composite system. The seed system includes the stam method, group method, strip method, patch method, strip stand method, aroup seed method, scattered seed method, single tree method, reserve seed methor, clerm cutting method. The sprout system includes the sprout method. The composite system includes the reserve spront method.

Forest meusuration. See Forest management.

Forest nursery. An area upon which young trees are grown for forest planting.

G., Baumschule, Saatkamp. F., pépinière.

Forest organization. See Forest management. 
Forest plantation. Forest growtl, extablished by setting ont young trees or by sowing seed, which has not reached the small pole stage.

(i., P’lanzung, Kultur. F., plantation.

I forest plantation, made hy setting out yomng trees, which has passed the mall polestage, is called a planted forest. A sown forest plantation which has passed the small pole stage is ealled a som forest.

Forest policy. The prineiples whieh govern the arministration of the forest for its best permanent use. Sef Forestry.

G., Forstpolitik. F., politique forestière.

Forest products. All usable material yielded by the forest.

Srn.: direct returns.

The following elasses are distinguished:

Major products inclute all wook harvested for any purpose.

G., Hauptnutzung. F., produits principaux.

Minor prodncts include all forest produets except woorl.

G., Nehenuntzung. F., menus protuits.

Forest protection. The safeguarding of the forest against any damage not caused by its own growth. See Forestry.

(i., Forstschutz. F., protection des forêts.

Forestral, $a$. l'ertaining to forestry.

Forest replacement. The restoration of forest growth on denuded areas.

G., Wieleraufforstung. F., rehoisement.

Forestry, $n$. The seience and art of making the best permanent use of the forest.

G., Forstwirtschaft, Forstwesen, Forstwissenschaft. F., seience forestière, foresterie.

The main branches of forestry are Forest polic!l, Silliculture, Forest momagement, Forist protection, and Forest utilizution.

Forest type. A forest or a part of a forest possessing distinctive characteristies of composition or habit of growth.

Forest utilization. The most protitable use of forest prolucts. See Forestry.

f., Forsthenutzmng. F., exploitation des bois.

Form class. All trees in a stand so similar in form that the same form factor is applicable in letermining their actual volume.

Syn.: form factor class.

Form factor. The ratio, expressed decimally, between the volume of a tree, or portion of a tree, and of a cylinder of the same height and lianeter. The volume of this eylinder multiplied by the form factor gives the actual volume of the tree or portion of the tree.

Srn.: factor of shape. G., Formzahl. F., enefficient de forme.

Three kinds of form factors are distinguished, aecording to the portion of the tree to which they refer:

A Trep form factor is userl for determining the actual volume of the whole tree; a Stem form factor for determining the volume of the stem; and a Timber form factor for determining the merehantable contents of stem, (rown, or both.

$A$ form factor is called absolute when the diameter of the tree is measured at any convenient height, the form factor referring only to that portion of the tree above the point at which the diameter is measured; normal, when the diameter is measured at a height in eonstant ratio to the total height of the tree; and artificial, when the breasthigh diameter is measured.

Form factor class. See Form elass. 
Future yield. The amount of wood which given trees upon a given area will contain after a given period.

Future yield table. A tabular statement of future yield.

Groen pruning. See Pruming.

(iround cover. All small plants growing in a forest, except young trees; such as ferns, mosses, grasses, and weeds. See Cuderbrush.

G., Bodendecke. F., couverture du sol.

(iround fire. See Forest fire.

(irom] methou. A method of conservative lumbering in which groups of young trees whieh have sprung np in openings caused by logging, insect damage, windfall, snowbreak, or other agency, are taken as starting points for the future forest; or if these are insuffiejent, small openings are purposely marle. Reproduetion by self-sown seed from the mature stand at the edges of these groups is secured by careful euttings, which extend the groups until they join. See Forest management.

Syn.: group system, shelterwood group system. G., Horst mil gruppenweise Verjüngung, Gruppenwirtschait.

(froup mixture. A mixed forest in which trees of the same species occur in groups not large enongh to be eonsidered pure stands.

(xroup seed method. A method of conservative lumbering in which the forest is reproduced after a single cutting, by leaving in groups seed trees of the kind desired. See Forest management.

(iroul) system. See Gromp method.

Hrowing stoek. See Stand.

Hahit, $n$. See Silvies.

II arden off, to. To prepare seedlings in the seedbed for transplanting by gradually exposing them to wind and sunlight.

Heel in, to. To store young trees for planting by laying them against the side of a treneh and covering the roots with earth.

Height elass. All trees in a stand whose heights are within prescribed limits.

G., Höhenklasse. F., classe le hanteur.

Height growtl. The inerease in height of a tree.

G., Höhenwuehs. F., croissance en hauteur.

Height measure. An instrument for measuring the height of a tree.

Sy̆n.: hypsometer. G., Höhenmesser. F., dendromètre.

High forest. See Seed forest.

High forest compartment system. See Stand method.

II igh or seedling forest system. See Seed system.

II igh pole. See Pole.

Hill planting. See Mound planting.

H umus, $u$. That portion of the forest floor in which decomposition is well advanced. sym. mold. G. and F., Humus.

Ilyosometer, $n$. See Height measure.

Improvement cutting. Sie Improvement thinning.

Improvement thinning. Usually the first thinning male when a forest is put moler management, to prepare it for the application of a regular system. Sice Thinning.

Syn.: improvement cutting, preliminary thinning. (i., Verbesserungshiel. F., coupe d'amélioration.

Income rotation. See Rotation. 
Increment, $n$. The volume or value of wood produced during a given period by the growth of a tree or of a stand. See Aceretion.

Syn.: volume growth. G., Zuwachs. F., aceroisement.

Three kinds of increment are distinguished:

Folume increment is the increase in volume of a tree or stand.

Quality increment is the increase in value per unit of volume.

Price increment is the increment resulting from an increase in the price of forest products indepemlent of quality increment.

Increment borer. See Accretion borer.

Increment gauge. See Aceretion borer.

Index, a. The highest aserage actually found upon a given locality. The term index applied to stand, dianeter growth, height growth, increment, and present and future yield is the equivalent of normal, when normal is used to describe the assumed standarl hased upon actual measurement.

Syn.: normal. G. and F., normal.

Index forest. That forest which in density, volume, and increment reaches the highest average which has been found upon a given locality. Measurements of such a forest provide a standarl for comparison with other forests of the same age and composition, grown under similar conditions.

Syn.: normal forest.

Indirect effects. See Forest influences.

Intermediate, u. Having the crown shated on the sides, but free to light at the top. See Crown class.

lutermediate yield. All material from thinnings or from any entting not intended to invite or assist reproduction. See Final yield.

G., 'wischennutzung. F., produits intermédiaires.

lutermittent Working. See Working.

Intolerant, $a$. Incapable of enduring heavy shade.

Syn.: light demanding. (i., lichtbedürftig. F., à tempérament robuste.

Irrenular lonest. Forest in which the trees differ considerably in age.

Syn.: uneven-aged forest. G., ungleichalteriger Bestand. F., peuplement mêlé.

Largere pole. See Pole.

large-pule forest. A forest of large poles.

Latrege sapling. See Sapling.

Large-sapling forest. A forest of large saplinge.

Lealf eallopy. See Crown coser.

Leal eorer. See Litter.

Leall litfor. See litter.

Lilt, $\therefore$. To pry up seedlings in the seedbed, so that they nay be pulled up by hand for transplanting.

Light demanding. See Intolerant.

Light sereen. Sep Shade frame.

Line ont, fo. To transplant seedlings from the seedled to rows in the forest nursery. (i., verschulen. F., repiquer.

litfer, n. That portion of the forest floor which is not in an advanced state of decomposition.

Syn.: leaf litter, leaf cover, duff. G., Streu. F., litière. 
Locality, $\|$. An area, comsichered with reference to forest-producing power; the facters of the lacalit!l are the altitude, soil, slope, aspect, and other lowal conditions influenting forest growth.

Srn.: site. G., Standort. F., station.

Loeality class. All localities with similar forest-producing power. Syn.: quality of locality. G., Standortsgüte, Standortsbonitït, Bonitüt. E., qualité de la station.

Low rule. 1. A tabular statement of the amount of lumber which can be sawed from hogs of given lengths and diameters.

2. A graduated stick for measuring the diameters of logs. The number of loard feet in logs of given diameters and lengths is shown npon the stick.

syn.: log scale, scale rule.

Log s('ale. siee Log rule.

Lowrer story. See Two-storied forest.

Low pole. See Pole.

Major products. See Forest products.

I ajor ride. See Compartment line.

Many-aged forest. A forest through all parts of which many rlifferent age classes of trees tend to distribute themselves. When all age classes are thws distributed, the forest is all-aged. These two terms replace selection forest, many-aged being substituterl for imperfect selection, and all-aged for perfect or ideal selection.

Marking hatchet. A hatchet for marking trees. A raised die is cut on the hear for stamping the face of the blaze.

Mature forest. Forest so old that growth in height is practically at an end and diameter growth is lecreasing.

Mean anmul inerement. The total increment of a tree or stand divided by its age in years.

Merchantable lengtl. The total length of that portion of the stem which can be used under given eonditions.

Syn.: possible merchantable length.

Merchantable volume. The total volume of that portion of the tree which can be used under given conditions.

Sin.: possible merchantable volume.

Meflod of snecessive thinnings. See Stand method.

Mild lunnus. Humus in a condition favorable to forest growth.

Syn. : forest humus. Ant.: sour humus. G., milder Humus. F., terreau forestier.

Minor products. see Forest products.

Minor rille. See Compartment line.

Mixel forest. Forest composel of trees of two or more speries.

G., gemischter Bestand. F., peuplement mélangé.

Mixed seedling and sprout forest. Sipe Composite forest.

Mold, $n$. See Humus.

Mother tree, $n$. See Seed tree.

Monnd planting. A method of planting on wet ground, in which the semls or young trees are planted on mounds, ridges, or hills.

Synn.: hill planting, ridge planting. G., Hügelpflanzung. F., plantation en buttes. 
National forest. A forest which is the property wi the United States.

Srn.: ferleral forest.

Forest belonging to the National (rovernment is in G., Staatswald; F., forêt domaniale, and in the British dependeneies, Crown forest.

National forest rescre. A tract of Jand set apart from the public domain by proclanation of the President under section 24 of the act of Mareh 3, 1891, or created by special act of Congress, and andnistered under laws of the Cnited States passed for that purpose, in order "to improve and protect the forest within the reservation, or for the purpose of securing favorable conditions of waterflows and to furnish at continuous supply of timber for the use and necessities of eitizens of the Tniterl States."

syn.: Fuleral forest reserve.

National park. A tract of Govermment land withdrawn by special act of congress from settlenent, oceupancy, or sale, under the laws of the Cnited States, for the benefit and enjoyment of the peojle.

Natural pruning. see Pruning.

Natural reproduction. See Reproduction.

Normal, a. Siee Index.

Normal forest. ice Index forest.

Normal form factor. Siep Form factor.

Nurse. n. I tree which fosters the growth of another in youth.

G., Schntzholz. F., essence d'abri.

Nursery growu. Grown in a forest nursery.

0ld-field growth. See Volunteer growth.

Old gerowtl. See First growth.

Open, a. Tee ('rown density.

Overmaturn forest. Forest in which, as the result of age, growth has almost entirely eeased, amblecay and deterioration have hegun.

Orertopled, a. IIaving the crown shaded from above, although a side or sides may be frees to light. see Crown class.

Orumood, $n$. See Two-storied forest.

Park forest. Sée Crown density.

Partial section analysis. See Tree analyis.

Partial simun analysis. See Tree analysis.

Patch method. The clean cutting of small patches to invite reprorluction by selfsown seed from the smrommling forest. Se Forest management.

(i., Keselhieh), Jïcherhieh. F., compes par tronées.

Pateh sowing. Sowing forest seed in spots. Sie seed spot.

(i., Plätzesaat, Plattensaat. F., semis par places.

Perioglic anmal increment. The total inerement for the perioul, divided by the number of years in the period. See Periodic incement.

Periodic incement. The volume of wool produced by the growth of a tree or stand in a specified number of years.

Periollor working. see Working.

Permanent samplo area. Sie bxperiment area.

Permanent sample plot. See Experiment area.

P'lysical rotation. See lintation.

l'it planting. Sie Trench planting. 
Planted forest. See Forest plantation.

Planting plan. A detailed scheme for forest planting on a given area.

Planting site. An area which is to be artificially stocked with forest growth.

Plot survey. See Valuation survey.

Pole, $n$. A tree from 4 to 12 inches in diameter breasthigh. Fe Tree clasi. G., Stange. F., perche.

A small pole is a tree from 4 to 8 inches in diameter hreasthigh. Syn.: low pole.

A large pole is a tree from 8 to 12 inches in diameter breasthigh. Syn. : high pole.

Pollard, $r$. To invite the production of shoots at the top of a tree by cutting back the crown.

G., köpfen. F., étêter, écimer.

Pollaril, $n$. A tree whose crown has been cut hack to invite the production of shoots.

G., Kopfholz. F., têtard.

Possible nerehantable length. See Merchantable length.

Possible merehantable volume. See Jerchantable volume.

Preliminary eximination. A recomnoissance of a forest to determine whether the preparation of a working plan for its management is arlvisable, or a recomoissance to determine the advisability of forest planting.

Preliminary thinuing. See Improvement thimning.

Preparatory euttings. see Stand method.

Preparatory stage. See Stand method.

Present yield. The anount of wood at present containel in given trees upon a given area.

G., Vorrath. F., matériel debout, matériel sur pierl.

Present yield table. A tabular statement of the amount of wood at present contained in given trees upon a given area.

Price increment. See Increment.

Private forest. A forest which is the property of an individual, corporation, company, or private institution. G., Privatwald. F., foret particulière.

Protection forest. A forest whose chief value is to regulate stream flow, rrevent erosion, hold shifting sand, or exert any uther indirect benetirial effect.

G., Schntzwald, Bannwald. F., foret de protection.

Pruning., $n$. The removal of branches from standing trees by natural or artificial means.

G., Aufästung. F., élagage.

The clearing of the stem through the death and fall of branches for want of light is known as naturul pruning. (G., Astreinigung. F., blagage naturel.) When living branches are removed by cutting them close to the stem the operation is known as green pruniny (G., Grün:istung. F., élagage le liranche's rivantes); when it is confinerl to dead hranches, as dry pruning ( $\mathrm{F}$., Trockenïstumg. F., élagage (le branches mortes).

Puddle, r. To dip the roots of yomeng trees in thin murl.

Pudale, $n$. A mixture of soil or mold and water, forming thin mud, in which the roots of young trees are dipped to retard drying ont during transplanting.

$29273-$ No. $61-05-3$ 
Pure forest. Forest composed of trees of one species. In practice, a iorest in which 80 per cent of the trees are of one species.

G., reiner lestand. F., peuplement pur.

Quality incerment. See Increment.

Quality of locality. See Lorality class.

Quinemx planting. A methon of planting in which young trees are set in the center and at eich corner of successive symares.

G., Fünfverband, Kreuzplanzung. F., plantation en quineonce.

Reforest, $x$. See Restock.

Rerencration, $u$. Sée Reproduction.

Rrgeneration rutting. Sipe Reproduction entting.

Regular forest. Forest in which the trees are approximately of the sa... at are.

syn.: even-aged forest. G., gleichalteriger Bestand. F., peuplement uniform.

Romoval cutlines. Sire stamel method.

Remuval stace. See Stand wethod.

Reproduction, $n$. 1. The process by which a forest is renewed.

Syn.: regeneration. G., Verjüngung. F., régénération.

Vaturul reproduction is the renewal of a forest by self-sown seeds or hy sprouts.

G., natürliche V'erjüngung. $F$, réçénération naturelle.

- Irtificial reproduction is the renewal of a forest by sowing or plantin.

G., künstliche Verjüngung. F., régénération artificielle.

2. Seedlings or saplings from spronts ur from self-sown seed.

Repundution cutting. Any cutting intended to invite or assist reproduction.

syn.: regeneration cutting. G., Verjüngungshieb. F., coupe de régénération.

Reproduction period. The space of time required for the renewal of a stand.

Reserve seed method. That method of conervative lumbering in which, in a stand which is being reprodueed by seli-sown seed, a number of trees are left nucut for a period, usually a secomd rotation, after the stand itself is reproduced. see Forest management.

Syn.: system of high forest with standards. (i, Leberhaltbetrieb. F., traitement en futaie avec résorve sur conpe définitive.

Reserve sprout forest. Two-storiel forest, in which spronts form the lower and seetlings, or selectel, healthy sprouts, the upper story.

Syn.: coppice with standards, standard coppice, stored coppice. G., Mittelwald. F, taillis (omprosc, taillis sous futaie.

Reserve sprout meflow. That method of conservative lumbering in which an overwoor composed of seenling tress, or selecterl spronts, is maintained above a stanil of sprouts. Ser Forest manigement.

Syn.: standarl coppice system. G., Mittelwahlbetrieb. F., régine du taillis composé.

Restuck, $x$. To renew a forest, either by natural or artificial means.

Syn.: reforest. G., aufforsten. F., reboiser.

Ride, $n$. iee Compartment line.

Ridge planting. Sire Mound planting.

Rock, $n$. In forest description rock refers to those "haracteristies of the mulerlying formation which affect the forest; as, for example, its onterop, composition, and the rapidity of its disintegration.

Rock in, to. To plant young trees in openings in the ground made by prying or rocking a spade back and forth. 
Root collar. That place at the base of a tree where the swelling which is the direct result of the ramitications of the roots lyegins.

G., Wurzelhals. F., ('ollet.

Root sucker. See Sprout.

Rotation. $n$. The perioul represented by the age of a forest, or a prart of a forest, at the time when it is cut, or intencled to be cut.

G., T'mtrieb, l'mtriebseit. F., révolution.

The following classes of rotation are distinguished:

Finmerial rotention, muler which a forest yields the highest net interest on its rapital value, calculating at compound interest.

Income rotation, muler which a forest yields the highest net refurn, caleulating without interest.

Syu.: motation of the highest income.

Silvical rotation, the rotation most favorable to the natural reproulution of the forest under a given method.

Syn.: physieal rotation, silvieuitural rotation.

Technical rotation, under which a forest yields the material most suitahle for a rertain purpose.

Volume rotution, under which a forest yielde the greatest quantity of material.

Syn.: rotation of the greatest volume.

Rotation of the greatest rolume. See Rotation.

Rotation of the highest income. See Rotation.

Row planting. A methor of planting in which the young trees are placed in rows, the distance between the rows being greater than the distance letween the young trees in the rows. In planting seeds or seedlings in the forest mursery this method is known as drill planting.

G., Reihenpflanzung. F., plantation en lignes.

Sample area. See Valnation area; Experiment area.

Sample plot. Sce Valuation area; Experiment area.

Sample tree. A tree which in diameter, height, and volume is representative of a tree class.

G., Probestamm. F., tige d'expériente.

A class sample tree is a tree which in diameter, height, and rolume represents the arerage of several tree classes.

syn.: arithmetical mean sample tree.

Sapling, $n$. A tree 3 feet or over in height, and less than 4 inches in diameter breasthigh. Sice Tree class.

A small sapling is a sapling from 3 to 10 feet in height.

A large sapling is a sapling 10 feet or over in height.

Scald, n. See Sun scali.

scale rule. See Log rule.

Scattered seed method. That method of conservative lumbering in which reproduction is provided for by leaving, after a single cutting, scattered seed trees of the kind desired. See Forest management.

Seratcher, $n$. An instrument used for marking trees. It usually consists of a hooklike gouge fastened to a flat, elliptical iron hoop, with wooden handle plates on the opposite side from the gouge.

Syn.: bark blazer, bark gonge, 'rniser's lark hlazer, tree scribe. (1., Risser. F., griffe.

screen, $n$. See shate frame. 
Seroul growth. Forest growth which comes up naturally after cutting, fire, ur other disturbing cause. Sie First growth.

Section analysis. Sep Tree analyis.

Seedlom, $n$. A specially propared area, usually in the forest nursery, for the raisjug of seredlings:

(i., Saatheet. F., couche de semis.

sreel rultings. see stamel method.

Sud forest. A forest (omposed wholly or mainly of trees grown from seed.

syn. high forest. (i., Hochwali, Samenwald. F, futaie, haute futaie.

Seeding stage. we stand methorl.

sectlinw. n. 1. I tree grown from seed.

(i., Kernwuchs. F., lorin de semence.

2. I tren grown from seed which has not reached a height of 3 feet. Sie Tree chis:

G., Nömling, Keimling. F., jeune brin.

Seed spot. A suall area, usually in a burn or in an opening in the forest, which is sown with tree seerl.

Seed system. One of the three great systems of forest management. Enler it reproduetion is obtained from seed. See Forest management.

Syn.: high or seedling forest system. G., Hochwaldbetrieb, Namenholzbetrieb. F., ringines de lat futaie.

Soed frow, n. Any tree which bears seet; specifically, a tree which provides the seed for natural reprodustion.

syn.: mother tree. G., Intterhaum, samenbaum. F., protr-graine, semencier.

Semd year. I year in which a given species of tree hears serd; sperifically, a year in which a given speries bears seed abmulantly.

G., Sauronjahr. F., anniv de semence.

Sulection forest. Sir Many-aged forest.

Sederetion method or systrum. Se single tree methexd.

Self-sum n sede Strictly, disseminated without the intervention of human or aninal agency; in eommon practice, soerl sown by any ageney other than man.

semimature lorest. Forest in which rapiel growth in hejght has rouluinated, but diameter growth has not loxgun to fall wif.

Sevelanee culfing. The "utting of all trees upon a narrow strip before natural pruning has far advanowl, in order that the trees hordering this strip may, as the result of partial "xpesure, beome wiml-fim thromgh the develogment of strong ront-s. Thus severance cuttings are marle te strengthen the trees on the edge of a stand which will later be entirely exposed through the removal of the stand which now protects it.

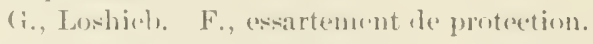

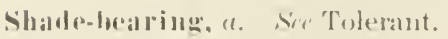

Sllable-enduring. иe. Se, Tolerant.

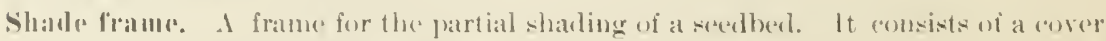

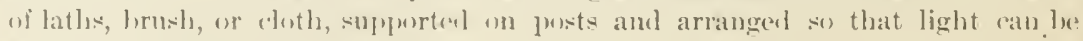
aluittul as ilesired.

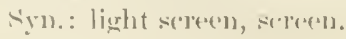

Slialli, 11 . Siestem. 
Sloclterbelt, $m$. Natural or artificial forest maintaines as a protection from wind or :muा:

Syll.: shelterwood, wind mantle. G., Waldmantel, schutmantel, F, rideatu.

A narrow shelterbelt in which true forest comblitions do not exist, is a windbreak when maintained as a protection against wind, and as smolmeuk when maintained als al protection against snow.

Slielterwood, $n$. Sire shelterbelt.

Shelterwood eompartment system. Siestand nothexl.

Shelterwood gronp system. Nee Gromp methor.

shelterwod selection system. See Single tree method.

sloot. $n$. See Sprout.

Silvical, u. Pertaining to silvies.

Nilvical rotation. See Rotation.

Nilvies, $u$. 1. The science which treats of the life of trees in the forest.

2. The habit or behavior of a tree in the forest.

Syn.: habit, silvicultural cliaracteristics.

silricultural claracteristies. See Silvies.

Silvicultural rotation. See Rotation.

Silvieulture, $n$. The art of producing and tending a forest; the applination of the knowledge of silvies in the treatment of a forest. The Forestry.

G., Waldbau, Holzzucht. F., sylviculture.

Single tree method. That method of conservative lmubering in which reproduction from self-sown seed under the shelter of the okl stand is invited by the cutting of single trees. This cutting may be made thronglout the forest, as in some woollots, or in definite portions of the forest in turn. See Forest management.

Syn.: selection method, selection system, shelterwood selection system. G., l'länterbetrieb, Plïnterwirtschaft, Femelbetrieb. F., jardinage, régime te la futaie jardinée.

Singlo tree mixture. A mixture in which trees of different speries vecur singly.

site, $n$. sice Lucality.

slope, $n$. The gradient of the land surface. In forest lescription the following terms are used to define the slope, each of which has its equivalent in percentages of the horizontal distance and in degrees:

$$
\begin{aligned}
& \text { Level }=0-5 \%=.0-3.0^{\circ} \\
& \text { Gentle }=5-15 \%=3.0-8.5^{\circ} \\
& \text { Moderate }=15-30 \%=8.5-16.5^{\circ} \\
& \text { Steep }=30-50 \%=16.5-26.5^{\circ} \\
& \text { Very steep }=50-100 \%=26.5-45.0^{\circ} \\
& \text { Precipitous }=\text { over } 100 \%=0 \text { rer } 45.0^{\circ}
\end{aligned}
$$

Small pole. See Pole.

Small-pole forest. A forest of small poles.

Suall sapling. See sapling.

Sinall-sapling forest. A forest of imall saplings.

Suowbreak, i. 1. The breaking of trees by snow.

G., Schneebruch. F., bris de neige.

2. An area on which trees have been hroken by snow.

3. sice Shelterbelt. 
Soil. $n$. In forest leseription the origin, "rmpusition, depth, and moisture of the forest soil are consiclered mnder soil. Its depth is clefines by the following terms, each of which has its equivalent in inches:

Very shallow $=$ less than 6 inches.
Shallow $=6$ to 12 inches.
Ioderate $=12$ to 24 inches.
Deep $=24$ to 36 inches.
Very rlee] $=$ over 36 inches.

The nuisture of the soil is defined by the following terms:

Het: when water irips from a piece held in the hand withont pressing.

Yoist: when water trips from a jiece pressed in the hand.

Fish: when no water brips from a piece pressed in the hand, though it is umuistakably present.

In\%: when there is little or no trace of water.

Iry dry: when the soil is parched. Such soils are msinlly caked and rery hard, sand being an exceptisn.

Somr lommus. Ilumus harmful to forest growth owing to the presence of humic or similar aejels produced hy decomposition morler excess of moisture and lack of air. syn.: acid humus. Int.: miln humus. G., sanerer IImnns. F., humus tourbenx.

Sown forest. iee Forest plantation.

Sprout, $u$. A tree which has grown from a stmmp or root.

Syn.: copfice shoot, root sucker, stool shoot, stump shoot. (i., Stockansichlag. F., rejet rle sonche.

A shoot is a spront which has not reached a height of 3 feet. Sec Tree class.

Sprout forest. A forest consisting wholly or mainly of spronts.

Syní: coppice, coppice forest. G., Niederwall. F., taillis.

Surout mothod. That method of conservative lumbering in which reprouluction is olitained by spronts. See Forest management.

Fyn.: coppice methor] or system. G., Nierlerwaldbetriel,. F., régime dn taillis simple.

Spront system. One of the three great systems of forest management, in which reproluetion is securer by sprouts. Sfe Forest management.

Syn.: coppice system. (i., Stockansschlaghetrieb, Niederwaldhetrieh. F., régime clu taillis simple.

Squar planting. A method of planting in which the distance between the row is equal to the listance between the young trees in the rows.

(i., Qnadratpflanzung. F., plantation en carré.

Stagleaded, a, we Dry toppet.

Stand, $n$. All growing trees in a forest or in part of a forest.

Syn.: growing stock. G., Bestand. F., peuplenent.

Siandard, $n$. A tree from 1 to 2 feet in cliameter breasthigh. , see Tree elass.

Standard coppice. See lieserve sprout forest.

Staularil coppice sistem. Sep Reserve sprout methoul.

Standarl-forest. $n$. A forest of standarts. G., Baumbolz. F., futaie, hante futaie.

Stand class. All stands of similar density, height, and volume for a given age or diameter and a given locality elass. The index stand may constitute the first stand class.

(x., Bestamlesgüte. F., qualité du peuplement.

Stand flre. See Forest fire. 
Stand method. That method of conservative lumbering in which reproduction is secured from self-sown seed by means of successive cuttings marle throughout the mature stand, thus leading to the production of a new stand approximately even aged. These successive cuttings encourage seed production, create conditions favorable to the growth of seedlings, and gradually remove the remaining trees of the mature stand as the young growth develops. See Forest management.

Syn.: compartment system, high forest compartmont system, method of successive thinnings, shelterwood compartment system. (i., schlagweise Verjüngung. F., régime de la futaie régulière.

The series of euttings, which vary in number and duration aceording to the degree of difficulty with which reproduction is effected, is divided into the following four kinds:

Piepuratory cutings fit the stand for its reproduction by the removal of dead, dying, or defective trees, and prepare the ground for the germination of seerls.

G., Vorbereitungsschlag. F., coupe préparatoire.

A stand in which one or more preparatory cuttings have been male is in the prepuratory stage.

Seed cuttings encourage seed proluction by the further opening of the stand, and adnit light in quantity favorable for the development of young growth.

G., Besamnngsshlag. F., coupe d'ensemencement.

A stand in which one or more seed cuttings have been made is in the seeding stage.

Remocal cuttings gradually remove the mature stand which wonls otherwise retard the development of the young trees.

G., Lichtschlag. F., coupe claire.

$A$ stand in which one or more removal cuttings have been made is in the remoral stage.

The final cutting is the last of the removal cuttings, in which all of the old stand still remaining is cut.

(̇., Abtriebsschlag, Endhieb. F., coupe définitive.

Stand table. A tabular statement of the number of trees of each species and diameter class upon a given area.

State forest. A forest which is the property of a state.

Stem, $n$. The trunk of a tree. The stem may extend to the top of the tree, as in some conifers, or it may be lost in the ramification of the crown, as in most broadleaf trees. In tree description the stem is described as long or short, straight or crooked, eylindrical or tapering, smooth or knotty.

Syn.: bole, shaft, trunk. (i., Stamm. F, trone.

Stem analysis. See Tree analysis.

Stem density. The extent to which the total number of trees in a given forest approaches the total number which the index forest of the same age and composition contains. It $\mathrm{i}$ s ordinarily expressed as a decimal, 1 being taken as the numerical equivalent of the stem density of the index forest.

G., Bestockungselichte, Bestandesdichte. F., consistance du peuplement.

stem form fictor. See Form factor.

Stool, $n$. See Stump.

Stool shoot. See Sprout.

Stored coppice. See Reserve sprout forest.

Stratify, $v$. To preserve tree seeds by spreading them in layers alternating with layers of earth or sand. 
strip methol. That methor of conservative lumbering in which reproduction is securerl on ("an-eut strips by self-sown sem from the adjoining forest. See Forest management.

G., Coulissenhieh. F., compe par bumles alternes.

Siripstand method. A modification of the stand method in which reproduction cuttings are not marle simultaneously throughout the staml, but the stand is treated in narrow strips at such intervals that reproduction cuttings are generally groing on in three strips at one time, one strip being in the removal stage, one in the seenling stage, and one in the prepraratory stage. See Forest managenent.

Strip survey. See Valuation survey.

sinb. n. That portion of the stem left standing when a tree is accilentally broken off.

Stump, $n$. That portion of the stem below the cut marle in felling a tree.

Syn.: stool. (i., Strek. F., souche.

Stnmp age. The age of a tree as determined by the number of annual rings upon the face of the stump, without allowance for the period recpuired for the growth of the tree to the height of the stump.

Stump analysis. See Tree analysis.

Stump height. 'The distance from the ground to the top of the stump, or from the root collar when the ground level has been disturbed. (In a slope the average distance is taken as the stmmp lieight. See (utting height.

Stump sloot. See sprout.

Subcompartment, $n$, se Compartment.

Sun scald. An injury to the cambium caused by sudden exposure of a tree to strong sunlight.

Syn.: seald. G., Sonnenlurand. F., brûlure, conps sle soleil.

suppressed, a. IIaving growth more or less seriously retarded by shade. See Crown class.

G., nnterdrückt. F., dominć.

Sillace flre. See Forest fire.

Sustaind working. Sie Working.

Sustained yield. Sie Working.

System of high forest with standaris. See Reserve seed method.

Technical rotation. See Rotation.

Thicket, $n$. A stand of saplings.

G., Dickicht. F., fourré.

Thin, a. See Crown density.

Thinning, n. The remnval of a portion of the trees with the object of improving the stand without inviting natural reproduction. The following kinds of thinnings are distingnished: cleaning, improrement thimming, arecetion thiming.

G., Durchforstung. F., coupe d'éclaircie.

Timber form farefor. wer Form factor.

Timberlaud, n. See Forest.

Timber trace. See Forest.

Tolerance, n. The capacity of a tres to endure shade. 
'Tolerant, $u$. Capable of enduring more or lest heary shate.

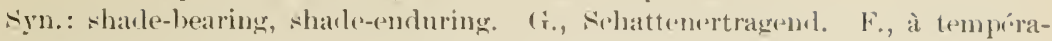
ment délicat.

Total incement. The total volmme of wool prowluesl hy the growth of a trees or stand up to the time it is cut.

'Town forest. A forest which is the property uf a dity, town, or village.

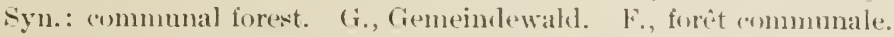

Transplant, $r$ 1. To take up a yomg tree and set it ont again in another place.

2. To transfer seedlings from the seedbed to anothur plare in the forest nursery; or from the latter to the planting site.

(i., verpflanzen, versehnlen. F., transplanter.

Transplant, n. A seedling which has been transplantod once or wereral times. (i., Schulpflanze. F., plant repiqué.

'Tral tres. A tree dearlenerl or felled at a time when ilestrutive bark beetles will be attracted to it and enter the bark. After they have enterem, the lark is peeled and exposed to the sun, burned, or hurierl, as the rase may require, to destroy the insert.

G., Fanghaum. F, arbre-piège.

Tree analysis. A series of measurements and observations npon a felled tree to determine its growth and life history.

Syn.: stem analysis. G., Stammanalyse. F., analyo the tige.

Tree analyses vary with their purpose, and may incluele all or a part of the following, or may recuire additions to meet special needs. The nsual measurements comprise the length of each section, the liameter inside and outsicle tles bark, the total age, the age and wilth of the sapwood, the diameter growth at given periods on the upper end of each section, the dianeter breasthigh, the total height, and the clear, used, and merchantable lengths. The observations. determine the class, form, and condition of the tree.

Although a tree analysis may inclutle many combinations of the alove measure. ments, two important classes are clistinguisherl:

A stump anclysis includes measurements of the diameter growth at given periouls upon the stump only, no matter what other measurements it may comprice.

A section analysis includes measurements of the dianeter smowth at given periouls upon more than one section.

When, in a stmmp or section analysis, the measurement of the liameter growth at given periols covers only a portion of the total clianeter wowth, the analysis is a partial stump analysis or a partial section anulysis.

Treaclass. All trees of approximately the same size. The iollowing tree classes art distinguished: seelling, shoot, small sopling, large stepling, small pole, large pole, standard, ceteran.

Tree form factor. See Form factor.

Tree scribe. See serateher.

Tranch planting. A method of planting on ary grmunl, in which the seets of young trees are set in pits or trenches.

Syn. : pit planting.

Triangular planting. A method of planting in which the unit of arrangenent is an erquilateral triangle, at each apex of which young trees are placed.

G., Dreieckverbanıl. F., plantation en triangle.

Trunk, n. See Stem.

$29273-$ No. $61-05-1$ 
Two-storiod forest. ('omprising on the same area two claseses, which vary consider-

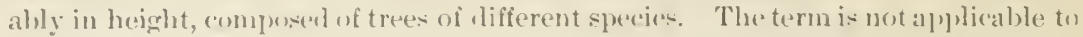
fores under reproduction, in which the appearance of two stories is the temprory resilt of an ineomplete proness, but to these forests of which the two stories of growth are a natural aurl peruanent feature.

(i., zweihiebier. F., à demble citalger.

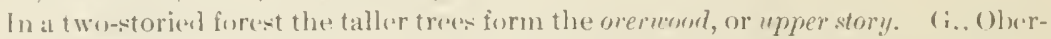

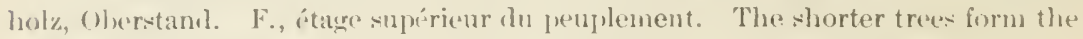

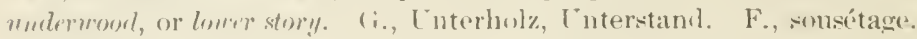

Underloruslı, ". All large, woudy plants, such as witch-hobble, laurel, striped maple', and devil's club, which grow in a iorest, but do not make trees. Sie (immol (') $(1)$ (')

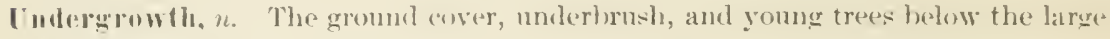
sapling stage.

Conderplan1. $\iota$. To plant young trees muler an existing stand.

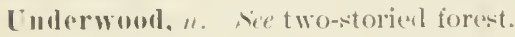

Uneren-aged forest. Ser I rregular forest.

Elupe story. Sie Two-storied forest.

Csid longtli. The smm of the lengthe of logs cut from a tree.

Syn.: actual merchantable length.

lisul volums. The sum of the volumess of logs cut from a tree.

syn.: actual merchantable volume.

Valuation areal. A forest area of known size upon which measurements or other detailed studies are made for the determination of the stamb or yield. Sep lixperi ment area.

syn.: sample area, sample plot. (i., I'robefliche, Versuchsfläche. F., surfare d'expérience, placer d'essai.

Valuation survey. The measmement or other detailed study of the stand upon a valuation or experinent area.

Two kinds of valuation survey are distinguished:

1. The stipl snery eomprises the musurement of a staml, or a given portion of it, upon strije dsually 1 chain wide.

2. The plot surry comprises the measurement of the stand, or a given portion of it, mpon isolaterl plots not in the form of strips.

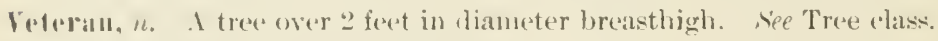

Vieterall forest. A forest of veterans.

(i., Althol\%. F., vieille futaie.

Virgin forest. The first growtl.

Volums growll. sere Inerement.

Vulume increment. Sie Increment.

Volune rotation. Sie Rotations.

Voluma table. A tahular statement of the volume of trees in buard leet or other mits upou the basis of their diameter breanthigh, their liameter breasthigh and leeight, their age, or their age and height.

(i., Massentafel. F., tarif de (mbage.

Volunfere growll. Foung tress which have sprung up in the open, as white pine in wld fields, or cherry and aspen in burns. Sep Arlvance growth.

sym.: old-field growth.

Wreed frees. A tree of a species which has little or no value. G., Unbolz. F., morts-bois. 
Wiudbrak, $u$. 1. The breaking of trees by wind.

2. vee Shelterhelt.

3. See Wintlall.

Windfall. 1. A tree thrown by wint.

2. An area on which the trees have been thrum by wint.

Syn. windbreak. (i., Windbruch. F, volis.

Wind-firm, $u$. Able to withstand heavy wiml.

G., sturmfest, winlfest. F., resistaut an rent.

Wind unantle. ser Shelterbelt.

Woodland. $n$. se Forest.

Woollot, $n$. siee Forest.

Work, $v$. To harrest the final yield under a working plan.

Working, n. The harvesting of the final yieli under a working plan.

G., Betrieb. F., exploitation.

Working is anmul when cuttings are made each year; periodic when they are made after uniform periods of two or more ytars; and intermittent when they are mate at irregular intervals. Sustuined annual, periodic, or intermittent workings are those under which the amount of wood ent is so regulated that the productive capacity of the forest does not decrease, but produces a sustrimed yield (G., Nactlhal tsbetrieb. F., exploitation à rendement soutenu), which likewise may be annual, periodic, or intermittent.

Working area. The total forest area managed uncler a working plan.

Syn.: working eircle. (i., Wirtschaftseinheit. F., unité l'exploitation.

Working cirele. Ser Working area.

Working plan. A detailer and comprehensive scheme for the best permanent use of a torest.

G., Wirtschaftsplan. F., plan d'exploitation.

Working plan renewal. The preparation of a new working plan for a given tract, when the present working plan has been carrien out, or changed "onulitions require its revision.

Yield, $n$. The amount of woul at present upon, w' which after a given periorl will be upon, a given area. sée Present yielı; Future yield; Accislent yield; Intermediate yield; Final yield; Working.

(i., Ertrag. F., rendement.

Yield table. sice Present yield table; Future yield table. 




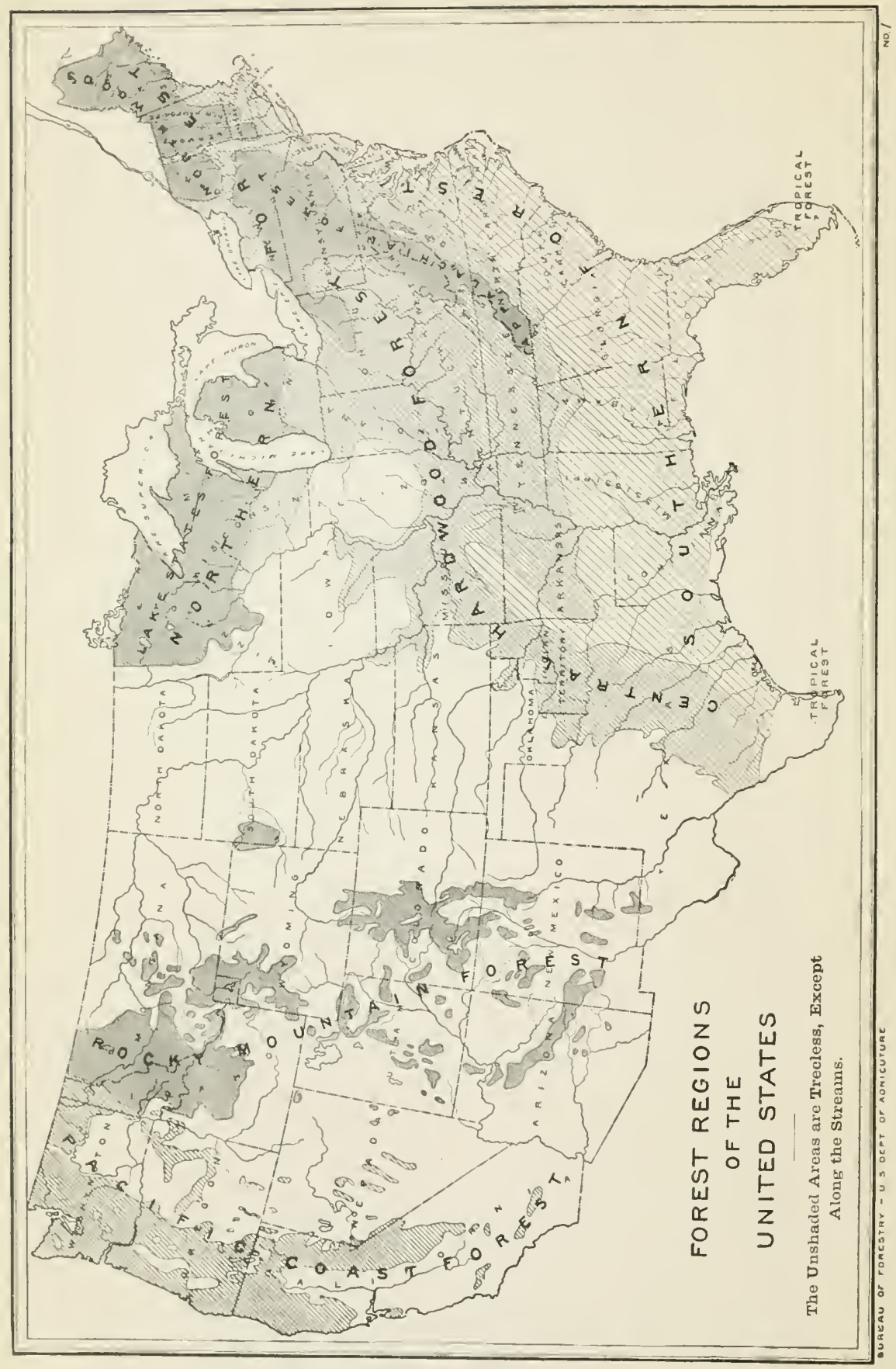




\section{LOGGING TERMS.}

[Letter in parentheses following definitions indieate the forest regions (see map) in which the terms as defined are used.

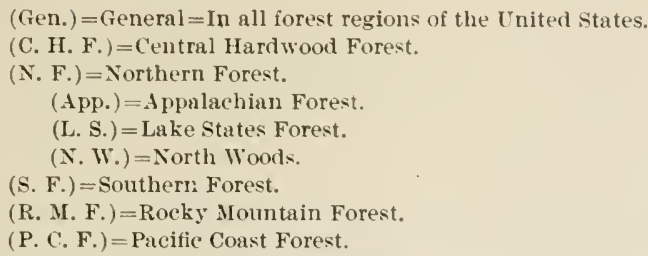

In a few instances very local terms are ascribed to a state instead of to a forest region.]

Alder grab. The stem of an alder, or other small tree, which is bent over and plugged into a hole bored in a boom stick, or secured in some other way, to hold a boom or logs inshore. (N. F.)

Alligator, $n$. 1. A boat used in handling floating logs. It can be moved overland from one body of water to another by its own power, usually applied through drum and cable. (N. W., L. S.)

2. A device, often made from the fork of a tree, on which the front end of a $\log$ is placed to facilitate skidding on swampy ground. (S. F.)

Anchor line. A line attached to a small buoy and to one fluke of an anchor used in towing a raft of logs. It is employed to free the anchor when fast to rocks or snags. (N. F.)

Apron, $n$. 1. A platform projecting downstream from the sluiceway of a dam to launch well into the stream logs which pass through the sluiceway. (Gen.)

2. A platform built of timbers at the foot of a slide, which guides in the desired direction logs leaving the slide. (Gen.)

Ark, $n$. See Wanigan.

Back line. See Haul back.

Ballhooter, $n$. One who rolls logs down a hillside. (App)

Bank, $x$. See Bank up, to.

Bank, $n$. 1. See Landing.

2. The logs cut or skidded in one day above the required amount and held over by the saw crew or skidders, to be reported when the required daily number is not reached. (X. F.)

Banking ground. See Landing.

Bank up, to. To pile up logs on a landing. (Gen.)

Syn.: bank.

Barker, n. One who peels bark in gathering tanbark. (Gen.)

Syn.: peeler, spudder.

Barking iron. See Spud. 
Bark mark. I symhol rhepperd intu the sirle of a log to indieate its ownership; when nsed with the (mel mark it serves as an alditional means of irentitication. (Gen.) Sir Mark.

Syn.: sibe mark. (N. F.)

Bark marker. One who ants the hark mark on lings. ((ien.)

Barn lonss. One who has elaarge of the stables in a logging camp. (Gen.)

Syn.: fereler. (N. II.)

Batten. u. I log less than 11 inches in dianeter at the small oncl. (Maine.)

Battery, "T. Two or more donkey engines for draggines logs, set at intervals on a long skid roat. (l'. ( '. li.)

Bearer, $n$. sieswanper.

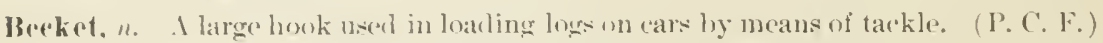

Bud a trese. to. To level up the path in which a tree is to fall, wo that it may not be shattered. (I'. ( . F.)

Bicycle, ". A traveling block, used on a cable in steam skichling. (S. F.)

biguess sealu. Séf Full scalc.

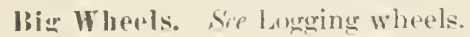

Binder, n. A springy pole used to tighten a binding chain. (fien.) syn.: jim binder.

binding chain. A rhain used to bind together a loars of logs. (Gen.) syn.: wrapper (biain. (X. F.)

Binding logs. Legs placed on the top of the chain binding a loak, in order to take w1 the slatek. (Gen.)

Birl. ". To cause a floating lour to rotate rapialy by trealing upon it. (Gon.)

Bitrh chaiu. A short, heary chain with hook and ring, need to fasten the bower end of a gin pole to a sled we wa when bading logs. (N. F.)

Blaze, $r$. To mark, by entting into trees, the eourse of a boundary, roat, trail, or the like. (lien.)

syn.: spot. (N. Wr.)

Block, $n$. See Brail.

Blow down. See Wimlfall.

Blue jay. See Roall monkey.

Bluing, $n$. The result of fungus attak, which turns the sapwod of eertain trees bine. (cirin.)

Bul, n. Sie Dray.

Bubber, ". . Se bealliead.

Bob lues, tu. To transport logs on a hob or dray. (N. F.)

IBoly woud. Cord wond eut from those purtions of the stems of trees which are (lear of branches. (N. F.)

Bulstur, n. Sire linnk.

Bomin, $n$. Lags or timbers fastened together end to ond and used to hold floating logs. The term sometimes inchules the logs inclosed, as a boom of loge. (Gen.)

Bounuagr, n. Toll for use of a loom. (Gen.)

Buoum buoy. Sié Buom stay.

Boom chain. A short chain which fastens boom sticks end to end. (Gen.)

Bowm company. A corporation chagaed in handling foating logs, and owning booms and booming privileges. (I. l. .) 
Bowm piu. A wooklen plug used to fasten to bonm sticks the chain, rope, or withe which holds them together. (Gen.)

Boom rat. One who worke on a boom. (N. F.)

Boom stay. A heary weight used to anchor hooms in deep water; its position is inclicated by al prole or float attached to it. (X. F.) syn.: boom buoy.

Boom stick. A timber which forms part of a boom. (Gen.)

Bottle butted. Sie swell butted.

Bottum sill. See Mudsill.

Brail. $\because$ To theten logs in brails.

Brail. $u$. A section of a $\log$ raft, six of which make an average tow. (L. \&.) syn.: block. (S. F.)

Braki sled. A logging sled so constructed that, when the pole team lolds back, a heary irom on the side of each runner of the forward sled is forced into the roatbet. (X. F.)

Brand, n. See Mark.

Break out. to. 1. To start a slerl whose rumers are irnzen to the ground. ( $\mathrm{X}$. II., L. ..)

2. To open a logging road atter heary snowfall. (N. W., L. S.)

Breastwork log. See Fender skid.

Briar, $n$. A crosscut saw. (Gen.)

Bridle, $n$. A device for controlling the speed of logs on a skid road. It consists of a short rope with $t w o$ hooks at one end, which are driven into the first log of the turn; at the other end is a clamp which runs over the cable. (P. C. F.)

Bridlp man. One who follows a turn of logs down the skid road and tents the "bridle." (P. C. F.)

Broalleal, a. see Hardwool.

Brow skill. The chief bean in a trame to mhich tackle for loalling lugs on cars is fastenerl. (P. C. F.)

syn.: draw skid, lead log.

Brush a road, to. To cover with brush the mudholes and swampy places in a logging road, to make it solicl. (N. F.)

Bruslu snow feuce. A snowbreak to protect a logging roal; used most commonly on wide marshes. It consists of brush which is set upright in the ground before it freezes. (N. F.)

Brutting erew. A crew which rolls logs down slopes toosteep for teams. (App.)

Buck, $x$. 1. To saw felled trees into logs. (P. C. F.)

2. To bring or carry, as to buck water or wood. (Gen.)

Bucker. n. 1. One who saws felled trees into logs. (P. C. F.) Syn.: cross cutter. 2. One who brings or carries. See Burk.

Buckwheat. $x$, se Hang up, to.

Buckwheater, $n$. A novice at lumbering. (Gen.)

Bull chain. 1. A rery heavy chain, to which a number of short chains, with hooks on one end and logs on the other, are attached. It is used to draw logs from the mill pond up the gangway. (cien.)

2. See Jack chain.

Bull cook. See Chore boy. 
Bull donkey. I large donkey engine which, by trum and eable, lrags logs from the place where they are yarded to a lanting. (P. C. F.)

Bully, $n$. A common name for the forman or bus of a logging camp. (N. F.)

Bummer, n. I small truck with two low wheels and a long pole, used in skidding $\log s$ (N. F., A. F.)

syn.: Arag cart, skinhler.

Bunch load. 16. To encirele several logs with a chain and load them at once, by stean or horsepwer. (N. F.)

Bunch Iogs. to. To collect loges in one place for loaling. (Gien.)

Bumk,r. Toplace mpen the bunks, as to "bunk a log." (Gen.)

Bunk, и. 1. The leavy timber ujon which the logerest on a logging sled. (N.F.) Sirn.: lolster.

2. The cross hean on a logr car or truck, on which the logs rest. (Gien.)

3. A log ear or truek. (s. F., P. C. F.)

Bunk ehaill. See Toggle thain.

Bunk hook. The hook attachenl to the end of the bunk on a logging ear, which may be raised to hold the logs in place or lowered to release them. (Gen.)

Bunk loal. I load of logs not over one log ileep; i. a., in which every log rests in the louks. (Gen.)

lintk spikes. Sharp spikes set upright in the bunks of a logging sled to fold the logs in place. (N. F.)

Bush a roat, fo. To matk the route of a legging roul across a marsh or the ices by setting up busher. (X.F.)

But1. n. The hase of a tree, or the big end of a log. (Gen.)

Butt cut. 1. The tirst log above the stump. (lien.)

syn.: butt log. (Gen.)

2. In gathering tanbark, the section of bark taken from the butt of a tree before felling it for further peeling. (X. F.)

Butt lowk. The hook hy which the cable is attacherl to the tackle on the logs. (I'. C. F.)

Butt long. Siee Butt rist.

Butt off, 10. 1. To cut a piece from the end of a log on aceonnt of a defeet. 'Gen.) Syn.: long lutt, to. (P., ( . F., A H.)

2. To square the end of a log. (N. F.)

Buttress, $n$. A wall or abutment huilt along a stream to prevent the logs in a drive from cutting the bank or jamming. (Gen.)

lButt team. In a logging tean of four or more, the pair nearest the loat. (rien.)

('anp inspector. A lazy lumberjack, who genes from one logging ramp to another, working only a short tine in each. (N. F.)

('annon a log, 10. In loading logs hy steam or horse power, to send up a log so that it swings crosswise, instead of parallel to the load. (X. F.)

Caut lowr. Sie Cant hook.

Cant look. A tool like a peavey, but having a toe ring and lip at the end insteal of a pike. See Peavey. (Gen.)

Syn.: rant dog.

('al, n. A cone of sheet iron or steel, with a hole in the ent through which a chain passes, which is fitterl over the enel of a log before snaking it, to prevent eatching on stumper, roots, or other obstacles, in stean skidding. (s. F.) 
('at auturan, $n$. A small raft carrying a windlass and grapple, used to recover sunken logs. (Gen.)

Syn.: sinker loat (Gen.), monitor, pontoon (P. C. F.).

Catch boom. A boom fastened across stream to atch aml hold floating logs. (Gerr.)

Catface, n. A partly healed over fire scar on the stem of at tree. (P. C. F.)

Catpiece, $n$. A small stick in which holes are male at rexular intervals, placed on the top of uprights firmly set in floating boons. The uprights are fitterl to enter the holes in the catpiece, so as to narrow or willen the space between the broms at the entrance to a sluiceway or sorting jack. The catpiece is held hy the uprights high enongh above water to allow lows to float freely unler it. (N. W., L. S.)

Cattyman, $n$. An expert river lriver. (N. F.)

Center jam. A jam formed on an obstacle in the mirkle of a stream, and which does not reach either shore. (Gen.)

Syn. : strean jam.

Chain grapples. See Grapples.

Chain tender. See sled tender.

Check, $n$. A longitulinal crack in timber caused by too rapid seasoning. (Gen.) Syn.: season check.

Cheese block. See Chock block.

Chock block. A small wedge or block used to prevent a log from rolling. (Gen.) Syn.: cheese block. (P. C. F.)

Cloker, $n$. A noose of wire rope by which a log is thaggerl. (l'. C. F.)

Choker man. The member of a yarding crew who fastens the choker on the logs. (P. C. F.)

Chopper, $n$. See Faller.

Chore boy. One who cleans up the sleeping quarters and stable in a logging camp, cuts firewood, builds fires, and carries water. (Gen.)

Syn.: bull cook, flunkey, shanty boss.

Chunk, $x$. To elear the ground, with engine or horses, wi obstructions which can not be removed by hand. (P. C. F.)

Chunk up, to. To collect and pile for burning the slash left after logging. (N. W. L. S.)

Churn butted. See swell butted.

Chute, $n$. see slide.

Coal off, to. To eut a forest clean for charcoal wook. (X. F.)

Comm issary, $n$. A general store for supplying lumbermen. (App., S. F.) See Van.

Conk, n. 1. The decay in the wood of trees caused by a fungus. (N. F., P. C. F.)

2. The visible fruiting organ of a tree fungus. (X. F., l'. C. F.)

Conky, a. Affected by conk. (N. F., P. C. F.)

Cook camp. The building used as kitehen and lining room in a logging camp. (Gen.)

Syn.: cook house, cook shanty.

Cookee, $n$. Assistant cook and lishwasher in a logging camp. (Gien.)

Cook house. See Cook (amp).

Cook shanty. See Cook camp.

Corkserew, $n$. A geared logging locomotive. (1'. C. F.)

Syn.: stem-winder. (App.) . 
Corner hiuds. Four stout ahains, userl on logging sleds, to bind the two ontside logs of the lower tier to the banks, and thus give a firm bottom to the load. (N. F.)

('orner man. In building a camp or barn of logs, one who notehes the logs so that they will fit rloscly and make a square corner. (N. F.)

(oupliug erall. Siec iraples.

('ral), 1 . A small rait bearing a winllass and anchor, used to move log rafts upst ream or acrose a lake. (N. F., S. F.)

Cratle, n. A framework of timbers in which ocean-going rafts of logs are luilt. (P. C. F.)

(radlu kuolls. Small kmolls which reguire grading in the construction of logging roakls. (N. W., L. s.)

Cray chaiu. The short chain used to hold up that tongue of asprinkler slerl which is inut in use. (N. F.)

Crib. n. Specilieally, a ratit of logs; loosely applied to a brom of logs. (N. F.)

Crih logs, to. To surround floating logs with a boom and lraw them by a winullass on a raft (a crab), or to tow them with a steamboat. (N. W., L. S.)

Cruss chains. Chains connecting the front and rear sleds of a logging sled. ( $\mathrm{X}$. F.)

Cooss entter. See bucker.

Corss lanl. The cleared space in which a team moves in cross bauling. ( $\mathrm{X}$. F.)

('ross lanul, to. To hanl cars or sleels with logs by horsepower aur eroteh or loading chain. (ien.)

Crotch, $x$. To ent notches on opposite sides of a log near the end, into which dogs are fastenerl. (P. C. F.)

C'roteli. $n$. vee Dray.

('rotch cluain. A tackle for loading logs on steds, cars, or skichways loy cross hauling. (Gen.)

('rotels tongue. Two pieces of woor, in the form of a $V$, joining the front and rear sleds of a logging sled. (N. W., L. S.)

('ruise, $x$. To estimate the amount and value of standing timber. (Gen.)

Syn.: estimate, value.

Cruiser, 2 . One who eruises. (Gien.)

syn.: estimator, land looker, valner.

('ull. n. Logs which are rejecterl, or parts of logs deslueted in measurement on account of lefects. (Gen.)

('u1,, A scason's output of logs. (Cien.)

Cut a log, 10. To move one ent of a log forwarel or backwanl, so that the log will roll in the desired lirection. (Cren.)

Cut ofr. An artificial channel hy which the course of a stream is straighteneel, to facilitate log driving. (N. F.)

Dearon seat. The bench in front of the sleeping lunks in a logring camp. (N.F.)

Dealener, $n$. A heavy log or timber, with spikes set in the lutt em, so fastened in a $\log$ slide that the logs pasing umler it come in contact with the spikes and have their speed retarled. (Gen.)

Deadhead, u. A smuken or partly sunkinn log. (Gen.) Syn.: sinker (fen.), bobber (X. F.).

Dealiman, $x$. A fallen tree on the shore, or a timber to which the hawser of a boo'n is attacherl. ( .. F., P. C. F.)

Dotwlwater. See Stillwater. 
Decker, $n$. One who rolls logs upon a skidway or log deck. (Gen.)

Decking chain. See Loading thain.

beck up, to. To pile logs upon a skilway. (Gen.)

beer foot. A V-shaped iron catch on the side of a logging car, in which the binding chain is fastenerl. (Gen.)

Dehorn, $r$. To saw off the ends of logs bearing the owner's mark and put on a new mark. (Kentucky.)

Diugle, $n$. The roofed-over space between the kitchen and the sleeping quarters in a logging camp, commonly used as a storeroom. (N. W., L. S.)

Hinkey. $n$. A small logging locomotive. (App., S. F.)

Dog, $n$. A short, heary piece of steel, bent and pointerl at one end and with an eye or ring at the other. It is used for many purposes in logging, and is sometimes so shaped that a blow directly against the line of draft will loosen it. (Gen.)

Syn.: tail hook. (l. C. F.)

Dog boat. See Rigging sled.

Dogger, $n$. One who attaches the dogs or hooks to a lng before it is steam skiddecl. (S. F.; P. C. F.)

Dog look. 1. The strong hook on the end of a dogwarl. (X. F.)

2. A hook on the end of a haul-up chain of a size to permit its being hooked into a link of the chain when the latter is looped around a log or other object. (P. C. F.)

logs, $n$. See skidding tongs.

Dowwarly, $n$. A rope with a strong hook on the end, which is userl in breaking dangerous jams on falls and rapids and in moving logs from other difficult positions. (N. F.)

J)g wedge. An iron wedge with a ring in the butt, which is driven into the end of a $\log$ and a chain hitched in the ring for skidding the $\log$ ly horsepower; also used in gathering up logs on a drive by running a rope through the rings and pulling a number of logs at a time through marshes or partially submerged meadows to the channel. (N. F.)

Dolly, $n$. See Upright roller.

Dolphin, $n$. A eluster of piles to which a boom is secured. (P. C. F.)

Donkey, $n$. A portable steam engine, equipped with drum and cable, used in steam logging. Siee Road donkey; Yarding donkey; Bull ionkey; Spool donkey. (P. C. F.)

Donkey sled. The heary sled-like frame upon which a lonkey engine is fastened. (P. C. F.)

Dote, $n$. The general term used by lumbermen to denote decay or rot in timber. (Gen.)

Doty. a. Decayed. (Gell.) Syn.: dozy.

Double couplers. Two compling grats joined by a short cable, nsed for fastening logs together. (P. C. F.)

syn.: four paws.

Donble header. A place from which it is possible to haul a full loal of logs to the landing, and where partial loads are topped out or finished to the full hauling capacity of teams. (N. W., L. S.)

Down-hill clevis. I brake on a logring sled, comsisting of a clevis encircling the runner, to the bottom of which a heavy square piece of iron is welled. (N.F.)

Dozy, a. See Doty. 
J)an ralrt. Sep Bimmtur.

Hoax in, to. Sie Dray in, to.

Jran ruall. Siep Dray ruad; (iutter roat.

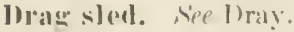

Draw hook. Sie Gooseruserk.

Hram skid. Ste Brow skirl.

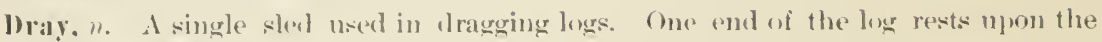
slerl. (X. F.)

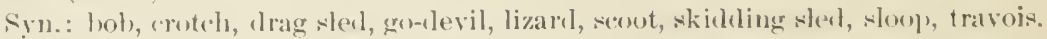

10ray in, to. To alrag logs from the place where they are cut directly to the skid. way or landing. (N. F.)

syn.: drag in, to.

Draly roadl. I narrow mad, cut wide enough to alluw the palssage of a teants and drav. $(\mathrm{N}, \mathrm{F}$.

Ern.: llage roarl.

I)rive, $\%$ ' To fluat logs or timbers from the forest to the mill or shipping point. (C)(נ).)

sin. : Hoat.

Drive. 11. 1. A bocly of logs or timbers in process of leing floated from the forest to the mill or shipjoing point. (Gen.)

2. That part of logging which comsists in floating logs or timbers. (Gen.)

brum lows. to. To haul loge hy drum and eahle out of a hollow or cove. (A]p.)

Dry-ki, n. Trees killed liy floorling. (N. F.)

1)ry pick. 10. As applied to a jant, fo renure logs singty while the water is cut wff. (X. F.)

101, roll, 10. In sacking the rear, to moll stranded logs into the hed of the stram from which the water has been cut off preparatory to flockling. (N. F.)

1019 rot. Deedy in timber without apparent imoisture. (fien.)

Dry slinle. See Slicle.

Dry sloup, 10. To slong, logs on bate sroumel when the slope is so steep that it would be dangerous to slon, on snow. (N. F.)

Dudler, n. See Dudley.

Dndley, n. An engine for hauling logs, which propels itsolf and drags its load by revolving a large npoul around which are several turns of a cable fixed at each end of the track. (l'. C. F.)

syru. alucller.

Dufle, $n$. The personal ledongings of a woxksman or lomberjack which he takes into the wools. (G(口n.)

Syn.: dumnager. (N. IV.)

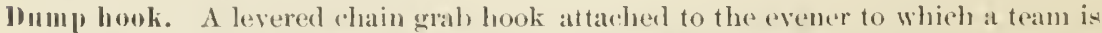
hitclued in loading logs. A muvement of the lever roleases the hook from the logring ('hain without stopping the team. (N. F.)

Dinim logs, fo. 'To roll logs over a bluff, or from a logging ear or sleal inte the water. (ren.)

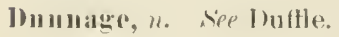

Dust a dam, to. 'Tu fitl np with earth or gravel the eracks or small holes hetween pauks in the gate of a splash daun. (N. W'.)

Dntelnuan, $n$. A short stick plateel transversely between the onter logs of a leat to divert the load towarl the middle and so keep any logs from falling ofi. ( $\mathrm{N}$. F.) 
End mark. See Mark.

Eslimate, r. See Cruise.

Estimalor, $n$. See Cruiser.

Faer log. See Head log.

Faller, $n$. One who fells trees. (ren.) sire Head faller; seeond faller Syn.: sawyer (Gen.), chopper (Аpls.).

Falling ax. An ax with a long helve and a long, narrow bit, designed especially for felling trees. (Cien.)

Falling wedge. A wedge used to throw a tree in the desired direction, ly driving it into the saw kerf. (Gen.)

Feeder, n. See Barn boss.

Frnder boom. See Shear boom.

Frnder skid. A skid placed on the lower side of a skidding trail on a slope to hold the log on the trail while being skidded. (Gen.)

Syı.: breastwork log, glancer, shear skid.

Fid hook. A slender, flat hook used to keep another hook from slipping on a chain. (N. W., L. S.)

Filer, $u$. One who files the crosscut saws in the woods. (Gen.) Syn.: saw fitter.

Filter, $n .1$. One who notches the tree for felling and after it is felled inarks the log lengths into which it is to be cut. (N. F.)

2. One who cuts limbs from felled trees and rings and slits the hark preparatory to peeling tanbark. (N. F.)

Float, $x$. See Drive.

Float road. A channel cleared in a swamp and used to float cypress logs from the woods to the boom at the river or mill. (S. F.)

Flood, $x$. See Splash.

Floosl dam. See Splash dam.

Flume, r. To transport logs or timbers by a flume. (Gen.) Srn.: sluice.

Flums, $n$. An inclined trough in which water runs, used in transporting logs or timbers. (Gen.) Syn.: sluice, water slide, wet slicle.

Flunkiy, n. 1. In awistant, usually either to the engineer of a donkey engine or to the cook in a loggring camp. (P. C.F.)

2. Siee Chore boy.

Flying drive. I drive the main portion of which is put through with the utmost dispatel, withont stopping to yick rear. (N. F.)

Fly rollway. A skidway or landing on a steep slope, from which the logs are released at once by removing the brace which holds them. (N. F.)

Fore-and-aft road. A skid road nade of logs placed paralled to its direction, making the roal resemble a chute. (P. C. F.)

syn.: stringer roakl.

Fonr paws. wee Donble couplers.

Froge, $n$. 1. The junction of two branches of a flume. (P. C. F.)

2. A timber placed at the month of a slicle to direct the discharge of the logss. (Gen.) Syn.: throw ont.

Full stale. Measurement of logs, in which no reduction is made for lefects. ( ( ien).

Syn.: bigness seale. (N. F.) 
(iangway, $n$. The incline plane up which logs are moved from the water into a sawmill. (Gen.)

Syn.: jack larlder, log jack, log way, slip.

(iap stick. The pole plaed across the entrance of a sorting jack to close it, when not in use. (Gen.)

fiee lluow. A heavy, wooden lever, with a eurved iron point, used to break ont logging slerls. (N. F.)

syul. starting bar.

fiin pole. A pole seenred by guy ropes, to the top of which tackle for loading logs is fastened. (Gien.)

Glancer, $n$. see Fender skid.

d:lancing boum. Nee shear boom.

Alisse slids. Freshly peeled skirls up which logs are slid instead of rolled when being loaded. ( $\mathrm{X}, \mathrm{F}:$ )

Syn.: slip, skids.

(Fo-bark road. A roal upon which unloaded logging sleds can return to the skidways for reloading, withont meeting the loaled sleds en route to the landing. (X. F.)

Syn.: short roakl.

(io-devil. See Dray.

Goosenerk. n. 1. A wooken bar nsed to couplertwo logging trucks. (Gen.)

Syn.: rooster. (P. C. F.)

2. The point of draft on a logeing slerl; it tonsists of a rurved iron hook bolted to the roll. (N. F.)

Syn.: „lraw hook.

3. I curved iron driven into the botton of a slide to check the speed of descending logs. (App.)

Goosepen. A large hole burned in a standing tree. (P. C. F.)

(xrab hook. A hook having a narrow throat, arlapted to grasp any link of a chain. (Gen.)

(Grab) link. See slipgrab.

(krabs, $n$. see skidrling tongs.

inall skiplen. A short iron pry or hammer, wased to remove the skirlang tongs from a log. (App., S. E.)

(irapples, n. 1. Two small iron dogs joined by a short chain, and used to couple logs end to end when skidding on mountains, so that several logs may be skidded by one horse at the same time. ( N. F.)

Syn.: chain grapples, coupling grab. (P. (..F.)

2. See Skilling tongs.

(ivarel a dam, to. To cover with gravel or earth the npstream side of the timber work of a dam, to make it water tight. (N. F.)

(imasire, $n$. we Road monkey.

(irijes. "1. Sepe Skidding tongs.

(irount loader. Sire Fend-up mau.

firouser, $\%$. A large and long stick of squared timber slarpened at the lower end and places in the bow of a steam logging boat; it takes the place of an anchor in shallow water, and can be raised or lowered by steam power. (X. IV. L. S.)

dillarl a libl, to. To keep a logging road on a steep decline in comblition for use. (N. F.) 
Gun, $\iota$. To aim a tree in felling it. In the case of very large, brittle trees, such as redwood, a sighting device (gumning stick) is used. (l. C. F.)

Syn.: point, swing. (Gen.)

Gumning stick. See Gun.

Gutterman. See Swanper.

(tutter roal. The path followed in skidling logs. (Gien.)

Syn.: drag road, ruway, skidding trail, snaking trail.

Handbarrow. Two strong, light poles held in position by rungs, upon which bark or wool is carried by two men. (N. W., I. S.)

Syn.: ranking bar.

Hand pike. A piked lever, nsually 6 to 8 feet long, for handling floating logs. (Gen.)

Hand shidder. One who accompanies a log as it is leeing dragged and places short skids beneath it. (P. C. F.)

Hang the boom, to. To put the boom in place. (Gen.)

Iапм ир, to. 1. To fell a tree so that it catches against another instead of falling to the ground. (Gen.)

Syn.: lodge (Gen.), buckwheat (App.)

2. As applied to river driving, to discontinne; thus a drive may be "hung up" for lack of water or for some other reason.

Hardwood, u. As applied to trees and logs, broadleafed, belonging to the dicotyledons. (Gen.)

Syn, : broadleaf.

Hallwoml, $n$. A broalleafed, or dicotyledonous, tree. (Gen.)

Haul, $n$. In logging, the distance and route over which teams must go between two given points, as letween the yard or skidway and the landing. (Gen.)

Haul back. A small wire rope, traveling between the donkey engine and a pulley set near the logs to be dragged, used to return the eable. (P. C. F.)

Syn.: back line, pull back, trip line.

Haul up. A light chain and hook by which a horse may he hitched to a cable in order to move it where desired. (P. C. F.)

Hay road. See Tote roal.

Hay wire outfit. A contemptuous term for loggers with poor logging equipment. (N. F.)

Heal block. The $\log$ placed under the front encl of the skids in a skidway to raise them to the desired height. (N. F.)

Heal driver. An expert river driver who, during the drive, is stationed at a point where a jam is feared. Heal drivers usually work in pairs. (…․)

Syn.: log watch (N. F.), jam racker (P. C. F.)

Head filler. The chief of a crew of fallers. (I'. C. F.)

Head log. 1. The front bottom log on a skidway. (N. F.)

Syn.: face log.

2. The front log in a turn. (P. C. F.)

Syn.: lead log.

Head push. See straw boss.

Healyuarters, $n$. In logging, the distributing point for supplies, equipment, and mail; not usually the executive or administrative center. (Gen.)

Heal troe. In steam skidding, the tree to which the cable upon whinh the traveler runs is attached. (S. F.) 
Hrallworks, n. A platiorm or raft, with windlass or "anstan, which is attacher to the front of a log ratit or hoom of lowe, for warping, kelgeing, or winding it through lakes and still water, hy hand ur horse power. (N. W., I. S.)

Helper, $n$. iee siceond faller.

Hoist, $n$. we Loaling tripod.

Hulding hum. See Storage lomm.

How tender. The foreman of a yaring arew; specifically, one who directs the attaching of the callele to a tmm of logs. (I'. C. F.)

Horse dam. A temporary lam male by placing large loges across a stream, in oriler to raise the water behind it, so as to float the rear. (N. F.)

Horse logs. to. In river driving, to drag strandled logs back to the stream by the nse of peaveys. (N.F.)

Ilovel, n. A stable for lugring teams. (N. W., L. S.)

lea a roal. to. To sprinkle water on a logring roarl so that a coating of ire may form, these facilitatiner the hanling of logs. (N. F.)

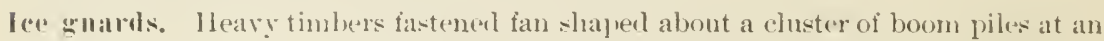
angle of anproxinately: 30 degreses to the surface of the water. They prevent the destruction of the boom by iree, through forcing it to mount the guarls and be broken $11 \%$. (N. F.)

Jack chaiu. An endless spiked (hain, which moves logs from one point to another, usially from the mill pond into the sawmill. (Gen.)

syn.: bull (hain. (P. C. F.)

Jack laduer. See Gangway.

Jakkot, u. 1. A contemptuons expression applied to an unskillum piece of work in logging. (X. F.)

2. An irregular pile oi logs. (App.)

Jam. 1 . A stoppage or congestion of logs in a stream, due to an obstruction or to low water. (Gen.)

Jan cracker. See lleal driver.

Jammer, n. An improved form of gin, momted on a movable framework, amd used to load logs on sleds and ras ly horsepwer. (N. F.)

Jan, to hreak a. To stant in motion logs which have jammed. (Gen.)

Jay loawk, to. To strip ome t-font length of bark from a tanhark oak, leaving the treestamling. (P. C. F.)

Jibou. $r$. To remove a dog from a log. (X. W., l. ...)

Jimper, $r$. To pull a log ly horwewwer wer a level place in a slide. (Gen.) Syn.: lazy haus, to.

Jiu biuler. Sce Bincler.

Johber, u. A logging contratetor or suberontractor. ((ien.)

Joblupr's sul. A term applied to the moon in a jobber's or contractor's logging iamp, on acount of the carly ambl late hour of eommeneing and ending work. (I. $11 .$, L. S.)

Jumjer, $n$. A sled shoul with woml, nsed for hauling supplies over hare gromm intu a loggring (anulp. (X. F.

Sin.: tute slert.

Katylial, $u$, sice logrging wherels.

lieg log. In river driving, a log which is so caught or wedged that a jam is formed and held. (Gen.) 
Kilhig, $n$. A short, stont pole used as a lever or brace to direct the fall of a tree. (N. W. )

Kuot, r. See Limb.

Kuot bumper. See Limber.

Kunter, $n$. Sie Limber.

Iaker, $n$. A log driver expert at handling logs on lakes. (N. F.)

Landing, n. 1. A place to which logs are hauled or skidded preparatory to transportation by water or rail. A rough and tumble landing is one in which no attempt is made to pile the logs regularly. (Gen.)

Syn.: lank, banking grouml, log dump, rollway, yad.

2. A platform, usually at the fout of a skitl road, where logs are collected and loaded on cars. A lightning landing is one having snch an incline that the logs may roll upon the cars without assistance. (cien.)

Landiug man. One who unloads logging sleds at the landing. (N. F.)

Landing. to break a. To roll a pile of logs from a landing or bank into the water. (Gen.)

Land looker. See Cruiser.

Lap, ", , or Lapwood, ". Tops left in the woods in logging. (Gen.)

Lash pole. A cross pole which holds logs together in a raft. (Gen.)

Lazy haul, to. See Jigger.

Lead, $n$. A snatch block with a hook or loop for fastening it to convenient stationary objects, used for guiding the eable by which logs are dragged. (P. C. F.)

Lead line. A wire rope, with an eye at each end, used to anchor the snatch block in setting a lead. (P. C. F.)

Lead log. See Brow skid; Head log.

Lightuing landing. See Landing.

Liml, $r$. To remove the limbs from a felled tree.

Syn.: knot. (P. C. F.)

Limber, $n$. One who cuts the limbs from felled trees. (Gen.)

Syn.: knotter (P. C. F.), knot bumper (App.).

Line horse. The horse which drags the eable from the yarding engine to the log to which the cable is to be attached. '(F.C. F.)

Lizard, ". see Dray.

Loaller, u. 1. One who loads logs on sleds or cars. (Gen.)

2. See Steam loader.

Loadiug ahain. A'long chain used in loading or piling logs with horses. (N. F.) Syn. : lecking chain.

Loaling jack. A platformed framework upon which logs are hoistent from the water for loading upon cars. (N. F.)

Loaling tripod. Three long timbers joined at their tops in the shape of a tripor, for holding a pulley block in proper position to load logs on cars from a lake or stream. (L. S.)

Syn.: hoist.

Lock down. A strip of tough wook, with holes in the endw, which is laid across a raft of logs. Rafting pins are iliven through the holes into the logs, thus holding the raft together. (N. F.)

Lodge, to. See Ilang up, to.

Logan, $n$. See Pokelogan. 
Iog deck. The platform upon a loading jack. (Gen.)

logr 4 mul. Sée Landing.

log fixer. Sie Roswer.

losgerer, $n$. One engaged in logging.

Logring sled. The heavy double sled nsed to haul logs from the skidway or yard to the landing. (N. F.)

Syn.: twin slerls, two slerls, wagon sled.

logging-sled road. I roat, leading from the skidway to the landing. (N. F.)

Logrging wheels. A pair of wheels, nsally about 10 feet in diameter, for transporting logs. ( $\quad$ ien.)

Syn.: lig wheels, katydid, timber wheels.

Log jack. See Gangway.

log scale. The contents of a log, or of a number of logs considered collectively. (Gen.)

Log, fo. To cut logs and deliver them at a place from which they ean be transported by water or rail, or, less frequently, at the mill. (Gen.)

Log watch. See Head driver.

Logway, $n$. See Gangway.

Loug butt, to. see Butt off, to.

loose-tongued sloop. See swing dingle.

Lubber lilt, to. To raise the end of a log by means of a pry, and through the use of weight instead of strength. (N. F.)

Lug hooks. A pair of tongs attached to the middle of a short bar, and nsed by two men to carry small logs. (Gen.)

Lumber, $v$. To log, or to manufacture logs intolumber, or both. (Gen.)

Iumberjack, $u$. One who works in a logging camp. (Gen.)

Lumberman. $n$. One engaged in lumbering. (Gen.)

Mark, $\|$. A letter or sign indicating ownership, which is stamperl on the ends of logs. (Gen.) See Park mark.

Syn.: brand, end mark.

Mark caller. In sorting logs, one who stands at the lower end of the sorting jack and calls the different marks, so that the logs may be guided into the proper channels or pockets. (Gen.)

Marker, $n$. One who puts the mark on the end of logs. (ren.)

Markw1, 1 . A $\log 19$ inches in dianeter at the small end and 13 feet long. (New. York.)

Syn.: standarl.

Marking haumer. I hammer hearing a raised device which is stamped on logs, to indicate whership. (liru.)

Syn.: marking iron.

Marking iron. See Narking hammer.

Mateli, $r$, see Mate.

Mater, To place together in a raft logs of similar size. (Gen.)

Syr1.: matel.

dill pond. The pond near as samill in which logs to be rawn are held. (cien.)

Monitor. See Catamaran.

Moss, $r$. To fill with moss the crevices between the logs in a logging camp. (X. F.)

Ind, $v$. To till with soft clay the ("revices between the logs in a logging canp. (X. F.) 
Mudboat, $n$. A low sled with wide runners, used for hauling logs in swamps. (S. F., N. F.)

Mudsill, $n$. The bed piece or botton timber of a dan which is placed across the? stream, usually resting on rocks or in mud. (Gen.)

Syn.: bottom sill.

Nick, $n$. See Undercut.

Nose, $x$. To romud off the end of a log in order to make it drag or slip more easily. (Gen.)

Syn.: snipe.

Notch, $v$. To make an undercut in a tree preparatory to felling it. (Gen.) Syn.: underent.

Noteh, $n$. Sie Undercut.

Peaker, $n$. 1. A load of logs narrowing sharply toward the top, and thus shaped like an inverted V. (Gen.)

2. The top log of a load. (Gen.)

Peavey, $n$. A stont lever 5 to 7 feet long, fitted at the larger end with a metal socket and pike and a curved steel hook which works on a bolt; used in handling logs, especially in driving. A pearey differs from a eant hook in having a pike instead of a toe ring and lip at the end. (Gen.)

Peeky, a. A term applied to an unsoundness most common in bald cypress. (S. F.) Syn.: peggy.

Peeler, $n$. See Barker.

Peggy, a. See Pecky.

Pickaroon, $n$. A piked pole fitted with a eurved hook, used in holding boats to jams in driving, and for pulling logs from brush and eddies out into the eurrent. (Gen.)

Pick the rear, to. See Sack the rear, to.

Pier dam. A pier built from the shore, usually slanting downstream, to narrow and deepen the channel, to guide logs past an obstruction, or to throw all the water on one side of an island. (N. F.)

Syn.: wing dam.

Pig, $n$. See Rigging sled.

Pig tail. An iron device driven into trees or stumps to support a wire or small rope. (P. C. F.)

Pike pole. A piked pole, 12 to 20 feet long, used in river lriving. (Gen.)

Pitch pocket. A cavity in wood filled with resin. (P. C. F., R. M. F.)

Pitch streak. A seam or shake filled with resin. (Gen.)

Plng aud kuock down. A device for fastening boom sticks together, in the absence of chains. It consists of a withe seenred by wooden plugs in holes bored in the booms. (N. F.)

Pocket boom. A boom in which logs are held after they are surted. (Gen.)

Point, $x$. See Gun.

Pokelogan, $n$. A bay or pocket into which logs may float off during a drive. (N. W., I. S.)

Syn: logan.

Pond man. One who collects logs in the mill pond and Hoats them to the gangway. (Gen.)

Pontoon. See Catanaran. 
Prize logs. Log: which ("ome to the sorting jack withut markw llenoting ownership. (N. F.)

l'ull back. Tee lJanl hack.

Pull boat. A flathoat, "arrying a steam skidder or a donkey, nowed in logging ('ypress. (S. F.)

P'ull the briar, to. 'To nse a crosicut saw. (N. F.)

Put iu, to. In logging, to deliver logs at the lamling. (cien.)

(Qnickwater, $\|$. That part of a stream which has fall enough to create a lecided inrent. (cien.)

Ant.: stillwater.

lialf(r) tam. A dam in which long timbers are set on the upstream side at an angle of 20 to 40 degrees to the water surface. The pressure of the water against the timbers holds the clam solidly against the stream bed. (N. F.)

Syn.: seli-loading dam, slant clam.

RaII juike. A tree broken off by wind and with a splintered end on the portion left standing. (N. F.)

Rauk, r. To haul and pile regularly, as, to ronk bark or cord wood. (Gen.)

Ranking loar. See Handbarrow.

Ranking jumper. A wood-shod sled upon which tanbark is hauled. (N. F.)

kave, $n$. A piece of iron wr wood which secnres the bean to the runners of a logging sled. (N. W., L. . S.)

Rear, . The upstream end of a drive; the logs may be either stranded or floating. "Floating rear" comprises those logs which may be floated back into the current; "dry rear," those which must be ilragged or rolled back. (Gen.)

Receiving boom. siestorage boom.

Risle, n. The sicle of a long upm which it rests when being draggerl. (Gen.)

Rislı a log, to. To stand on a floating log. (Gen.)

ligging, "1. The cables, blocks, and hooks nsed in skidding logs by steam power. (Gen.)

Riggring sled. A sled used to hanl hooks and blocks on a skid roat. (P. C. F.) Syn.: dog boat, pig.

Rimging slinger. 1. A member of a yarting erew, whose chief duty is to place (hokers or grabs on logs. (I'. C. F.)

2. One who attaches the rigging to trees, in steam skidding. (S. F.)

Ring, n. A section of tanbark, usually + feet long. (N. F.)

Ring rot. Decay in a log, which follows the ammal rings more or less clusely. (Gen.)

Rise, $n$. The difference in diameter, or taper, between two points in a log. (cien.)

liver louss. The foreman in charge of a log itrive. (X. F.)

River driver. One who works on a log drive. ((ien.)

River rat. A log driver whose work is chiefly on the river; contrasted with Laker. (N. F.)

Roal doukey. A donkey engine momnted on a heavy sled, which drags logs along a skid roat by winding a cable on a drum. It has a serond drum for the hanl-back. (P.C. F.)

Road gang. That portion of the crew of a logging cann) who ent ont legging roals and keep them in repair. (N. F.) 
Road monkey. One whose duty is to keep a logging roarl in proper condition. (N. W., L. S.)

Syn.: blue jay, greaser. (I. C. F.)

Roll, $u$. The crosshar of a logging sled into which the tongue is set. (N. II., I. S.) Syn.: roller.

Roller, $n$. See Roll; Tpright roller.

Rolling dall. I dim for raising the water in a shallow stream. It hat no sluiceways, but a smooth top of timber over which, uncler a sufficient liead of water, logs may slide or roll. (Gen.)

Roll the boom, to. To roll a boom of logs along the shore of a lake against which it is held by wind, by the use of a calle operater by a steamboat or kertge. The cable is attached to the onter side of the boom, hanled up, then attacherl again, thus propelling the boom by revolving it against the shore when it would be impossible to tow it. (N. W., L. S.)

Rollway, $n$. see Landing.

Rooster, $n$. See Goosencek.

Rosser. $n$. One who barks and smooths the ride of a log in order that it may slide more easily. (N. F.)

Syn.: log fixer (P. C. F.), slipper, scalper (App.).

Rough and tumble landing. See Landing.

Round timber. Pine trees which have not been turpentined. (S. F.)

Round turn. A space at the hear of a logging-sled road, in which the sled may be turned round without unhitching the team. (N. F.)

Ruuner chain. A chain bound loosely around the forwarl end of the runners of a logging sled as a brake. (N. W., L. S.)

Runuer log. A curver iron attached to a runner of the hind sted of a logging sled, which holds the loader sled on steep hills by being forced into the hed of the road by any backward movement. (N. F.)

Runway. See Gutter road.

Rutter, $n$. A form of plow for cutting ruts in a logging road for the runners of the sleds to run in. (N. W., L. S.)

Sack the rear, to. To follow a drive and roll in logs which liave loilged or grounded. (Gen.)

Syn.: pick the rear, to.

Sack the slide, to. To return to a slide logs which have jumped out. (Gen.)

Saddle, $n$. The depression cut in a transverse skid in a skid road to guide the logs which pass over it. (P. C. F.)

Sadllebag, $v$. As applied to a boom, to eatch on an obstruction ani double around it. (Gen.)

Sampson, $n$. An appliance for loosening or starting logs by horsepower. It msually consists of a strong, heavy timber and a chain terminating in a heary swamp hook. The timber is placed upright beside the piece to be mored, the chain fastened around it, and the hook inserted low down on the opposite side. Leverage is then applied by a team hitched to the upper enil of the upright timber. (N. F.)

Sampson a tree, to. To direct the fall of a tree by means of a lever and pole. (N. F.)

Sap stail. Discoloration of the sapwood. (Gen.)

Saw fitter. See Filer. 
Sawyer, $n$. See Faller.

Seale book. A book erpecially designed for recording the contents of scaled logs. (Gen.)

Sealer, $n$. One who determines the volume of logs. (Gen.)

Sealper, $n$. Sipe Rosser.

seoot, $n$. , see Dray.

Season check. See Check.

second faller. The subordinate in a crew of fallers. (P. C. F.)

Syn. helper. (N. F.)

Self-loading dam. Se Rafter dam.

Send-up man. That member of a loading crew who guides the logs up the skids. (Gen.)

Syn.: ground loarler. (N. F.)

send up, 10. In loading, to raise logs up skids with cant hooks, or hy steam or horse power. (Gen.)

Setting, $n$. The temporary station of a portable sawmill, a yarding engine, or other machine user in logging. (Gen.)

Shake, $n$. A crack in timber, due to frost or wind. (Gen.)

Syn.: Windshake.

Shanty boat. See Wanigan.

Shanty hoss. See Chore hoy.

Shear boom. A boom so secured that it guides floating logs in the desired direction. ( $\mathrm{N} . \mathrm{F}$.

Syn.: fender boom, glaneing boom.

Shear skid. See Fender skid.

Shoot a jam, to. To loosen a log jam with dynamite. (Gen.)

shore bold. The attachment of the hawser of a raft of logs to an object on the shore. (N. W., L. S.)

Short road. See (io-back road.

Shot holes. Holes marte in wood by boring insects. (App.)

Side jam. A jam which has formed on one side of a stream, usually where the logs are forced to the shore at a bend by the current, or where the water is shallow or there are partially submerged rocks. (N. F.)

Side malk. See Bark mark.

Side winder. A tree knocked down unexpectedly by the falling of another. (Gen.)

Signal man. One who transmits orders from the foreman of a yarding crew to the engineer of the yarding donkey. (P. C. F.)

Single ont, to. To float logs, usually cypress, one at a time, from the woorls to the float road. (S. F.)

sinker, $n$. Sep Deadhead.

sinker boat. sie Catamaran.

Skid, $v$. 1. To draw logs from the stump to the skidway, landing, or mill. (Gen.) Syn.: snake, twitch.

2. As applied to a road, to reenforce by placing logs or poles across it. (Gell.)

skid, $n$. A log or pole, commonly used in pairs, upon which logs are handled or piled (Gen.); or the log or pole laid transversely in a skid road (P. C. F.). 
Skilder, n. 1. One who skids logs. (Gien.)

2. A sieam engine, wsually operating from a railroar track, which skids logs by means of a cable. (Gen.)

Syn.: steam skidder.

3. The foreman of at crew which constructs skid roads. (P. C. F.)

4. See Bummer.

Skidling chain. A heavy chain msed in skidding logs. (Gen.)

skidding hooks. Ser skidding tongs.

Skidding sled. Sie Dray.

Skidding tongs. A pair of hooks attached hy links to a ring and used for skidding logs. (Gen.)

syn.: grips, grapples, grals, skidding hooks.

skideling trail. See Gutter road.

Skid grease. A heary oil applied to skids to lessen the friction of logs dragged orer them. (P. (.. F.)

skid road. 1. A road or trail laading from the stump to the skidway or landing. (iren.)

Syn.: travois roarl. (N. F.)

2. A road over which logs are dragged, having heavy transverse skids partially sunk in the ground, usually at intervals of ahout 5 feet. (P. C. F.)

Skid «p. to. 1. To level or reenforce a logging roal by the use of skids. (Gen.)

2. To collect logs and pile them on a skiciway. (Gen.)

skidway, $n$. Two skids laid parallel at right angles to a road, usually raised above the ground at the end nearest the road. Logs are usually piled upon a skidway as they are brought from the stump for loaling upon sleds, wagons, or cars. (Gen.)

Skidway, to break a. To roll piled logs off a skidway. (Gen.)

sky looker. see Top loater.

slack water. In river driving, the temporary slackening of the current caused by the formation of a jam. (Gen.)

Slant dam. Siee Rafter dam.

slash, $n$. 1. The débris left after logging, wind, or fire. (Gen.)

Syn.: slashing.

2. Forest land which has been logged off and npon which the limbs and tops remain, or which is deep in débris as the result of fire or wind. (Gen.)

Slashing, $n$. See Slash.

sled tender. 1. One who assists in loading and unloading logs or skidding with dray. (N. F.)

Syn.: chain tender.

2. A member of the hauling crew who accompanies the turn of logs to the landing, unhooks the grabs, and sees that they are returned to the yarding engine. (P. C. F.)

Slide, $n$. A trough built of logs or timber, used to transport logs down a slope. (Gen.)

Syn.: chute, dry slicle, slip.

slide tender. One who keeps a slide in repair. (Gen.)

slip, n. 1. See Slide.

2. See Gangway. 
Slip srab. A pear-shaped link attadhel hy a swivel to a skidling evener or whifletree, through which the skidling chain is passed. The chain rans freely when the slip grab is held sideways, bul catehes when the grab is straight. (N. F.)

Syn.: grablink.

Slipper, $u$. See Roser.

slip skids. Se tilisse skids.

slowp. n. See Dray.

Sloop logs. to. To haul logs down steep slopes on a dray or sloop equipped with a tongue. ( $\mathrm{N}, \mathrm{F}$.

Ninugh pie. Usually a second-rate river llriver who is ascigned to picking logs ont of sloughs in advance of the rear. (N. F.)

sluice, $v$. 1. Sire Flume.

2. To float logs through the sluiceway of a splash dam. (N. F.)

3. See Splash.

sluice, $n$. See Flume.

Sluice gate. The gate closing a sluiceway in a splash dam. (Gen.)

sluiceway, $n$. The opening in a splash dam through which logs pass. (Gen.)

Snake, $r$. Sce Skid.

Snaking trail. see Gutter rowl.

Snateh tram. Sief Tow tean.

suil, $r$. In river lriving, to be carries away purposely, but ostensibly by accident, on the first portion of a jam that moves; to ride away from work under guise of being accidentally earried off. (N. W., L. S.)

Snipe, $r$. Sre Nose.

Sinipre, $n$. One who noses logs before they are skidrled. (Fren.)

suow a road, 10. To cover bare spots in a logging road with snow, to farilitate the passage of sleds. (N. F.)

Snow slide. I temporary slide on a steep slope, made ly dragging a large log through deep snow which is soft or thawing; when frozen solidly, it nay be used to slide logs to a point where they can be reached by sleds. (N. W.)

snub,r. To (heck, usually by means of a snub line, the speed of logging sleds or logs on steep slopes, or of a log raft. (lien.)

Sollwood, a. As applierl to trees and logs, needle-leafed, coniferons. (Gen.)

Softwood, $n$. A needle-leafed, or coniferons, tree. (Gen.)

Solid jam. 1. In river driving, a jam formed solidly and extending from bank 0 bank of a stream. (N. F.)

2. A drive is said to be "in a solid jam" when the stream is full of logs from the point to which the rear is cleared to the mill, sorting jack, or storage hoom. (N. F.)

Sorting boom. A strong boom used to guide logs into the sorting jark, to both sides of which it is usually attached. (Gen.)

Sorting gap. See Serting jukt.

Sorting jack. A raft, secured in a stream, through an opening in which logs pass to be sorted by their marks and diverted into pocket boonss or the downstream channel. (Gen.)

Syn.: sorting gap.

Spanish wimdlass. A device for moving heavy objects in logging. It consists of a rope or chain, within a turn of which a lever is inserted and power gained by twisting. (N. F.)

Syn.: twister. 
Spiked skid. A skicl in which spikes are inserted in order to keep logs from sliding baek when being loaded or piled. (Gen.)

Splash, $v$. To drive logs by releasing a head of water confined lyy a splati dam. (Gen).

Syn.: flood, sluice.

Splash boards. Boards placed temporarily on top of a molling dan to heighten the dam, and thus to inerease the heat of water available for river lriving. ( $\mathrm{X} . \mathrm{F}$.)

splash dam. A dan luilt to store a head of water for driving logs. (Gen.) Syn.: flood dam. (Gen.)

Split roof. A ruof of a logging canp or barn made by laying strips split from straight-grained timber. The strips run from the ridge pole to the eaves, and break the joints with other strips, as in a shingle roof. (N. F.)

spool donkey. A donkey engine for winding eable, equipped with a spool or capstan, instead of a drum. (P. C. F.)

Spool tender. One who gruides the cable un a spool donkey. (P. C. F.)

Spot, $r$. See Blaze.

spring board. A short board, shod at one end with an iron calk, which is inserted in a notch cut in a tree, on which the faller stands while felling the tree. (P. C. F., S. F.)

Spring pole. 1. A springy pole attached to the tongue of a logging sled and passing over the roll and under the beam, for holding the weight of the tongue off the horses' necks. (N. F.)

2. A device for steadying a crosscut saw, so that one man can use it instead of two. (P. C. F.)

Sprinkler, $n$. A large wooden tank from which water is sprinkled orer logging roads during freezing weather in order to ice the surface. (N. W., L. S.)

Syn.: tank.

sprinkler sleds. The sleds upon which the sprinkler is mounted. They consist of two sleds whose runners turn up at each end, fastened together ly eross chains, and each having a pole, in order that the sprinkler may be hauled in either direction without turning around. (N.F.)

spul, $n$. A tool for removing bark. (Gen.)

Syn.: barking iron.

Spudder, $n$. See Barker.

Stag, $x$. To cut off trousers at the knee, or boots at the ankle. (N. F., P. C. F.)

staudard, $n$. See Market.

starting bar. See ciee throw.

stay boom. A boom fastened to a main boom and attached nystream to the shore to give added strength to the main boom. (Gen.)

Steam hauler. A geared locomotive used to haul loaded logging sleds over an ice road. It is equipped with a spiked metal belt which runs over sprocket wheels replacing the driving wheels, and is guided by a sled, turned by a steering wheel, upon which the front end rests. (N. F.)

Steam jammer. See Steam loader.

Steau loader. A machine operated by steam and used for loading logs upon cars. (Gen.)

Syn.: loader, steam jammer.

steam skidder. See Skidder.

Stem winder. See Corkscrew. 
Stillwater. That part of a stream having such slight fall that no current is apparent. Ant.: quickwater. (fien.)

Syu.: deadwater.

Stock logs, to. To deliver logs from stump to mill or railroal. (S. F.)

Storage boom. A strong boom used to hold loge in storage at a sawmill. (Cren.) Syn.: holding hoon, receiving boom.

straw boss, $n$. A subforeman in a logging camp. (N. W., L.S.) Syn.: head push.

stream jam. See Center jam.

stringer road. See Fore-and-aft road.

Stumpage, $n$. The value of timber as it stands meut in the woods; or, in a general sense, the standing timber itself. (Gen.)

Swamp, $v$. To clear the ground of underbush, fallen trees, and other olstructions preparatory to constructing a logging road or opening out a gutter road. (Gen.)

swamper, $n$. One who swamps. (Gen.)

Syn.: beaser, guttermian. (N. F.)

swamp hook. A large, single hook on the end of a chain, used in handling logs, most commonly in skiflding. ( (ien.)

Sway har. 1. A strong bar or pole, two of which couple and hold in position the tront and rear sleds of a logging sled. (N. F.)

2. The bar used to (ouple two logging cars. (Gen.)

swell butted. As applierl to a tree, greatly enlarged at the base. (Gen.) Syn.: bottle butted, chum butted.

Swing, $v$. See Gun.

Swing dingle. A single sled with wood-shod rmmers and a tongue with lateral play, used in hauling logs down steep slopes on bare grouncl. (N. F.)

Syn.: loose-tongned sloop.

swing team. In a logging team of six, the pair between the leaders and the butt team. (P. C. F.)

Tail chain. A heavy chain bound around the trailing end of logs, as a brake, in slooping on steep slopes. (N. W.)

Taildown, to. To roll logs on a skidway to a point on the skids where they can be quickly reached by the loaling erew. (N. F.)

'Tail hold. 1. A means of obtaining increased power in moving a log by tackle. The eable is passed through a block attached to the log and the end fastened to a stationary olject, so that hauling on the other end gives twice the power which would be attained by direet attachment of the cable to the log. (P. C. F.)

2. The attachment of the rear eut of a donkey sled, usually to a tree or stump. (P. C. F.)

'Tail look. See Dog.

Tally board. A thin, smooth board used by a scaler to record the number or volume of logs. (Gen.)

Tally man. One who records or tallies the measurements of logs as they are called by the scaler. (N. F.)

Tank, n. See Sprinkler.

Tank conductor. One who has charge of the crew which operates a sprinkler or tank, and who regulates the flow of water, in icing logging roads. (N. F.)

Tank heater. A sheet-iron cylinder extending through a tank or sprinkler, in which a fire is kept to prevent the water in the tank from freezing while icing logging roads in extremely cold weather. (N. F.) 
Tanking. The act of hauling water in a tank, to ice a logging roal. (N. F.)

Tee, $n$. A strip of iron abont 6 inches long with a hole in the center, to which a short chain is attacherl; it is passed through a hole in al gate plank, turned cross. wise, and so nsed to holl the plank when tripped in a splash dam. (N. W.)

Throw, r. See Wedge a tree, to.

Throw line. See Trip line.

Throw out. See Frog.

Tide, $n$. A freshet. In the Appalachian region logs are rolled into a stream and a "tide" awaited to carry them to the boom. (A pp.)

Timber wheels. See Logging wheels.

Toe ring. The heavy ring or ferrule on the end of a cant hook. It has a lip on the lower edge to prevent slipping when a log is grasped. (Gen.)

Toggle chain. A short chain with a ring at one end and a toggle hook and ring at the other, fastened to the sway bar or bunk of a logging sled, and used to regulate the length of a binding chain. (N. F.)

Syn.: bunk chain.

Toggle look. A grab hook with a long shank, used on a toggle chain. (N. F.)

Tonging, $v$. Handling logs with skidding tongs. (N. F.)

Top chains. Chains used to secure the upper tiers of a load of logs after the capacity of the regular binding chains has been filled. (Gen.)

Top load. A load of logs piled more than one tier high, as distinguished from a bunk load. (Gen.)

Top loader. That member of a loading crew who stands on the top of a load and places logs as they are sent up. (Gen.)

Syn.: sky hooker. (N. F.)

Tote, $v$. To haul supplies to a logging camp. (N. F.)

Tote road. A road used for hauling supplies to a logging camp. (N. F.) Syn.: hay road.

Tote sled. See Jumper.

Tow team. An extra team stationed at an incline in a logging road to assist the regular teams in ascenting with loaded sleds. (N. F.)

Syn.: snatch team.

Trailers, $n$. Several logging sleds hitched behind one another and pulled by 4 to 8 horses driven by one man, thus saving teamster's wages. (N. F.)

Tram, $n$. See Tramway.

Tramway, $n$. A light or temporary railroad for the transportation of logs, often with wooden rails and operated by horsepower. (Gen.)

Syn.: tram.

Travois, n. See Dray.

Travois road. See Skid road.

Trip, $v$. See Wedge. a tree, to.

'Trip, $n$. See Turn.

Trip a dam, to. To remove the plank which closes a splash dam. (N. F.)

Trip line. 1. A light rope attached to a dog hook, used to iree the latter when employed in breaking a jam, a skidway, or a load. (N. F.)

Syn.: throw line.

2. See Haul back.

Tripsill, $n$. A timber placed across the bottom of the sluiceway in a splash dam, against which rest the planks by which the dam is closed. (Gen.) 
'Trougli roof. A roof on a logring camp or barn, made of small logs split lengthwise, hollowed into tromgls and laid from ridge pole to eaves. The joints of the lower tier are covered ly inverted tronghs. (N. F.)

Turkey, $u$. A bag containing a lumberjack's outfit. To "histe the turkey" is to take one's jersonal belongings and leave camp. ( ( W. W. I. S.)

'Turı, $и$. 1. A single trif autl return male by one team in hauling logs-e. g., a four-turn roal is a road the length of which will permit of only four round trips per day. (N. F.)

Syn.: trip. (Gen.)

2. Two or more logs coupled together end to end for hauling. (P. C. F.)

'Turnout, $n$. A short side ruad from a logging-sled roarl, to allow loaded sleds to pass. ( (I. W., L. S.)

'Twill sleds. Siee Logging sled.

'Twister, $n$. See Spanish windlass.

Twiteh, $r$. See skid.

Two sleds. See Logging sled.

Indereut, $r$. See Sotch.

Inderent, $и$. The notch cut in a tree to determine the direetion in which the tree is to fall, and to prevent splitting. (ien.)

syu.: notch (Gen.), nick (S. F.).

Endereutter, $n$. I skilled woodman who chops the mulereut in trees so that they shall fall in the proper direction. (Gen.)

Inion drive. A drive of logs belonging to several owners, who share the expense pro rata. (N.F.)

Ipright roller. A flanged roller placed upright at a bend in a skid road to direet the cable. (P. C. F.)

syn.: roller, dolly.

Valur, r. see Cruise.

Values, $n$. See Cruiser.

$Y a n, n$. The small store in a logging camp in which clothing, tobacco, and medicine are kept to supply the (rew. (N. W., L. ...) See Commissary.

Wagon sledl. see Logging sled.

Wanigan, $u$. A houseboat usul as sleeping yuarters or as kitchen and dining room by river drivers. (N. W., L. S.)

Syn.: ark (X. F.), shanty buat (S. F.).

Water ladder. Pole guiles up aud down which a barrel slides in filling a sprinkler l,y horsepower. (N. W., L. s.)

Water slide. iee Flume.

Welge a tree, to. To topjle over with wedges a tree that is being felled. (Gen.) Syil.: throw, trip.

Wot slide. See Flume.

Whilletree neckyoke. A heavy logging nexkyoke, to the ends of which short whiflletrees are attached by rings. From the ends of the whittletrees wide straps run to the breeching, thus giving the team added power in holding back loads on steep slopes. (N. F.)

White water man. A log driver who is expert in breaking jams on rapids or falls. (N. F.)

Willow maker. A broken limb hanging loose in the top of a tree, which in its fall may injure a man below ( $\mathrm{N} . \mathrm{F}$.), or a breaking cable (P. C. F.). 
Winwam. to make a. In felling trees, to lorge several in such a way that they - support each other. (N. F.)

Wiudfall, $n$. An area upon which the trees have been thrown by wind; also, a single tree thrown ly wind. (Gen.)

Syn.: hlow down, wind slash. (N. F.)

Windslatke, $n$. See Shake.

Wind slash. See Winlfall.

Wing dam. Sice Pier dam.

Wing jam. A jan which is formed against an obstacle in the stream and slants upstream until the upper end rests solidly against one shore, with an open channel for the passige of logs on the opposite side. (N. F.)

Woodpecker, $u$. A poor chopper. (Gen.)

Wrapper ehail. See Binding chain.

Yard, $n$. See Landing.

Yarding donkey. A donkey engine momted upon a heary sled, used in yarding logs by drum and cable. (P. C. F.) 






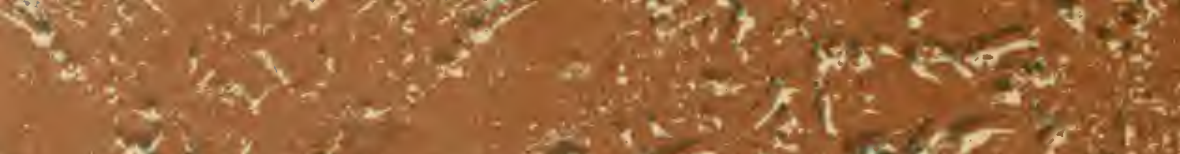

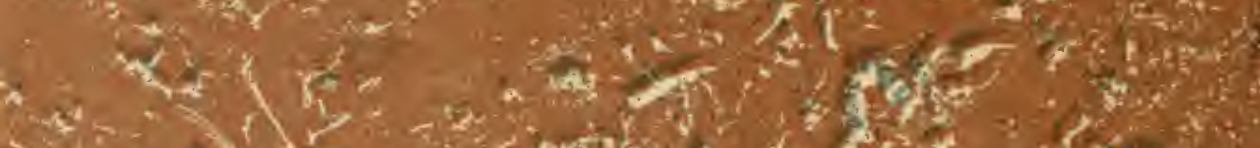

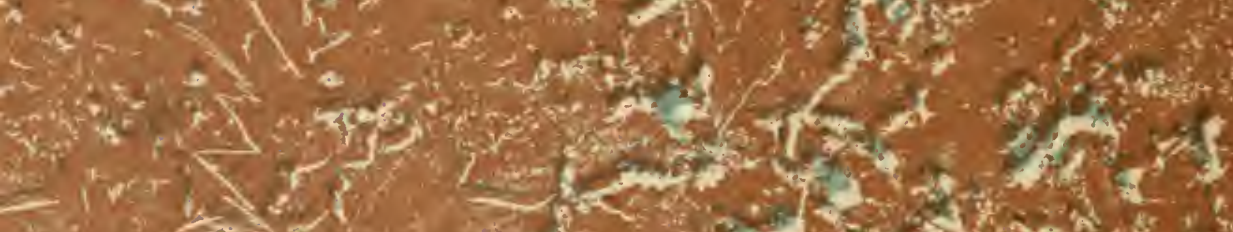

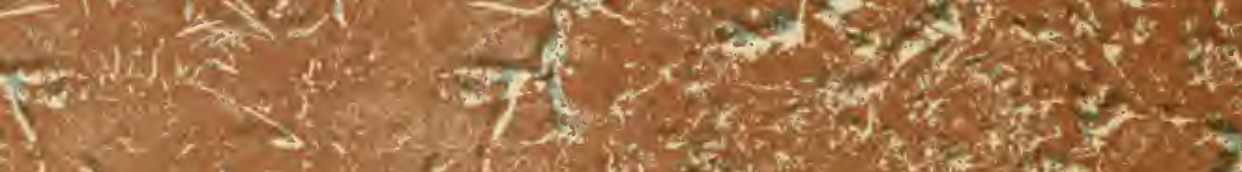

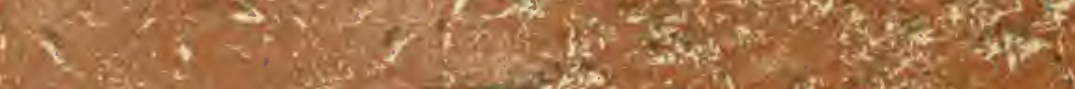

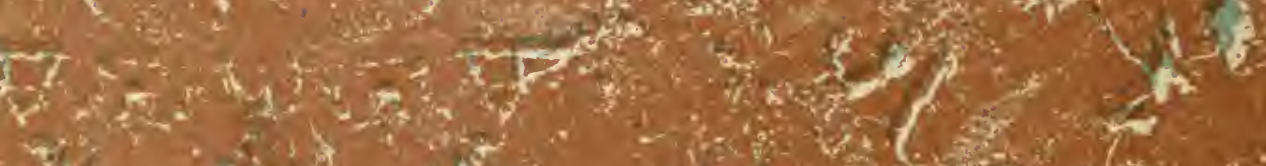

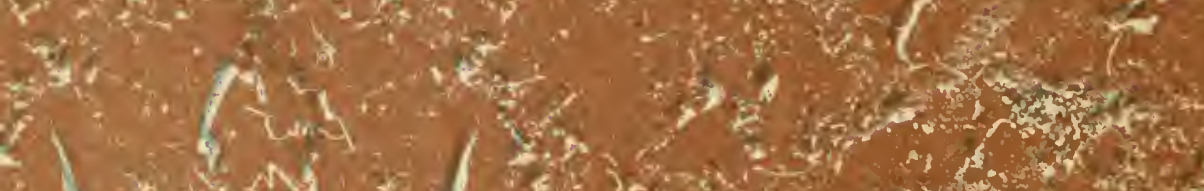

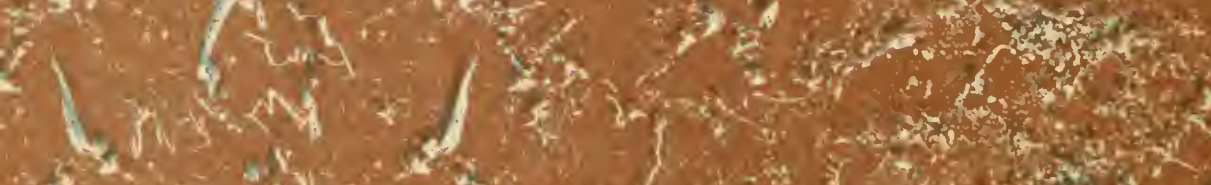

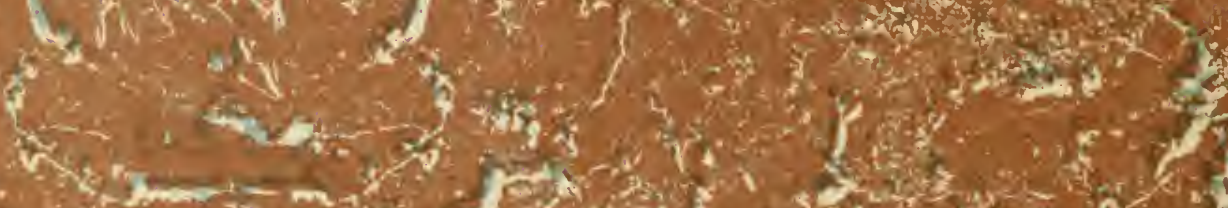

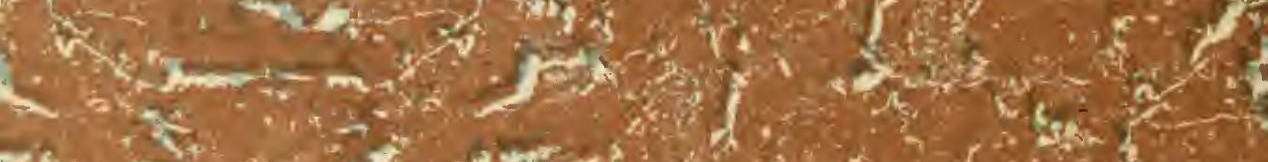

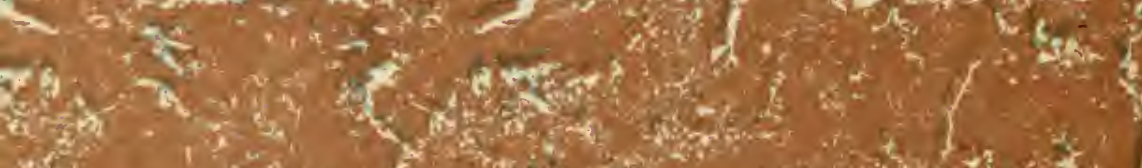
Why

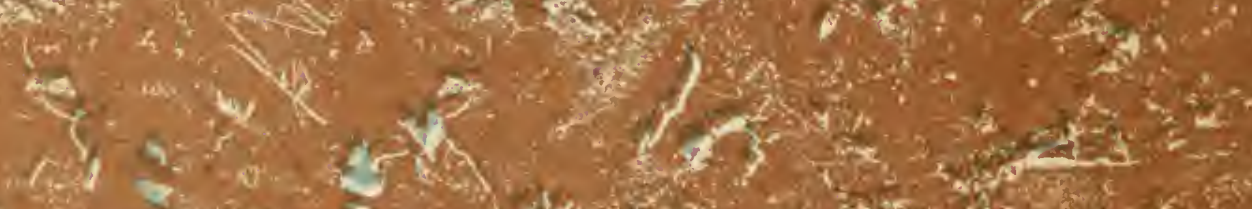

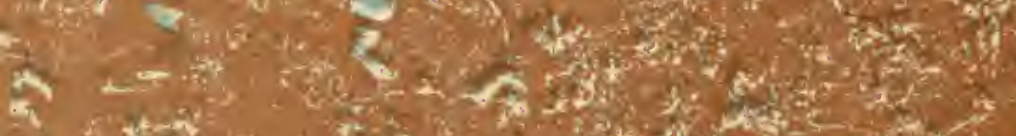

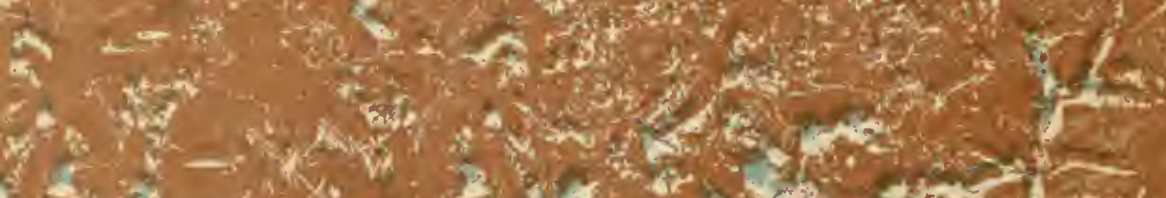

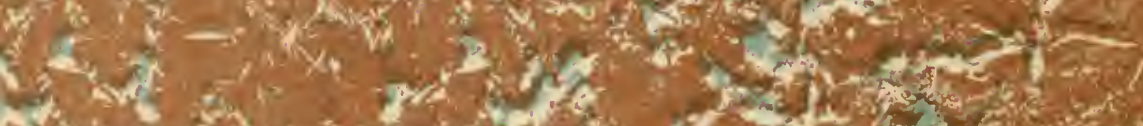

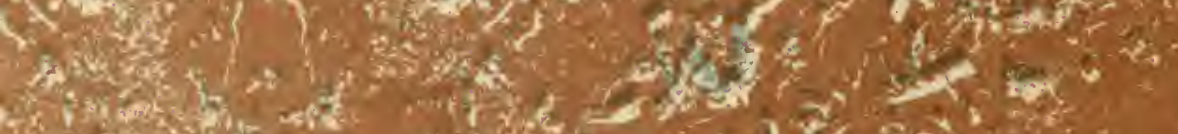
(3) 


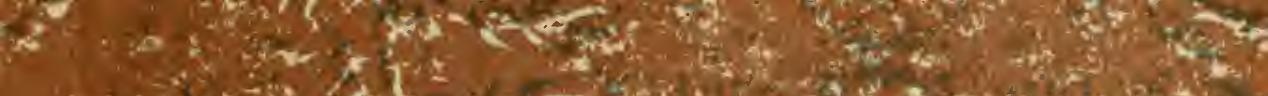

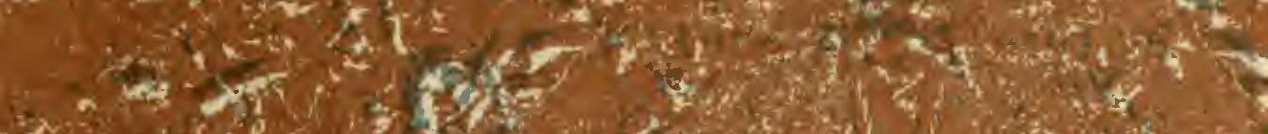

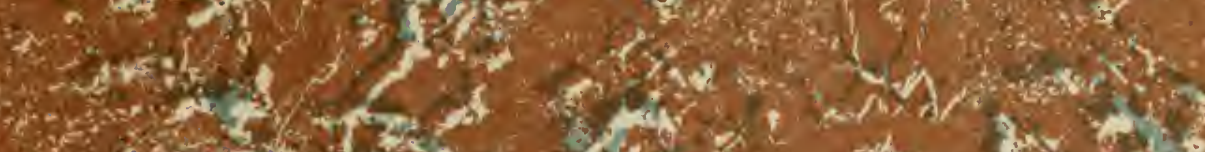

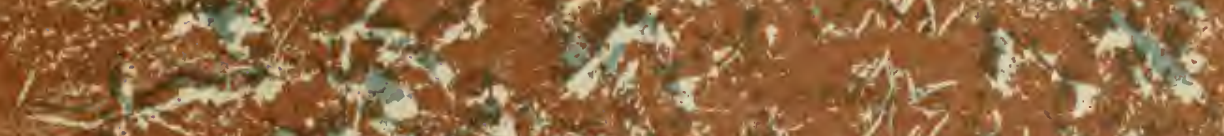
$27 x^{2}=0$

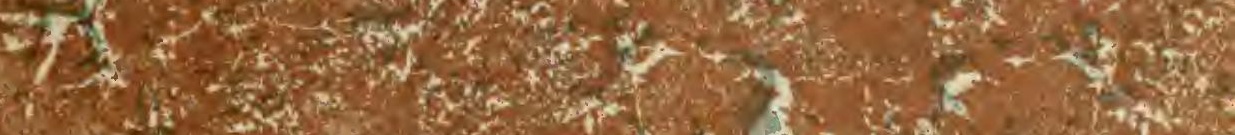

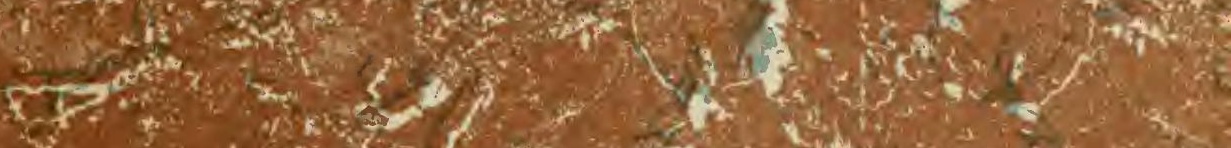

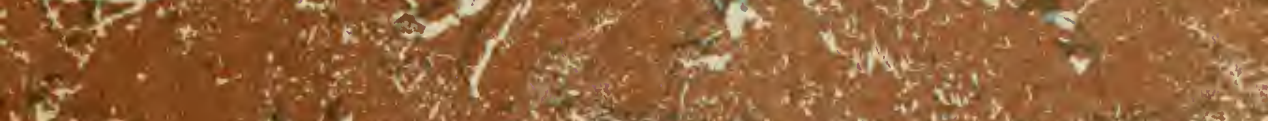

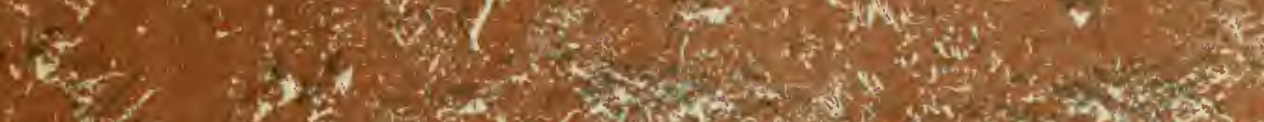

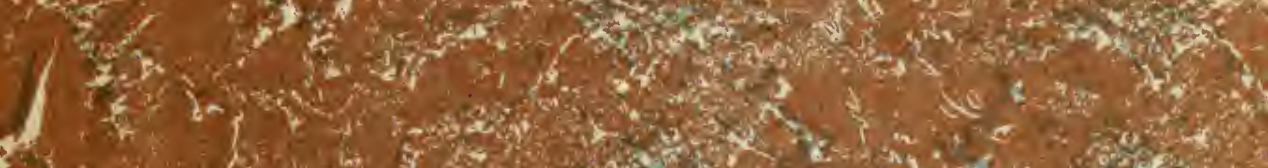

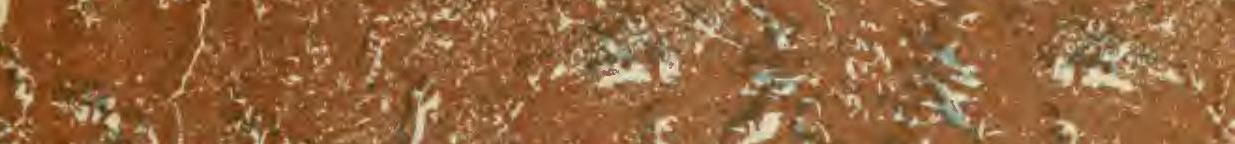

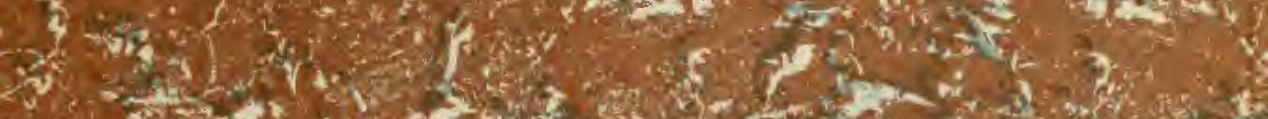
T.

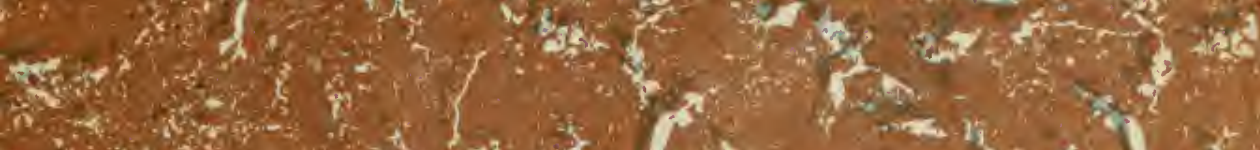

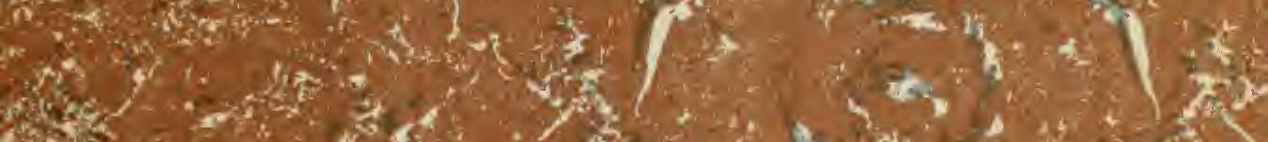
$4-7 e^{2} \cdot y^{2}$

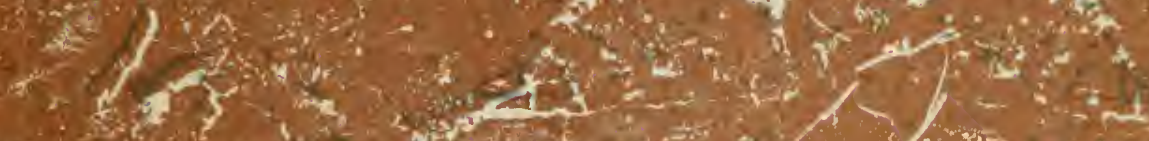

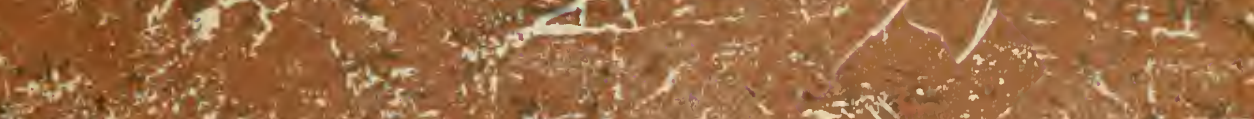

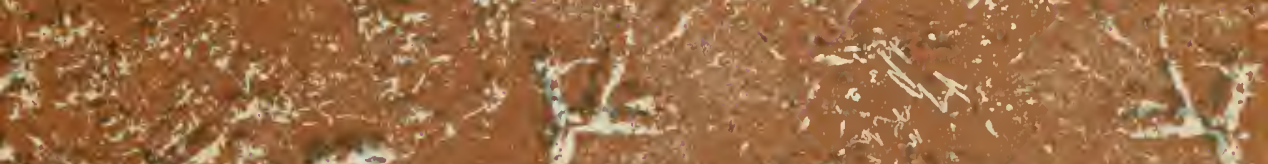

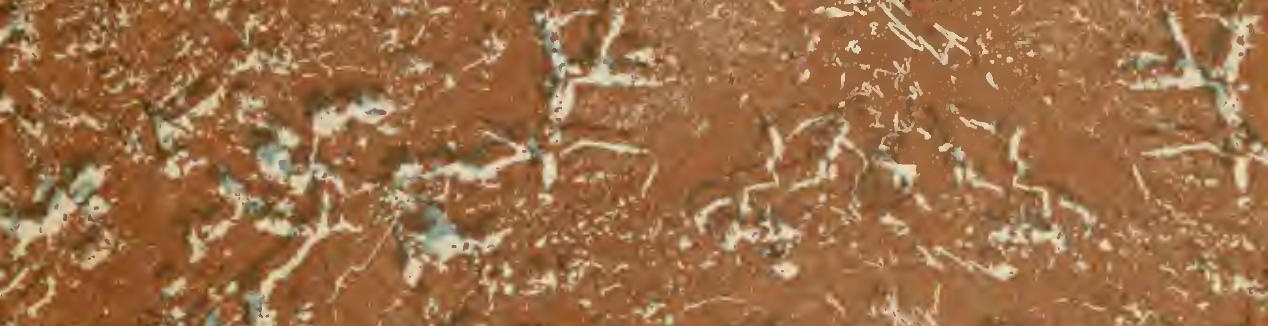

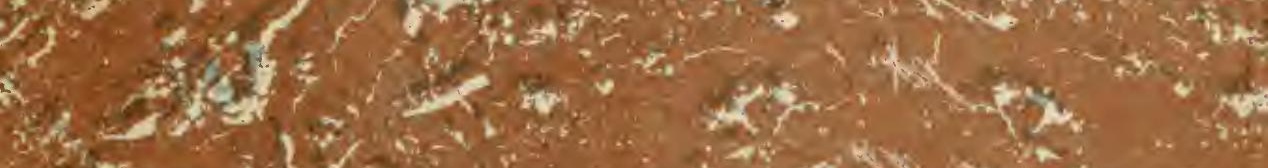

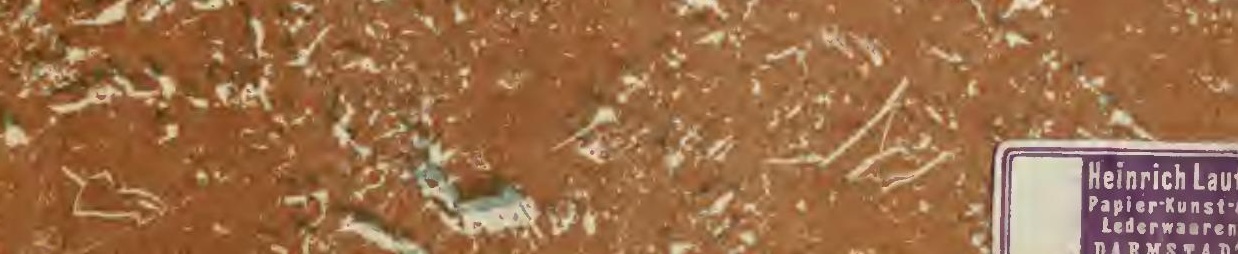


and

WNa

5.

$\sin 3 \times 2$

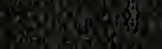

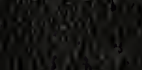

$\lim _{10}$

4.m.

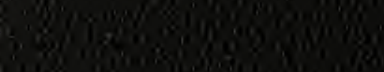

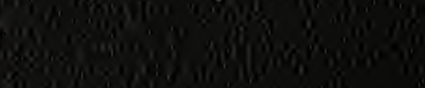

biong

(4)

low 0 in

asing

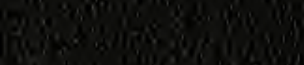

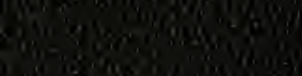

Las 